Rafael Mafei Rabelo Queiroz

\title{
A TEORIA PENAL DE P. J. A. FEUERBACH E OS JURISTAS BRASILEIROS DO SÉCULO XIX: a construção do direito penal contemporâneo na obra de P. J. A. Feuerbach e sua consolidação entre os penalistas do Brasil
}

Tese de doutoramento apresentada como requisito parcial para a obtenção do título de doutor em direito, junto ao Departamento de Filosofia e Teoria Geral do Direito da Faculdade de Direito da Universidade de São Paulo, sob orientação do Professor Associado José Reinaldo de Lima Lopes. 
São Paulo-SP, janeiro de 2008

Para as três mulheres da minha vida: Tathi, Laura e Isaura. 
Este trabalho foi parcialmente financiado pela Coordenação de Aperfeiçoamento de Pessoal de Nível Superior (CAPES), do Ministério da Educação, e pelo Serviço Alemão de Intercâmbio Acadêmico (Deutscher Akademischer Austauschdienst-DAAD). 


\section{Agradecimentos}

A realização deste trabalho teria sido absolutamente impossível sem a participação e apoio de duas pessoas:

Tathiane dos Santos Piscitelli, minha esposa, que passou cada dia dos últimos anos dando-me apoio, ideias e opiniões, e mostrou, mais uma vez, o quanto ela, que já é insubstituível nos momentos de calmaria, torna-se particularmente maravilhosa nos de tormenta; e José Reinaldo de Lima Lopes, orientador participativo e exigente, que nunca poupou esforços para contribuir com o desenvolvimento deste trabalho, e ao mesmo tempo jamais deixou que eu me eximisse de meus ônus e deveres de pesquisador. Toda alegria e alívio que o término de uma tese trazem são, neste caso, parcialmente anestesiados pelas saudades de ter sido seu aluno, que desde já sinto. Não vejo como, em nosso tempo de vida, poderei algum dia retribuir as muitas coisas que ele fez por mim, na academia, na profissão e na vida.

Outros amigos que ajudaram na troca de ideias e consulta a fontes também devem ser mencionados: Davi Tangerino, Luiz Gustavo Bambini de Assis e Thiago Acca. Flávio Riva e Fernanda de Deus colaboraram muito na coleta de materiais bibliográficos.

A banca de qualificação foi especialmente importante para o desenvolvimento desta pesquisa. Não é exagero dizer que, não fossem os preciosos comentários dos professores Sérgio Salomão Shecaira e Ronaldo Porto Macedo Jr., além dos de meu orientador, este trabalho teria seguido rumos incertos e perigosos, que não posso e nem quero imaginar quais teriam sido, mas que seguramente teriam redundado em uma tese sensivelmente pior.

Àqueles que fizeram fácil a chegada e a vida na Alemanha, também agradeço: No Instituto Max Planck, Prof. Ulrich Sieber, Johanna Rinceanu, Jan Simon e Pablo Galain; Daniela Cernko e Andreas Armborst. No quesito "facilitando a vida no 
exterior", destacam-se, como era de se esperar, os amigos brasileiros, especialmente Régis Anderson Dudena, Janaísa Martins Viscardi e Eduardo Oliveira. Se o ano de 2008 é um a ser lembrado por toda a minha vida por ter sido especialmente feliz, isso deve-se em boa parte a essas pessoas.

Minha irmã, Laura, esteve sempre por perto no ano de conclusão desta tese; e minha mãe, Isaura, além do apoio de costume, ajudou-me também com a revisão do trabalho. A elas, agradeço com muito carinho. Ao meu pai, que não está mais aqui para ver e participar disso tudo, também devo eterna gratidão: os três anos em que fui doutorando jamais teriam acontecido se os 28 anteriores não tivessem sido como foram.

$\mathrm{Na}$ Direito GV, encontrei, nos últimos quatro anos, um ambiente único de amizade e estímulo acadêmico. Agradeço a todos os seus membros, de ambos os lados da Rua Rocha, por fazerem isso possível.

Enfim, mas não em último lugar, devo também agradecer a todas as pessoas que, pela amizade, pelo carinho, pelo apoio, pelas conversas despretensiosas e pelos e-mails divertidos, tornaram humanamente possível a tarefa de fazer um doutorado, coisa que, hoje eu sei, é capaz de diluir a fé mais inabalável e pulverizar a mais sólida autoestima. À minha família, à família da minha esposa e aos meus amigos, agradeço por essa grande ajuda, que me deram mesmo sem saber. 
SuMÁRIO

Introduçã 0 ..............................................................................................................................

I. Os pontos de partida.

I. Uma história da dogmática penal. II. Algumas justificativas. III. A pesquisa e sua metodologia. IV. O direito penal contemporâneo: uma história de semelhanças. 1 . Os pontos constitutivos do direito penal contemporâneo. 2. Direito penal contemporâneo e racionalidade penal moderna. V. A estrutura do trabalho.

II. "Crimes" e "penas" às vésperas do direito penal contemporâneo

I. Introdução. II. Pontos de partida metodológicos e institucionais. 1. Fazer justiça.

2. Direito Público versus Direito Privado e a posição do "direito penal". 3. O quadro institucional. 3.1. Códigos, princípios e segurança jurídica. III. "Delito" ou "Crime". IV. Punição. 1. O direito de punir. 2. A medida e a oportunidade da punição. V. Criminoso e responsabilidade. VI. Cartas à mesa.

III. P. J. A. Feuerbach e a construção do Direito Penal Contemporâneo

I. Introdução. II. Como era o direito penal à vésperas de Feuerbach? 1. Christoph Carl Stübel. 2. Ernst Ferdinand Klein. 3. Karl Grolman. III. A separação entre direito e moral. IV. A necessidade do Estado e a importância das instituições. V. A construção de um novo objeto teórico. VI. Que vale como delito criminal? 1. Legalidade. 2. A especificidade do delito criminal. VII. Que vale como pena criminal? 1. Uma concepção de ser humano. 2. O mal da pena. VIII. Um direito penal com cara de direito penal.

IV. O direito penal contemporâneo no Brasil do século XIX

I. Introdução. II. Pressupostos teóricos do direito penal contemporâneo na formação inicial dos juristas brasileiros. III. Os debates em torno do código de 1830. 1. Codificação brasileira e direito penal contemporâneo. 2. Parte geral e parte especial. 3. Direito penal e processo penal. IV. Obras gerais. 1. José Maria Avellar Brotero. 2. Vicente Ferrer Neto Paiva. 3. Heinrich Ahrens. 4. José Dias Ferreira. V. Obras especificamente penais. 1. A influência duradoura: Paschoal José de Mello Freire. 2. Os franceses. 2.1. Pellegrino Rossi. 2.2. J. Ortolan. 3. Itália: Giandomenico Romagnosi. 4. Os primeiros penalistas brasileiros. 4.1. 
Manuel Mendes da Cunha Azevedo. 4.2. Manuel Januário de Bezerra Montenegro. 4.3. Thomaz Alves Jr. 4.4. Braz Florentino Henriques de Souza. 4.5. Joaquim Augusto de Camargo. 4.6. João Vieira de Araújo. VI. Resumindo.

V. Que significa tudo isso?

I. Retomando. II. O toque de Midas do direito penal.

Referências bibliográficas 365

LiSTA DE ABREVIAÇões

AH: FEUERBACH, Paul Johann Anselm. 1797. Anti-Hobbes, oder über die Grenzen der höchsten Gewalt und das Zwangsrechte der Bürger gegen den Oberherrn. Gießen: Müllerschen Buchhandlung, 1797.

Annaes: Brasil. 1826-30. Annaes da Câmara dos Deputados. Disponível em: http://www.camara.gov.br/publicacoes.

Kritik: FEUERBACH, Paul Johann Anselm. 1796. Kritik des natürlichen Rechts als Propädeutik zu einer Wissenschaft der natürlichen Rechte. Altona: s.e., 1796.

Revision: FEUERBACH, Paul Johann Anselm. 1799/1800. Revision der Grundsätze und Grundbegriffe des positiven peinliches Rechts. 2 V. Erfurt: Henningschen Buchhandlung.

Über die Strafe: FEUERBACH, Paul Johann Anselm. 1800. Über die Strafe als Sicherungsmittel vor künftigen Beleidigungen des Verbrechers, nebst einer näheren Prüfung der kleinischen Strafrechtstheorie. Chemnitz: Georg Friedrich Tasché.

Untersuchung: FEUERBACH, Paul Johann Anselm. 1798a. Philosophisch-juridische Untersuchung über das Verbrechen des Hochverraths. Erfurt: Henningsschen Buchhandlung. 
From the obscurity in which the limits of a law, and the distinction betwixt a law of the civil or simply imperative kind and a punitory law, of are naturally involved, results the obscurity of the limits betwixt a civil and a penal code, betwixt a civil branch of the law and the penal. The question, What parts of the total mass of legislative matter belong to the civil branch, and what to the penal? supposes that divers political states, or at least that some one such state, are to be found, having as well a civil code as a penal code, each of them complete in its kind, and marked out by certain limits. But no one such state has ever yet existed.

Jeremy Bentham, An Introduction to the Principles of Moral and Legislation, 1789.

La pénalité se lie avec toutes les branches du droit ensemble, et avec chacune d'elles séparément, considérée soi dans ses principes généraux de droit naturel, soit dans ses principes positifs.

J. Ortolan, Cours de Legislation Pénale Comparée, 1839.

O Direito Criminal tem duas relações: uma publica, e outra particular. A primeira é a que respeita á imposição da pena, á infração do preceito da lei, á referencia para com a consequente sancção repressora. A segunda é a que refere-se á indemnisação, ao interesse particular da satisfação do damno operado. Não obstante estes dous caracteres distinctos do direito criminal, que faz com que elle importe ao Estado e ao individuo, com que participe do direito publico e particular, elle é incluido por todas as legislações no deminio deste segundo ramo, ou antes do poder judiciario: por isso que mais que muito convem premunir os direitos individuaes, e as liverdades publicas, não só do arbitrio, mas mesmo da influencia do poder administrativo.

Pimenta Bueno, Direito Publico Brazileiro e Analyse da Constituição do Império, 1857. 


\section{INTRODUÇÃO}

Quando lemos os mais populares cursos e manuais de direito penal, brasileiros ou estrangeiros, chama-nos a atenção a quantidade de discussões pontuais que os penalistas têm por ofício e profissão: diferentes teorias da pena, da dosimetria penal, da tipicidade, da culpabilidade, do erro e assim por diante. Se atentarmos para o fato, nem sempre lembrado, de que o direito penal é uma realidade de tipo institucional e que depende, por isso, de um certo comportamento consensual para que possa chegar a existir, não deixa de ser surpreendente que, em meio a tanta disputa, ele consiga ainda sobreviver com a unidade que hoje apresenta, ou mesmo que algum dia tenha chegado a se formar enquanto disciplina jurídica. Ainda mais se considerarmos que, no momento histórico dessa formação - entre meados dos séculos XVIII e XIX -, as sociedades pelas quais esse tipo de direito penal logrou espalhar-se eram, do ponto de vista político e social, incrivelmente diferentes umas das outras: da França pós-revolucionária a outros estados com uma monarquia nobilitária ainda forte; dos estados alemães tão influenciados por filosofias jurídicas secularizantes a países onde vingou uma versão conservadora e religiosa de Iluminismo, como Itália e Portugal; de nações que combatiam a escravidão com amparo em teorias políticas liberais a lugares em que o trabalho servil era amplamente presente, como no Brasil ou no sul dos Estados Unidos.

Do ponto de vista histórico, esses mesmos cursos e manuais dão uma importante pista sobre aquilo que talvez tenha sido o sentido comum que levou tantos pontos de dissenso a uma unidade teórica que resultou no direito penal como hoje 
conhecemos: o combate às práticas punitivas absolutistas e o velho mundo penal do Antigo Regime, com suas penas bárbaras e excessivas, desproporcionais e aleatórias, além de suas estratégias criminalizantes confessionais e moralizadoras, que foram substituídas por técnicas "mais humanas e racionais" de punição, bem como por um estudo científico das leis que a fundamentam (Foucault, 1987). De fato, quando lemos o Livro V das Ordenações Filipinas, não reconhecemos nele o nosso direito penal: tudo lá nos parece ora curioso, ora involuído. Ele parece ser parte de um outro mundo, que ficou para trás a partir do século XVIII, quando os códigos penais iluministas entraram em cena. Nesses códigos, e nas obras jurídicas escritas a partir deles, já conseguimos encontrar o nosso direito penal, ainda que com muitas diferenças pontuais em relação àquilo que hoje estudamos sob essa rubrica; mas trata-se, ao menos, de dois objetos comparáveis, porque minimamente semelhantes. Mesmo reconhecendo que ele estava longe de ser perfeito, esse direito penal que nasce no século XVIII parece representar indubitavelmente uma melhora em relação ao "direito penal" do "velho livro de capa rota", e consideramos natural que ele o tenha substituído.

Porém, quando voltamos aos textos dos juristas da época de surgimento desse novo direito penal e da derrocada das práticas de castigo do Antigo Regime, nosso estado de inquietação é novamente aguçado: neles, tomamos conhecimento de que, em meio ao Iluminismo europeu e por muito tempo depois de Beccaria, muitos dos pontos hoje tidos por elementares desse nosso direito penal melhorado e humanizado, superador dos horrores absolutistas, estavam ainda em aberto e postos a debate: havia penalistas inteligentes e competentes que não tinham conseguido separar com clareza os ilícitos criminais dos ilícitos morais; havia dúvidas quanto à pertença do direito penal ao direito público ou privado; havia múltiplas representações do que deveria ser a parte geral do direito penal; havia dificuldades em casar a ideia de que a legislação criminal cabia exclusivamente ao soberano com aquela segundo a qual os direitos individuais podiam fazer frente a esse poder penal inoponível; e, sobretudo, havia muitas dúvidas sobre como superar as controvérsias aparentemente insuperáveis entre as teorias punitivas retributivistas e utilitaristas. A bem da verdade, a própria existência do direito penal, como o ramo autônomo do direito 
que hoje conhecemos, era posta em dúvida por um pensador do calibre de Bentham, que tanto influenciou os juristas que o sucederam: o direito penal como um ramo cerrado e exclusivo do direito, independente do direito civil, é algo difícil de se conceber, e quase impossível de se efetivar, dizia ele em $1791 .{ }^{1}$ Esses pontos de disputa, note-se bem, dizem respeito àquelas coisas que, hoje, são por nós tidas como elementares e inquestionáveis: nós brigamos sobre a culpabilidade ser componente do delito ou pressuposto da pena, ou sobre as teorias psicológicas ou normativas do erro, mas ninguém duvida que o direito penal existe e faz parte do direito público, ou que sua parte geral contém uma teoria do delito e uma teoria da pena. Elas não são, portanto, disputas internas ao direito penal; são, isto sim, disputas que se referem aos seus limites e pressupostos teóricos - ou seja, à sua própria forma de existência enquanto objeto teórico-jurídico.

Se as controvérsias em torno dos fundamentos mais básicos do direito penal eram assim tão grandes, como é, então, que esse nosso direito penal, como objeto teórico, conseguiu se formar? Porque é que hoje enxergamos com tanta naturalidade que o direito penal existe, ou que ele faz parte do direito público, ou que a legalidade é-lhe fundamental, se pessoas tão inteligentes quanto nós não conseguiam enxergar isso há mais ou menos duzentos anos? Este trabalho mostra como a construção dogmática de nosso direito penal foi, acima de tudo, um sofisticado trabalho teórico de conciliar elementos à primeira vista inconciliáveis, porque partes de dois mundos distintos: um mundo velho, em que se destacavam (i.a) uma teoria absolutista do poder político que advogava em favor do Estado um poder punitivo exclusivo e incontrastável, associado ao caráter magnânimo do soberano, muito mais fácil de se arquitetar em teoria do que de se efetivar na prática, bem como (i.b) uma doutrina retributivista e moralizante da punição; e, ao lado desse mundo velho e em grande parte em oposição a ele, um mundo

\footnotetext{
${ }^{1}$ That branch which concerns the method of dealing with offences, and which is termed sometimes the criminal, sometimes the penal, branch, is universally understood to be but one out of two branches which compose the whole subject of the art of legislation; that which is termed the civil being the other. Between these two branches then, it is evident enough, there cannot but be a very intimate connection; so intimate is it indeed, that the limits between them are by no means easy to mark out" (Bentham, 1823, XVII, 1, I). Mais adiante: "The question, What parts of the total mass of legislative matter belong to the civil branch, and what to the penal? supposes that divers political states, or at least that some one such state, are to be found, having as well a civil code as a penal code, each of them complete in its kind, and marked out by certain limits. But no one such state has ever yet existed".
} 
novo, impregnado por dois movimentos de sentidos rivais a esses primeiros: (ii.a) o ideário político liberal, que se opunha, no plano teórico, à inoponibilidade do poder político do soberano a partir da ideia de limitação e racionalização do exercício do poder político, dentro do qual encontrava-se o direito de punir; e (ii.a) a filosofia moral "sensualista" e utilitarista, que disputava com a teoria moralizante retributivista no campo dos fundamentos da punição. A despeito dessas controvérsias, contudo, havia um sentido comum, compartilhado pelos autores da época da fundação do nosso direito penal, de que a solução desses impasses políticos e filosóficos era um elemento fundamental para possibilitar um estudo verdadeiramente científico e não sectário daquilo que responde, em essência, pelos mais passionais debates do nosso mundo moral e político: crimes, penas, punição e paz social. Esse sentido é o que impulsionou a busca pela construção de um objeto teórico que, eventualmente, conseguiu ser costurado da forma que hoje nós conhecemos e resultou em nosso direito penal contemporâneo.

$O$ foco de investigação desta tese foi duplo. Em um primeiro momento, focou-se a formação do direito penal contemporâneo, sobretudo a partir da obra de Paul Johann Anselm von Feuerbach, que é tido no presente, quase à unanimidade, como o fundador da moderna dogmática penal. Uma vez verificados em Feuerbach os grandes sentidos por trás da formação desse nosso direito penal e a forma de sua articulação dentro de uma teoria dogmático-jurídica, a investigação passou a tratar de sua chegada e consolidação no pensamento jurídico brasileiro do século XIX, ligando esses mesmos sentidos à realidade institucional do Brasil de então.

Ao fazer tudo isso, este trabalho joga luzes diferentes no tema da desnaturalização do direito penal contemporâneo, por um ponto de vista até então pouco explorado: a própria constituição teórica da disciplina. Mais ainda, ele permite reabrir, em bases bem fundamentadas, os debates sobre a missão de direito penal na sociedade em que vivemos, bem como sobre a sua capacidade para dar conta dela, tendo em vista as ferramentas e objetivos que o próprio direito penal chamou para si no momento de seu nascimento como o ramo do direito que hoje conhecemos. Ao mesmo tempo, mostra também como foi possível que um mesmo tipo de direito penal tenha conseguido 
se espalhar com tanta uniformidade por sociedades tão diferentes no século XIX, como eram o caso dos diversos países europeus e de uma de suas ex-colônias latinoamericanas - o Brasil. 


\section{OS PONTOS DE PARTIDA}

\section{UMA HISTÓRIA DA DOGMÁTICA PENAL}

Este trabalho tem por objetivo investigar o processo histórico de formação do direito penal tal qual hoje conhecemos, bem como situar a doutrina penal brasileira do século XIX dentro dele. O direito penal como hoje conhecemos será chamado ao longo desta tese de "direito penal contemporâneo". Em linhas introdutórias e muito gerais, a ideia central da investigação é explicitar o sentido normativo por trás de duas etapas históricas da formação do direito penal contemporâneo: a primeira diz respeito à formação teórica do nosso direito penal, ou seja, à nossa forma hoje em dia já naturalizada de enxergar um ramo particular do direito que trata dos crimes e das penas criminais; a segunda, à chegada e consolidação desse tipo de teoria jurídico-penal no Brasil.

Esta tese pressupõe que existem alguns traços comuns às diversas teorias dogmáticas do direito penal hoje existentes, que formam os (borrados) limites teóricos da disciplin desde algum tempo. Esses limites estão compreendidos naquilo que se poderia considerar uma definição elementar do nosso direito penal, que bem poderia ser oferecida a qualquer primeiranista de um curso de direito: "o direito penal é um ramo do direito que pertence ao direito público e cuida da definição de crimes e imposição de penas criminais segundo as leis penais vigentes, dividindo-se em uma parte geral (que traz as regras gerais referentes a todos os crimes e penas) e uma parte especial (que cuida das regras particulares a cada crime em espécie)". Tais traços 
comuns, que pertencem mesmo a teorias dogmáticas diferentes ou rivais entre si, são os dados que nos permitem reconhecer que, mesmo quando discordamos profundamente sobre tópicos específicos do direito penal (como as regras sobre o erro de proibição ou a responsabilidade penal de dirigentes corporativos), estamos ainda discutindo dentro dos limites de uma área particular do direito chamada "direito penal". Esses traços comuns compreendem, note-se bem, tanto elementos substantivos, quanto elementos prima facie puramente formais do direito penal enquanto objeto teórico: eles fornecem, em outras palavras, não só um conteúdo mínimo do nosso direito penal (legalidade, crimes e penas), mas também uma particular forma de disposição desse conteúdo dentro de uma disciplina (a sua separação em relação a outras disciplinas jurídicas, inclusive o processo penal, bem como sua disposição em parte geral e parte especial). Dada a importância da ideia de direito penal contemporâneo como instrumento metodológico desta tese, um item separado deste primeiro capítulo (III, adiante) é dedicado apenas a ele.

A hipótese central deste trabalho é que a formação histórica deste direito penal que hoje conhecemos, e que hoje temos por natural (de fato, é muito difícil enxergar um direito penal sem crimes, penas e legalidade, ou mesmo um mundo onde um direito penal não exista), é um fenômeno que pode ser historicamente explicado como a formação de um discurso normativo particular em torno da forma oficial de tratamento jurídico de ilegalidades. Por "historicamente explicado", quero dizer que, em primeiro lugar, é possível reconhecer, através de uma pesquisa histórica, o caráter contingente de todos esses pontos constitutivos da definição de "direito penal contemporâneo", que hoje parecem propriedades meramente descritivas da disciplina; e, em segundo lugar, que esses pontos contingentes podem ser vistos como postulações de caráter normativo por parte dos juristas da época da formação do direito penal contemporâneo, sobre qual seria a melhor forma de lidar com os problemas jurídicos referentes a "crimes" e "penas" naquele momento histórico em que viviam, e diante das realidades institucionais e do ambiente intelectual de seu tempo. Supõe-se, ademais, que essas postulações giravam em torno de dois temas centrais da filosofia política e moral de então, que foram acomodados na dogmática penal do direito penal contemporâneo e 
dão-lhe desde então a cara e o conteúdo que conhecemos: (i) um debate filosóficopolítico sobre a maneira de viabilizar os propósitos fundamentais de um corpo social, e o papel da violência estatal (com destaque para a pena criminal) nessa empreitada; e (ii) um debate filosófico-moral sobre a realização justa e eficiente da punição estatal, em um mundo moderno dividido por teorias da punição absolutistas e utilitaristas. Assim, ao afirmar que essa explicação histórica é capaz de revelar a formação de um "discurso normativo particular", quero dizer que os pontos básicos pelos quais hoje descrevemos a disciplina do direito penal não são, se atentarmo-nos bem, meros elementos de um discurso descritivo, mas sim de uma proposição normativa sobre a forma correta e adequada de lidar com os problemas hoje tido por criminais, que hoje já naturalizamos e que, por isso, equivocadamente encaramos como mera descrição.

Do ponto de vista cronológico, esta tese parte também da hipótese de que este direito penal contemporâneo formou-se com robusteza apenas no século XIX. Antes disso, ainda que já houvesse, evidentemente, discussões jurídicas sobre "crimes" e "penas", eles davam-se fora dos quadro teóricos de uma disciplina do "direito penal" tal qual hoje concebemos. Se, de um lado, o reconhecimento da existência de tais discussões permite-nos ampliar os horizontes do "direito penal" até as práticas punitivas de outras sociedades muito afastadas do tempo presente, a afirmação do tipo do direito penal contemporâneo exige, por outro lado, que se reconheça que o sentido do tratamento jurídico da punição era, nessas outras épocas, significativamente diferente daquele que é hoje. O tipo do direito penal contemporâneo pretende justamente possibilitar, metodologicamente, não só a localização temporal do processo de formação desse nosso objeto teórico, com também a predicação dos sentidos por trás das ações que levaram à construção do direito penal como hoje ele existe, identificando a normatividade que subjaz a inflexão da teoria jurídica no sentido da construção do nosso direito penal. 


\section{Algumas justificativas}

A metodologia da pesquisa exige algum detalhamento, como também o exigem seus objetos e hipóteses. Antes disso, porém, deve-se oferecer algumas justificativas para o objetivo desta tese - mesmo porque meus objetos, hipóteses e metodologia ficarão certamente mais claros dessas explicações iniciais. É preciso começar oferecendo explicações porque o objeto desta pesquisa poderá causar algum desconforto a quem esteja acostumado com as linhas de trabalho que há algum tempo vêm sendo majoritárias na historiografia penal, em um sentido bastante amplo da expressão (nos estudos de natureza histórica que tenham por objetos as práticas punitivas, o controle social e o saber jurídico sobre o crime, a pena e o criminoso). Esse estranhamento pode ser formulado através de algumas perguntas simples: por que estudar a doutrina penal? Não faria mais sentido estudar as práticas penais (a forma pela qual o direito penal "verdadeiramente" funciona) ao invés de jogar luzes sobre o mundo de fantasia em que muitas vezes vivem os doutrinadores do direito penal, sobretudo aqueles mais próximos do chamado "período humanitário", como Feuerbach ou os brasileiros do século XIX? Pode-se chamar essas perguntas de perguntas "foucaultianas", não porque sejam perguntas que Foucault faria (eu particularmente creio que ele próprio não se espantaria diante de meu objeto), mas sim porque elas refletem uma espécie de ceticismo que uma particular tradição histórica derivada de Foucault ajudou a cultivar: a descrença nas ideias jurídico-penais como objetos de estudo histórico, em favor de investigações sobre as práticas punitivas e do funcionamento real dos mecanismos oficiais de controle social.

Desde que Foucault publicou, na década de 1970, seu Vigiar e Punir, difundiu-se entre os estudiosos das chamadas ciências criminais (direito penal, processo penal, criminologia, política criminal, história do direito penal etc.) a visão de que os penalistas têm tendências a delírios e devaneios, e por isso precisam ser sempre puxados de volta à realidade por seus colegas de outras disciplinas que tenham vocação mais científica e menos dogmática. Isso é evidentemente uma caricatura que, como toda caricatura, tende a exagerar as características mais salientes do objeto em que se foca. A 
pertinência desse exagero, entretanto, pode ser demonstrada por dois exemplos que serão já conhecidos por aqueles que tenham alguma leitura em direito penal.

O primeiro é a distinção celebrizada pela criminologia crítica (cf. Baratta, 1982; Shecaira, 2004: 330 e ss.), e hoje já internalizada por alguns autores da dogmática penal, de que a pena tem funções declaradas, às quais correspondem as categorias da teoria dogmática da pena, mas também funções reais ocultas ou latentes:

O poder estatal concede às suas instituições funções manifestas, que são expressas, declaradas e públicas. Trata-se de uma necessidade republicana; um poder orientador que não expresse para que é exercido não pode submeter-se ao juízo da racionalidade. Porém, em geral, essa função manifesta não coincide por completo com o que a instituição realiza na sociedade, ou seja, com suas funções latentes ou reais. (...) O poder estatal com função manifesta não-punitiva e funções latentes punitivas (ou seja, que não exprime diretamente suas funções reais) é muito mais amplo do que aquele que ostensivamente tem a seu cargo as funções punitivas manifestas. (Zaffaroni e Batista, 2003: 88.)

O segundo é a teoria penal de Claus Roxin, cuja espinha dorsal está na postulação de que é necessário funcionalizar as categorias dogmático-penais, deixandose-lhes introduzir as decisões valorativas da política criminal (Roxin, 2002), para romper com o excessivo conceitualismo e abstração que teriam transformado os penalistas em acadêmicos desligados da realidade punitiva do mundo em que viviam. $\mathrm{O}$ projeto roxiniano de ligar o "mundo dos valores político-criminais" com o "mundo das categorias dogmático-penais" e a leitura que ele faz de seus antecessores têm como pressupostos, evidentemente, a ideia de que esses são dois mundos separáveis ao menos do ponto de vista epistemológico, e que por isso seria possível, ao menos em tese, estudá-los isoladamente (ainda que o próprio Roxin entenda que um tal isolamento seja esterilizante para a dogmática penal).

Ainda que Roxin e a Criminologia Crítica representem movimentos de certa forma antitéticos dentro do mundo das ditas ciências criminais, os dois exemplos servem bem para ilustrar o ponto que interessa a esta tese: no universo do direito penal 
os platonistas têm um porto seguro, já que há nele tanto um mundo conceitual (a dogmática) quanto um mundo real (as práticas punitivas, as decisões político-criminais etc.). Não há nada de muito novo nessa constatação. Ao menos desde Hart, a teoria jurídica tem enfatizado a importância das regras para a constituição do campo teórico do direito e o seu papel constitutivo em relação a muitas instituições sociais, bem como a importância metodológica de se fazer a ponte entre essas regras e as práticas sociais normativas de nosso mundo. A grande diferença é que, enquanto a teoria do direito e a dogmática penal contemporâneas preservam a importância do mundo das regras representado pela dogmática jurídica, a historiografia penal a tem frequentemente ignorado em detrimento das práticas punitivas, privilegiando a realização fática do direito penal no lugar do arcabouço conceitual de sua dogmática, muitas vezes visto como mero conjunto de postulações desejosas e sem importância real em vista das práticas punitivas do mundo empírico.

Pode-se vislumbrar duas explicações diferentes para isso, que talvez sejam cumulativas. Em primeiro lugar, tem sido assumido que, na tradicional divisão de trabalho dos saberes penais, a dogmática penal ocupa-se das coisas abstratas conceitos, princípios, regras -, enquanto os outros saberes, entre os quais a história do direito penal, devem trazer as informações fáticas com que ela, a dogmática, vai trabalhar. Essa é uma visão que vem de longa data e é bem ilustrada pela denominação de "ciências auxiliares" que muitas vezes se empresta a todas as disciplinas que compõem o mosaico de saberes a partir do qual o direito penal se constrói. ${ }^{2}$ Ademais, e talvez conexamente, tem-se assumido que uma história da dogmática penal seria algo de pouca importância, especialmente dentro do período histórico do Iluminismo. Afinal, se Foucault está certo em dizer que os discursos humanizadores da pena acabaram por construir a sociedade disciplinar, fazer uma história da dogmática penal iluminista equivaleria, na melhor das hipóteses, a escrever uma "história das boas intenções" e, na

\footnotetext{
${ }^{2} \mathrm{Na}$ literatura penal tradicional, isso é extremamente comum. Veja-se, por todos, Basileu Garcia (1956, T. I: 39 e ss.). Entre os estrangeiros isso era também frequente (Feuerbach, Lehrbuch: 6). Ainda que hoje a expressão "ciências auxiliares" venha sendo preterida, a representação circunscrita do papel da dogmática penal com frequência permanece. Roxin (2006: 4 e ss.), na esteira de Liszt, fala do direito penal como parte de uma ciência penal global.
} 
pior delas, a ajudar a perpetuar as grandes mentiras do direito penal liberal supostamente humanizador.

Apesar disso tudo, quero defender aqui a posição de que um estudo histórico a respeito da dogmática penal desse período não só é sensato, como também é relevante. Digo isso por duas razões metodológicas diferentes, uma jurídica e outra histórica.

A razão jurídica é que, se ao leigo é permitido enxergar as teorias jurídicas sobre o crime e a pena como não mais do que um conjunto de boas intenções, ou como uma metafísica delirante que não desce à realidade dos cárceres - porque "a vida como ela é" nunca equivale às pregações acadêmicas dos penalistas -, um jurista sabe, instintivamente, que esse ponto de vista tem algo de problemático para a descrição da prática social de que ele é parte: tal abordagem desconsidera o fato de que os juristas não enxergam doutrinas jurídicas como mera expressão de opiniões em sentido fraco, mas sim como postulações de caráter normativo, que exigem de nós um comportamento conforme, ou uma boa justificativa para um comportamento desobediente. Dizer "o melhor fundamento para a pena criminal é A, B, ou C" é diferente de dizer "o melhor acompanhamento para sorvete de chocolate é X, Y, ou Z". Apesar de, em ambos os casos, estarmos diante de afirmações ontologicamente subjetivas, cada uma dessas frases tem não só pretensões distintas, mas recebe também um tratamento social diferente no mundo em que vivemos, especialmente dentro da comunidade jurídica. Juristas não se importam como os seus colegas tomam sorvete, mas são capazes de debater à exaustão quando surgem opiniões jurídicas divergentes sobre um tema jurídico que julguem importante, cada qual tentando convencer a parte contrária com o uso de argumentos racionais. E todos nós juristas sabemos que esses debates fazem sentido, mesmo reconhecendo que tende a zero a probabilidade de atingirmos opiniões consensuais em muitos desses temas. Por isso, doutrinas jurídicas não são meras dissertações em que juristas abrem seus corações sobre determinado tema jurídico, e nem são apenas pensamentos desejosos sobre temas de seu deleite: são argumentos sobre aquilo que seus autores entendem certo ou errado à luz do direito (e portanto 
devido ou indevido), e por isso esperam que os outros acolham suas postulações, a menos que ofereçam boas razões para não fazê-lo.

Não bastasse isso, negligenciar as doutrinas jurídicas implica eliminar da pauta de estudos do direito uma parcela importante daquilo que ele deve ser enquanto disciplina acadêmica, já que essa prática de oferecer definições, justificativas e postulações com pretensões normativas é constitutiva do próprio direito enquanto objeto teórico: as doutrinas jurídico-penais são condições de tratamento dos problemas penais sob o ponto de vista jurídico (da construção de juízos práticos pautados no direito penal, portanto), já que fornecem a linguagem dentro da qual pensar "problemas reais" em termos jurídico-penais é possível. ${ }^{3}$ Assim, a reconstrução histórica do direito penal, como prática social que é, não pode ser feita apenas através das práticas punitivas; ao contrário, deve ser feita também a partir do estudo histórico das ideias dos juristas sobre o crime e a pena - a "doutrina" dos penalistas.

Além dessas razões jurídicas, há também uma razão histórica pela qual o estudo das ideias jurídico-penais faz-se importante: há um leque grande de hipóteses históricas relevantes sobre o direito penal que apenas uma pesquisa que toma a sério a doutrina jurídica como objeto é capaz de testar. Destaco aqui aquelas que se ocupam dos processos de (re)definição dos institutos de direito penal, das relações entre inovações teóricas anteriores e subsequentes e das implicações dessas mudanças para as categorias dogmáticas com as quais os penalistas acabam por "construir" o direito penal como objeto teórico, estipulando o campo de validade de argumentos e justificativas jurídico-penais; ou, como é o caso desta pesquisa, da própria construção histórica do direito penal tal qual ele hoje existe, com os traços fundamentais que conhecemos.

No que diz respeito ao pensamento jurídico amplamente considerado, um bom exemplo disso está em As palavras e a lei (2004), de José Reinaldo de Lima Lopes: as mudanças nas definições em alguns conceitos-chave do pensamento jurídico

\footnotetext{
${ }^{3}$ Adoto nestre trabalho a posição de Lopes (2004: 27 e ss.), segundo quem o direito pode ser adequadamente descrito como uma realidade social institucional, em termos searleanos (Searle, 1995). Aceito também a postulação de MacCormick (1986) de que nós juristas somos profissionais cuja formação nos permite reconhecer, interpretar e organizar as regras que dão corpo ao direito como realidade institucional.
} 
(ius e lex) foram mais do que simples mudanças de opinião dos juristas ao longo da história; foram, isto sim, o processo pelo qual o direito moderno, dentro do qual hoje vivemos, foi criado. Um historiador que não tenha a dimensão de que as mudanças nas teorias jurídicas acabam por resultar em mudanças no próprio direito pode perder dimensão da finitude histórica de categorias jurídicas que hoje nos parecem naturais: a ideia de lei como um comando, ou a dicotomia direito público versus direito privado, a existência do Estado como o ente político que hoje conhecemos (Skinner, 1989) ou, como argumenta-se nesta tese, a própria existência do direito penal como um ramo autônomo do direito, dotado das características elementares expressas na já citada definição dada ao primeiranista imaginário. Ou seja: as perguntas históricas "como e por que se formou o pensamento jurídico moderno?", "como e por que se formou o Estado?", ou "como e por que se formou o direito penal ${ }^{4}$ ?" não podem ser respondidas senão a partir de uma investigação histórica que dê às doutrinas jurídicas ou políticas um papel central.

\section{A Pesquisa e SUA METOdologia}

A pergunta-chave desta pesquisa é também de um tipo que não pode ser respondida sem um estudo histórico que tome a dogmática jurídico-penal como principal objeto de estudos. Um comparativo metodológico útil pode estabelecer-se entre ela e outras pesquisas congêneres, entre as quais destaco a de Andrei Koerner (1999) e, dada a semelhança de objetos, principalmente a de Gizlene Neder (2000). Uma passada de olhos sobre esses trabalhos ajuda a responder aquela que é a principal pergunta metodológica desta investigação: qual é a melhor forma de precisar os sentidos por trás da formação história do direito penal contemporâneo, e como eles se refletem na dogmática penal brasileira do século XIX?

O argumento de Neder é, em síntese, o seguinte: o pensamento jurídico-filosófico do Iluminismo luso-brasileiro ligado ao crime, ao criminoso e à sanção penal foi, tanto no Brasil quanto em Portugal, produto de um Iluminismo

${ }^{4} \mathrm{O}$ direito penal considerado como área do direito com uma dogmática própria, claro está. 
incompleto, pois a ilustração coimbrense não conseguiu depurar-se devidamente do forte tradicionalismo religioso impregnado na vida intelectual portuguesa, que se manifestava, entre outras formas, através da submissão hierárquica no campo das ideias Trata-se da incorporação da já conhecida tese sobre o iluminismo católico português (Cabral de Moncada, 1950, v. III), e a investigação do impacto desse iluminismo no pensamento jurídico-penal luso-brasileiro.

Neder colheu indícios dessa dificuldade de mudança de paradigma (do tradicionalismo barroco para a modernidade ilustrada) em um conjunto vasto de livros e documentos, bastante representativos da circulação de ideias em Portugal e no Brasil durante o final do século XVIII e início do XIX. Sobre um deles, os Estatutos da Universidade de Coimbra (1772), constatou o seguinte:

Sobre o exame das disciplinas preparatórias o Estatuto ordenava que, ao término deste, o aluno receberia uma certidão (se fosse aprovado) que lhe permitiria fazer a matrícula. Se o estudante achasse que fora injustiçado pela avaliação, poderia fazer um novo exame na presença do reitor. Se este achasse que a queixa foi improcedente, ordenaria que o suplicante não fosse admitido em exame algum. (Neder, 2000: 123-4. Destaques originais.)

A relevância da passagem comentada está, para a autora, no fato de que as expressões em destaque (ordenar, suplicar), "remetidas à religiosidade da cristandade ocidental", tenham sido usadas num estatuto destinado à modernização do ensino, de matriz ilustrada, o que apontaria para "indícios claros de uma padrão de submissão e obediência rígido" (cit.: 124). Mais adiante, sua pesquisa concluirá, por isso e por outras coisas semelhantes, que a intelectualidade jurídica brasileira do século XIX era (e talvez ainda permaneça)

muito dedicada a citar os mesmos livros "consagrados", a repetir e reproduzir ideias e interpretações afiançadas por "cânones" professados por "eminências" que, por sua vez, exigem a corte de seus discípulos, que, por sua vez, devem tomar cuidado para não sombrear os mestres, estes sim, verdadeiros donos do poder/saber. (Neder, 2000: 205). 
Duas observações podem ser feitas a partir do trabalho de Neder. A primeira é um conjunto de virtudes: a pesquisa tem o mérito de identificar que existe um momento-chave para a construção da maneira contemporânea pela qual lidamos com nossas estratégias de controle social, e que a virada do século XVIII para o século XIX é um período crucial para a compreensão histórica desse fenômeno. A autora chama atenção, ademais, para a historicidade das instituições jurídicas, algo para que os juristas nem sempre atentam, dado o caráter preferencialmente normativo (ao invés de histórico-empírico) de nossa forma de pensar. Nós, do direito, pensamos sempre através de juízos formados a partir de categorias universais, no sentido lógico da expressão. "As leis", diz MacCormick, "tipicamente trabalham em termos universais: quem quer que seja um consumidor, e que, sendo um consumidor, tenha sofrido um dano, o fabricante do produto danoso será responsável, independentemente de prova de sua culpa, a indenizar o consumidor que sofreu o dano" (MacCormick, 2005: 36). ${ }^{5}$ Dado que a forma-padrão de se pensar juridicamente tem tendências universalizantes, não é difícil também que nós juristas, conscientemente ou não, universalizemos certas categorias jurídicas, transformando indevidamente essa universalidade lógica em uma falsa universalidade empírica, atribuindo consequentemente características "naturais" aos elementos centrais dos sistemas jurídicos das grandes famílias do direito.

Prova disso é que não é incomum encontrarmos trabalhos jurídicos que, a pretexto de fazerem "direito comparado", percorrem em poucos parágrafos um conjunto grande de sistemas jurídicos do mundo todo e "demonstram" que um determinado instituto jurídico, seja ele qual for, está difundido por toda parte. Não vai aqui nenhuma crítica ao direito comparado, cuja utilidade é enorme, para a história do direito moderno inclusive. ${ }^{6}$ Deve-se apenas enfatizar o ponto de que a universalidade das premissas com que trabalhamos no raciocínio jurídico pode levar-nos a cair em

\footnotetext{
5 "Statutes typically deal in terms of universals - "whoever is a consumer, whoever being a consumer suffers an injury, whenever the injury results from a defect in a product, the producer of the product that does injury is liable without proof of fault to compensate the injured consumer"".

${ }^{6}$ Um dos métodos de trabalho mais comuns ao humanismo jurídico foi, lembremo-nos, a determinação do conteúdo dos direitos das gentes (ius gentium) a partir de estudos comparativos entre os sistemas jurídicos de diferentes povos (Tuck, 1979: 38 e ss.).
} 
armadilhas históricas, e o trabalho de Neder dá pistas de como evitá-las: a despeito de o Iluminismo ter conseguido influenciar amplamente as reformas do direito em geral, e do direito penal em particular, os produtos dessas reformas realizaram-se de maneira diferente de parte a parte, e é tarefa da história mostrar a forma específica como isso se deu em cada sociedade.

Esse mesmo trabalho revela, entretanto, a grande dificuldade de se fazer uma história desse tipo: como dizer quando, no campo das ideias jurídicas, um período histórico termina (no caso, o Antigo Regime) e outro (a contemporaneidade) começa? Um dos critérios de Neder, como mostrado nos comentários sobre os Estatutos, foi o vocabulário dos autores e documentos investigados: expressões próprias do religiosismo pré-pombalino ("ordenar", "suplicar") seriam indícios de que a modernidade jurídica luso-brasileira estaria com um pé no "atraso", manifestando "obediência e submissão" (é esse o subtítulo de seu livro) a autores canonizados, ao invés da independência intelectual característica dos literati.

Esse critério vocabular tem um problema: os intelectuais lusobrasileiros não dispunham de outro palavreado político-jurídico para se expressar senão aquele de Portugal de fins dos setecentos, que era, por razões óbvias, recheado de conceitos compartilhados não só com o catolicismo, mas com outros elementos da vida cultural portuguesa. Essa forma de compartilhamento é uma característica da linguagem política (e jurídica) que a historiografia do pensamento político tem registrado há algum tempo:

A linguagem da política não é, obviamente, a linguagem de um modo de investigação intelectual singularmente disciplinado. Ela é retórica, a linguagem em que homens falam para todos os propósitos e de todas as formas em que homens se articulam e comunicam como parte da atividade e da cultura da política. (...) É da natureza da retórica, e sobretudo da retórica política - que serve para reconciliar homens que perseguem diferentes atividades e uma diversidade de objetivos e valores - que a mesma fala desempenhará, simultaneamente, diversas funções linguísticas distintas. (Pocock, 1971: 17). ${ }^{7}$

\footnotetext{
7 "The language of politics is obviously not the language of a single disciplined mode of intellectual inquiry. It is rhetoric, the language in which men speak for all the purposes and in all the ways in which men may be found articulating and communicating as part of the activity and the culture of politics.
} 
A linguagem política (e jurídica) é, por isso, poliglota, nos dizeres de Pocock, porque as mesmas palavras podem jogar papéis diferentes em diferentes discursos. A levar-se o critério vocabular às últimas consequências, um autor lusobrasileiro que quisesse construir uma teoria verdadeiramente ilustrada, depurada de quaisquer elementos antigos, teria de inventar um vocabulário novo, o que não é exigível, inclusive por conta do projeto político que, não raro, acompanha as teorias jurídicas: um jurista, ao divulgar uma teoria, não quer apenas apaziguar as inquietudes de seu espírito intelectual; quer também que ela seja aceita por sua comunidade intelectual com a melhor resposta para o problema nela enfrentado, o que envolve, entre outras coisas, comunicá-la com propriedade, através de um vocabulário minimamente aceito pelo universo cultural em que ele se insere. Isso implica que teorias políticas e jurídicas, em razão de terem quase sempre um conjunto de instituições como referentes, não podem ser construídas, na história ou no presente, senão fazendo menção à tradição textual que é, ao menos em parte, a própria constituinte dessas instituições, ${ }^{8}$ e que trará consigo sempre as marcas de universos culturais anteriores.

A história das ideias políticas tem alguns bons exemplos disso. Tomás de Aquino construiu uma teoria política que é considerada por muitos o nascimento da "ciência política" propriamente dita; mas fê-lo utilizando conceitos emprestados da filosofia aristotélica, atribuindo-lhes significados ligeiramente diversos daqueles que tinham nas teorias de seus contemporâneos, especialmente no tocante ao termo civitas. "Tomás não inventou a terminologia - todos estavam familiarizados com o termo civitas -, mas deu-lhe um novo significado, e o sucesso de uma nova teoria é garantido se ela empregar terminologia familiar", diz Ullman (1968: 98 e ss.). Em matéria penal,

Political speech can easily be shown to include statements, propositions and incantations of virtually every kind distinguished by logicians, grammarians, rhetoricians and other students of language, utterance and meaning; even disciplined modes of inquiry will be found there, but coexisting with utterances of very different kinds. It is of the nature of rhetoric and above all for political rhetoric - which is designed to reconcile men pursuing different activities and diversity of goals and values - that the same utterance will simultaneously perform a diversity of linguistic functions".

\footnotetext{
${ }^{8}$ Sobre a referência de textos jurídicos com a tradição textual que os precede, especialmente no caso romano-germânico, v. Hespanha, 1990; sobre regras normativas como instrumentos constitutivos de realidades institucionais, v. Searle, 1992.
} 
Paul Johann Anselm Feuerbach, que terá um papel importante nesta tese, é também ilustrativo desse fenômeno. Jurista alemão que viveu o influxo da filosofia crítica, Feuerbach construiu toda a sua teoria filosófica e jurídica utilizando-se do ferramental teórico da teoria kantiana, e entretanto chegou (ainda que "kantianamente") a diversas posições que a maioria hoje consideraria anti-kantianas: ele dizia, por exemplo, que o direito e a moral não precisam concordar entre si, já que temos direito a praticar imoralidades; que a pena criminal deveria basear-se em critérios utilitários; e que os súditos tinham direito de resistência perante o soberano. Tudo isso, entretanto, a partir dos conceitos kantianos que eram, a seu tempo, a moeda intelectual mais aceita no mundo filosófico de língua alemã.

Por outra frente, o bom trabalho de Andrei Koerner (1999), mostra que tampouco a legislação serve como indicativo para o ponto de inflexão teórica que esta investigação busca. Sua pesquisa revelou que na transição política do Império para a República no Brasil, a polícia e o Judiciário tiveram papel importante na permanência de práticas penais tipicamente escravistas sob a vigência do novo ordenamento republicano. Sua investigação focou-se no funcionamento dos mecanismos oficiais de controle social e no papel do Judiciário nesse processo. Uma de suas conclusões mais relevantes foi que polícia e Judiciário interpretavam e aplicavam o novo ordenamento jurídico republicano à luz das anteriores práticas pré-republicanas (escravistas) de controle social. Para uma história das práticas jurídicas, como a feita por Koerner, o método é perfeitamente cabível. Mas o trabalho mostra, a contrario sensu, que as referências legislativas, apesar de úteis, são perigosas para uma história das ideias jurídicas, pois é esperável que a interpretação das novas legislações seja feita dentro dos parâmetros intelectuais da velha cultura jurídica, de forma a acomodá-las no sistema de pensamento jurídico anterior. Dito de outra forma, a cultura jurídica do passado dá sempre o con-texto de interpretação dos diplomas jurídicos do presente, de forma que há uma perene inter-textualidade histórica no trabalho de interpretação de um texto jurídico qualquer (Hespanha, 1990a: 191 e ss.), podendo até mesmo os novos textos serem "capturados" pela cultura jurídica anterior. ${ }^{9}$ Como também é possível, ao

\footnotetext{
${ }^{9}$ Hespanha (1998: 37) lembra que na cultura portuguesa de transição para a modernidade, era comum que, sobretudo no norte do país, as fontes jurídicas "oficiais" (reais, escritas), que deveriam ser, segundo a
} 
contrário, que os primeiros passos de um novo paradigma teórico-jurídico sejam dados sob a vigência do ordenamento jurídico que perderá futuramente o sentido com a mudança de paradigma.

Dessa forma, a utilidade de um tipo normativo como o direito penal contemporâneo surge evidente: ele ajuda a dar precisão analítica a um campo de estudos que, por seu material constitutivo (a linguagem política), é essencialmente amorfo. Este tipo normativo é, nesta tese, a representação dogmática do direito penal contemporâneo, que já foi ligeiramente apresentado, mas que agora será tratado com mais vagar. Se o direito penal contemporâneo dá, de fato, os limites da teoria jurídico-penal sobre o qual ocorrem as disputas dogmáticas pontuais, então é provável que ele seja acessível a partir dos elementos (majoritariamente) consensuais da dogmática atual; pois, ao contrário, ele não seria o marco dentro da qual as disputas dogmáticas ocorreriam, mas seria ele mesmo uma parte dessas disputas. É preciso, portanto, apontar quais são esses pontos consensuais da dogmática, bem como o sentido que os fez passar a operar em conjunto dentro de um sistema teórico de direito penal.

\section{O DIREITO PENAL CONTEMPORÂNEO: UMA HISTÓRIA DE SEMELHANÇAS}

Como foi dito já no parágrafo de abertura deste capítulo, a ideia de "direito penal contemporâneo" é central para a construção desta tese. Tal expressão, recordemo-nos, pretende designar os pontos teóricos mais fundamentais do nosso direito penal, que todas as teorias dogmático-penais têm em comum já há muito tempo, e sobre os quais praticamente não há dissenso entre os penalistas. É o caso, por exemplo, das percepções de que o direito penal pertence ao direito público ou de que ele se divide em parte geral e parte especial. Uma investigação sobre a formação histórica de uma disciplina articulada em torno desses pilares precisa ser feita a partir de um

nova orientação política da monarquia absoluta, prevalecentes em face daquelas que imperavam na velha tradição (doutrinadores, costumes), eram muitas vezes integradas e misturadas a essas velhas fontes que pretendiam substituir, perdendo "a sua qualidade de critério decisivo e imperativo na 'invenção' da solução jurídica" e transformando-se em "apenas um tópico entre tantos outros, num sistema argumentativo cuja estratégia é agora dominada pela preocupação de alcançar um acordo", e não de se deixar decidir à moda moderna (autoritariamente e sem preocupação com o elemento do consenso). 
ponto de vista hermenêutico, e o direito penal contemporâneo é uma ferramenta metodológica fundamental para isso.

A apresentação desse ferramental é oportunidade para oferecer mais uma justificativa que, pelo caráter excessivamente generalizante do "direito penal contemporâneo", parece necessária. Com efeito, este é um segundo ponto em que esta investigação poderia estar na contramão, já que em ambas as áreas para as quais ela poderá ter relevância - o deslocamento de ideias jurídico-políticas e o desenvolvimento da dogmática jurídico-penal -, é muito mais comum a estratégia metodológica de se focalizar diferenças muito específicas entre teorias particulares do que semelhanças muito gerais entre elas. Sobre o deslocamento de ideias jurídicas, por exemplo, o conhecido trabalho de Afonso Arinos de Mello Franco (1972) mostra como o Poder Moderador da Constituição de 1824 foi estrategicamente modificado ao ser importado para o Brasil: enquanto na teoria de Constant a separação entre os poderes moderador e executivo seria a chave de toda organização política, a constituição imperial deu ao Poder Moderador em si - que era exercido pelo imperador, também chefe do Executivo - este rótulo laudatório. No que tange ao direito penal, Hoffman-Holland (2007: 12-47) aponta que a construção de uma dogmática penal cumpre necessariamente três etapas, respondendo a última ${ }^{10}$ delas por um trabalho de concretização e síntese a partir da diferenciação dos conceitos. Se assim é, por que então diluir todas as diferenças entre as muitas teorias penais dos séculos XIX e reuni-las no grande balaio do "direito penal contemporâneo", como aqui chamado? Que utilidade poderá ter uma história feita a partir das semelhanças mais gerais, que ademais nos parecem hoje óbvias, quando os caminhos metodológicos mais comuns das disciplinas que me interessam apontam para o esmiuçamento detalhado de seus conteúdos?

A resposta é simples: a necessidade de um tipo normativo generalizante (ao invés de especificador) decorre do objeto e propósitos deste trabalho. Afinal, a tese que se pretende afirmar é que: (i) que há uma forma hoje em dia mais ou menos naturalizada de enxergarmos o tratamento jurídico de certas situações sociais

\footnotetext{
${ }^{10}$ As duas outras são: descrições e reduções ( $1^{\mathbf{a}}$.); e desenvolvimento de conceitos seletivos (trennscharfe Begriffe) e definições ( $2^{\mathrm{a}}$.).
} 
ligadas ao crime e à pena, chamada "direito penal"; (ii) que essa forma corresponde a objeto jurídico normativamente construído que, assim sendo, tem muito pouca coisa de natural; (iii) que essa não naturalidade por ser demonstrada pelas contingências de sua construção histórica, por meio dos sentidos específicos por trás das obras de seus primeiros formuladores; e (iv) que esse nosso direito penal contemporâneo espalhou-se por diversas culturas jurídicas ocidentais, o Brasil inclusive, na forma daquilo que hoje reconhecemos como um certo tipo de dogmática penal, que reflete as características do direito penal contemporâneo porque se constrói a partir dele e dentro dele. Pois bem, se assim o é, não estou preocupado, portanto, com o desenvolvimento particular de institutos penais específicos ou a comparação entre penalistas atuais, hipótese em que o detalhamento e a diferenciação, aí sim, seriam-me muito mais úteis. A preocupação aqui é com algo que é pressuposto a todos os institutos penais particulares, e a todas as teorias gerais do direito penal hoje feitas: a consolidação dos limites normativos sobre os quais as disputas teóricas interiores à disciplina têm ocorrido há mais de um século, e os significados que isso tem para o direito penal atual como prática social.

Uma ilustração bastante singela ajudará a esclarecer o que se quer dizer com tudo isso. As pessoas que hoje trabalham com computadores estão, há quase duas décadas, acostumadas com uma certa interface de relacionamento entre os computadores e seus usuários: clica-se sobre um ícone, abre-se o programa em uma janela e disponibilizam-se menus pelos quais o usuário pode escolher as funções específicas que queira executar, como abrir um documento salvo, começar um novo documento, alterar suas características de funcionamento, executar um comando etc. Isso se chama "interface gráfica". Se a um jovem de 15 anos de idade for solicitada uma definição de um programa computacional, ou mesmo de um computador, é bem possível que seu conceito de software inclua alguns dos seguintes elementos (ou todos eles): ícones, cliques, janelas e menus. Alguém que trabalhe com computadores há mais tempo, entretanto, perceberá que há algo de problemático na utilização de todos esses elementos como integrantes de uma definição, pois eles não são elementos conceituais de programas ou computadores, mas sim características que hoje ambos têm em razão das interfaces gráficas que foram escolhidas em detrimento de outras opções antes 
existentes, e com que predominantemente trabalhamos no presente: que interagem com o usuário por linguagem predominantemente visual, e não escrita (daí os ícones); que recebem comandos mais pelo mouse e menos pelo teclado (daí os cliques e menus); e que permitem a execução de múltiplos aplicativos concorrentemente (daí as janelas, que se maximizam e minimizam). Nos tempos em que o sistema operacional predominante resumia-se a uma tela preta com um cursor piscante e tínhamos de digitar comandos em linguagem quase cifrada ("dir", "autoexec", "format a:"), a definição de software dada por um jovem de então certamente seria outra. Mas como hoje naturalizamos um certo tipo de sistema operacional, é possível que naturalizemos também, por conseguinte, um conceito correlacionado de computadores e programas de computador. E, se as coisas continuarem dessa mesma forma por tempo suficiente, é provável que daqui a muitos anos os programas e os computadores sejam tidos como coisas que têm, conceitualmente, os elementos de cliques e menus; e toda a memória sobre o tempo das telas pretas e cursores piscantes seja esquecida e eliminada dessa conceituação (ou sirva apenas para mostrar como era primitiva a vida na década de 1980), fazendo com que esqueçamos que mouses e ícones são apenas um jeito melhor que concebemos para cumprir tarefas que antes realizávamos por uma interface textual, e que, portanto, há uma escolha normativa por trás de sua consolidação - mesmo que, depois de feita, o acerto dessa escolha pareça óbvio e a preferência por ela pareça natural.

O direito penal contemporâneo nasce do pressuposto de que, a despeito das diferenças que pode haver nos diferentes "softwares" do direito penal de hoje (diferenças entre teorias dogmáticas, códigos e regramentos administrativos), todos eles rodam sob um mesmo "sistema operacional", que se pode chamar de direito penal contemporâneo, conferindo certa unidade e impondo suas marcas sobre todas as diferenças teóricas que pode haver entre uma e outra dogmática particular. É o propósito desta tese mostrar que este nosso direito penal é resultado de um conjunto de mudanças teóricas e institucionais que representaram, no entender de seus executores, um jeito supostamente melhor de cumprir certas tarefas de que o ordenamento jurídico até então vinha dando conta de outras maneiras, como nossos computadores portáteis nos parecem hoje melhores que os velhos desktops de telas verdes. Feito isso, esta tese 
mostrará não só que não há nada de natural no fato de nosso direito penal contemporâneo ser hoje como é, como também que a reflexão histórica sobre a sua fundação nos permite reabrir algumas portas esquecidas e reavaliar se ele é, de fato, a melhor forma de cumprir com o papel que dele se espera, como pensavam os mais brilhantes penalistas de dois séculos atrás.

\section{Os PONTOS CONSTITUTIVOS DO DIREITO PENAL CONTEMPORÂNEO}

O primeiro traço distintivo deste nosso direito penal diz respeito à sua própria existência autônoma, como um objeto destacado de outros dentro da ciência do direito. No início da modernidade, como destacam Pires (1998a) e Cartuyvels (1996), as penas hoje-ditas-criminais não eram específicas de um direito penal, como as penas criminais o são para o direito penal contemporâneo. Aquilo que nós hoje chamamos de "pena criminal", e que circunscrevemos aos limites teóricos do direito penal, era uma parte acessória de todo o direito, prescrevendo um castigo a alguma conduta qualquer. Fazendo uma analogia, os castigos "penais" eram algo como as multas hoje em dia: não há um direito das multas; ao contrário, elas espalham-se por todo o ordenamento e pertencem a diversos ramos do direito. Nesse sentido, dizia Mello Freire (Instituições, III, V), por exemplo, que o direito de punir assistia ao rei, seja em relação aos delitos públicos, seja em relação aos particulares: o jurista português não referia-se ao direito de punir estritamente criminal, como hoje fazemos quando discutimos as teorias da pena criminal; mas, ao contrário e num plano mais geral, referia-se ao direito do soberano de fazer uso da força no cumprimento de seu munus governamental de fazer respeitar o direito. Dessa forma, quando os juristas pré-contemporâneos falavam de "crimes" e "penas", muitas vezes eles não tinham em mente, como nós hoje, os ilícitos e respostas jurídicas de um ramo particular do direito em meio a tantos outros; e mesmo quando eventualmente se referiam ao "crime" como algo mais restrito, não necessariamente o faziam com referência ao objeto material de um ramo particular e destacado do direito público. Como anota Tomás y Valiente (1992: 206), os juristas da modernidade raramente estavam preocupados em especificar o delito criminal em meio ao conjunto 
das ilicitudes em geral; ao contrário, os "crimes" das doutrinas jurídicas précontemporâneas significavam, não raras vezes, um conjunto largo, amorfo e heterogêneo de violações a comandos jurídicos prescritos por regras oficiais imperativas, assim como as "penas" designavam a forma devida, por direito e por justiça, de o soberano reagir a essas violações.

Essa era uma marca do discurso jurídico regalista do momento de transição política para a modernidade, segundo a qual o papel principal do rei era preservar a ordem social e garantir o respeito às leis. Nesse sentido, destaca Tomás y Valiente que desde a baixa Idade Média já se assistia a um progressivo fortalecimento da associação entre, de um lado, a garantia da paz e, de outro, o ordenamento jurídico estatal - isto é, "a lei real e os oficiais e juiz nomeados pelo monarca". Essa tarefa de pacificação e garantia do respeito às leis era principalmente vista como algo exequível pela promulgação de leis "para castigar as alterações da paz social em qualquer de suas manifestações (a vida, a propriedade, a honra...)", atribuindo-se ao soberano "a tutela da ordem pública e da paz interior nos reinos". ${ }^{11}$ Nesse mesmo sentido, Arno e Maria José Wehling dão exemplos de como, na cultura jurídica ibérica, a ideia de respeito às leis e punição de delitos, em sentido amplo, associava-se igualmente ao objetivo político de preservação da paz. ${ }^{12}$ Contudo, a falta de uma "teoria geral do delito (criminal)" e da "pena criminal", como hoje temos, deixava a matéria punitiva espalhada por todo o ordenamento, e não reunida nos escaninhos de uma disciplina estrita como hoje se dá com o nosso direito penal. Essa representação horizontalizada dos "crimes" e das "penas" era preferencialmente associada a elementos culturais pré-contemporâneos, como não poderia deixar de ser: em um mundo de contínua importância da teoria política tomista, que impunha uma visão unitária da natureza e do mundo, em que direito e moral, crimes e pecados eram conceitos reciprocamente permeados, e que

\footnotetext{
11 "Así, ao largo de la Baja Edad Media, en un proceso erizado de dificultades y resistencias (...) se va abriendo paso la idea de que la garantía de la paz es función del ordenamiento jurídico general, es decir, de la ley real y de los oficiales y jueces nombrados por el monarca. La tutela del orden público, de la paz interior en los reinos, se atribuye al rey. Esto significa que lo monarca dará leyes para castigar las alteraciones de aquella paz en cualquiera de sus manifestaciones (la vida, la propriedad, la honra...)" (Tomás y Valiente, 1992: 25).

12 "No preâmbulo da Recopilación de Leyes de los Reinos de las Indias, de 1680, o discurso ainda é o mesmo: o primeiro e maior cuidado dos Senhores Reis nossos gloriosos predecessores, e nosso, é dar leis com que aqueles reinos sejam governados em paz e justiça" (A. Wehling e M. C. Wehling, 2004: 31).
} 
mantinha ademais a metodologia casuística tradicional do direito romano, a construção de uma definição geral e abstrata do delito criminal e a organização dos diversos tipos de delitos a partir dessa definição não estavam entre as primeiras preocupações dos juristas. Os reflexos dessa tradição particularista sentiam-se na cultura jurídica castelhana ainda em fins do século XVIII e início do século XIX, quando muitos "criminalistas" - como Alvarez Posadilla (XVIII) e Vilanova y Mañez (XIX) - ainda definiam o delito como uma violação voluntária a qualquer norma jurídica (Tomás y Valiente, 1992: 208), sem qualquer preocupação em fazer suas doutrinas começarem por definições gerais dos delitos ou das penas criminais, como as nossas começam em teorias do delito (criminal) e da pena (criminal). Some-se a isso que, até a representação definitiva, na teoria e na prática institucional, do poder político central e soberano como responsável pela solução (leia-se "supressão autoritária") de muitos conflitos de natureza preponderantemente individual (sobre honra e propriedade, por exemplo), o caráter trans-individual das disputas jurídicas continuava vivo no imaginário coletivo, acentuando a indistinção entre violações que são atualmente penais ou civis, quando não entre violações jurídicas e morais. ${ }^{13}$

$\mathrm{O}$ caso dos juristas castelhanos mencionados indica que a imagem desse "direito penal" episódico e horizontal sobreviveu na cultura jurídica do continente século XVIII adentro, em diferentes medidas. A partir de fins do século XVII, muitos doutrinadores europeus já tratavam os crimes como parte exclusiva do direito público. Assim faziam, ilustrativamente, Jean Domat, cujo Tratado das Leis Civis dedicava o Livro III do tomo dedicado ao direito público aos "delitos e crimes" (Domat, 1828); e Blackstone (1765-9: VI, 1), que representava os crimes como algo já diferente dos ilícitos privados (misdemeanors), por serem violações de leis públicas. Mas em nenhum desses casos havia ainda diferenciação entre os "crimes" e os demais ilícitos de direito

${ }^{13}$ Esta é, segundo Hespanha, uma das permanências do direito tradicional que se misturou com o direito oficial no alvorecer da modernidade portuguesa: "É este caráter trans-individual dos conflitos que explica, por um lado, a fluidez das fronteiras entre o direito (ius), a moral (fas) e o costume (mos), e ainda a referência, permanente no discurso jurídico tradicional, a padrões éticos de contuda (praecepta iuris sunt haec: honeste vivere, alterum non laedere, suum cuique tribuere); por outro lado, explica ainda a indistinção entre as sanções "penais" e as sanções "civis" da qual resultam quer a "penalização" de questões, hoje em dia, nitidamente civis (por exemplo, a prisão por dívidas), quer a "civilização" de questões, actualmente, de natureza penal (por exemplo, a aceitação de penas puramente privadas de reparação penal)" (Hespanha, 1988: 35-6). 
público, como hoje diferençamos claramente entre ilícitos penais e administrativos, por exemplo. Esse processo final de especificação é uma das marcas do direito penal contemporâneo.

Além dessa diferenciação qualitativa entre o ilícito penal e outros ilícitos de natureza pública, o processo de autonomização do direito penal envolveu ainda a sua separação em relação ao direito processual penal. Depois de se diferençar no meio da massa das normas jurídicas, num primeiro momento, foi também necessário que, em seguida, o direito penal substantivo se destacasse do direito penal processual a fim de se circunscrever a algo minimamente parecido com aquilo que hoje reconhecemos como o seu campo material por excelência: definir os crimes e as penas, bem como as regras para a sua imputação. Antes, ao contrário, viam-se como "criminais", indistintamente, todas as regras estatais cujo propósito fosse cuidar de crimes e sua penalização, independentemente de se tratar de sua definição em abstrato ou de sua persecução e julgamento em concreto, ainda segundo a lógica de que tudo isso fazia parte da tarefa pública de preservar a ordem interna de um Estado. Na mesma época de Feuerbach (o "pai da moderna ciência penal"), Karl Grolman, seu amigo mas adversário intelectual, divulgava uma doutrina penal ainda relativamente misturada com elementos processuais e "confundindo" institutos que são, para nós, claramente separados pela nítida distinção entre as duas disciplinas: Cattaneo (1979: 278) aponta, por exemplo, que "corpo de delito" e "tipicidade" ("Thatbestand") eram, para Grolman, sinônimos. ${ }^{14}$

Esse tratamento unitário do direito material e processual pertencia à tradição jurídica romano-germânica e vinha de longa data. Segundo Hespanha (1990a: 192), a representação metodológica do "direito criminal" foi feita por muito tempo segundo uma lógica processual. Isso se vê, por exemplo, no Livro V das Decretais de Gregório IX, que tanta influência tiveram na cultura jurídica portuguesa até a chegada

\footnotetext{
14 "Corpo de delito" era a evidência concreta do fato criminoso. O código criminal bávaro de 1751 falava em "defeito no corpo de delito" para descrever qualquer falha na apuração do concreto "fato típico" (pede-se vênia para o anacronismo), e previa nesses casos uma pena diminuída: "Wo in dem corpore delicti oder sonst in dem Process ein solcher Mangel erscheint, daß die erforderliche Prob dadurch in billichen Zweiffel geräth; so greifft statt der ordentlichen nur eine mildere Straff Platz". (Cap. I, § 24). Não há nele qualquer menção a algo semelhante a um princípio da legalidade como hoje existe.
} 
de Mello Freire, onde as matérias do direito criminal eram apresentadas segundo a ordo legalia: "de acordo com o modelo expositivo das Decretais, o tratamento segue a ordem do processo; se inicia pela acusação, segue com a regulação dos distintos delitos e termina com o regime de provas e da sentença" (Hespanha, 1990a: 192). Na última parte da Lei das Sete Partidas, outro documento de relevo para a história do direito ibérico, via-se a mesma coisa: o "livro criminal" (VII) começava pela acusação (Título 1), definia então os diversos tipos de delitos (Títulos 2 a 28), chegava às provas e formas de julgamento (Títulos 29 e 30), passava pelas penas e suas espécies (Título 31) e terminava no perdão (Título 32).

Essa etapa final do processo de autonomização material do direito penal, que levaria a sua separação do processo penal, demorou muito mais para consolidar-se, uma vez que o processo foi, inicialmente, o elemento mais importante para a consolidação do poder punitivo nas mãos exclusivas dos reis. Nesse sentido, Langbein (1974) diz que na Europa do século XVI houve diversas tentativas de impor uma racionalidade moderna a uma "justiça criminal" ainda embrionária, o que pode ser visto como uma primeira emancipação do campo criminal; mas aponta que isso foi feito muito mais pela organização do processo do que pela definição abstrata de crimes e penas. No mesmo sentido, Sbriccoli (2002: 174) aponta a importância das practicae criminalis para uma primeira autonomização da matéria criminal. Os ecos disso sentemse até o século XIX, quando muitos dos primeiros códigos criminais modernos ainda tratavam em conjunto o direito penal material e processual. ${ }^{15}$ Falando da doutrina criminal do Antigo Regime, Arno e Maria José Wehling anotam que ele possuía caráter "predominante processual e procedimental" (2004: 551). Com o passar dos anos, o direito penal virou o jogo, por assim dizer: os problemas jurídicos processuais, que foram inicialmente o caminho pelo qual o "criminal" ganhou emancipação, perderam espaço na disciplina conjunta e acabaram desgarrando-se do nosso direito contemporâneo estritamente penal, relegados a problemas "adjetivos", como alguns penalistas ainda hoje referem-se ao processo penal. Entender esse processo de

\footnotetext{
${ }^{15}$ Hespanha (1990a: 193) anota que, nos primeiros códigos modernos de fins do século XVII (toscano e austríaco), o paradigma da ordo legalia ainda permaneceu.
} 
autonomização é outro ponto-chave para a compreensão histórica da dogmática do direito penal contemporâneo.

Sobre a separação do direito penal em relação ao processo penal, é preciso indicar com mais especificidade como ela será investigada, já que isso pode render polêmicas mais adiante. Ao apreciar o projeto de código criminal de Pascoal José de Mello Freire, Hespanha (1990b: 411-3) postula que a separação entre as duas disciplinas pode ser aferida a partir da mudança na estrutura expositiva do direito penal: quando o direito penal é representado segundo a já citada lógica processual, haveria indistinção entre as duas coisas; quando, ao contrário, ele é representado como ostentando uma estrutura determinada por suas próprias necessidades, a partir das definições de seus institutos fundamentais (com uma parte geral, portanto), haveria distinção entre as disciplinas. Um conjunto mais representativo de obras criminais do século XVIII mostra, entretanto, que este critério pode ser problemático, pois ainda que a lógica da ordo legalia das Decretais tenha deixado de ser seguida em muitas obras, o conteúdo do "direito criminal", enquanto objeto teórico-jurídico, ainda reunia direito substantivo e processual, se bem que de outra forma: o direito penal era apontado como a "parte teórica" da disciplina, e o direito processual, a sua "parte prática". É isso que se vê, por exemplo, em Ernst Klein (1796), autor adiante comentado. Assim, se a mudança na ordem de apresentação da disciplina denuncia que o direito penal começava a sua emancipação por meio de seu relativo desligamento metodológico das preocupações práticas do campo criminal, não é possível afirmar que isso indique, por si só, o seu pleno desligamento teórico do direito processual - ainda que tal mudança seja um passo necessário para tanto. Se considerarmos ademais a grande inventividade que havia nas doutrinas que postulavam uma tal separação absoluta entre direito material e direito processual, o melhor critério para investigar essa separação parece ser a busca por manifestações explícitas nesse sentido por parte dos autores estudados.

A progressiva especificação teórica que levaria ao direito penal contemporâneo suscitou um grande debate sobre a "posição enciclopédica" da nova disciplina. Ou seja, quanto à posição do direito penal dentro do direito público ou do direito privado. Este é outro ponto constitutivo do direito penal contemporâneo. Como 
o processo de especificação teórica do direito penal envolveu diversas etapas, os juristas eram forçados a todo momento a rever sua posição dentro dessa dicotomia, que tem sido a porta de entrada das classificações do direito desde o início da modernidade (Lopes, 2004: 70 e ss.). Assim, se alguns juristas do século XVII já classificavam o direito penal com segurança dentro do direito público, muitos outros juristas do século XIX ainda demonstravam dificuldades em fazer o mesmo com segurança. Não só porque viam aspectos substantivos de relações privadas nos ilícitos criminais (proteção da propriedade privada, por exemplo), mas também porque havia muita coisa privada no processo criminal, como o início da persecução caber muitas vezes à parte ofendida e não aos procuradores públicos. Esse era, a propósito, outro elemento herdado da tradição jurídica pré-contemporânea: tratando das repúblicas italianas renascentistas, Stern (1995: 203-4) apurou que quase um terço dos "crimes" eram perseguidos por iniciativa das partes, ${ }^{16}$ o que só mostra o quanto o elemento privado e dispositivo vinha sendo até então relevante na realização da "justiça criminal", mesmo quando a matéria punitiva era já associada ao dever político do soberano de preservar a paz. Isso leva a um ponto importante em que a teoria do direito penal contemporâneo toca a sua realização prática: a postulação de que o ramo criminal pertence exclusivamente ao direito público reclama a existência de órgãos estatais capazes de levar adiante a tarefa de persecução criminal - o procurador de Foucault, ou o ministério público para nós brasileiros -, que quase nunca estavam prontos e acabados nos primeiros instantes em que convinha às teorias. ${ }^{17}$ Isso mostra também o quanto a situação do direito penal dentro do direito público não foi apenas um problema teórico; foi também um problema político. ${ }^{18}$

\footnotetext{
${ }^{16}$ Os números levantados por Stern são: 38,4\% dos casos iniciaram-se por conhecimento público; $17,5 \%$ por denúncia de um reitor; $15,8 \%$ por inquisição oficiosa; e $28,2 \%$ por acusação privada.

${ }^{17}$ Langbein (1976) lembra, por exemplo, que a eliminação das penas de sangue do rol punitivo da modernidade em favor da pena restritiva de liberdade foi um processo longo, principalmente pelo aspecto prático nele envolvido: enquanto as penas corporais podiam ser aplicadas sem delongas e instantaneamente, a privação de liberdade demanda um aparato físico e humano (prisões, vigilantes) cuja construção prolongou-se no tempo.

18 Tomás y Valiente anota que este processo de publicização esteve longe de ser uma marcha aproblemática: "el caráter público del Derecho Penal no se impuso de una vez para siempre, sino que para ello hubo que vencer, aun en los siglos de la Edad Moderna, serios obstáculos. Derecho Penal estatal en esta época no quiere decir que la ley penal sea igual para todos los homens y en todos los lugares, ni que ésta deje al juez resueltos todos o casi todos los problemas, para evitar, por ejemplo, su aplicación por vía
} 
Além disso, a mistura do público e do privado em matéria criminal dava-se também pelo aspecto substantivo. Na tradição do Digesto, ${ }^{19}$ a distinção entre delitos públicos e privados já existia, mas ela tinha uma função estrutural completamente distinta da dicotomia moderna entre ilícitos públicos e ilícitos privados. A ideia de "interesse público", que fundamenta os ilícitos públicos do tempo presente, não alicerçava os publica delicta do livro 48 do Digesto (Hespanha, 1990a: 190). Roubo (D. 47.8) e furto (D. 47.2.1) não eram delitos públicos, por exemplo, porque atingiam uma vítima privada em seus interesses particulares (patrimônio); ao passo em que plágio e peculato (D. 48.13) eram públicos, por não dizerem respeito a um interesse particular (Hespanha, 1990b: 410). A falta de ligação entre "interesse público" e "pena pública" fazia com que, na tradição pré-contemporânea, as soluções privadas de conflitos fossem frequentes mesmo para casos que hoje consideramos inequivocamente como sendo de interesse público: a Lei das Sete Partidas (VII, 1, 22) permitia que o "delinquente" se recompusesse com a vítima em casos de penas de morte ou de mutilação de membros - o que incluía o homicídio e o estupro -, ficando isento de punição em tal caso. ${ }^{20}$ Por aí já é fácil ver o quanto não era tarefa simples romper com a tradição de um "direito criminal" ao mesmo tempo público e privado, que tinha séculos de existência e bibliotecas inteiras de doutrinadores respeitados que lhe conferiam sentido e autoridade.

Por todas as razões até aqui expostas, a especificação do direito penal passou também pela postulação de significados específicos para os conceitos de "crime", ou "delito", e "pena", bem como para as regras para sua imputação. Esses elementos, quando circunscritos ao campo do "criminal", em um primeiro momento, e do especificamente "penal", mais adiante, tiveram de ganhar significados mais restritos.

de interpretación analógica extensiva; ni tampoco que ele poder real consiga imponer su ley y su autoridad en todas las contiendas u ofensas delictivas surgidas entre los reyes persiguen, y en la que fracasaron frecuentemente aunque al final triunfaram" (1992: 26).

${ }^{19} \mathrm{O}$ livro 47 tratava dos delitos privados (delicta privata), e o 48, dos delitos públicos (delicta publica ou crimina).

20 "Cómo aquel que es acusado puede facer avenencia con su contenedor sobre pleyto de la acusacion. Acaesce á las vegadas que alguns homes son acusados de tales yerros, que si les fuesen probados, que ricibiren pena por ellos en los cuerpos de muerto ó de perdimiento de miembro: et por miedo que han de la pena trabájanse de face avenencia con sus adversarios, pechándoles algo porque non anden mas adelante por el pleyto" (Siete Partidas, VII, 1, 22). 
No pensamento jurídico desta fase de transição, é aí que começa a radicalizar-se a diferença entre a gravidade dos ilícitos "criminais" em relação aos "civis", primeiramente, e, em um momento seguinte, aos demais ilícitos públicos; bem como às especiais propriedades das penas criminais. $\mathrm{O}$ argumento aqui é em essência o mesmo de Foucault (1987, 2005): se "crimes" sempre foram vistos como comportamentos indesejáveis, e "penas" como a maneira oficial de lidar com eles - é isso que confere o mínimo de unidade às práticas punitivas de povos históricos tão distintos -, o reformismo da modernidade e do Iluminismo vai ligar essas ideias a, de um lado, uma nova antropologia filosófica e, de outro, um conjunto de reformas institucionais do início da idade contemporânea, ligadas aos novos objetivos políticos da punição. No campo teórico, isso levará a um novo significado para os vocábulos em questão. Tudo isso em conjunto terá como resultado mudanças metodológicas que resultarão em algo já muito próximo (se bem que não idêntico) ao conteúdo material do direito penal contemporâneo.

Com efeito, e a despeito de todos os reparos que têm sido postos a esta visão pela criminologia chamada crítica, é um ponto fundamental de praticamente toda a dogmática penal contemporânea que o delito criminal tem propriedades substantivas específicas, que são dadas pelo "conceito material de delito" (Roxin, 2006: 8 e ss.) e em geral envolvem a importância dos bens jurídicos por ele protegidos, ou o caráter especialmente nocivo do delito criminal. Tais propriedades separam, normativamente, a substância do ilícito penal em relação às demais irregularidades do ordenamento jurídico, sejam elas de direito privado, sejam de direito público. A postulação do que seja o tal conteúdo material do delito, é claro, varia de autor para autor. Mas ainda assim, é possível dizer que todos compartilham, em um certo nível de generalidade, a ideia da danosidade do delito criminal no plano normativo mais geral de suas diferentes conceituações. De fato, pareceria absurda nos dias de hoje uma teoria que sustentasse que o ilícito criminal é aquilo que de mais inofensivo ou desimportante há na sociedade.

O instituto dogmático-penal que mais se liga à representação estrita do delito criminal é a legalidade, que tem no direito penal contemporâneo um papel fundamental. Se é verdade que há um grande conjunto de princípios que são relevantes 
para o nosso direito penal, é verdade também que a legalidade é o mais fundamental de todos eles, por uma razão simples: ela é, além de uma orientação normativa para todo o direito penal, também um instrumento constitutivo de seu objeto teórico. Uma legalidade rígida e taxativa é, mais do que qualquer elemento substantivo que se refira à danosidade ou lesividade social da conduta, o elemento que é inequivocamente reconhecido como aquilo que distingue, ao menos à primeira vista, a matéria bruta penal das demais esferas de normatividade, jurídicas ou não. Assim, a legalidade foi não só o instrumento político que permitiu romper com a noção pré-moderna de que "o delito é um pecado e o pecado é um delito" (Tomás y Valiente, 1992: 219-20) - ruptura essa que aparece exemplarmente na definição de Hobbes de "crimes" (1651a, XXVII) ${ }^{21}$-, mas também um instituto que ganhou um destacado papel metodológico dentro do campo teórico do direito penal contemporâneo. Em outras palavras, é ela que determina o campo de trabalho da dogmática penal, qual seja, as leis estatais que definem crimes e impõem penas.

Não se está negando aqui, é bom frisar, o fato sabido e ressabido de que as leis estatais tinham, desde os primórdios da modernidade, a função de estabelecer ilícitos. Como anota Tomás y Valiente (1992: 24), no direito penal do alvorecer das primeiras monarquias absolutas já havia a compreensão de que os reis tinham poder para definir quais atos são delitivos, e quais as penas a eles cabíveis. Mas ao mesmo tempo, é também sabido que o exercício efetivo do poderio criminal era não só limitado pela complicada rede de poderes políticos da época, que envolvia múltiplas esferas de poder político (de que a Igreja é um exemplo especialmente importante para o campo penal), ${ }^{22}$ mas também por circunstâncias materiais nem sempre favoráveis à efetiva aplicação da intervenção estatal teoricamente mais eficiente (Langbein: 1976). O mesmo Tomas y Valiente lembra que, muitas vezes, para a conveniência tanto dos reis quanto da Igreja, o "direito penal" real aliava-se ao eficiente aparato inquisitivo ou

\footnotetext{
21 "A Crime, is a sinne, consisting in the Committing (by Deed, or Word) of that which the Law forbiddeth, or the Omission of what it hath commanded. So that every Crime is a sinne; but not every sinne a crime". A diferença entre "crimes" e "sinnes" em Hobbes é comentada no capítulo seguinte.

${ }^{22}$ Sbriccoli (1974: 31) comenta que os príncipes da modernidade tiveram de disputar também com os juristas a autoridade da punição. As leis régias eram tentavam esvaziar o campo da autorictas doutrinária em matéria punitiva, o que não impedia que acabassem "capturadas" pela interpretação dos jurisconsultos no velho sistema do ius commune.
} 
eclesiástico, resultando daí uma "teologização do direito penal secular" (1992: 86). O resultado disso é que, ao menos até a difusão das ideias de Thomasius e Kant sobre a separação entre direito e moral - e, em muitos lugares, ainda depois disso -, os movimentos políticos de criminalização e descriminalização de condutas eram ainda vistos em meio a um quadro muito mais amplo de proibições derivadas de outras esferas de normatividade da vida social. Ou seja, o poderio constitutivo em matéria penal das primeiras monarquias absolutas está longe de ostentar o "toque de Midas" que tem a legalidade do direito penal contemporâneo, que por um simples rito político formal é capaz de criar o delito criminal e ameaçar com a pena corporal uma conduta que antes era, de fato e de direito, livre e permitida.

É uma postulação desta tese que a legalidade tal qual conhecemos tem duas funções distintas, se bem que recíproca e diretamente implicadas, cuja separação é, para fins históricos, de grande utilidade: a primeira é política; a segunda, metodológica. A função política da legalidade diz respeito sobretudo a seu papel negativo, de contenção, sendo produto da influência liberal-iluminista sobre o direito penal. É principalmente ela que corporifica a ideia de garantia que associamos às leis penais, proibindo que alguém receba uma penalização senão em conformidade com aquilo que prevê uma lei anterior. É a esse papel da legalidade que muitos dos clássicos da política do século XVII fazem referência quando exigem, como Beccaria, a proteção contra arbítrios cometidos por juízes criminais. O Marquês, por exemplo, dizia que "só as leis podem decretar as penas dos delitos; e esta autoridade deve residir unicamente no legislador, que representa toda a sociedade unida pelo contrato social" (Beccaria, 1774: III). ${ }^{23}$

Isso é significativamente diferente do que dizemos hoje sobre a legalidade penal. Na lição de Roxin (2006: 141), exemplificativamente, a legalidade penal é composta de dois princípios distintos: "não há crime ou delito sem lei" (nullum crimen sine lege) e "não há pena sem lei" (nulla poena sine lege). Em Beccaria, note-se, o primeiro princípio não está ainda formulado em sua lição sobre o papel das leis

23 "sólo las leyes pueden decretar las penas de los delitos; y esta autoridad debe residir únicamente en el legislador, que representa toda la sociedad unida por el contrato social". 
criminais. Se repararmos bem, aliás, o primeiro capítulo do "pequeno grande livro" diz respeito à origem das penas, e não à origem dos delitos criminais. A diferença de que falo pode ser apreciada também em nível legislativo: nos primeiros códigos de fins do século XVIII e início do XIX, era comum que a garantia da legalidade fosse expressa através da proibição à punição de crimes ou delitos senão conforme as penas previstas nas leis: já se dizia que, sem a lei, não poderia haver punição. Mas isso é ainda bem diferente de dizer que o delitos ou crimes não existem sem que uma lei penal anterior os constitua, ${ }^{24}$ e que a tal lei é, além de necessária, também plenamente suficiente para autorizar uma punição conforme ao direito.

Mais uma vez, isso está ligado à já referida concepção horizontalizante da matéria punitiva pré-contemporânea: enquanto o "criminal" era visto como a prerrogativa punitiva do soberano, o traço distintivo dessa matéria era mais a pena do que os delitos. É só com a necessidade de circunscrição e diferenciação do ilícito estritamente penal dentro de uma disciplina própria, diferente inclusive das outras que compõem o direito público interno, que os esforços de especificação teórica reconhecerão a estrita legalidade como o pedigree da matéria substantiva do direito penal contemporâneo.

Quero dizer com isso, portanto, que a legalidade imediatamente anterior ao ao direito penal contemporâneo já continha, ao menos no nível das postulações acadêmicas, algo semelhante à função garantista que hoje nela vemos, mas não carregava ainda a propriedade de constituição dos delitos criminais, que é por corolário definidora do campo material de incidência do direito penal como aparato teórico e, assim sendo, tem um papel metodológico importantíssimo para a constituição do objeto teórico do direito penal contemporâneo. Não é por acaso que, ao contrário de Beccaria, nossos manuais de direito penal hoje falam de legalidade não só quando comentam os princípios garantistas de direito penal, mas também para estipular, logo de início, onde começa e onde termina a disciplina. O conceito de direito penal é muitas vezes dado a partir da legalidade, em outras palavras. Francisco de Assis Toledo diz, na

\footnotetext{
${ }^{24}$ É nesse sentido a redação do artigo $1^{\circ}$ do nosso Código Penal de 1984: "Não há crime sem lei anterior que o defina, nem pena sem prévia cominação legal".
} 
primeira página de seu Princípios Básicos de Direito Penal, que o direito penal é antes de qualquer coisa "aquela parte do ordenamento jurídico que estabelece e define o fatocrime, dispõe sobre quem deva por ele responder e, por fim, fixa as penas e medidas de segurança a serem aplicadas". (Toledo, 1991: 1. Destaques meus). ${ }^{25}$

Para fins de uma história da formação do direito penal contemporâneo (que é uma prática social que institucionaliza um campo do saber jurídico), é importante determinar quando as coisas passaram a representar-se dessa maneira. Por isso, esta segunda característica da legalidade não pode ser desprezada e nem obscurecida pela primeira, e é uma tarefa analítica importante separar uma coisa da outra.

Prosseguindo na tipificação do direito penal contemporâneo, é possível dizer que todos os penalistas do tempo presente têm um sentido compartilhado também em relação ao que seja a pena criminal. Certamente vem de tempos muito remotos a ideia de que a pena criminal é uma coisa essencialmente ruim e que deve representar uma privação para quem a recebe. Do ponto de vista do direito penal contemporâneo, entretanto, há um dado teórico distintivo em relação à pena com que ele trabalha. Ao contrário do que houve na filosofia moral a partir do século XVII, quando as correntes utilitaristas e retributivistas começaram uma disputa teórica quanto aos fundamentos da punição (que ainda hoje não acabou), no direito penal contemporâneo essas duas correntes tiveram, após um primeiro momento de embates, uma convivência posterior relativamente pacífica, e acabaram por juntar-se relativamente bem nas diferentes teorias da pena que hoje ele compreende.

Em diversos penalistas e códigos a partir do século XIX, é muito comum encontrarmos teorias "mistas" ou "conciliatórias" da pena criminal, que refletem a noção de que a punição penal fundamenta-se a um só tempo em prevenção e retribuição. Fazendo vistas grossas a todas as polêmicas filosóficas subjacentes, os professadores das teorias mistas acolhem, na lição de Basileu Garcia, "a teoria da justiça absoluta", por aceitarem "a função retributiva da pena", mas admitem, "por outro lado,

${ }^{25}$ Em seguida, Toledo acrescenta que, em outro sentido da expressão, "direito penal" entende-se como ciência penal; mas, mantendo a dependência da legalidade constitutiva para a definição do objeto teórico da disciplina, aponta que esta ciência constitui-se em um conjunto de conhecimentos e princípios que torna possível "a elucidação do conteúdo das normas penais e dos institutos em que se agrupam" (cit.: 2). 
que a pena tenha funções utilitárias" de prevenção criminal (1956, T. I: 75). A lista dos adeptos desse sincretismo é grande, e inclui autores de respeito: Garcia menciona Rossi, Garraud, Guizot, Broglie, Jouffroy, Cousin e Carmigniani. Mais contemporaneamente, Maurach costuma ser apontado como defensor da teoria mista. Para que se tenha uma ideia do peso dessa posição no direito penal do século XX, o Tribunal Constitucional Nacional da Alemanha (Bundesverfassungsgerricht) ao menos em duas ocasiões diferentes explicitou aceitar que a sanção penal objetiva a "prevenção e ressocialização do sujeito", mas também a "expiação e retribuição do injusto cometido" (Roxin, 2006: 91). Por isso, pode-se dizer que a especificação do conteúdo substantivo do direito penal contemporâneo tem nesta matéria um indicativo importante dos seus porquês.

Uma última característica relevante do direito penal contemporâneo está em sua particular forma de organização teórica, que faz com que a disciplina do direito penal seja representada com um conjunto de regras articuladas em duas partes, por nós chamadas de parte geral e parte especial. Também isso que parece a forma natural de representação da disciplina não é a sua aparência necessária, mas sim a marca de uma determinada orientação metodológica com a qual convivemos desde a modernidade tardia. A legislação penal do Antigo Regime era, recordemo-nos, organizada por outra lógica: a lei buscava cobrir seu campo de incidência por uma técnica preferencialmente casuística, de enumeração tópica, elencando com riqueza descritiva suas hipóteses de cabimento, de modo a gerar um rol extenso que se revelou, com o tempo, difícil de operar. É nesse sentido a opinião de Sbriccoli (1974: 29), para quem a legislação penal pré-iluminista era frequentemente ancorada em "situações contingentes, episódios particulares e problemas específicos". ${ }^{26}$ Esse percurso casuístico seguia, ademais, a lógica temporal do processo (ordo legalia), ao invés de principiar pelas definições elementares de delitos e penas.

Tal técnica legislativa, que inicialmente serviu bem aos propósitos de centralização do poder político nas mãos dos reis, passou a ser vista como um problema quando a concentração de poder dela resultante tornou-se indesejável por certos grupos

\footnotetext{
26 "Altra caratteristica "interna" della legislazione penale in materia politica è constituita dal sua frequente ancoraggio a situayioni contingenti, ad episodi particolari o a problemi specifici".
} 
sociais. Emprestando um modelo de racionalidade já existente séculos antes, os juristas da era das codificações combateram-na advogando o uso da boa razão, que tornaria possível a cobertura de todo o campo jurisdicional com princípios jurídicos fundamentais determinantes da decisão em cada caso concreto, mesmo na falta de dispositivos legais pontuais. Assim, por exemplo, no discurso preliminar de apresentação da primeira versão do Código Civil napoleônico (um marco histórico da nova forma de legislar que se tornaria hegemônica a partir de então), Portalis e seus companheiros diriam que

A função das leis é estabelecer, em termos gerais, as máximas gerais da lei, é estabelecer princípios ricos em consequências, ao invés de se ocupar com os particulares das questões que podem emergir em cada assunto (1801: 6). ${ }^{27}$

Mais do que uma técnica legislativa, essa orientação expressava um modelo epistemológico fundado em uma racionalidade idealista e abstrata, que marcou toda a produção intelectual nas ciências humanas daquele tempo, e não só a legislação. Tanto assim que, mesmo enquanto ainda vigia em diversos lugares a Constitutio Criminalis Carolina de Carlos V (1532), muitos dos criminalistas do século XVIII reorganizavam os dispositivos nela contidos de forma a produzir doutrinas criminais já com alguma aparência de maior organização (aos nossos olhos contemporâneos), mesmo antes de os códigos vigerem em seus reinos. ${ }^{28}$ Mesmo no século XVII, traços evidentes dessa orientação metodológica já são visíveis: Pufendorf (1682), por exemplo, estruturava sua teoria do direito como um conjunto de desdobramentos lógicos de um princípio primeiro de sociabilidade humana; e sua doutrina da sociabilidade pode ser chamada, grosso modo, de uma parte geral de sua teoria do direito. Essa metodologia, que se sofisticou ao longo de dois séculos, seria imprimida ao conteúdo material básico

27 "The function of the statute is to set down, in broad terms, the general maxims of the law, to establish principles rich in consequences, and not to deal with the particulars of the questions that may arise on every subject".

${ }^{28}$ No caso específico dos estados alemães, costuma-se apontar a Landrecht prussiana de 1794 como um marco da produção legislativa de matriz moderna. Em matéria penal, a mais conhecida foi o código bávaro de 1813. Antes dele, o Codex Juris Bavarici Criminalis (1751), de Maximilian Joseph, já havia organizado a legislação criminal então vigente, mas preservando ainda vários traços pré-contemporâneos (cf. Cap. III, seguinte). 
de que falei até aqui (crimes, legalidade, penas etc.) e resultaria em um objeto teórico com a "cara de código" com que hoje estamos acostumados.

No caso do direito penal contemporâneo, porém, há um dado adicional muito relevante: não só ele se divide em uma parte geral e uma parte especial, como também a sua parte geral tem um conteúdo específico que já conhecemos bem: uma teoria do delito, onde a já citada legalidade penal joga um papel fundamental; e uma teoria da pena, cuja porta de entrada é a disputa entre as ditas teorias absolutas e relativas, e (muitas vezes) sua contemporização em uma das muitas "teorias mistas" de que há pouco se falou. Tais definições gerais nem sempre existiam no início da modernidade, dada a proliferação do "criminal" por todo o ordenamento jurídico, e, quando existiam, não representavam os pilares de uma disciplina jurídica específica, em razão do já mencionado perfil horizontalizante do "direito penal" anterior. ${ }^{29}$

Estes são os traços fundamentais do direito penal contemporâneo, portanto: (i) sua existência como um objeto teórico autônomo, distinto inclusive do direito processual penal; (ii) sua pertença ao direito público interno; e (iii) sua divisão em uma parte geral, composta de uma teoria do delito fortemente escorada na legalidade, e uma teoria da pena que contemporiza entre as disputas retributivistas e utilitaristas. Quem explicar como esses elementos tornaram-se a espinha dorsal do

\footnotetext{
${ }^{29}$ Neste ponto, estou em desacordo com Tomás y Valiente. Para ele, já seria possível localizar, nos primeiros juristas modernos, uma teoria do delito e uma teoria da pena. (1992: 87) Para isso, seria necessário colher nos diversos ilícitos espalhados pelo ordenamento, que eram chamados pelos juristas de "delitos" ou "crimes", os seus elementos constitutivos. Assim procedeu Tomás y Valiente para "encontrar" a teoria do delito de então. Sua ideia foi dar conteúdo a uma distinção que está em Durkheim, entre leis que meramente obrigam à reparação da situação anterior, e leis que aplicam penas por sua violação (cit.: 210). Ora, diz o historiador espanhol, se tal distinção é uma marca de todos os ordenamentos jurídicos, mesmo os mais primitivos, então deve ser possível encontrar uma teoria do delito tardo-medieval e do início da modernidade. Por esse caminho, ele postula que a teoria do delito do século XV teoria os seguintes elementos: o religioso ou moral (pecado), o social (dano comum) e o pessoal (ofensa) (cit.: 243). O problema dessa postulação é que, mesmo sendo uma tal teoria do delito formulada a partir dos juristas pré-contemporâneos, essa definição geral não estava neles: como já foi dito, havia juristas castelhanos do fins do século XVIII e início do XIX que não tinham qualquer preocupação em fornecer uma definição sintética do delito criminal. Ter isso em mente ajuda a evitar anacronismos: quando os já mencionados Alvares Posadilla e Vilanova y Mañés, às vésperas do século XIX, deram definições que não se preocupavam em distinguir o ilícito civil do penal, Tomás y Valente as trata como "incompletas e toscas" (1992: 208); sem perceber que, se essa distinção é para nós o mínimo existencial de uma teoria penal, ela podia ser bem menos relevante no direito penal pré-contemporâneo, já que para os autores de uma cultura jurídica em que o "direito penal" era um direito de acompanhamento, marcar a especificidade da disciplina - que é sobretudo o que se consegue por meio de uma teoria geral do delito e da pena criminais - simplesmente não era uma preocupação premente.
} 
nosso direito penal terá explicado o surgimento do direito penal como hoje o conhecemos.

\section{Direito Penal Contemporâneo e Racionalidade Penal Moderna}

A ideia do direito penal contemporâneo com que trabalho nesta tese é diretamente inspirada pela "racionalidade penal moderna" de Álvaro Pires. A racionalidade penal moderna é apresentada por ele principalmente nos capítulos que escreveu para a Histoire des Savoirs sur le crime \& la peine (1998). Por ela, Pires pretende explicar o surgimento da racionalidade com que se criou um sistema de pensamento fechado, distinto das demais áreas do direito, que nos aprisiona em uma "garrafa de moscas"30 em matéria punitiva. Do ponto de vista do saber, diz Pires (1998a), a racionalidade penal moderna foi desenvolvida a partir das três grandes teorias da pena criminal, formuladas nos séculos XVIII e XIX: a teoria utilitarista da dissuasão, a teoria retributivista expiatória e as teorias ressocializadoras e neutralizadoras de matriz positivista.

Dessa teoria da racionalidade penal moderna, duas coisas são fundamentais. A primeira delas é a verificação de que o processo de construção das nossas formas presentes de lidar oficialmente com a punição é produto de um certo desenvolvimento de saberes teóricos que impactam o fundamento substantivo daquilo que é o nosso atual direito penal. Nesse sentido, a teoria de Pires está em acordo com a tese de Foucault (1987) sobre a construção do saber que fundamenta a sociedade disciplinar, como também estão os fundamentos desta pesquisa. A bem da verdade, é corrente em trabalhos de história do direito penal hoje já clássicos (Sbriccoli, 2004 e

\footnotetext{
${ }^{30}$ Trata-se de uma expressão emprestada de Paul Watzlawick. As garrafas de mosca foram utilizadas em experimentos de psicologia cognitiva que investigavam reações animais instintivas do ponto de vista do conhecimento de certas circunstâncias. Eram grandes garrafas com um grande funil em seu gargalo. Quando vista pelo lado de fora, a larga abertura convidava as moscas a entrarem; mas, uma vez dentro, elas não sentiam segurança para sair pelo gargalo que, internamente, lhes parercia estreito e perigoso, e acabam por morrer dentro do vidro, mesmo que a saída permanecesse tão desimpedida quanto estava quando entraram (Pires, 1998a: 7 e ss.). A racionalidade penal moderna é para Pires uma garrafa de moscas, de que nós temos "medo" de sair, e que nos impede de pensar novas formas institucionais de lidar com a violência social.
} 
1974; Cartuyvels, 1996) a percepção da especificação do "penal" e seu relativo descolamento em relação às demais áreas do direito.

A segunda é a percepção de que as teorias da pena que hoje tratamos como adversárias alimentam-se reciprocamente e fundamentam a construção da racionalidade penal moderna como um sub-sistema de pensamento. Se é verdade que trabalhos recentes de filosofia moral têm revisto a ideia da separação absoluta entre teorias da punição utilitaristas e retributivistas, afirmando pontos de contato entre as duas (Hare, 1997: 147 e ss.; Byrd, 1989), é também verdade que o trabalho de Pires foi pioneiro em aplicar essa revisão aos fundamentos da racionalidade da punição. Como um dos itens do tipo de direito penal contemporâneo envolve justamente a incorporação, por parte dos penalistas, do sincretismo das teorias mistas da pena, é evidente o paralelo aqui entre os caminhos teóricos desta pesquisa e aqueles tomados por Pires.

Entretanto, há algumas diferenças entre o direito penal contemporâneo e a racionalidade penal moderna que são importantes de se explicitar. Afinal, o fato de ambas as coisas serem (a meu ver) inteiramente compatíveis não significa que, metodologicamente, sejam idênticas, e nem que levem a resultados que se sobrepõem por completo.

A primeira diferença diz respeito ao objeto de cada uma: enquanto Pires ocupa-se sobretudo das teorias dos grandes filósofos que cuidaram do tema da punição a partir do século XVIII, esta tese se ocupa, em sua maior parte, dos juristas e da forma de construção de um objeto teórico-jurídico que hoje chamamos "direito penal", e que tem as características que acabam de ser expostas. Ainda que haja estreitas ligações entre filosofias da pena e teorias do direito penal, as duas coisas não se equivalem; pois, se é verdade que as teorias da punição pertencem por excelência à filosofia moral, e que o raciocínio jurídico é uma forma de raciocínio prático, é verdade que ele tem sido considerado uma subespécie altamente institucionalizada dessa espécie de raciocínio (MacCormick, 1978: 272). Isso traz ao jurista alguns ônus teóricos que, se ignorados, podem comprometer a explicação histórica do pensamento jurídico propriamente dito. Já para um trabalho filosófico, ao contrário, tais requisitos 
institucionais são em princípio suprimíveis, ainda que não haja problema algum em levá-los em consideração. Por outro lado, como Kant bem percebia e fez consignar em diversas passagens de sua obra, os filósofos são, por seu método, principalmente ocupados em resolver problemas teóricos muitas vezes suscitados por suas próprias teorias, ao passo em que os juristas em geral não perdem do horizonte a dimensão prática necessariamente ligada à sua disciplina. Assim, enquanto Beccaria e Kant debatiam qual pena deve-se considerar mais justa por critérios puramente racionais, nossos juristas do Império, que conheciam a ambos, tinham ademais de postular qual seria a melhor forma de julgar uma comutação de penas de presos que cumpriam pena de galés sem ter sido condenados a tanto, dada a inexistência em número suficiente de estabelecimentos penais adequados. ${ }^{31}$ Para falar nos termos dos silogismos que geralmente dão a forma dos juízos prático-jurídicos, os juristas preocupam-se não só com a construção da premissa maior, mas principalmente com a predicação da menor a postulação da resposta jurídica a um caso concreto, que sempre levará em conta os aspectos práticos do problema.

Isso implica, e aqui já adianto a segunda diferença, que a reconstrução histórica da criação do direito penal contemporâneo só pode feita do ponto de vista interno (Hart, 1994: passim; MacCormick, 1978: 275 e ss.), por vezes também chamado de hermenêutico (MacCormick, 1986), ao contrário da reconstrução da racionalidade penal moderna, que pode bem ser feita a partir de um ponto de vista externo à dogmática penal. $\mathrm{O}$ fato de Pires representar a racionalidade penal moderna como um sub-sistema de pensamento mostra bem, a propósito, como ele se utiliza mais de uma teoria social (que contempla o direito externamente) do que de uma teoria hermenêutica do direito, que o enxergue pelo lado de dentro. Daí resulta que a explicação histórica do direito penal contemporâneo, muito mais do que a racionalidade penal moderna, tenha de se atentar preferencialmente a como os juristas articularam e rearticularam o seu

\footnotetext{
${ }^{31}$ Esta matéria foi de fato apreciada pela Seção de Justiça do Conselho de Estado, em 23/12/1846, em que se debateu a inteligência do art. 49 do Código Criminal de 1830. A decisão do Conselho, contrariando o juiz consulente e o Procurador da Coroa, foi a de que os presos em questão não estavam de fato cumprindo pena de galés por não estarem empregados em trabalhos públicos (a despeito de terem de usar a calceta aos pés e a corrente de ferro). Votaram os conselheiros Carneiro Leão, Lopes Gama e Bernardo Pereira de Vasconcellos.
} 
campo de saber até chegar à representação de um objeto teórico que nós, também como juristas, reconhecemos como o nosso direito penal.

Os impactos dessas duas diferenças podem ser concretamente percebidos quando consideramos o tema da separação entre direito penal e processo penal. Enquanto para a racionalidade penal moderna é indiferente a separação entre as duas disciplinas, pois ambas estão, do ponto de vista externo, de acordo na realização de um mesmo tipo de intervenção jurídica sobre os fenômenos de violência social, para o direito penal contemporâneo, e do ponto de vista interno, é fundamental separar uma coisa da outra; pois, ainda que nós juristas não neguemos que o direito e o processo penal têm importantes pontos de contato para fins de realização prática dos objetivos da justiça criminal amplamente considerada, nós também reconhecemos, com a mesma naturalidade, que direito penal e processo penal são disciplinas inequivocamente distintas quando considerados os seus fundamentos estritamente jurídicos. Em uma periodização histórica, a diferença a que isso leva é brutal: basta dizer que, enquanto Beccaria é para Álvaro Pires um dos percursores da racionalidade penal moderna, ele é para mim um autor que ainda está de fora do direito penal contemporâneo, por seguir representando o direito penal e o processo penal conjuntamente em um mesmo ofício jurisdicional de prevenir crimes e efetivar a punição criminal. A distinção entre direito e processo só pode ser explicada, no que diz respeito aos argumentos jurídicos que lhe serviram de fundamento, a partir de um ponto de vista hermenêtico, coisa que a racionalidade penal moderna não pode dar.

Um segundo exemplo no mesmo sentido está na representação conjunta de retributivismo e utilitarismo nas teorias da pena criminal. Enquanto Pires (1998c) aponta preferencialmente os pontos em que as distintas teoria da pena criminal recomendam uma estratégia semelhante de práticas punitivas, está fora de seu objeto mostrar como os juristas articularam a criação de teorias mistas com bases filosóficas em princípio incompatíveis. Isso faz com que se obscureça a formulação histórica dos argumentos jurídicos contra os quais lutam, no tempo presente, as teorias que pretendem refundamentar a punição criminal (Roxin, 2006; Jakobs, 1998) em outras bases que não as das teorias mistas; e, mais ainda, faz com que se torne difícil avaliar o 
quanto essas novas teorias são realmente inovadoras, já que os argumentos especificamente jurídicos utilizados para resolver os impasses entre "sensualistas" e "idealistas", conforme as expressões da época, permanecem trancados no baú da história das ideias penais, persistindo em consequência a naturalidade conferida pelo passar dos anos às teorias da pena com que há muito tempo convivemos.

O ponto de vista interno não só permite descobrir coisas que se convém descobrir, mas também evitar coisas que se convém evitar. A mais importante delas é o anacronismo de avaliar negativamente as doutrinas penais do passado por não encontrar nelas aquilo que esperamos das do tempo presente. Este é, a meu ver, o problema da já mencionada ${ }^{32}$ avaliação negativa de Tomás y Valiente sobre os juristas pré-contemporâneos cujas doutrinas não continham uma teoria geral do delito especificamente criminal: se nos colocarmos no lugar desses juristas e enxergarmos que uma tal teoria não tinha grande relevo estrutural no pensamento jurídico daquele tempo, é possível dar-lhes outra avaliação que, do ponto de vista histórico, parece mais precisa.

Ao final, não espero que nenhuma das conclusões desta pesquisa seja incompatível com a racionalidade penal moderna. Porém, tampouco descarto que algumas de suas interpretações mais pontuais destoem das de Pires quando houver alguma eventual intersecção entre elas, justamente por ele não considerar internamente algumas doutrinas jurídicas que cita en passent. Mas, ao fim e ao cabo, é esperado que várias das conclusões desta investigação corroborem historicamente as suas referentes à "garrafa de moscas"33 da racionalidade penal moderna. Espera-se também, seja pela especificidade do seu objeto, seja principalmente pelas particularidades do seu método, que esta pesquisa consiga detectar alguns nexos de causalidade histórica no campo das ideias jurídico-penais que a sua explicação filosófica não é capaz de dar (porque não se propõe a isso, claro está).

\footnotetext{
${ }^{32} \mathrm{~V}$. nota de rodapé n. 30 , retro.

${ }^{33}$ Cfr. nota 13 , retro.
} 


\section{A estrutura do trabalho}

O trabalho dividir-se-à em duas grandes partes. A primeira cuidará da formação do direito penal contemporâneo enquanto objeto teórico; e a segunda, do momento e da forma de chegada e estabelecimento desse direito penal no pensamento jurídico brasileiro.

$\mathrm{Na}$ primeira parte, cuidar-se-á do "direito penal" entre os séculos XVIII e XIX. ${ }^{34}$ Isso será feito em dois capítulos distintos: primeiramente (Cap. II), mostrar-se-á como, desde ao menos meados do século XVII, a matéria-prima intelectual do direito penal contemporâneo foi substantiva e formalmente trabalhada pelos juristas em um sentido particular que, posteriormente, possibilitaria a construção do objeto teórico que hoje conhecemos por direito penal. No capítulo seguinte (Cap. III), mostrarse-á como essa matéria-prima intelectual foi reunida e forjada naquilo que conhecemos hoje como a dogmática penal; e, especificamente, como isso foi feito por um penalista da virada do século XVIII para o XIX, tido como ícone da formação de nossa dogmática penal: Paul Johann Anselm von Feuerbach. O foco em Feuerbach deve-se ao fato de muitos trabalhos de direito penal do presente indicarem-no como o precursor do direito penal tal qual hoje o conhecemos, o que evidencia sua importância enquanto fonte para um estudo histórico como este. ${ }^{35}$

A segunda parte do trabalho cuidará de como essa forma específica de direito penal chegou e se estabeleceu no direito brasileiro. A ideia é ver como os sentidos por trás da construção do direito penal contemporâneo na obra de Feuerbach mostram-se presentes, ou não, nas doutrinas brasileiras do século XIX. A hipótese com que se trabalha é que, se de um lado as realidades políticas e institucionais entre o Brasil e a Europa eram sabidamente diferentes, por outro lado é possível que elas tenham se acomodado em sentido semelhantes que fortaleceram a consolidação desse direito penal entre nós.

\footnotetext{
${ }^{34}$ Esta periodização é sugerida especialmente pelas conclusões de Pires (1998). Como a formação do direito penal contemporâneo dá-se na circunscrição do pensamento jurídico moderno, também a pesquisa de Lopes (2004) traz indícios nesse sentido. Sobre o caso luso-brasileiro, v. Neder (2000).

${ }^{35}$ Explicações metodológicas mais detalhadas são fornecidas na primeira parte do Cap. III.
} 
Esta segunda parte contará apenas com um capítulo, se bem que bastante extenso. O Capítulo IV investigará, nos juristas brasileiros e também em outros importantes juristas estrangeiros muito lidos por aqui, como os sentidos por trás das postulações teóricas que resultaram, em Feuerbach, em uma dogmática muito semelhante ao direito penal contemporâneo, vão se articulando na doutrina corrente por aqui, e em face das realidades institucionais e do ambiente intelectual do Brasil de então. 


\section{II. "CRIMES" E "PENAS" ÀS VÉSPERAS DO DIREITO PENAL CONTEMPORÂNEO}

\section{INTRODUÇão}

Se é sensato pensar que a formação do direito penal, como uma área particular do direito com as características que hoje conhecemos, pode ser estudada historicamente, então deve ser possível encontrar explicações contingenciais para o surgimento dessa nossa forma de encarar os problemas jurídicos ligados ao crime, ao criminoso e à punição. O objetivo deste capítulo é dar o primeiro passo no sentido de possibilitar algumas dessas explicações sob o ponto de vista histórico. Este primeiro passo consiste, resumidamente, em rememorar o material intelectual com que teve de trabalhar a geração de juristas que construiu o direito penal contemporâneo. Em palavras simples, e através de uma analogia vulgar: a geração de teóricos que criou o nosso direito penal teve de jogar com certas cartas que estavam à mesa, e que lá haviam sido postas por um leque variado de problemas jurídicos (conceituais, metodológicos, institucionais etc.) tanto de sua época quanto de épocas anteriores. Neste capítulo, pretende-se mostrar que cartas foram essas; e no capítulo seguinte, como P. J. A. Feuerbach, um jurista-ícone do momento de criação do nosso direito penal, fez seu jogo a partir delas.

Um dos sentidos em que é possível afirmar a historicidade da construção do direito penal é através da postulação de que a criação dos elementos 
constitutivos da nossa dogmática penal, como a conhecemos hoje, deu-se por meio de um processo de oferecimento de respostas teóricas a um conjunto de problemas que impactavam diretamente a compreensão jurídica do crime, do criminoso e da punição, além da própria conceituação do direito penal como objeto teórico autônomo. Se isso é verdade, rememorar esses problemas é um passo fundamental para os propósitos desta tese. O objetivo deste capítulo é, portanto, meramente descritivo: serão apenas indicados alguns importantes temas jurídico-políticos no debate intelectual que antecedeu a geração de Feuerbach, pois, penso, esses temas ajudam a entender muitos dos porquês do caminho específico que resultou no nosso direito penal. Não se arriscará qualquer interpretação mais agressiva dos autores aqui tratados não só porque interpretá-los às minúcias tiraria o foco do trabalho, mas também porque uma interpretação com tal profundidade é desnecessária diante do propósito do capítulo, que é simplesmente o de relembrar um conjunto limitado de problemas históricos do pensamento jurídico - e não o de buscar uma resposta filosófica para cada um deles.

Em termos metodológicos, é importante fazer constar que há uma grande diferença entre este capítulo e os dois outros que o seguirão: enquanto este segundo capítulo será majoritariamente retrospectivo, os dois seguintes serão prospectivos. Quero dizer com isso que o conteúdo deste capítulo é determinado por um olhar para trás a partir do presente: nós, hoje, sabemos quais são os temas da filosofia jurídica dos séculos XVII e XVIII que, uma vez criado o direito penal contemporâneo, foram situados dentro de seus domínios teóricos: a fundamentação do direito de punir ou a conceituação de "crimes" e "penas", por exemplo. Dessa forma, buscar no pensamento jurídico daquele tempo aquilo que, no século XIX, seria fundamental para a construção do nosso direito penal é algo que pode ser feito retrospectivamente: olhando para os pontos constitutivos do nosso direito penal do presente, e procurando-os no pensamento jurídico dos momentos imediatamente anteriores à sua criação. Nos dois capítulos seguintes (3 e 4), esta regra já não valerá: saber como o nosso direito penal contemporâneo se formou e estabeleceu-se no Brasil a partir do material intelectual que será rememorado neste segundo capítulo é algo que tem de ser feito prospectivamente, ou seja, tentando colocar-se no lugar dos juristas de 
então e enxergar qual era o novo direito penal que eles buscavam construir -mesmo que, olhando retrospectivamente a partir do tempo presente, este "novo" direito penal esteja para nós já velho e naturalizado. É por isso que foi dito, no primeiro capítulo, que a reconstrução histórica do direito penal contemporâneo, considerada como uma teoria jurídica normativa, só pode ser feita de um ponto de vista interno: é preciso colocar-se na posição de seus fundadores e entender o porquê de ele ter sido o escolhido, entre as diversas opções teoricamente concebíveis para o tratamento jurídico dos problemas que hoje temos por criminais.

Salvo um ou outro caso pontual, este capítulo tampouco contém explicações históricas para os pontos nele tratados. Seu objetivo é, repito, apenas fornecer o pano de fundo intelectual dentro do qual o processo de criação história do direito penal contemporâneo, descrito nos dois próximos capítulos, teve lugar.

O inventário de problemas deste capítulo retrospectivo será feito a partir das obras de alguns autores-chave das gerações imediatamente antecedentes a Feuerbach, entre os quais destaco Hobbes, Kant e Beccaria, entre outros que aparecerão com menos frequência, mas que nem por isso são em si menos importantes. A razão dessa escolha é simples: além da evidente importância histórica que têm os três não só para o direito penal, mas para o pensamento jurídico contemporâneo como um todo, eles são três dos autores com quem Feuerbach intensamente debateu os pontos de partida de sua teoria do direito, em geral, e de sua dogmática penal, em particular. Ou seja: neles estão, possivelmente, as amarras teóricas que o próprio Feuerbach julgou ter de desatar para construir a dogmática penal tal qual conhecemos hoje. Isso tudo sem dizer, é claro, que esses autores têm, ainda no presente, uma importância que vai muito além do singelo papel de pano de fundo histórico que ganharam nesta tese.

A Hobbes, Feuerbach dedicou um livro todo: Anti-Hobbes, ou dos limites da força superior e o direito de resistência do cidadão contra o soberano (1797). Mesmo sem ter sido propriamente um jurista, é certo que Hobbes ofereceu, do ponto de vista filosófico, notórios argumentos em um debate que é central a qualquer teorização jurídico-penal, qual seja, a definição dos direitos e deveres de cidadãos e do 
soberano, aí incluso o direito de punir. Ademais, falando agora do ponto de vista histórico, Hobbes tem sido tomado por certos penalistas contemporâneos como um autor-chave para a compreensão de como a modernidade penal lida com as dificuldades de justificativa da sanção penal em certas hipóteses. ${ }^{36}$

A Kant atribui-se a paternidade da retribuição como fundamento da pena fora dos domínios de uma doutrina jurídica confessional. ${ }^{37}$ Mais importante ainda é o fato de a filosofia moral de Kant ser ainda hoje tida como a depositária mais confiável de um ponto de partida muito caro ao nosso direito penal: o princípio de que as pessoas têm direitos que se sobrepõem às necessidades e conveniências da punição. Os postulados retributivos kantianos são vistos como um santuário de proteção contra as práticas e filosofias utilitaristas de tendência autoritária, diz Norrie (1991: 2). Por fim, é importante levar em conta o fato histórico de que Kant influenciou profundamente a geração dos penalistas do Iluminismo, especialmente Feuerbach (Cattaneo: 1970, 27 e ss.).

Quanto a Beccaria, sua relevância para o pensamento penal contemporâneo é tão evidente que pouco precisa falar-se a respeito. O Lehrbuch de Feuerbach, como grande parte dos livros de direito penal desde então, é recheado de referências ao Marquês, o que serve para indicar que seu "pequeno grande livro"38 teve não só o impacto político pretendido pelo autor, como também influenciou decisivamente a concepção da dogmática penal contemporânea. Como um utilitarista em matéria penal, a importância de Beccaria pode ser considerada tão grande quanto a

\footnotetext{
${ }^{36}$ Para uma visão geral sobre a filosofia penal de Hobbes e sua importância histórica, v. Norrie (1991: 1538). Para um trabalho especificamente dedicado aos aspectos filosóficos da punição em Hobbes, v. Kremkus (1999). Sobre a importância de Hobbes para a formação da criminologia clássica, v. Ruggiero (2006: 8-26).

${ }^{37}$ Autores importantes argumentam que a justificação retributiva da sanção penal é coisa que já estava posta a debate jurídico-filosófico muitos séculos antes dele, ao menos desde Santo Anselmo. Sobre a doutrina emendatória de Santo Anselmo, v. Berman (1983: 179 e ss.). Para uma comparação entre essa doutrina e a justificação kantiana da pena, v. Pires (1998: 159 e ss.).

${ }^{38}$ Dada a grande discussão que há sobre a fidedignidade das muitas edições de Dos Delitos e Das Penas, trabalhei com múltiplas edições da obra, todas indicadas na bibliografia (mesmo as não citadas no texto). Escolhi eleger como material de trabalho principal o fac-similar da primeira edição espanhola, por ser a mais antiga que consegui (1774), além da mais antiga edição italiana a que tive acesso (1834), que é comentada.
} 
de Bentham, também mencionado vez por outra neste capítulo, com a vantagem de sua produção intelectual ser quase toda focada nos assuntos de interesse desta tese. Esta importância está não só no presente, mas também em sua época: na Doutrina do Direito, Beccaria é o único autor nominalmente mencionado por Kant no momento de suas críticas às outras teorias filosóficas sobre a pena criminal (Kant, 1797: 185). Os debates parlamentares por ocasião da aprovação do Código Criminal de 1830, bem como os livros dos penalistas estrangeiros e brasileiros que eram correntes por aqui durante o século XIX, são também repletos de referências a ele. Isso tudo sem mencionar sua importância para a formação da sociedade disciplinar, conforme Vigiar e Punir (Foucault, 1987).

Além desse restrito conjunto de personagens, há também um pequeno conjunto de temas que é preciso definir; porque, evidentemente, não é meu objetivo apresentar as teorias de Hobbes, Kant e Beccaria e mais outros tantos autores em sua integralidade, não só por falta de leitura em todas as áreas que elas abrangem, mas principalmente porque seria despropositado e desnecessário fazê-lo aqui. Este capítulo ocupou-se apenas de um pequeno conjunto de temas que são úteis para se entender o material intelectual com que a geração de Feuerbach teve de trabalhar para construir o direito penal contemporâneo, problemas esses escolhidos com o olhar retrospectivo há pouco mencionado. Por esse ponto de vista, é possível apontar quatro temas-chave que merecem investigação. Em primeiro lugar, (i) o conceito de "direito penal", enquanto objeto teórico-jurídico, no pensamento jurídico-penal pré-contemporâneo, e sua própria existência autônoma (ou não) enquanto objeto teórico. Em segundo lugar, (ii) o conceito de "crime", e a determinação das questões de autoridade a ele relacionadas: quem pode estabelecer uma conduta como criminosa, e quais condutas podem sê-lo. Em terceiro lugar, (iii) que coisas valiam como pena e sobre quais doutrinas fundamentava-se o direito de punir. Por fim, (iv) quais eram as regras que presidiam a persecução dos culpados e a imposição das penas. Esses quatro problemas são portas de entrada para outros problemas, anteriores e mais amplos. A questão da competência para a definição dos delitos, por exemplo, tange amplamente a doutrina das relações entre direito e moral, e a (in)dependência do delito criminal em relação às condutas moralmente 
proscritas; esta questão, quando ligada aos problemas que hoje chamaríamos de processuais, mas que à época eram tratados em conjunto, traz também fortes elementos de filosofia política para o debate, pois gira em torno não só dos limites dos poderes políticos do soberano, como também das formas adequadas para o seu exercício. Já a doutrina do direito de punir pressupõe alguma teoria antropológica, o que a faz depender diretamente dos desenvolvimentos da filosofia moral de seu tempo, que, é sabido, estava dividida pelos debates entre retributivistas e utilitaristas. E assim por diante. Por essa razão, alguns desses temas filosóficos terão de ser brevemente comentados nas páginas seguintes.

A fim de acomodar organizadamente esses diferentes debates neste capítulo, ele será dividido em quatro grandes partes, cada uma subdividida da maneira que convier à exposição textual das matérias. Uma primeira seção (item II) conterá três debates que considero serem pontos de partida, tanto metodológicos quanto políticos: são realidades institucionais inegáveis para os juristas daquele tempo, e é importante saber o peso e a importância desses temas para que, nos dois capítulos seguintes, seja possível colocar-se adequadamente em um ponto de vista minimamente semelhante ao dos criadores do direito penal contemporâneo. $\mathrm{O}$ primeiro ponto diz respeito à redefinição da noção de "fazer justiça" na filosofia jurídica da modernidade, uma vez que essa ideia é um leitmotif do direito em geral, e particularmente do direito penal determinar a forma justa de reação em face do ilícito cometido. Um segundo tópico é a separação entre direito público e direito privado, uma criação da modernidade que, em fins do século XVIII e começo do XIX, já estava solidadamente estabelecida e representava, como de resto ainda hoje representa, a porta de entrada para a dogmática de qualquer ramo específico do direito (além, é claro, da colocação do "direito penal" nessa divisão). O terceiro ponto compreende os reflexos mais estritamente políticos das mudanças teóricas descritas nos primeiros dois: as reformas legislativas e o movimento de codificação, como processo de redistribuição de poder em face do decadente arranjo político absolutista. Após esses pontos de partida, seguirão mais três partes que cuidam de outros temas que podem ser considerados como o núcleo duro do direito penal substantivo: (i) a concepção de "crime"; (ii) a definição da "pena" e, por corolário, a 
investigação do estado da arte da doutrina jurídica sobre o direito de punir; e, por fim, (iii) as doutrinas sobre a "responsabilidade penal" e a representação teórica do "criminoso".

\section{Pontos de partida metodológicos e institucionais}

\section{FAZER JUSTIÇA}

Até a modernidade, as discussões sobre a justiça eram a espinha dorsal do direito. Dentro do tema da justiça, concentravam-se discussões que hoje em dia estão dispersas por variadas especialidades das ciências humanas (direito, política, economia, filosofia). A justiça abrangia a forma de atribuição dos bens individualmente apropriáveis, mas também dos bens coletivos ou universais, tudo em vista do bem comum. Na classificação tomista, aí estavam abrangidas as três formas de justiça: a universal (ou legal), que tinha por objeto o bem comum; e as particulares (comutativa e distributiva) (Lopes, 2004: 205-7). Não era possível responder a problemas jurídicos sem a noção de justiça; ou melhor, sem ela sequer seria possível entendê-los. "O eixo de todo o direito era a justiça, era o que tornava inteligível a pergunta (quaestio, problema) e a resposta (solutio, determinatio)" (Lopes, 2004: 212). Os juristas acabavam, por isso, metodologicamente muito próximos da filosofia.

As dificuldades das instituições medievais em lidar com os problemas políticos da modernidade levaram a propostas de reestruturação de todo aparelho institucional. Nos modernos, uma parte importante da velha justiça, a justiça legal, esvaziou-se: o problema dos fins da sociedade deixou de ser jurídico e transformou-se em político, de competência do soberano - aquele que não tinha de confrontar suas decisões com outras esferas de poder político, ao menos na teoria. A relação do direito para com as decisões políticas passou a definir-se em termos de obediência: "a justiça legal deixou de ser propriamente uma forma totalmente especial da justiça para 
transformar-se em uma relação de obediência: a justiça legal consistiria, para os modernos, em obedecer" (Lopes, 2004: 209).

Hobbes é um bom exemplo das mudanças havidas na ideia de "justiça". Em De Cive, ele retoma uma explicação de justiça dada nos Elements of Law, entre a (in)justiça de uma ação e a (in)justiça de um homem, para em seguida esclarecer a diferença entre justiça distributiva ("proporção geométrica") e comutativa ("proporção aritmética"). Ao lembrar a antiga afirmação de que a justiça teria um quê de igualdade, Hobbes dá dois exemplos a partir dos quais questiona a aplicação da velha ideia de justiça (1651b, III, VI): é verdade, diz ele, que há sentidos diferentes de igualdade, como quando comparo o peso de duas quantidades de prata, ou quando analiso a igualdade com que essa prata é dividida entre um grupo de cem homens; e que há formas geométricas (proporcionais, meritórias) ou aritméticas (nominais, absolutas) pelas quais essa prata pode ser distribuída. "Mas o que tem isso a ver com justiça?", pergunta em seguida; "Isso não é a explicação de justiça, mas sim de igualdade". É justo que eu venda meus bens por quanto quiserem pagar por eles, uns mais e outros menos; e é justo que eu distribua coisas desigualmente, desde que cumpra com aquilo que foi acordado entre mim e cada um dos beneficiários. $\mathrm{O}$ ponto em que a igualdade tem a ver com justiça, diz Hobbes, é muito específico:

Uma vez que somos todos iguais por natureza, um homem não deve arrogar para si mais direitos do que ele dá a outrem, a menos que ele tenha conseguido essa vantagem igualitariamente [fairly], através de um contrato. (1651b, III, VI). ${ }^{39}$

A justiça, portanto, tem a ver com o cumprimento do que foi pactuado. Fora daí, a justiça, no sentido próprio do termo, não existe. A injustiça consistiria, ao contrário, em não cumprir com suas promessas, o que vale não só em relação a outros súditos, mas também em relação ao soberano: se eu prometo cumprir as leis ao entrar na sociedade civil, então não faz sentido desobedecê-las. "Hobbes não nos

\footnotetext{
39 "Since we are all equall by nature, one should not arrogate more Right to himselfe, then he grants to another, unlesse he hath fairly gotten it by Contract".
} 
pede que fundemos o Estado mas simplesmente o reconheçamos (...) Reconhecendo-o, obedeceremos; a obediência define o homem justo" (Ribeiro, 2004: 211).

Ao fazer isso, Lopes diz que Hobbes apropriou-se da distinção entre comutação e distribuição e deu-lhe um novo papel. O terreno dos direitos seria, por excelência, o da justiça comutativa, que cuida de trocas ou acordos. Quando surge desacordo, recorre-se então a um árbitro, que não julga comutativamente, mas distributivamente. Portanto, quando há acordo prévio, justo é o cumprimento do acordo; quando não há acordo, justo é o respeito àquilo que o árbitro decidir, por um critério de equidade. Ou seja, "a equidade é equiparada à justiça do árbitro, não à dos contratantes" (Lopes, 2004: 224). A passagem respectiva do Leviathan é a seguinte:

No sentido próprio, Justiça comutativa é a justiça de um contratante; isto é, o cumprimento de um acordo, ao comprar, ao vender; ao contratar, ou ser contratado; emprestar, e tomar emprestado; trocar, permutar, e outros atos contratuais. E Justiça distributiva, a justiça de um árbitro; ou seja, o ato de definir o que é justo. (1651a, $\mathrm{XV}) .^{40}$

A figura do árbitro, portanto, é a de quem define o que é justo - ou seja, o árbitro é aquele que faz as regras: "a justiça do árbitro é a do legislador, que instaura ordem onde esta não existe ou deixou de existir. $\mathrm{O}$ árbitro parece, pois, estar acima das regras, exatamente como o soberano" (Lopes, 2004: 225). Daí resulta que fazer as leis é coisa diferente de aplicá-las: no primeiro caso, estamos no campo da política; no último, estamos no terreno do direito. Ainda que, por muito tempo, o fazer as leis e o julgá-las tenha se concentrado em uma só figura política - o rei absolutista, de concepção juscêntrica e fundada no direito (A. Wehling e M. J. Wehling, 2004: 27) -, é importante, do ponto de vista analítico, separar as duas coisas. No pensamento político hobbesiano, um dos mais influentes da modernidade, fazer justiça segundo as leis é simplesmente dar cumprimento aos pactos, e não criar leis novas.

\footnotetext{
40 "To speak properly, Commutative Justice, is the Justice of a Contractor; that is, a Performance of Covenant, in Buying, and Selling; Hiring, and Letting to Hire; Lending, and Borrowing; Exchanging, Bartering, and other acts of Contract. And Distributive Justice, the Justice of an Arbitrator; that is to say, the act of defining what is Just".
} 
No âmbito das doutrinas referentes à atividade punitiva estatal, essa mudança teórica faz-se sentir ao menos por três caminhos distintos, se bem que estreitamente relacionados entre si. Em primeiro lugar, segundo Sbriccoli (2004: 171), a lógica da reação estatal ao ilícito torna-se crescentemente autoritária, no sentido neutro e puramente descritivo do termo: o "crime" é cada vez mais visto não como uma ofensa à vítima, mas como uma ofensa ao império soberano da lei que tem no rei o seu representante; e, por isso, a racionalidade punitiva abandona progressivamente uma orientação distributiva e mais voltada à composição, em favor de uma orientação retributiva e mais preocupada com a "devolução" da violação ao pacto expresso pela legislação, bem como de reafirmação da autoridade da lei. Não é por outra razão que no direito penal moderno e contemporâneo, não só a medida da gravidade do delito tornouse um problema central (porque isso ajuda a medir a intensidade da reação punitiva), mas também essa medição dá-se frequentemente por alguma escala que envolve preferencialmente a retórica do dano ao corpo social, por oposição à lógica do dano à vítima, antes mais relevante. Note-se bem a importância deste ponto, pois ele dá uma nova orientação que servirá de regra-base para as regras de responsabilidade (imputação e culpabilidade) do direito penal contemporâneo: a medida da pena é a gravidade do delito, que é dosada com alguma independência em relação ao dano concreto sofrido pela vítima. Ou, dito em outras palavras: a verdadeira vítima do crime é a sociedade, o corpo social; a vítima concreta, que sofreu a ação delitiva, vai pouco a pouco sendo relegada ao papel de mero objeto da ação criminosa. Nesse aspecto, os mundos moderno e contemporâneo parecem registrar um profundo continuísmo: tornou-se muito difundida na modernidade a ideia de que o "delito" violava o pacto social expresso nas leis e materializado no Estado e que por esse critério é que se deveria determinar a forma de sua punição, algo que parece ter sido aproveitado na contemporaneidade. Gaetano Filangieri, um dos autores que estava na ante-sala do direito penal contemporâneo e que muito influenciou Feuerbach na sua doutrina da responsabilidade, dizia que "o delito não é nada mais que a violação de um pacto", e que "na medida em que o pacto violado é mais precioso para a sociedade, maior deve ser a pena" (1827, T. III: 139). ${ }^{41}$ Ao fazer isso, Filangieri estava dando um passo decisivo para ligar um então

41 "Il delitto, como si è altrove detto, non è altro che la violazione d'un patto. A misura que il patto che si viola è più prezioso alla società, la pena dev'essere maggiore, si perche la società ha un maggior motivo 
nascente direito criminal ao objetivo de "conservação da ordem social" (Seelman, 2001: $6)$.

Passemos agora a Kant, expoente máximo de uma tradição filosófica que se canonizou como adversária de Hobbes. Kant preserva a justiça distributiva como problema de justiça propriamente dita, não restringindo esta última ao universo dos pactos. Mas, assim como Hobbes, ele reforça a imagem da justiça distributiva como a justiça de quem faz as regras. Segundo ele, a justiça pública, como princípio formal de uma legislação racional, divide-se em três: (i) justiça protetora, que julga somente qual é a conduta intrinsecamente justa quanto à forma; (ii) justiça comutativa, que declara as matérias que são suscetíveis de um lei jurídica (ou seja, aquilo que se pode juridicamente possuir); e (iii) a justiça distributiva, que declara o que e sobre quê, a sentença de um tribunal está de acordo com a lei. Esta última é, portanto, a justiça que diz respeito ao arbitramento de conflitos, e por isso é considerada por Kant a questão mais importante entre todas as que se referem à administração da justiça (1797: 41). Tanto assim que, para ele, o critério verdadeiramente distintivo entre um estado civil e um estado natural não é a oposição entre paz ou guerra, e nem a existência ou não de sociedades, pois tudo isso pode acontecer em qualquer um dos dois estados; é, isto sim, a existência de uma justiça distributiva, ou seja, de um aparato institucional para a resolução regrada de conflitos. Só um Estado dotado de justiça distributiva pode ser chamado de um Estado de direito público.

O Estado de Natureza pode não ser necessariamente violento, mas será necessariamente repleto de controvérsias quanto aos direitos de cada um de seus membros (Kant, 1797: 44). Nessa situação, qualquer direito que se tenha é provisório, pois falta uma autoridade para arbitrar conflitos sobre o "meu e teu" e garantir o cumprimento e o respeito às decisões por ela tomadas. Isso marca uma diferença importante nas filosofias políticas de Kant e Hobbes: enquanto para Hobbes a entrada na sociedade civil dava-se sobretudo por razões de preservação, na filosofia kantiana ela se operava por razões privadas, ligadas à garantia da propriedade, por assim dizer. ${ }^{42}$ Mas verificava-se também em Kant a distinção entre a competência de criar regras (para a 
solução distributiva de conflitos) e aplicá-las aos conflitos individualmente considerados. O poder criador de regas, ou poder legislativo, era o poder soberano, em relação ao qual não se poderia conceitualmente conceber um poder superior; o aplicador das regras seria o poder judicial. ${ }^{43}$ Em suas palavras:

Cada Estado encerra em si três poderes, isto é, a vontade universalmente conjunta numa pessoa tripla (trias politica): o poder soberano, na pessoa de legislador, o poder executivo (segundo a lei) na pessoa do governo e o poder judicial (como reconhecimento do Meu de cada qual segundo a lei) na pessoa do juiz (potestas legislatoria, rectoria et judiciaria). (Kant, 1979: 158). ${ }^{44}$

Convém lembrar que Kant é, na filosofia política, um pensador classicamente associado à inoponibilidade do poder soberano ("legislativo"). Em apreciação a seus escritos sobre a Revolução Francesa, Ricardo Terra (2003) qualifica-o como um autor com grande apego ao respeito pelo direito positivo, inimigo da revolução e defensor incondicional de reformas apenas por vias institucionais. Ou seja, também no filósofo de Königsberg se vê a noção de que a autoridade das leis é incontrastável, que a violação das leis públicas é intolerável, e que sua aplicação concreta pela via judicial é um exercício sobretudo de obediência ao exercício político de sua concepção em abstrato pela via legislativa.

Tem-se, portanto, que era difundida a visão de que o papel do soberano seria o de trazer a paz aonde os homens viviam em conflito (Hobbes), ou

\footnotetext{
${ }^{42}$ Nesse sentido manifesta-se Ricardo Terra: "A necessidade de sair do estado de natureza não está fundada na busca da autoconservação, não provém da observação empírica dos conflitos entre os homens, mas é uma exigência racional a priori. Essa exigência vincula-se ao postulado jurídico prático que afirma a possibilidade de ter algo como seu". (Terra, 2004: 37).

${ }^{43}$ Para o imaginário jurídico do direito criminal, a importância da separação de poderes é principalmente sentida na oposição entre processos acusatórios e inquisitórios: com a ideia de que o julgamento é uma tarefa estrita, e não deve se misturar às outras, as tarefas de investigação e julgamento, antes reunidas em uma só autoridade nos procedimentos de natureza inquisitorial, acabam por se separar entre juízes e polícia. Os resquícios dessas propostas de separação são especialmente perceptíveis nos debates sobre organização da polícia na França pós-revolucionária (Marra, 2001: 354; Napoli, 2001: 163).

44 "Ein jeder Staat enthält drei Gewalten in sich, d. i. den allgemein vereinigten Willen in dreifacher Person (trias politica): die Herrschergewalt (Souveranität) in der des Gesetzgebers, die vollziehende Gewalt in der des Regierers (zu Folgen dem Gesetz) und die rechtsprechende Gewalt (als Zuerkennung des Seinen eines Jeden nach dem Gesetz) in der Person des Richters (potestas legislatioria, rectoria, et judiciaria)".
} 
eliminar a controvérsia onde sem ele a discórdia imperaria (Kant) por meio do arbitramento distributivo dos conflitos sociais. Isso era feito através da legislação, à qual os súditos prometeriam obediência em troca de paz (Hobbes), ou deviam obedecer como um mandamento da razão pura (Kant).

Pois bem, nesse ofício político do soberano, o uso da força pública entre outras coisas, por meio da punição dos delitos (violações às leis públicas) - tinha um papel importantíssimo. Não só era corrente o pensamento de que a soberania estatal era responsável pela pacificação que só através dela podia-se obter, mas também o direito amplamente considerado, como suas prerrogativas de uso da força, era visto como uma ferramenta sine qua non para dar conta dessa missão. A despeito da diferença que há entre os autores aqui citados, uns mais individualistas e liberais do que outros, um traço perene pode ser notado nos discursos de todos, como registrou Seelman em atenção a outros pensadores da mesma época: "da orientação à razão de Estado à orientação da felicidade da soma dos cidadãos, para o qual o Estado é apenas um meio", a pena visa à "saúde" e "segurança", ou coisas semelhantes: "'tranquilitas' (Böhmer), 'tranquillité et sûreté' (Jaucourt), 'tranquilitas et securitas' (Kemmrich)" (Seelman, 2001: 12). Fazer justiça em matéria penal era, portanto, fazer valer a lei, punir as sua violações, e consequentemente preservar a paz e tranquilidade sociais. A importância desses pontos é absolutamente capital: é fundamental guardar em mente que, nas doutrinas dos modernos e pré-contemporâneos, o direito é instrumento para a preservação da paz social (em sentido amplo: seja evitando a guerra, seja eliminando controvérsias menores) a serviço da administração pública, e em benefício de todo corpo social. Esse papel é representado, a esta altura, como munus de um ramo do direito que se começaria a chamar de "direito público", e é nesse âmbito que os problemas "criminais" passariam a ser preferencialmente tratados. 
2. Direito PÚBlico VERSUS DIREITO PRIVAdO E A POSIÇÃo DO "DIREITO PENAL"

Com a lei positiva (lex) ganhando destaque entre as fontes do direito $(\text { ius })^{45}$ e o crescente volume das fontes locais, os direitos de fundamento não-positivo perderam espaço e, paralelamente, deu-se um processo de afirmação de um campo particular do saber jurídico chamado "direito público". Nele, os autores procuravam "separar com mais clareza um campo particular de investigação, que progressivamente se concentrava nas estruturas do Estado e nas leis fundamentais, como a das sucessões monárquicas" (Lopes 2004: 203). Além dessas mudanças institucionais, havia a visão de que as leis públicas serviam a um propósito diferente das leis privadas: elas visavam a manter ordem e eliminar os conflitos (garantido a sobrevivência dos súditos ou preservando o "meu e teu" para todos), enquanto as privadas, a reger relações exclusivamente particulares. A modernidade assiste, por isso tudo, ao nascimento de uma distinção fundamental no pensamento jurídico que até hoje nos acompanha: direito público versus direito privado. Mais de um século antes da geração de Feuerbach, essa oposição já era usada como fundamento metodológico de importantes obras jurídicas, como as Loix civiles dans leur ordre naturel (de 1694), de Jean Domat.

Como já foi comentado no capítulo anterior, a distinção entre "público" e "privado" já existia na tradição do direito romano, mas era presidida por uma lógica totalmente distinta: público era aquilo que se ligasse diretamente ao Estado e seu corpo de funcionários, enquanto privado era aquilo que se relacionava a particulares. Os elementos modernos do "interesse público" e "interesse privado" não estavam na base da distinção. É por isso que diversos "crimes" que na tradição romana eram privados (roubo e furto) passariam a ser considerados públicos na tradição moderna e contemporânea (Hespanha, 1990a: 180; 1990b: 410 e 426). No âmbito do direito público moderno, tratavam-se os problemas relacionados não só às leis que estabeleciam ilícitos e cominavam-lhes sanções, mas também à organização do aparato de justiça como um todo (Cartuyvels, 1996: 19 e ss.). Ou seja, tudo aquilo que dizia respeito, direta ou indiretamente, ao interesse público e às condições para a sua

\footnotetext{
${ }^{45}$ Sobre a importância da lex em perante os iura, v Tuck: 1979: 8 e ss.; Hespanha, 1987: 130 e ss.; Lopes, 2004: 71 e ss..
} 
preservação. Por isso, as doutrinas de direito público frequentemente principiavam pela postulação da finalidade do Estado e das condições para o legítimo exercício de suas estruturas de poder. Por esse caminho, desembocava-se no já comentado tema da paz pública, que por razões evidentes colocava o direito ombro a ombro com a filosofia política. Tudo isso aparece na lição de Mello Freire sobre as diferenças entre direito "público" e "particular":

Sendo todo o direito, usado por qualquer nação, público ou particular, facilmente todos entendem que é igual a distinção no Direito Civil Português. (...) O direito público respeita à sociedade em geral, e determina os direitos dos imperantes e dos cidadãos. O supremo direito, no qual naturalmente se contêm todos os mais, pertence ao Imperante, e por ele deve proteger a Nação e realizar todos os atos, sem os quais não se podem obter convenientemente a segurança interna e externa dos cidadãos e a salvação do povo, que é a suprema lei. [Em nota:] O fim da sociedade é a segurança dos cidadãos, por isso o príncipe que detém o supremo poder (expressão pela qual entendemos o direito de dirigir a seu arbítrio as acções dos súbditos), deve, na medida das suas forças, libertar a Nação dos inimigos internos e externos, e para este fim realizar todos os atos que reputar necessários, sem que possa algum dia ser obrigado a prestar contas de seus atos" (Instituições de Direito Civil Português, 1779: I, I-II e nota. Destaques meus).

Por essa passagem, três coisas são possíveis de se anotar: (i) a distinção direito público versus direito privado já era àquela altura (fins do século XVIII) a porta de entrada para os estudos das "leis civis", ou seja, leis positivas de um Estado; (ii) a imagem do soberano como exclusivo responsável para a consecução dos fins mais "nobres e excelentes" da sociedade já estava também estabelecida; e (iii) entre todos esses fins, o mais destacado era a manutenção da paz pública. Mas, note-se bem, esse era um papel que cabia a todo o direito público. É isso que se vê majoritariamente nas obras dos modernos e pré-contemporâneos: as normas de direito público tinham a função de reduzir os conflitos, seja entre indivíduos (direito público interno), seja entre estados (direito público externo).

O direito público tinha, como se pode ver, uma importante relação com o tema da paz social, que teve grande importância na filosofia política e jurídica da 
Europa dos séculos XVII e XVIII. A busca da paz era, em Hobbes, o comando fundamental da natureza para o homem. ${ }^{46}$ Consequentemente, o soberano, constituído pela renúncia de todos os súditos a seus direitos como forma de obter a paz, ${ }^{47}$ teria como principal atribuição garantir as condições de sobrevivência de todos os membros de um mesmo Estado: ${ }^{48}$

O fim de uma República - Segurança particular -, a causa final, fim, ou desígnio dos homens (que naturalmente amam liberdade e domínio sobre os homens) na introdução dessa restrição sobre eles mesmos (em que os vemos vivendo em Repúblicas) é a antevisão da própria preservação, e por conseguinte de uma vida mais contente; isto é, de sair daquela miserável condição de guerra, que é necessariamente consequente das paixões naturais dos homens, quando não há poder visível que os mantenha em um estado sublime, e os amarre pelo medo da punição ao cumprimento de seus pactos, e observação dessas leis da natureza apresentadas nos capítulos XIV e XV. (1651a, XVII). ${ }^{49}$

Pode-se representar isso como resultado das profundas impressões deixadas pelos conflitos do século XVII europeu no espírito de Hobbes e outros pensadores daquele tempo. Apenas para uma situação temporal dos fatos, O Leviathan foi publicado pela primeira vez em 1651, portanto três anos após o fim da Guerra dos Trinta Anos e dois

\footnotetext{
46 "It is a precept, or generall rule of Reason, "That every man, ought to endeavour Peace, as farre as he has hope of obtaining it; and when he cannot obtain it, that he may seek, and use, all helps, and advantages of Warre." The first branch, of which Rule, containeth the first, and Fundamentall Law of Nature; which is, "To seek Peace, and follow it." The Second, the summe of the Right of Nature; which is, "By all means we can, to defend our selves". (1651a, XIV. Destaques meus.)

47 "From this Fundamentall Law of Nature, by which men are commanded to endeavour Peace, is derived this second Law; "That a man be willing, when others are so too, as farre-forth, as for Peace, and defence of himselfe he shall think it necessary, to lay down this right to all things; and be contented with so much liberty against other men, as he would allow other men against himselfe". (1651a, cit. Destaques meus.)

${ }^{48}$ É nesse sentido a opinião de Renato Janine Ribeiro, para quem a sobrevivência é uma meta comum ao direito de um estado e ao estado de natureza (2004: 93).

49 "The End Of Common-wealth, Particular Security The finall Cause, End, or Designe of men, (who naturally love Liberty, and Dominion over others,) in the introduction of that restraint upon themselves, (in which wee see them live in Common-wealths,) is the foresight of their own preservation, and of a more contented life thereby; that is to say, of getting themselves out from that miserable condition of Warre, which is necessarily consequent (as hath been shewn) to the naturall Passions of men, when there is no visible Power to keep them in awe, and tye them by feare of punishment to the performance of their Covenants, and observation of these Lawes of Nature set down in the fourteenth and fifteenth Chapters".
} 
anos após a decapitação de Carlos I. Na curta biografia que escreveu de Hobbes, Tuck (2001) conta que o filósofo inglês nasceu de um parto apressado provocado pelo terror que sentiu a sua mãe ao saber que a Armada espanhola estava a caminho da Inglaterra; e que, por isso, Hobbes dizia-se filho do medo, sentimento que ele próprio reconhecia perenemente presente em sua filosofia política. Tratando especificamente de sua doutrina da punição, Cattaneo (1984: 184) chega a dizer que ela é no fundo uma "razionalizzazione della paura". E, como é bem sabido, o século seguinte (XVIII) tampouco entrou para a história europeia como uma época de paz, em especial pela violência da Revolução Francesa e o subsequente período do terror jacobino. Na Doutrina do Direito, Kant fez consignar em uma nota de rodapé a repulsa pela violência não só da então-recente deposição de Luis XVI, mas também da condenação e execução de Carlos I que tanto marcaram Hobbes: "O homem imbuído das ideias do direito se horroriza com a dupla recordação dos regicídios solenes de Carlos I e Luís XVI" (Kant, 1797: 167 , nota 1$).^{50}$

Pois bem, todos esses autores concordavam que a tarefa de preservação da ordem e manutenção da paz tinha algo de importante a ver com o uso público da força, que contra outras nações dava-se através da guerra, e dentro dos limites políticos de um Estado, através da punição estatal - da "pena", portanto. Segundo Sbriccoli (1974: 12), também o moderno conceito de soberania levava água para este moinho: a ideia de que o poder soberano é um poder político que deve garantir sua sobrevivência a qualquer custo convidava ao exercício da punição contra os perturbadores da ordem e da paz, que eram os fins mais comumente associados à existência do Estado. Aqui está um primeiro ponto de contato entre duas coisas que nos parecem hoje intimamente associadas: cominação de penas como forma de obtenção de um consenso entre súditos que permita a vida em conjunto, e a responsabilidade do Estado pela efetivação da punição. As leis do direito privado, dizia Kant, serviam para regrar o exercício de autonomia das pessoas; as do direito público, para evitar as interferências indevidas no espaço de autonomia de cada um.

\footnotetext{
${ }^{50}$ A frase completa é: "Die formale Hinrichtung ist es, was die mit Ideen des Menschenrechts erfüllte Seele mit einem Schaudern ergreift, das man wiederholentlich fühlt, sobald und so oft man sich diesen Auftritt denkt, wie das Schicksal Kar I. oder Ludwig XVI".
} 
Mas, afinal, onde estava o "direito penal" a esta altura? Ele já existia? E, em caso afirmativo, onde ele se situava nesta divisão? Ainda no século XVII, o "direito penal", anacronicamente falando, era meramente a parte do direito que estabelecia penas para as hipóteses da violação de leis proibitivas, usualmente de direito público. Como será mostrado nos próximos capítulos, o nosso direito penal contemporâneo, como algo totalmente distinto de outros ramos do direito público ou privado, firmou-se apenas século XIX adentro. Na época de Hobbes, por exemplo, ainda que se falasse em "crime", "pena" e "direito de punição", a "lei penal" não parecia ter uma existência autônoma em relação ao restante do direito positivo. Falando do início da modernidade, Sbriccoli (2004) e Birocchi (2002: 253) lembram que as matérias jurídicas de "direito penal" apareciam misturadas junto a conceitos e regras de direito privado. Tomás y Valiente (1992: 24) lembra, com muito acerto, que a prévia colocação do direito penal no âmbito das vinganças particulares até o início da modernidade reforçava o seu aspecto privado. Pires, no mesmo sentido, diz que no século XVII,

o direito positivo da República, a lei Civil, não está ainda subdividido entre uma justiça civil desligada e uma justiça penal. (...) o direito penal aparece aqui como um "direito de acompanhamento", no sentido de que cada proibição jurídica se faz acompanhar de uma sanção (chamada "lei penal") (Pires, 1998a: 27).

É também a opinião de Cartuyvels:

\footnotetext{
"Se a representação da lei penal evolui com o passar do tempo em direção a uma concepção autônoma, ela repousa inicialmente em uma concepção auxiliar: o direito penal é o guardião do conjunto das normas jurídicas" (Cartuyvels, 1996: 12).
}

Em Hobbes, essa representação acessória do "direito penal" aparece da seguinte maneira:

A Lei Civil (segundo os dois ofícios do legislador, o primeiro de julgar, e o segundo de constranger os homens a acatarem seus julgamentos) tem duas partes; uma distributiva, e outra vindicativa, ou penal. A distributiva é, que todo homem tem 
seu próprio direito, isto é, ela estabelece regra para todas as coisas, pelas quais podemos saber o que é propriamente nosso, o que é dos outros; de forma que outros não possam impedir-nos do livre uso e gozo daquilo que é nosso; e nós não podemos interferir naquilo que é deles; e o que é de direito que cada homem faça ou omita, e o que não é. Vindicativa é aquela onde se define a punição a ser aplicada àquele que quebrar a Lei. (1651b, XIV, I. Destaques meus. $)^{51,52}$

\begin{abstract}
A mesma concepção acessória da lei penal aparece também em Pufendorf. O "penal" é uma parte de todas as leis "civis" (positivas), note-se bem:
\end{abstract}

A força das leis civis consiste em que uma sanção penal é adicionada a seus preceitos, respeitante ao fazer ou ao omitir; em outras palavras, que há uma definição da penalidade que, em um tribunal, esperará pelo homem que deixou de fazer aquilo que deveria ter sido feito, ou que fez aquilo que não deveria ter sido feito $(1682, \mathrm{XII}, 4)$. $^{53}$

É verdade que nessa época, já eram velhos alguns documentos legislativos que reuniam, em apartado, matérias mais ou menos exclusivamente "criminais". É o caso, exemplarmente, da Constitutio Criminalis Carolina de Carlos V, de 1532, ou mesmo das Ordenações Filipinas que vigiam no Brasil a partir do século XVII. ${ }^{54}$ Mas, como será dito logo adiante, a Carolina e outros documentos semelhantes

\footnotetext{
51 "Again, the civill Law (according to the two offices of the. Legislator, whereof one is to judge; the other to constrain men to acquiesce to his judgements) hath two parts; the one distributive, the other vindicative, or penall. By the distributive it is, that every man hath his proper Right, that is to say, it sets forth Rules for all things, whereby we may know what is properly ours, what another mans; so as others may not hinder us from the free use and enjoyment of our own; and we may not interrupt others in the quiet possession of theirs; and what is lawfull for every man to doe or omit, and what is not lawfull. Vindicative is that whereby it is defined what punishment shall be inflicted on them who break the Law".
}

${ }^{52}$ Segundo Pires, Hobbes modificou um pouco sua linguagem no Leviathan e passou a falar de "duas leis" (uma distributiva e outra penal) ao invés de "duas partes". Mas, diz ele, ainda não se pode falar de uma "lei penal" no sentido contemporâneo da expressão, seja porque a noção de castigo no Leviathan ainda era excessivamente ampla (não restrita à pena criminal), seja porque todo o direito positivo ainda era tomado como uma representação repressiva (1998a: 30).

53 "And the force of the civil laws consists in this, that a penal sanction is added to the precepts in regard to doing or leaving undone; in other words, that there is a definition of the penalty which, in the court of the state will await the man who has failed to do what was to be done or has done what should have been left undone".

${ }^{54}$ A matéria criminal concentrava-se principalmente no Livro V das Ordenações. 
explicam-se mais como estratégias de consolidação jurídico-política de um Estado moderno, do que como produtos do reconhecimento da autonomia e especificidade do "criminal" em relação ao resto do direito "civil". Cartuyvels lembra, insistindo na falta de especificidade do "criminal" àquela altura, que tais compilações legislativas costumavam tratar conjuntamente tanto dos procedimentos civis quanto criminais. (Cartuyvels, 1996: 22). Essa estratégia de consolidação estatal por meio da organização das regras para a cominação de penas foi seguida inclusive no caso brasileiro: o Código de Processo Criminal de 1832, mais do que definir as regras do processo, organizava o sistema de justiça contenciosa do Brasil independente, e continha disposições provisórias sobre a administração da justiça civil; e no pensamento de Bernardo Pereira de Vasconcellos, redator do Código Criminal de 1830, as regras "materiais" e "processuais" deveriam ser sido aprovadas em conjunto num diploma unitário (assim era o seu projeto), ${ }^{55}$ e não separadamente como de fato ocorreu.

Segundo Cartuyvels, a separação da matéria criminal não apareceu com força na pauta até a segunda metade do século XVIII: exemplificativamente, os códigos absolutistas de Maximilian-Joseph III, da Bavária, já mostravam a individualização de um direito substantivo especificamente penal (Codex Juris Bavarici Criminalis, 1751). Em termos teóricos, Pires (1998b: 93-6) identifica em Beccaria (1774) a semente da ideia de que o "direito criminal" é algo por seus fundamentos distinto do restante do "direito civil", bem como de que a pena criminal é regida por princípios distintos; mas, como qualquer novidade teórica, isso não é coisa que se consolidou do dia para a noite. Quatro anos após Dos Delitos e Das Penas, o Nakaz (Instrução) de Catarina II foi publicado, preservando a imagem horizontalizada de um "direito penal" como guardião de todas as leis civis, a despeito da declarada influência dos Iluministas - Beccaria inclusive - sobre a obra. ${ }^{56}$ Cartuyvels (1996: 160) diz que o Nakaz previa uma classificação de crimes, o que mostra alguma indicação de uma autonomia do penal em relação ao civil, ainda que tímida. Um verdadeiro código penal moderno - ilustrado, com vocação reformista, monopolizador da legislação - só veio

\footnotetext{
$\overline{{ }^{55} \text { Annaes, 05/05/1827: } 23 .}$

${ }^{56}$ Diz Cartuyvels: "Catherine II accorde ao droit pénal un statut "auxiliaire": en tant que gardien des lois civils, le rôole du droit pénal consiste à sanctionner d'une peine les atteintes aus lois civiles" (1996: 159).
} 
em 1787, com José II da Áustria. Mas veio ainda em meio a muitas "codificações" generalizantes, às quais faltava a especificidade por disciplinas como hoje conhecemos, como no caso das Leggi e Costituzioni da Sardenha de 1770. Contudo, precisar a data exata em que a representação autônoma de um ramo penal do direito aparece pela primeira vez não é necessário. Basta guardar em mente que no pensamento jurídico europeu da segunda metade do século XVIII, a visão do "criminal" como uma parte substantivamente autônoma do direito ainda não era hegemônica, mas já estava em vias de se construir.

Com sua progressiva autonomização, o "criminal" passou a ter de ser inserido na grande divisão teórica então existente, e com a qual ainda hoje convivemos, de direito público versus direito privado. Como nós hoje sabemos, o direito penal ficou para o direito público. Mostrar os caminhos teóricos pelos quais isso foi feito é algo que só pode ser feito do ponto de vista interno e com a orientação prospectiva dos próximos capítulos. Por ora, cumpre apenas mostrar que, ao contrário do que pode parecer, isso não é uma questão óbvia ou desimportante. Se analisarmos bem, veremos que situar o direito penal dentro do direito público não era uma coisa assim tão natural.

Tome-se, por exemplo, a já citada distinção hobbesiana entre justiça dos pactos e justiça do árbitro. Por um de seus fundamentos (garantir a paz, que é o fim da sociedade), o direito penal estaria mais próximo da justiça do árbitro, que é aquela que define, por meio das leis, as regras que trazem paz para um terreno de conflitos; por outro fundamento igualmente importante (a lei violada), o direito penal está mais próximo da justiça dos pactos, já que cuida da violação de um acordo assumido perante o soberano (obedecer às leis), e acordos são a essência dos contratos, que são o instrumento mais característico do direito privado. Também em Kant, como já visto, a justiça distributiva era vasta e compreendia toda a justiça contenciosa. O direito público definia-se, amplamente, como aquele que garantia os direitos de cada um por meio de leis públicas. Já o direito privado seria aquele cujas regras se estabelecem por convenção, e não por um imperativo racional. Naquele momento histórico, porém, já havia um conjunto grande de condutas criminalizadas que os juristas não concebiam como "naturalmente criminais", mas, ao contrário, criminais apenas por conveniência 
política - os delitos políticos, ou policiais. Pela divisão kantiana, esses ilícitos criminais menores teriam de ser situados dentro do direito privado. Isso tudo sem mencionar o fato de que Kant tratava tanto os ilícitos públicos quanto os privados como "crimes": ele distinguia a justiça civil da justiça criminal, mas o ilícito perseguido pela punição chamava-se sempre "crime" (Verbrech), fosse ele público ou privado (1797: 190).

Outros elementos substantivos também complicavam a definição de onde ficaria o direito penal. Em primeiro lugar, havia a já mencionada tradição do direito romano, amparada por séculos de tradição e bibliotecas inteiras de opiniões doutorais, segundo a qual havia tanto crimes públicos quanto crimes puramente privados, que diziam respeito apenas ao ofensor e à vítima. Ademais, os juristas da modernidade percebiam com mais clareza algo que continua sendo evidente, mas que a naturalização do direito penal contemporâneo nos impede de ver: aquilo que se chama "crime", e que se pune portanto por uma pena "criminal" em nome do "interesse público", envolve no mais das vezes uma ofensa cometida por um particular, contra a esfera individual de um outro particular - seu corpo, seu patrimônio, sua honra etc. Blackstone tinha isso claro para si, e tentava justificar como podia ser público um ilícito que quase sempre começava e acabava entre pessoas e direitos privados:

Em todos os casos o crime [público] inclui um dano [privado]: toda ofensa pública é também um ilícito privado, e algo mais; ela afeta o indivíduo, e ao mesmo tempo afeta a comunidade. Assim, a traição de planejar a morte de um rei envolve uma conspiração contra um indivíduo, que é também uma lesão civil: mas como essa espécie de traição, em suas consequências, tende principalmente à dissolução do governo, e à destruição por essa via da ordem e paz sociais, isso faz dela um crime [público] da maior magnitude. O assassinato é uma lesão à vida de um indivíduo; mas a lei da sociedade considera principalmente a perda que o Estado sobre ao ser privado de um membro seu, e o exemplo pernicioso que ele dá, para que outros façam o mesmo. O roubo pode ser considerado pelo mesmo ponto de vista: é uma injúria à propriedade privada; mas, fosse isso apenas, uma satisfação civil das perdas e danos poderia dar conta dele: o mal público é todas as coisas, que para fins de prevenção nossas leis consideram ofensas capitais. (Blackstone, Complementariedades: IV, I, 6). ${ }^{57}$

57 "In all cases the crime includes an injury: every public offence is also a private wrong, and somewhat more; it affects the individual, and it likewise affects the community. Thus treason in imagining the king's 
Prova da dificuldade da questão é que em meados do século XIX, António Joaquim Ribas, em seu Direito Administrativo Brasileiro, via-se em apuros ao ter de situar o direito penal dentro do direito público ou do direito privado. O direito público, dizia ele, "ensina os princípios constitutivos do poder social em seus diversos ramos, e reguladores da sua acção, tanto em relação aos proprios subditos como ás sociedades estranhas" (1866: 27-8). Ribas o dividia entre: (i) Direito Público Interno (que abrangia o "Direito Político ou Governamental" - nosso Direito Constitucional - e Direito Administrativo) e (ii) Direito Público Externo (que abrangia o "Direito Internacional ou das Gentes" e o Direito Eclesiástico). Quanto ao direito privado, este se definia como "o complexo das leis que regem as relações dos indivíduos entre si, e determinão os seus direitos e deveres recíprocos" (Ribas, 1866: 31), e incluía o Direito Civil, o Direito Comercial e o Direito Internacional Privado. Sobre o "Direito Criminal", o administrativista dizia o seguinte:

Quanto ao Direito Criminal, muito se tem discutido, se é ramo do Direito Publico ou Privado. Entre nós a punição de alguns crimes é direito do offendido, que elle póde annullar pelo perdão, ou pelo não uso no prazo da prescripção; e naquelles mesmos em que se procede ex-officio, a sociedade, representada pelo ministerio publico, apparece como parte offendida, como pessoa jurídica, perante o poder judicial, a requerer a applicação da lei penal. (1866: 32).

Ribas estava dizendo que, apesar de operar majoritariamente por mecanismos de direito público (Ministério Público, ação ex-officio), havia no direito criminal duas partes com interesses conflitantes: uma vítima (a sociedade, ou a vítima em si) e um criminoso; e as engrenagens do direito penal muitas vezes eram movidas não pelo interesse público, mas pelo exercício de um direito subjetivo do ofendido. Ora,

death involves in it conspiracy against an individual, which is alfo a civil injury: but as this species of treason in it's consequences principally tends to the dissolution of government, and destruction thereby of the order and peace of society, this denominates it a crime of the highest magnitude. Murder is an injury to the life of an individual; but law of society considers principally the loss which the state sustains by being deprived of a member, and the pernicious example therby set, for others to do the like. Robbery may be considered in the same view: it is an injury to private property; but, were that all, a civil satisfaction in damages might atone for it: the public mischief is the things, for the prevention of which our laws have made it a capital offence". 
pensava Ribas, "partes em conflito", "direito subjetivo", "ofendido" são coisas próprias do direito privado, e não do público! Para piorar o estado de confusão em que o professor paulista se via, devemos lembrar que o Código Criminal de 1830 tinha uma parte toda dedicada aos "crimes privados". Portanto, apesar de ter cara de direito público, o direito penal tinha muitos elementos com a lógica do direito privado. $\mathrm{O}$ administrativista acabou mesmo por classificar o "Direito Criminal" como parte do direito privado, ainda que, talvez pela polêmica da posição, tenha apenas sugerido a resposta. $^{58,}{ }^{59}$ Esta posição, frise-se bem, não era exclusiva de Ribas: Pimenta Bueno, possivelmente o publicista mais importante do Império, também via o direito criminal como uma disciplina híbrida, a um só tempo pública e privada: ela seria pública no que respeita "á imposição da pena, á infracção do preceito da lei, á referencia para com a consequente sancção repressora"; e seria privada no que se refere "á indemnisação, ao interesse particular da satisfação do damno operado", para ao fim anotar que ele é incluído "por todas as legislações" no domínio do "direito particular", e não do direito público (Pimenta Bueno, 1857b: 13-4). Vê-se, portanto, que se tratava de um debate em aberto, de que certamente tiveram de se ocupar os formadores do direito penal contemporâneo.

\section{O QUADRO INSTITUCIONAL}

Finalmente, há também fatores institucionais importantes de ser considerados. No que tange especificamente ao direito penal contemporâneo, essa relação com as instituições políticas é, do ponto de vista histórico, especialmente

\footnotetext{
${ }^{58}$ Ao mencionar as maneiras como o Direito Administrativo colabora com o direito privado, Ribas dirá mais adiante que a Administração Pública ajuda na prevenção do crime, cuja punição é papel do direito penal.

${ }^{59}$ Por essa razão, penso que Cartuyvels (1996: 11) talvez tenha se expressado mal ao dizer que no século XVIII, o direito penal afirmou com força "sua dimensão estatal e sua inscrição na esfera do direito público". Hoje sabemos que o direito penal ficou para o direito público: isso é um consenso para nós. Certamente muitos autores do século XVIII pensavam assim também. Em fins do século XVII, Jean Domat, no Loix civiles dans leur ordre naturel, já situava o direito penal integralmente dentro do direito público. Mas em meados do século XIX, um autor esclarecido como Ribas não só tinha dúvidas disso, como também acusava a existência de reiterados debates sobre a matéria. Como veremos no Cap. IV, esta dúvida era compartilhada por outros brasileiros, bem como por muitos juristas europeus.
} 
significativa: a consolidação da jurisdição real e da soberania política do rei deram-se muitas vezes a partir do "direito criminal", ou seja, por meio da obtenção do monopólio jurisdicional sobre a definição de ilícitos jurídicos ("crimes"), seu processamento e sua punição. Isso tem uma importante relação com a acepção horizontalizada e acessória do "criminal" no início da modernidade: definir "crimes" e "penas" era, em face da já comentada visão acessória do direito penal, estabelecer todas as proibições públicas e a forma de sua persecução. Não é por acaso que, diante de bruscas mudanças políticas que reclamaram rearranjos institucionais ao longo da história, as legislações criminais eram com frequência as primeiras a ser feitas ou refeitas - caso inclusive do Brasil independente, lembremo-nos. Nesse sentido, e para os fins deste capítulo, convém salientar duas coisas: a primeira diz respeito ao processo de construção do monopólio legislativo estatal e de afirmação do soberano frente às demais instâncias de poder político; a segunda, à onda de reformas institucionais anteriores e concomitantes ao Iluminismo que tiveram o "criminal" por objeto, muitas vezes visando à limitação desse mesmo poder com o apoio em princípios jurídicos liberais. O tema mais evidente a partir do qual esses dois pontos podem ser acessados é o do movimento de codificação, em sentido amplo: ou seja, não apenas os códigos penais modernos produzidos sobretudo no século XIX; mas também os processos de sistematização e organização legislativa dos séculos XVII e XVIII, que não são propriamente códigos na acepção estrita do termo, mas já dão boas ilustrações tanto dos problemas institucionais que estavam em pauta, quanto das racionalidades jurídicas com que eram tratados.

Como já foi dito, ganhou força nos séculos XV e XVI a marcha da centralização jurídica no poder real. A crítica de que a multiplicidade de leis e jurisdições levava a uma insustentável proliferação de processos era ainda um lugarcomum entre juristas dos séculos XVII e XVIII. É nesta época que se formam, segundo Cartuyvels (1999), as bases políticas e intelectuais dos movimentos de codificação: a primeira é o propósito político de concentração do poder jurisdicional na justiça real, que se deu inicialmente pela organização do amontoado de leis vigentes; a segunda, a metodologia com que as muitas sistematizações legislativas da época foram feitas. ${ }^{60}$

\footnotetext{
${ }^{60}$ Hespanha (1997) lembra que já no século XV foram feitos trabalhos de compilação legislativa, de que as Ordenações Afonsinas seriam exemplo. Não é desse tipo de sistematização que estou falando. Elas já
} 
A organização das leis em um só corpo era normalmente encomendada pelo rei, ou por um ministro, a juristas de confiança. Christian Wolff, Samuel Cocceius e Ludovico Antonio Muratori são exemplos de nomes que, no século XVII, receberam encomendas tais. Essas sistematizações legislativas, que no mundo moderno persistiram até a consolidação do movimento codificador (final do século XVIII), muitas vezes abrangiam em um mesmo corpus matérias que hoje tratamos de forma totalmente separada. Tais sistematizações eram feitas dentro da matriz intelectual do jusnaturalismo moderno, o que evidentemente as impactava metodologicamente. Em termos simples, o ponto inicial era organizar a confusão das leis vigentes, de acordo com alguma racionalidade clara e precisa.

A progressiva desimportância do direito romano-justinianeu frente ao direito local deixou os primeiros juristas da modernidade metodologicamente órfãos: os legistas, que eram sobretudo treinados para interpretar e "atualizar" os velhos textos clássicos, foram então postos diante da tarefa de conferir sentido e sistematicidade a um direito que já nascia em parte atualizado (Hespanha, 1997: 132-3). Àquela altura, a geometria era vista como uma espécie de linguagem universal da razão e dominava as atenções de intelectuais de diversas áreas. Johannes Kepler, matemático e astrônomo do século XVI, achava que a geometria era o "idioma" pelo qual Deus revelava os mistérios da natureza aos homens; ela seria, por assim dizer, a língua de Deus. Kepler buscou construir um modelo de universo a partir da sobreposição concêntrica das formas geométricas puras, pois entendia que a forma física do universo (a localização dos astros) não poderia ser aleatória, porque obra divina. $\mathrm{O}$ cosmos não seria caos, mas sim harmonia - Harmonices Mundi - e a geometria seria o modelo a partir do qual a harmonia universal se formava. Assim, os planetas, em suas localizações respectivas, seriam como que os vértices dessas formas geométricas tridimensionais puras, chamadas de sólidos platônicos. Ora, se a geometria dava a harmonia do universo e permitia até mesmo desvendar o mistério cosmográfico (Mysterium Cosmographicum) de Kepler, que maravilhas não faria ela para organizar um punhado de leis confusas! Assim como cubos, pirâmides e esferas são as formas elementares a partir das quais se constrói o universo, deve haver algo equivalente para o direito; pontos de partida têm a vocação política centralizadora, mas não a metodologia que caracterizou as codificações. 
elementares e auto-evidentes que permitissem organizar logicamente o conjunto de leis válidas, que seriam deduções desses pontos de partida, desses principia - princípios.

Eram os princípios de direito natural, acessíveis pelo exercício da razão abstrata. Tais princípios variavam de autor para autor, mas sempre logravam o efeito prático de organizar sistematicamente um conjunto de leis que antes apareciam dispersas e disformes. Em Domat, por exemplo, a lei fundamental era o amor, que se desdobrava em duas leis naturais: amar a Deus e amar ao próximo:

\begin{abstract}
Assim, nós descobrimos, na semelhança do homem a Deus, em que consiste a sua natureza, em que consiste sua religião, em que consiste sua primeira lei: pois sua natureza não é outra coisa além desse ser criado à imagem de Deus, e capaz de possuir esse bem-soberano que deve ser sua vida e sua beatitude; sua religião, que é a reunião de todas as suas leis, não é outra coisa senão a luz e o caminho que o conduzem a essa vida; e sua primeira lei, que é o espírito da religião, é aquela que o comanda à busca e ao amor do seu bem-soberano, onde ele deve se elevar em relação às outras forças de seu espírito e de seu coração que são feitas (Domat, 1828: 4). ${ }^{61}$
\end{abstract}

A partir daí, ele organizava todo o direito: o casamento e a relação de paternidade seriam as primeiras formas de engajamento (engagement) jurídico, porque mais diretamente relacionadas à lei natural do amor; ${ }^{62}$ e cometer um crime seria uma forma de desobedecer a essa mesma lei. Em Pufendorf, o princípio elementar era a

\footnotetext{
61 "Ainsi, nous découvrons, dans cette ressemblance de l'homme à Dieu, en quoi consiste sa nature, en quoi consiste sa religion, en quoi consiste sa première loi: car sa nature n'est autre chose que cet être créé à l'image de Dieu, et capable de posséder ce souverain-bien qui doit être sa vie et sa béatitude; sa religion, qui est l'assemblage de toutes ses lois, n'est autre chose que la lumière et la voie qui le conduisent à cette vie; et sa première loi, qui est l'esprit de la religion, est celle qui lui commande la recherche et l'amour de ce souverain-bien, où il doit s'èlever de toutes les forces de son esprit et de son coeur qui sont faits pour le posséder".

62 "L'engagement que fai le mariage entre le mari et la femme, et celui que fait la naissance entre eux et leurs enfans, forment une société particulière dans chaque famille, où Dieu lie ces personnes plus étroitement, pour les engager à un usage continuel des divers devoirs de l'amour mutuel" (Domat, 1828: 8).
} 
sociabilidade: ${ }^{63}$ respeitar contratos seria fazer valer o mandamento natural da sociabilidade, e cometer crimes seria desrespeitá-lo.

Essa metodologia tornava possível enxergar o direito de forma taxonômica: de um tronco axiológico central, nascia o disciplinamento jurídico particular de assuntos específicos e variados. Tudo aquilo que não estivesse em conformidade com esses princípios jurídicos universais estaria fora do direito. Por esse caminho, as sistematizações jurídicas dos séculos XVII e XVIII acabaram por eliminar uma parte do direito romano do quadro das normas jurídicas. O velho direito justinianeu definitivamente não era caro aos reformistas do século XVIII: o projeto de código prussiano de Samuel Cocceius (1751), por exemplo, foi rejeitado porque considerado excessivamente romanista (Cartuyvels, 1996: 123). Em muitas das sistematizações legislativas do século XVIII, proibiu-se a utilização do direito romano (iura e comentários) que fosse contrário aos princípios do direito natural moderno. ${ }^{64}$

\footnotetext{
${ }_{63}$ "Thus then man is indeed an animal most bent upon self-preservation, helpless in himself, unable to save himself without the aid of his fellows, highly adapted to promote mutual interests; but on the other hand no less malicious, insolent, and easily provoked, also as able as he is prone to inflict injury upon another. Whence it follows that, in order to be safe, he must be sociable, that is, must be united with men like himself, and so conduct himself toward them that they may have no good cause to injure him, but rather may be ready to maintain and promote his interests. The laws then of this sociability, or those which teach how a man should conduct himself, to become a good member of human society, are called natural laws". (Pufendorf, 1682, III, 7-8).

${ }^{64}$ Para nós brasileiros, o exemplar mais conhecido de algo assim é a Lei da Boa Razão (1769), que em certo trecho diz o seguinte: "Mando por uma parte, que debaixo das penas ao diante declaradas se não possa fazer uso das ditas Alegações, e Decisões de Textos, ou de Autoridades de alguns Escritores, em quanto houver Ordenações do Reino, Leis Pátrias, e usos dos Meus Reinos legitimamente aprovados também na forma abaixo declarada: E Mando pela outra parte, que aquela boa razão, que o sobredito Preâmbulo determinou, que fosse na praxe de julgar subsidiaria, não possa nunca ser a da autoridade extrínseca destes, ou daqueles Textos do Direito Civil, ou Abstractos, ou ainda com a concordância de outros; mas sim, e somente: Ou aquela boa razão, que consiste nos primitivos princípios, que contém verdades essenciais, intrínsecas, e inalteráveis, que a Ética dos mesmos Romanos havia estabelecido, e que os Direitos Divino, e Natural, formalizaram para servirem as Regras Moraes, e Civis, entre o Cristianismo: Ou aquela boa razão, que se funda nas outras Regras, que de universal consentimento estabeleceu o Direito das Gentes para a direcção, e governo de todas as Nações civilizadas: Ou aquela boa razão, que se estabelece nas Leis Políticas, Económicas, Mercantis, e Marítimas, que as mesmas Nações Cristãs tem promulgado com manifestas utilidades, do socego público, do estabelecimento da reputação, e do aumento dos cabedais dos Povos, que com as disciplinas destas sábias, e proveitosas Leis vivem felizes à sombra dos tronos, e debaixo dos auspícios dos seus respectivos Monarcas, Príncipes Soberanos: Sendo muito mais racionável, e muito mais coerente, que nestas interessantes matérias se recorra antes em casos de necessidade ao subsídio próximo das sobreditas Leis das Nações Cristãs, iluminadas, e polidas, que com elas estão resplandecendo na boa, depurada, e sã Jurisprudência; em muitas outras erudições úteis, e necessárias; e na felicidade; do que ir buscar sem boas razões, ou sem razão digna de atender-se, depois de mais de dezassete Séculos o socorro às Leis de uns Gentios; que nos princípios Morais, e Civis foram muitas vezes perturbados, e corrompidos na sobredita forma".
} 
A relação entre natureza e organização das leis permaneceu durante a era das codificações, se bem que modificada. Segundo Cartuyvels (1996: 63 e ss.), os primeiros juristas modernos que pregavam a razão natural como recurso organizador faziam uso de uma imagem universalista da razão e da natureza. Por isso, o jusnaturalismo moderno aceita tanto teorias em que Deus não tem um papel constitutivo imprescindível, ${ }^{65}$ como outras em que ele aparece mais ativamente, de que Domat é exemplo. Uma natureza uniforme e a-histórica casa-se bem com o voluntarismo divino, ainda que possa existir sem ele. Essa possibilidade de união dá a base daquilo que Tomás e Valiente (1992: 94) considera, referindo-se às bases da ilustração penal europeia, uma absorção de Deus por parte da razão. A partir do século XVIII, porém, uma imagem mais particularista de natureza começa a ganhar força. No Nakaz de Catarina II, essa mudança já vem clara: o critério organizador de sua Instrução não é mais a razão jurídica abstrata, mas sim o Código de Leis do Czar Alexei Michailowitsch (1648). "Se a referência a uma racionalidade conforme à natureza está presente, essa natureza não é mais associada ao espírito do sistema", diz Cartuyvels; o empirismo de Catarina II "desconfia das miragens da abstração", pois as leis, "por mais razoáveis que sejam, não se devem transformar em uma "arte da Lógica", mas manter-se à razão de um bom pai de família". Por isso, "sua concepção da natureza, que remete a Montesquieu, é fundamentalmente diferente da imagem veiculada pela corrente do jusnaturalismo racionalista", pois não contém "um referente universal que articula um plano único, válido para todos os tempos e lugares, identificável por uma razão geométrica", mas sim "uma disposição particular própria a cada povo" (Cartuyvels, 1996: 157). Esta inflexão denuncia, ainda segundo Cartuyvels, o momento em que movimento codificador moderno ganhava impulso. Até então, as sistematizações legislativas não tinham ainda toda a força política que os códigos do século XVIII tiveram. Muitas vezes, os "códigos" dos séculos XVI e XVII reafirmavam o velho direito, dando ao direito real um papel meramente complementar e subsidiário. Essa mistura da vocação centralizadora com privilégios e direitos locais foi bem anotada por

\footnotetext{
${ }^{65}$ Dois exemplos importantes nesse sentido são: Hugo Grócio, com sua famosa postulação de que sua teoria subsistiria "mesmo se Deus não existisse"; e Pufendorf, que tem uma teoria "religiosamente ativa, mas teologicamente neutra" (Carr e Seidler, 1999: 150-1), de forma que Deus nela figura como um mero pressuposto (Hochstrasser, 2000: 41 e ss.).
} 
Arno e Maria José Wehling, alertando que a afirmação do Estado moderno não evitava que em pleno século XVIII, nos Estados da burocracia absolutista ainda existiam "setores do Estado e mecanismos institucionais que continuavam a emitir privilégios e isenções, gerando assim novos direitos particulares" (2004: 15). É só no final do século XVIII que essa razão abstrata começava a mostrar-se tanto legisladora quanto sistematizadora: a estrutura arborizante e taxonômica do jusnaturalismo permaneceu nos códigos, mas eles ganharam uma forte vocação reformadora que até então não tinham, ${ }^{66}$ tendendo a suprimir particularismos em favor da legislação real.

Nos "códigos" do século XVIII a já mencionada visão geometrizante, segundo a qual tudo começa em princípios amplos e termina nas disciplinas particulares, aparece exemplarmente. A organização contemporânea dos códigos, divididos em uma parte geral e outra parte especial, é produto dessa matriz organizadora de racionalidade, que procurava encontrar o fio condutor comum (a parte geral) de todas as disciplinas jurídicas particulares (a parte especial). Não por acaso, a historiografia costuma apontar a influência dos jusnaturalistas objetivistas (e anti-voluntaristas) ${ }^{67}$ para o ideário codificador: tanto Tarello (1976: 133 e ss.) quanto Cartuyvels (1996: 72 e ss.) indicam, por exemplo, a importância de Wolff e Leibniz nesse sentido. ${ }^{68} \mathrm{O}$ processo de emancipação do direito penal contemporâneo operar-se-á principalmente pela constituição de um conjunto de princípios que serão exclusivamente seus, e levarão os juristas a postular o seu descolamento do restante do direito. Mas não sem polêmica, é claro, pois os juristas nem sempre concordavam sobre o conteúdo e divisão da parte

${ }^{66}$ O Código Penal de José II, da Áustria (1787), foi o primeiro código moderno puramente penal do direito europeu (Cartuyvels, 1996: 264). (Isso, aliás, serve como mais um indício de que a construção do direito penal, como objeto autônomo de outras áreas do direito substantivo, é uma construção da segunda metade do século XVIII.) Foi também o primeiro a trazer uma divisão entre uma parte geral e uma parte especial, mas ainda diferente de nossa estrutura contemporânea: o código tinha uma grande bipartição, entre delitos criminais e delitos políticos; dentro de cada uma dessas divisões, havia sub-divisões em parte geral e especial.

${ }^{67}$ Hespanha (1997: 160) chama de "jusnaturalismo objectivista" aquele que postulava o fundamento do direito natural em uma razão objetiva situada "não nos indivíduos, mas na ordem cósmica ou na convivência humana", fugindo assim dos dilemas "sensualistas" em que se afundavam alguns pensadores como Hobbes, Hume, Kant.

68 Ainda que, em especial no caso de Wolff, seu objetivismo estivesse muito mais direcionado à organização do direito comum do que à elaboração de códigos. Mesmo assim, Tarello anota que ele exerceu influência decisiva sobre importantes figuras da codificação nos estados italianos dos oitocentos, como Giovanni Lampredi (Tarello, 1976: 545-6, e nota 128). 
geral do direito, ou de disciplinas jurídicas em particular. Isso é algo que será visto com vagar nos dois capítulos seguintes, quando serão mostradas as razões que os penalistas ofereciam para postular a independência teórica de sua disciplina.

Por ora, e no tema das alterações institucionais importantes para o surgimento do direito penal contemporâneo, vale mencionar inicialmente como os primeiros códigos "penais" dividiam seus conteúdos em partes gerais e especiais nem sempre homogêneas, e quase sempre distintas da nossa: nosso direito penal contemporâneo, como é sabido e ressabido, tem (i) uma parte geral, que compreende as regras gerais de "crime" e "respostas penais" (penas e medidas de segurança); e (ii) uma parte especial, com as disposições específicas e variáveis de cada delito, organizadas segundo o bem jurídico protegido (vida, patrimônio etc.) e dispostas segundo uma certa ordem de gravidade, que pode variar de um código para outro. Se voltarmos aos diplomas legislativos de fins do século XVIII, porém, veremos que uma parte geral assim compreendida estava longe de ser um consenso.

Em segundo lugar, é importante apontar também a separação, quando ela existia, entre direito material e direito processual. Algumas vezes separavam-se as duas coisas, mas o que estava em jogo aí não era a diferença substantiva entre direito material e processual, mas sim o propósito político de criar instituições jurisdicionais mais eficientes que fizessem o equilíbrio de poderes jurisdicionais pender para o lado do rei, em detrimento dos poderes políticos localistas (Tomás y Valiente, 1992: 25) e também da jurisdição eclesiástica. ${ }^{69}$ Tanto assim que a parte "processual" de muitos códigos penais incluía o regramento de processos civis. ${ }^{70}$ Mas já começava a desenharse alguma diferença metodológica entre o "material" e o "processual": o primeiro cuidava de definir crimes e penas, e o segundo cuidava da efetivação prática dos comandos da legislação criminal. Por isso, não é incomum que os autores da época

${ }^{69}$ A influência do direito eclesiástico na jurisdição real fez-se sentir até muito pouco tempo antes do direito penal contemporâneo. No Código Criminal Bávaro de 1751, o rol das penas leves incluía expressamente as penas canônicas (Cap. I, § 9, "h"); e entre as penas intermediárias estava a queima da letra "B" no rosto do condenado - significando "blasphemator" (Cap. I, § 8).

${ }^{70}$ Nesse sentido, e apenas exemplificativamente: as Reggie Constituzioni de Sabóia (1723/29), as Leggi e Costituzioni de Carlos-Emanuel III da Sardenha (1770) e o Codice Estense de Módena (1771), entre outras. 
dividissem o "Direito Criminal" em uma parte teórica, que equivaleria mais ou menos ao direito penal substantivo; e outra parte prática, que seria o direito penal processual. De qualquer forma, as duas coisas ainda eram vistas como partes de uma mesma e única disciplina, e assim continuaram sendo enxergadas majoritariamente século XIX adentro.

É hora de averiguar como isso se mostrava nos diplomas legais précontemporâneos. Comecemos pelas "codificações" italianas dos setecentos. ${ }^{71}$ As primeiras foram as consolidações do direito real da Saboia (1723, 1729), promovidas por Vítor Amadeu II. Trata-se de uma compilação em seis volumes de leis antigas fundadas principalmente sobre o direito comum, com o propósito destacado de organizar as fontes do direito (Cartuyvels, 1996: 49). Como era regra em sua época, não se trata ainda de um código que se ungia no papel de fonte exclusiva do direito: em caso de lacuna, permitia-se recorrer a outras fontes, como a jurisprudência dos magistrados e o direito comum (cit.: 50). Entretanto, havia algum conteúdo modernizador das leis, sobretudo em seu aspecto anti-nobilitário (e consequentemente centralizador), ${ }^{72}$ o que era fundamental para a construção de um estado moderno em uma sociedade agrícola de fortes traços feudais, como era o Piemonte de então (Tarello, 1976: 199). Em 1770, Carlos Emanuel III promulgou a terceira e final versão das Leis e Constituições de Sua Majestade, a partir da Sardenha, ${ }^{73}$ seu principal propósito foi corrigir a segunda versão, de 1729. Segundo Cartuyvels, o espírito das luzes ainda estava ausente aqui, seis anos após a publicação de Beccaria: não só faltava-lhe a vocação absolutista, pois o Código ainda não se dava o atributo de fonte exclusiva; como também as disposições contra judeus e "vagabundos", fartas nas versões de 1723 e 1729, permaneceram integralmente. "O reino da Sardenha fica fechado sobre ele mesmo, pouco inclinado a

${ }^{71}$ Os códigos e compilações legislativas a partir do século XVIII são muitos. Escolhi comentar aqueles aos quais Cartuyvels dá mais importância em seu trabalho, dado tratar-se da melhor obra disponível sobre a formação dos códigos penais modernos.

${ }^{72}$ As Costituzioni (Livro III, Tit. 22, § 9) vetavam, por exemplo, a invocação da autoridade doutrinal por parte dos advogados, bem como a motivação das decisões judiciais nessa mesa autoridade. (Tarello, 1976: 201).

73 A casa de Sabóia dominava tanto a Sabóia quanto a Sardenha. O mesmo Vitor Amadeu II, que promovera as codificações de 1723 e 1729 no Piemonte, já se tornara rei da Sardenha em 1720. Carlos Emanuel III foi um de seus filhos. 
escutar o movimento da razão burocrática, humanista e utilitarista que agita a Europa central" (Cartuyvels, 1996: 57). ${ }^{74}$

As Leggi e Costituzioni mostram que não só a indistinção entre direito penal e processual, como também a falta de preocupação com a estipulação de uma parte geral para as disposições "criminais". Seu Título I cuida dos "Juízes das Causas Criminais", estabelecendo regras de competência segundo os diversos tipos de delito. Perceba-se bem que há aqui uma permanência de um elemento organizativo da ordo legalia, com o "direito criminal" seguindo a ordem processual e a disciplina iniciandose onde se inicia o processo, isso já às vésperas do século XIX. As matérias predominantes processuais (secretarias, acusadores, carcereiros, corpo de delito, sentenças, recursos etc.) seguem até o título XXXIII, mas sempre misturadas com assuntos que hoje são, para nós, puramente penais: nos títulos XX e XXI, por exemplo, a disciplina das sentenças compreende regras de dosimetria da pena, incluindo causas de aumento para os contumazes. Somente no título XXXIV cuida-se "dos diversos tipos de delitos, e suas penas", mas falta qualquer "parte geral" quanto a essas coisas: imediatamente, passa-se à definição dos crimes de maledicência e blasfêmia (Cap. I), seguidos do crime de lesa-majestade (Cap. II), e assim por diante.

O Código Penal de Leopoldo I da Toscana, de 1786 - a Leopoldina vai mais ou menos no mesmo sentido (Cartuyvels 1996: 205 e ss.). A despeito de contar já profundas influências iluministas que ainda faltavam nos diplomas da Casa de Saboia, também faltava-lhe a grande vocação reformadora que caracteriza os códigos modernos: Tarello (1976: 548) diz que ele pouco reduzia a influência de outras fontes do direito, pois permitia ( $§$ CXVIII) que os juízes recorressem a outras leis do Grãoducado, desde que condizentes com o espírito da reforma.

Leopoldo I concebeu um código dividido em quatro partes. Elas continham, respectivamente: (i) uma introdução geral; (ii) regras processuais; (iii) penas e punição dos delitos e (iv) delitos diversos e suas penas. A colocação da matéria processual em um livro aparte de todo o restante indica já uma primeira separação entre

\footnotetext{
74 "Le royaume de Sardaigne reste fermé sur lui-même, peu encline à écouter le mouvement de la raison bureucratique, humaniste et utilitariste qui agite l'Europe centrale".
} 
as duas matérias, mesmo que venham em um único diploma legal; ao mesmo tempo, o fato de as regras criminais começarem pelo processo apontam, mais uma vez, certa sobrevivência da cultura jurídica anterior. Por isso, não deve causar espanto que, como será mostrado nos capítulos seguintes, tenha continuado frequente na doutrina, por muito tempo depois da Leopoldina inclusive, a colocação das regras substantivas e processuais dentro de uma só disciplina - "o direito criminal"; se o código da Toscana indica já um início de separação, ela está longe de ser a divisão absoluta entre direito material e processual como hoje conhecemos.

Se Cartuyvels vê a Leopoldina bem próxima dos códigos contemporâneos, a avaliação de Tarello é um pouco distinta: o professor italiano a vê ainda ligeiramente distante, especialmente pela mistura que ela ainda preservava entre direito substantivo e processual. ${ }^{75}$ De mais a mais, ainda segundo Tarello, a sua redação é demonstrativa, e não imperativa. Ele não nega, entretanto, que o código da Toscana possa ser considerado um precursor da moderna legislação criminal em outros aspectos relevantes. O primeiro deles é o processo, em que diversas práticas pré-iluministas, como a tortura judiciária, foram abolidas. $\mathrm{O}$ outro diz respeito, e agora em concordância com Cartuyvels, às penas: adesão à ideologia proporcionalística, a redução e tipificação das possibilidades de pena, a abolição da pena de morte (Tarello, 1976: 550-1)

Quanto ao direito material, o código de Leopoldo I trazia alguns "princípios gerais", seguidos de uma apresentação dos tipos de pena. Um desses princípios cuidava da estreiteza com que se deviam interpretar as leis penalizadoras, evitando punições arbitrárias por parte dos magistrados, o que indicava a influência de Beccaria sobre o trabalho (Cartuyvels, 1996: 207). A mesma influência se nota quando a Leopoldina trata das penas: elas deveriam ser, além de céleres, as menores possíveis diante das características do culpado e das necessidades de causar uma impressão durável no público. ${ }^{76}$ A pena de morte foi abolida. Tarello (1976: 542) indica que

\footnotetext{
75 "Non si distingue la materia penal sostanziale, cioè delitti e pene, dalla materia processuale; sotto questo profilo il codice leopoldino non può venire considerato come un passo avanti vero le codificazioni a confini disciplinari moderni (...); non solo, ma il diritto e la procedura non sono nemmeno separati entro il codice, come parti distinte" (Tarello, 1976: 548).

${ }^{76} \S \S 2,3,8$ e 9.
} 
Leopoldo I cercara-se de ministros que representavam os mais arrojados iluministas italianos daquele tempo - Pompeo Neri, Giulio Rucellai, Francesco Gianni -, e que tudo isso refletia-se em sua reforma penal. Entretanto, se o código era rico quanto a novos princípios para as penas, ele era ainda empobrecido no que diz respeito aos princípios gerais dos delitos. As regras gerais que contém a Leopoldina, são muito mais ligadas à moderação das penas do que às propriedades gerais e constitutivas dos crimes.

Por isso, pode-se dizer que o código de Leopoldo I mostra não só como uma parte geral com o conteúdo da nossa, contemporânea, ainda não estava pronta, mas também que a importância da legalidade àquela época, e na esteira de Beccaria, dizia muito mais respeito ao controle do excesso das penas do que à constituição substantiva do delito (como é a legalidade do direito penal contemporâneo, segundo postulado no primeiro capítulo desta tese). A superlatividade das penas em relação às propriedades constitutivas do delito é insinuada inclusive pelo título do Livro III do código (sua "parte geral", lembremo-nos): "Vista sobre as penas e punição dos delitos". ${ }^{77}$ Não se pode dizer que já havia na Leopoldina uma "teoria geral do delito" nem remotamente semelhante àquilo que hoje conhecemos, nem uma legalidade criadora (em que pese a ampla influência iluminista), nem muito menos uma parte geral como a nossa - ainda que alguma parte geral, de fato, já se esboçasse. Essa "parte geral" tinha apenas nove artigos, a maioria deles contendo princípios relativos às penas. Esse tipo de "parte geral do direito penal" majoritariamente ocupada das penas (e não tanto dos delitos) era, aliás, uma marca dos códigos imediatamente anteriores ao direito penal contemporâneo. Exemplificativamente, o Codex Juris Bavarici Criminalis (Bavária), de 1751, tinha uma parte geral sobre "os delitos criminais e as penas", mas ela cuidava quase que exclusivamente destas últimas: mesmo a distinção dos delitos criminais era dada a partir das penas a eles acopladas. ${ }^{78}$ Isto inclusive reforça a postulação de que o "criminal" vinha sendo visto como a parte punitiva do direito em geral: o problema do

\footnotetext{
${ }^{77}$ Vedute sopra le pene, e punizione dei delitti.

${ }^{78}$ Codex Juris Bavarici Criminalis (1751), § 1: "Es seynd nicht alle Frevel und strafbare Thaten für Criminal zu achten, sondern nur jene, welche entweder mit Leibs- und Lebens-Straf angesehen, oder sonst so beschaffen seynd, daß sie von Rechts- oder Gewohnheits wegen, ad Forum Criminale gehören".
} 
direito criminal era principalmente a pena, ao passo em que hoje é tanto o delito quanto a pena.

O Código Penal de José II da Áustria, ${ }^{79}$ de 1787 , é considerado por muitos o primeiro código penal moderno (Sbriccoli, 2004: 190; Cartuyvels, 1996: 264). Cavanna (1975: 37) aponta que o código josefino marca definitivamente a chegada da consolidação em sentido estrito, em lugar do mero remanejamento ou certificação das normas anteriormente existentes. Aponta ainda que o texto da Josefina era profundamente marcado pela racionalização iluminista do direito penal, tendo sido influenciado por Marat, Beccaria e o ilustrado austríaco Joseph Von Sonnenfels (cit.: 41-3).

No tocante à forma de representação do "criminal", o código josefino tem um dado interessante: ele compreende duas partes gerais, uma para os "crimes", e outra para as "graves transgressões de polícia". Sbriccoli (2004: 190) saúda-o incondicionalmente como uma obra de estrutura moderna, mas é sabido que importantes reformadores daquele tempo desgostaram a Leopoldina por entender que suas duas partes gerais tiravam-lhe a sistematicidade - e esse predicado, lembremo-nos, era uma obsessão dos juristas imediatamente posteriores ao Antigo Regime. Segundo Cavanna, a tal duplicidade foi uma das razões pelas quais a aceitação da Josefina na Lombardia foi tão difícil. Beccaria, o grande inspirador de José II, teria se manifestado contrariamente à substituição das velhas instituições lombardas pelo novíssimo código iluminista em razão dessa duplicidade (Cavanna, 1975: 52-3). Havia, por exemplo, dois conjuntos de disposições gerais relativas às condutas proibidas ("dos delitos", na primeira parte; e "das graves transgressões de polícia", na segunda), e também havia duplicidade nas disposições gerais sobre as respectivas penas. São praticamente dois códigos reunidos em um só, mas vistos como parte de um mesmo "direito criminal".

A Josefina já marca uma divisão substancialmente nítida entre as regras de direito material e as de direito processual: as primeiras ficam a cargo da Seção

\footnotetext{
${ }^{79}$ A despeito de conhecido como José II da Áustria, seu império ia muito além daquilo que hoje conhecemos como Áustria, incluindo também partes de Alemanha, Polônia, Itália, Croácia, Hungria e outros mais.
} 
Primeira, e as últimas, da Seção Segunda. Note-se bem: o processo criminal não vem mais em primeiro lugar, o que é muito significativo. No que diz respeito ao direito substantivo, há também uma divisão aparente entre parte geral e especial, ainda que o código não marque expressamente onde terminam as disposições gerais e começam as especiais. De qualquer forma, os primeiros capítulos cuidam das regras gerais para todos os delitos e penas, bem como as regras para a sua imputação. Aqui já se está, sem dúvida, diante de uma arquitetura criminal bastante parecida com a do direito penal contemporâneo.

Apesar dessas pequenas semelhanças, a representação do "direito criminal" como dotado de duas partes gerais, uma para crimes e outra para "contravenções", mostra a falta de unidade nos princípios de um só ramo do direito que abrangesse as duas coisas. Como comentarei nos capítulos seguintes, esta será uma fresta pela qual os ilícitos criminais ganharão autonomia em relação a outros ilícitos públicos (administrativos); mas, no código de José II, não era a autonomia do "penal" que se buscava - tanto assim que tudo era matéria "criminal". De quebra, perdia-se ainda a sistematicidade de um direito criminal unitário, que rendeu ao diploma inimigos do calibre de Beccaria. Por fim, deve-se anotar que o conceito de legalidade com que o diploma austríaco trabalhava era ainda empobrecido ( $\$ \S 12$ e 19), já que diziam respeito à interpretação das leis e à tipificação das penas, mas não de constituição dos delitos. No Código Penal Lombardo de 1797, feito na esteira do josefino mas já no império de seu irmão, Leopoldo II, a mesma legalidade fraca permanece: o $\S 1^{\circ}$ dizia que os crimes serão punidos apenas segundo as disposições do código, e não que o código cria os crimes. ${ }^{80}$

Por fim, e às vésperas já do século XIX, cabe uma breve passada de olhos sobre a Landrecht prussiana de 1794. Trata-se de um código geral para todos os estados prussianos de então. Os primeiros passos nesse sentido vinham sendo dados desde 1780, quando Frederico II ordenou as compilações, em dois livros, das leis particulares da cada província, formando um primeiro "código provincial", que vigeria

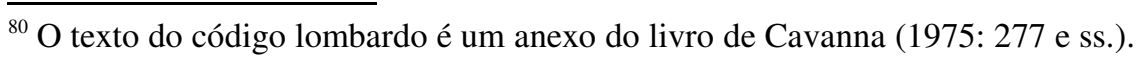


ao lado de um segundo código, "nacional" e válido para toda Prússia. Cartuyvels faz o seguinte comentário sobre a relação desses dois diplomas:

\begin{abstract}
Fundado sob um a mistura de princípios de direito natural encontráveis nas constituições de Justiniano e dos territórios alemães, o código geral fadava-se a exercer uma função subsidiária: servir de fontes do direito aos juízes em casos de lacuna do direito provincial (Cartuyvels, 1996: 333).
\end{abstract}

Após longos trabalhos, complicados trâmites e alguns adiamentos, a Landrecht entrou em vigor em junho de 1794. Segundo Hermann Conrad, seu conteúdo colocava lado a lado um direito tipicamente iluminista, escorado na igualdade, com um direito romano purificado e atualizado e as legislações locais. ${ }^{81}$

A Landrecht era uma compilação gigantesca, com quase 20.000 artigos. Sua preocupação era sobretudo burocrática, de reorganização das fontes. Em matéria penal (Livro XX), foi um diploma de vocações reformadoras, como, aliás, também as tinha Frederico II, que se correspondia com Voltaire e em 1749 já havia publicado um texto de juventude sobre a necessidade de uma legislação civilizada para a Prússia (Schmidt, 1980: 447). Conrad (1965: 4) aponta que, ao contrário do que era majoritário em seu tempo, a Landrecht não tratou de matéria processual. Sua preocupação era sobretudo organizar as fontes de direito material. Só por aí já aparecia, evidentemente, alguma separação entre direito material e direito processual, pois via-se que era possível tratar juridicamente uma coisa sem a outra.

$\mathrm{O}$ dito Livro XX abria-se com uma introdução, "dos delitos e das penas", que era seguida de disposições especiais sobre cada delito. O parágrafo $9^{\circ}$ previa uma espécie de princípio da legalidade, mas a sua redação, note-se bem, é dúbia, pois não deixa claro se as leis criam os delitos (a despeito de se exigir o requisito da externalidade, que em geral diferençava os ilícitos políticos dos morais e religiosos):

\footnotetext{
81 "Neben dem Naturrecht, der natürlichen Billigkeit und einem gereinigten römischen Recht gab die preußische kodifikation auch dem einheimischen rechter einen breiten Raum" (Conrad, 1965: 4).
} 
$\S 9^{\circ}$. Ações e omissões não proibidos pelas leis não podem ser tratados como delitos, sem que resultem em desvantagem verdadeira para um ou outro. ${ }^{82}$

A Landrecht preenchia sua parte geral com uma "teoria dos delitos" e uma "teoria das penas", por assim dizer. Ainda que não dividida entre as duas coisas, a matéria dos seus artigos introdutórios diz respeito exclusivamente às regras gerais sobre delitos (com destaque para a moralidade) e penas. Nessas últimas, destacavam-se as regras sobre "culpabilidade", para usar uma expressão anacrônica. Se a teoria do delito exigia a legalidade, a teoria da pena exigia a reprovabilidade moral da conduta. Havia seção inteira chamada "moralidade dos delitos" (Moralität der Verbrechen). O parágrafo 16 falava expressamente que só uma ação moralmente livre poderia ser julgada como delito e receber a respectiva pena. ${ }^{83}$ Já se estava, aqui, com uma representação teórica bem mais semelhante ao direito penal contemporâneo.

\subsection{CÓDIGOS, PRINCÍPIOS E SEGURANÇA JURÍDICA}

A metodologia da parte geral e parte especial teve também uma importante relação com um ideal político que cabe ser analisado ainda aqui, quando se fala de codificações: a ideia de que os códigos (os "criminais" principalmente), além de formas de organização de leis que sem eles seriam confusas, são também um instrumento de proteção dos súditos em face dos poderes punitivos do soberano. É muito importante ter em mente que essa inflexão já havia se dado em meados do século XVIII, às vésperas portanto do direito penal contemporâneo. Mas o seu impulso máximo deu-se com a Revolução Francesa, como bem anota Paolo Napoli:

\footnotetext{
${ }^{82}$ Allgemeines Landrecht für die Preußischen Staaten (1794), §. 9: Handlungen und Unterlassungen, welche nicht in den Gesetzen verboten sind, können als eigentliche Verbrechen nicht angesehen werden, wenn gleich Einem oder dem Andern daraus ein wirklicher Nachtheil entstanden seyn sollte.

${ }^{83} \S .16$. Wer frey zu handeln unvermögend ist, bey dem findet kein Verbrechen, also auch keine Strafe statt.
} 
A noção de 'limite' ao exercício de um poder se impõe com uma evidência indiscutível, graças ao esse ato normativo fundador que é a 'Declaração dos direitos do homem e do cidadão' de 1789, introduzindo parâmetros jurídicos inéditos, seja para os detentores do poder público, seja para os cidadãos. (Napoli, 2001: 159). ${ }^{84}$

Se a racionalidade organizadora dos princípios serviu inicialmente para criar instituições criminais mais eficientes em favor do rei (e em detrimento de outros poderes políticos concorrentes), os mesmos princípios foram, em um momento posterior, invocados para controlar aquilo que os iluministas tinham por "arbítrio". A noção de que o rei, porque soberano, tinha ampla liberdade de criminalização passou a ser combatida pela postulação de que os princípios, como regras racionais e inegáveis que eram, constrangeriam-no inclusive nesse aspecto. Hespanha (1997: 160) salienta, como já anotei em rodapé, que o jusnaturalismo objetivista foi um dos principais cavalos de batalha contra a ideia de que o soberano, porque soberano, legisla segundo sua vontade e não se submete a regras. É por isso que Pastor (2005: 138) afirma que o ideal da codificação, ao menos do âmbito do direito penal, expressa a pretensão de regulação "total e sistemática" de um ramo do direito - "total" indicando o aspecto político de controle absoluto por meio de regras racionais, e "sistemático" indicando o aspecto organizador.

Na nossa visão contemporânea sobre códigos penais e princípios de direito penal, é sobretudo esta ideia que sobrevive, ao menos em uma visão garantista de direito penal. Ferrajoli (2000: 173 e ss.) diz que os princípios são a melhor forma de que dispomos para atenuar a arbitrariedade inerente a um sistema judicial baseado em provas que, por questões epistemológicas, nunca conseguirá cumprir perfeitamente a regra da estrita legalidade a que está submetido. ${ }^{85}$ Tanto Ferrajoli quanto Pastor insistem

\footnotetext{
84 "La notion de 'limite' à l'exercise d'un pouvoir s'impose avec une indiscutable évidence, grâce à cet acte normatif foundateur qui est la 'Déclaration des droits de l'homme et du citoyen' de 1789, introduisant des paramètres juridiques inédits, tant pour les détenerus des pouvoirs publics que pour les citoyens".

85 "El hecho de que las decisiones penales mediante las que se ejerce el poder de disposición no versen sobre la verdad procesal no quiere decir que no deban o no puedan ser justificadas. Quiere decir solamente que son motivables no ya mediante aserciones cognoscitivas susceptibles de verificación y confutación, sino sólo o predominantemente con juicios de valor, no vinculados en cuanto tales a previsiones legales taxativas. Pero también los juicios de valor son susceptibles de argumentación y de
} 
que os códigos, a despeito das suas limitações inerentes, são a melhor estratégia legal para efetivar esse garantismo por sua particular forma lógica de organização, em que os fundamentos racionais do ordenamento penal aparecem evidentes e soberanos: segundo Pastor (2005: 145), o código é a forma contemporânea que o direito encontrou para efetivar os princípios do nullum crimen em matéria penal, e da nulla coactio em matéria processual penal. ${ }^{86}$

$\mathrm{Na}$ história das ideias penais, nenhuma obra é mais representativa dessa inflexão no papel dos princípios jurídicos e das leis penais que Dos Delitos e Das Penas (1774). ${ }^{87}$ Como anota Tomás y Valiente (1992: 101), é sobretudo contra os excessos punitivos estatais que escreve Beccaria. $\mathrm{O}$ jovem marquês ligava expressamente a punição de um delito à pré-existência de uma lei que lhe cominasse penas. Insistia, ainda, com base na filosofia política do recém-publicado livro de Rousseau (1762), que o Estado fora constituído para garantir a paz que sem ele não existiria, mas que o fora apenas com base nas mínimas parcelas de liberdade concedidas por cada súdito e que, por isso, era um mandamento racional que as penas fossem tão mínimas o quanto possível (tendo sempre em vista o fim de pacificação social), e não tão máximas quanto quisesse o soberano. Em face desses objetivos e a partir da filosofia política reformista e iluminada, Beccaria formula aquilo que deveria ser para ele o princípio de todo o direito punitivo estatal, informando toda e qualquer legislação penalizadora ou cominação concreta de penas:

Consideradas simplesmente as verdades aqui expostas, se convence com evidência que o fim das penas não é atormentar e afligir um ser sensível, e nem desfazer um

control conforme a criterios pragmáticos de aceptación. Estos criterios no son más que los principios generales del orgenamiento, es decir, principios políticos expressamente enunciados en las constituciones y en las leyes o implícitos en ellas y extraíbles mediante elaboración doctrinal" (Ferrajoli, 2000: 173).

86 "La codificación penal es el major instrumento para asegurar los fines que deve cumplir la ciencia del derecho. Pero también lo es, como ya se adelantó, para cubrir las exigencias de principio nullum crimen, en materia sustantiva, y el principio nulla coactio, en materia procesal" (Pastor: 2005: 145).

${ }^{87}$ Tomás y Valiente (1992: 85 e ss.) dá a Montesquieu a mesma importância de Beccaria, enquanto pensador das reformas do Direito Penal. Mas reconhece também que Beccaria foi mais efetivo do que Montesquieu na motivação real de reformas, seja pela combatividade juvenil de seu texto, seja pelo momento político favorável em que foi lançado. Dado que Beccaria cita expressamente Montesquieu em Dos Delitos e Das Penas, penso que não há qualquer prejuízo em tomar apenas o seu livro como exemplar do reformismo ilustrado em matéria penal. 
ilícito já cometido. (...) Devem ser escolhidas aquelas penas e método de imposição que guardem proporção com o delito cometido, produzam uma impressão mais eficaz e durável sobre os ânimos dos homens, e menos dor sobre o corpo do réu. $(1774, \mathrm{XLII}){ }^{88}$

Ou seja, uma "parte geral" das leis penais aparece aqui não mais como mera ferramenta organizadora de lei vigente, mas sim como axioma informador e regulador de todas as práticas jurídicas da punição de ilícitos públicos.

\section{III. "Delito" ou "Crime"}

A postulação de que o "penal" ganhou tardiamente autonomia é reforçada pela análise do conceito de "crime" em importantes obras jurídicas a partir do século XVII. Os textos jurídicos desde de então mostram como o "crime" passou por um processo desvinculação das demais infrações (legais, morais, religiosos) até ganhar um significado muito mais restrito às vésperas do direito penal contemporâneo. Esse processo deu-se em etapas. Primeiramente, circunscreveu-se o conceito de "delito" ou "crime" ao âmbito das infrações políticas, ou seja, às leis políticas de um Estado. Falando do alvorecer da modernidade, Sbriccoli (2002: 173 e ss.) lembra, na linha do que já se comentou no capítulo anterior, que o conceito de delito criminal era extremamente fraco pois, na linha do já citado caráter horizontal do direito penal de então e por conta da representação da violência estatal como o instrumento primordial para a garantia da paz, o seu objetivo era ser o mais amplo possível, gerando uma "doutrina penal" de pretensões expansivas. No mesmo sentido, Arno e Maria José Wehling (2004: 28) lembram que a concepção integrada do universo, de matriz tomista, favorecia a integração de "fundamentos teológicos, preceitos morais e normas jurídicas", situação que permaneceu forte durante o Antigo Regime. Tudo isso, é

88 "Consideradas simplemente las verdades has aquí expuestas, se convence con evidencia, que el fin de las penas no es atormentar y afligir un Ente sensible, ni deshacer un delito ya cometido. (...) Luego debrán ser escogidas aquellas penas, y aquel método de imponerlas, que guardada la proporcion, hagan una impresion mas eficaz y mas durable sobre los ánimos de hombres, y la menos dolorosa sobre el cuerpo del reo". 
evidente, era muito mais convidativo a uma doutrina criminal abrangente, projetada sobre todo o direito, do que confinada aos estreitos limites teóricos de uma entre muitas outras disciplinas. Quase paralelamente, operou-se a diferenciação dos "crimes" em relação aos ilícitos privados, identificando-se-lhes com os ilícitos de direito público, por oposição aos de direito privado. Por fim, deu-se sua especificação em relação aos demais ilícitos públicos, chegando então a algo próximo do conceito restrito de "crime" que seria um dos pontos de partida do direito penal contemporâneo.

Hobbes cuida deste tema no capítulo XXVII do Leviathan. Inicialmente, ele distingue os "pecados" (Sinnes) dos "crimes". A especificidade desses últimos está no fato de virem definidos nas leis civis, enquanto os pecados são dados pelas leis da natureza. "De forma que todo crime é um pecado; mas nem todo pecado é um crime" (1651a, XXVII). ${ }^{89}$ Os crimes são ou comissões fáticas, que incluem o proferir de "palavras prescritas pela lei", ou omissões em relação a deveres legais. Ao contrário dos pecados, os crimes não existem na simples resolução de cometê-los: é preciso algum ato exterior que os dê sensibilidade. A palavra latina Crimen, diz Hobbes, deriva do latim Cerno, que significa perceber ou discernir; e por isso os crimes são os únicos pecados que podem ser levados ao conhecimento de um juiz. ${ }^{90}$ Assiste-se já aqui ao primeiro passo de um processo de especificação do delito jurídico na modernidade, que passará a ser definido como aquilo que provoca perturbação social (externa), e que terá em Thomasius e Kant seus mais fortes divulgadores e conseguirá acomodar-se ao individualismo do século XVIII, como bem anota Hespanha. ${ }^{91}$

Há duas coisas importantes a ser salientadas nessa passagem do Leviathan. A primeira delas, que é o principal objeto deste item, é que a palavra "crime"

89 "A Crime, is a sinne, consisting in the Committing (by Deed, or Word) of that which the Law forbiddeth, or the Omission of what it hath commanded. So that every Crime is a sinne; but not every sinne a Crime".

90 "In like manner the Latines by Peccatum, which is Sinne, signifie all manner of deviation from the Law; but by crimen, (which word they derive from Cerno, which signifies to perceive,) they mean onely such sinnes, as my be made appear before a Judge; and therfore are not meer Intentions". (1651a: XXVII).

91 "Cette redefinition découle d'un nouveau concept de délit qui, dorénavant, est conoçu, très strictement, comme un fait qui porte atteinte à l'ordre extérieure de la société, considérée comme la somme de l'utilité publique avec l'utilité des particuliers". (Hespanha, 1990b: 403). 
não tem em Hobbes a conotação que hoje lhe atribuímos: ela significa para ele, genericamente, toda e qualquer violação a um comando provindo da lei positiva ("lei civil"), por oposição a violações a outros comandos puramente morais ou religiosos. A violação à lei positiva já mostrava a esta altura, portanto, alguma especificidade e autonomia em relação à violação de outros comandos práticos. Para entender como isso aparece no Leviathan, é preciso compreender propriamente aquilo que Hobbes quis dizer com sinne - que hoje em dia traduz-se como "pecado" -, e o que significa a afirmação de que o "crime" é um sinne definido em lei, já que a sua afirmação de que "todo crime é um pecado" parece sugerir justamente o oposto de uma laicização punitiva.

"Pecado" (Sinne) em Hobbes significa uma violação a qualquer comando que imponha um dever - "a transgression of a Law". Como as leis para Hobbes são naturais ou humanas, sinne significa o descumprimento de uma norma de conduta natural (moral) ou de uma lei humana ("civil", positiva). Na primeira das inferências a partir de seu conceito de "crime", Hobbes diz que não pode haver escusa para o sinne porque a proibição que dele advém não depende de autoridade ou declaração, mas apenas da razão humana, que faz evidente o mandamento de que ninguém deve fazer para o outro aquilo que não quer seja feito a si mesmo. Essa é para ele a segunda lei moral da natureza, derivada da lei fundamental de que a paz deve ser buscada $^{92}$ (1651a, XIV). Só crianças e loucos podem ser escusados a esse respeito, diz. Afirmar que um "crime" é um "pecado" quer dizer apenas que violar uma lei civil é

\footnotetext{
92 "From this Fundamentall Law of Nature, by which men are commanded to endeavour Peace, is derived this second Law; "That a man be willing, when others are so too, as farre-forth, as for Peace, and defence of himselfe he shall think it necessary, to lay down this right to all things; and be contented with so much liberty against other men, as he would allow other men against himselfe." For as long as every man holdeth this Right, of doing any thing he liketh; so long are all men in the condition of Warre. But if other men will not lay down their Right, as well as he; then there is no Reason for any one, to devest himselfe of his: For that were to expose himselfe to Prey, (which no man is bound to) rather than to dispose himselfe to Peace. This is that Law of the Gospell; "Whatsoever you require that others should do to you, that do ye to them." And that Law of all men, "Quod tibi feiri non vis, alteri ne feceris." (1651a, XIV)
} 
também descumprir com um dever natural específico, segundo o qual o homem deve (ought), e é seu dever (duty), não descumprir um ato voluntário seu. ${ }^{93,} 94$

Entretanto, ele insistia em diferençar os "crimes" em meio à grande massa dos "sinnes" em geral. Ao fazer isso, Hobbes estava postulando justamente o oposto daquilo que sugere uma leitura contemporânea literal da citada passagem: "crimes" não se confundem com violações às leis morais, pois eles têm um requisito institucional adicional: o seu caráter político, dado pela violação de um comando emitido por uma autoridade pública através de uma lei. Só diante desses requisitos institucionais adicionais a pessoa acusada de um "crime" pode ser levada à presença de um juiz e responsabilizada pelo seus atos "criminosos", porque sem leis civis, os "crimes" não existem, ainda que tenha havido violação de leis naturais; pois na violação de leis práticas não civis, cada homem é seu próprio juiz e não deve satisfações ao soberano. ${ }^{95}$ Portanto, o "crime" é acima de tudo uma falta política - a violação de um pacto expresso pelas leis. O propósito firme e decidido de matar alguém é um "pecado", mas não um "crime", diz ele. ${ }^{96}$ Vê-se aqui outra marca daquilo que Sbriccoli (2002: 178) identifica como um dos traços do nascente direito penal moderno: o dano social

${ }_{93}$ And when a man hath in either manner abandoned, or granted away his Right; then is he said to be OBLIGED, or BOUND, not to hinder those, to whom such Right is granted, or abandoned, from the benefit of it: and that he Ought, and it his DUTY, not to make voyd that voluntary act of his own (1651a XIV).

${ }^{94}$ A ideia do dever moral de cumprir as próprias promessas não está só em Hobbes: aparece também como fundamental em outros autores relevantes do jusnaturalismo moderno. Ela é a forma de justificar o porquê de termos de cumprir as regras sem ter de se recorrer ao respeito à vontade de Deus. Por esse caminho, diz Hochstrasser (Hochstrasser, 2000), essas teorias não chegam a negar a Deus; mas transformam-no num mero pressuposto. Esse passo foi decisivo no processo de secularização do direito. Também Kant, na polêmica com Constant sobre o direito de mentir (Über ein vermeintes Recht aus Menschenlibe zu lügen, 1797), onde ele argumentou que o direito tem uma inafastável pretensão à verdade (Höffe, 2005: 214).

95 "From this relation of Sinne to the Law, and of Crime to the Civill Law, may be inferred, First, that where Law ceaseth, Sinne ceaseth. But because the Law of Nature is eternall, Violation of Covenants, Ingratitude, Arrogance, and all Facts contrary to any Morall vertue, can never cease to be Sinne. Secondly, that the Civill Law ceasing, Crimes cease: for there being no other Law remaining, but that of Nature, there is no place for Accusation; every man being his own Judge, and accused onely by his own Conscience, and cleared by the Uprightnesse of his own Intention" (1651a, XXVII).

${ }^{96}$ Note-se bem o quanto isso é semelhante com a já citada ideia de Filangieri, de que o delito é a violação de um pacto social, o que é mais indicativo de como elementos de uma filosofia política absolutista como a de Hobbes migram para o discurso punitivo de um liberal como o pensador italiano. (Isso, aliás, reforça o já citado caráter poliglota da linguagem política, mostrando a facilidade com que ideias políticas de velhos paradigmas ajustam-se a paradigmas novos.) Sobre este ponto na teoria de Filangieri, v. Seelman (2001). 
proveniente da desobediência à lei (desordem, abalo à paz) é mais importante do que o simples obedecer por obedecer, que se circunscreverá cada vez mais ao campo da moral.

Hobbes fazia distinção entre "crimes públicos" e "crimes privados" (1651a, XXVII). A diferença era, em primeiro lugar, substantiva: nos crimes privados, a lesão dava-se apenas contra um particular; enquanto, nos crimes públicos, além do particular, também a República era vitimada. Mais ainda, havia também uma diferença processual: o processo nos crimes privados era movido por um particular, enquanto nos públicos, fazia-se em nome da República. ${ }^{97}$ Mas é importante notar como, a despeito dessa diferença, a palavra "crime" era ainda utilizada em sentido muito amplo, para referir-se a todo ilícito jurídico, fosse ele público ou privado. ${ }^{98}$

Blackstone, o conterrâneo de Hobbes que mais se destacou como jurista no século XVIII, já propagava uma acepção mais restrita de "crimes" nos seus Commentaries on the Laws of England. Ele cuidou da natureza dos "crimes" no quarto livro dos Commentaries, voltado às "violações públicas" (Public Wrongs). Tais ofensas podem ser de dois tipos: (i) "crimes" ou - na tradução presente ${ }^{99}$ - (ii) "contravenções" (misdemeanors). Essas duas modalidades de ofensas públicas não se confundiam com

\footnotetext{
97 "Lastly, because in almost all Crimes there is an Injury done, not onely to some Private man, but also to the Common-wealth; the same Crime, when the accusation is in the name of the Common-wealth, is called Publique Crime; and when in the name of a Private man, a Private Crime; And the Pleas according thereunto called Publique, Judicia Publica, Pleas of the Crown; or Private Pleas. As in an Accusation of Murder, if the accuser be a Private man, the plea is a Private plea; if the accuser be the Soveraign, the plea is a Publique plea". (1651a, XXVII. Destaques meus.)

${ }^{98}$ É interessante apontar que o Código Criminal de 1830 dividia sua parte especial em "crimes públicos" e "crimes privados", mas todos eram matéria estritamente criminal.

99 Não é necessariamente correta, do ponto de vista histórico, a tradução de "misdemeanors" por "contravenções". Pois misdemeanors são simplesmente um tipo menos grave de ilícito criminalmente apenado, que poderiam, naquele tempo, ser tanto "contravenções", quanto "delitos". Como a tradição jurídica brasileira, seguindo o caminho do Código de 1830, sempre tratou "delitos" como sinônimos de "crimes", traduzirei "misdemeanors" por contravenções, com a ressalva de que isso quer apenas significar um tipo de ilícito apenado com penas públicas menos severas.
} 
as violações privadas, as "lesões civis" ("civil injuries"). ${ }^{100}$ A especificidade dos "crimes" era explicada da seguinte maneira:

A distinção entre violação públicas e privadas, entre crimes e contravenções e lesões civis, parece consistir principalmente no seguinte: as violações privadas, ou lesões civis, são uma infração ou privação de direitos civis que pertencem a indivíduos, considerados meramente enquanto indivíduos; violações públicas, ou crimes e contravenções, são uma quebra e violação de direitos e deveres públicos, devidos à comunidade como um todo, considerada enquanto comunidade, em sua capacidade social agregada. Se eu tomo de algum homem o pedaço de terra que a lei conferiulhe por direito, isso é uma lesão civil, e não um crime; pois aqui apenas o direito de um indivíduo é relevante, e a questão não tangencia o público, qual de nós em posse da terra: mas traição, assassinato e roubo são propriamente elencados entre os crimes; uma vez que, além da lesão a indivíduos, eles atingem o próprio ser da sociedade; que não pode possivelmente subsistir, onde ações desse tipo são sofridas e escapam impunes. $(1765-9$, IV $, \mathrm{I}, 5) .{ }^{101}$

\section{Blackstone sustenta sua definição de crime em Beccaria, ${ }^{102}$ que} publicara seu livro poucos anos antes. No marquês já se via o processo de especificação teórica do conceito de infração penal: o "delito" era tido como algo distinto não só da

100 "We are now arrived at the fourth and last branch of these commentaries; which treats of PUBLIC WRONGS, or crimes and misdemeanors. For we may remember that, in the beginning of the preceding volume, wrongs were divided into forts or species; the one private, and the other public. Private wrongs, which are frequently termed civil injuries, were the subject of that entire book: we are now therefore, lastly, to proceed to the consideration of PUBLIC WRONGS, or crimes and misdemeanors". (Blackstone, 1765-9: VI, I, 1).

101 "The distinction of PUBLIC WRONGS from private, of crimes and misdemeanors from civil injuries, seems principally to consist in this: that private, or civil injuries, are an infringement or privation of the civil rights which belong to individuals, considered merely as individuals; wrongs, or crime and misdemeanors, are breach and violation of the public rights and duties, due to the whole community, considered as community, in it's social aggregate capacity. As if I detain a field from another man, to which the law has given him a right, this is a civil injury, and not a crime; for here only the right of an individual is concerned, and it is immaterial to the public, which of us in possession of the land: but treason, murder, and robbery are properly ranked among crimes; since, besides the injury done to individuals, they strike at the very being of society; which cannot possibly subsist, where actions of sort are suffered to efcape with impunity".

102 Pires (1998a) diz que em Beccaria encontram-se as raízes da especificação substantiva do ilícito puramente penal. A análise de Blackstone mostra que, ao menos para os seus contemporâneos, ele não era visto assim: o nobre inglês usa Beccaria para sustentar uma definição de "crime" que compreende ainda todos os ilícitos públicos, não distinguindo, por exemplo, ilícitos penais e administrativos. 
falta moral, mas também das demais violações à lei civil. Se na definição de "crime" em Hobbes a distinção relevante é entre a violação à lei moral ("pecado") e a violação às leis "civis" ("crime"), em Beccaria a distinção mais relevante é entre o cometimento de um "delito" e outras formas de transgressão à lei, sejam elas civis ou morais. Só a violação à lei criminal é um "delito", e só a esse tipo de violação se refere o "direito penal" ou "criminal", com suas penas respectivas. É importante ressalvar que em Dos Delitos e Das Penas, o uso da palavra "delito" nem sempre tem, evidentemente, a especificidade com que hoje a utilizamos. Algumas vezes, as noções de "delito", "pena" e "criminoso" parecem ter acepção mais geral, referentes à ordem jurídica como um todo (Pires, 1998b); mesmo porque esse era o significado corrente até então, e o constante uso de textos clássicos para o estudo das questões "criminais" perpetuava o seu emprego com significados às vezes alargados. Mas um olhar atento à maneira de sua utilização e ao argumento geral de Beccaria mostram como o autor queria distinguir o ilícito penal de outras faltas comportamentais, políticas ou morais.

Em primeiro lugar, vale dizer que, assim como Hobbes, Beccaria separava expressamente os deveres jurídicos de outros deveres morais, em especial os religiosos. Neste ponto, a distinção-chave é muito parecida com Hobbes: há comportamentos nossos que são internamente exigíveis, e há outros que são apenas externamente exigíveis. Na literatura jurídica e política da época, esse ponto era quase sempre remetido à filosofia de Christian Thomasius (e a partir do século XVIII, à de Kant). ${ }^{103}$ Os deveres jurídicos seriam apenas externos: nada daquilo que se passe dentro da minha cabeça teria relevância para o (des)cumprimento dos meus deveres políticos e jurídicos. O contraponto de Beccaria é sobretudo o dever religioso: quem toma o pecado como medida da gravidade de um delito incorre na falácia de equiparar a relação Deushomem (dever religioso) a uma relação homem-homem (dever político e jurídico) (1774, VII). Assim, por exemplo, se o suicídio é sem dúvida um dever religioso, ele não pode ser considerado um dever político em razão da ausência de dano externo da conduta. Note-se bem: Beccaria não está interessado em negar a existência de deveres religiosos ou morais. Como jusnaturalista que era, reconhecia a existência desses

${ }^{103}$ Tomás y Valiente (1992: 231-2) anota, entretanto, que a distinção entre foro interno e externo já era freqüente na escolástica medieval. 
últimos e muita coisa em sua obra dependia deles: nos deveres morais estavam, por exemplo, os fundamentos de seu contratualismo. Ainda assim, Beccaria procurou associar os deveres jurídicos, e sua respectiva violação, a um tipo específico de pacto, que envolveria um número plural de pessoas e diria respeito aos interesses materiais da vida humana. Por isso, diz ele que as relações entre seres humanos "são relações de igualdade" e que a "necessidade, exclusivamente, fez nascer, do choque das paixões e da oposição dos interesses, a ideia de utilidade comum, que é a base da justiça humana" (1774, VI). O dever jurídico distingue-se, portanto, dos deveres religiosos e morais porque representa a violação de um pacto entre iguais, que permite o julgamento do transgressor por um semelhante seu; ao passo em que na violação de um dever religioso, o julgamento é feito por Deus, "que é ao mesmo tempo Legislador e Juiz" (cit.). ${ }^{104}$

Separados os deveres jurídicos dos demais, o passo seguinte foi a separação do ilícito penal dos demais ilícitos jurídicos. Para isso, Beccaria associou ao "delito" (i) o descumprimento de um conjunto específico de deveres jurídicos, e não de todo e qualquer dever jurídico; e (ii) a uma forma específica de punição desses descumprimentos.

Em Dos Delitos e Das Penas, lê-se repetidas vezes que o "delito" é um tipo específico de violação, porque atinge frontalmente o interesse público. Diz ele que entre todas as desordens que resultam da reunião de seres humanos em uma comunidade, chamam-se "delitos" apenas "as ações opostas ao bem público" (1774, VI), e por isso "o dano feito à sociedade é a verdadeira medida dos delitos" (1774, VIII). Mesmo aqueles delitos que têm por objeto apenas bens e ações individuais são pensados a partir do interesse público. "Todos os delitos, mesmo os privados, ofendem a sociedade", diz (1774, VIII). É um caminho semelhante ao que escolheria Blackstone pouco depois: nos "crimes" contra privados, uma só conduta faria nascer duas relações, uma privada e outra pública; e é também já uma inversão em relação à então prevalecente lógica do direito romano: o delito poderia ter por objeto uma vítima

\footnotetext{
${ }^{104}$ Também no §XXXIX Beccaria diz que não falará dos pecados, que são um gênero particular de delitos. Nesta passagem, a palavra "delitos" vem usada em acepção ampla e abrange também os deveres religiosos.
} 
privada e seus bens privados, e mesmo assim ser de natureza pública, por violar o interesse público.

O bem público, que é o terreno dos delitos, não precisa, "para ser descoberto, de "quadrantes ou telescópios, pois se apresenta à primeira vista a qualquer entendimento mediano" (1774, VIII); enquanto o interesse privado, apesar de legítimo, é variável de pessoa a pessoa. Fosse o delito pensado a partir do interesse privado, diz Beccaria, "seria necessário formar não só um código particular para cada cidadão, mas também uma nova lei para cada delito" (1774, VII). O critério material de separação entre o direito penal e o direito civil, portanto, é o seguinte: o primeiro cuida dos interesses consensuais da sociedade, enquanto o último pertence à esfera de discussão de tudo aquilo que, dentro dos limites autorizados pelo interesse público, seja particular ou individual. ${ }^{105}$ Dessa forma, não espanta que Blackstone, que tomava de Beccaria a definição de delito, definisse os "crimes" como as violações às leis de direito público.

Por essa razão, enquanto o ilícito privado voltar-se-ia contra um particular, o ilícito público dirigir-se-ia contra toda a comunidade política, fosse a vítima-objeto uma pessoa privada ou pública. Dado que no pensamento político moderno e contemporâneo o soberano era concebido como a figura que representaria politicamente a comunidade e guardaria as ferramentas necessárias à sua consecução e conservação, descumprir uma lei pública seria, antes de qualquer outra coisa, desobedecer a uma ordem soberana com vistas à preservação da harmonia social, voltada ao bem de toda a comunidade. Logo, soberano e o interesse coletivo que ele representaria, e em função do qual ele existiria, seriam os ofendidos pelas violações às leis públicas. Essa foi uma importante inovação do mundo moderno: no começo da Baixa Idade Média,

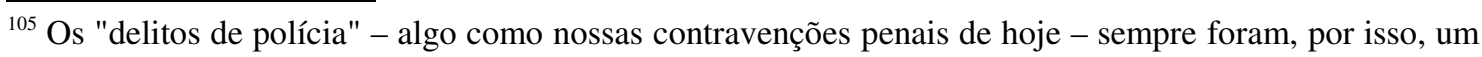
terreno desconfortável para os teóricos do direito penal liberal que, como Beccaria, conceituavam o delito a partir do consenso. A solução foi postular que os delitos de polícia, porque variáveis de uma sociedade para outra, estariam fora do consenso, e ficavam fora do núcleo central do "verdadeiro" direito penal; falando anacronicamente, eram uma mistura entre direito penal e direito administrativo. Beccaria tem um ensaio de maturidade em que se dedica ao tema: trata-se do comentário ao Código Penal Austríaco de José II, e está publicado na coletânea de Beccaria organizada por Sergio Romagnoli (1958. Beccaria. Opere. Firenze: Sansoni).
} 
um crime não era geralmente concebido como uma ofensa dirigida à ordem política como tal, ou contra a sociedade em geral, mas sim como uma ofensa dirigida contra a vítima e contra aqueles com que ela se identificava - seus parentes, ou sua comunidade territorial, ou sua classe feudal (Berman, 1983: 181).

Nas épocas de Hobbes, Beccaria e Kant, já havia se estabelecido que o soberano e a sociedade, a quem ele representava e por quem ele existia, eram os principais atingidos pela quebra da lei. É essa a origem, segundo Foucault (2005: 80), do conceito de "infração": ${ }^{106}$ a vítima sofre a ação, mas o soberano sofre a infra-ação. Isso aparece em Blackstone com grande clareza: ${ }^{107}$

O rei, em quem concentra-se a majestade de toda a comunidade, deve pela lei ser a pessoa lesionada por toda infração do direito público pertencente à comunidade, e é portanto em todos os casos, o persecutor autorizado de toda ofensa pública. (1765-9, IV, I, 2. $)^{108}$

Em muitas teorias políticas iluministas, a representação do detentor da soberania pública era feita, como em Kant ${ }^{109}$ ou Beccaria, ${ }^{110}$ mais no legislador do que no rei. Mas, seja como for, permanecia a ideia de que as leis públicas, e as violações aos seus comandos - os "crimes" - eram, ao contrário das violações às leis de índole

\footnotetext{
${ }^{106}$ No mesmo sentido, Pires (1998: 21).

${ }^{107}$ A Landrecht prussiana de 1794 também afirmava taxativamente que quem cometesse um crime feria não só a vítima, mas também o Estado: "§. 7. Wer durch eine freye Handlung jemanden widerrechtlich Schaden zufügt, der begehet ein Verbrechen, und macht sich dadurch nicht nur dem Beleidigten, sondern auch dem Staate, dessen Schutz derselbe genießt, verantwortlich".
}

108 "The king, in whom centers the majesty of the whole community, is supposed by the law to be the person injured by every infraction of the public right belonging to that community, and is therefore in all cases the proper prosecutor for every public offence".

${ }^{109}$ Kant diz que todo estado do direito público contém três poderes em si, sendo que o poder soberano Herrschergewal (Souveranität) - está no legislador (Gesetzgeber), que não se confunde com o poder executivo do regente (Regierer), que deve seguir a lei posta pelo poder soberano (Kant, 1797: VL).

${ }^{110}$ No capítulo III de Dos Delitos e Das Penas, Beccaria diz que o representante da vontade da sociedade é o poder de legislar, e não de aplicar as leis. É importante lembrar que na ordem jurídica do Antigo Regime - contra qual Beccaria escreve - o poder jurisdicional estava freqüentemente nas mãos do Rei. $\mathrm{O}$ Livro III (Direito Público) das Instituições de Mello Freire é exemplar nesse sentido. Daí o porque de o arbítrio judicial ser um tema tão importante para quem, como os iluministas franceses, queria limitar o poder real. 
privada, perturbações que extrapolavam os interesses da vítima material do delito por repercutirem sobre toda a sociedade.

Finalmente vale acrescentar que, mesmo em fins do século XVIII, para um influente autor do direito penal contemporâneo como Bentham, a distinção do delito civil e do delito penal era, do ponto de vista substantivo, muito pequena, para não dizer nenhuma. A única coisa que permitiria inequivocamente separar a jurisprudência civil da jurisprudência penal, ou criminal, seria a punição criminal, dizia ele. $\mathrm{O}$ "delito jurídico" era algo que não se restringia a uma área particular do direito, mas, ao contrário, "dominava toda a legislação" (1830, T. I: 47). Para além disso, as matérias civis e penais misturavam-se a todo tempo, sendo impossível confiná-las por qualquer outro critério aos domínios de um ou outro ramo da jurisprudência (civil ou penal). $\mathrm{O}$ que acontecia, por conveniências metodológicas, sempre segundo Bentham, é que a pena criminal acabava funcionando como um "buraco negro" teórico: ela atraía todo e qualquer ilícito civil a ela ligado para os domínios do direito criminal ou penal (ele não distinguia entre os dois termos), fazendo com que esse objeto passasse a se considerar um ilícito criminal em lugar de civil (Principles, XVII, 2, IX). ${ }^{111}$ Por isso, a busca por características distintivas do ilícito criminal era uma busca vã: a constituição do delito não era problema do penalista; era-o, apenas, a pena e sua imposição.

$$
* * *
$$

Portanto, o que se pode notar no que respeita ao conceito de "crime" é que, em primeiro lugar, influentes juristas e pensadores dos momentos anteriores à formação do direito penal contemporâneo não lhe davam uma definição uniforme: os do século XVII (Hobbes, Pufendorf) usavam a expressão para representar a violação a toda e qualquer lei positiva, mesmo quando, como mostrado em Hobbes, já distinguiam entre as leis relativas ao "público" e ao "privado". Essa pouca distinção entre delitos civis e criminais aparece ainda em fins do século XVIII, na obra de Bentham. Ademais, deve-

111 "It should seem then, that, wherever a simply imperative law is to have a punitory one appended to it, the former might be spared altogether: in, which case, saving the exception (which naturally should seem not likely to be a frequent one) of a law capable of answering its purpose without such an appendage, there should be no occasion in the whole body of the law for any other than punitory, or in other words than penal, laws". 
se registrar que, mesmo quando o conceito de "crime" ou "delito" era utilizado com uma conotação mais estreitamente associada com as violações legais que repercutem sobre a ordem pública (Beccaria, Blackstone), esses conceitos designavam ainda toda e qualquer violação de uma lei pública, sem referência a um ramo específico como o nosso direito penal dos dias de hoje. O máximo que havia estava em Beccaria e no código josefino, que diferençavam entre os "delitos" e os "crimes políticos", ou infrações meramente policiais. A especificação do ilícito propriamente criminal dentro do direito público, por meio de uma sólida especificação teórica, é algo que foi legado aos fundadores do direito penal contemporâneo, e os capítulos seguintes mostrarão como isso se deu.

\section{Punição}

A exemplo do que acontecia com o "delito", faltava no início do direito moderno um conceito abstrato de "pena criminal" (Tomás y Valiente, 1992: 353). A necessidade de conceituar abstratamente a pena a que se assiste na modernidade denuncia o esforço teórico de diferençá-la de outras formas de intervenção estatal, bem como das penitências que apenas diziam respeito às violações de foro interno. Nesse tocante, houve uma grande quantidade de permanências, na modernidade jurídica, de elementos pertencentes a doutrinas do passado. Segundo Pires (1998a: 33 e ss.), ao menos desde a Baixa Idade Média, as doutrinas teológico-jurídicas da punição, de que a de Santo Anselmo é exemplar, já trabalhavam com alguns elementos que, como "cápsulas", passaram para gerações posteriores e encontraram, em diferentes períodos, diversos ambientes culturais e institucionais que os permitiram aflorar ora com mais, ora com menos força. Esses elementos incluíam: (i) uma concepção estrita de punição, que não se confundia com a reparação civil; (ii) a percepção de que a punição deveria ser um mal, e consequentemente implicar algum tipo de sofrimento ou restrição; (iii) a postulação de que a punição deve ser aplicada por (ou em benefício de) uma certa autoridade; bem como (iv) a defesa de que a quantidade da pena não pode implicar uma punição inferior à magnitude do ilícito (pecado) praticado (Pires, 1998a: 32-3). É evidente que a doutrina de Santo Anselmo, como teológica que era, deve ser vista no 
quadro de uma concepção de justiça divina, tendo Deus como autoridade. Mas ainda assim, é importante perceber que, naquilo que Berman (1983) identifica como o século de formação do direito ocidental - 1050 a 1150, o século da Revolução Papal -, alguns dos pontos substantivos que seriam utilizados para a noção de "pena" no direito penal contemporâneo já estavam postos. O mesmo Berman (1983: 180) lembra que Anselmo foi acusado por seus contemporâneos de haver adotado uma visão excessivamente "jurídica" ou "legalista" do castigo, por sua preocupação sobre como a correção divina (a iustitia de Deus) manifestava-se em formas e regras; e lembra, também, que o direito penal ocidental tem uma forte matriz teológica (1983: 181 e ss.). ${ }^{12}$

A despeito desse traços perenes, é claro que muita coisa nova foi juntada na modernidade à velha ideia de pena como "um sofrimento aplicado pela autoridade em razão do mal praticado". Essas novidades não foram sem importância, e respondem por aquilo que seria, em fins do século XIX, o maior conflito teórico já havido dentro dos domínios do direito penal contemporâneo, a saber, a disputa entre classicismo e positivismo criminal quanto aos fundamentos, natureza e funções das respostas penais (penas e medidas de segurança). Na história do pensamento jurídicopenal, elas podem ser rememoradas por dois temas, distintos porém interligados: (i) as doutrinas do direito de punir; e (ii) a representação antropológica de ser humano com que tais doutrinas trabalhavam.

Por meio desses dois tópicos, é possível acessar aquele que era o mais importante debate teórico da filosofia moral (e, por consequência, das doutrinas jurídicas sobre a punição) do direito penal pré-contemporâneo: as disputas entre retributivistas e utilitaristas. Como já foi dito no primeiro capítulo, essa disputa permanece até hoje viva na filosofia moral; e, como será mostrado nesse item, ela era também viva na doutrina jurídica anterior ao direito penal contemporâneo. Neste tema, porém, há um dado curioso no direito penal contemporâneo: como os penalistas de hoje em dia bem sabem, "idealistas" e "sensualistas" sempre tiveram uma convivência razoavelmente pacífica dentro do nosso direito penal, haja vista a grande quantidade de adeptos das "teorias mistas da pena", que se baseiam, a um só tempo, na retribuição do

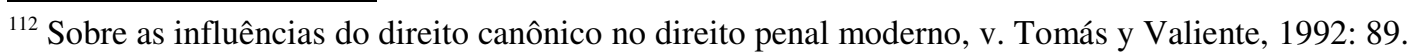


mal e na prevenção dos delitos, na linha do já citado Filangieri: "importância do pacto social violado" e "maldade no coração". Esse trabalho de pacificação teórica foi outro importante legado dos fundadores do direito penal contemporâneo para as gerações de penalistas que os sucederam. Para mostrar nos capítulos seguintes como isso ocorreu, é preciso, antes, rememorar o estado em que se encontravam as doutrinas sobre o fundamento do direito de punir e a imagem teórica do "criminoso" com que se trabalhava então.

\section{O DIREITO DE PUNIR}

Falando de forma muito elementar, em muitos autores modernos o fundamento da ordem política está no consentimento ideal de um ser humano racional em relação aos direitos e deveres de súditos e soberano, com vistas a um determinado fim. Tal acordo teria por objeto garantir aos súditos uma vida pacífica dentro de uma ordem social regrada, e a punição tinha algo importante a ver com isso. Do ponto de vista moral, era também comum que os pensadores dos séculos XVII e XVIII enxergassem no mesmo homem tanto aptidões intelectuais quanto paixões, que seriam fontes de impulsos que às vezes ajudavam (e às vezes atrapalhavam) na consecução de certos objetivos socialmente úteis; e que enxergassem na pena um meio para estimular os recalcitrantes a abster-se de ações indesejáveis ou ruins. Há, note-se bem, uma grande presença de elementos de filosofia política nessas ideias "penais", o que também é marca do alargamento do "criminal" em face dos objetivos políticos do Estado: se na baixa Idade Média as teorias sobre o direito de aplicar uma punição eram assunto extremamente técnico e de domínio exclusivo dos legistas, a elevação da punição a uma das ferramentas centrais para o cumprimento da missão política do Estado moderno tornou-a objeto de interesse de um público mais extenso, incluindo os filósofos políticos da modernidade e da ilustração (Hespanha, 1990a: 193). As teorias sobre o direito de punir, que antes tinham de ser desemaranhadas em meio a um conjunto pouco manejável de regras e opiniões doutrinárias, passaram a interessar a todo o corpo social, 
e por isso passaram a vir expressas em linguagem menos técnica, quando não francamente panfletária, como nos casos de Beccaria e, em certas ocasiões, Voltaire.

Importante aqui é registrar que no imaginário daquele tempo, havia duas forças intelectuais - paixões e razões - trabalhando em conjunto dentro do intelecto humano. Essa complicada equação ética foi resolvida de maneiras distintas por distintos autores. Ainda pelas mesma linhas gerais, é possível dizer que algumas raras vezes, a razão e as paixões concordavam e trabalhavam bem em conjunto. A fundação da sociedade civil era um desses casos. Dado que sobreviver é melhor do que morrer, e que viver na ordem é melhor do que vier no caos, temos de conceber uma forma de garantir nossa sobrevivência em um ambiente minimamente regrado. Falando especificamente de Hobbes, é isso que Dyzenhaus (2001: 463) chama de uma visão externa da sociedade civil: o interesse individual (self-interest) dos homens compele-os a ver que qualquer ordem é preferível ao caos e que a submissão aos atos de vontade alguém é a melhor forma de atingir algum tipo de ordem. Neste pequeno espaço de cooperação entre razão e paixões, concebe-se a plausibilidade de, na situação hipotética de passagem do estado de natureza para a sociedade civil, um ser humano abrir mão do direito de fazer "tudo aquilo que quisesse, como quisesse e com quem quisesse" para aceitar viver sob as limitações das leis. Em Kant, a passagem do estado de natureza para o estado civil não era um mandamento instintivo, mas sim um imperativo moral puramente racional. A razão, nesse caso, permitia reconhecer um dever de fundação do Estado e dava aquilo que seria o postulado primeiro do direito público: "Tu deves, em uma relação de coexistência necessária, sair com todos os demais [de uma condição natural] e passar para a condição jurídica, isto é, um estado de uma justiça distributiva" (Kant, 1797: 42). ${ }^{113}$

De qualquer forma, e mesmo com as profundas diferenças entre Kant e Hobbes e às antropologias pressupostas a suas respectivas teorias políticas, o certo é que a sociedade civil fundava-se com um consentimento dos súditos, seja porque tinham medo, seja porque agiam de acordo com uma máxima moral de direito público.

\footnotetext{
113 "Aus dem Privatrecht im natürlichen Zustande geht nun das Postulat des öffentlichen Rechst hervor: du sollst, im Verhältnisse eines unvermeidlichen Nebeneinanderseyns, mit allen Anderen, aus jenem heraus, in einen rechtlichen Zustand, d. i. den einer austheilenden Gerechtigkeit, übergehen".
} 
Para a fundamentação do direito de punir, entretanto, as coisas já não corriam assim com tanta fluidez. Em Hobbes, os instintos humanos que teriam possibilitado a fundação da sociedade civil seriam, ao mesmo tempo, incompatíveis com a outorga de um direito de se deixar punir. Afinal, se temos por instinto rejeitar dor e sofrimento e preferir vida à morte, por que aceitaríamos previamente nossa própria punição? Uma importante mudança no fundamento do direito de punir em Hobbes, dos Elements of Law ao De Cive, parece estar ligada a isso: enquanto no primeiro a punição fundamenta-se na renúncia ao direito de resistência (1650 II, XX, 7), no De Cive (1651b, VI, V) seu fundamento está na renúncia ao direito de assistência dos demais súditos em relação ao punido.

Sua posição no Leviathan é mais difícil de precisar, pois há na obra passagens que apontam em direções distintas. Segundo a tese de Gauthier de que o soberano é um superior de jure (e não meramente de fato), os súditos teriam obrigação de acatar as ordens do soberano inclusive no tocante à punição (apud Norrie, 1991: 15). Norrie indica a plausibilidade dessa interpretação ao lembar a passagem que trata da resistência ao soberano: "se aquele que tentar depor seu soberano for morto, ou punido pela tentativa, ele é autor de sua própria punição, como será, institucionalmente, autor de tudo o que o soberano fizer". 114

De outra parte, dada a importância da auto-preservação para a ética hobbesiana, não é tão tranquila a posição de que os súditos concederiam um tal direito ao soberano. Aliás, Hobbes afirma expressamente no Leviathan que um homem jamais outorgaria ao soberano o direito de lhe punir:

\footnotetext{
Mas eu também afirmei anteriormente, que antes da instituição da República, todo homem tinha o direito de fazer tudo, e de fazer qualquer coisa que julgasse necessária para sua preservação; subjugando, ferindo, ou matando qualquer outro homem para esse fim. E isso é o fundamento daquele direito de punir, que é exercido em toda República. Pois os súditos não deram ao sobreano aquele direito; mas apenas ao renunciar o seu, fortaleceram o soberano para que usasse o
}

\footnotetext{
114 "Besides, if he that attempteth to depose his Soveraign, be killed, or punished by him for such attempt, he is author of his own punishment, as being by the Institution, Author of all his Soveraign shall do" (1651a, XVIII).
} 
seu próprio, como achasse conveniente, para a preservação de todos: então esse direito não foi dado a ele, mas deixado a ele apenas. (1651a, XXVIII. Destaques meus.) $)^{115}$

Essa última passagem indica que a teoria de Hobbes dá a razão pela qual eu não posso intervir na punição de um terceiro, mas não indica aquela pela qual é justa a minha própria punição, uma vez que, como já foi dito, o campo da justiça é para ele o dos acordos e, pela teoria antropológica com que trabalha, ninguém acordaria previamente com sua própria pena. Em outras palavras, ela pode explicar a punição como o exercício de uma força superior e irresistível, mas não justifica o direito de punir, ao menos não enquanto um direito civil. ${ }^{116}$ Por isso, diz Norrie (1991: 17) que a punição é em Hobbes o exercício de um poder de fato que o soberano carrega consigo do estado de natureza, e não propriamente um direito proveniente do acordo com seus súditos. ${ }^{117}$ De acordo com Ribeiro, isso torna inclusive justa a resistência à pena de morte em sua teoria: "socializei-me para garantir a vida, precária na condição natural de guerra; se o próprio soberano a ameaçar, devo reaver a liberdade para defendê-la" (2004: 93).

A formação do direito de punir em Beccaria é bastante diferente. Seu contratualismo punitivo aparece evidente em sua famosa passagem sobre a cessão das partes mínimas de liberdade:

Foi, pois, a necessidade que obrigou os homens a ceder parte de sua própria liberdade: e é certo que cada um não quer colocar no depósito público senão a porção menor que seja possível, aquela que baste a mover os homens para que o

\footnotetext{
115 "But I have also shewed formerly, that before the Institution of Common-wealth, every man had a right to every thing, and to do whatsoever he thought necessary to his own preservation; subduing, hurting, or killing any man in order thereunto. And this is the foundation of that right of Punishing, which is exercised in every Common-wealth. For the Subjects did not give the Soveraign that right; but onely in laying down theirs, strengthned him to use his own, as he should think fit, for the preservation of them all: so that it was not given, but left to him, and to him onely".

${ }^{116}$ Nesse sentido, Ribeiro (2004: 92) diz que, ficando a punição fora do terreno dos pactos, o direito de punir é apenas um direito que o soberano trouxe consigo do estado natural, por não havê-lo renunciado ao entrar no estado civil.
}

${ }^{117}$ No mesmo sentido, Ribeiro (2004: 93), para quem o direito que o soberano hobbesiano tem de matar um súdito seu decorre do direito de natureza que continua em suas mãos. 
defendam. $\mathrm{O}$ agregado de todas essas pequenas porções de liberdade possíveis forma o direito de castigar" $(1774$, II).

Há aqui duas diferenças importantes em relação a Hobbes. A primeira diz respeito à possibilidade de transferência de direitos de punição dos súditos para o soberano: enquanto Hobbes rejeita que o direito de punir tenha seu fundamento em um ato de transferência, Beccaria admite-o expressamente. A segunda toca à extensão, no âmbito das possibilidades, do direito que o soberano tem de punir. Enquanto em Hobbes o soberano torna-se um ser com poderes absoluta e infinitamente maiores que os súditos, em Beccaria não: o soberano do marquês só tem o direito de aplicar a pena mínima necessária, porque a pena mínima restringe minimamente a liberdade dos súditos e foi só essa parcela mínima que eles concordaram em ceder. Qualquer penalização excedente, diz Beccaria, "é abuso e não justiça: é Fato, e não Direito" (1774, II). Se notarmos bem, entretanto, há aqui um ponto de importante semelhança com a teoria hobbesiana, e que diretamente se relaciona com o conteúdo de uma doutrina da responsabilidade criminal: a ideia de que, pela psicologia humana, a aceitação da própria punição é algo difícil de se conceber. Se em Hobbes não aceitaríamos a nossa própria punição, em Beccaria não aceitamos nada além da punição absolutamente mínima.

A fundamentação kantiana para o direito de punir é feita de maneira puramente ideal. Não se trata de uma fundamentação política da pena, como em Beccaria, mas da busca por uma razão categórica pela qual a punição é cabida. Kant tampouco busca uma definição da pena com vistas à antropologia humana passional, com faz Hobbes; ao contrário, rejeita-a expressamente. Na primeira de suas principais obras éticas, a Fundamentação da Metafísica dos Costumes, Kant dizia que o principal problema da filosofia moral do século XVIII era a mistura indevida de elementos naturais e metafísicos, e postulava que nenhuma teoria moral poderia ser bem construída com base na antropologia, mas tinha de sê-lo, ao contrário, em conceitos de razão pura válidos a priori; de forma a distinguir a mera regra prática (praktische Regel) da verdadeira lei moral (moralisches Gesetz) (Kant, 1785: 7). Nesse campo mais 
elementar dos nossos conceitos morais, a desobediência da lei é um mal que só pode ser reparado pela punição do culpado através da pena de intensidade equivalente: moralidade ou justiça são os fundamentos da punição (Pires, 1998c: 165), e não uma certa específica autorização política, como em Beccaria, ou uma lei do mais forte remanescente do estado de natureza, como em Hobbes. E, mais do que isso, não se exige que ninguém concorde previamente com a própria punição, como Kant (1797: 185) anota ao refutar o argumento "sofista" de Beccaria (o adjetivo é dele próprio); exige-se, apenas, que se reconheça a sua conformidade com a lei moral.

Pensando a pena somente a priori, a teoria penal de Kant não tem grandes rodeios ou sofisticações, e aproxima-se deveras daquilo que Pires e Berman apontam como vestígios pré-modernos da doutrina teológica da punição, se bem que secularizada. Dado que todos os homens são racionais, e que uma doutrina da moralidade só faz sentido a partir desse pressuposto, o crime só pode ser entendido, em uma metafísica da moral, como uma ação comandada racionalmente à delinquência: não há outra saída senão assumir que a máxima do criminoso é dar-se ao crime por regra, diz ele. ${ }^{118}$ A punição, em consequência, é aplicada apenas e tão-somente em razão de o "criminoso" ter escolhido, por livre arbítrio, delinquir; e não pode fundamentar-se em qualquer efeito prático, ${ }^{119}$ sob pena de tornar-se imoral por violar sua dignidade. ${ }^{120}$ Para ser justa, essa pena deve ser medida e especificada a partir do crime cometido, na mais estreita proporcionalidade possível. ${ }^{121}$ Este é um elemento que, como anota Seelman (2001: 5-6), tem importância crucial para as doutrinas da imputação e responsabilidade

\footnotetext{
118 "Eine jede Übertretung des Gesetzes kann und muss nicht anders, als so erklärt werden, dass sie aus einer Maxime des Verbrechers (sich eine solche Unthat zur regel zu machen) entspringe; denn, wenn man sie von einem sinnlichen Antrieb ableitete, so wäre sie nicht von ihm, als einem freien Wesen, begangen, und könnte ihm nicht zugerechnet werden"(1797: 185).

${ }^{119}$ Rechtliche strafe (...) kann niemals blos als Mittel, ein anderes Gute zu befördern, für den Verbrecher selbst, oder für die bürgerliche Gesellschaft, sondern muss jederzeit nur darum wider ihn verhängt werden, weil er verbrochen hat; denn der Mensch kann nie blos als Mittel zu den Absichten eines Anderen gehandhabt und unter die Gegenstände des Sachenrechts gemengt werden, wowider ihn seine angeborne Persönlichkeit schützt, ob er gleich die bürgerliche einzubüssen gar wohl verurtheilt werden kann" (Kant, 1797: IL, E).

${ }^{120} \mathrm{Na}$ filosofia moral kantiana, "dignidade" significa o valor de todas as coisas que são fins em si mesmas, e que portanto não podem ser comparadas por qualquer critério de quantificação umas com as outras. O "preço", ao contrário, dá o valor de todas as coisas que são fins e podem ser substituídas por outras de valor equivalente. Esta distinção é apresentada na Fundamentação da Metafísica dos Costumes (Kant, 1785: 64).
} 
no direito penal contemporâneo. Pode-se dizer, portanto, que no campo exclusivo da moralidade, a doutrina kantiana não fazia mais do que apontar para alguns fundamentos elementares a respeito da punição (seu propósito nem era mais do que esse, aliás): (i) a pena só pode ser aplicada em face de um crime cometido por um ser humano responsável, sendo vedada a punição de inocentes e daqueles que agem fora de consciência; (ii) ela deve guardar proporcionalidade ao ilícito cometido; (iii) são permissivos morais da punição a responsabilidade penal do agente e a natureza do delito cometido, e não qualquer utilidade que dela se possa esperar; e (iv) salvo condições muito excepcionais, negligenciar a punição devida equivale a uma injustiça.

Mesmo assim, sua filosofia da pena era à época controvertida (como, de resto, hoje continua sendo). Como já mencionei, Kant polemizava explicitamente com a doutrina penal de Beccaria, que tanta repercussão e aceitação nos meios ilustrados teve. Mais ainda, ele oferecia, a título de fundamento metafísico do direito de punição, uma doutrina que era vista por muitos penalistas como distante da realidade, já que todos aceitavam com mais facilidade a ideia de que o crime era cometido por paixões do que a postulação apriorística da máxima moral da delinquência habitual e voluntária, especialmente nos meios intelectuais varridos pelo influxo do utilitarismo. $\mathrm{O}$ próprio Kant reconhecia que era "absolutamente incrível" que, na prática, alguém cometesse um crime movido apenas por maldade, sem levar em conta os benefícios materiais que esperava do crime. Mas, no terreno da metafísica da moral, só a maldade (uma vontade deliberadamente de delinquir, pela já citada máxima do criminoso) poderia ser o carro-chefe de uma filosofia da punição, dizia. ${ }^{122} \mathrm{O}$ resultado disso é que, nas doutrinas jurídicas daquele tempo - que, como Kant mesmo concedia, tinham os

\footnotetext{
${ }^{121}$ Pires (1998c: 182) fala em princípio da "proporcionalidade imperativa", ou "proporcionalidadehorizontal-imperativa".

${ }^{122}$ Na Doutrina do Direito, Kant disse que, mesmo fazendo parte de uma metafísica dos costumes, o direito era essencialmente orientado para a prática, pois as relações jurídicas concernem apenas as relações exteriores e práticas entre as pessoas (Kant, 1797: 32). No prefácio do livro, isso é dito ainda de maneira mais clara: mesmo sendo pura a noção do direito, diz o filósofo, ela é sempre baseada na aplicação empírica de todos os casos que podem acontecer no mundo real. Na teoria de pena kantiana, segundo Cattaneo (1984: 189), isso implicava que, se de um lado Kant trabalhava por uma metodologia puramente ideal, no terreno da metafísica, ele sabia, de outro, do efeito intimidador da pena, e o reconhecia em certas passagens (mesmo sem tirar daí a legitimidade para o castigo).
} 
olhos mais voltados para a prática ${ }^{123}$-, sua teoria estava longe de oferecer todos os critérios operacionais de que um jurista precisaria para construir toda uma teoria da pena, ainda que fornecesse relevantes pontos de partida para a conceituação de seus elementos teóricos fundamentais.

\section{A MEDIDA E A OPORTUNIDADE DA PUNIÇÃo}

Ainda que falemos sempre em "direito de punição", Pires (1998a: 19) lembra que as doutrinas dos autores modernos frequentemente acoplam ao direito de punir uma espécie de obrigação de punição. Seja qual for a razão pela qual o soberano pode punir alguém, esse ius puniendi não parece ser um ius moderno ao pé da letra, ou seja, uma faculdade subjetivamente exercível pelo agente; mas, ao contrário, um ius como forma objetivamente correta de comportamento diante de uma dada situação - a violação de uma lei penal. Trata-se, portanto, da permanência de traços de um ius prémoderno em um uso moderno e contemporâneo do termo. ${ }^{124}$

Mesmo Hobbes, que concede ao soberano a exclusividade em matéria de pensar o exercício do poder em busca dos fins sociais, não olha com simpatia a renúncia à punição quando ela é devida. A segunda inferência que ele tira de sua definição de punição é a seguinte: "Ser negligenciado, e preterido pelo favor público, não é uma punição; porque nenhum mal é por esta via infligido; ele é apenas deixado no estado em que se encontrava antes" (1651a, XVIII). ${ }^{125}$

No direito penal de muitos países, há hoje um instituto chamado perdão judicial, ${ }^{126}$ que dá ao condenado o direito de não ser apenado em certas hipóteses em que "as consequências da infração atingirem o próprio agente de forma tão grave

\footnotetext{
${ }^{123} \mathrm{~V}$. nota retro.

${ }^{124}$ Sobre a mudança no conceito de ius na modernidade, v. Lopes (2004) e Tuck (1979).

125 "Secondly, that to be neglected, and unpreferred by the publique favour, is not a Punishment; because no new evill is thereby on any man Inflicted; he is onely left in the estate he was in before".

${ }^{126}$ Parte Geral do Código Penal (Lei 7.209/84), art. 107, inc. IX.
} 
que a sanção penal se torne desnecessária". ${ }^{127}$ A doutrina da punição em Hobbes proibia a renúncia ao dever de punir mesmo nessas situações:

Quanto a certas ações, há anexadas pela natureza diversas consequências danosas; como quando um homem, ao agredir outro, é ele próprio golpeado, ou ferido; ou quando adoece ao realizar algum ato ilegal; o dano sofrido, por estar em acordo com Deus, que é o autor da natureza, por dizer-se infligido, e portanto uma punição divina; mas não deve ser chamado punição no que respeita aos homens, porque não foi infligido pela autoridade humana. (1651a, XXVIII). ${ }^{128}$

Isso tudo não implicava, contudo, uma obrigação absoluta de punir ao menos não em termos teóricos. A imagem do rei absoluto moderno, lembremo-nos, é a do governante ao mesmo tempo severo e magnânimo, figura paternal que educa pelo castigo, mas também que mostra sua bondade pelo perdão. Diversas passagens do Leviathan apontam contra a ideia da obrigatoriedade da punição, em especial aquelas que tratam do direito de clemência por parte do soberano, uma vez que o perdão estaria de acordo tanto com as leis da natureza, quanto com o objetivo da sociedade civil - a paz (1651a, XV). ${ }^{129}$ No mesmo sentido, Hobbes dirá, mais adiante no mesmo capítulo XXVIII do Leviathan, que a punição só é admissível quando tiver a possibilidade de dispor "o delinquente, ou (por seu exemplo) outros homens, a obedecer as leis". ${ }^{130}$

Entretanto, é seguro dizer que há ao mesmo tempo no Leviathan uma contundente recomendação política para punição (Pires 1998a: 38): diz-se lá que só a "punição severa e constante" seria capaz de impedir os crimes. Como a pena é um instrumento

${ }^{127}$ Parte Especial do Código Penal (Dec.-lei 2848/40), com redação dada pela Lei 6.416/77.

128 "Sixthly, whereas to certain actions, there be annexed by Nature, divers hurtfull consequences; as when a man in assaulting another, is himselfe slain, or wounded; or when he falleth into sicknesse by the doing of some unlawfull act; such hurt, though in respect of God, who is the author of Nature, it may be said to be inflicted, and therefore a Punishment divine; yet it is not contained in the name of Punishment in respect of men, because it is not inflicted by the Authority of man".

${ }^{129}$ Segundo Pires (1998a), o direito de perdão por parte do soberano é reafirmado em um folhetim escrito por Hobbes e publicado postumamente.

${ }^{130}$ Entretanto, essa restrição parece muito singela: pela adversativa empregada (ou dispor a vontade do delinquente ou a de outros homens), a utilidade da punição estava praticamente sempre presente, já que para dispor a vontade dos outros homens bastava a possibilidade de a impressão da punição gerar uma representação apta de ser levada em conta no processo de deliberação dos demais súditos. 
guiador de vontades, deixar de aplicá-la poderia levar ao rompimento da ordem; pois as paixões contra as quais ela atua, que são para Hobbes causas de muitos crimes, são "perpetuamente atuantes; enquanto a razão não está perpetuamente presente para resistilas: e portanto quando a esperança de impunidade aparece, seus efeitos persistem" (1651a, XVII). ${ }^{131}$ É oportuno lembrar que no capítulo do Leviathan que cuida dos "crimes" (violações às leis civis), Hobbes trata os exemplos de impunidade como motivos para a atenuação das penas, pois são como que uma forma de o próprio soberano levar o súdito a cometer delitos. ${ }^{132}$

A posição dos autores do Iluminismo sobre o tema, entre eles Beccaria, já é por demais conhecida por meio da interpretação de Foucault: a eliminação dos exageros das punições suplicantes como as de Damien deu lugar a uma maneira racionalmente calculada de conceber a punição dos delitos, de forma que ela pudesse ser executada em caráter infalível. É a comunicação "simbólica da punição" (1987: 88), que pretende fazer associar imediatamente, no espírito do delinquente potencial, as ideias do delito e de sua punição. A teoria da pena de Beccaria é um exemplo evidente disso: ela pedia punições a um só tempo proporcionais e consistentes (Ruggiero 2006: 17), que, desde que prontamente aplicadas (como ele pregava), criariam a associação de causa (delito) e efeito (pena) nas mentes do todos. A obrigação de punir em Beccaria é fundada no papel dissuasório da pena. "Beccaria diz que, nas mentes de criminosos em potencial, a ideia sedutora de um crime vantajoso deveria vir

\footnotetext{
${ }^{131}$ A passagem completa é a seguinte: "As for the Passions, of Hate, Lust, Ambition, and Covetousnesse, what Crimes they are apt to produce, is so obvious to every mans experience and understanding, as there needeth nothing to be said of them, saving that they are infirmities, so annexed to the nature, both of man, and all other living creatures, as that their effects cannot be hindred, but by extraordinary use of Reason, or a constant severity in punishing them. For in those things men hate, they find a continuall, and unavoydable molestation; whereby either a mans patience must be everlasting, or he must be eased by removing the power of that which molesteth him; The former is difficult; the later is many times impossible, without some violation of the Law. Ambition, and Covetousnesse are Passions also that are perpetually incumbent, and pressing; whereas Reason is not perpetually present, to resist them: and therefore whensoever the hope of impunity appears, their effects proceed. And for Lust, what it wants in the lasting, it hath in the vehemence, which sufficeth to weigh down the apprehension of all easie, or uncertain punishments".

132 "The same Fact, if it have been constantly punished in other men, as a greater Crime, than if there have been may precedent Examples of impunity. For those Examples, are so many hopes of Impunity given by the Soveraign himselfe: And because he which furnishes a man with such a hope, and presumption of mercy, as encourageth him to offend, hath his part in the offence; he cannot reasonably charge the offender with the whole." (1651a XXVII).
} 
sempre associada à de sua pronta punição. Saber que a punição é infalível é, na opinião de Beccaria, a maior prevenção ao crime" (Maestro, 1973: 29). A suavização das penas teria por contrapartida a sua infalibilidade, portanto. O marquês deixa isso claro na sua opinião sobre a clemência e o perdão aos condenados:

À medida em que as penas são mais doces, a clemência e o perdão são menos necessários. Feliz daquela nação em que sejam funestos! A clemência, esta virtude que alguma vez foi em um soberano o complemento de todas as obrigações do trono, deveria ser excluída de uma perfeita legislação, onde as penas fossem suaves, e o método de julgar, regrado e rápido. Parecerá esta verdade dura aos que vivem na desordem do sistema criminal, em que os perdões e graças são necessários, à proporção do absurdo das leis, e da atrocidade das sentenças (1774, XLVI). ${ }^{133,134}$

Por tudo isso, falar em "direito de punir" nem sempre é a melhor forma de descrever essas teorias. Tanto em Beccaria quanto em Hobbes, o direito de punir parece versar não só sobre a autorização jurídico-moral para a punição, mas também sobre uma certa política punitiva ligada ao adequado cumprimento do dever político de manutenção da paz. Por essa fresta, vê-se mais uma vez o quanto o "direito criminal" era, àquela altura, pesadamente imiscuído em filosofia política. Do ponto de vista prático, a punição racionalmente calculada parece ser, por um mandamento prudencial, a forma objetivamente correta de lidar com o delito nos autores das vésperas do direito penal contemporâneo. Daí o porque de este item haver começado dizendo que o ius puniendi guardou uma pequena porção de um ius pré-moderno: ele não só dá as hipóteses em que o soberano tem a facultas de aplicar a punição, mas faz uma fortíssima recomendação política de como ela deve ser administrada para a boa consecução do objetivo constitutivo da sociedade civil.

\footnotetext{
133 "A Medida que las penas son mas dulces, la clemencia y el perdon son menos necesarios. ¡Dichosa aquella Naciona en que fuesen funestos! Esta clemencia, esta virtud, que ha sido alguna vez en un Soberano el suplemento de todas las obligaciones del trono, debería ser excluida en una perfecta Legislacion, donde las penas fuesen suaves, y el método de juzgar arreglado y corriente. Parecerá esta verdade dura á los que viven en el desorden des systema criminal, en que los perdones y las gracias son necesarias, á proporciona de lo absurdo de las Leyes, y de la atrocidade de las sentencias".

${ }^{134}$ Muitas edições brasileiras de Beccaria têm estrutura diferente da original. Nelas, esta passagem está no $\S \mathrm{XX}$ (Certeza e infalibilidade das penas. Graça).
} 
Ruggiero (2006: 8 e ss.) não parece dar grande importância a essa distinção entre a autorização para punir e a política da punição nos dois autores. ${ }^{135}$ Ele sustenta que Beccaria e Hobbes teriam concepções opostas sobre os efeitos da punição estatal. Segundo ele, a violência estatal (punição) seria, em Hobbes, inversamente proporcional à violência civil (desobediência às leis): quanto mais punição, menos desobediência; já em Beccaria, essa relação seria oposta, porque diretamente proporcional: quanto menos violência estatal (pena criminal), menos violência civil (delitos). Sua leitura tem, de fato, algum apoio nos textos de Hobbes e Beccaria: é verdade que o soberano hobbesiano tem a superioridade absoluta do uso da força em relação a seus súditos; e que Hobbes sugere que, sem o exercício da punição, o controle da violência civil seria impossível. É também verdade que Beccaria condena as formas excessivas de violência, em especial a pena de morte; e que o mesmo Beccaria diz que as penas têm de ser moderadas. Mas Ruggiero subestima aquilo que os dois autores têm em comum, e que lhes dá uma importante unidade que, para o objeto desta tese, precisa ser destacada: a postulação de que abrir mão da "pena criminal" não é recomendável, bem como de que sua aplicação tem o papel instrumental de evitar o "crime". ${ }^{136}$

No retributivismo kantiano, tido como o "rival" do pensamento utilitarista de Hobbes e Beccaria, a mesma obrigação de punir aparecia, ainda que sob outro fundamento: não empírico-utilitário, mas moral-racional. ${ }^{137} \mathrm{~A}$ pena é, em Kant, um imperativo categórico, bem ilustrado por seu conhecido exemplo da ilha que se dissolverá (Kant, 1797: 185). É um dever incontornável da autoridade pública responsável por sua aplicação e execução. A pena criminal não seria

\footnotetext{
${ }^{135}$ Isso é plenamente justificado pelo objeto de seu trabalho, que é a representação da violência nos dois autores, e não propriamente as suas teorias da pena.

${ }^{136}$ A despeito de todas as considerações de Ruggiero sobre o soberano hobbesiano, a oitava estabelece uma limitação de natureza utilitária à aplicação da pena, de forma que, nessas hipóteses, a pena seria considerada um ato de hostilidade mesmo preenchidas as demais condições da punição (violação da lei, aplicação por um soberano, prévia cominação legal do delito e da pena etc.). A punição aplicada fora desses critérios é, para Hobbes, um "ato de hostilidade", ou seja, é um atentado contra a paz, que é o próprio objetivo da sociedade civil. Por tudo isso, parece excessivamente simplista dizer que o soberano hobbesiano mantém a paz através do uso máximo da pena, já que ela despreza o fato de que essa aplicação é regrada por uma racionalidade prática que nem sempre recomenda a aplicação da maior pena, mas sim da pena mais adequada com vistas a determinado fim.

${ }^{137}$ Essa semelhança entre utilitaristas e retributivistas é, diga-se de passagem, um dos pilares da racionalidade penal moderna (Pires, 1998a).
} 
um dever hipotético ou condicionado relativamente, por exemplo, à possibilidade de fazer justiça de outro modo ou de obter a paz entre duas partes, mas um dever incondicionado; A lei criminal (aí compreendida a penal que ela deve prescrever) é uma exigência absoluta da razão e da moral, sem atenção a outras considerações (Pires, 1998c: 179). ${ }^{138}$

No que diz respeito à quantificação da pena, Pires (1998a: 137 e ss.) lembra que as teorias utilitaristas frequentemente trabalhavam com algo que ele chama de "princípio da proporcionalidade vertical e excesso moderado da pena", como era o caso de Beccaria. Esse princípio postula que o mal da pena deve ser moderadamente superior ao benefício trazido pelo crime: "Para que uma pena obtenha seu efeito, basta que o seu mal exceda o bem que nasce do delito; e neste excesso de mal, deve ser calculada a infalibilidade da pena, e a perda do bem que o delito produzirá", dizia Beccaria (DDDP, XXVII). Nos retributivistas, defendia-se uma pena rigorosamente correspondente ao mal do delito. Trata-se, segundo Pires, da ideia de uma igualdade obrigatória entre a pena, para o mais ou para o menos: em Kant, por exemplo, "a noção de proporcionalidade é governada pela de igualdade e é representada pela imagem da balança (...). Kant quer evitar a desproporção entre as faltas e os castigos em todas as direções, e não apenas no excesso da punição" (Pires, 1998c: 182).

O critério para a determinação e medida da pena era dado, no retributivismo, pela natureza e consequência do crime. Com efeito, Kant gasta uma longa parte de sua teoria da pena na Doutrina do Direito mostrando como buscar a proporcionalidade taliônica para os mais diversos casos: no caso de uma ofensa verbal, por exemplo,

a contrariedade que se pode fazer experimentar no orgulho pode igualar o insulto proferido pelo ofensor à honra de outra; por exemplo, se o juiz o condenar não somente a dar satisfação em público, como também a beijar a mão do ofendido" (Kant, 1797: 85).

\footnotetext{
138 "La peine n'est pas un devoir hypothétique ou conditionné relativement, par example, à la possibilité de fair justice d'une autre façon ou d'obtenir la paix entre les parties, mais un devoir inconditionné. La loi criminelle (y compris la peine qu'elle doit prescrire) est une exigence absolue de la raison et de la moralité, sans égard a d'autres considerations".
} 
Ou ainda, se um nobre maltratar um cidadão de condição social modesta, poderia não só ser condenado a uma prisão desconfortável, como também a dar-lhe "uma reparação de honra", maneira pela qual ele seria punido em sua vaidade e o princípio da igualdade seria reafirmado. E, é claro, se o criminoso cometeu uma morte, ele deveria morrer, e não haveria qualquer comutação capaz de satisfazer à justiça. Isso o situava distante de Beccaria, que pregava sempre que a pena fosse a menor possível para fins de prevenção, e não a mais parecida com o delito em sua gravidade, ainda que ele defendesse também a correspondência material entre delitos e penas. ${ }^{139}$

Os pontos mais reveladores da doutrina de Kant sobre a obrigatoriedade da punição estão, porém, em sua análise do direito de perdoar. É o direito que mais dá brilho ao soberano, mas que, em contrapartida, maiores injustiças pode suscitar (Kant, 1797: 188). Ao contrário do que poderia sugerir sua metafísica da pena, Kant aceitava a possibilidade de perdão em alguns casos, se bem que restritíssimos. Nos crimes privados - cometidos por particulares contra particulares, isto é -, o perdão seria inaceitável, e representaria enorme injustiça; e na maioria dos crimes públicos, também. Apenas nos crimes de lesa-majestade o soberano poderia indultar o culpado, e ainda assim observada a condição de que o indulto não causasse perigo à segurança pública (Kant, cit.). Em outra oportunidade anterior na Doutrina do Direito, aliás, Kant já acenara com a possibilidade da não punição quando isso fosse vital à própria conservação da sociedade: se houver uma conspiração revolucionária que tente o assassínio do rei e envolva todos os súditos de um Estado (ou quase todos) e a aplicação da pena de morte devida a cada um deles por justiça colocar a própria existência do Estado em risco, tais penas podem não ser aplicadas (Kant, 1797: 184). Mas neste caso, acrescenta, não se tratará de uma lei pública, mas de uma comutação de

\footnotetext{
${ }^{139}$ As teorias política e a antropológica de Beccaria sugeriam que deveria haver múltiplas penas criminais disponíveis: se a pena é legítima quando for útil e mínima, e o ponto ótimo de sua utilidade está no excesso moderado da punição em relação ao delito, era necessário que a intensidade da pena fosse calculável em comparação com o benefício do delito. Assim, diz ele que para os furtos, as penas pecuniárias seriam apropriadas; (1774, XXII); para roubos - "furtos misturados com violência" -, a pena deveria ser igualmente "um misto de corporal e servil"; para as injúrias pessoais, a melhor pena seria a infâmia (1774, XXIII), porque faz incidir sobre o condenado um ridículo maior do que aquele que ele pretendeu atribuir à vítima; para outros tantos delitos, Beccaria recomenda, sempre por sua lógica de proporcionalidade, penas outras como banimento (XXIV), perdimento de patrimônio (XXV), privação de liberdade por longos intervalos de tempo (XXVIII) etc.
} 
penas ordenada ad hoc pelo rei, por uma razão de estado. Note-se bem: o retributivismo de Kant é ligado a uma razão de Estado, e não ao simples pagar o mal pelo mal.

$$
* * *
$$

Portanto, vê-se que as respostas dos autores imediatamente anteriores ao direito penal contemporâneo às perguntas fundamentais de nossa teoria penal ("por que se pode punir?"; "como deve-se punir?"; e "quando deve-se punir?") estavam longe de um consenso.

Elas discordavam frontalmente no tema do direito de punir: aqui, as diferenças nas teorias políticas, antropológicas e morais daquele tempo mostravam-se com força. No que diz respeito à forma de punição, tampouco havia qualquer uniformidade de princípios, fora a ideia de proporcionalidade; e, a bem da verdade, nem mesmo quanto à proporcionalidade a concordância era integral, haja vista as diferenças entre Kant e Beccaria. No debate sobre a oportunidade da punição estavam as maiores semelhanças entre os autores citados, ao menos se consideradas a suas conclusões, muito parecidas entre si: todos defendiam a obrigação política ou moral da punição infalível. Porém, faziam-no por razões teóricas absolutamente distintas: Kant pelo imperativo categórico da punição ao crime; Beccaria e Hobbes, pelas teorias antropológicas que faziam da pena quase um instrumento de adestramento dos súditos. Por baixo de uma couraça de aparente consenso repousavam portanto disputas teóricas viscerais também neste tópico. 


\section{Criminoso e responsabilidade}

Um último elemento teórico relevante para os fundamentos do nosso direito penal diz respeito à noção de imputabilidade criminal com que trabalhavam os autores imediatamente anteriores à formação do direito penal contemporâneo, e a imagem teórica do "criminoso" - ou, nos dizeres de Tomás y Valiente (1992: 243), o "tipo social do delinquente" - por ela implicada.

Falando em linhas muito gerais, era bastante corrente entre os autores dos séculos XVII e XVIII a opinião de que haveria algumas situações em que o cometimento de um "crime" não implicava punição a seu autor, por ele ter atuado fora dos limites da responsabilidade jurídica; e que, portanto, a realização do resultado proibido, em tais casos, não faria de seu autor um "criminoso". Essa era uma doutrina já firmemente presente no pensamento jurídico precedente: o direito romano já distinguia vários casos de impunibilidade de crimes a depender das circunstâncias em que fosse cometido, além de diferençar, na punição de certos atos, aqueles cometidos com dolus ou culpa (por exemplo, Dig. L, 17, l. 63); e na tradição escolástica, o homicídio não pertencia à categoria dos pecados, mas sim à dos "atos maus por natureza, mas que podem ser lícitos e permitidos em situações concretas", como no caso da legítima defesa (Tomás y Valiente, 1992: 231). ${ }^{140}$ Mas a modernidade e o individualismo que a caracteriza vão circunscrever cada vez mais esses problemas ao âmbito da individualidade dos seres humanos. Os conflitos "criminais", que antes eram predominantemente contemplados sob uma lógica transindividual ou comunitária (Hespanha, 1988: 35), preservam na modernidade uma importante dimensão coletiva (se bem que pensada em termos de Estado, ou comunidade política), mas têm acentuado o seu caráter intraindividual, focando a disputa entre o homem e seus próprios impulsos com o apoio da sua razão. Não por acaso, culpabilidade e imputação estão entre os temas mais candentes do direito penal contemporâneo; e certas "punições criminais" do mundo pré-moderno, que eram vistas mais pela lógica da perturbação da ordem

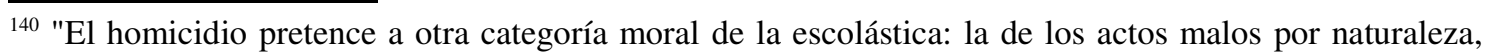
pero que pueden ser lícitos y permitidos en ocasiones concretas. Por ejemplo, sugún la terminología de la época, el homicidio en legítima defensa es 'justo', moral y juridicamente."
} 
comunitária, e menos pela da responsabilidade moral - como no caso das "penas" aplicadas a animais (Tomás y Valiente, 1992: 301) - parecem-nos hoje tão sem sentido.

Seja como for, importa salientar que nos pré-contemporâneos, era comum a visão de que a imposição de uma pena jurídica dependia de o condenado ter atuado com uma certa "liberdade". Mas as variações da filosofia moral daquele tempo faziam dessa ideia simplória, herdada da cultura jurídica do passado, um poço de contradições e problemas teóricos. Tome-se, apenas como exemplo, a passagem em que Blackstone trata daqueles que podem responder por "crimes":

As diversas petições e escusas que protegem o executor de um ato proibido de receber a punição, que ele de outra forma encontraria, podem ser reduzidas a uma única consideração: o querer ou defeito da vontade. Um ato involuntário, da mesma forma que não tem mérito algum, tampouco pode induzir culpa. A concorrência da vontade, quando ela tem sua escolha de fazer ou evitar o fato em apreço, é a única coisa que faz ações humanas louváveis ou culpáveis. De fato, para que se dê um crime completo, cognoscível pelas leis humanas, deve haver tanto vontade quanto ação. Pois ainda que in foro conscientiae um desígnio fixo ou vontade de praticar um ato ilegal seja quase tão desprezível quanto a própria comissão, como nenhum tribunal temporal pode alcançar o coração, ou vasculhar as intenções da mente, se eles não são demonstrados eternamente através de uma ação, ele não poderá punir aquilo que não pode conhecer. (Blackstone, IV, 2. Destaques meus) ${ }^{141}$

A doutrina de Blackstone quanto à responsabilidade compreende, como se vê, dois âmbitos distintos: o primeiro, representado pela "vontade", diz respeito ao âmbito interno e deliberativo dos seres humanos, que podemos chamar "moral"; o segundo, por ele chamado de "ação", respeita à atuação externa de uma conduta -

141 "All the several pleas and excuses, which protect the committer of a forbidden act from the punishment which is otherwise annexed thereto, may be reduced to this single consideration, the want or defect of will. An involuntary act, as it has no claim to merit, so neither can it induce any guilt: the concurrence of the will, when it has it's choice either to do or to avoid the fact in question, being the only thing that renders human actions either praiseworthy or culpable. Indeed, to make a complete crime, cognizable by human laws, there must be both a will and an act. For though, in foro conscientiae, a fixed design or will to do an unlawful act is almost as heinous as the commission of it, yet, as no temporal tribunal can rearch the heart, or the intentions of the mind, otherwise than as they are demonstrated by outward action, it therefore cannot punish for what it cannot know". 
podemos chamá-lo de "sensorial". Esses dois elementos, o moral e o sensorial, são articulados em uma doutrina sobre a "liberdade" exigida para a punição de um "crime".

Justamente neste ponto se mostravam as profundas discordâncias teóricas entre os autores daquele tempo, que resultavam em problemas brutais para uma teoria da responsabilidade "criminal". Serão mencionadas aqui duas polêmicas nessa seara, que julgo serem as mais importantes para o propósito deste capítulo. A primeira delas diz respeito à própria definição de "liberdade" com que trabalhavam os autores até aqui vistos; a segunda, à relação entre essa mesma liberdade e a suscetibilidade de um agente sofrer punição por seus atos.

No tocante ao primeiro ponto, basta dizer que havia, em linhas gerais, duas relevantes representações da ideia de "liberdade" nas gerações anteriores a Feuerbach e ao direito penal contemporâneo (Pires, 1998a): a primeira ligava "liberdade" à ideia de livre-arbítrio moral, e teve em Kant seu mais prestigioso representante; a segunda dava a "liberdade" uma acepção mais empobrecida, definindoa meramente como ausência de obstáculo a uma ação corporal, e notabilizou-se através de Hobbes. Essas duas acepções de liberdade têm diferentes impactos sobre a noção jurídico-penal de responsabilidade. Mas, por outro lado, elas se reforçam mutuamente no que diz respeito à construção de um certo estereótipo do criminoso.

$\mathrm{Na}$ teoria moral de Kant, que é aquela que importa para os fundamentos de sua teoria do direito, "liberdade" é livre-arbítrio: a faculdade de agir segundo leis representadas, diz Kant na Fundamentação, é uma propriedade que deve ser considerada a priori como presente em todo ser racional. Entretanto, estímulos sensíveis (prazeres, gostos) concorrem com os mandamentos morais puramente racionais no intelecto humano, enquanto móveis da ação. Dessa forma, um dever moral que é objetivamente necessário torna-se subjetivamente contingente: pode ou não ser realizado na prática, a depender de o agente escolher, ou não, agir de acordo com esse dever em detrimento de suas vontades meramente sensíveis (Kant, 1785: 36). A desobediência à lei moral objetiva, numa situação em que o sujeito deve ser considerado livre para poder obedecê-la (situação essa que é a regra em Kant), é a base de sua 
responsabilidade. É isso que dá, em sua filosofia jurídica, os conceitos de "ação" e "autor":

\begin{abstract}
Ação é uma conduta submetida a leis de obrigação, consequentemente também na medida em que o sujeito é considerado como livre em seu arbítrio. O agente é considerado, através de um tal ato, como causador de suas consequências, e estas, juntamente com a própria ação, podem ser-lhe imputadas se a lei, por força da qual a obrigação sobre ele paira, é-lhe previamente conhecida. (Kant, 1797: 24). ${ }^{142}$
\end{abstract}

Segundo Höffe (2005: 216), está na ideia de autonomia o fundamento último da possibilidade de se agir moralmente na filosofia kantiana. Kant a chama de "princípio supremo da moralidade" (oberstes Prinzip der Sittlichkeit), e define-a assim:

\begin{abstract}
Autonomia da vontade é a constituição da vontade por meio da qual ela é para si mesma uma lei (independentemente de toda constituição dos objetos da vontade). O princípio da autonomia é portanto: escolher sempre de modo que as máximas da escolha estejam compreendidas, ao mesmo tempo, como leis universais no ato de querer. ${ }^{143}$
\end{abstract}

Só com a vontade autônoma podemos agir moralmente, na acepção estrita da expressão.

Ainda segundo a leitura da Kant feita por Höffe, há três maneiras diferentes pelas quais alguém pode agir em cumprimento a um dever moral: primeiramente, pode-se cumpri-lo com vistas a um interesse próprio; em segundo lugar, pode-se cumpri-lo por inclinação e simpatia pelo comportamento moralmente devido (ajudar alguém, por exemplo); e, por último, pode-se cumpri-lo simplesmente pelo reconhecimento do dever enquanto tal. É só neste último caso que se está, propriamente,

\footnotetext{
142 "That heisst eine Handlung, sofern sie unter Gesetzen der Verbindlichkeit steht, folglich auch sofern das Subject in derselben nach der Freiheit seiner Willkühr betrachtet wird. Der Handelnde wird durch einen solchen Act als Urheber der Wirkung betrachtet, und diese, zusammt der Handlung selbst, können ihm zugerechnet werden, wenn man vorher das Gesetzt kennt, kraft welches auf ihnen eine Verbindlichkeit ruht".

143 "Autonomie des Willens ist die Beschaffenheit des Willens, dadurch derselbe ihm selbst (unabhängig von aller Beschaffenheit der Gegenstände des Wollens) ein Gesetz ist. Das Prinzip der Autonomie ist also: nicht anderes zu wählen, als so, dass die Maximen seiner Wahl in demselben Wollen zugleich als allgemeines Gesetz mit begriffen sein" (Kant, 1797: 440).
} 
diante de uma ação moralmente boa. "A moralidade não pode ser constatada na ação mesma, mas somente em seu fundamento determinante, no querer" (Höffe, 2005: 1934). Isso está na base de uma distinção feita por Kant, a partir da filosofia de Thomasius, e que será muito aproveitada por Feuerbach em sua teoria penal, entre a moralidade e a legalidade de uma ação: enquanto a ação para ser legal precisa ser externamente conforme à lei, a ação moral precisa sê-lo internamente (Kant, 1797: 18). Ou seja, a moralidade está mais na vontade que move a ação do que em sua execução propriamente dita. A ação moral pressupõe, portanto, uma tal vontade capaz de guiar moralmente uma ação; que não é uma vontade sensorial, passional, mas sim um querer da razão, que permite reconhecer o dever como tal e transformar-lhe na razão subjetiva da conduta. Trata-se de uma "vontade racional", segundo Walker (1999: 40). Ao contrário, a ação conforme à lei jurídica pode muito bem prescindir disso: é indiferente para o direito se eu respeito a lei por agir segundo uma máxima moral ou pela razão egoística do medo da pena; o que importa é respeitá-lo externamente, ou seja, em minha ação sensível no mundo. As questões internas só terão relevância quando influenciarem a ação e manifestarem-se sensivelmente por meio da liberdade externa (Höffe, 2005: 235).

Dessa forma, a vontade racional distingue-se da vontade sensorial porque ela é capaz de, pelo uso da razão pura, dar máximas ${ }^{144}$ - princípios subjetivos do querer (Kant, 1785: 21, nota) - moralmente boas para a ação. Segundo Höffe (2005: 208-15), máximas moralmente ruins não podem ser aceitáveis como máximas porque, se formuladas como tais, ou não podem ser pensadas (suicidar-se diante de uma vida enfadonha), ou não podem ser queridas (falsas promessas). Se forem pensadas e seguidas, a conduta será, a priori, absolutamente reprovável do ponto de vista moral como no caso do criminoso que age segundo a máxima de delinquir habitualmente. Mas o ponto importante aqui é que essas máximas, que valem absolutamente, bem como a reprovabilidade por seguir máximas imorais, dependem da dita autonomia. A ideia de autonomia como auto-legislação está, por isso, estreitamente ligada à existência de um livre arbítrio (Reath, 1994: 458 e nota 39). Não se trata, é claro, de negar que haja razões sensíveis que concorram com a máxima racional como móveis da ação; trata-se, ${ }^{144}$ Para o conceito de máximas em Kant, v. Höffe (2005: 203-7). 
isto sim, de enfatizar que, no plano dos fundamentos de uma teoria moral sobre a responsabilidade e a punição (como é aquele em que Kant opera), as coisas têm de ser conduzidas no plano da razão pura, sem a mistura de elementos sensíveis ou do estímulo, sob pena de se perpetuarem "as doutrinas morais bastardas e confusas" (Kant, 1785: 34) contra as quais ele se via escrevendo.

A acepção kantiana da "liberdade" para fins de sua teoria da responsabilidade e da punição é estritamente moral, portanto, e é assim resumida por Pires:

o homem pode determinar-se independentemente do impulso dos estímulos sensíveis. A vontade é uma causalidade entre os seres vivos, e a liberdade é a propriedade que tem essa causalidade (humana) de pode agir independentemente de causas estranhas que a determinam (Pires, 1998c: 169 e ss.).

Essa liberdade moral deve pertencer, pelo método de Kant, a um mundo moral, onde temos uma forma transcendental de liberdade que nos permite dar-nos máximas independentemente de fatores empíricos que possam guiar nossas ações. "Ações praticadas por respeito à lei moral não seriam possíveis se fôssemos apenas parte de um sistema determinista", diz Walker (1999: 47).

Mas esse mundo moral, transcendental, é contrastado com o mundo real em que vivemos; e nossas ações não são tomadas no mundo moral, mas sim no mundo sensível, onde existimos, e onde diversos fatores influenciam nossos comportamentos. Um e outro tipo de ações são bastante diferentes, porque a primeira, na sua qualidade de ideal, não é sensorialmente influenciada; enquanto a segunda, porque real, necessariamente o é. Por essa razão, é difícil pensar em uma ação real que seja absolutamente livre, no sentido moral do termo, porque nossas ações reais são sempre tomadas no tempo e no espaço existentes, e invariavelmente sujeitas a estímulos que decorrem necessariamente do fato de existirmos fisicamente. É claro que Kant sabia disso e levava esse fato em consideração: logo na abertura da segunda parte da Fundamentação, ele mesmo diz não acreditar que, na prática, qualquer ação possa ser 
tida como $100 \%$ baseada apenas no cumprimento dos deveres morais: "De fato é absolutamente impossível, através da experiência, apontar um só caso com plena certeza em que a máxima da ação funde-se só na representação do dever", dizia ele (Kant, 1785: 29). ${ }^{145}$

Mesmo assim, no campo do direito, que se preocupa com a liberdade externa e as ações executadas no mundo em que vivemos (Höffe, 2005: 236), a imputação supõe que tais ações sejam executadas por sujeitos responsáveis. Mais uma vez, e assim como se dava com sua noção de "pena", não é difícil perceber o quanto a teoria kantiana colocará dificuldades para doutrinas jurídicas que, voltadas à prática que eram, tinham de aplicar o direito de punir criminalmente no mundo dos fatos, e não no universo transcendental da razão pura.

A doutrina moral kantiana situava-se no extremo oposto daquela que Hobbes oferecera pouco mais de um século antes no Leviathan. Lá, o filósofo de Malmsbury distinguia entre dois tipos de "liberdade". A primeira é definida no Cap. XXI do livro:

Liberdade significa (em sentido estrito) a ausência de oposição; (por oposição, quero dizer impedimentos externos ao movimento;) e pode ser aplicada tanto a criaturas inanimadas e irracionais, quanto às racionais." (1651a, XXI.) $)^{146}$

Neste primeiro sentido, o conceito aplica-se tanto a uma pessoa e seus movimentos (voluntários e involuntários), quanto a um animal solto na floresta, ou ainda a um rio que corra desimpedido (van Mill, 1995: 444). Não aparece aqui a ideia de vontade humana, note-se bem, e nem se circunscreve, como em Kant, a ideia de liberdade ao mundo dos seres racionais.

\footnotetext{
145 "In der That ist es schlechterdings unmöglich, durch Erfahrung einen einzigen fall mit völliger Gewissheit auszumachen, da die Maxime einer sonst pflichtmässigen Handlung lediglich auf moralischen Gründen und auf der Vorstellung seiner Pflicht beruht habe".

146 "Liberty, or FREEDOME, signifieth (properly) the absence of Opposition; (by Opposition, I mean externall Impediments of motion;) and may be applyed no lesse to Irrational, and Inanimate creatures, than to Rationall".
} 
No parágrafo seguinte, Hobbes define o que é um homem livre: é aquele que "nas coisas em que, por sua força e inteligência ele é capaz de fazer, não é impedido de fazer aquilo que tenha vontade de fazer" (1651a, XXI). ${ }^{147}$ Trata-se de um segundo tipo de liberdade, que inclui um elemento volitivo que não aparece na anterior: aqui, o homem pode, por sua vontade, agir conforme ou contrariamente aos impulsos sensoriais que recebe. Segundo van Mill (1995: 445), a diferença entre a primeira e a segunda liberdades é que só esta última passa pelo intelecto humano.

Mas, apesar de reconhecer que a liberdade de uma ação humana tem algo de diferente da liberdade do correr da água de um rio, Hobbes sugere que essa distinção é de pouca relevância; porque, seja ação voluntária ou movimento inanimado, liberdade será sempre ausência de impedimento, de forma que um homem será dito livre na mesma medida em que um rio o é: quando não houver obstáculos à sua ação. Qualquer outra acepção de "livre" que não esta é tida por ele como absurda. ${ }^{148}$

Dessa forma, o aparelho intelectual do homem hobbesiano não precisa ser tão complexo como o de Kant para sustentar as teorias ética e política do Leviathan. Consequentemente, sua teoria da punição não depende de um intelecto capaz de reconhecer deveres morais - de um livre arbítrio, portanto -, mas apenas de uma psicologia associativa elementar, que permita a realização de cálculos de custobenefício: o mesmo intelecto que sugere ao homem que saia do estado de natureza e entre no estado civil indica também que não receber uma pena é melhor do que ser apenado, e que portanto deve-se agir no sentido de evitá-la. Por isso, a declaração pública de penas e sua aplicação infalível guiarão as paixões dos súditos (1651a, XXVII).

\footnotetext{
147 "And according to this proper, and generally received meaning of the word, A FREE-MAN, is "he, that in those things, which by his strength and wit he is able to do, is not hindred to doe what he has a will to".

148 "And therefore if a man should talk to me of a Round Quadrangle; or Accidents Of Bread In Cheese; or Immaterial Substances; or of A Free Subject; A Free Will; or any Free, but free from being hindred by opposition, I should not say he were in an Errour; but that his words were without meaning; that is to say, Absurd" (1651a, V).
} 
Já Beccaria parece estar no meio do caminho entre ambas as posições (Pires, 1998a): ele não nega categoricamente o livre-arbítrio, como Hobbes; mas sua teoria da pena não depende dele: ela trabalha, ao contrário, com o mesmo aparato psicológico associativo hobbesiano. Daí o porque da pena ter de ser, além de infalível, imediata:

É dito que a prontidão das penas é mais útil, porque quanto menor é a distância do tempo que passa entre a pena e o delito, tanto mais forte e durável o ânimo da associação destas duas ideias, Delito e Pena; de tal modo, que sejam considerados o primeiro como causa, e o último como efeito conseguinte e necessário. (DDDP, $\mathrm{XIX)})^{149}$

A posição de Beccaria, um autor comumente mais associado ao direito penal contemporâneo do que Hobbes ou Kant, é denunciadora do sincretismo que, desde o primeiro capítulo, tenho dito ser uma das marcas da teoria da pena de nosso direito penal: a acomodação, em uma mesma disciplina, de imagens distintas da racionalidade humana, que implicam diferentes fundamentos e critérios diretores para a punição criminal. Em Filangieri, um autor mais dogmático do que Beccaria e, cronologicamente, mais próximo da consolidação do direito penal contemporâneo, essa mistura começa já a mostrar-se com uma cara que já não é, para nós do presente, tão desconhecida: a gravidade do delito e a reprovabilidade da conduta levam em conta, a um só tempo, parâmetros de utilidade social e reprovabilidade moral. Assim, a medida dos delitos (1827: cap. XXXVIII) leva em conta, primeiramente, a importância social do pacto violado: o delito "é maior na violação de pactos que têm maior importância para o corpo social; é menor na violação dos que têm influência menor" (cit.: 140); mas, adicionalmente, a reprovabilidade do delito é também medida pela "maior malvadeza do coração, maior inclinação a violar outras leis" (cit.: 141). ${ }^{150}$

\footnotetext{
149 "He dicho que la prontitud de las penas es mas util, porque quanto es menor la distancia del tiempo que pasa entre la pena y el delito, tanto es mas fuerte y durable en el ánimo de la asociacion de estas dos ideas, Delito y Pena; de tal modo, que se consideran el uno como causa, y la otra como efecto consiguiente y necesario".

${ }^{150}$ Para uma explicação mais detalhada sobre a imputabilidade em Filangieri, v. Seelmann, 2001.
} 
O sincretismo de Filangieri reforça a sugestão de Pires de que, apesar das diferenças viscerais entre essas posições teóricas, elas acabam conseguindo conviver em razão de um elemento que têm em comum: em todas elas, evitar o crime depende apenas do uso dos recursos intelectuais de que dispõe qualquer ser humano com faculdades mentais minimamente desenvolvidas, sejam elas morais (Kant), psicológicas (Hobbes), ou um pouco das duas coisas (Beccaria). Daí o porque de todos sustentarem, em linhas muito gerais, que o criminoso nega sua própria humanidade e chama para si todo o mal que recebe pela prática do crime. Apesar de todas as diferenças entre Hobbes, Beccaria e Kant, eles compartilham a posição de que a pena é algo que o criminoso dá a si mesmo. Em Kant, o criminoso merece moralmente a pena; em Beccaria, ele dá causa à pena (DDDP, XIX); e em Hobbes, o atentado político contra a autoridade do soberano faz do agente "autor de sua própria punição" (1651a, XVIII). Isso já aparece como algo muito semelhante à nossa ideia contemporânea da responsabilidade penal: o Estado apenas dosa e executa a pena de que o apenado foi, ele mesmo, o autor.

Postas as coisas dessa maneira, é fácil ver que a imagem do criminoso que surge a partir de qualquer um desses caminhos teóricos: com exceção dos casos de indisponibilidade das faculdades intelectuais mais elementares, o criminoso ou "escolhe" receber uma pena, ou despreza seus instintos psicológicos que mandam ele evitar o mal e sofrimento que ela representa. Ora, alguém assim ou é mau, ou é um inconsequente sem amor pela vida, ou é um descontrolado, ou um rebelde que pega em armas contra os valores sociais mais básicos, ou mesmo um idiota. Seja como for, por qualquer desses caminhos, a representação do "criminoso" está longe de ser lisonjeira.

Hobbes (1651a, XXVII) diz que só três coisas explicam o crime: ou um erro de entendimento; ou um erro de raciocínio; ou uma força repentina das paixões. O erro de entendimento chama-se "ignorância": é o desconhecimento de um dado fático, como a lei. Já o erro de raciocínio não diz respeito à limitação de conhecimento, mas ao mau uso da razão: deliberar a partir de falsos princípios, por exemplo. Quanto ao erro das paixões, estes ocorrem quando os instintos do homem os comandam em sentido contrário àquilo que uma deliberação racional exigiria. Em alguns casos, essas 
explicações do crime funcionam como justificativas dos atos: ou seja, fazem com que a conduta deixe de ser ilícita: a ignorância (erro de entendimento) do estrangeiro quanto às leis de uma nação que não lhe tenham sido declaradas pode escusá-lo; ${ }^{151}$ como também o crime cometido sob determinação do sentimento de medo corporal, que é uma paixão. ${ }^{152}$ Fora desses casos, o crime é explicável, mas não justificável: ou o sujeito ignora situações fáticas que lhe foram apresentadas (ou são auto-evidentes), ou não faz uso adequado de suas capacidades intelectuais, ou tem suas ações determinadas por sentimentos indesculpáveis, como ódio, luxúria, ambição, crença na impunidade etc.

Em Beccaria, pode-se dizer que há mesmo dois tipos de homem reunidos em um único sujeito ideal: um antes do cometimento do crime, e outro depois. O primeiro é o sujeito racional que deliberou entrar no estado civil; que reconhece o mal da pena e age no sentido de evitá-lo; e que é capaz de obedecer as leis de forma a garantir "a felicidade maior ao maior número" de cidadãos; um sujeito, portanto, que merece a empatia e o respeito de seus iguais. A pena aplicada de forma célere é prontamente reconhecida por esse sujeito deliberante (como o efeito de que o crime é a causa), e ele buscará evitá-la, abstendo-se de delitos. Já o "delinquente", este vem retratado como "infeliz" e "miserável" - os adjetivos repetem-se incontáveis vezes em Dos Delitos e Das Penas: os condenados são "vítimas miseráveis" de um juiz (DDDP, IV); o torturado é um miserável e será condenado mesmo que inocente (XVI); o furtador é um "miserável e desesperado" que pertence à parcela "infeliz" da sociedade a quem o direito de propriedade deixou nua (XXII); a família de um capo é "infamada e miserável"; os condenados na história são "milhares de infelizes" a quem a "miséria" obrigou a punições bárbaras (XXVII); e assim por diante. ${ }^{153}$ É por isso que Pietro Costa

\footnotetext{
151 "But ignorance of the Civill Law, shall Excuse a man in a strange country, till it be declared to him; because, till then no Civill Law is binding". (1651a, XXVII).

152 "For not every Fear justifies the Action it produceth, but the fear onely of corporeall hurt, which we call Bodily Fear, and from which a man cannot see how to be delivered, but by the action. A man is assaulted, fears present death, from which he sees not how to escape, but by wounding him that assaulteth him; If he wound him to death, this is no Crime; because no man is supposed at the making of a Common-wealth, to have abandoned the defence of his life, or limbes, where the Law cannot arrive time enough to his assistance". (1651a, XXVII).

${ }^{153}$ Essa duplicidade entre o homem ideal e o homem real era uma forma comum de lidar com a oposição entre razão e paixões. Ela figurava como um dos fundamentos da teoria jurídica de Christian Wolff, por exemplo. Para ele, as obrigações e os direitos teriam por sujeito em geral o "Homem Moral". Este
} 
(1974: 360-1), tratando as teorias jurídicas do liberalismo clássico como um projeto jurídico totalitário em relação à vida social, observa com muito acerto que o delinquente transforma-se, nesse imaginário, em um ser externo, um corpo estranho, que se põe contra a sociedade e fora dela.

Apesar disso tudo, tanto em Kant quanto em Beccaria, o "delinquente" preserva sua dignidade e mantém os seus direitos. Beccaria fala mais de uma vez em "delinquente cidadão" (DDDP, III e XXV), indicando que mesmo o condenado permanece com seus direitos de cidadão; e em Kant, o tratamento do ser humano como uma finalidade em si mesmo ("dignidade humana") persiste em relação ao criminoso (Pires, 1998c: 193 e ss.). Cattaneo diz, nesse sentido, que a "parte melhor" da teoria de ambos é o "sentimento humanitário e a ideia de dignidade humana" (1981: 61). ${ }^{154}$ A bandeira política da humanização dos castigos e procedimentos criminais é por demais conhecida, e nada precisa ser dito a esse respeito num capítulo cujo único propósito é recordar coisas já não tão óbvias. Mas a visão do delinquente como um ser externo e incompreensível às vezes falava mais alto, mesmo num autor com uma antropologia tão pacifista como Rousseau: ele retratava o criminoso como um pária que tinha de ser combatido e eliminado. No quinto capítulo da Parte II de O Contrato Social, o teórico do bom selvagem diz que:

todo criminoso, ao atacar o direito social, torna-se por suas ações rebelde e traidor da pátria; ele deixa de ser membro ao violar suas leis, e declara-lhe guerra. Então a conservação do Estado é incompatível com a sua, sendo preciso que um dos dois pereça, e quando matamos o culpado, é menos como cidadão e mais como inimigo". (1772: 57-8). ${ }^{155}$

homem, dizia Wolff, é uma ficção, mas mesmo assim de utilidade reconhecida. "Nos fazemos a abstração de tudo no homem, exceto as qualidades que o rendem capaz de obrigações e direitos" (1758, I: XXIV). Wolff esclarece que sua distinção é a mesma que faziam os teólogos quando falavam do "homem carnal" e do "homem espiritual". Também os primeiros "criminalistas", como Romagnosi, preservavam essa visão (1791: 13).

154 "Ancora oggi la soluzione più soddisfacente dei problemi e delle gravi difficoltà che pone l'instituto giuridico della pena consiste nel scegliere la parte migliore della dottrina di Beccaria e della dottrina di Kant; e questa parte migliore è il sentimento umanitario e l'idea della dignità umana."

155 "D' ailleurs tout malfaiteur, attaquant le droit social, devient par ses forfaits rebelle \& traitre à la patrie; il cesse d'en être member en violant ses loix, \& meme il lui fait la guerre. Alors la conservation de l'Etat est incompatible avec la sienne, il faut qu'un des deux périsse, \& quando on fait mourir le coupable, c'est moins comme Citoyen que comme ennemi". 
Seja qual for o caminho tomado, é certo que evitar o crime dependia, para todos esses autores, apenas do agente. Pelo adequado uso de suas faculdades mentais, o homem saberia, seja pelo guia de sua razão, seja pelo reconhecimento do contra-estímulo da pena, que não deve cometer crimes. Se os cometer, ou é inimigo, ou é ignorante, ou é mau, ou é um miserável cuja condição impede-lhe de exercer suas faculdades humanas mais elementares. Mas é penalmente responsável, porque escolheu dar a si mesmo uma pena através do cometimento do crime. Falando especialmente de Hobbes e Kant, Norrie (1991) cuida detidamente dos problemas teóricos que surgem para as teorias da punição de ambos por conta dessas "imagens esquizofrênicas" do homem. Esse é, aliás, um dos pontos de partida a partir dos quais Cesare Lombroso escreveu, pouco mais de cem anos após Beccaria e Rousseau, seu mais famoso livro. No prefácio à primeira edição de L'Uomo Delinquente, de 1876, lê-se a seguinte passagem:

Aqueles que acompanham julgamentos criminais e estudam os resultados em visitas às prisões, ou examinando estatísticas, desiludem-se pelo debate interminável em torno da punição. (...) Aqueles que têm contato direto com os criminosos, tais como os membros de sua família ou os funcionários das prisões, sabem que eles são diferentes das outras pessoas, com mentes fracas ou doentes que raramente podem ser curadas. (...) E ainda assim os legisladores, acreditando que são raras as exceções ao livre-arbítrio, ignoram os conselhos dos psiquiatras e dos oficiais das prisões. Eles não entendem que a maior parte dos criminosos de fato não têm livre-arbítrio. (2006: 43)

O escárnio com que Lombroso é usualmente tratado muitas vezes impede o adequado entendimento daquilo que ele dizia. Nesta passagem, ele postula que não adianta concebermos mecanismos de prevenção criminal que dependam do bom funcionamento do intelecto humano (cálculo de custo-benefício, juízos morais etc.) se as pessoas que cometem crimes são justamente aquelas em que esses freios mentais não funcionam adequadamente. Em outras palavras: se todos temos clara a imagem de que o criminoso é louco, ou amoral, ou um rebelde incorrigível, ou um idiota 
descontrolado, então não faz sentido prevenir o crime a partir de um mecanismo que dependa do bom funcionamento da razão - a pena dissuasória de Beccaria, por exemplo -, como se ele fosse bem ajustado como nós, "homens de bem". Em uma passagem do primeiro capítulo d'O homem delinquente, Lombroso diz que o erro do combate ao crime nos séculos XVIII e XIX esteve em o legislador enxergar o criminoso a partir de si próprio; em esperar que os mesmos freios morais que funcionavam no legislador racional funcionassem também no delinquente Ao contrário, diz o médico calabrês, devemos tratá-lo como aquilo que, todos sabemos, ele é: um diferente, um esquisito, um anormal. Lombroso apenas situou em pessoas distintas ("o homem de bem" versus "o criminoso") um conjunto de características humanas contraditórias que já existiam em autores bem anteriores à Antropologia Criminal. ${ }^{156}$ Trata-se do mesmo ponto de partida kantiano de distinção absoluta entre moralidade e determinismo, mas apenas fazendo a balança pender agora para o outro lado: descartando totalmente o livre-arbítrio e elevando o determinismo a critério-chave para a imposição de uma pena. Há, como se vê, um certo continuísmo na representação teórica do criminoso entre clássicos e positivistas, ao contrário da oposição absoluta que se costuma apregoar; continuísmo esse que já foi observado por Foucault:

O criminoso, designado inimigo de todos, que têm interesse em perseguir, sai do pacto, desqualifica-se como cidadão e surge trazendo em si como que um fragmento selvagem de natureza; aparece como o celerado, o monstro, o louco talvez, o doente e logo o "anormal". É a esse título que ele se encontrará um dia sob uma objetivação científica, e o tratamento que lhe é correlato. (Foucault, 1987: 85).

\section{As cartas à mesa}

Por esse voo de pássaro sobre temas penalmente relevantes em alguns pensadores importantes dos séculos XVII e XVIII, é possível ver que já estavam postos diversos dos elementos teóricos a partir dos quais o nosso direito penal se constrói; mas que, ao mesmo tempo, eles ainda estavam longe de ser articulados em um sentido semelhante àquilo que, no primeiro capítulo, identifiquei como os pilares do direito

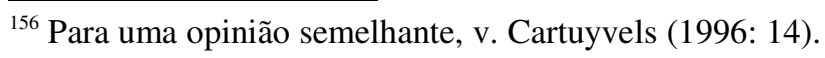


penal contemporâneo. Mas havia, ao menos, certos pontos de unidade (se bem que nem sempre atingidos pelos mesmos caminhos) que já sugeriam os termos-chave do direito penal como hoje o conhecemos: tanto no tocante ao papel da violência estatal na consecução da paz social, quanto da especificação e um ramo do direito que dele se ocupasse. Além, é claro, da percepção de que o crime era algo socialmente indesejável, e o criminoso tinha de ser combatido. Isso pode ser apontado como um sentido compartilhado aos filósofos e juristas pré-contemporâneos, que ajudará a entender a criação específica do direito penal contemporâneo. Esses pequenos pontos de consenso, porém, são capazes de dar as bases a partir das quais um projeto do direito penal contemporâneo será possível, orbitando em torno do caráter político e socialmente danoso do delito, bem como da intolerabilidade do criminoso e infalibilidade da punição, que só em casos muito extremos pode deixar de ser aplicada (pensemos no quanto são restritas as excludentes de culpabilidade em em ordenamentos penais tão complexos quanto os de hoje).

Antes de fundar uma disciplina jurídica com esse conteúdo, entretanto, havia ainda muito trabalho a se fazer: pois se, de um lado, havia esse "macroconsenso", havia também, de outro, grandes disputas teóricas que minavam uma possível unidade da disciplina, todas indicadas pela falta de acordo quanto aos elementos fundamentais do direito penal contemporâneo.

Em primeiro lugar, ainda que a separação entre direito público e direito privado já estivesse razoavelmente estabelecida no pensamento jurídico do século XVIII, duas coisas ainda permaneciam nebulosas. Em um primeiro momento, viu-se que não era unânime na doutrina a representação de um "direito criminal" que se distinguisse dos demais ramos do direito: nos pensadores do século XVII (Pufendorf, Hobbes), ele aparecia como a mera parte penal das leis positivas unitariamente consideradas ("leis civis"); enquanto nos do século XVIII (Kant, Beccaria, Blackstone), ele era visto como a parte punitiva do direito público como um todo, mas sem se distinguir de outros ramos do direito que também pertencessem ao direito público. Quando, no século XIX, alguns juristas já acusavam uma separação de um "direito criminal" como um objeto autônomo, eles revelavam dificuldades em situá-lo dentro da 
classificação do direito público versus direito privado, seja pelos aspectos processuais de natureza dispositiva contidos na parte processual do direito criminal (Ribas), seja ainda pela grande quantidade de bens privados (propriedade, honra, vida) que se imiscuíam nas leis "criminais" (como já anotara Blackstone), que, de outra parte, eram vistas como as grandes protetoras da paz e segurança sociais - as finalidades do próprio Estado e, nesta qualidade, de interesse do direito público.

Os conceitos-chave do nosso direito penal contemporâneo - "crime", "pena", "responsabilidade" - já apareciam ganhando certa autonomia dentro do pensamento jurídico século XVIII adentro, mas ainda estavam longe de ser representados como constituintes da disciplina autônoma que hoje conhecemos. Haverá, portanto, mais uma grande quantidade de trabalho de especificação teórica a se esperar, nos próximos capítulos, de Feuerbach e sua geração. Em nenhum dos autores lidos verificou-se uma clara distinção do ilícito criminal e sua separação dos restantes ilícitos jurídicos, ainda que alguns deles já acusassem uma distinção, nem sempre fundamentada a contento, entre o ilícito público e o ilícito privado. A coisa mais próxima de um conceito restrito de crime apareceu no código austríaco de 1787, que distinguia os crimes não só dos ilícitos privados, mas também de ilícitos policiais menos graves. Da mesma forma, se a "pena" já era vista como algo diferente da mera reparação pecuniária pelos juristas do século XVIII (Blackstone, Beccaria, Kant), ainda faltavam elementos que permitissem a sua exata distinção em relação a outras formas de intervenção estatal próprias do direito público.

O problema da pena jurídica abria também as portas de um assunto espinhoso da filosofia moral pré-contemporânea, a saber, as divergências entre as doutrinas morais do livre-arbítrio (Kant) e dos simples psicologismos (Hobbes), que colocaram um importante autor como Beccaria no meio do caminho entre uma e outra corrente. Para a estipulação de regras jurídicas sobre a imputação de penas, esta é uma questão central, e, como sabemos pelos embates entre os chamados "clássicos" e "positivistas", continuou polarizando opiniões século XX adentro. 
A falta de consenso quanto às bases constitutivas de um "direito criminal" que só no século XVIII começou a se formar implicava, ademais, uma representação metodológica pouco uniforme da nova disciplina. Além da dificuldade em inserir consensualmente o novo saber dentro de um dos ramos da grande divisão teórica do direito moderno - direito público ou privado -, a passagem de olhos pelas sistematizações legislativas do século XVIII mostrou que, quando os "códigos criminais" começaram a aparecer, tampouco havia consenso sobre como representá-lo de acordo com a lógica de uma parte geral e outra parte especial, que era não só a maneira preferida de construção dos códigos, como também um cânone científico quanto à produção de conhecimento jurídico. Com efeito, nas primeiras manifestações do "criminal" como um objeto autônomo, a aplicação da lógica da parte geral e parte especial levou à construção de coisas bastante distintas do direito penal que nós hoje já naturalizamos. Como mostrado por uma breve passada de olhos por alguns códigos do século XVIII, algumas vezes a parte geral cuidava apenas de penas, mas não de delitos (Leopoldina, da Toscana); outras vezes, havia duas partes gerais distintas, com princípios distintos para "crimes" e "ilícitos policiais" (Josefina, da Áustria); e em outras ainda, a parte geral simplesmente não tinha conteúdo (Leggi e Costituzioni da Sardenha). Como será visto nos capítulos seguintes, essa falta de homogeneidade refletia-se também na doutrina: além de todas essas variantes, o direito penal foi por muito tempo visto pela doutrina como a parte geral ("teórica") do "direito criminal", sendo as regras processuais a sua parte especial ("prática"). Ainda que essas coisas já acusem algumas distinções que, para o direito penal contemporâneo, são importantes (direito penal versus direito material; crimes versus contravenções), não é difícil ver o quanto esses autores ainda estavam em um mundo teórico distinto do nosso; e, mais importante ainda, como a representação metodológica do "direito criminal" que é para nós pacífica e evidente era, ainda em fins do século XVIII, um ponto em aberto.

As primeiras manifestações do "criminal" como uma parte autônoma do direito, com seus formuladores pioneiros ainda pisando em ovos, revela ainda algumas coisas importantes que o nosso direito penal ajuda a esconder, porque já solidamente construído sobre princípios "inegáveis" que não precisam de regressos tão 
distantes para a sua demonstração; coisas essas que indicam a estreita e necessária ligação entre os pontos fundantes do direito penal e outros temas que, hoje, foram depositados na filosofia do direito e do Estado. Em primeiro lugar, viu-se a a grande proximidade entre as doutrinas sobre o direito de punir criminalmente e as filosofias morais da punição e da responsabilidade, que os penalistas do presente comodamente reuniram em teorias mistas que só há pouco ${ }^{157}$ voltaram a ser questionadas quanto à evidente contradição que carregam dentro de si. No âmbito da filosofia kantiana em especial, desenhava-se uma distinção entre legalidade e moralidade que, como será visto nos dois capítulos seguintes, mostrou-se fundamental para a construção do conceito de legalidade penal tal qual hoje o conhecemos. Em segundo lugar, há também uma estreita ligação entre a punição estatal e as doutrinas dos fins do Estado, uma vez que na filosofia política dos séculos XVII e XVIII, a utilização da força estatal ligava-se à necessidade (prática ou racional) do Estado: a redução de conflitos e a eliminação do dissenso, seja para fins de sobrevivência, como em Hobbes, ou para garantir o "meu e o teu", como em Kant. Isso fazia com que a discussão sobre a própria legitimidade dos "crimes" e "penas" fosse então travada no âmbito da filosofia política, que hoje vemos como externo ao nosso estrito direito penal contemporâneo (a despeito de ele continuar dependendo dessas mesmas discussões filosóficas para a sua legitimação).

Por tudo isso, é possível perceber como, em fins do século XVIII, os elementos teóricos fundamentais para a construção do direito penal contemporâneo já estavam em grande parte postos a público, como cartas à mesa; mas percebe-se também que faltava ainda alguém fizesse a partir delas um jogo que resultasse no nosso direito penal. Começava-se a desenhar já alguma existência autônoma do "criminal", mas faltavam (i) sua distinção em relação a outros ilícitos públicos, bem como (ii) a sua separação do direito processual. Essa nova disciplina já começava a ser pensada, naturalmente, a partir da distinção entre direito público e direito privado, ainda que não fosse ponto pacífico a sua colocação diante dela. $O$ papel protetivo da legalidade em face das penas estatais aparecia também, mas ela ainda não era representada com a função constitutiva da ilicitude como hoje conhecemos, salvo os exemplos minoritários de um ou outro código moderno. A pena estatal já se apresentava também como

\footnotetext{
${ }^{157}$ Para boas críticas ao sincretismo das teorias da pena, v. Jakobs (1988)
} 
merecedora de uma teoria particular não só para a sua fundamentação, como também de regras particulares de imputação; mas, na esteira do "criminal" que então existia, elas referiam-se ainda a todo o direito público, e não a uma disciplina jurídica estrita como o nosso direito penal. Finalmente, a representação teórica desse "criminal" já se fazia em parte geral e especial, mas permanecia em aberto o conteúdo não só da disciplina como um todo, como também de cada uma dessas partes. Foi possível ver também que esses elementos todos não ensejavam ainda a concepção de um direito criminal como objeto autônomo, tal qual hoje conhecemos; e, por óbvio e como corolário, tampouco haviam ainda sido montados da forma que reconhecemos inequivocamente como o nosso direito penal enquanto objeto teórico.

As informações contidas neste capítulo dão, portanto, alguma ideia dos sentidos que se espera encontrar na formulação teórica do direito penal contemporâneo.

Em primeiro lugar, pode-se esperar que haverá um cabo-de-guerra em torno da posição enciclopédica do "direito criminal", entre direito público e privado. Considerado o criminal como uma disciplina ampla, referente a toda a parte punitiva do direito positivo, esta determinação não era assim tão fácil, já que haveria tanto crimes públicos quanto crimes privados. Ademais, a divisão entre direito material e direito processual tampouco mostrava-se determinante, e as duas coisas apareciam misturadas. Havendo, como de fato havia, diversos elementos dispositivos (ou seja, de que as partem pode dispor) no processamento dos "crimes", isso era mais um complicador para essa tarefa de classificar. É de se esperar que a resposta a este problema passe pela restrição do conceito teórico de "crime", pois enquanto ele significasse lesões públicas e privadas, seria difícil encaixá-lo em um lugar ou outro, exclusivamente. A mesma especificação teórica do "crime" poderá também aproveitar ao melhoramento de dois outros elementos que estavam na pauta às vésperas do direito penal contemporâneo: (i) o processo de monopolização do poder criminal nas mãos do soberano, em primeiro lugar; e (ii) o projeto político (oposto) de limitação desse mesmo poder criminal do soberano, que entraria em pauta fortemente com o Iluminismo. A tarefa aqui, é de se esperar, não será fácil, pois exigirá solução de um impasse entre dois projetos políticos 
de sentidos aparentemente opostos: consolidar a exclusividade do poder criminal sobreano versus limitar o exercício desse mesmo poder através do próprio direito criminal.

Essa discussão terá de passar ainda por um refinamento da doutrina do direito de punir, que não só exigirá a articulação dessas duas correntes adversárias, como também precisará acomodar o impasse teórico mais relevante da filosofia moral imediatamente anterior ao direito penal contemporâneo. Isso envolverá formular uma teoria do direito de punir que seja capaz de, a um só tempo, dar as mãos a uma antropologia racionalista e moralizante, que trabalha preferencialmente com uma teoria da punição criminal fundada em responsabilidade e retribuição; e também a uma antropologia fundada em uma elementar psicologia associativa, que trabalha preferencialmente com uma doutrina da pena como causas e efeitos, e com a manipulabilidade das ações humanas pela punição em favor de determinadas vantagens políticas. 


\section{P. J. A. FEUERBACH E A CONSTRUÇÃO DO DIREITO PENAL CONTEMPORÂNEO}

\section{INTRODUÇão}

O propósito deste capítulo é apontar como os elementos mostrados no capítulo anterior foram moldados na nossa forma contemporânea de enxergar o direito penal como objeto teórico. Ao invés de mostrar isso a partir das obras de diversos penalistas, escolhi fazê-lo através de um só autor: Paul Johann Anselm von Feuerbach (1775-1833).

Há algumas razões que indicam o acerto de se focar nos trabalhos de Feuerbach. A primeira delas diz respeito à posição histórica de sua obra dentro do processo de formação da dogmática penal contemporânea. Boa parte dos escritos de Feuerbach, inclusive suas principais obras jurídico-penais - Revision der Grundsätze und Grundbegriffe des positiven peinlichen Rechts (Erfurt, 1799-800); Die Strafe als Sicherungsmittel vor künftigen Beleidigungen des Verbrechers (Chemnitz, 1800); e Lehrbuch des gemeinen in Deutschland geltenden peinlichen Rechts ( $1^{\mathrm{a}}$ ed. Gießen, 1801) - foram publicadas quando a Bavária ainda não dispunha de um código penal de corte moderno. Feuerbach trabalhou principalmente com a ordenação penal de Carlos V (Constitutio Criminalis Carolina, 1532) como matéria-prima legislativa, além de outras leis locais. Ainda que a Constitutio tenha sido um passo decisivo no processo de secularização, racionalização e publicização do processo penal alemão (Langbein, 1974: 
167-210), ela ainda está fora do direito penal contemporâneo no que tange à definição dos crimes e o estabelecimento de penas. A ordenação carolíngia já havia passado por processos anteriores de "modernização", é verdade, destacando-se nesse sentido o código penal bávaro de 1751; mas ainda estava longe de amoldar-se ao tipo do direito penal contemporâneo: além da falta de separação nítida entre direito material e direito processual, as próprias representações de "crime" e "pena" com que o Codex Juris Bavarici Criminalis trabalhava eram radicalmente diferentes daqueles que Feuerbach, apenas meio século depois, legaria à cultura jurídica europeia. ${ }^{158}$ Dessa forma, a teoria penal de Feuerbach teve de "modernizar" um enorme volume de legislação arcaica e doutrinas jurídicas que os códigos modernos (inclusive o bávaro, de 1813, de que Feuerbach foi o principal redator) deixaram organizados para as gerações subsequentes de penalistas. Isso significa que todo o esforço de construção intelectual do direito penal contemporâneo, que desde os códigos penais de finais do XVIII e início do XIX tornouse objeto de apropriação estatal por meio da codificação, é explícito e detalhado nos trabalhos do penalista alemão. Ele pertence, portanto, à geração que, por assim dizer, fundou o direito penal como hoje o conhecemos. Por isso Naucke (1975: 861-2) insiste tanto em postular que a sua doutrina deveria ser mais utilizada para a compreensão histórica do direito penal com que hoje trabalhamos.

Mas, é evidente, Feuerbach não fez isso sozinho; essa construção foi, como acaba de ser dito, produto dos trabalhos de toda uma geração intelectual. Por que, então, escolhê-lo, especificamente? Não haveria outros juristas dessa época que pudessem prestar-se ao mesmo papel? A resposta é indubitavelmente afirmativa: sim, houve outros juristas que poderiam ser objeto deste mesmo estudo. Mas há uma

\footnotetext{
${ }^{158}$ Um pequeno exemplo disso é dado pelo art. $6^{\circ}$ do diploma em referência: "As penas capitais são também agravadas frequentemente por meio de adições (Zusätze), e o pobre pecador (Sünder) levado ao local de execução, aprisionado em grilhões em brasa, amarrado em laços, com as mãos cortadas, a língua arrancada, o corpo preso à roda, queimado, esquartejado, sendo suas partes penduradas em praça pública. Esta última entretanto, para a moderação de custos excessivos, pode ser omitida". No original: "Jetztgedachte Capital-Straffen werden auch öfters durch Zusätze geschärfft, und der arme Sünder zur Richt-Statt geschleiffet, mit glühenden Zangen gerissen, Riemen aus ihm geschnitten, die Hand abgehauet, die Zunge ausgerissen, der entseelte Cörper auf das Rad gelegt, verbrannt, geviertheilt und die Viertheil an offener Strassen ausgeheckt. Welch Letzteres jedoch zu Vermeydung ohnnöthiger Kösten, hinführt unterlassen werden soll".
} 
segunda razão pela qual Feuerbach, se não é a melhor escolha, é tão boa quanto a melhor.

Feuerbach não tinha como primeira opção a carreira de jurista, mas sim a de filósofo. Os primeiros anos de seus estudos superiores foram dedicados integralmente à filosofia, na Universidade de Jena, importante centro de difusão da filosofia crítica na Europa central, onde acabou por se doutorar em 12 de setembro de 1795 (Radbruch, 1934: 210). Feuerbach queria ser professor de filosofia, e sua carreira fora, até a sua formatura, inteiramente trilhada nesse sentido.

Entretanto, em 1796, teve de se casar às pressas com Eva Wilhelmine Maria Tröster, para regularizar uma relação pré-matrimonial que renderia o primeiro filho do casal, Ernst Wilhelm, nascido em 20 de dezembro do mesmo ano. Cedendo às pressões de seu pai - com quem sempre tivera uma relação inconstante, cheia de altos e baixos - e à necessidade prática de sustentar uma família, ${ }^{159}$ Feuerbach tornou-se jurista. Mas a mudança não foi tão brusca quanto poderá parecer: o direito sempre fora um dos principais objetos de preocupação do Feuerbach-filósofo. Seu primeiro livro, Kritik des natürlichen Rechts als Propädeutik zu einer Wissenschaft der natürlichen Rechte (1796), é dedicado a um dos problemas-chave da filosofia jurídica de seu tempo: a fundamentação dos direitos do homem. Alguns escritos universitários anteriores, publicados em revistas filosóficas da época, também tinham o direito como principal tema. Mesmo depois de iniciados seus estudos propriamente jurídicos, em setembro de 1796, Feuerbach ainda publicaria uma importante obra sobre um tema fundamental da filosofia política: Anti-Hobbes, ou sobre os limites da força suprema e o direito de resistência dos súditos em face do soberano (1797). Entre direito e filosofia, portanto, Feuerbach sempre teve, para usar uma expressão popular, um pé em cada canoa. E a boa compreensão de sua obra penal passa, necessariamente, pelo conhecimento de seus pressupostos filosóficos. ${ }^{160}$

\footnotetext{
${ }^{159}$ Segundo os biógrafos de Feuerbach, até os primeiros anos do século XIX, quando publicou Revision (1799-800) e o Lehrbuch, Feuerbach penava para sustentar sua esposa e seu filho. (Radbruch, 1934: 29 e ss.; Naucke, 1975: 863).

${ }^{160}$ A importância da fase filosófica de Feuerbach para a compreensão de seu trabalho penal é atestada pela obra que Mario Cattaneo (1970) dedicou a ele, focando detidamente seus escritos de juventude em lugar de apenas seus escritos criminais já amadurecidos.
} 
Por essa dupla afinidade temática, todos os pressupostos filosóficos que Feuerbach usou para construir sua dogmática penal, em geral, e sua teoria da pena, particularmente, estão clara e detalhadamente expostos nas obras filosóficas anteriores a seus trabalhos jurídicos. Isso não é coisa simples de se encontrar, sobretudo numa época em que o modelo de organização universitária de muitos países dividia seus juristas entre tarefas teóricas e práticas. A própria obra especificamente jurídica de Feuerbach é exemplar disso: seu Lehrbuch, o mais conhecido dos trabalhos jurídicos que escreveu, é muito rasteiro na exposição de seus fundamentos teóricos e, segundo Zaffaroni (in Feuerbach, 1989: 13), mal serve para precisar as bases de sua teoria do direito . Mas, ao contrário, se considerado o conjunto da sua obra, sua produção filosófico-penal é um ótimo exemplar daquilo que Foucault identificou como sendo o caminho metodológico do reformismo iluminista: de uma filosofia política a uma filosofia do direito penal. ${ }^{161}$ Se a ideia desse trabalho é buscar os sentidos por trás da formação do direito penal contemporâneo que aparece exemplarmente na obra de Feuerbach, há que se buscá-los, portanto, também em seus estudos de filosofia moral e política.

Uma terceira razão para a escolha de Feuerbach vem do fato de ele representar exemplarmente a conciliação entre duas vertentes teóricas da moderna teoria penal que muitos autores, com acerto ou não, ${ }^{162}$ julgam inconciliáveis: retributivismo e utilitarismo. Essa união, como vem sendo dito, é um dos traços constitutivos de nosso direito penal contemporâneo. Pois bem, é unânime entre os intérpretes de Feuerbach a avaliação de que ele foi marcadamente influenciado pelo retributivista Kant, não só em sua teoria do direito natural, como também em sua teoria penal; ao mesmo tempo, é também unânime entre os penalistas atuais que Feuerbach teria sido o pai de uma das vertentes do utilitarismo penal, a hoje chamada "teoria de prevenção geral negativa"

\footnotetext{
161 "A reforma do direito criminal deve ser lida como uma estratégia para o remanejamento do poder de punir, de acordo com modalidades que o tornam mais regular, mais eficaz, mais constante e mais bem detalhado em seus efeitos; enfim, que aumentem os efeitos diminuindo o custo econômico (...) e seu custo político (...). A nova teoria jurídica da penalidade engloba na realidade uma nova "economia política" do poder de punir. Compreende-se então por que essa reforma não teve um ponto de origem único". (Foucault, 1987: 69).

${ }^{162}$ Roxin (2006: 83-6) diz que as teorias unificadoras apenas somam as dificuldades individuais de cada uma das teorias, sem resolvê-las. Pires (1998a), olhando em escopo mais amplo, com o qual eu tendo a concordar, diz, ao contrário, que as teorias preventivas e retributivas alimentam uma mesma racionalidade penal.
} 
(Feuerbach a chamava de "teoria da coação psicológica"). É o que Cattaneo (1984: 188) chama de um "utilitarismo mascarado pela justiça", assim descrito por Naucke: "a tentativa de Feuerbach de ligar, no âmbito da pena, utilidade e justiça, abriu - contra as concepções kantianas ou kantianisadas - a carreira do utilitarismo travestido de justiça no âmbito das penas" (apud Cattaneo, cit.). ${ }^{163}$ Para o bem ou para o mal, este sincretismo marcou o desenvolvimento do direito penal contemporâneo, e se a origem desta mistura pode ser observada em Feuerbach, está aí mais um indício histórico de sua posição central na formação de nosso direito penal como objeto teórico.

Além do mais, Feuerbach teve uma carreira jurídica que conseguiu unir em iguais medidas a teoria com a prática, se bem que com pesos distintos ao longo de sua vida. Após ser estudante de filosofia em Jena e interessar-se profundamente por Kant e Rousseau (Naucke, 1975: 863-4), foi professor de direito em Jena, Kiel e Landshut, trabalhou no Departamento de Justiça de Munique até 1814 - quando escreveu o código bávaro de 1813 - e em seguida tornou-se juiz, tendo atuado em Bamberg e Ansbach. A despeito disso, o Feuerbach-jurista é invariavelmente saudado como kantiano e jusnaturalista, o que obscurece dois dados fundamentais para a sua compreensão: como jurista, ele teve uma carreira cada vez mais voltada para a prática, o que às vezes temperava o idealismo de matriz kantiana a partir do qual ele trabalhava; e como reformador e codificador, ele dava grande importância à dimensão prática, particularista e local do direito, não se resumindo a um mero divulgador de um direito natural aprioristicamente conhecido, ao contrário do que sugere Zaffaroni (in Feuerbach 1989), para quem o direito natural tinha em Feuerbach sempre precedência sobre o direito positivo. Uma leitura atenta de seus textos feita por destacados intérpretes do presente destaca, ao contrário, ${ }^{164}$ o perene trabalho de equilibrio entre o idealismo de um direito natural provindo da razão pura e o caráter (cada vez mais) prático de sua ciência

163 "In der Tat, Feuerbachs Versuch, Zweckmässigkeit mit Gerechtigkeit in der Strafe zu verbinden, eröffnet - gegen die kantische oder kantianisierenden Auffassungen - die Karriere der Zweckmässigkeit im Strafen im Gewand der Gerechtigkeit". Originalmente em: W. Naucke, Die Kriminalpolitik des Marburger Programms 1882, Zeitschrift für die gesamte Strafewchtswissenschaft, Heft 3, 1882, p. 537.

${ }^{164} \mathrm{O}$ equilíbrio entre teoria e prática é um tema constante nos trabalhos dos biógrafos de Feuerbach. Para uma visão resumida, v. Naucke, 1975; para um trabalho mais completo, v. Radbruch, 1934; sobre o reequilíbrio entre teoria e prática como chave interpretativa para o segundo projeto de código penal bávaro de Feuerbach, v. Schubert, 1978. 
do direito - o próprio Feuerbach, aliás, dedicou um escrito à posição teórica do direito, que ele via preso em um meio caminho entre a teoria e a prática (Feuerbach, 1969). Trata-se, portanto, de um pensador que buscava um balanço entre o mundo das ideias e o mundo das ações - duas facetas que têm reconhecida importância para o campo do direito, mas que nem sempre se põem de acordo.

Em quarto lugar, Feuerbach notabilizou-se não só por sua teoria da pena, mas também por sua teoria forte da legalidade penal. Ele é por muitos apontado como o precursor histórico mais imediato do princípio da taxatividade penal, e seus brocardos legalistas ainda são lembrados pelos penalistas do presente como parte do núcleo duro do princípio da legalidade em matéria penal (Arnold, 2003; Gropp, 1990: 90 e ss.). Se, pelo que foi visto até aqui, uma das marcas do direito penal précontemporâneo é a falta de uma noção específica e estrita de um delito criminal, o princípio da legalidade em matéria penal dá uma importante pista dos caminhos metodológicos pelos quais ele poderá aparecer.

Por fim, alguns dos mais importantes penalistas contemporâneos continuam enxergando a dogmática penal que fazem à imagem e semelhança da sua. Zaffaroni, por exemplo, diz que "Feuerbach coroou o que se pode considerar a primeira estruturação de uma parte geral de direito penal em sentido moderno" (in Feuerbach, 1989: 18). Roxin é ainda mais explícito, chamando-o de "o fundador da ciência penal alemã moderna" (2006: 78). ${ }^{165}$ Knopf (1936: 29), no mesmo sentido, diz que seu Lehrbuch dá os fundamentos da moderna ciência penal no século XIX, ${ }^{166}$ e a opinião de Naucke (1975: 861) não é diferente. Não há outros autores históricos da dogmática penal que sejam tão explicitamente reconhecidos nesse sentido. ${ }^{167}$ Ora, se a hipótese

\footnotetext{
165 "Sie ist in der historisch wirkungsmöchtigsten Form entwickelt worden von Paul Johann Anselm v. Feuerbach, der als Begründer der modernen deutschen Strafrechtswissenschaft gilt".

166 "Feuerbach, ein Kind der Aufklärungszeit, von freiheitlichen Gedanken erfüllt, von tiefer innerlicher, im besten Sinne des Wortes liberaler Gesinnung, findet in der kritischen Philosophie Kants sein wissenschaftliches Rüstzeug. Sein Lehrbuch wird die Grundlage der modernen Strafrechtswissenschaft des 19. Jahrhunderts".

${ }^{167} \mathrm{O}$ nome de Beccaria certamente supera o de Feuerbach no tocante ao reconhecimento de sua importância histórica para o direito penal atual. Mas, concordando com Roxin, penso que Feuerbach foi mais importante especificamente para o desenvolvimento da dogmática penal contemporânea, enquanto Beccaria o foi para a racionalidade penal moderna.
} 
aqui é que Feuerbach é um autor-chave para a compreensão do processo histórico de formação do direito penal contemporâneo, o fato de os penalistas atuais acusarem nele essa origem é um dado importante para corroborar essa suposição, e serve bem para justificar o porquê de sua escolha.

Dito isso, mostrarei a partir dos próximos itens como Feuerbach juntou alguns dos elementos do pensamento jurídico e da racionalidade penal modernas e construiu, através deles, aquilo que nós hoje reconhecemos como o nosso direito penal. A tarefa deste capítulo doravante é, portanto, bastante simples: apontar como a teoria específica de Feuerbach moldou, com um sentido predominantemente conciliatório em faces das disputas políticas e morais da filosofia de sua época, os elementos teóricos que estavam disponíveis a seu tempo na forma do nosso direito penal contemporâneo, cujos pontos principais relembro aqui:

(i) o direito penal (substantivo) é uma área autônoma do direito, destacada inclusive do direito processual penal;

(ii) o direito penal tem um conjunto de princípios próprios, destacando-se entre eles o princípio da legalidade, segundo o qual as leis estatais são as únicas fontes dos ilícitos criminais;

(iii) o ilícito penal tem um significado estrito: ele difere dos ilícitos morais e civis, bem como das outras infrações do direito público;

(iv) a pena criminal (e sua imputação) distingue-se das penas civis, como também dos castigos morais;

(v) o direito penal pertence ao direito público, mas cuida também de direitos individuais; e

(vi) o direito penal, como objeto teórico, tem uma organização particular: divide-se em uma parte geral, que dá a disciplina jurídica dos delitos e das penas em geral; e uma parte especial, que cuida dos delitos em particular e elenca-os de forma organizada. 


\section{Como era o direito penal às vésperas de Feuerbach?}

Antes de apresentar a teoria de Feuerbach, entretanto, é importante expor a representação teórica do "direito penal" em outros juristas de sua época. Isso dará a ideia de como a construção do direito penal contemporâneo foi trabalho de toda uma geração, que trouxe à pauta os temas e institutos fundamentais com os quais construiuse um objeto teórico particular; ou seja, que a criação do nosso direito penal não foi a tarefa hercúlea de uma só pessoa. Mas, ao mesmo tempo, mostrará também como a teorização específica de Feuerbach foi contingencialmente importante para a construção do direito penal contemporâneo, pois ainda que o material intelectual já estivesse disponível para vários autores de seu tempo, e já estivesse sendo articulado com sentidos semelhantes ao nosso direito penal, foi Feuerbach, e não um outro qualquer, que os moldou efetivamente naquilo que reconhecemos como o nosso direito penal. No capítulo seguinte, serão vistas as teorias de diversos outros penalistas europeus, com esse mesmo propósito. Por ora, o objetivo é apenas mostrar a inventividade de Feuerbach dentro do meio intelectual alemão, onde se formou e para o qual produziu seus trabalhos.

\section{Christoph Carl StüBel}

Na obra de Christoph Carl Stübel (1764-1828), quase todos os elementos individuais com que se construiu o direito penal contemporâneo já estavam presentes; mas a forma específica com que foram colocados em conjunto formou um objeto teórico que ainda era diferente do nosso direito penal, em pontos sutis porém fundamentais.

Stübel já acusava a divisão do direito entre público e privado (1795: 6). Além disso, um dado em especial chama a atenção na obra do professor saxão: ao contrário do que ainda faziam muitos acadêmicos em seu tempo, ele já reconhecia o 
direito penal (peinliches Recht) como um ramo específico do direito, e não simplesmente como a parte penal de todas as leis positivas:

\begin{abstract}
Uma lei penal em sentido estrito é uma prescrição que proíbe as imediatas lesões de um direito natural de resistência sob ameaça de uma pena, e aquela parte da ciência do direito que contem as relações jurídicas cujas leis são derivadas dessas leis chama-se Ciência do Direito penal em sentido estrito. (Stübel, 1795: 15-6). ${ }^{168}$
\end{abstract}

Também chama atenção a concepção de pena com que Stübel trabalhava, pela tentativa de definir a especificidade da pena criminal em oposição a outros usos legítimos da força estatal. Dizia ele que o Estado cumpre seu papel de manutenção da paz por dois modos distintos: (i) criando estímulos para que os cidadãos cumpram os seus deveres e (ii) criando obstáculos ao descumprimento desses mesmos deveres (1795: 12). Tais obstáculos poderão ser de dois tipos: ou a defesa (Vertheidigung), voltada às infrações já em curso; ou a prevenção (Prävention), que se destina a evitar que infrações venham a ocorrer. Uma das formas de exercer a prevenção é através de um contra-estímulo ao infrator em potencial: assegurando-lhe, em outras palavras, que seu ato infracional acarretar-lhe-á um mal que deixe de tornar vantajoso o ilícito. Stübel chama essa modalidade de prevenção moral (moralische Prävention):

À oposição violenta contra a intenção esclarecida de promover uma infração, ou deve-se resistir através de força física, ou simplesmente deve-se dar à vontade livre uma melhor direção, a implicar uma outra resolução que, com o externar dessa intenção, evite a tal ação, pelo convencimento do infrator de que ele não vai ganhar coisa alguma com a lesão; ao contrário, vai perder muito mais. Esse tipo de coação pode ser chamada de prevenção moral, para diferençar-se da prevenção física. (Stübel, 1795: 13). ${ }^{169}$

\footnotetext{
168 "Daher ist ein eigentliches peinliches Gesez eine Vorschrift, welche die unmittelbare Verlezzung eines natürlichen Zwangsrechts unter Androhung einer Strafe verbietet, und derjenige Theil der Rechtswissenschaft, welcher die Rechte und Verbindlichkeiten in sich begreift, die aus diesen Gesezzen entlehnt sind, heisst die peinliche Rechtswissenschaft im eigentlichen Sinne".

169 "Der gewaltsame Widerstand gegen die erklärte Absicht, eine Verlezzung zu unternehmen, soll entweder die dazu in Anwendung kommenden physischen Kräfte überwinden, oder blos dem freien Willen eine bessere Richtung geben, und zu einer andern Entschliessung nöthigen, in dem mit der Aeusserung dieser Absicht eine solche Gewalt verbunden wird, die den Drohenden überzeugt, er werde bei der Ausführung derselben nichts gewinnen, sondern vielmehr verliehren. Auch diese Art der Gewalt kann Prävention und zum Unterschiede der physischen, eine moralische genennt werden".
} 
A ideia do contra-estímulo é, como se sabe, um dos pontos centrais da teoria da pena de Beccaria (Pires, 1998b); e, tal qual formulada por Stübel, ela é, ao menos no que diz respeito aos pressupostos antropológicos, semelhante à teoria da coação psicológica de Feuerbach (v. item VII adiante), pois ambas compartilham o ponto de partida de que é possível mexer com a cabeça das pessoas para evitar que os crimes aconteçam, e que a pena é útil nesse sentido. Mas em uma análise mais detida, as duas posições são diferentes em pontos decisivos: em Feuerbach, como veremos, a pena, por si só, não é capaz de cumprir com o seu papel preventivo; ele necessita, adicionalmente, da lei penal. Por isso, Feuerbach deu à legalidade a função propagandística de garantir a liberdade externa de todos os súditos ${ }^{170}$ - a "condição jurídica" - através da ameaça da pena, posição essa que teve um papel decisivo para sua dogmática penal: desvinculando liberdades jurídicas de deveres morais, Feuerbach construiu um direito penal com a faceta tipicamente liberal a que estamos acostumados, valorizando, por exemplo, a descrição e a clareza do conteúdo proibitivo das leis, coisa que em Stübel não se vê: ele fala, é claro, da legalidade, pois esse era um tema importantíssimo no cenário político jurídico de então, mas apenas num contexto de organização das fontes (Stübel, 1795: 33 e ss.), e não de publicização e detalhamento do conteúdo proibitivo das leis penais, como nós hoje enxergamos o chamado "princípio da legalidade". Em outras palavras, e utilizando um anacronismo a título de exemplo: a legalidade de Stübel não implica taxatividade, como faz a legalidade de Feuerbach. ${ }^{171}$

Além disso, Stübel reuniu todos os elementos teóricos do direito contemporâneo anteriormente citados de uma forma que ainda não resultaria naquilo que hoje reconhecemos como o nosso direito penal: apesar de já haver reconhecido a autonomia do direito penal em relação ao direito civil, ele incluía nessa nova disciplina certas matérias que, hoje sabemos, foram contingencialmente deslocadas para outros

\footnotetext{
${ }^{170} \mathrm{~V}$. item III adiante.

${ }^{171}$ Nesse sentido, Bohnert, falando da taxatividade em Feuerbach: "Das Bestimmtheitserfordernis des Strafgesetzes ist für Feuerbach keiner Ausnahme unterworfen oder - wie er im Anschluss an Kant gerne formuliert - "kategorisch" und ist in dieser Hinsicht ein Grundsatz" (1982: 9-10). Ainda sobre a taxatividade em Feuerbach, v. Knopf, 1936: 29.
} 
saberes, notadamente o processo penal (Stübel 1795: 29 e ss.). A diferença entre direito penal e processo penal não era, para ele, de caráter substantivo, mas sobretudo funcional: enquanto o direito penal cuidava dos fundamentos teóricos das penas jurídicas, o processo penal cuidava de sua aplicação prática. Stübel tratava-os, portanto, como sub-divisões de um mesmo objeto teórico. Por essas razões, é seguro dizer-se que a sua obra ainda não chega a construir um objeto teórico que esteja dentro do direito penal contemporâneo.

\section{ERnst Ferdinand KLein}

O mesmo se pode dizer dos Fundamentos do Direito Penal Comum Alemão e Prussiano, de 1796, de Ernst Ferdinand Klein (1743-1810). ${ }^{172}$ Trata-se um autor de grande prestígio em seu tempo: Klein foi um dos principais redatores da Landrecht prussiana de 1794. Assim como visto com Stübel, seus trabalhos acusavam já muitos dos elementos a partir dos quais seria possível construir o direito penal contemporâneo como objeto teórico, mas Klein igualmente não o fez. Vale destacar que ele é citado incontáveis vezes no Lehrbuch de Feuerbach e foi um dos autores com que Feuerbach mais debateu diretamente - um debate áspero, diga-se de passagem (Cattaneo, 1970: 281). A segunda parte de Über die Strafe als Sicherungsmittel vor künftigen Beleidigungen des Verbrechers, de Feuerbach, (1800: 119 e ss.) é, por exemplo, toda dedicada a sua disputa com Klein. A polêmica entre ambos tomou proporção tão grande, com sucessivos ataques e contra-ataques de parte a parte, que no prólogo à primeira edição de seu Lehrbuch, Feuerbach excluiu-se do embate e declaradamente colocou-se em posição de ignorar tudo aquilo que partisse da pena de Klein:

De sua parte, o autor considera terminada sua polêmica com o Sr. Klein e não vê nenhuma razão para responder aos últimos escritos desse doutrinador. Uma vez, pode-se desculpar o combate no âmbito literário, porque ocasionalmente é perdoável e também proveitoso, mas deter-se muito tempo pela mesma coisa é exaustivo e

${ }^{172}$ Grundsätze des Gemeinen Deutschen und Preussischen Peinlichen Rechts. Halle: Hemmerde und Schewtschke, 1796. 
irritante para os debatedores, e para os que assistem, é ridículo. (...) Que o Sr. Klein siga o seu caminho, pois o autor seguirá pelo seu. Falemos o que pensamos e façamos o que pudermos. Talvez, o tempo e o justo tribunal do mundo dirão quem fez mais e melhor. (Lehrbuch, XII-XIII). ${ }^{173}$

Um primeiro ponto de relevo da obra de Klein diz respeito à sua concepção de ilícito criminal: o professor de Halle já concebia o delito penal como algo qualitativamente diferente de outros tipos de ilícitos jurídicos, pelos danos especialmente danosos nele implicados, tal qual fizera Stübel:

Ações e omissões que, também sem leis positivas, compreendam uma injúria à sociedade em geral, ou seus membros em particular, são em si mesmas apenáveis, ou quando o objeto da ação ilícita não possa ser recuperado ao estado em que anteriormente se encontrava, ou quando o ofensor, através dessa recuperação e reparação, não perca mais do que a esperada vantagem, sem outros meios aplicáveis e adequados para evitar semelhantes injúrias. (Klein, 1796: 11). ${ }^{174}$

Note-se que, mesmo fazendo vistas grossas para a importância dos aspectos formais para a constituição do ilícito penal, Klein já demonstra um esforço de distinção, pela via material, daquele grupo de ilícitos jurídicos que merece uma pena criminal; e essa distinção relaciona-se tanto com a gravidade do crime, quanto com a necessidade da pena. Está-se, portanto, saindo do terreno da concepção horizontalizada do delito, para entrar-se no terreno do delito estritamente criminal.

\footnotetext{
173 "Seinen Streit mit Hrn. Klein hält der Verfasser von seiner Seite für beendigt. Er findet keine Gründe, den neuesten, ihm entgegensetzten Abhandlungen dieses Gelehrten zu antworten. Einmal sich auf dem literarischen Kampfsplatz tummeln, ist verzeihlich, vielleicht auch gut: auf ihm lange verweilen und immer um dieselbe Sache kämpfen, ist ermüdend und langweilig für die Streiter un für die Zuschauer wenigstens lächerlich. (...) Herr Klein gehe seinen Weg, der Verfasser wird den seinigen gehen. Was wir denken, kollen wir sagen und, was wir können, thun. Die Zeit und das gerechte Gericht der Welt mag einst entscheiden, wer das meiste und das beste that".

174 "Handlungen und Unterlassungen, welche, auch ohne positive Gesetze, eine Beleidigung der Gesellschaft überhaupt, oder ihrer Mitglieder insbesondere in sich schliessen, sind and sich strafbar, wenn entweder der vorige Zustand nicht wieder hergestellt werden kann, oder der Beleidiger durch Wiedererstattung und Ersatz nichts weiter als den gehosten Vortheil verliert, andre Mittel aber, ähnliche Beleidigungen zu verhüten, gar nicht anwendbar oder unzureichend sind".
} 
Klein concebia a pena como um instrumento de proteção social pela via do desestímulo: "As penas só se legitimam como meio de autodefesa, e não como simples vingança para anular um mal com o outro" (Klein, 1796: 8). ${ }^{175}$ É especialmente importante apontar que o autor oferecia também uma distinção substantiva entre o conceito de "pena", em sentido estrito, e as ações corretivas ou emendatórias (castigos, penitências), ainda que admitisse que as duas coisas pudessem ser administradas em conjunto. Este é um passo importante no processo de especificação de uma matéria própria do direito penal. Diz Klein:

\begin{abstract}
Na medida em que a pena simplesmente intenciona a prevenção das ações externas contrárias ao direito, é uma pena em sentido estrito. Ela se chama castigo, quando intenciona a melhora do criminoso. Mas o castigo pode ser ligado a uma pena. Sob a pena emendatória, visa-se a evitar que o ofensor cometa infrações no futuro. A pena emendatória nesse sentido, como o simples castigo, opõe-se à pena exemplar. (Klein, 1796: 8-9). ${ }^{176}$
\end{abstract}

Porém, assim como Stübel, Klein não fazia distinção substantiva entre direito penal material de direito penal processual: um seria a parte teórica do direito penal, e outro a sua parte prática. Mesmo a distribuição do conteúdo das matérias do "direito material" e "direito processual" em Klein é ainda diferente de nossa lógica contemporânea, tornando ainda mais evidente do que em Stübel a relativa indistinção entre as duas áreas: na Parte Geral de seu "direito penal" incluem-se lições sobre o funcionamento da justiça penal, como, por exemplo, as regras para determinação da competência das causas criminais (Klein, 1796: 36-43). ${ }^{177}$ Trata-se, claramente, de uma

175 "Strafe lässt sich nur als Mittel der Selbstvertheidigung rechtfertigen, nicht als bloße Rache, um ein Uebel mit dem andern zu vergelten".

176 "Insofern die Strafe blos die Verhinderung der äußerlichen gesetzwidrigen Handlung beabsichtigte, ist sie eine Strafe im engeren Sinne. Sie wird Züchtigung genannt, insofern sie die Besserung des Gezüchtigten zum Zwecke hat. Bloße Züchtigung ist nur vermöge eines Erziehungsrechtes erlaubt. Sie kann aber in Fällen, wo ohnedies eine Strafe eintreten würde, wohlthätig mit dieser verbunden werden. Unter den beßerenden Strafen pflegen auch diejenigen verstanden zu werden, welche den Zwek haben, den Beleidiger selbst von ähnlichen gesetzwidrigen Handlungen abzuhalten. Den beßerenden Strafen in diesem Sinne sowohl, als der bloßen Züchtigung, wird die exemplarische Strafe entgegensetzt".

${ }^{177}$ A separação é hoje mais clara: o direito penal define o local de consumação do delito (Lei 7.209/84, art. $6^{\circ}$.), enquanto o processo penal determina a competência jurisdicional fazendo uso, ou não, do local da consumação do delito como critério (Decreto-lei 3.689/41, art. 69, inc. I). 
permanência do método de representação teórica do direito penal a partir da ordem de sua realização processual.

Isso indica que Klein estava ainda fora do direito penal contemporâneo por um passo pequeno, mas importante. A representação conjunta do direito penal e processo penal em sua obra explica-se pela existência de uma área distinta, na prática, das demais áreas do direito, porque já dotada, àquela altura, de uma jurisdição própria - já existia uma justiça criminal, à qual competia julgar matérias criminalmente sancionadas. Mas essa matéria prática ainda não havia se desdobrado em um direito material e um direito processual distintos, como é hoje, ainda que já se acusasse alguma diferenciação entre as duas coisas.

\section{Karl Grolman}

Um último conjunto de evidências históricas importantes está na obra de Karl Grolman (1777-1843), o professor de Gießen com quem Feuerbach igualmente polemizou. ${ }^{178}$ Também esta fonte aponta no mesmo sentido das demais: diversos dos elementos necessários para a construção do nosso direito penal já estavam presentes, mas eles foram reunidos de uma forma que não resultaria no direito penal contemporâneo. Grolman tem duas obras importantes para uma história da dogmática penal: a primeira, Sobre a Fundamentação do Direito Penal e da Legislação penal, ${ }^{179}$ foi publicada em 1799 - ou seja, dois anos antes do Lehrbuch de Feuerbach, mas quatro anos depois do Anti-Hobbes, onde os primeiros fundamentos de sua teoria penal foram publicados; a segunda, Fundamentos da Ciência Jurídico-Penal, ${ }^{180}$ foi publicada em 1805. Por questões cronológicas, é a primeira que mais interessa a esta pesquisa.

Grolman começa a construir seu direito penal através de ideias que são fundamentais também para o nosso, entre as quais destaca-se, primeiramente, a

\footnotetext{
${ }^{178}$ Sobre as contendas entre Feuerbach e Grolman, v. Cattaneo, 1970: 282 e ss.

179 1799. Ueber die Begründung des Strafrechts und der Strafgesetzgebung, nebst einer Entwicklung der Lehre von dem Maaßtabe der Strafen und der juridischen Imputation. Gießen: G. F. Heyer.

${ }^{180}$ 1805. Grundsätze der Criminalrechtwissenschaft. Gießen / Darmstadt: G. F. Heyer.
} 
postulação da necessidade de regras específicas de imputabilidade, no sentido amplo da expressão (ou seja, aptidão para receber uma pena); e, mais adiante, uma conceituação de um tipo específico de pena, que não abrangeria toda e qualquer resposta jurídica a uma violação da lei. Por uma via ou por outra, trata-se de esforços de construção de um objeto teórico pelo método da especificação de um certo conteúdo que ainda hoje pertence ao direito penal: a pena criminal e as regras para sua imputação.

\section{Entretanto, no que diz respeito à diferenciação substantiva entre o} ilícito criminal e os ilícitos morais e suas respectivas penas, Grolman constrói seu discurso a partir de uma linguagem ambígua, como se vê a partir de seu conceito de pena criminal (Strafe):

A primeira característica [da pena] que nós descobrimos é sem dúvida a seguinte: que a pena consiste em um mal sensível, que os homens encontram em razão de sua culpa. Daí diferençarmos pena de prêmio, e pensarmos que essa última consiste em um bem, que a nós é dado por causa de uma ação meritória, e aquela primeira em um mal que a nós é infligido, por causa de nossa culpa. (...) Uma segunda característica é: que ela não é nem reparação, nem defesa. Por isso ouve-se sempre: este homem é obrigado a repor a coisa danificada, mas ele não recebeu pena. (...) Finalmente: só se pode falar de uma pena se aquele que a recebe é capaz de reconhecê-la como um mal em razão daquilo que ele deve. (Grolman, 1799: 42-4) ${ }^{181}$

Note-se que, ao mesmo tempo em que a definição de Grolman poderia conduzir-nos para o conceito contemporâneo de pena criminal e de imputação, ela poderia também sustentar uma visão moralizante da pena (penitência, expiação); pois Grolman não procurou, por exemplo, diferençar entre pena e castigo, como,

\footnotetext{
181 "Das erste Merkmal, welches wir auffinden, ist ohne Zweifel dieses: daß Strafe in einem sinnlichen Übel bestehe, welches den Menschen wegen seiner Verschuldung trifft. Daher setzen wir Strafe der Belohnung entgegen, und denken uns, so gewiß diese in einem Gute besteht, welches uns wegen einer verdienstlichen Handlung (meritum= ertheilt wird, unter jener ein Übel, welches uns, durch unsre Schuld (demeritum) veranlasst, zugefügt wird. (...) Ein zweites Merkmal, welches der Sprachgebrauch unverkennbar in den Begriff des Strafübels legt, ist: daß es weder Zwang zur Entschädigung noch zur Nothwehr sey. Darum hört man so häufig daß Urtheil_ dieser Mensch sey zwar verbunden, den gestiften Schaden zu ersetzen, aber Strafe habe er nicht verdient. (...) Endlich ist es gewiß, daß der Sprachgebrauch nur dann ein dem Menschen zugefügtes Übel (...) ein Strafübel nennt, wenn der, welchem es zugefügt wird, dasselbe als ein durch seine Verschuldung veranlasstes Übel zu betrachten, und als Übel zu empfinden im Stande ist".
} 
lembremos, fez Klein; e nem estabeleceu diferenças entre os requisitos psicológicos ou morais para a imputação de um castigo (moral) ou de uma pena (jurídico-penal), já que ambos dependem para ele de livre-arbítrio em sentido estrito: capacidade de se reconhecer que a pena recebida deve-se ao mal da ação. Esse caminho deixava pouca margem para uma diferenciação dos elementos subjetivos da imputabilidade penal, que é extremamente relevante para a distinguir a imputação penal das demais. Essa relativa indiferenciação está também na base de sua concepção emendatória de pena ${ }^{182}$ - esta foi sua grande polêmica com Feuerbach ${ }^{183}$-, ressalvado que uma concepção emendatória de pena não é, por si só, incompatível com o direito penal contemporâneo. ${ }^{184}$

Essa falta de especificidade do campo penal é reforçada pela noção de ilícito com que trabalhava Grolman. Sua teoria não tratava de um ilícito penal formal e materialmente diferente dos demais (jurídicos e morais); ao contrário, estabelecia poucas diferenças substantivas entre ilícitos jurídicos e ilícitos morais, apesar de reconhecer a legalidade como um fator necessário para o direito penal estatal. As leis postas pelo Estado, dizia Grolman, tinham de sê-lo de tal forma que todos os indivíduos as reconhecessem como suas próprias leis morais. ${ }^{185}$ Ao comentar os fundamentos das leis penais positivas, Grolman diz o seguinte:

\footnotetext{
${ }^{182}$ Zaffaroni (in Feuerbach, 1989) diz que Grolman entendia pena como defesa. Para fins históricos, essa não é a melhor forma de definir sua teoria, porque os penalistas da época davam à palavra "defesa" uma acepção muito restrita: o afastamento de uma agressão atual. Grolman, ao contrário, sustentava que a pena servia para emendar o criminoso e prevenir a sociedade em relação a ofensas futuras. Assim ele era lido por Feuerbach (Lehrbuch, 18). Cattaneo (1973) lembra que Grolman especificamente distinguia o direito de defesa do direito à segurança ou prevenção, sendo a pena mais ligada a este último; e, num dos poucos estudos históricos até hoje feitos a seu respeito, Karl Molitor o considerou o pai da prevenção especial (1950. Die Straftheorie der Spezialprävention bei Karl von Grolman). Ainda que, num uso contemporâneo da expressão, seja possível dizer que a pena era defesa para Grolman - como também o era para muitos positivistas, por exemplo -, para fins históricos é melhor dizer que ela a via como um instrumento emendatório, corretivo; por isso, penso eu, a analogia com um castigo é perfeitamente cabível, e reforça a tese da relativa indiferenciação entre o penal e o moral em sua obra.

${ }^{183}$ A primeira parte de Über die Strafe als Sicherungsmittel vor künftigen Beleidigungen des Verbrechers (1800) é toda dedicada à refutação da teoria da pena de Grolman.

184 A teoria penal positivista, por exemplo, tinha a concepção emendatória de pena - a chamada "prevenção especial" - como um de seus fundamentos.

${ }^{185}$ Isso o distancia da filosofia kantiana, que tinha também uma abordagem moralizante da pena, mas separava agudamente legalidade e moralidade.
} 
O homem não pode se sujeitar à vontade de um indivíduo, que seja apenas a decisão subjetiva de um terceiro, sem sacrificar a sua personalidade. A lei (a decisão objetiva) deve portanto ser tal, que verdadeiramente todos os indivíduos a reconheçam como suas próprias decisões subjetivas (Grolman, 1799: 100). ${ }^{186}$

Tem-se aqui, portanto, uma legalidade conceitualmente dependente da moralidade, pois Grolman exigia que as leis positivas (objetivas) fossem conformes às leis morais individuais (subjetivas), como regras de condutas que os súditos dariam a si mesmos. Essa ideia, que era para Feuerbach inaceitável, ${ }^{187}$ depauperava a prerrogativa político-criminal de criação de ilícitos penais independentes da moralidade e a serviço das conveniências políticas do soberano, prerrogativa essa que o direito penal contemporâneo confere ao Estado a partir da concepção política de "crimes" e da ideia de legalidade penal como fonte exclusiva para a criação de proibições penais. A pouca importância da legalidade penal na teoria de Grolman foi notada por Cattaneo:

A lei penal não tem uma posição central na concessão de Grolman: ele diz a tal propósito que o Estado não deve ignorar os meios que possam levar a uma situação em que não haja ameaças a direitos; um dos meios mais eficazes para atingir tal escopo é o do fazer conhecer antecipadamente na lei a pena que seguirá necessariamente à violação dessa mesma lei. A lei é portanto um dos meios voltados a esse escopo, e tem uma posição subsidiária em relação ao direito de punir compreendido como direito de prevenção (Cattaneo, 1970: 284-5). ${ }^{188}$

Em Feuerbach a legalidade também tinha uma papel acentuadamente intimidatório, é verdade; mas ela tinha adicionalmente, como veremos, uma

\footnotetext{
186 "Dem Willen eines Individuums, dem selbst blos subjectiven Urtheil eines Dritten, kann sich der Mensch nicht unterwerfen, ohne seine Persönlichkeit auszuopfern. Das Gesetz (das objective Urtheil) müßte daher ein solches sein, - welches wirklich alle Individuen als ihr subjectives Urtheil erkennen".

${ }^{187}$ Inaceitável porque franqueava aos súditos a possibilidade de avaliar a legitimidade das leis, o que Feuerbach não aceitava, a não ser em casos extremos.

188 "La legge penale non ha una posizione centrale nella concezione di Grolman: egli dice a tale proposito che lo Stato non deve trascurare i mezzi che possono portare a far sì che non avvenga nessuna minaccia ai diritti; uno dei mezzi piu efficaci por raggiungere questo scopo è quello di far conoscere in anticipo nella legge la pena che seguirà necessariamente alla violazione della legge stessa. La legge è quindi uno dei mezzi rivolti a questo scopo, e ha una posizione sussidiaria rispetto al diritto di punire, inteso come Präventions-Recht".
} 
característica constitutiva do direito penal, como hoje a concebemos; e não meramente instrumental, como Grolman postula. Cattaneo (cit.) aponta que Grolman tratava a ofensa (Beleidigung) a um dever e o ilícito (Unrecht) como crimes, enquanto Feuerbach separava os crimes (Verbrechen) das demais formas de ilicitude. Isso é determinante para a especificidade que o ilícito criminal ganhou na obra de Feuerbach, especificidade essa que ainda mantemos no presente. Um importante indício histórico que reafirma a diferença entre os dois autores está na resenha da obra de Grolman escrita por Feuerbach e publicada em abril de 1798 no Allegemeine Literatur-Zeitung. Em uma passagem da resenha, Feuerbach diz o seguinte:

Causa-nos muita surpresa que ofensa [Beleidigung] ou ilicitude [Unrecht] sejam tomados como sinônimos diretos de crime [Verbrechen]. Se cada crime é uma ofensa, pode toda ofensa ser chamada de um crime? Se eu quebro unilateralmente um contrato válido, ou não pago por um empréstimo contraído por um determinado período, então serei eu um ofensor e terei eu ultrapassado a esfera de liberdade de terceiros da mesma forma que, se eu matasse ou enganasse meu credor. Mas quem ousaria chamar os primeiros de crimes? Por isso, é preciso diferençar entre esses conceitos (Feuerbach, 1798b: 66). ${ }^{189}$

Finalmente, é importante dizer que Grolman ainda era um autor que trabalhava com uma acentuada indiferenciação entre direito penal e processo penal. Assim como Stübel, a relação entre direito penal e processo penal ainda eram dadas em termos de teoria versus prática. É justamente em Grolman que Cattaneo (1989: 278) anota a sinonímia entre "fato típico" e "corpo de delito", mostrando o quanto essa visão unia coisas que hoje nós temos por regra separar entre as duas disciplinas.

Por tudo isso, pode-se dizer que a especificidade do direito penal contemporâneo ainda não se via na obra de Grolman. A relativa indiferenciação entre a

\footnotetext{
189 "Es muß uns gleich sehr befremdend vorkommen, daß Beleidigung oder Unrecht geradezu mit Verbrechen für gleichbedeutend genommen wird. Wenn auch jedes Verbrechen eine Beleidigung ist; kann denn jede Beleidigung ein Verbrechen genannt werden? Wenn ich einen gültigen Vertrag einseitig breche, oder ein zu bestimmter Zeit versprochenes Darlehn nicht abliefere, so bin ich Beleidiger und habe das Freyheitsgebiet des andern eben so gut überschritten, als wenn ich meinen Gläubiger gemisshandelt oder gemordet hätte. Wird sich aber der scharfsinnige Vf. jenes ein Verbrechen zu nennen getrauen? Indessen ist die Verwechslung diese Begrieffe nothwendig".
} 
esfera das proibições penais e morais afeta sobretudo o instituto da legalidade em sua obra, que aparece bastante diferente daquilo que hoje conhecemos: a legalidade é uma condição importante para o funcionamento do direito penal estatal, mas, como instituto jurídico, ela não ocupa ainda o papel teórico e político central que hoje lhe atribuímos.

\section{$* * *$}

Pelos autores analisados, vê-se que, na mesma época em que Feuerbach escreveu suas principais obras jurídicas, que são hoje reconhecidas como a fundação da dogmática penal alemã contemporânea, havia outros importantes juristas que, a despeito de terem escrito trabalhos perfeitamente alinhados ao estado da arte da doutrina jurídico-penal de seu tempo, ainda estavam fora do marco teórico daquilo que hoje reconhecemos como nosso direito penal. As razões que os excluem desse marco são, basicamente, de duas ordens.

Em primeiro lugar, faltava a pelo menos um deles uma noção específica de delito criminal e de pena criminal, dois dos pontos-chave do direito penal contemporâneo. Trata-se de Grolman, que buscou qualificar substantivamente o delito criminal apenas como algo socialmente danoso, o que lhe apresentava a dificuldade de diferenciação entre o ilícito criminal e os ilícitos morais. Nele ainda não estava clara uma separação que para nós é hoje absolutamente evidente: o crime é um tipo de ilícito particular entre os ilícitos jurídicos, que não tem nada a ver com nossos deveres morais (ainda que ocasionalmente coincidam uns e outros). Em nenhum dos autores vistos, aliás, a legalidade foi apresentada com o papel constitutivo e a função de destaque, tanto política quanto metodológica, que hoje nela depositamos. Ademais, faltava ainda a representação do direito penal material como algo separado do direito penal processual. Tal indiferenciação aparece em Klein e Stübel. O direito processual é, para eles, a mera realização prática do direito penal: não há uma distinção substantiva entre as duas áreas, como sendo ramos jurídicos fundados em princípios e métodos próprios que redundam em objetos teóricos distintos. 
Entretanto, nessas obras já são identificáveis alguns dos principais sentidos que estão subjacentes ao direito penal contemporâneo: em primeiro lugar, a busca por uma definição estrita do ilícito criminal, ainda que isso tenha sido feito diferentemente (e nem sempre com o mesmo sucesso) por esses autores todos; em segundo lugar, a relação desse sentido específico do crime com o papel político de defesa social por parte do Estado, aliando o exercício da violência ao objetivo de manutenção da ordem; e, mais ainda, a busca também de regras para a imposição de penas, cuja definição oscilava entre um mal moral (Grolman) e um instrumento de defesa do corpo social (Klein). Não havia, porém, consenso sobre como representar isso em uma dogmática penal compreensiva de todos esses embates.

Resta agora ver como Feuerbach levou adiante a tarefa de, a partir dos mesmos elementos teóricos de seus contemporâneos, construir o direito penal como o objeto intelectual que hoje conhecemos. Dado que o direito penal contemporâneo é aqui interpretado a partir dos sentidos das teorias que o fundam, e na obra de Feuerbach esses sentidos aparecem principalmente nos trabalhos de filosofia, é importante esclarecer dois fundamentos filosóficos por ele desenvolvidos, que tiveram direta relação com sua específica formulação da dogmática penal: (i) a separação entre direito e moral; e (ii) a importância das instituições estatais. Pois ambas alimentarão um mesmo instituto jurídico-penal que, ao lado da pena criminal, é a base do direito penal contemporâneo, e que, não por acaso, celebrizou Feuerbach tanto quanto a sua teoria da pena: a legalidade penal. 


\section{A SEParação entre direito e moral}

No final do século XVIII, quando Feuerbach lançou seus primeiros escritos, já havia um consistente movimento de emancipação do direito em relação à moral. Para nós, que nascemos e crescemos em uma cultura jurídica positivista, tal separação pode parecer bastante clara: ${ }^{190}$ a moral cuida só de assuntos importantíssimos nas relações entre homens, enquanto o direito dá regras também para coisas específicas e menos importantes; a moral não pode ser alterada deliberadamente, enquanto regras jurídicas o podem; a moral ocupa-se de ações intencionais, enquanto o direito dá grande importância também às ações involuntárias (culposas); a moral trabalha com um tipo de sanção (pressão social), enquanto o direito, com outros tantos (penas criminais, multas, indenizações etc.); ${ }^{191}$ e outras coisas mais. Mas, para os homens de fins do século XVIII, essa separação não estava posta assim tão claramente, como já se viu na doutrina penal de Grolman. Lembremos que, àquela altura, todos ainda eram jusnaturalistas, em um sentido alargado da expressão; pois, a despeito de as bases filosóficas do positivismo já estarem presentes e difundidas na filosofia jurídica de então (em Feuerbach inclusive), foi só na segunda metade do século XIX que a doutrina jurídica positivista ganhou toda a sua força. Diga-se de passagem que mesmo um autor laicizador como Kant menciona Deus em diversos momentos de sua filosofia moral, por exemplo. Esta ligação conceitual entre direito e moral não era exclusividade do pensamento jurídico europeu: falando dos sistemas jurídicos ibéricos, americanos e africanos, Arno Wehling e Maria José Wehling anotam que

\footnotetext{
nas três esferas jurídicas encontramos a mesma relação indissociável entre o direito, a moral social e a religião. Das Ordenações portuguesas às normas consuetudinárias supostamente "primitivas" das comunidades indígenas, as regras jurídicas fluíam de uma concepção integradora da moral e da religião "oficiais" (A. Wehling e M. J. Wehling, 2004: 13).
}

\footnotetext{
${ }^{190}$ Recentemente, entretanto, tem havido importantes autores da teoria do direito que negam esta premissa e postulam uma ligação conceitual entre direito e moral. Destaca-se nesse sentido especialmente Robert Alexy. Para sua abordagem mais recente sobre a moralidade do direito, v. Alexy (2008).

${ }^{191}$ Essas são as principais diferenças entre moral e direito apresentadas por Hart (1994: 173 e ss.).
} 
Em outras palavras: se os juristas positivistas do século passado rebaixaram a moral como uma parente distante e pobre do direito-ciência, os autores de finais do século XVIII viam essa relação de forma bem diferente. A moral não era, em comparação com o direito, um saber empobrecido: ela era levada a sério pelos juristas, e todos achavam que o direito tinha alguma relação importante com a moral. Consequentemente, o parentesco entre os dois saberes não era, para eles, tão longínquo: direito e moral eram, além de igualmente importantes, também saberes muito próximos, porque ambos tinham por função dizer às pessoas como agir bem diante de certas situações, consideradas as regras de conduta pertinentes a cada caso. Como postulava Kant, ações jurídicas e ações morais eram sujeitas a uma só razão prática, e a unidade dessa razão tinha de ser preservada. Assim, os juristas não se viam como pessoas que tinham por função apenas descrever o ordenamento jurídico em detalhes; tinham, também (e principalmente), de postular qual a ação juridicamente correta de ser tomada à luz de determinadas circunstâncias, o que os aproximava metodologicamente da filosofia moral. A proximidade entre as duas áreas mostra-se exemplarmente até mesmo em Bentham, tido como um destacado representante da influência dos métodos científicos no estudo do direito. Em Principles, ele esclarece que a ética em geral pode ser definida como "a arte de dirigir as ações dos homens à maior quantidade possível de felicidade" (XVII, 1, II). ${ }^{192}$ Essas ações, a serem dirigidas à felicidade maior, são ou as nossas próprias ações, ou as de terceiros: o direcionamento das nossas próprias ações à felicidade chama-se "ética privada"; o direcionamento das ações alheias a esse mesmo fim, quando se referir a outros seres humanos (e não a animais, por exemplo), chama-se "governo", que, "no tocante às medidas pelas quais se expressa, é distinguido através do nome de legislação" (cit.). ${ }^{193}$ É fácil ver, por esse caminho, a proximidade entre das duas

192 "Ethics at large may be defined, the art of directing men's actions to the production of the greatest possible quantity of happiness, on the part of those whose interest is in view."

193 "What other agents then are there, which, at the same time that they are under the influence of man's direction, are susceptible of happiness. They are of two sorts: 1. Other human beings who are styled persons. 2. Other animals, which, on account of their interests having been neglected by the insensibility of the ancient jurists, stand degraded into the class of things. As to other human beings, the art of directing their actions to the above end is what we mean, or at least the only thing which, upon the principle of utility, we ought to mean, by the art of government: which, in as far as the measures it displays itself in are of a permanent nature, is generally distinguished by the name of legislation: as it is by that of administration, when they are of a temporary nature, determined by the occurrences of the day". 
coisas: não só ética e direito produziam coisas semelhantes (razões para nossas ações praticáveis), como também faziam-no com vistas a um mesmo fim (o aumento da felicidade). ${ }^{194}$

Pois bem, Feuerbach defendia a autonomia conceitual entre direito e moral. A versão mais bem acabada de seu argumento nesse sentido está em Crítica do Direito Natural como Propedêutica para uma Ciência dos Direitos Naturais, de 1796. ${ }^{195}$ Lá, ele teve o declarado propósito de estipular um conceito de direito natural que fosse absolutamente independente da moral, de forma a possibilitar o surgimento de uma ciência jurídica verdadeiramente autônoma (algo que, segundo ele, não havia sido feito até então - nem mesmo por Kant):

A pergunta sobre os fundamentos do Direito não é uma pergunta diletante (...). Ela é ligada aos maiores interesses da razão e do coração humanos. De sua resposta depende a existência ou inexistência da Ciência do Direito, sua possibilidade ou impossibilidade, e é da maior importância como condição essencial de uma Ciência do Direito não apenas em aspectos teóricos, mas também práticos (Kritik, 231-2) ${ }^{196}$

Feuerbach escreveu contra duas opiniões dominantes entre os pensadores alemães de seu tempo, que tinham, a seu ver, o defeito comum de conectar conceitualmente o direito à moral. Ele chamava essas teorias de "absolutas" e "relativas", conforme as diferentes relações que elas postulavam entre um e outro saber.

194 "Now private ethics has happiness for its end: and legislation can have no other. Private ethics concerns every member, that is, the happiness and the actions of every member, of any community that can be proposed; and legislation can concern no more. Thus far, then, private ethics and the art of legislation go hand in hand. The end they have, or ought to have, in view, is of the same nature. The persons whose happiness they ought to have in view, as also the persons whose conduct they ought to be occupied in directing, are precisely the same. The very acts they ought to be conversant about, are even in a great, measure the same". (Bentham, 1823, XVII, 1, VIII).

${ }^{195}$ Kritik des natürlichen Rechts als Propädeutik zu einer Wissenschaft der natürlichen Rechte. Trata-se do segundo livro de Feuerbach dedicado ao tema. O primeiro foi sua tese Über die einzig möglichen Beweisgründe gegen das Dasein und die Gültigkeit der natürlichen Rechte, publicado um ano antes (1795), com que Feuerbach doutorou-se na Universidade de Jena.

196 "Die Frage über den Grund des Rechts ist daher keine müßige Frage (...). Sie ist and das heiligste Interesse der Vernunft und des menschlichen Herzen geknüpft. - Von ihrer Beantwortung hängt das Daseyn oder Nichtdaseyn der Rechts-Wissenschaft, ihre Möglichkeit oder Unmöglichkeit, ab, und ist als nothwendige Bedingung einer Wissenschaft der Rechte nicht blos in theoretischer, sondern auch in praktischer Hinsicht von der äußersten Wichtigkeit". 
As chamadas teorias absolutas situavam os direitos no campo do moralmente permitido: tudo aquilo que é deixado livre de proibição pela moral corresponderia a nossos direitos naturais. As ditas teorias relativas eram as que tratavam nossos direitos como produtos do dever moral: o direito corresponderia ao outro lado da moeda do dever moral de nãointerferência, e todos os direitos seriam, portanto, passivos. Por um caminho ou por outro, Feuerbach percebia que a doutrina dos direitos naturais acabava esvaziada, tornando-os meros negativos dos deveres morais; e que isso não deixava espaço para o surgimento de uma ciência do direito natural metodologicamente independente da filosofia moral.

A postulação da autonomia conceitual dos direitos naturais não era coisa fácil de se fazer, pelo já mencionado fato de o direito e a moral serem à época representados como dois saberes que cuidavam de um mesmo tipo de ação humana (as ações práticas): dado que nós temos apenas uma razão para assuntos práticos (se tivéssemos duas, elas poderiam nos ordenar coisas diferentes e a própria ideia de uma racionalidade prática poderia desaparecer), e que essa razão tem de abrigar todos os saberes relacionados às coisas praticáveis, como a moral e o direito, segue-se então que deveria haver uma relação necessária entre direito e moral. Daí o porquê de serem tão comuns as chamadas definições absolutas e relativas, contra as quais Feuerbach escreveu.

A tarefa de Feuerbach foi muito facilitada pela filosofia moral de Kant, que havia difundido uma década antes de Kritik - na Fundamentação da Metafísica dos Costumes (1785) e na Crítica da Razão Prática (1788) - os conceitos de "moralidade" e "legalidade". Como comentado no capítulo anterior, a moralidade kantiana exigia o cumprimento de um dever apenas pelo senso íntimo de cumprimento do próprio dever racionalmente reconhecível; ao passo em que a legalidade não se preocupava com as razões internas de conformidade da conduta, bastando-lhe o cumprimento externo da exigência. Contudo, entre os intérpretes mais importantes de Feuerbach, é unânime a posição de que ele foi o primeiro autor a dar um tratamento jurídico exaustivo à distinção entre direito e moral - anterior inclusive ao próprio Kant, 
ainda que utilizando-se do ferramental teórico da filosofia crítica. Nesse sentido a opinião de Cattaneo:

\begin{abstract}
A teoria da separação entre direito e moral de Feuerbach é mais profunda e coerente que aquela elaborada por Kant em sua obra especificamente filosófico-jurídica: é uma concessão que vem em encontro à exigência da determinação autônoma do conceito de direito, a partir do sentido do conceito kantiano de moralidade. Feuerbach tratou portanto, em minha visão, melhor do que qualquer outro autor, das específicas consequências jurídicas (...) dos princípios da filosofia moral de Kant. (Cattaneo, 1970: 158). ${ }^{197}$
\end{abstract}

Também Hartmann diz que Feuerbach usou conceitos kantianos ("moralidade", "legalidade"), mas estabeleceu uma doutrina filosófico-jurídica da separação conceitual entre direito e moral antes de Kant. ${ }^{198}$ Isso porque Kant era um dos autores que conceituava os direitos como sub-produtos de deveres de terceiros: onde faltassem deveres, faltariam também direitos.

O ponto de partida de Feuerbach foi encontrar um fundamento para o direito que não estivesse nos deveres de terceiros; e que deveria ser positivamente ligado com a razão, pois o fundamento do direito só poderia ser uma autorização positiva da razão pura prática. Com isso, Feuerbach rejeitava tanto que nossos direitos correspondessem a meros deveres de terceiros, quanto que o direito teria uma relação apenas indireta com a razão pura, porque intermediado pelas proibições morais. "Nosso problema", dizia ele, "é encontrar o fundamento apropriado para o direito em algo

\footnotetext{
197 "La teoria della separazione fra diritto e morale di Feuerbach è più profonda e coerente di quella elaborata da Kant nella sua opera specificamente filosofico-giuridica: è una concezione che viene incontro all'esigenza della determinazione autonoma del concetto di diritto, prendendo le mosse dal concetto kantiano di moralità. Feuerbach ha dunque a mio avviso tratto, meglio di qualsiasi altro, le specifiche conseguenze giuridiche (...) dei principi della filosofia morale di Kant".

198 "Wenn man berücksichtigt, dass Feuerbach die kantische Philosophie zur Auffindung eines Unterschiedes zwischen dem Recht und der Moral benutzt, besteht meiner Meinung nach kein Anlaß, zu leugnen, dass Feuerbach, fußend auf Kant, vor Kant diesen Unterschied von den Positionen des subjektiven Idealismus aus hervorgehoben hat" (Hartmann, 1961: 10, n. 23).
} 
distinto da lei moral e com fundamento no próprio beneficiário do direito"199 (Kritik, 238).

A saída teórica de Feuerbach foi postular a existência de uma única razão prática, mas que contaria com duas distintas e independentes capacidades (Vermögen): uma capacidade moral, que dá os deveres morais; e uma capacidade jurídica, totalmente distinta, que dá os direitos racionais. ${ }^{200} \mathrm{Com}$ isso, preservava-se a unidade da razão ${ }^{201}$ - a moralidade continuava vista como o parâmetro por excelência de avaliação das ações praticáveis ${ }^{202}$-, ao mesmo tempo em que se permitia a postulação da autonomia conceitual entre direito e moral. Ou seja, Feuerbach não negava a proximidade entre direito e moral; mas, se até então o direito aparecia sempre como um filho da moral (porque era a partir dela definido, positiva ou negativamente), Feuerbach redefiniu esta relação de parentesco: direito e moral tornaram-se irmãos. ${ }^{203}$ Ao mesmo tempo, ele mantinha-se dentro da tradição moderna de oposição entre direitos e deveres: ${ }^{204}$ a lei moral (Sittengesetz) estabeleceria deveres; e os direitos naturais (Naturrechte) confeririam liberdades.

O caminho pelo qual Feuerbach chegou a tal solução foi simples: se recordarmos a posição kantiana de que o cumprimento de um dever moral depende da atitude interna de obediência à lei moral; e que esse adimplemento deve dar-se apenas

199 "Unser Problem lautet daher so: einen vom Sittengesetz verschiedenen in dem berechtigten Subjekt an sich gelegenen Grund des Rechts zu finden".

200 "Das Recht kann, wie gezeigt worden, nicht aus dem Sittengesetz, als einem Produkt der reinen praktischen Vernunft hergeleitet werden. Nun aber ist doch die reine praktische Vernunft Grund des Rechts. Folglich muß das Recht in einem eignen Rechte gebenden Vermögen der praktischen Vernunft gegründet sey" (Kritik, 243-4).

${ }^{201}$ A unidade da razão era um ponto fundamental da teoria moral kantiana, lembremo-nos. (Kant, 1785: 89).

${ }^{202}$ A moralidade era, para Feuerbach, o fim supremo de todos os seres racionais: "Hieraus folgt auch Moralität as Endzweck der Welt. - Endzweck der Welt ist ein Zweck, dem alle andern Zwecke in der Welt als Mittel untergeordnet sind. Er soll das letzte Glied in der Reihe der Zwecke, er soll das Unbedingte $\mathrm{zu}$ dem Bedingten seyn. Nun aber kenne wir keinen unbedingten Zweck als Moralität, folglich ist Moralität Endzweck der Welt" (Kritik, 276). É outra ideia de evidente inspiração kantiana, conforme principalmente a segunda parte da Fundamentação da Metafísica dos Costumes (1785).

${ }^{203}$ A metáfora fraternal, frise-se, é do próprio Feuerbach (Kritik,303).

${ }^{204}$ Sobre a distinção moderna entre direitos e deveres, v. Cap. II, item I.1. 
pela inclinação racional para o cumprimento do dever, então, diz Feuerbach, é também racionalmente necessário que seja criada a condição que é pressuposta ao cumprimento da lei moral: a garantia de autonomia externa. Em outras palavras: se o cumprimento coagido de um dever moral não vale, porque só a ação livre pode se deixar guiar pela lei moral, então é preciso que a razão prática queira, da mesma forma, que essa condição a liberdade externa - seja garantida. A moral é o querer racional de um dever; e o direito, o querer racional dessa liberdade externa que é condição do cumprimento do dever:

A razão deve, portanto, em virtude de sua forma, fornecer algo além, através do que se torne possível a harmonização do dever com o seu verdadeiro realizar. Por isso ela deve oferecer algo que possibilite ao sujeito o cumprimento da legislação moral em sua total amplitude. (Kritik, 255). ${ }^{205}$

Como o direito tem esse papel no mundo prático, ele deve operar também com um instrumento praticamente efetivo: a sanção. A moral, porque exige um cumprimento totalmente espontâneo, não trabalha com sanções, pois elas nos determinam através de estímulos sensíveis, o que é por si só incompatível com a espontaneidade que lhe é requerida; mas o direito, que está apenas preocupado com o respeito externo à esfera de liberdade e autonomia dos outros sujeitos, tem essa possibilidade de coação. A coação está, para Feuerbach, conceitualmente implicada na ideia de direito. "Eu ter direito a isto ou àquilo significa que minha razão faz-me possível clamar coativamente esta ou aquela ação" (Kritik, 261). ${ }^{206}$ É o mesmo argumento de Kant, para quem a coação também era inerente ao conceito de direito (Kant, 1797: 34). Liberdade externa e possibilidade de coação dão a substância do direito natural em Feuerbach, enquanto o seu principium essendi é a capacidade jurídica da razão prática, por vezes chamada de "função jurídica da razão".

\footnotetext{
205 "Die Vernunft muß daher, vermöge ihrer Form, außer den Pflichten, noch etwas setzen, wodurch Einstimmung des Sollens mit der wirklichen Realisirung desselben möglich wird, d. h. sie muß etwas setzen, wodurch es dem Subjekt möglich wird, die Verbindlichkeiten und das Sittengesetz in seinem ganzen Umfange zu erfüllen".

206 "Ich habe zu dieser oder jener Handlung ein Recht, heißt: meine Vernunft macht es mir möglich, diese oder jene Handlung mit Zwang zu behaupten".
} 
É importante frisar que, se esta postura implicava uma ligação funcional entre direito e moral, ela demandava, por outro lado, uma independência substantiva entre as duas coisas: porque se a razão exige a opção espontânea pela ação moralmente boa, então ela pede também que a ação imoral esteja disponível; pois sem isso, a ação moralmente boa não poderia ser objeto de escolha, em sentido próprio. Esta ideia de que quem quer os fins quer também os meios era também parte das teorias de Kant e Wolff, mas utilizada em outro contexto, como um imperativo (hipotético) de prudência, e não como imperativo categórico de fundamentação do direito (Kant, 1785: 39). Para Feuerbach, é racional que nós tenhamos direitos externos a ações imorais, pois só assim garantem-se as condições para o verdadeiro exercício da moralidade. "A razão", diz ele, "tem de sujeitar também ações imorais a sua sanção, na medida em que o livre cumprimento da lei moral é uma condição para o cumprimento dos fins supremos. Direitos externos são aqueles que têm por objeto ações imorais" (Kritik, 289). ${ }^{207}$ Ou seja, Feuerbach empregava a teoria kantiana de um jeito que nem o próprio Kant havia feito. Se do ponto de vista interno a moral exige a moralidade, do ponto de vista externo o direito nos garante livre acesso à imoralidade. $\mathrm{O}$ único limite de liberdade a ações imorais é dado pela lei moral suprema, que proíbe a instrumentalização de outros seres racionais. ${ }^{208}$ Com isso, preserva-se a unidade da razão prática, por um lado, mas separa-se o justo (valoração jurídica) do bom (valoração moral), por outro. Garantia-se por essa via um objeto exclusivo para a ciência dos direitos do homem, como Feuerbach diz na frase de fechamento de Kritik:

Nossa teoria dá portanto uma ciência do direito natural em toda sua grandeza, e dá a mais satisfatória resposta às grandes perguntas: sobre os direitos externos e internos, sobre o foro interno e externo, sobre a unificação da justiça com o bem, sobre a resposta juridicamente possível e moralmente possível. (Kritik, 307). ${ }^{209}$

207 "(...) so muß sie auch unmoralische Handlungen ihrer Sanktion unterwerfen, in wie ferne freie Befolgung des Sittengesetzes Bedingung der Erreichung des höchsten Zweckes ist. Aeußere rechte sind solche Rechte, die unmoralische Handlungen zur Materie haben".

${ }^{208}$ Ou seja: temos direito a tudo aquilo que não seja tratar a outro ser racional como um meio arbitrário para atingirmos nossas finalidades arbitrárias; ou, negativamente: não temos direito a nada daquilo que implique tratar um ser racional como meio arbitrário para nossos fins arbitrários. V. Kritik, 295.

209 "Unsere Theorie setzt daher das Naturrecht in seine Würde als für sich bestehende Wissenschaft ein, und gibt auf die großen Fragen: über das äußere und innere Recht, über das Forum externum und internum, über die Vereinigung der Gerechtigkeit mit der Güte, über das rechtlichmögliche und 
Essa duplicidade de funções da razão prática, que à primeira vista poderia parecer uma saída teórica fácil, ${ }^{210}$ teve significados teóricos e políticos muito relevantes. Do ponto de vista penal, é importante ressaltar que essa doutrina implicava tanto limites político-criminais, quanto deveres repressivos. Os primeiros dizem respeito às ações imorais: se a alternativa da imoralidade é condição da moralidade, então o Estado não pode criminalizar condutas simplesmente porque sejam imorais: se o fizer, levará as pessoas ao cumprimento da ação moral do ponto de vista exclusivamente externo, não deixando margem para o adimplemento verdadeiramente voluntário. Algumas vezes, o Estado apenará tais condutas, é evidente, sobretudo quando o dano acarretado por sua violação for muito grave (como no caso de um homicídio); mas ao fazê-lo, há uma perda significativa implicada para a moralidade, pois elimina-se a possibilidade do cumprimento dos deveres morais respectivos. O campo político (em lugar do moral) vai se afirmando em sua teoria como o terreno preferencial dos delitos jurídico-penais, por conseguinte. Já os deveres repressivos referem-se à obrigatoriedade de garantir o espaço dos direitos externos: o Estado deve proibir todas as ações que impliquem violação da esfera de liberdade externa das pessoas. E, é claro, a afirmação da possibilidade de termos direitos a ações ilícitas marcava acentuadamente a separação entre ilícitos jurídicos e morais, coisas que, lembremo-nos, apareciam confusas em Grolman. Knopf (1936: 30) trata essa separação como uma das pedras angulares da doutrina penal feuerbachiana.

Essa visão, expressa sobretudo por Cattaneo, encontrou poucos anos depois um importante contraponto, nascido especialmente da pesquisa de Schubert (1978). Se o Feuerbach jovem teria separado com clareza o direito da moral, o Feuerbach maduro teria retrocedido nesse sentido, pois o seu projeto de código penal bávaro de 1824 - que jamais entrou em vigor - voltava a penalizar uma série de condutas contra os costumes, que haviam sido permitidas no diploma de 1813, tais quais a bigamia (Cap. VI, arts. 12 e 13), o adultério (Cap. VI, arts. 14-16) e a sodomia (Cap. moralischmögliche die befriedigendste Antwort".

${ }^{210}$ Segundo Cattaneo (1970), muitos dos contemporâneos de Feuerbach criticaram sua teoria das duas capacidades de uma só razão prática, acusando-a de excessivamente simplória. 
VI, art. 19). Isso é interpretado por Schubert como uma revisão da posição feuerbachiana de que o direito deveria apenas cuidar dos delitos de foro externo: "em um código que queira ocupar-se apenas de lesões a direitos, "crimes de volúpia" (Verbrechen der Wollust) não têm lugar" (1978: 191). ${ }^{211}$ Cattaneo (1979), em resenha ao trabalho de Schubert, interpreta essa reviravolta como uma mudança de opinião provocada pelas dificuldades práticas do direito penal, que Feuerbach teria conhecido especialmente como juiz; nesse mesmo sentido, Naucke (1975) já havia acusado no Feuerbach tardio a resignação de um jurista experiente no tocante às reais possibilidades de implementação prática de um direito penal conforme à razão pura.

Neste ponto, há algumas coisas que precisam ser esclarecidas: (i) a interpretação do projeto de código bávaro de 1824 é muito difícil, pois trata-se de um trabalho sobre o qual Feuerbach deixou poucos registros. Contrariado por o diploma não ter vingado, ele inclusive disse que havia destruído os manuscritos em vida; eles só tornaram-se publicamente conhecidos no século XX e hoje estão confiados à biblioteca da Universidade de Heidelberg, dados que foram pela família de Feuerbach a Gustav Radbruch, então professor daquela instituição que trabalhava na biografia do jurista bávaro. É também importante esclarecer, ademais, que (ii) a mera criminalização de condutas "imorais" não implica, por si só, o retrocesso a um direito penal confessional: falando da doutrina de Mello Freire, Hespanha (1990a; 1990b) aponta, com muito acerto, que a criminalização de desvios sexuais pode muito bem dar-se por uma lógica de preservação da paz pública, já que tais condutas causavam inegavelmente, naquelas épocas, desassossego e perturbação social. Assim, a criminalização do bestialismo, como feito no projeto de 1824 de Feuerbach, não necessariamente visava à implementação de uma determinada concepção moral a partir do direito penal, podendo casar-se com a estratégia penal de prevenção de lesões a bens jurídicos, defendida por Feuerbach desde a primeira edição do Lehrbuch. Na mudança de posição de Feuerbach no projeto de 1824, há que se levar em conta, ademais, (iii) o componente político necessariamente envolvido na feitura de um diploma legal. A limitação do conceito de "crime" promovida pelo código bávaro de 1823 fora muito criticada a seu tempo, como

211 "Die wichtigste Neuerung am sechsten Hauptstück is seine Existenz. Für "Verbrechen der Wollust" gibt es im Gesetzbuch, das nur von Rechtsverletzungen handeln will, noch keinen offiziellen Platz". 
anota Schubert (1979: 35): o professor de Kiel A. F. J. Thibaut (1802: 35), por exemplo, teceu fortes críticas à ideia feuerbachiana de que crimes são apenas as condutas que implicam lesões a direitos externos. Para quem quer ver seu código aprovado, diminuir as hostilidades ao texto da lei é sem dúvida algo importante, e isso deve ter passado pela cabeça de um Feuerbach já amadurecido e experiente. Por fim, (iv) se para uma história do pensamento de Feuerbach essa questão é importante, ela é menos relevante para uma história que, como a desta tese, ocupa-se do direito penal que Feuerbach legou para as gerações posteriores, já que este último indubitavelmente é aquele que foi construído na primeira fase de sua vida intelectual, e funda-se portanto na postulação de uma separação forte entre legalidade e moralidade.

Sendo assim, não deixa de ser relevante anotar os impactos metodológicos duradouros que derivam da separação entre direito e moral do primeiro Feuerbach. Como anota Radbruch, a dogmática penal de Feuerbach tomou, por esse caminho, contornos de uma doutrina verdadeiramente liberal, ${ }^{212}$ por ter o propósito destacado de garantia e preservação da esfera interna de cada cidadão, seja contra interferências estatais, seja contra interferências de outros sujeitos racionais. Em termos metodológicos, é importante também notar que essa opção teórica é capaz de dar pinceladas privatistas (porque foca-se em interesses individuais mais do que no interesse público) a um saber que tem por objeto uma matéria essencialmente pública, gerando-se assim uma área do direito híbrida, com nuances de direito público e privado. Isso é produto de uma certa opção teórica na formulação do objeto da disciplina, que compreende tanto a proteção da esfera íntima dos cidadãos (autonomia), quanto a garantia de interesses coletivos (paz pública) por meio do exercício exclusivo da violência penal - a liberdade individual do liberalismo iluminista e a tarefa repressiva do rei absolutista, portanto.

\footnotetext{
${ }^{212} \mathrm{O}$ liberalismo do primeiro Feuerbach não é isento de polêmicas, entretanto. Importantes intérpretes de sua obra (Schubert, 1824) apontam que a efetividade de seu direito penal de coação psicológica dependia de penas draconianas e aterrorizantes; entretanto, se isso é filosoficamente verdade, do ponto de vista histórico, não é menos verdade que ele canonizou-se como o grande liberal da dogmática penal iluminista.
} 


\section{A neCESSIDAde do Estado E a IMPORTÂnCIa das InSTITUiÇões}

A posição de Feuerbach no tocante aos temas-chave da teoria política de seu tempo é também importante para mostrar o caráter historicamente contingente do tipo de dogmática penal que ele ajudou a construir: muitos dos elementos de sua teoria penal ficam melhor explicados, do ponto de vista histórico, se se têm em mente certos pontos de partida que derivam de sua filosofia política. Tome-se como exemplo sua teoria da pena como coação psicológica, que até hoje o celebriza: a primeira e mais detalhada explicação de seus fundamentos vem na obra feuerbachiana especificamente dedicada ao direito de resistência dos súditos em face do soberano, o Anti-Hobbes. ${ }^{213}$

Anti-Hobbes foi publicado em 1797, portanto apenas um ano depois de Kritik des natürlichen Rechts; de forma que, evidentemente, a pauta de preocupações teóricas e práticas de Feuerbach não foi tão modificada entre uma obra e outra. Pode-se mesmo dizer, como faz Cattaneo, ${ }^{214}$ que o Anti-Hobbes é um segundo passo na mesma direção que Feuerbach já havia caminhado com seu primeiro livro: enquanto o primeiro ocupava-se, com vistas a sua concepção de moralidade, da dedução do direito natural em uma perspectiva individualista e idealista, o segundo cuidava do homem inserido em uma comunidade civil, com a mesma metodologia e o mesmo norte moral de Kritik. Nesse campo, Feuerbach tratou de dois temas que se mostraram essenciais para o específico caminho que tomou sua teoria penal dali em diante. Em primeiro lugar, os conceitos de pena estatal e os limites político-morais da pena; e, ainda, a importância das instituições estatais para a construção de uma ordem social racionalmente aceitável, tema que tinha em seu coração a questão da legalidade, que desde então tem se mostrado tão importante para a dogmática penal.

Feuerbach escreveu em meio a um conjunto de acontecimentos importantes de seu tempo. Internamente, travava-se nos estados alemães uma disputa

\footnotetext{
${ }^{213}$ 1797. Anti-Hobbes oder über die Grenzen der höchsten Gewalt und das Zwangsrecht der Bürger gegen den Oberherrn. Gießen: Müllerschen Buchhandlung. Doravante, simplesmente AH.

214 "Se la Kritik conteneva una deduzione razionalistica del concetto di diritto naturale, svolta in una prospettiva aprioristica, con l'attenzione rivolta essenzialmente all'uomo singolo, l'Anti-Hobbes rappresenta il passagio alla considerazione dei problemi relativi al fondamento e alle condizioni della possibilità di esistenza dello Stato" (Cattaneo, 1970: 181).
} 
com vistas à implementação de uma ordem política pós-feudal. A Alemanha foi, como se sabe, uma nação em que esse obstáculo só veio a ser superado muito tardiamente. Talvez o exemplo mais evidente disso esteja no movimento de codificação: enquanto no Brasil a Constituição de 1824 afirmava a unidade nacional e impunha os códigos, ${ }^{215}$ eles tiveram uma difícil penetração na vida política alemã: em 1814, Savigny publicava seu Da Vocação de Nosso Século para a Legislação e a Jurisprudência, condenando os códigos impostos pelo legislativo nacional e defendendo a utilização de um direito romano modernizado como base da cultura jurídica alemã. Dessa forma, temas ligados à consolidação política do liberalismo permaneceram na pauta dos intelectuais germânicos desde o século XVIII, e Feuerbach é ele próprio um exemplo da perenidade desses tópicos. Para a teoria penal, esses debates tangenciam um conjunto relevante de instituições como as teorias dos fins da sanção criminal, a doutrina da dosimetria pena ou a regra da legalidade penal.

Para além das fronteiras dos estados alemães, a Revolução Francesa e seus desdobramentos tiveram também grande impacto sobre Feuerbach, que foi profundamente marcado pelos grandes temas da filosofia política iluminista: jusnaturalismo racionalista, contratualismo, individualismo etc. Feuerbach foi um grande adversário da monarquia nobilitária. Mas, como contemporâneo do terror pósrevolucionário, condenava com a mesma veemência os excessos democráticos e desqualificava os jacobinos como "utópicos da liberdade" - a expressão consta de sua dissertação de doutorado (1795: 48). Ao meio termo, posicionava-se a favor de uma monarquia constitucional, o que, segundo Hartmann, ${ }^{216}$ situava-o na típica posição da emergente burguesia alemã de fins do século XVIII: favorável a reformas, mas contrário a qualquer tipo de reviravolta mais radical. Essa moderação era de fato propagada por

\footnotetext{
215 "Organizar-se-ha quanto antes um Codigo Civil, e Criminal, fundado nas solidas bases da Justiça, e Equidade". (Constituição de 1824, art. 179, inc. XVIII).

216 "Mäßigung und Ordnung, Gesetzlichkeit und gesetzmäßige Freiheit, diesen Schlachtruf der deutschen Burgeoisie, der für sie typisch ist und sie auf dem Wege des Verrats der Revolution und zur Verschwägerung und zur Teilung der macht mit dem deutschen feudalen Junkertum begleitete, erhebt Feuerbach frühzeitig" (Hartmann, 1961: 37). Segundo Naucke (1975: 875-6), Hartmann corresponde à melhor visão do que era a leitura da Alemanha Oriental sobre Feuerbach, servindo de bom balanço para as leituras predominantemente ocidentais que dele são feitas.
} 
Feuerbach: "em nosso tempo, o homem liberal que não seja jacobino tem de ser um regalista convicto", dizia ele (apud Naucke, 1975: 877). ${ }^{217}$

Anti-Hobbes é uma obra que tem como principal objeto o direito de resistência dos súditos contra o soberano, formulado por Feuerbach nos seguintes termos: "É verdadeiramente exigida por justiça uma incondicional obediência dos súditos e um ilimitado e supremo poder de coação do soberano?"(AH, 7.). ${ }^{218}$

A finalidade do Estado apresentada nesta segunda obra é uma decorrência direta dos conceitos de liberdade oferecidos em Kritik (Hartmann, 1961: 31). Liberdade moral, lembremos, referia-se à ausência de coação interna; enquanto liberdade jurídica, apenas à ausência de uma coação externa. ${ }^{219}$ Assim sendo, a primordial função de um Estado seria garantir essas condições, já que o fim último da humanidade é a moralidade ${ }^{220}$ e todos os outros fins - o do Estado inclusive subordinam-se a ele. O Estado seria a solução ao desafio que a razão pura prática colocou perante os homens para dar cumprimento a seu dever supremo: "encontrar uma condição em que a liberdade dos homens esteja segura. Ou, em outras palavras: uma condição de segurança, em que o homem seja livre, como deve ele ser de acordo com sua natureza racional" $(A H, 19-20) .{ }^{221}$ Por isso, diz Zaffaroni que Feuerbach foi um adversário da visão rousseauniana do estado de natureza bucólico: "a razão quer a liberdade, e não natureza" (in Feuerbach, 1989: 19).

\footnotetext{
$\overline{217 \text { "In unseren Zeiten muß }}$ der liberale Mann, der nicht Jakobiner ist, ein entschiedener Royalist sein".

218 "Sollte unbedingter Gehorsam der Unterthanen und eine unbegrenzte über allen Zwang erhabene Gewalt des regenten von der Gerechtigkeit wirklich geboten seyn?"

219 "Die juridische Funktion [der Vernunft] muß daher, als Grund des Rechts, ebenfalls noch mehrere Merkmale in ihrem Wesen enthalten. Die juridische Freiheit ist eben so, wie die moralische, eine bloße Negation, nur mit dem Unterschiede, dass sie dort in Verneinung einer bestimmten Nöthigung, hier in der Verneinung eine Nöthigung überhaupt besteht" (Kritik, 249).

${ }^{220} \mathrm{Na}$ mesma linha da já mencionada passagem de Kritik (276), um dos parágrafos de abertura de AntiHobbes reforça a posição de Feuerbach nesse sentido: "Die Behauptung der Freiheit ist des Menschen Pflicht. Denn diese Freiheit ist die formale Bedingung aller besonderen Rechte des Menschen und ihre Ausübung, (die nur in concreten Handlungen und Rechten möglich ist) die Bedingung zur Moralität und zur möglichen Erreichung des höchsten Zwecks" (AH, 14).

221 "einen Stand aufzufinden, in welchem die Freiheit des Menschen gesichert ist, oder mit andern Worten: einen Stand der Sicherheit, in welchem der Mensch so frei ist, als er es seiner vernünftigen Natur gemäß, seyn soll".
} 
Ao mesmo tempo, essa concepção do Estado como um garantidor de liberdades situa Feuerbach, segundo Naucke (1962), mais próximo dos iluministas do que de Kant. O filósofo de Königsberg, de fato, concebia o Estado mais como um garantidor de direitos privados, como já comentado. Também Zaffaroni diz que a visão de Feuerbach do Estado como um garante faz dele mais iluminista e menos kantiano (in Feuerbach, 1989: 19). Cattaneo, no mesmo sentido, diz que

os iluministas sustentavam a exigência do Estado, pois colocavam-no um certo escopo (a defesa da humanidade), e constatavam que tal escopo poderia ser atingido apenas em um Estado: é esse exatamente o procedimento seguido por Feuerbach, que se avizinha dos iluministas ainda pelo fato de manter a possibilidade do aperfeiçoamento moral do homem apenas através do Estado. (Cattaneo, 1970: 238)..$^{222}$

A criação do Estado deu-se, na teoria de Feuerbach, por meio da celebração de três pactos diferentes. Trata-se de um contratualismo escalonado, por assim dizer, que é exposto em detalhes na Investigação Filosófico-Jurídica sobre o Crime de Alta Traição (1798a). ${ }^{223}$ Primeiramente, haveria um pacto de união social (Gesellschaftsvertrag, ou pactum unionis): aquele pelo qual os homens abandonam o estado de natureza e unem-se com vistas à formação da sociedade civil. É neste contrato que está estipulado que o fim da sociedade civil é garantir a liberdade dos cidadãos, bem como que no ato de sua fundação dá-se a união das forças de todos em favor da vontade geral (Untersuchung, 44). Em seguida, viria o pacto de sujeição (Unterwerfungsvertrag), que determina quem será o soberano (Untersuchung, 50). Ao fim de tudo estaria o pacto de constituição (Verfassungsvertrag), que expressa as escolhas políticas do Estado: de que maneira organizar-se-á o poder político, quais os seus limites e qual a forma como ele deve ser exercido (Untersuchung, 57).

222 "Gli illuministi sostenevano l'esigenza dello Stato, poiché si ponevano un certo scopo (la difesa dell'umanità), e pois constatavano che tale scopo poteva venire raggiunto soltanto in una compagine statale: questo è esattamente il procedimento seguito da Feuerbach, il quale si avvicina agli illuministi anche per il fatto di ritenere possibile il perfezionamento morale degli uomini soltanto attraverso lo Stato".

223 1798. Philosophisch-juridische Untersuchung über das Verbrechen des Hochverraths. Erfurt: Henningschen Buchhandlung. Doravante, apenas Untersuchung. 
Na parte em que Feuerbach fala do pacto de constituição, há um trecho de marcante importância. A passagem, em sua literalidade, é a seguinte:

\begin{abstract}
Volto-me agora ao último pacto fundamental da união civil, que é o pacto de constituição; que determina os limites arbitrários (willkührlichen Grenzen) do poder soberano, bem como a forma pela qual sua vontade (Willen) deve ser exercida (Untersuchung, 57). ${ }^{224}$
\end{abstract}

Vale notar que, ao falar dos limites do poder soberano, Feuerbach usa o adjetivo "arbitrário", derivado de "arbitrariedade" ou "arbítrio" (Willkür, na grafia atual); e para falar do exercício da vontade do soberano, escolhe o substantivo Willen. As escolhas não são acidentais. Willkür e Willen têm significados distintos e importantes na filosofia moral kantiana, de que Feuerbach era um leitor muito atento. Segundo Walker,

ambos os termos podem ser traduzidos por "vontade", mas um livre arbítrio (Willkür) é uma vontade no sentido vulgar do termo, capaz de escolha entre as exigências da moralidade e as exigências de nossos motivos e desejos não-morais ("patológicos"). (...) Wille (vontade), entretanto, é a vontade considerada como puramente racional, e um livre Wille (vontade) é uma vontade autônoma (Walker, 1999: 44).

Ou seja, Feuerbach estava dizendo que os celebrantes do pacto constitucional têm liberdade de vontade, em sentido forte (Willkür), para escolher os limites - os contornos, o desenho institucional - das formas políticas do Estado que fundam; mas que, seja qual for a forma política escolhida, o Estado deverá ser sempre conduzido de acordo com o objetivo que a razão pura prática impõe ao soberano, que tem de racionalmente querer (willen), como manda a razão pura, a finalidade do Estado, que é a preservação da liberdade de todos. ${ }^{225}$ Por essa razão, ele começou Anti-Hobbes

\footnotetext{
224 "Ich wende mich nun zu den letzten Grundvertrag des bürgerlichen Vereins. Und dieser ist der Verfassungsvertrag, welcher die willkürlichen Grenzen der höchsten Gewalt und die Art, wie sie ihren Willen äußern soll, bestimmt".

${ }^{225}$ Dessa forma, a arbitrariedade na escolha das formas políticas do Estado não seria absolutamente ilimitada: não se poderia querer uma forma de Estado que impossibilitasse a realização dos próprios fins
} 
deixando clara a natureza a-histórica de sua investigação, como fizera Kant no prólogo da Metafísica dos Costumes: a razão histórica do surgimento de diferentes Estados e formas de governo era sempre variável, disse ele; mas isso não importava, pois os fundamentos primeiros do Estado e sua importância para a vida social não vinham da história, mas sim da razão pura. ${ }^{226}$ Nesse mesmo sentido, a vontade geral de que fala Feuerbach é sempre Willen, e nunca Willkür: ou seja, uma vontade racionalmente conduzida no sentido daquilo que todos reconhecem ser o objetivo dos homens.

Essa visão do Estado terá relevantes impactos em sua teoria jurídicopenal. Em primeiro lugar, o Estado terá o dever racional de se auto preservar, pois ele é um meio necessário para a realização do fim supremo da humanidade. Logo, as condutas que visem à aniquilação ou diminuição do Estado deverão ser duramente apenadas, porque precisam ser reprimidas a todo custo. Ou seja: tornam-se matéria penal por excelência, e sujeitam-se às penas mais graves. Em segundo lugar, o Estado terá o dever racional de usar os instrumentos que estejam à sua disposição e sejam apropriados ao cumprimento de seu fim - sendo um deles, é claro, a força física (sanção, pena). Em terceiro lugar, qualquer pessoa que interfira com a execução dessa tarefa estatal estará interferindo, indiretamente, na realização dos fins supremos da humanidade, e torna-se dela um opositor político; pois o Willen do soberano e o Willen da comunidade e de cada um de seus membros, como produtos da mesma faculdade de razão pura, não podem senão estar de acordo. Além disso, o direito penal será, para Feuerbach, um fenômeno estatal: ainda que haja direitos naturais, e que haja um direito natural de se defender (tratado sobretudo em Kritik), o direito penal em sentido estrito

do Estado, pois isso implicaria, ao mesmo tempo, querê-los e não querê-los (por agir de forma a anulálos), o que seria uma contradição inaceitável para a razão pura prática. Eis aí a importância de se manter a unidade da razão pura prática, com ele fizera em Kritik: Feuerbach era capaz de manter a postulação de que as formas do Estado poderiam ser livremente (Willkür), mas ao mesmo tempo condenar certos arranjos institucionais que, como o jacobinismo, eram a seu ver incompatíveis com os fins do Estado e, por conseguinte, com o dever supremo dos homens em matéria prática.

226 "Wir müssen also bis zum Begriff des Staats, einer Entstehung und seinem Zwecke zurückgehen. - Bei diesem Geschäfte, dürfen wir aber weder die Geschichte, noch die Erfahrung um Rath befragen, so gute Dienste sie uns auch sonst in anderen Wissenschaften, oder in den angewandten Theilen unserer Wissenschaft leisten können. Denn wir fragen nach Begriffen, nach denen wir die Erfahrung selbst beurtheilen und meistern wollen: wir fragen nicht: welches der Zweck der Staaten in der Erfahrung ist? sondern, welches der Zweck derselben, bei allem nur möglichen Widerspruche der Erfahrung, seyn soll?". 
só se dá em âmbito estatal: tanto assim que ele é um direito do Estado, e não dos cidadãos (Lehrbuch, 1; 22)

Somado isso com a sua doutrina da separação entre direito e moral, estavam postos os alicerces teóricos para a construção de uma dogmática penal de corte liberal, como a que ainda hoje temos. O que começa a ser ver aqui, portanto, é a inflexão política que transformou o "direito penal" não só no direito da força do soberano (como já era ao menos desde o século XVI), mas ao mesmo tempo no direito de proteção de individualidades: é racional não só querer o Estado e seu aparato punitivo, como também a preservação das liberdades de todos os seus súditos. Para a separação entre direito penal e processo penal, isso é de extrema importância: pois enquanto o processo era e continuou sendo visto com o conjunto de regras voltadas à efetivação da prerrogativa punitiva do $\operatorname{Estado}^{227}$ - a parte prática do direito criminal, como visto em Klein e Stübel -, o direito penal de Feuerbach poderá, por esta via teórica, ganhar aqui, ao menos em parte, uma função distinta, que logo se revelará oposta: assegurar as liberdades dos súditos perante o direito estatal de punir.

\section{A CONSTRuÇão de UM NOVo ObJETo TEÓRICO}

O primeiro elemento de nosso direito penal refere-se, por óbvio, à sua existência autônoma enquanto área do direito. Nesse sentido, a primeira parte do capítulo mostrou que em diversos autores alemães contemporâneos de Feuerbach, já havia sido posta com clareza a distinção entre o direito penal e o restante do "direito civil",228 mas que, por outro lado, ainda havia em fins do século XVIII uma relativa indiferenciação entre direito penal substantivo e direito penal processual, e também pouca especificidade desse amplo direito criminal dentro do direito público, já que as "penas" eram majoritariamente vistas como a punição soberana aos ilícitos públicos.

\footnotetext{
${ }^{227}$ A despeito de o processo ter passado também por uma ampla reforma de cunho iluminista a partir do século XVIII, como mostra exemplarmente a progressiva abolição da tortura processual dos ordenamentos europeus.

${ }^{228}$ No cenário europeu, porém, isto não era consensual, como será mostrado no capítulo seguinte.
} 
Digo que essa indiferenciação é relativa porque, relembremo-nos, esses autores distinguiam entre uma parte teórica do direito penal (direito substantivo) e uma parte prática do direito penal (direito processual); mas insisto que essa forma de enxergar direito e processo penal reflete uma relativa indiferença entre das duas, já que, postas as coisas dessa maneira, direito penal e processo penal são representados como dois ofícios distintos dentro de um mesmo saber, porque fundam-se em princípios comuns e, por conseguinte, acomodam-se dentro de um mesmo objeto teórico. Mas, bem sabemos, não é essa a nossa forma de enxergar a relação entre direito e processo penal: ainda que haja uma ligação funcional evidente entre as duas áreas, direito penal e processo penal são, para nós, duas disciplinas autônomas - tanto assim que o nosso processo penal tem uma parte teórica própria, ${ }^{229}$ coisa não poderia existir quando ele era visto como a mera parte burocrática de uma ciência penal compreensiva.

O primeiro passo dado por Feuerbach em seu Lehrbuch é não deixar dúvidas de que o direito criminal é um objeto teórico totalmente independente, destacado tanto do direito civil quanto do restante do direito público:

O direito criminal (ciência do direito penal, direito punitivo) é a ciência dos direitos que, fundados em leis penais, tem o Estado contra os súditos, como transgressores dessas leis. Ele é por isso uma parte do direito público, distinguindo-se dos direitos civis, que instruem as pessoas privadas, e também dos direitos do Estado, como uma parte coordenada do direito público, que compreendem os fundamentos da constituição do Estado. (Lehrbuch, 1$)^{230}$

\footnotetext{
${ }^{229}$ Estou longe de pretender inserir-me no debate quanto à existência ou não de uma teoria geral exclusiva do processo penal. Entre nós, Dinamarco, Cintra e Grinover (Teoria Geral do Processo, Malheiros, diversas edições) postulam a existência de uma teoria geral do direito processual como um todo, comum aos direitos processual civil e penal. Tucci e Pitombo (2002. Teoria do Direito Processual Penal: jurisdição, ação e processo penal, RT), ao contrário, sustentam a independência conceitual entre direito processual civil e direito processual penal. Esta diferença é irrelevante para o meu argumento, pois interessa-me apenas o fato de que ambas as correntes enxergam o direito penal como algo distinto do direito processual penal, pouco importando se equiparam ou diferenciam os fundamentos teóricos do processo civil e penal.

230 "Das Criminalrecht (Strafrechtswissenschaft, peinliches Recht) ist die Wissenschaft der Rechte des Staats, welche durch Strafgesetze gegen Unterthanen, als Übertreber derselben, begründet sind. Es ist daher ein Theil des öffentlichen rechts und unterscheidet sich von dem Civilrechte, in so ferne dieses Rechte der Privatperson lehrt, und von dem Staatsrechte, als einem ihm coordinierten Theile des öffentlichen Rechts, in so ferne dieses die durch die Verfassung des Staats begründeten Rechte darstellt".
} 
Como já foi comentado no capítulo anterior, classificar o direito penal na bipartição entre público e privado não era tarefa simples. Para fazê-lo, seria muito útil uma especificação substantiva do direito penal como um ramo do direito sui generis. O direito penal, que já vinha se destacando institucionalmente dos demais pela existência dos recentes códigos inteiramente dedicados à matéria punitiva, passou a destacar-se em Feuerbach também por seus fundamentos materiais.

Ainda que não haja indicação nas fontes de que esse tenha sido o propósito de Feuerbach ao construir um objeto teórico tão restrito para o direito penal, o fato é que o objeto por ele construído não tinha dificuldades para ser classificado dentro do direito público. Pois o direito civil, como Feuerbach diz, seria inteiramente ocupado das relações de pessoas privadas umas com as outras; e o restante do direito público, visto como a regulação dos fundamentos e exercício do poder estatal, seria inteiramente ocupado dos assuntos do Estado. A definição das formas institucionais de uma Estado era para Feuerbach, lembremo-nos, um exercício arbitrário (Willkür) das prerrogativas políticas do soberano, que requeria saber altamente especializado e não dizia respeito aos indivíduos a não ser quanto a seus princípios elementares. ${ }^{231} \mathrm{O}$ que, por corolário, indica que o direito penal nem podia ser visto como totalmente ocupado de assuntos privados, por não ser parte do direito civil; e nem como indistintamente misturado ao direito público, porque, segundo ele comentava em passagens do Lehrbuch, o direito penal distinguia-se de outras normas publicísticas. Ou seja, sobrava-lhe apenas a posição de fazer parte do direito público, mas como um objeto teórico distinto das demais áreas do direito público. De mais a mais, ao restringir o objeto do direito penal à definição de crimes e penas, Feuerbach conseguia transformá-lo em um direito do Estado contra os súditos infratores das leis (Lehrbuch, 1), eliminando elementos facultativos típicos de direito privado que à época pertenciam também ao processo criminal, onde a iniciativa para a persecução de muitos crimes ficava também a cargo

\footnotetext{
${ }^{231}$ Feuerbach diz, no Anti-Hobbes, que as pessoas não têm legitimidade ou capacidade técnica para julgar os meios e fins eleitos pelo governante: "Die Staatskunst ist eine gar große, schwer zu erlernende und schwer auszuübende Kunst. Sie setzt die entschiedensten Talente, verbunden mit den tiefsten und weitumfassendsten Kentnisse voraus". (AH, 61). "(...) und es wird, hoffe ich, keines Beweises bedürfen, daß es dem Volke unmöglich sey, über das Vernünftige einer Regierung überall etwas vernünftiges zu bestimmen, und auf die erkannte Zwecklosigkeit oder Zweckdrigkeit ein Zwangsrecht, oder rechtmäßigen Ungehorsam zu gründen". (AH, 63).
} 
do ofendido. ${ }^{232}$ Essa separação absoluta entre o direito material e processual penal aparece taxativamente em Feuerbach, que a postula em poucas palavras:

A doutrina sobre o meio pelo qual o direito efetiva os direitos que lhe conferem as leis penais (processo criminal) é, na verdade, parte do direito processual em geral, e permanece vinculado ao direito criminal apenas para a conveniência do ensino acadêmico. (Lehrbuch, 4). ${ }^{233}$

Assim, o direito penal renunciava qualquer preocupação prática quanto às formas de fazer processar os infratores das leis criminais ou à execução de suas penas. Essas tarefas pertencem ao processo penal e ao direito de execução penal, ${ }^{234}$ respectivamente. A separação entre direito material penal e direito processual penal em Feuerbach é tão profunda que este último sequer é representado como um dos "saberes auxiliares" do direito penal - e, frise-se, o rol de ciências auxiliares é extenso o suficiente a ponto de incluir o estudo de línguas clássicas (Lehrbuch, 6). O problema do direito penal é, para Feuerbach, analisar a legislação criminal - aquela dá ao Estado o direito de aplicar penas -, de acordo com princípios filosóficos racionalmente evidentes:

A ciência do direito punitivo positivo é composta por: 1) os princípios sobre a punição das ações antijurídicas em geral - parte filosófica (geral), e a partir daí 2) os direitos particulares do Estado que visam à punição das categorias especiais de ações jurídicas individuais - parte positiva (especial). (Lehrbuch, 4). ${ }^{235,236}$

\footnotetext{
${ }^{232}$ Era justamente o processo criminal e seus elementos privados que dificultavam, como visto nos comentários do Conselheiro Ribas, a classificação do direito criminal como inteiramente pertencente ao direito público.

233 "Die Lehre von der Art, wie der Staat gesetzmäßig seine Rechte aus Strafgesetzen geltend macht (Criminalprocess) ist eigentlich Theil des Prozessrechts überhaupt und wird mit dem Criminalrechte selbst nur aus Bedürfnissen des akademischen Unterrichts verbunden".

${ }^{234}$ Sobre a despreocupação de Feuerbach com a execução penal, v. Cattaneo, 1979: 428-9; Schubert, 1978: 72-3. Também por razões filosóficas Feuerbach evitava a execução da pena, pois ela implicava a instrumentalização do criminoso e, por conseguinte, a violação de sua dignidade, em termos kantianos (Cattaneo, 1984: 186).

235 "Die Wissenschaft des positiven peinlichen Rechts geht 1) aus von den allgemeinen Grundsätzen über Bestrafung rechtswidriger Handlungen überhaupt, - philosophischer (allgemeiner) Theil, und stellt alsdann 2) die besonderen Rechte des Staats in Hinsicht auf Bestrafung einzelner Arte rechtswidriger Handlungen dar - positiver (besonderer) Theil."
} 
Algumas coisas importantes podem ser extraídas da última citação do Lehrbuch. A primeira delas é registrar que esse objeto bastante restrito que Feuerbach elegeu para a sua ciência penal foi por ele subdivido em parte geral e parte especial, como ainda o é hoje, e como já faziam também outras obras e códigos de seu tempo. Nesse aspecto, portanto, nenhuma novidade. Essa forma de divisão tinha estreita relação com o papel organizador que o jusracionalismo anterior e contemporâneo a Feuerbach atribuía à ciência do direito, e principalmente com os critérios de organização impostos pelo modelo geometrizante da racionalidade jurídica moderna, como já foi dito. Organizar significava, primeiramente, por ordem àquilo que parecia bagunçado numa época em que o velho direito romano lutava para sobreviver, e normas jurídicas diversas pululavam de fontes variadas, de forma nem sempre harmônica. Não por acaso, muitos dos livros de direito penal de fins do século XVIII dedicavam algum importante espaço ao problema das fontes do direito penal, algo que hoje para nós parece um apêndice desimportante dos livros didáticos da disciplina: postulavam o que era válido como lei criminal, o que não o era, e como as diferentes fontes do direito relacionavam-se umas com as outras. Se a ciência do direito penal definia seu objeto, como dizia Feuerbach, a partir das leis penais, então determinar quais eram as leis válidas era de fundamental importância não só do ponto de vista prático-jurisdicional, mas também teórico, pois por esse caminho fixava-se âmbito de extensão da disciplina. Por isso, já no quinto parágrafo do Lehrbuch lê-se o seguinte:

As fontes do direito criminal comum alemão são: I) a filosofia do direito penal, na medida em que sua aplicação não seja limitada por leis penais positivas; II) as leis penais positivas do antigo Império, entre as quais as leis estrangeiras recebidas na Alemanha, especialmente as de direito romano e as de direito canônico, e as leis nacional, tanto a Ordenação Judicial Penal de Carlos V, de 1532, quanto as demais leis imperiais $($ Lehrbuch, 5$) .^{237}$

\footnotetext{
${ }^{236}$ Essa representação do objeto da ciência penal como totalmente dependente das leis penais, juntamente com a postula antropológica e política de Feuerbach, darão à legalidade um papel central em sua teoria papel esse que guardamos até hoje.

237 "Die Quellen des gemeinen deutschen Criminalrechts sind: I) die Philosophie des Strafrechts, so weit diese in ihrer Anwendung nicht durch positiv gesetzliche Bestimmungen beschränkt wird; II) die positiven Strafgesetze des ehemaligen deutschen Reichs; wohin gehören fremde in Deutschland ausgenommene Gesetze, nämlich des Römischen und des Canonischen Rechts; einheimische, und zwar die peinliche Gerichtsordnung Carls V. v. J. 1532, nebst anderen Rechtsgesetzen".
} 
Somado tudo isso, deve-se notar que estava dado o primeiro passo para a construção de um novo objeto teórico, que consistia em: (i) definir um objeto próprio, o direito penal, distinto dos demais direitos públicos e privados, o processo penal inclusive; (ii) determinar o seu conteúdo, dado pelas leis penais válidas; e (iii) moldá-lo de acordo com a "filosofia do direito penal", que lhe dará a "cara de código" com que hoje estamos acostumados: aqui, ver-se-á como a parte geral do direito penal contemporâneo ganhou o conteúdo que até hoje guarda - uma teoria do delito e uma teoria da pena.

A parte geral, como ponto de partida filosoficamente fundado, não começava nas leis positivas. Ao contrário, a filosofia impunha uma certa metodologia de trabalho ao estudo das leis penais. Ela tampouco era positivamente fundamentada em qualquer outro dado da experiência. Com efeito, na primeira nota de rodapé de sua parte geral propriamente dita, Feuerbach dirá, seguindo com o mesmo idealismo de AntiHobbes, que a história não proporciona nenhum fundamento seguro para a ciência do direito penal. ${ }^{238}$ Ao invés disso, ela era filosoficamente desenrolada a partir de pontos de partida anteriores, porque mais gerais e evidentes, que indicavam o marco inicial da construção dogmática do direito penal. A partir daqui, deixava-se a apresentação do objeto e dos materiais de trabalho e entrava-se na dogmática penal, em sentido estrito. $\mathrm{Ou}$, falando nos termos ainda hoje postos por muitos cursos e manuais de direito penal: saía-se dos prolegômenos para entrar na parte geral dos delitos criminais. ${ }^{239}$

Por tudo isso, a primeira coisa apresentada na parte geral do direito penal (Lehrbuch, 8-18) são os "princípios primeiros do direito criminal" (obersten Grundsätze des Criminalrechts). São eles que fazem a ponte ente a parte puramente ideal da disciplina - os seus princípios primeiros - e a parte geral das leis penais.

\footnotetext{
238 "So vielfach lehrreich eine geschichtliche Entwicklung des Strafrechts ist; so führt sie doch auf keine Weise zu einer sicher Grundlage für dem Leben dienende Wissenschaft oder für Gesetzgebung".

${ }^{239}$ Assim apresentam-se as Instituições de Direito Penal de Basileu Garcia (1956), por exemplo; ou, mais atualmente, a obra homônima de Miguel Reale Jr. (2002).
} 


\section{O primeiro desses princípios era dado por sua filosofia do Estado,} anteriormente apresentada a público no Anti-Hobbes. Feuerbach toma como um ponto de partida evidente que o Estado é necessário como garante das liberdades (elemento do novo liberalismo), e que só através do uso da força ele poderá cumprir o seu papel de pacificação social (elemento prevalecente da filosofia política do Antigo Regime). ${ }^{240} \mathrm{~A}$ citação é longa, mas muito importante para ser omitida:

A união da vontade e da força dos indivíduos proporciona o fundamento da sociedade civil para a garantir liberdade recíproca a todos. Um estado é uma sociedade civil organizada constitucionalmente mediante a submissão a uma vontade comum, sendo seu principal objetivo a criação da condição jurídica, ou seja, a existência conjunta dos homens conforme as leis do direito (Lehrbuch, 8). ${ }^{241}$

Qualquer lesão jurídica contraria o objetivo do Estado, ou seja, que no estado não tenha lugar nenhuma lesão jurídica. Por isso, o Estado tem o direito e o dever de desenvolver instituições que impeçam tais lesões (Lehrbuch, 9). ${ }^{242}$

As instituições requeridas pelo Estado devem ser instituições coativas, sobretudo fundadas na coerção física do Estado, que anula as lesões jurídicas através de uma de duas formas: 1) Preventivamente, quando impede uma lesão ainda não consumadas; (...) 2) Posteriormente à lesão, obrigando o ofensor à reparação ou reposição $\left(\right.$ Lehrbuch, 10). ${ }^{243}$

Mas a coerção física é insuficiente para evitar as lesões jurídicas, já que a coerção prévia só é possível diante da existência de fatos reais que permitam antecipar a

\footnotetext{
${ }^{240}$ A presença desses dois elementos é uma constante em diversos momentos da obra de Feuerbach, o que mostra como ele surge em um momento de transição entre o velho mundo da ordem política absolutista e o novo mundo da política liberal.

241 "Die Vereinigung des Willens und der Kräfte Einzelner zur Garantie der wechselseitigen Freiheit Aller, begründet die bürgerliche Gesellschaft. Eine durch Unterwerfung unter einen gemeinschaftlichen Willen und durch Verfassung organisierte bürgerliche Gesellschaft, ist ein Staat. Sein Zweck ist die Errichtung des rechtlichen Zustandes, d. h. das Zusammenbestehen der Menschen nach dem Gesetze des Rechts".

242 "Rechtsverletzungen jeder Art wiedersprechen dem Staatszwecke, mithin ist es schlechthin nothwendig, daß im Staate gar keine Rechtsverletzung geschehen. Der Staat ist also berechtigt und verbunden, Anstalten zu treffen, wodurch Rechtsverletzungen überhaupt unmöglich gemacht werden".

243 "Die geforderten Anstalten des Staats müssen nothwendig Zwangsanstalten seyn. Dahin gehört zunächst der physische Zwang des Staats, der auf doppelte Art Rechtsverletzungen aufhebt, 1) zuvorkommend, indem er eine noch nicht vollendete Beleidigung verhindert, (...); 2) der Beleidigung nach folgend, indem er Rückerstattung oder Ersatz von dem Beleidiger erzwingt".
} 
ocorrência da lesão. (...) A coerção posterior, por sua vez, só é possível após ocorrida a lesão jurídica, e tem como objeto a obtenção de um bem como reparação. Por isso, a coerção física é insuficiente para: 1) a proteção de direitos irreparáveis (...) 2) a proteção de direitos reparáveis, mas que se tornam irreparáveis com frequência (Lehrbuch, 11). ${ }^{244}$

Dado que, por sua filosofia moral, o fim supremo do homem é a moralidade, e que esse fim pressupõe algumas condições necessárias, garantir essas condições é fundamental, sobretudo em relação àquelas que sejam insubstituíveis como a existência do Estado e a vida humana, por exemplo. Assim, ainda que a própria moralidade exija o respeito ao Estado e à vida alheia, ela não é suficiente para protegêlas, dado o fato de serem irreparáveis na hipótese de uma lesão. Por isso, a proteção das condições fundamentais da moralidade dá-se, adicionalmente, pela vida da legalidade e, necessariamente, pela imposição de uma pena estatal.

Está aqui um primeiro passo para a estipulação de um critério substantivo de especificação dos ilícitos penais, que já aparecia nos contemporâneos de Feuerbach, e que até hoje sustentamos: o direito penal cuida de nossos bens jurídicos mais importantes, protegendo-os por meio das sanções criminais.

O segundo princípio decorria da incapacidade de o Estado dar conta de seu papel valendo-se apenas da coação física. Ora, se o Estado não consegue impedir fisicamente o cometimento de crimes a contento (Lehrbuch, 12), então é preciso que ele o faça psicologicamente. Para isso, Feuerbach recorria a uma imagem antropológica muito corrente na filosofia moral de seu tempo, citada no capítulo anterior: aquela segundo a qual os homens podem ser guiados por seus estímulos sensoriais: ${ }^{245}$

\footnotetext{
244 "Physischer Zwang reicht aber nicht hin zu Verhinderung der Rechtsverletzungen überhaupt. Denn der zuvorkommende Zwang ist nur möglich unter der Voraussetzung von Thatsachen, aus den der Staat entweder die Gewissheit oder doch ihrer Wahrscheinlichkeit erkennt. (...)Physischer Zwang ist daher nicht hinreichend 1) zum Schutz unersetzlicher Rechte (...), auch nicht 2) zum Schutz der an sich ersetzlichen Rechte, weil sie oft unersetzbar werden".

${ }^{245}$ Para uma curta exposição sobre a importância da antropologia de Feuerbach para o desenvolvimento de sua teoria de Feuerbach, v. o ensaio preliminar de Zaffaroni, na tradução argentina do Lehrbuch (Feuerbach, 1989).
} 
Todas as violações têm sua causa psicológica na sensibilidade, na medida em que os desejos humanos é o que impulsiona o homem, por prazer, a cometer a ação. Esse impulso sensível pode ser anulado se todos souberem que sua ação será seguida, infalivelmente, de um mal maior do que o desgosto proveniente da abstenção do fato (Lehrbuch, 13). ${ }^{246}$

Para fundar a convicção geral sobre a vinculação entre os ilícitos e esse mal, é necessário que uma lei estabeleça o mal como necessária consequência do delito (ameaça legal) (Lehrbuch, 14). ${ }^{247}$

O mal cominado por uma lei estatal e infligido em virtude dessa lei é uma pena civil (poena forensis). A razão de sua necessidade e existência está na necessidade de preservar a liberdade recíproca de todos mediante o cancelamento do impulso sensível dirigido às lesões jurídicas (Lehrbuch, 15). ${ }^{248}$

O fundamento jurídico da pena é a causa de que depende a possibilidade jurídica da pena. (...) O fundamento jurídico para infligir a pena é a sua prévia cominação legal. (Lehrbuch, 17). ${ }^{249}$

Ou seja: o Estado exerce a coação psicológica através da ameaça da pena; e como a ameaça só se efetiva uma vez comunicada aos súditos, esse meio de comunicação - a lei penal - é o fundamento jurídico da aplicação concreta de uma pena criminal. Esses eram os dois pontos de partida racionalmente auto-evidentes do direito penal. Por essa via, registre-se, o valor da legalidade era duplamente reforçado: seja

\footnotetext{
246 "Aller Ubertretungen haben ihren psychologischen Entstehungsgrund in der Sinnlichkeit, in wiefern das Begehrungsvermögen des Menschen durch die Lust an Oder aus der Handlung zur Begehung derselben angetrieben wird. Dieser sinnliche Antrieb kann dadurch aufgehoben werden, dass jeder weiß, aus seine That werde unausbleiblich ein Uebel folgen, welches grösser ist, als die Unlust, die aus dem nicht nicht befriedigten Antrieb zur That entspringt".

247 "Damit nun die allgemeine Ueberzeugung von der nothwendigen Verbindung solcher Uebel mit Beleidigungen begründet werde, so muß ein gesetzt dieselben als nothwendige Folge der That bestimmen (gesetzliche Drohung)".

248 "Das von dem Staate durch ein Gesetz angedrohte, und, kraft dieses Gesetzes, zuzufügende Uebel, ist die bürgerliche Strafe (poena forensis). Der allgemeine Grund der Nothwendigkeit und des Daseyns derselben ist die Nothwendigkeit, der Erhaltung der wechselseitigen Freyheit Aller, durch Aufhebung des sinnlichen Antriebs zu Rechtsverletzungen".

249 "Rechtsgrund der Strafe ist ein Grund, von welchem die rechtliche Möglichkeit der Strafe abhängt. (...) Der Rechtsgrund der Zufügung ist die vorhergegangene Drohung des Gesetzes".
} 
pela filosofia do Estado, seja pela filosofia moral que fundamentava o sistema penal de Feuerbach, as leis estatais eram indispensáveis. Vale dizer: a formalidade da lei penal ganhava uma importância até então inédita em outros contemporâneos seus. Este ponto, de tão relevante, merece um item em separado.

\section{Que VALE COMO UM DELITO CRIMINAL?}

\section{LegaLIDADE}

A legalidade em Feuerbach implica, resumidamente, que o crime é uma infração à lei e só existe dentro de um estado político (Lehrbuch, 31). Em Untersuchung, recordemo-nos (v. item IV), Feuerbach trata o pacto constitucional como o terceiro e definitivo passo para a saída do estado de natureza e entrada na sociedade civil; e esse pacto não diz respeito à união das pessoas em uma comunidade civil, pois a isso refere-se o pacto de união social ( $1^{\circ}$ passo); e nem à escolha e nomeação de um soberano, pois a isso refere-se o pacto de sujeição ( $2^{\circ}$ passo). O pacto de constituição diz respeito, isto sim, às formas políticas do Estado, ou seja, ao desenho institucional escolhido por critérios de conveniência política, através do qual o soberano executará sua tarefa pública de garantir a condição jurídica - preservar a liberdade externa dos súditos e garantir as condições para a moralidade, em outras palavras. Mas, ainda que a forma particular de cada Estado seja uma escolha política contingente, e não uma dedução racional necessária, é exigido que alguma forma institucional seja escolhida, pois o pacto de constituição é um elemento necessário, e não meramente acidental, da passagem do estado de natureza para o estado civil. Ou seja, Feuerbach postula, por seu contratualismo em três passos, que construir um conjunto de instituições políticas é, para o cumprimento dos fins do Estado, tão importante quanto unir-se em sociedade ou apontar um soberano, mesmo que o desenho político de cada Estado possa variar. ${ }^{250}$

\footnotetext{
${ }^{250}$ A ideia de que as instituições políticas tinham um papel fundamental na proteção da liberdade individual serviu como pilar de diversas teorias penais daquele tempo; não era, portanto, uma exclusividade de Feuerbach. Stübel (1795: 5), por exemplo, postulava que o poder soberano dava sustentação às ações privadas através das instituições, protegendo-as contra adversidades tão-logo o cidadão precisasse de sua ajuda.
} 
Assim, não surpreende que elementos puramente formais, que podem ser inadvertidamente menosprezados, acabem por ganhar papel de destaque em sua teoria jurídica. Para a teoria penal, a legalidade é um desses elementos e merece especial atenção.

"Legalidade", como já foi dito e redito, significa exigir uma conduta (ação ou omissão) coativamente, com o respaldo de uma sanção estatal. Ela é o principal instrumento pelo qual o Estado realiza seu fim: através da sanção, ele é capaz de exigir coativamente o respeito, por todos os súditos, aos limites da liberdade externa dos demais.

$\mathrm{Na}$ teoria de Feuerbach é importante notar, primeiramente, que em relação a alguns ilícitos, notadamente os crimes de polícia, a legalidade é inteiramente constitutiva da proibição jurídica (e não meramente da possibilidade de punição, como antes era majoritário): enquanto em certos crimes conta o indivíduo e contra o Estado haveria um dever moral prévio a exigir a conduta (independentemente da pena), nos crimes políticos, que existem por mera conveniência do Estado, só a legalidade cria a exigência comportamental; e, em ambos os casos, só a legalidade permite a imposição de uma pena estatal, pois a existência de uma lei prévia é, em sua teoria, uma condição objetiva de punibilidade:

\footnotetext{
"O fundamento objetivo de toda punibilidade é a existência de uma realidade de fato que seja prevista em uma lei penal. Uma ação que não se enquadre em nenhuma lei penal não é punível perante um tribunal de direito externo". (Lehrbuch, 80). ${ }^{251}$
}

Por isso, acerta Naucke (1975: 881) ao tratar os brocados feuerbachianos como as portas de entrada de um direito penal estatal como até então não havia sido construído, e até hoje não superada. ${ }^{252}$

251 "Der objective Grund aller Strafbarkeit ist das Vorhandenseyn einer Thatsache, welche unter der Drohung eines Strafgesetzes enthalten ist. Eine Handlung, die unter keinem Strafgesetze steht, hat vor dem Gerichtshof des äussern rechts keine Strafbarkeit".

252 "[nulla poena sine lege] enthält die Grundvoraussetzung für ein rechtsstaatliches Strafrecht. Feuerbach selbst hat das aufgefasst, und er hat diese Grundvoraussetzung in einer bis heute nicht übertroffenen Weise auseinandergelegt" (Naucke, 1975: 880-1). 
Em segundo lugar, a lei é na teoria feuerbachiana um instrumento imprescindível para uma atuação eficiente do direito penal, pois Feuerbach a via como a garantia efetiva de que todos abster-se-iam da conduta ilícita. Lembremo-nos de que, segundo sua antropologia, dirigimos nossas ações praticáveis ou por dever (racionalmente), ou por estímulo (sensorialmente). ${ }^{253}$ A moral exige condutas pela via do dever, e não pode fazê-lo por meio de uma pena; ao passo em que a legalidade, com a coação que a segue, faz atuar por estímulo. Por isso Feuerbach insistia tanto, recordemo-nos, que a ideia de direito implica um direito à coação (Kritik, 259 e ss.): sem a pena, a legalidade perderia o ganho de direcionamento das ações humanas que a sensualidade lhe confere; e que a moralidade, que depende do reconhecimento racional e espontâneo do dever, não pode aproveitar.

Além de conformar condutas pela ameaça da pena, a legalidade era também importante para comunicar o conjunto proibitivo, sobretudo daquelas condutas que não são crimes segundo o "direito das gentes" (jus gentium) (Lehrbuch, 86, nota a) - ou seja, as condutas contingencialmente proibidas em cada Estado particular. O poder punitivo criminal em relação à maioria dos delitos resultaria, portanto, do exercício do poder político de cada estado individual, segundo os objetivos e estratégias que lhe fossem ocasionalmente convenientes. Somando-se isso à necessidade de uma atuação eficiente do direito penal, a legalidade fuerbachiana implicava também uma certa taxatividade avant la lettre, dado que a penalização de condutas cuja proibição não era acessível pela razão pura exigia uma descrição pormenorizada da conduta, dentro do paradigma iluminista de certeza do direito (Cattaneo, 1979: 429). Essa busca pela precisão comunicativa do direito penal foi, de fato, uma marca constante da carreira de Feuerbach: seu projeto de código de 1824 dedicou diversos capítulos à técnica de construção das leis penais, sempre visando a precisar o conteúdo da proibição. ${ }^{254}$

Somadas essas duas coisas com a separação filosófica de direito e moral levada a cabo em Kritik, têm-se as bases para a formulação de uma das mais

\footnotetext{
${ }^{253}$ Segundo Kaulbach (1972: 297), a mesma oposição entre direito racional e direito real que existia em Kant fazia-se também presente em Feuerbach - "os extremos da razão e da empiria", em suas palavras.

${ }^{254}$ Projeto de Código Penal da Bavária de 1824, $1^{\text {a }}$ parte, item III (Von der Aulsegung der Strafgesetze), arts. $7^{\circ}$. a 11 . Sobre a legalidade no projeto de 1824, v. Schubert, 1979: 73 e ss.
} 
importantes ideias do direito penal contemporâneo: a noção de legalidade como reserva de proibição. Ainda que alguns ilícitos jurídicos coincidam com ilícitos morais (não matar, por exemplo), é só através de um processo institucional específico - uma lei, um estatuto etc. - que esses ilícitos tornam-se propriamente jurídicos, e são juridicamente exigíveis sob pena de cominação das sanções juridicamente impostas por um tribunal estatal; e para os demais ilícitos penais que existem por mera conveniência política do soberano, a legalidade é inteiramente constitutiva do delito criminal. Em qualquer hipótese, a ameaça da pena, que é a razão de ser do direito penal, sempre dependerá de uma lei positiva.

A lei penal é, portanto, aquilo que faz a ponte entre os fundamentos racionais do direito penal e a sua existência prática, servindo-lhe ainda como condição necessária para seu funcionamento legítimo e eficaz. É relevante registrar aqui que a legalidade jogava um papel fundamental na superação de diversas pendências institucionais e filosóficas que dão sentido ao direito penal contemporâneo: ela reforça o poder penal como um poder político do estado civil, ao mesmo tempo em que garante, pela reserva de proibição, as liberdades dos súditos contra o exercício arbitrário desse mesmo poder; e presta-se, ainda, ao incremento da eficiência da intimidação preventiva, já que "estimula" ao comportamento lícito ao unir um efeito desagradável (a pena) à conduta criminosa. Tanto assim que, dos princípios filosóficos primeiros apresentados por Feuerbach no início de sua parte geral (v. item V), que têm clara conexão com os embates da filosofia moral e política de então, os três princípios dogmáticos derivados são, todos eles, diretamente relacionados à ideia de legalidade penal, como constituidora do delito e comunicadora da ameaça penal (Bohnert, 1982: 9-10). Trata-se dos três brocardos pelos quais Feuerbach é até hoje lembrado por muitos penalistas:

Da precedente dedução derivam-se os seguintes princípios primeiros do direito punitivo: toda pena jurídica dentro do Estado é a consequência jurídica, fundada na necessidade de preservar os direitos externos, de uma lesão jurídica e de uma lei que comine um mal sensorialmente perceptível. (Lehrbuch, 19). ${ }^{255}$

\footnotetext{
255 "Aus obiger Deduction ergibt sich folgendes höchste Princip des peinl. Rechts: Jede rechtliche Strafe im Staate ist die rechtliche Folge eines, durch die Notwhendigkeit der Erhaltung äusserer Recht begründeten, und eine Rechtsverletzung mit einem sinnlichen Uebel bedrohenden Gesetzes" (nulla poena sine lege). (...) II) Die Zufügung einer Strafe ist bedingt durch das Daseyn der bedrohten Handlung (nulla
} 
Daí surgem, sem exceção alguma, os seguintes princípios: I) Toda pena imposta pressupõe uma lei penal (nulla poena sine lege). (...) II) A imposição de uma pena está condicionada à existência da ação cominada (nulla poena sine crimine) (...) III) $\mathrm{O}$ fato legalmente previsto (o pressuposto legal) está condicionado pela pena legal (nullum crimen sine poena legali). Consequentemente, o mal, como consequência jurídica necessária, vincular-se-á mediante a lei a uma determinada lesão jurídica (Lehrbuch, 20). ${ }^{256}$

Do ponto de vista histórico, é muito importante anotar que houve uma relativa mudança funcional no princípio da legalidade penal: ele tem, hoje, a principal função de atuar como uma garantia do indivíduo perante o poder estatal. Sua função é, sobretudo, garantista: "o princípio da legalidade", diz Roxin, "serve para evitar uma punição arbitrária e incalculável sem lei, ou baseada em uma lei obscura ou retroativa" (Roxin, 2006: 139). ${ }^{257}$ Kindhäuser (2006: 41), no mesmo sentido, fala do princípio da legalidade como instrumento da função garantista do Estado de Direito, que exige lei escrita, prévia, determinada e específica. Mas em Feuerbach, o autor que muitos reconhecem como o criador do princípio da legalidade penal, tal princípio só parcialmente tem relação com a preservação de garantias individuais: em termos teóricos, seu papel é delimitar o campo de estudos da ciência do direito penal; e, em termos políticos, garantir a efetividade da coação psicológica:

Para fundar a convicção geral acerca da vinculação necessária entre as ações e esse mal [a pena], é necessário que: I) uma lei o estabeleça como uma necessária consequência do delito (previsão legal). Para que a imaginação de todos tome por real a conexão abstrata da cominação legal deverá, também, II) mostrar essa relação na realidade, e por isso, apenas se o ilícito ocorrer, deverá ser infligido o mal a ela conectado (Execução) (Lehrbuch, $\S 13){ }^{258}$

\footnotetext{
poena sine crimine). (...) III) Die gesetzlich bedrohte That (die gesetzliche Voraussetzung) ist bedingt durch die gesetzliche Strafe (nullum crimen sine poena legali). Denn durch das Gesetz wird an die bestimmte Rechtsverletzung das Uebel als eine nothwendige rechtliche Folge geknüpft".

256 "Hieraus fießen folgende, keiner Ausnahme unterworfen, untergeordneten Grundsätze: I) Jede Zufügung einer Strafe setzt ein Strafgesetz voraus (nulla poena sine lege)".

257 "Dagegen dienst das (...) Gezetzlichkeitprinzip der Vorbeugung gegen eine willkürliche, nicht berechenbare Bestrafung ohne Gesetz oder auf Grund eines unbestimmten oder rückwirkenden Gesetzes".
} 
É por isso que, nos mais atentos intérpretes contemporâneos de Feuerbach, sua legalidade não é apenas ligada à vulgata liberal de proteção dos súditos em face do Estado: ela aparece também com um papel ativo, conformador e dirigente. Segundo Naucke, "a lei deve proteger o cidadão perante o Estado, mas deve também ameaçá-lo e aterrorizá-lo, moldando o cidadão" (1975: 881); ${ }^{259}$ e acrescenta que esses dois aspectos - o liberal e o dirigente - pertencem a um só tempo à doutrina da legalidade feuerbachiana. Schubert (1979: 71) vai além, apontando que o direito liberal de Feuerbach funcionava paradoxalmente por uma lógica do terror.

Isso tem, novamente, relação direta com a filosofia moral e política de Feuerbach que: (i) por seus pressupostos antropológicos, exigia que a pena fosse previamente declarada ao homem para determiná-lo de acordo com o sentimento de afastamento do mal sensível; e (ii) por sua doutrina da separação entre direito e moral e da arbitrariedade política do soberano, permitia a criminalização de condutas cuja proibição não era auto-evidente, reclamando por isso a prévia cominação a fim de que todos se determinassem pela repulsa à pena. É, como se vê, uma acomodação dogmática de dois sentidos políticos distintos que tinha (como ainda hoje tem) o direito criminal moderno: perseguidor implacável da criminalidade e mantenedor da paz social e, em meio ao influxo iluminista, defensor das liberdades individuais e limitador dos arbítrios criminais do soberano.

Ainda que o direito penal não fosse inteiramente definido por Feuerbach como um direito de garantia - o direito penal era o conjunto de direitos do Estado contra os criminosos, e não dos indivíduos contra o Estado, recordemo-nos -, esses elementos davam à sua legalidade penal a propriedade de limitação à atuação

\footnotetext{
258 "Damit nun die allgemeine Uberzeugung von der nothwendigen Verbindung solche Uebel mit Beleidigungen begründet werde, so muß I) ein Gesetz dieselben als nothwendige Folge der That bestimmen (gesetzliche Drohung). Und damit die Realität jenes gesetzlich bestimmten idealen Zusammenhangs in der Vorstellung Aller begründet werde, muß II) jener ursächliche Zusammenhang auch in der Wirklichkeit erscheinen, mithin, sobald die Übertretung geschehen ist, das in dem Gesetz damit verbundene Uebel zugefügt werden (Vollstreckung, Execution)".

259 "Das Gesetz soll den Bürger vor dem Staat schützen, es soll ihm aber auch drohen und ihn schrecken, es soll den Bürger anpassen (...) Diese beiden Seiten der Lehre vom Gesetz gehören bei Feuerbach zusammen".
} 
penal do Estado, tão típica da dogmática penal clássica, e que nós hoje reconhecemos como a mais importante função do princípio da legalidade. Feuerbach dirá, por exemplo, que a lei prevalece a todo custo, "não dependendo a sua aplicação de um juízo especial sobre sua adequação ao fim ou ao direito" (Lehrbuch, 74), bem à moda kantiana; que "a sentença jurídica é apenas um meio de aplicação da lei" (Lehrbuch, 75), lembrando Beccaria; e que uma ação não pode ser apenada sem prova inequívoca que indique sua contrariedade à lei (Lehrbuch, 83). Ou seja: a teoria de Feuerbach dá à legalidade penal o papel teórico central que ainda hoje lhe atribuímos e, mesmo sem transformar o direito penal em um direito cujo único sentido seria garantista, ela sugeria o seu papel protetivo em diversas oportunidades, sobretudo se considerarmos que o papel do direito como um todo era, para ele, a garantia das liberdades externas de todos. Não há, portanto, qualquer impropriedade em remeter os fundamentos do princípio da legalidade contemporâneo a Feuerbach, do ponto de vista de uma história das ideias jurídico-penais.

Por conseguinte, se considerarmos, como é certo considerar, tanto o papel teórico quanto o papel político do princípio da legalidade no direito penal contemporâneo, a relevância histórica de Feuerbach surge evidente. Mas nem sempre é isso que se vê na historiografia jurídico-penal. Muitos de seus comentadores atuais apontam, com razão, que ele não inventou a ideia de legalidade penal. Wolf (1951: 546), por exemplo, remete a ideia do nullum crimen, nulla poena sine lege à Carta Magna e, mais proximamente, à declaração de direitos da Revolução Francesa. Bohnert (1982: 6) aponta no mesmo sentido. Entre nós, Hungria (1953: 35-6) diz que Feuerbach não inventou a legalidade, apenas cunhou o brocardo do nullum crimen. Eles têm uma certa razão; afinal, Beccaria $(D D D P$, III) já havia dado à legalidade um papel de destaque antes mesmo de Feuerbach nascer.

Mas isso não quer dizer que Feuerbach não tenha feito nada de novo com a legalidade; ou que o seu reconhecimento como o formulador do princípio da legalidade pelos penalistas contemporâneos deva-se ao mero acidente histórico de ele ter tido a felicidade, ou sorte, de ser redator do código bávaro de 1813, como afirma Bohnert (1982: 7). Pois, se é verdade que Feuerbach não inventou a legalidade, é 
também verdade que ele deu à ideia de legalidade um papel fundamental, do ponto de vista metodológico, para o direito penal contemporâneo: ou seja, aquilo que era até então uma orientação de caráter preponderantemente político-criminal, como é o caso exemplar de Dos Delitos e Das Penas, ou uma estratégia de organização das fontes do Estado, como aparece em Klein, transformou-se em Feuerbach na pilastra que, ao lado da ideia de pena criminal, sustenta todo o edifício teórico do direito penal: Feuerbach construiu toda a sua parte geral em cima das leis penais e respectivas penas, e declarou expressamente que onde não há leis penais, não há direito penal, e a ciência penal carece aí de objeto. ${ }^{260}$ A legalidade é, portanto, constitutiva do objeto de estudos da ciência do direito penal, ${ }^{261}$ e não é um dos muitos institutos que aparecem na lição sobre as fontes do direito, como até então ocorria.

Convém anotar aqui que os dois pontos pelos quais Feuerbach é até hoje muito lembrado - sua teoria da legalidade e sua teoria da pena (que será comentada pouco adiante) - correspondem exatamente ao núcleo central de nossa parte geral do direito penal (teoria do delito e teoria da pena). Se os autores vistos no capítulo anterior estavam ainda à busca de uma parte geral, Feuerbach encontrou a nossa parte geral contemporânea com precisão. É por isso que seu Lehrbuch parece-nos já tão familiar e próximo de um direito penal como o nosso, mesmo trabalhando sobre a Constitutio Criminalis Carolina e não sobre um código moderno qualquer; e que o Código Bávaro de 1813, de que ele foi o principal redator, já é tão facilmente classificável entre os códigos inaugurais do direito penal contemporâneo.

Somado isso ao que foi dito no capítulo anterior, já temos um conjunto considerável de fatos históricos que nos permitem insistir na tese principal desse trabalho: a historicidade do direito penal contemporâneo. Porque mesmo a

\footnotetext{
${ }^{260}$ Lembremo-nos: Feuerbach abre o Lehrbuch definindo a ciência do direito penal como aquela que tem por objeto o estudo as leis penais estatais: "Das Criminalrecht (Strafrechtswissenschaft, peinliches Recht) ist die Wissenschaft der Rechte des Staats, welche durch Strafgesetze gegen Unterthanen, als Uebertreter derselben, begründet sind" (Lehrbuch, 1).

${ }^{261}$ Essa função metodológica da legalidade penal é até hoje preservada em livros didáticos correntes da disciplina, como mostra a seguinte passagem do Manual de Direito Penal de Mirabete: "À reunião das normas jurídicas pelas quais o Estado proíbe determinadas condutas, sob ameaça de sanção penal, estabelecendo ainda os princípios gerais e os pressupostos para a aplicação das penas e das medidas de segurança, dá-se o nome de Direito Penal" (Mirabete, 1990: 21. Destaques originais).
} 
legalidade, que é um dos indiscutíveis alicerces do nosso direito penal, conforme consta de praticamente todos os cursos e manuais da disciplina hoje existentes, e que nos parece tão "natural", pode ser historicamente explicada não só no que diz respeito à maneira específica de sua formulação (uma legalidade que separa o lícito do ilícito), mas também à posição de central importância a ela conferida.

Em primeiro lugar, a legalidade explica-se historicamente por ter se revelado um instrumento fundamental para colocar elementos de disputas teóricas existentes em fins do século XVIII e início do XIX a serviço de um mesmo direito penal, que assumiu a forma teórica que hoje conhecemos. A legalidade casava, por exemplo, a concepção de Estado como pacificador social e responsável pela administração da punição (cf. cap. II, item II) com a natureza predominante política do delito (cf. cap. II, item III): a lei era um instrumento pelo qual o Estado cumpria seu dever público de manter a paz; e a criminalização de condutas e imposição de penas era toda justificada por essa tarefa política do Estado. A determinação de quais condutas seriam punidas, e de como o seriam, tinha como fundamento apenas e tão-somente o cumprimento da tarefa política do soberano.

A legalidade explica-se historicamente, ademais, pelas reformas institucionais que buscavam fortalecer a justiça real em detrimento das demais instâncias de poder político, dando cada vez mais importância ao direito legislado e, principalmente, à parte específica do direito que cuidava da definição e persecução dos delitos (cf. cap. II, item V), já que isso implicava a apropriação do poder jurisdicional como um todo (fazer as leis e definir as penas respectivas, julgá-las e executá-las) por parte do Estado. Ao mesmo tempo, sua ligação com o ambiente intelectual de seu tempo surge evidente ao considerar-se sua relevância para a filosofia política liberal, de contenção do poder soberano em benefício dos direitos individuais. E, por fim, também pelo seu papel instrumental em face da antropologia própria da filosofia penal utilitarista, que a reclamava como um instituto de comunicação da ameaça da pena e, por conseguinte, de prevenção do crime. 


\section{A especificidade do Delito CRiminal}

O processo teórico de qualificação do delito jurídico-penal, por oposição aos meros desvios morais e principalmente aos demais ilícitos civis deu-se não só por um lado formal (legalidade), mas também um pouco por um lado substantivo. Digo "um pouco" porque a teoria de Feuerbach é bastante empobrecida nesse sentido: o recheio à couraça da legalidade penal é bem menos trabalhado do que a forma da legalidade em si mesma.

No que diz respeito à distinção entre o ilícito penal e as infrações morais, além da legalidade, também a externalidade servia para separar uma coisa da outra. Como já comentado, a esfera interna dos homens era o terreno da moralidade, e a externa, o do direito. Essa distinção era corrente à época de Feuerbach, de forma que não foi decisiva a sua contribuição nesse sentido: a Constitutio Criminalis Carolina., em 1532, já exigia "trabalhos sensíveis" para a constituição de um delito (art. 178); ${ }^{262}$ e Stübel, poucos antes do Lehrbuch, insistia no mesmo ponto (Stübel, 1795: 13). Thomasius e Kant já haviam tornado essa distinção quase um lugar comum à época. Por isso, postulava Feuerbach que toda ação para ser julgada criminosa, pressupunha "a capacidade de ser exteriormente reconhecível, pois só uma ação externa pode lesionar a um direito" (Lehrbuch, 32). Mas adiante, ao comentar o problema do nexo de causalidade entre ação e resultado, ele foi ainda mais explícito:

É impossível que uma ação seja antijurídica sem chocar com o direito externo, pois só o é uma ação (exterior) que lesiona um direito, ou o põe em perigo . A mera intenção antijurídica não proporciona a uma ação nenhuma característica de ilicitude. Quem fala de participação em crime com um veneno falso, ou do homicídio de um cadáver, ou coisas semelhantes, confunde o moral com o jurídico, os fundamentos da polícia de segurança com o direito à pena, e deveria também

\footnotetext{
262 "Item so sich jemand eyner missethatt mit etlichen scheinlichen wecken, die zu Vollbringung der missethatt dienstlich sein mögen".
} 
condenar por tentativa de homicídio a qualquer bávaro que vá a uma igreja e reze pela morte de um desafeto. (Lehrbuch, 42 , nota c). ${ }^{263}$ e 264

O delito criminal distinguia-se também dos demais ilícitos civis. Aqui, o primeiro critério distintivo era a pena. Feuerbach fazia um uso da palavra "crime" que, como ainda era comum em seu tempo, por vezes referia-se a todo tipo de lesão jurídica (Lehrbuch, 21), mas majoritariamente referia-se ao ilícito especificamente criminal. O "crime criminal" seria aquele a que se cominasse uma pena criminal não civil; vale dizer, corporal e não pecuniária (Lehrbuch, 22). Essa era uma distinção já corrente em seu tempo: Bentham, diante das dificuldades de especificação da "jurisprudência penal" como um ramo autônomo o direito, afirmava que a única possibilidade de sua individualização segura estava na penalidade agregada à proibição legal: onde quer que uma pena criminal fosse acoplada a uma lei imperativa, então aquele comando, que de outra forma seria civil, passaria a pertencer ao direito criminal. ${ }^{265} \mathrm{Ou}$ seja, o crime, para ele, não se distinguia substancialmente dos ilícitos civis senão pela pena criminal que teria como consequência jurídica, reforçando a minha postulação de que a constituição do delito era um problema de segunda ordem na teoria criminal pré-contemporânea. Aqui está mais uma marca da tradição jurídica do "crime" horizontal: ele distinguia-se por sua consequência jurídica (a pena criminal), e não por suas propriedades substantivas particulares.

\footnotetext{
263 "Weil bürgerliche Strafbarkeit ohne eine dem äussern Recht widersprechende Handlung unmöglich, eine Handlung aber nur dann (äusserlich) rechtswidrig ist, wenn sie das Recht verletzt oder gefährdet. Die rechtswidrige Absicht allein giebt keiner Handlung das Merkmal der Rechtswidrigkeit. Wer von dem Verbrechen der Mittheilung eines vermeintliches Gifts, von dem Versuch der Tödtung eines Leichnams und dergl. spricht, verwechselt das Moralische mit dem Rechtlichen, die Gründe der Sicherungspolizey mit dem Recht zur Strafe, u. muß auch jenen Bayern eines strafbaren Versuchs der Tödtung schuldig erkennen, der nach einer Kapelle wallfahrtete, um da seinen Nachbar - todt zu beten".

${ }^{264}$ A externalidade servia também, como ainda hoje serve, como medida para a consumação ou não do delito. O delito acabado chamava-se, na em Feuerbach, delito perfeito; a tentativa próxima, crime começado; e a tentativa remota, crime preparado (Lehrbuch, 43).

265 "It should seem then, that, wherever a simply imperative law is to have a punitory one appended to it the former might be spared altogether: in, which case, saving the exception (which naturally should seem not likely to be a frequent one) of a law capable of answering its purpose without such an appendage, there should be no occasion in the whole body of the law for any other than punitory, or in other words than penal, laws" (Bentham, 1823, XVII, 2, IX).
} 
Havia, entretanto, um dado substantivo inovador na doutrina criminal de Feuerbach: além da externalidade e da legalidade, Feuerbach insistia na ideia de que os verdadeiros crimes eram aqueles que lesionavam diretamente direitos dos súditos ou do Estado. Por isso ele estabelecia a diferença entre ilícitos policiais e crimes: os primeiros não seriam antijurídicos em si mesmos, mas os últimos sim: crimes seriam as condutas que, contrariando leis estatais, violassem os direitos naturais (racionalmente reconhecíveis) dos cidadãos ou do Estado - "direitos que são independentes do exercício de qualquer ato de governo ou do reconhecimento do Estado"266 (Lehrbuch, 22). Assim o eram, por exemplo, os crimes que lhes visassem a anulação total e irreversível, como o homicídio (que anulava o indivíduo) ou o crime de alta traição (que anulava o Estado). Já os delitos politicamente definidos (policiais) eram aqueles que, por conveniência do Estado, reprimiam condutas que não eram em si mesmas ilícitas (Lehrbuch, 22). A diferença entre as duas coisas não era mero preciosismo conceitual, pois trazia também variações em sua dogmática: não seria possível, por exemplo, alegar erro de direito em relação aos verdadeiros crimes, já que a proibição da conduta era racionalmente acessível; mas tal alegação seria possível quanto às contravenções policiais (Lehrbuch, 86, nota 1). ${ }^{267}$ Essa diferença entre o crime em sentido estrito e as demais condutas penalmente repreendidas por mera conveniência do Estado foi aprofundada no projeto do código penal bávaro de 1824, como bem anota Schubert (1979: 27), pois o art. $2^{\circ}$ do Código de 1813, que referia-se conjuntamente a crimes e ilícitos policiais como "atos puníveis", foi suprimido. ${ }^{268}$

Além de indicar um conjunto de direitos que diziam respeito aos verdadeiros crimes à moda liberal, a definição de Feuerbach exigia também um certo nível de lesão a esses direitos para que uma conduta se pudesse dizer verdadeiramente

266 "Unabhängig von der Ausübung eines Regierungsacts und der Erklärung des Staats, gibt es Rechte (der Unterthanen im Staate oder des Staates selbst). Diese durch Strafgesetze gesichert, begründen den Begriff eines Verbrechens im engern Sinne".

${ }^{267}$ Segundo Hespanha (1988: 55), a limitação da desculpa e da ignorância para o descumprimento da legislação estatal é uma constante na substituição do velho direito costumeiro pelo direito estatal na modernidade.

${ }^{268}$ No projeto do código de 1824, Feuerbach usou apenas a palavra "crimes" (Verbrechen) para descrever o objeto do código; enquanto no código de 1813, o citado art. $2^{\circ}$ falava em "atos apenáveis" (strafbare Handlungen) para descrever diversos tipos de ilícitos (Verbrechen, Vergehen, Polizeiübetretungen), entre eles os crimes. 
criminosa: O parágrafo 11 do Lehrbuch dizia, na mesma linha de Klein, que os crimes precisavam ser prevenidos porque representavam lesões irreparáveis, ou de difícil reparação. No código de 1813, o impacto que daí resultava era também grande: a natureza jurídico do furto, por exemplo, variava conforme o valor do montante furtado. ${ }^{269}$

Entretanto, é importante notar que permanecia legítima a criminalização de condutas "não naturalmente proibidas", por critérios de conveniência política do Estado. O que significa que, se a restrição material do conceito de delito importava para os meandros do tratamento jurídico de crimes ou contravenções, ou para a definição dos limites possíveis do erro de direito, ela não restringia especialmente as possibilidades político-criminais de proibição de condutas sob ameaça de penas, que se submetiam apenas ao restritíssimo limite da moralidade como objetivo da humanidade (que, de resto, era válido para todas as disciplinas, e não só para o direito penal). $\mathrm{Na}$ prática, isso queria dizer que a maior parte das proibições penalmente relevantes era definida por critérios de exclusiva conveniência política do soberano, mesmo que não fossem "crimes" no sentido estrito do termo:

$\mathrm{Na}$ medida em que o Estado está justificado a procurar em forma mediata seu objetivo, valendo-se de leis de polícia e proibindo desse modo ações que em si não são antijurídicas, haverá direitos especiais do Estado a exigir a omissão dessas ações particularmente proibidas, que originariamente eram para os súditos juridicamente possíveis. (Lehrbuch, 22).

É especialmente por isso que, como já foi dito, nos limites políticos do Estado soberano, a eficácia das leis penais é inoponível e inquestionável. ${ }^{270}$ Afinal, a lei é um instrumento técnico-político cuja avaliação em primeiro lugar, não é dada ao súdito, que, como já fora dito no Anti-Hobbes, não tem conhecimento técnico para

${ }^{269}$ Código da Bavária de 1813, art. 379: "O furto é um delito (Vergehen), se o valor do furto consistir em mais do que a some de cinco guildas (Gulden) da moeda bávara (baierischer Reichswährung), porém não atingindo a soma de vinte e cinco guildas (...)". Art. 380: "Um primeiro furto simples, cujo valor não atinja a soma de cinco guildas, será punido como ilícito de polícia".

${ }^{270}$ Lembrando a já citada passagem do Lehrbuch a esse respeito: "A lei penal é válida por si mesma, não podendo depender sua aplicação de um juízo especial sobre sua adequação ao fim ou ao direito" (Lehrbuch, 74). 
questioná-la; e, mais importante ainda, tampouco é dada ao jurista, por estar fora do objeto da ciência do direito penal: pois ela começa nas leis penais, e o juízo de criminalização é, por definição, anterior à lei criminal que dele resulta. Por outro lado, como ilícito puramente político que é, o crime não existe para fora dos limites políticos do Estado - para além dos vínculos políticos entre súditos e soberanos, portanto: "dado que um crime é a infração a uma lei, e esta não é possível sem a obrigatoriedade da mesma, só aquele que esteja obrigado pela lei penal de um Estado pode estar obrigado por esse Estado" (Lehrbuch, 31).

Por tudo isso, pode-se perceber que Feuerbach já conseguia distinguir o crime em sentido estrito e outros ilícitos de natureza pública, mesmo que as consequências jurídicas para uns e outros fossem muito semelhantes.

$* * *$

Ao dizer todas essas coisas, Feuerbach não estava descrevendo o direito penal; estava, isto sim, construindo um certo direito penal, tal qual hoje conhecemos. No tocante à teoria da legalidade, ficou evidente como ela jogava em sua teoria um papel que ajudava a fazer pontes entre mundos distintos de ideias políticas, ao reforçar tanto a exclusividade do poder criminal do Estado, quanto a proteção das liberdades individuais dos cidadãos. O primeiro passo de Feuerbach na construção de seu direito penal consistia em definir um saber teórico distinto, a partir de uma metodologia própria, e ocupado de um objeto teórico exclusivo, que foi construído sobretudo pelo aspecto formal da legalidade, mas também um pouco pela via substantiva da lesão relevante a direitos externos. Ao fazer tudo isso, ele estava dando uma resposta normativa à pergunta fundamental (no sentido estrito da palavra: aquilo que fundamenta, que funda) da dogmática penal contemporânea: "que é um crime, ou ilícito criminal?". A resposta que Feuerbach deu, como vimos, dependia em certa medida do conceito de pena criminal, dada as vastíssimas possibilidades políticas de criminalização de condutas. Portanto, assim como precisou abrir sua dogmática penal com uma teoria do delito criminal, Feuerbach precisaria concluí-la com uma teoria da 
pena criminal. A semelhança com a atual divisão da parte geral do direito penal - teoria do delito e teoria da pena (com alguma variação terminológica) - não é, por óbvio, mera coincidência.

\section{Que vale COMO PENa CRIMINAL?}

\section{UMA CONCEPÇÃO DE SER HUMANO}

A teoria da pena de Feuerbach é ainda hoje o elemento mais conhecido de sua dogmática penal. Ela é citada, com maior ou menor detalhe, na maioria dos livros didáticos de direito penal, além de ser objeto de muitas teses acadêmicas. Entre os leitores mais atentos de Feuerbach, é difundida a constatação de que a sua teoria da pena é estreitamente vinculada a uma certa concepção de ser humano. Por isso, é fundamental que seja detalhada essa visão antropológica que lhe dá fundamento. Mesmo porque, considerando agora as especificidades desta investigação, essa antropologia determina um conjunto importante de características de sua teoria penal, as quais carregamos conosco até hoje: ela oferece um conceito muito idealista de culpabilidade, em primeiro lugar; ademais, ela sugere uma específica imagem teórica do criminoso que é ainda viva em nosso imaginário; e, aliada à sua concepção de pena, ela sugere também uma certa economia da punição que igualmente permanecemos sustentando em nossas práticas penais do presente. Ao mesmo tempo, ela reforça a ideia de que sua teoria queria acomodar mundos teóricos distintos e rivais, um baseado na concepção retributiva e moralizante de pena como castigo, e outro, na concepção utilitarista e psicológica de pena como desestímulo.

A visão antropológica de Feuerbach é resumida logo no início do Lehrbuch, pela seguinte afirmação:

Todas as condutas ilegais têm a sensualidade como causa psicológica, na medida em que as necessidades do homem é o que o move, por prazer, a cometer a ação. Esse impulso sensorial pode ser cancelado se cada um souber que à sua ação há de 
seguir, infalivelmente, um mal que será maior que o desgosto que virá da não satisfação de seu impulso à ação (Lehrbuch, 13). ${ }^{271}$

Por esta passagem, não é difícil enxergar que ele trabalhava com a mesma teoria contraditória de seus antecessores (v. cap. II): o homem é em parte racional, e em parte instintivo. Feuerbach é taxativo ao afirmar que só a sensualidade é causa de um crime; o que equivale a dizer que não há motivo propriamente racional para o cometimento de um crime. Nesse sentido, alinha-se com Kant, conforme comentado no capítulo anterior: se o crime for pensado como produto de uma máxima, ela será invariavelemente inaceitável do ponto de vista racional. Isso não quer dizer, frise-se, que o cometimento de crimes não possa ser objeto de apreciação racional: é possível estudar cientifica ou filosoficamente as razões que levam à criminalidade. Feuerbach quer apenas dizer que o móvel para uma ação criminosa jamais será a conformação a um dever moral provindo da razão pura, mas apenas os estímulos sensoriais. Daí segue que a pena pode ter um importante papel na proteção dos bens jurídicos que a política criminal escolha tutelar, se vista como contra-estímulo dirigida à anulação desses mesmos estímulos criminógenos.

Para fins de prevenção criminal, a teoria da pena de Feuerbach apoiava-se, destarte, em uma teoria psicológica bastante elementar: os homens inclinam-se para as coisas que lhes dão prazer e afastam-se daquelas que lhes trazem sofrimento, dor, desgosto etc. Se ele vislumbra no crime um prazer, ficará tendente ao cometimento do delito; para evitá-lo, basta tornar o efeito do crime mais desprazeroso do que a sua abstenção. A ameaça da pena funcionaria como um contra-estímulo psicológico, e coagiria - porque o estímulo determina - ao não cometimento do delito. Daí o porquê de Feuerbach haver originalmente batizado sua teoria, hoje conhecida por prevenção geral negativa, de "teoria da coação psicológica" (psychologischer Zwang). Não por coincidência, ao nomear os chamados conhecimentos auxiliares do direito

271 "Alle Uebertretungen haben ihren psychologischen Entstehungsgrund in der Sinnlichkeit, in wiefern das Begehrungsvermögen des Menschen durch die Lust an oder aus der Handlung zur Begehung derselben angetrieben wird. Dieser sinnliche Antrieb wird dadurch aufgehoben, dass jeder weiss, auf seine That werde unausbleiblich ein Uebel folgen, welches grösser is, als die Unlust, die aus dem nicht befriedigten Antrieb zur That entspringt". 
penal, a psicologia é o primeiro saber especificamente citado. ${ }^{272}$ Ao mesmo tempo, ele reconhecia uma teoria moral da punição como algo válido, ao acusar, como fizera Kant, a imoralidade inerente a toda ação criminosa voluntária.

Daí segue que, sendo a pena pensada como um instrumento de proteção de direitos que só se efetiva quando presentes os requisitos psicológicos com que Feuerbach trabalha, só ao ser humano individual pode dirigir-se o direito penal:

\begin{abstract}
Unicamente o indivíduo pode ser sujeito de um crime, não podendo sê-lo jamais uma pessoa moral (sociedade, universitas ou collegium). Qualquer que seja a sociedade, só os indivíduos podem ser criminosos, mesmo quando todos os membros de uma sociedade tenham querido e executado o crime. (Lehrbuch, 28). ${ }^{273}$
\end{abstract}

Seu conceito de "autor", pela mesma razão, é igualmente restrito a pessoas individuais: "Toda infração pressupõe uma determinada pessoa como causa efetiva. Chama-se autor a pessoa em cuja vontade e ação ocorra a causa eficiente que tem o crime como efeito (autor delicti)" (Lehrbuch, 44). Para além do indivíduo, a cominação da pena seria não um instrumento de proteção preventiva de direitos, mas uma aplicação despropositada e inútil da força coativa estatal.

\title{
2. O MAL DA PENA
}

Seja pela concepção de ser humano com que Feuerbach trabalhava, que necessitava de contra-estímulos para não cometer crimes; seja pela sua teoria da legalidade, que exigia uma certa atuação coativa do estado para ganhar a eficiência prática adicional que a institucionalização é capaz de conferir, não bastava a declaração formal da proibição de uma conduta em lei: era preciso, adicionalmente, que lhe fosse

272 "Zu den Hülfskenntnissen des Criminalrechts gehören A) Wissenschaften im eigentlichen Sinne, und unter diesen, außer den übrigen Theilen des positiven Rechts, vornehmlich: I) die Philosophie und zwar 1) die Pscychologie". (Lehrbuch, 6)

273 "Nur ein Individuum ist mögliches Subject eines Verbrechens; nie eine moralische Person (Gesellschaft, universitas oder Collegium). Blos die Einzelnen in einer Gesellschaft jeder Art sind die Verbrecher, selbst dann, wenn Alle das Verbrechen wollten un vollbrachten". 
acoplada uma pena - o estímulo sensível que determina ao comportamento lícito, coisa que a moralidade não pode fazer. Assim, da mesma forma que não poderia haver um crime sem uma lei que o desse legalidade, de nada adiantaria a lei sem uma sanção que lhe conferisse eficácia através da penalidade. Dessa forma, lei, crime e pena demandam-se e implicam-se reciprocamente, e constituem os alicerces da teoria penal de Feuerbach, claramente expressos pelos três brocados, já citados, pelos quais até hoje é lembrado em nosso direito penal contemporâneo: toda pena pressupõe uma lei penal (nulla poena sine lege); toda pena pressupõe uma conduta incriminada (nulla poena sine crimine); e todo crime deve ser apenado com a pena a ele prevista (nullum crimen sine poena legali) (Lehrbuch, 20). ${ }^{274}$ Ressalte-se, mais uma vez, que os elementos constitutivos de nossa parte geral do direito penal estão já claramente postos como os pilares da teoria penal feuerbachiana.

Assim como o conceito de crime era em sua teoria muito simples, também o era o conceito de pena: a pena é um mal sensível que se comina com a intenção de evitar crimes, disse Feuerbach no Anti-Hobbes. ${ }^{275}$ No Lehrbuch (133), Feuerbach disse que a pena é um "mal penalmente cominado" que tem como objetivo principal "o de afastar a todos do crime mediante sua ameaça". O conceito vinha desde Revision (1799), em que já definia pena como um "mal sensível". ${ }^{276}$ A ideia tradicional da pena como mal somava-se ao seu lado "sensível" e, portanto, ao seu potencial preventivo no mundo real. Mesmo sendo um exemplar produto da tradição metafísica kantiana, ${ }^{277}$ Feuerbach, jurista como era, não negava a importância da prática, e nem a

274 "I) Jede Zufügung einer Strafe setzt in Strafgesetz voraus. (Nulla poena sine lege.) (...) II) Die Zufügung einer Strafe ist bedingt durch das Daseyn der bedrohten Handlung. (Nulla poena sine crimine.) (...) III) Die gesetzlich bedrohte That (die gesetzliche Voraussetzung) ist bedingt durch die gesetzliche Strafe. (Nullum crimen sine poena legali.)".

275 "Üben wie hingegen Gewalt, um ein physiches Übel zuzufügen, das wir in der Absicht uns vor Beleidigungen zu sichern vorher angedroht haben, so ist dies Strafe" (AH, 203).

276 "Der Begriff der bürgerlichen Strafe wäre also folgender: sie ist ein vom Staate, wegen einer begangenen Rechtsverletzung zugefügtes, durch ein Strafgesetz vorher angedrohtes sinnliches Übel". (Revision, 56)

277 A bem da verdade, Cattaneo (1984) aponta que Kant reconhecia o caráter intimidatório da pena; ele apenas negava que isso pudesse fundamentar metafisicamente a punição. 
diminuía em face da teoria, ao contrário do que podem sugerir algumas passagens de sua obra, se consideradas isoladamente e fora de contexto. ${ }^{278}$

Esse mal poderá variar em conformidade com os objetivos paralelos que ele visar a atingir, que podem ser: (i) a intimidação direta do restante da população mediante a execução pública da pena; (ii) a segurança do Estado perante os criminosos apenados; ou (iii) o melhoramento do apenado. ${ }^{279}$ Qualquer coisa que seja um mal sensível definido pelas leis como consequência de um crime será, portanto, uma pena, independentemente dos objetivos paralelos a que visar. ${ }^{280,281}$

A definição singela de Feuerbach permitia unir, exclusivamente no que respeita ao conceito de pena, as duas correntes tradicionalmente adversárias da filosofia moral: utilitarismo e retributivismo; pois para uma ou para outra a pena precisa ser, substantivamente, um mal. Seja para retribuir o mal ao agente que o causou por culpa, seja para impedir o cometimento de novos delitos por parte do condenado ou do restante da comunidade, uma pena nunca poderá ser, como bem diz Roxin (2006: 55), passar férias em Palmas de Mallorca. Por isso, mesmo sendo Feuerbach um autor claramente utilitarista no que diz respeito à razão de existência de seu direito penal, ele é capaz de falar da pena como um mal satisfativo, em tom marcadamente retributivista e kantiano, sem entrar em contradição: "toda pena é pública, na medida em que satisfaz penalmente a lei mediante o sofrimento do infrator, e na medida em que ela esteja

\footnotetext{
${ }^{278}$ Refiro-me às passagens de abertura de quase todas as suas obras, quando Feuerbach descarta a possibilidade de a experiência (às vezes por ele chamada de "história") bastar para uma metafísica do direito, ou do Estado, ou da punição etc.

${ }^{279}$ Lehrbuch, 133.

${ }^{280}$ Como a pena é simplesmente um mal sensível, Feuerbach manifesta inclusive ceticismo quanto a ser possível chegar-se a um conceito mais detalhado de pena: "se é que um conceito de pena existe", diz ele (Lehrbuch, 16).

281 A restrição que Feuerbach impunha aos fundamentos da pena dizia respeito à pena com fins "preventivo-especiais", para usar outra expressão anacrônica. Grolman, por exemplo, dizia que a pena era, além de um constrangimento à boa conduta de todos pela ameaça da pena, também uma forma de evitar futuros atos criminosos por parte do condenado - uma anulação da possibilidade física (Aufhebung der physischen Möglichkeit) de cometimento do delito (Grolman, 1805: 8-20). Feuerbach não aceitava esse tipo de "prevenção especial negativa" como fundamento da pena, pois ele impedia o cumprimento do dever moral supremo de homem ao negar-lhe autonomia.
} 
ligada a um crime, ela é uma pena criminal" (Lehrbuch, 136). ${ }^{282}$ É o utilitarismo com roupas de justiça retributiva, como diz Naucke.

Esse ponto é muitíssimo importante: utilitarismo e retributivismo, que no campo filosófico são correntes éticas tradicionalmente tratadas como adversárias, ${ }^{283}$ aparecem na teoria penal de Feuerbach unificadas. É claro que essa contradição teórica cobrou seu preço mais à frente: retributivismo e utilitarismo exigem, por exemplo, espécies diferentes de pena, às vezes; e, principalmente, calculam e quantificam a pena por critérios distintos. (Pires, 1998b: 137-43; 1998c: 180-3). Este último ponto é, aliás, a chave da reformulação teórica empreendida por Roxin (2006: 85 e ss.). Jakobs (1998) sustenta que, por causa dessa indevida união, toda a teoria da pena contemporânea está fadada ao insucesso. Mas o fato é que, mesmo com todas as contradições implicadas, retribuição e prevenção entraram juntas para o direito penal contemporâneo e, até hoje, figuram lado a lado nos nossos livros de direito penal e até mesmo no nosso Código Penal:

O juiz, atendendo à culpabilidade, aos antecedentes, à conduta social, à personalidade do agente, aos motivos, às circunstâncias e consequências do crime, bem como ao comportamento da vítima, estabelecerá, conforme seja necessário e suficiente para reprovação e prevenção do crime (Lei 7.209/84, art. 59. Destaques meus).

Considerado seu jusnaturalismo racionalista, seu conceito de pena e sua antropologia, a teoria de Feuerbach antecipava, de todos os lados, as causas possíveis de cometimento de um crime: do ponto de vista racional, ninguém cometeria um crime porque ele é em si mesmo irracional, considerados os direitos e deveres racionais dos homens; e do ponto de vista empírico, ninguém cometeria um crime porque - considerando a pena como consequência necessária - ele é contra-instintivo, já

\footnotetext{
282 "Jede öffentliche Strafe (p. publica) ist in so ferne als sie durch Leiden des Uebertreters dem Gesetze genug thut, peinlich, und so ferne sie an ein Verbrechen geknüpft ist (im Gegensatz von Privatstrafen) Criminal-Strafe"

${ }^{283}$ Há, porém, muitos autores que não enxergam essa separação como absoluta. Isso se vê principalmente em estudos mais recentes dedicados à ética kantiana, seja em geral (Hare, 1997: 147 e ss.), seja no que diz respeito particularmente à sua teoria da pena (Byrd, 1989).
} 
que equivaleria a buscar a dor ao invés do prazer. Ou seja, uma tal teoria reforçava o papel estatal de garantia da ordem por meio da administração do castigo, em uma tônica semelhante à de Hobbes (ainda que por caminhos distintos). Nesse sentido, e ao contrário de uma leitura corrente que saúda Feuerbach como um liberal incorrigível (Zaffaroni, 1989), muitos estudiosos seus têm apontado, como Schubert, que o direito penal de Feuerbach era liberal em seus contornos, mas podia muito bem ser draconiano em seu conteúdo: como o crime é sempre uma fraqueza diante de um impulso, o legislador está sempre autorizado a prever o pior martírio como pena, a fim de evitar o delito. $^{284}$

O lado oposto da moeda, porém, é que a sua dogmática penal não conseguia lidar teoricamente com as pessoas que cometessem crimes, uma vez que ela era toda pensada preventivamente, e que cercava-se de evitar o crime tanto pelo lado racional, quanto pelo lado instintivo do homem. O cometimento do crime negava, portanto, as características mais elementares da antropologia de Feuerbach: pois o sujeito, além de agir irracionalmente, agia contrariamente ao impulso humano mais básico, qual seja, o de evitar a dor proveniente da pena. Por isso, sua teoria penal eximia-se de qualquer atuação referente ao criminoso: ele fica fora de sua construção teórica, na qualidade de um sujeito que negou até mesmo seus instintos humanos elementares e não se amolda aos pressupostos antropológicos a partir dos quais sua teoria é construída. A teoria de Feuerbach não cuida, em absoluto, da execução da pena, como que renunciando à preocupação com aquele que, por negar sua moralidade e seus instintos, não pode ser ajudado, por ser incompreensível. ${ }^{285}$ Por esse caminho, reforçava-se a imagem do criminoso já esboçada no capítulo anterior: um sujeito diferente, anormal e inexplicável. Ele carrega, portanto, o retrato teórico do criminoso

\footnotetext{
284 "Der stärkste Vorwurf gegen Feuerbachs Straftheorie geht dahin, ihre konsequente Befolgung in einem Gesetz müsse zu einem drakonischen, ja terroristischen Strafsystem führen. Da jedes noch so geringe Verbrechen durch die stärksten inneren Impulse veranlasst sein könne, sei der Gesetzgeber genötigt, um auch tatsächlich das Ziel der Verhinderung jeder Rechtsverletzung zu erreichen, die schrecklichsten Martern zu ersinnen und unterschiedslos auf alle Gesetzverstöße anzudrohen" (Schubert, 1978: 72).

285 Como lembram Cattaneo (1979: 428-9) e Schubert (1978: 72-3), um direito penal que traz em si o pressuposto de que o crime será evitado pela ameaça infalível da pena não precisa mesmo preocupar-se tanto com a execução da pena.
} 
que já fora pintado por autores anteriores, já vistos no capítulo passado, e que é também produto do choque entre os dois mundos opostos da filosofia moral da modernidade.

Há outro ponto em que retribuição e prevenção caminham de mãos dadas no direito penal contemporâneo, e que Feuerbach também preservou das gerações que o antecederam: ambas recomendam fortemente que a punição criminal seja infalível (sendo que a teoria preventiva recomenda, além disso que ela seja imediata). No psicologismo preventivo de Feuerbach - como no de Beccaria, já visto - o efeito intimidatório da pena só será efetivo se, a cada crime ocorrido, seguir-se infalivelmente a pena legal: é esse o sentido do terceiro, e menos divulgado, de seus brocardos principiológicos: nullum crimen sine poena legali (Lehrbuch, 20). Hobbes dizia, como vimos, que a não aplicação da pena pelo soberano seria um fator que convidaria os súditos ao cometimento de crimes; Feuerbach pensava de forma muito semelhante:

Para fundamentar a convicção geral acerca da vinculação necessária entre o mal [penas] e os atos ilícitos, é necessário: I) que uma lei a estabeleça como necessária consequência do fato. Para que a imaginação de todos tome como verdadeira esta conexão ideal da cominação legal, deve-se igualmente II) mostrar-se essa relação no mundo real, em razão de que, tendo lugar o ilícito, siga-se a execução do mal que a ele se conecta. A coação psicológica dá-se, portanto, mediante a efetividade harmônica dos poderes legislativo e executivo, que atuam segundo um objetivo ameaçador comum. (Lehrbuch, 14). ${ }^{286}$

Sem essa execução infalível da pena, a cominação penal perderia todo sentido:

O objetivo da ameaça da pena na lei é a intimidação de todos, como possíveis protagonistas de lesões jurídicas. O objetivo de sua aplicação é dar efetivo

\footnotetext{
286 "Damit nun die allgemeine Ueberzeugung von der nothwendigen Verbindung solcher Uebel mit Beleidigungen begründet werde, so muss I. Ein Gesetz dieselben als nothwendige Folge der That bestimmen (gesetzliche Drohung). Und damit die Realität jenes gesetzlich bestimmten idealen Zusammenhangs in der Vorstellung Aller begründet werde, muss II. Jener ursachliche Zusammenhang auch in der Wirklichkeit erscheinen, mithin, sobald die Uebertretung geschehen ist, das in dem Gesetz damit verbundene Uebel zugefügt werden (Vollstreckung, Execution). Die Zusammensimmende Wirksamkeit der vollstreckenden und gesetzgebenden Macht zu dem Zwecke der Abschreckung bildet den psychologischen Zwang".
} 
fundamento à cominação legal, pois sem a aplicação da pena a cominação legal seria um vazio (seria ineficaz). (Lehrbuch, 16). ${ }^{287}$

Portanto, ainda que seu conceito político de delito mantivesse o direito absolutista de graça, sua teoria da pena contundentemente recomendava o exercício infalível da punição como única forma de atuação sensata e eficiente do direito penal. Trata-se, portanto, de uma doutrina perfeitamente moldável à "semiotécnica das punições" de Foucault (1987: 86), apontada como um dos pilares do reformismo do século XVIII. Por isso, Feuerbach falava da pena como uma "consequência jurídica" do delito: "toda pena jurídica dentro do Estado é a consequência jurídica de uma lesão jurídica e de uma lei que comine um mal sensível, fundada na necessidade de preservar direitos externos". (Lehrbuch, 19). ${ }^{288}$ A pena é um verdadeiro dever do Estado (Verbindlichkeit des Staats) diante do cometimento do crime (Lehrbuch, 17), pois é seu dever "criar institutos mediante os quais impeçam-se as lesões jurídicas" (Lehrbuch, 9). Por tudo isso, Pires (1998d: 215) reconhece Feuerbach como o jurista mais importante para a ideia contemporânea de que o direito penal não tem como existir sem as penas criminais.

Tal qual o seu conceito de delito, a ideia da pena obrigatória tem, além do significado político de tratar a pena como o instrumento por excelência de manutenção da paz pública, também uma grande importância teórica: o direito penal e o delito criminal definem-se, direta ou indiretamente, a partir das penas criminais (corporais). Pois o direito penal estuda as leis que tratam de delitos criminais, entendidas como tais aquelas a cuja violação o Estado liga uma pena criminal de aplicação obrigatória. A teoria feuerbachiana, assim, transpira a pena criminal por todos os poros: não só porque seu objeto teórico define-se por meio dela, somada à legalidade; mas também porque ela remenda as contradições da filosofia de seu tempo e

\footnotetext{
287 "I. Der Zweck der Androhung der Strafe im Gesetz ist Abschreckung Aller als möglicher Beleidiger, von Rechtsverletzungen. II. Der Zweck der Zufügung derselben ist die Begründung der Wirksamkeit der gesetzlichen Drohung, in wiefern ohne sie diese Drohung leer (unwirksam) seyn würde".

288 "Jede rechtliche Strafe im Staate ist die rechtliche Folge eines, durch die Nothwendigkeit der Erhaltung äusserer Rechte begründeten, und eine Rechtsverletzung mit einem sinnlichen Uebel bedrohenden Gesetzes".
} 
reúne, em uma mesma teoria, a obrigação política de punir (como em Beccaria e Hobbes) com o caráter moral da pena criminal (como em Kant), e transforma-os numa obrigação jurídica de punir - definindo a pena como uma consequência jurídica do delito: nullum crimen sine poena legali.

Os traços principalmente retributivistas da teoria penal de Feuerbach aparecem destacadamente nos fundamentos subjetivos da punibilidade absoluta (Subjective Gründe der absoluten Strafbarkeit). Estes consistiam em dois institutos: a imputação (Zurechnung) e a culpabilidade, ou culpa (Schuld). É importante anotar que, ainda que já estejamos navegando aqui por conceitos familiares, esses institutos tinham na teoria de Feuerbach um papel bem particular: a culpa era para ele o conjunto dos elementos subjetivos (intelectuais) da imputação, e funcionava, como anota Buchenberger, ${ }^{289}$ como um guarda-chuva que abrangia tanto a intencionalidade quanto a negligência. A culpa era para ele, portanto, um pressuposto da imputação (Buchenberger, 1932: 29). Juntamente com os fundamentos subjetivos da punibilidade relativa, as regras de imputação e a culpabilidade serviam para determinar: (i) se um sujeito que tivesse dado causa a um resultado criminoso havia-o feito, ou não, de maneira responsável, de forma a poder responder pelo seu ato sujeitando-se a uma pena criminal; e, em caso afirmativo, (ii) qual deveria ser essa pena. Os fundamentos subjetivos da punibilidade absoluta - culpabilidade e imputabilidade - respondiam à primeira indagação; os fundamentos subjetivos da punibilidade relativa, à segunda, através dos institutos do dolo (intencionalidade antijurídica) e da culpa (imprudência) e principalmente à luz da legislação vigente.

O mesmo fundamento antropológico idealista e racionalista que serviu de base para a filosofia moral e política de Feuerbach dá também a base de sustentação de suas teorias da imputação e da culpabilidade, pois ambas dependem de sua imagem de ser humano. Não por acaso, Buchenberger (1932: 26) anota que seus conceitos de imputação e culpabilidade não podem ser compreendidos sem que se tenha em mente a sua teoria da pena. Mas, se até aqui o lado instintivo e do homem e a sua psicologia

\footnotetext{
289 "Schuld im Sinne Feuerbachs ist der intelektuelle Teil der Zurechnungsfähigkeit, der in den Schuld formen variiert wird, also Oberbegriff von Vorsatz und Fahrlässigkeit" (Buchenberger, 1932: 28).
} 
elementar haviam prevalecido na sua teoria para as causas do crime e para a essência da pena, os fundamentos da responsabilidade criminal em Feuerbach formam-se por um discurso fortemente calcado na ideia de livre-arbítrio moral: "ao tentar responder a questão relativa à relação entre imputação e culpa", diz Grünhut, "Feuerbach parte do pressuposto de que a imputação é inseparavelmente ligada à culpa pessoal, assumindo o livre-arbítrio" (Grünhut, 1922: 77).

Porém, assim como a sua teoria da pena "fez as pazes" entre retributivismo e utilitarismo, Feuerbach também juntou determinismo e livre-arbítrio na sua dogmática da responsabilidade penal, adotando o mesmo tipo de solução de compromisso. No Lehrbuch, ele começa apresentando seus conceitos de imputação e culpabilidade. A imputação, diz ele, é a relação de causalidade que há entre uma vontade individual contrária à lei penal (causa) e o fato criminoso (consequência), chamando-se imputável aquele que é suscetível de imputação por um fato criminoso. ${ }^{290}$ A culpa, diz ele, é determinada pela imputação: ${ }^{291}$ ninguém será considerado culpado de um crime que não se lhe possa jurídico-penalmente imputar. O conceito de imputação, note-se bem, é formado pela ideia da causalidade: a vontade é a causa, e o resultado criminoso é o efeito. Mas, para além disso, toda a sua ideia de culpabilidade é fundada em um juízo de imputação moral do ato ilícito. A culpabilidade expressa a reprovabilidade individual da conduta ilícita e dá a medida, por meio do dolo e da culpa, da pena merecida pelo sujeito. Em Revision, ${ }^{292}$ Feuerbach postula mesmo que o conceito puro de imputação restringe-se à "relação da ação com o sujeito livre"; e como o livre arbítrio é condição da moralidade, sem ela pode-se falar em legalidade ou ilegalidade,

290 "Die Beziehung einer (objectiv) strafbaren That als Wirkung auf eine dem Strafgesetz widersprechende Willensbestimmung des Thäters, als Ursache der selben, heißt die Zurechnung (Imputation), und der (äussere und innere) Zustand einer Person, vermöge welches ihr eine That zugerechnet werden kann, die Zurechnungsfähigkeit (Imputabilität)" (Lehrbuch, 84).

291 "Die Zurechnung bestimmt die Schuld (das Verschulden) als allgemein subjectiven Grund der Strafbarkeit" (Lehrbuch, 84).

292 "Der vorhergegebende engere Begriff, ist der reine Begriff der Imputation. Es ist hier von weiter nichts, als von der Beziehung der Handlung auf das freie Subject (...) Soll aber das Subject selbst für schuldig oder für das Gegentheil gehalten werden, so muss die That aus wirklicher Freiheit geschen seys, weil Freiheit die Bedingung der Moralität ist, und ohne diese zwar Legalität oder Illegalität (äussere Gesetzmässigkeit oder Gesetzwidrigkeit) aber keine Moralität oder Immoralität der Handlung vorhanden seyn kann" (Revision, I, 154-5). 
mas jamais em reprovabilidade moral da ação, o que é pressuposto para a imposição do mal-pena.

Para que se possa fazer o juízo de imputabilidade, é necessário, além da ligação causal entre vontade e resultado ilícito, também um juízo objetivo de contrariedade dessa vontade em relação à lei penal: a punição de qualquer ato, diz Feuerbach, "está condicionada por uma ilicitude da vontade como causa do crime" (Lehrbuch, 88). ${ }^{293}$ Mas não só: a imputação também supõe que tenha sido possível uma vontade lícita do agente, e ficará excluída "pela existência de um estado da pessoa que tenha cancelado a possibilidade, em geral, de atuar conforme o seu arbítrio ou de determinar-se adequando-o às leis penais" (cit.). ${ }^{294}$ Seelmann, falando de outros autores dessa mesma época, anota que às vésperas do direito penal contemporâneo, assiste-se à retribuição ganhando um novo papel na teoria jurídica da punição, o que parece mostrar-se também em Feuerbach: se antes a substância do delito estava na reprovabilidade moral da conduta, a partir de fins do século XVIII, em face do caráter cada vez mais político do ilícito criminal, ela transmuta-se em mero juízo de reprovação e restringe-se à punibilidade do ilícito (ao invés de constituir o próprio ilícito), dando os limites da responsabilidade do agente. ${ }^{295}$

Se esse juízo de contrariedade à lei penal dará a reprovabilidade da conduta, ele indica a culpabilidade do agente, portanto. (Note-se bem: mesmo fazendo uso de ideias anteriores - culpa, reprovação - esses elementos estão sendo reunidos de uma forma cada vez mais próxima do direito penal contemporâneo.) Assim, se estiver cancelada no agente a possibilidade de uma vontade lícita, ou de se orientar segundo uma tal vontade, excluir-se-á sua culpabilidade. Não há culpabilidade quando o resultado dá-se sem vontade, como, por exemplo, quando falta força física para realizar a conduta devida (Lehrbuch, 89); ou quando o agente encontrar-se em um estado mental

\footnotetext{
293 "Alle Strafbarkeit bedingt ist durch eine Gesetzwidrigkeit des Willens als Ursache des Verbechens".

294 "So wird die Strafbarkeit nothwendig ausgeschlossen durch das Daseyn eines Zustandes der Person, in welchem für sie die Möglichkeit aufgehoben war, entweder überhaupt nach Willkühr zu handeln oder ihre Willkühr den Strafgesetzen gemäß zu bestimmen".

${ }^{295}$ Seelman (2001: 18-21) refere-se a Filangieri especificamente, mas faz consignar diversas vezes, expressamente, que a doutrina da responsabilidade do autor italiano é grandemente compatível com a de Feuerbach.
} 
que não o permita ter consciência de seu dever penal e da punibilidade pelo seu descumprimento, como nas hipóteses de menoridade, desenvolvimento mental incompleto, embriaguez completa acidental, sonambulismo ou erro, entre outras (Lehrbuch, 90); ou, por fim, quando, mesmo existindo a consciência da lei penal, não seja possível que ela aja sobre os impulsos do agente, por encontrar-se ele em um estado de perigo que o faça agir instintivamente. Em nenhum desses casos pode-se dizer que uma vontade ilícita tenha sido causa da conduta; e, portanto, o agente não será imputável, e nem será reprovável o resultado danoso a que tenha fisicamente dado causa (por ação ou omissão) (Lehrbuch, 91).

Isso pode parecer contraditório dentro da teoria de Feuerbach: como seria possível adequar essa posição não determinista (porque exige liberdade moral) com a afirmação do $\S 13$ do Lehrbuch, que parece tão determinista ("Todas as violações têm sua causa psicológica na sensibilidade, na medida em que os desejos humanos é o que impulsiona o homem, por prazer, a cometer a ação")?

A melhor resposta parece ser a seguinte: Feuerbach aceita que os homens movem-se tanto por razão, quanto por instinto. Nesse sentido, ele está perfeitamente inserido nas disputas teóricas da filosofia moral de seu tempo, como visto no capítulo anterior. Por um mandamento de razão, ninguém cometeria um crime, pois o crime é essencialmente irracional e só acontece quando os instintos prevalecem sobre a razão. Logo, o direito penal, como meio de defesa, deve centrar-se em cancelar os instintos ilícitos das pessoas: daí o porquê de o mal da pena ter de ser maior do que a frustração da abstenção do crime; e, principalmente, daí o porquê da pena ter de ser um mal administrado em caráter infalível, como já visto. A estratégia preventiva do direito penal é, portanto, inteiramente pensada tendo em vista o lado instintivo do agir humano. Mas, como mal que é, a aplicação da pena tem de ser, além de útil, também justa, pois aplicar um mal indevido por critérios de utilidade seria instrumentalizar o apenado e renegar-lhe a possibilidade de exercer sua vida conforme a lei prática suprema - a moralidade. O juízo de justiça da pena dá-se pelas categorias da imputabilidade e da culpabilidade, e como juízo de justiça que é, compete à dogmática penal; o juízo de utilidade defensiva da pena pertence à política criminal e, como juízo político que é, 
compete exclusivamente ao soberano, que decide, desde uma vasta gama de possibilidades, as condutas que quer evitar por meio da pena criminal, para fins de pacificação social. Assim, se a dogmática penal tem pouco a dizer sobre a substância do crime e da pena, bem como sobre as estratégias de criminalização, que se definem politicamente, ela tem, por outro lado, muito a dizer sobre culpabilidade e imputação. Vale dizer, se a parte psicológica de seu modelo de ser humano reclamava uma política utilitarista de administração da pena, a parte moral desse modelo impunha-lhe um limite de justiça: nenhuma política penal pode, por razões utilitárias, ultrapassar os limites da punição de inocentes, ou do castigo excessivo (além da culpabilidade) dos culpados.

A melhor forma de dar conta desse sincretismo é ter em mente a divisão metodológica, também feita por Feuerbach, entre a previsão legal e cominação da pena, de um lado - tarefas políticas -, e, de outro, a sua imputação individual e concreta a um sujeito determinado - tarefa jurídico-penal.

No primeiro caso, culpabilidade e imputação são quase irrelevantes: o que vale é a missão política do direito penal e os instrumentos com que opera para dar conta de sua tarefa de manter a paz a todo custo. Por isso, o discurso moral sobre o merecimento individual da pena é-lhe àquela altura menos importante, prevalecendo uma antropologia simplória (os homens dirigem-se ao prazer e afastam a dor), bem à moda hobbesiana. É com base nessa visão que Feuerbach postula: (i) quais são as causas do crime; (ii) por que o papel da pena criminal é eminentemente dissuasório; e (iii) por que recomenda-se que a sua aplicação seja infalível. Assim, (i) o crime é causado pela busca instintiva de um prazer sensual; (ii) a pena é um grande desprazer; e (iii) os homens precisam ser estimulados a não cometer crimes, o que se faz pela ideia de que o mal da pena seguirá imediata e necessariamente a conduta ilícita. Trata-se sobretudo de um debate de formas, o que explica o já mencionado papel prevalecente da legalidade em sua teoria do ilícito criminal.

Uma vez cometido o crime, saímos do campo da racionalidade jurídico-política e entramos no campo da racionalidade jurídico-moral: é chegado o momento de determinar que pena o sujeito efetivamente receberá em razão do ilícito 
cometido. Feuerbach passa a utilizar então o vocabulário moral do livre-arbítrio, ainda que de forma incompleta: (i) ninguém pode ser punido se sua ação for absolutamente determinada (não livre); (ii) a lei penal exige a punição; (iii) só a punição criminal é capaz de satisfazer a lei penal; e (iv) quem age sem reprovabilidade não merece receber pena.

Por conseguinte, Feuerbach desenvolve ao mesmo tempo uma teoria preventiva da pena, com objetivo dissuasório e fundamentada em uma psicologia associativa, conjugada a uma teoria retributiva da culpabilidade, com objetivo de aplicação da pena justa e fundamento em uma teoria do livre-arbítrio moral. Ou seja: a razão de ser da pena criminal é a sua utilidade preventiva; mas só a finalidade preventiva não possibilita a sua aplicação, pois além de útil, a imposição de uma pena deve ser moralmente justa. Por essa união, retribuição e prevenção são retalhadas em uma mesma teoria da pena, como ainda hoje prevalece em nossos cursos e manuais. A lição de Mirabete não poderia ser mais clara nesse sentido:

\footnotetext{
Desde a origem até hoje, porém, a pena sempre teve o caráter predominantemente de retribuição, de castigo, acrescentando-se a ela uma finalidade de prevenção e ressocialização do criminoso. A retribuição e a prevenção são faces da mesma moeda (...) Enquanto se proclama na exposição de motivos da Lei de Execução Penal o princípio de que as penas e as medidas de segurança devem realizar a proteção dos bens jurídicos e a reincorporação do autor à comunidade, a realidade demonstra que a pena continua a ser necessária, como medida de justiça, reparadora e impostergável (...) (Mirabete, 1990: 247).
}

\section{UM DIREITO PENAL COM CARA DE DIREITO PENAL}

No prefácio à primeira edição do Lehrbuch, lê-se a seguinte passagem:

Depois da publicação de Revision, o autor passou por uma experiência nada incomum, porque esperada, como é de se esperar por qualquer um que não siga a corrente majoritária. Ergueram-se contra o autor diversos tipos de armas; combateu- 
se-lhe com injúrias e engodos em opúsculos e a partir das cátedras, ainda que raras vezes com razões claras. (Lehrbuch, X). ${ }^{296}$

Essas duas frases dão a ideia de quanto Feuerbach foi um autor polêmico em seu tempo, e do quanto foi inovadora a sua teoria. Se a sua doutrina sobre o crime e a pena nos parecem hoje elementares, a comparação entre sua teoria penal e as de seus contemporâneos, feita na primeira parte deste capítulo, mostra que as coisas que ele disse estavam longe de ser verdades pacificamente aceitas entre os penalistas de fins do século XVIII, mesmo os seus contemporâneos. Hartmann (1961: 68 e ss.), no mesmo sentido, aponta que Feuerbach escreveu a sua teoria penal contra a visão dominante de sua época, o que rendeu-lhe boas polêmicas, entre as quais as mais importantes - contra Klein e Grolman - foram comentadas ao longo do capítulo.

Escrevendo contra seu tempo, ${ }^{297}$ Feuerbach legou para as gerações posteriores de estudiosos de direito penal de língua alemã uma teoria penal que apresenta todas as características daquilo que se reconhece no direito penal contemporâneo:

(i) Uma ciência do direito penal autônoma, distinta tanto da filosofia moral, quanto das demais áreas do direito. Feuerbach distinguiu até mesmo o direito penal do processo penal e do restante do direito público, coisa pouco comum à época;

(ii) Dos fundamentos primeiros do direito penal (princípios morais e políticos), derivavam-se três princípios especificamente jurídico-penais que tinham a

296 "Nun noch ein kleines Wort an die Gegner des Verfassers. Er hat nach der Erscheinung seiner Revision eine Erfahrung gemacht, die ihn gar nicht befremdete, weil er sie erwartete und weil ein jeder sie erwarten muss, der sich nicht in dem Ströme der Gewohnheit fortreißen lässt. Man hat alle Arten von Waffen gegen ihn gebraucht: man hat ihn in Abhandlungen und von Kathedern herab - selten auch nur mit Scheingründen, öfters durch Schimpfwörter oder Spott, Bestritten".

${ }^{297}$ Wolfgang Naucke, um dos mais respeitados estudiosos de Feuerbach, insiste a todo instante no caráter inovador e fundador de sua teoria penal: "Im Alter von 25 Jahren hat [Feuerbach] die Grundbegriffe des damaligen Strafrechts revidiert, die auf den Satz "nulla poena sine lege" gegründete Theorie des psychologischen Zwanges formuliert und seinen Ruhm als energischer, kenntnisreicher, streitbarer Strafrechtstheoretiker begründet. Seinen wissenschaftlichen Arbeiten haben kein Gebiet des Strafrechts unberührt gelassen". (Naucke, 1975: 861). No que diz respeito à separação entre direito e moral, a doutrina feuerbachiana foi especialmente combatida (Knopf, 1936: 31 e ss.). Suas principais polêmicas, entretanto, diziam respeito à chamada teoria da coação psicológica, que gerou disputas especialmente com Grolman e Klein. 
legalidade como eixo central: o princípio da legalidade ganhou em sua obra, portanto, o status de espinha dorsal de toda a teoria penal. Ele cumpre não só um papel político importante (como em Beccaria), mas também um papel metodológico que até hoje preservamos, que consiste em estabelecer o campo de investigação do direito penal;

(iii) A legalidade penal, somada à pena criminal, permitia destacar o ilícito penal de todos os demais ilícitos, fossem eles políticos ou morais. Feuerbach não confundia, para usar exemplos seus, o crime de homicídio com a ofensa moral de rezar pela morte de um desafeto; nem os ilícitos civis com os delitos criminais; e muito menos os ilícitos penais com os demais ilícitos de direito público. Ao mesmo tempo, ele separava também os ilícitos mais graves para o campo dos verdadeiros "crimes": as leis de polícia ("contravenções") não seriam verdadeiramente antijurídicas, só os crimes o são (Lehrbuch, 22). Por isso, dizia ele na introdução do código bávaro, é só em relação aos crimes que temos, "em nossos corações", o conhecimento da proibição. (Qualquer relação com o "juízo profano de ilicitude"298 da atual doutrina da culpabilidade não é, evidentemente, mera coincidência.)

(iv) A pena criminal também ganhou em sua teoria um sentido bastante particular. Ao rejeitar a teoria "preventivo-especial" de Grolman, Feuerbach afirmava a distinção entre a pena criminal e os castigos emendatórios. Ao mesmo tempo, ao defender a ideia de que a pena útil tinha também de ser justa, reuniu em sua teoria duas correntes que, a despeito de serem amplamente vistas como incompatíveis pelos filósofos morais, figuram desde sempre em conjunto na dogmática da pena: utilitarismo e retributivismo. Isso leva à sua postulação de que a pena deve ser administrada segundo finalidades políticas, mas respeitando determinados tetos morais que impedem, por exemplo, a punição de inocentes por fins de utilidade social.

\footnotetext{
${ }^{298}$ Tome-se como exemplo a lição de Mirabete sobre a consciência de ilicitude necessária à formulação do juízo de proibição: "O agente, no erro de proibição, faz um juízo equivocado sobre aquilo que lhe é permitido fazer na vida em sociedade. Evidentemente, não se exige de todas as pessoas que conheçam exatamente todos os dispositivos legais, mas o erro só é justificável quando o sujeito não tem condições de conhecer a ilicitude de seu comportamento. Não se trata, aliás, de um juízo técnico-jurídico, que somente se poderia exigir dos mais renomados juristas, mas de um juízo leigo, profano, que é emitido de acordo com a opinião dominante no meio social" (Mirabete, 1990: 200. Destaques meus). Com a ressalva de que, em Feuerbach, não havia o elemento empírico que exigisse o juízo ser socialmente dominante. Mas a ideia é essencialmente a mesma.
} 
(v) Esses fundamentos foram montados em um objeto teórico que é bem familiar ao que hoje conhecemos. Em primeiro lugar, por sua estrutura: uma divisão em parte geral e parte especial, com os crimes organizados por ordem de generalidade e importância de acordo com os pressupostos políticos de sua teoria penal (importância do Estado e dos indivíduos). Se isso não era novidade, o fato é que essa parte geral foi dividida em uma teoria do delito e uma teoria da pena (algo que não era hegemônico àquele tempo), que respondiam às duas perguntas-chave para a afirmação da autonomia do direito penal: (a) que vale como um delito criminal? e (b) qual pena deve ser imposta por um delito cometido, e em que circunstância deve sê-lo?. Tudo isso antecedido de prolegômenos que buscavam dar alguma ordem à confusão de normas penais então existentes. Por fim, esse objeto teórico ganhou também uma determinada posição enciclopédica: foi colocado inteiramente no campo do direito público, a despeito de o direito penal não trabalhar apenas com interesses públicos, mas também com direitos das pessoas particulares. Isso é, em forma e conteúdo, a parte geral do direito penal com a qual hoje trabalhamos.

Esse conteúdo da parte geral, entretanto, não é um dado natural da nossa disciplina. Este capítulo mostrou que uma teoria do delito fundada na legalidade, ao lado de uma teoria da pena fundada na união entre retributivismo e utilitarismo, eram caminhos teóricos possíveis para resolver um conjunto importante de problemas teóricos e institucionais do mundo jurídico e político em que viveu Feuerbach (e, consequentemente, a geração de fundadores do direito penal contemporâneo). Para uma teoria política da centralização do poder nas mãos do soberano, a legalidade limitava o poder punitivo de eventuais jurisdições concorrentes e retirava a autoridade de outros textos que, até não muito tempo antes, ainda eram fontes do direito e jogavam ainda àquela altura um papel forte na interpretação das leis. Para uma teoria política da proteção individual, ao mesmo tempo, a lei penal como pré-requisito da punição reforçava ao mesmo tempo a postura liberal de limites a arbítrios no exercício do poder criminal por parte do soberano.

No que diz respeito à teoria da pena, o elemento utilitário ungia o soberano no poder de punir e exigia-lhe que tal poder fosse exercido em benefício do 
Estado: mantendo a paz e combatendo o crime pela infalibilidade da punição. $O$ elemento retributivo, ao mesmo tempo, evitava que a pena, como instrumento político, fosse usada de maneira arbitrária, pois sua "metafísica moral" proibia que inocentes fossem punidos, ou que a medida da pena fosse excessiva. Sobrevivia, portanto, a velha teoria moral retributiva da pena como castigo, aliada a uma nova concepção da punição como técnica preventiva.

Assim, considero o argumento deste capítulo devidamente demonstrado: na época de Feuerbach, todos estavam formulando teorias que, em muitos pontos, já eram muito parecidas com nosso direito penal; mas, em outros pontos significantes, eram ainda ligeiramente diferentes. Feuerbach, entretanto, reuniu todos os elementos disponíveis na teoria jurídica de seu tempo e construiu um direito penal que, como objeto teórico, já tinha a cara de nosso direito penal contemporâneo, ao menos no que diz respeito a seus traços metodológicos mais elementares (e por isso constitutivos).

Esse direito penal que Feuerbach ajudou a construir eventualmente ganhou a Alemanha. Seu Código Penal Bávaro de 1813 foi em grande parte responsável por isso. O Lehrbuch de Feuerbach tornou-se uma espécie de doutrina oficial do direito penal alemão, porque visto como interpretação autêntica do código. Ademais, seu código tornou-se modelo não só para outros estados alemães, mas também para outras localidades na Europa, como a Áustria, a Suécia a Polônia e os cantões suíços, além de outros no leste europeu. Também em alguns desses lugares a doutrina de Feuerbach ganhou ares de um "saber oficial": vinte anos após a sua morte, publicava-se em Zurique, por exemplo, um extenso comentário de quase mil páginas ao Lehrbuch. ${ }^{299}$ Charles Vatel traduziu o Código Bávaro para o francês em 1852, juntamente com alguns princípios da doutrina penal feuerbachiana tirados do Lehrbuch. Essa tradução foi a principal fonte da codificação penal argentina de 1866. Pouco tempo depois, também a codificação uruguaia de 1874 foi nela inspirada; e, pouco tempo antes, o mesmo código também serviu de modelo para o projeto de código nacional peruano, de 1859 (Duve, 2002). Ao lado de tantos outros códigos modernos, com destaque para o

299 Morstadt, Karl. 1997. Ausführlicher kritischer Commentar zu Feuerbachs Lehrbuch. Zurique: Schaffhausen. 
Francês, o código de Feuerbach orientou também a elaboração do Código Criminal do Império do Brasil, de 1830 (Zaffaroni e Batista, 2003: 434-5). Ou seja: uma certa representação teórica do direito penal, cuja construção aparece exemplar em Feuerbach, eventualmente espraiou-se por diversas culturas jurídicas. O próximo capítulo cuidará do estabelecimento desse direito penal na cultura jurídica brasileira, e dos sentidos específicos que ela teve no Brasil. 


\section{O DIREITO PENAL CONTEMPORÂNEO NO BRASIL DO SÉCULO XIX}

\section{INTRODUÇão}

Mostrado no capítulo anterior o processo de criação teórica do direito penal contemporâneo na obra de Feuerbach, que é tido por muitos como o pai da dogmática penal como ela hoje existe, bem como a inventividade de sua teoria em meio aos demais penalistas de seu tempo, este capítulo cuidará do processo de afirmação desse tipo de direito penal no pensamento jurídico brasileiro do século XIX. A tarefa aqui é, em poucas palavras, investigar o caminho histórico pelo qual, no século retrasado, os elementos teóricos constitutivos do direito penal contemporâneo passaram a ser articulados pelos juristas nacionais de forma a forjar um objeto teórico que ostentasse as grande linhas daquilo que hoje conhecemos como o direito penal.

É muito importante salientar que o objeto deste capítulo não é a chegada da doutrina de Feuerbach no Brasil. Este não é um trabalho de arqueologia de ideias feuerbachianas. Seu propósito é menos determinar os meandros históricos pelos quais suas ideias chegaram e ganharam espaço por aqui, e mais especificar como um certo tipo de direito penal, de que Feuerbach foi um dos principais personagens, consolidou-se entre nós. Para fins metodológicos, separar uma coisa da outra é fundamental, porque é possível que os doutrinadores que tenham servido de apoio imediato para a sustentação teórica desse novo direito penal fossem já da geração 
posterior a Feuerbach, no caso de o direito penal contemporâneo haver se afirmado tardiamente por aqui (como é de se supor). Mas o importante é ter em mente que esses autores posteriores estavam levando adiante um tipo de direito penal de que Feuerbach foi um dos inauguradores. Pellegrino Rossi, um dos penalistas mais citados no Brasil do século retrasado, reconhecia Feuerbach como o maior penalista da Alemanha, país que, para ele, representava a vanguarda da teoria jurídica de seu tempo (Rossi, 1872, T. I: 112); Heinrich Ahrens, autor alemão que escrevia também em francês e foi um dos jusnaturalistas mais lidos no Brasil do século XIX, ostentava uma imagem de direito penal muito semelhante à de Feuerbach em razão da influência da filosofia crítica em sua obra; o Código da Bavária de 1813, escrito por Feuerbach, foi um importante modelo não só para a confecção do Código de 1830, como também para a sua interpretação por penalistas posteriores: Alves Jr. (1864) e Camargo (1881-2), por exemplo, citam-no a todo instante, e vez por outra também fazem referências nominais a Feuerbach. Suas ideias, portanto, estiveram indubitavelmente presentes no pensamento jurídico brasileiro, e eram conhecidas e respeitadas pelos juristas lidos aqui, fossem eles brasileiros ou estrangeiros.

O capítulo anterior, entretanto, não serve apenas como conjunto de curiosidades teóricas sobre como se formou o direito penal contemporâneo. Ele não é um antiquário de ideais penais. Ao contrário, a investigação histórica nele contida serve para indicar algo que, como foi dito no primeiro capítulo, perdeu-se com a naturalização do direito penal contemporâneo: os sentidos por trás da formação do nosso direito penal, enquanto a prática social normativa que é. A análise da obra de Feuerbach mostrou, neste aspecto, que a criação do direito penal contemporâneo pode ser bem compreendida se atentarmos para os sentidos políticos (finalísticos) e teóricos (metodológicos) nela compreendidos. Sob os dois pontos de vista, o direito penal contemporâneo é um poço de contradições. O primeiro de seus pilares - a doutrina do delito criminal - servia a um só tempo a dois propósitos que podem ser vistos como adversários: de um lado, (i) a concentração do poder político criminal na pessoa do soberano em detrimentos de outras fontes concorrentes de jurisdição, que levou à equiparação do "criminal" uma lesão de direito público; e, de outro lado (ii) a proteção 
individual contra a superlatividade desse mesmo poder criminal, que a partir de fins do século XVII inflou o "direito criminal" com a filosofia política iluminista e levou ao confinamento teórico das definições de delitos e penas (em relação à realização prática do poder criminal) em um "direito penal" puramente conceitualista e defensivo, construído com a mesma metodologia individualista da filosofia política do Iluminismo. Com isso, a teoria do delito contemporânea cumpria, a um só tempo, a tarefa de dar poder criminal ao soberano frente a quaisquer outras jurisdições, mas também de lhe retirar esse mesmo poder diante dos direitos individuais, controlado que era por uma razão universal. No tocante à doutrina da pena criminal, havia também contradições pela mescla de filosofia moral nela encontrada: além de todos os sincretismos políticos e metodológicos que ela carrega juntamente com a teoria do delito, a teoria da pena do direito penal contemporâneo juntou ainda as imagens antropológicas adversárias de "idealistas" e "sensualistas", combinando teorias da punição predominantemente retributivas (como a de Kant) e utilitaristas (como as de Hobbes e Beccaria) em uma só doutrina da pena que se pretendia preventiva sem estar em desacordo com os fundamentos absolutos da justiça punitiva. Trata-se, como visto nos capítulos anteriores, de um projeto de composição entre dois mundos políticos e teóricos distintos: o da justiça criminal pacificadora e da teoria moral retributiva, de um lado, e o dos direitos individuais protetores e a teoria moral sensualista de base empírica, de outro. Foi a busca de superação dessas controvérsias, políticas e morais, que fez a parte geral do direito penal contemporâneo compreender aquilo que ainda hoje nela depositamos: uma teoria do delito e uma teoria da pena.

Como o grande objeto deste capítulo é o ideário jurídico do século XIX no Brasil, é importante ter em conta os estudos de referência que se ocupam da formação intelectual da elite política brasileira, em geral, e do ensino jurídico, em particular. Tem-se em mente especialmente as obras de Alberto Venâncio Filho (2004), Sérgio Adorno (1988) e José Murilo de Carvalho (2003), além de, mais recentemente, o trabalho de José Reinaldo de Lima Lopes (2007). Por caminhos diferentes, todos esses trabalhos fornecem elementos metodológicos importantes para esta investigação. 
Um primeiro conjunto de elementos diz respeito ao ensino jurídico no Brasil do século XIX. Alberto Venâncio Filho faz péssimo juízo do ensino do direito no Império. Segundo ele, os cursos jurídicos deixavam muito a desejar, qualquer que fosse o prisma de análise. As suas condições materiais eram deficientes, tanto em Pernambuco quanto em São Paulo: quando não funcionaram de improviso em edifícios religiosos, ocuparam prédios de fazer vergonha, como no caso específico de Recife. Descontadas algumas honrosas exceções, o corpo docente ficava abaixo da crítica: ${ }^{300}$ algumas vezes, por falta de envolvimento em razão da baixeza dos vencimentos ou da ocupação em atividades profissionais paralelas, em geral no meio político; outras, por insuficiência pedagógica dos lentes. Os alunos, por fim, estavam no mesmo nível das instalações e de seus mestres, sempre segundo Venâncio: acostumados com um ensino deficiente e pouco cobrados nos exames, desfrutavam de uma vida acadêmica intensa na cidade de São Paulo, mas que nada tinha a ver com os estudos jurídicos, mesmo no caso daqueles que mais se destacaram como juristas. "Ser estudante de Direito era, pois, sobretudo, dedicar-se ao jornalismo, fazer literatura, especialmente a poesia, consagrarse ao teatro, ser bom orador, participar dos grêmios literários e políticos, das sociedades secretas e das lojas maçônicas" (Venâncio Filho, 2004: 136).

Venâncio Filho conclui, por tudo isso, que, apesar das muitas tentativas de reforma, o ensino jurídico no Império ficou muito aquém do que deveria, a despeito de reconhecer que as faculdades de São Paulo e Pernambuco (Olinda e posteriormente Recife) foram importantes centros para a circulação de ideias no Brasil durante o século XIX. Em sua opinião, os "rapazes bisonhos" que frequentavam as duas academias, "mergulhados nos ambientes dessas escolas", "formados, retornavam a seus lares, à sua província ou à sua aldeia natal - e eram ali outros tantos focos irradiadores do velho idealismo utópico, aprendido nas acadêmicas de onde tinham saído" (Venâncio Filho, 2004: 163).

\footnotetext{
300 Venâncio Filho aponta como exceções: (i) João Crispiniano Soares, posteriormente Conselheiro Crispiniano, lente de Direito Romano e divulgador da Escola Histórica de Savigny; (ii) Joaquim Inácio Ramalho, posteriormente Barão de Ramalho, catedrático de Processo e Prática Forense; e (iii) Antônio Joaquim Ribas, posteriormente Conselheiro Ribas, catedrático de Direito Administrativo e autor do já mencionado Direito Administrativo Brasileiro (1866).
} 
O trabalho histórico de Venâncio é uma das importantes fontes para a sociologia das profissões jurídicas feita por Sérgio Adorno em Os Aprendizes do Poder (1988). Dessa forma, não surpreende que, no tocante ao pensamento jurídico brasileiro do século XIX, a imagem construída por Adorno seja igualmente pouco laudatória. Referindo-se especificamente ao caso paulista, diz ele que a história da Academia de São Paulo "faz sobressair a ausência de um efetivo ensino jurídico no Império, que apenas esporadicamente produziu juristas de notoriedade nacional e doutrinadores do Direito", apesar de ter sido "celeiro de um verdadeiro "mandarinato imperial" de bacharéis" (Adorno, 1988: 79).

Após comentar as obras de alguns professores de São Paulo, Adorno anota, prosseguindo em seu tom crítico, que

a academia de Direito de São Paulo produziu uma safra numericamente inexpressiva de jurisconsultos, em favor de um contingente quantitativamente significativo de advogados, administradores, parlamentares, oradores, jornalistas e artistas. A prática de conciliar tendências filosóficas antagônicas e de harmonizar ideias jurídicas de distintas filiações ontológicas e gnosiológicas, minimizou os pressupostos críticos da atividade didático-pedagógica, e, em contrapartida, fez sobressair seu lado reverso: uma formação puramente ornamental, nutrida, em parte, da exposição quase literal de doutrinadores do Direito e de comentários de códigos, sem qualquer efeito construtivo e modificador de comportamentos (Adorno, 1988: 102-3.)

Ao relacionar a quantidade de "jurisconsultos" com a "ausência de um efetivo ensino jurídico no Império", Adorno faz uma ligação entre, de um lado, a qualidade do ensino jurídico à época e, de outro, a qualidade do pensamento jurídico de então - supõe-se que o "jurisconsulto" seja por ele tido como o exemplar de um pensamento jurídico de qualidade, como parece ser o caso. Seu raciocínio é bastante lógico: dado que o ensino era ruim, também foi ruim o pensamento jurídico dele resultante, implicando a existência minguada de juristas de qualidade. Alberto Venâncio Filho não discordaria muito dessa opinião, já que a baixa qualidade do pensamento jurídico imperial é um leitmotif de seu trabalho. Mas o raciocínio de Adorno tem uma premissa que, para um estudo de história do pensamento jurídico, pode ser um 
complicador metodológico, qual seja, a colocação em polos opostos do "jurisconsulto" e das demais atividades intelectuais mencionadas, entre as quais a advocacia e a vida pública. Com efeito, ele parece tomar a existência de profissionais majoritariamente dedicados a atividades acadêmicas como um elemento fundamental para a elevação da qualidade do pensamento jurídico e, em sentido contrário, a falta de tais profissionais como denunciadora de um ensino jurídico "puramente ornamental" e "sem qualquer efeito construtivo e modificador de comportamentos".

Ainda que a plausibilidade dessa hipótese seja bastante grande, é também possível que proferir um juízo de mérito quanto ao pensamento jurídico do Império apenas por esse critério seja um passo apressado. As primeiras pistas nesse sentido são dadas, aliás, por um excerto do texto de Venâncio Filho. A certa altura, por ocasião dos comentários à carreira docente na Faculdade de Direito de São Paulo, há uma passagem da Memória Histórica escrita por Pedro Lessa em 1885 onde se lê o seguinte:

Com nosso inverterado hábito de imitar as leis e regulamentos franceses, preferimos, então, ter um número considerável de professores em país que é tão difícil recrutar pessoal habilitado para ter alta e honrosa função, a seguir o exemplo, dado pelas universidades alemãs e italianas, onde é muito limitado o número de lentes, incumbindo-se cada um de dois ou mais cursos. (Lessa, apud Venâncio Filho, 2004: 120.)

O comentário de Pedro Lessa chama atenção para o modelo de carreira docente então vigente nas faculdades de direito do país, que mais se aproximava do francês que do alemão ou italiano. Na França, os professores dividiam suas atividades entre afazeres práticos, usualmente na alta burocracia, e atividades docentes. Isso é atestado pela biografia dos principais juristas franceses daquele tempo. François Guizot, um grande nome do direito público do século XIX e muito lido pelos publicistas brasileiros do Império, cultivava todos os vícios apontados por Adorno como óbices à produção da boa ciência: além de ter guardado intensa atividade política por toda sua vida - chegou inclusive a primeiro ministro da França, em 1847 -, tomava-lhe 
muito tempo a literatura, tendo ele traduzido quase toda a obra de Shakespeare para o francês. Jean-Jacques Cambacérès, por sua vez, passou a vida alternando os principais cargos da burocracia francesa e, não obstante, foi o principal redator do Código Civil napoleônico (1804), cuja qualidade é indiscutível. Na Alemanha, ao contrário, a atividade professoral era mesclada no mais das vezes com outras atividades puramente acadêmicas, ainda que com alguns eventuais intervalos para afazeres de natureza mais prática, em geral em empregos estatais. Assim foi com Savigny, que, exceção feita ao pequeno período de seis anos em que atuou como alto-chanceler (Grosskanzler) do sistema judiciário da Prússia, trabalhou como professor em diversas universidades alemãs por quase toda a sua vida produtiva, boa parte dela gasta rodando a Europa em busca de velhos textos de direito romano; ou mesmo com Feuerbach, que só após haver produzido intensamente como professor em diversas universidades alemãs dedicou-se por alguns anos à magistratura e outros cargos burocráticos.

Tudo isso é dito para, mais uma vez, defender-se a pertinência e relevância deste trabalho e chamar a atenção para alguns pontos metodológicos fundamentais da etapa de investigação compreendida neste capítulo. Primeiramente, o fato, já por demais conhecido e comprovado por pesquisas como as de Venâncio Filho e Adorno, de que nossas academias ou faculdades de Direito tinham poucas condições materiais ou institucionais para a produção de conhecimento jurídico de qualidade não implica, por si só, que nenhum pensamento jurídico relevante tenha existido no Brasil do século XIX e, portanto, não desqualifica um estudo histórico que, como este, tome-o como objeto principal de investigação. Por corolário, e seguindo as pistas históricas oferecidas pelos trabalhos de Adorno e Venâncio Filho, a orientação metodológica que se pode tomar é que uma investigação sobre o pensamento jurídico no Brasil do século XIX não pode ser feita apenas nos compêndios de nossos cursos de direito ou na produção intelectual de nossos professores, ainda que, obviamente, eles sejam material de consulta obrigatória para uma pesquisa como esta. É preciso focar, também, outros âmbitos de expressão de ideias jurídicas que se faziam sentir no Brasil de então. ${ }^{301}$

\footnotetext{
${ }^{301}$ Estou, portanto, em concordância com Lopes, que ao comentar a produção intelectual dos juristas do Segundo Reinado, diz: "[a divisão entre tarefas acadêmicas e práticas] não foi obstáculo para que houvesse, fora dos estreitos muros da academia, um pensamento jurídico, nem que dentro da academia se produzisse alguma coisa. Convivemos tradicionalmente com juristas fora de posição de cátedra há muito
} 
$\mathrm{Na}$ procura por vida inteligente fora das academias, chega-se ao conhecido estudo da elite política imperial realizada por José Murilo de Carvalho (2003). Sua tese é que a formação do Brasil no século XIX, como nação e país, foi possível graças à relativa homogeneidade ideológica da elite política daquele tempo; homogeneidade essa que não se atingiu por semelhanças de classe social, como na Inglaterra, ou de profissões, como nos Estados Unidos, mas sim pela formação e treinamento da classe dirigente (Carvalho, 2003: 25-44). Esse processo de homogenização dava-se ao longo de uma vida, aperfeiçoando-se sobretudo por anos de carreira na burocracia. Mas começava, na vasta maioria das vezes, no ensino jurídico (cit.: 65-88).

Há duas importantes constatações da pesquisa de Carvalho que oferecem importantes balizas metodológicas para esta investigação. A primeira diz respeito ao nível de educação formal dos membros da elite política imperial, nas diferentes funções que podiam ocupar. Se, comparando-se com o nível educacional da população em geral, todas as carreiras políticas eram "uma ilha de letrados num mar de analfabetos", é certo que havia duas carreiras que eram especialmente distintivas pelo altíssimo nível de educação formal de seus ocupantes: a de ministro de Estado e a de conselheiro de Estado. A partir de meados do século XIX, mais de 95\% dos ministros tinham educação superior. Os conselheiros eram ainda mais educados: 70 dos 72 integrantes do Conselho de Estado a partir de 1840 tinham estudos superiores completos (Carvalho, 2003: 78-9). Pois bem, se considerarmos que: (i) a produção teórica em direito é praticamente exclusiva dos formados na área; (ii) a elite política vinha tendo acesso, desde o século XVIII, a estudos de cânones e de leis em Coimbra e, a partir de 1827, no Brasil; e que (iii) grande parte dos bacharéis almejava um cargo na burocracia, como mostram os trabalhos de Carvalho, Adorno e Venâncio Filho, fica fácil ver que, se quisermos procurar pelo estado da arte da doutrina jurídica do Império, a produção intelectual dos ministros e conselheiros de Estado talvez seja um bom lugar para se vasculhar.

tempo no Brasil (e fora do Brasil): Rui Barbosa não foi professor, nem Pimenta Bueno, Uruguai, Teixeira de Freitas ou Nabuco de Araújo; não o foi tampouco décadas depois João Mangabeira. Foram, porém, juristas e deixaram seu traço" (Lopes, 2007: 8). 
Essa suspeição é confirmada pelo recente trabalho de Lopes (2007), que investigou as atas da Seção de Justiça do Conselho de Estado enquanto local de formação de um pensamento jurídico brasileiro. Objetando-se a algumas das conclusões das pesquisas de Venâncio Filho e Adorno, ele argumenta que uma parte do pensamento jurídico brasileiro do século XIX pode ser encontrado nas atas das consultas aos conselheiros. A historiografia recebeu bem a novidade metodológica para a qual Lopes chamou a atenção, o que levou ao surgimento de interessantes novas hipóteses sobre o governo imperial (Oliveira, 2007) ou a cultura jurídica brasileira de então (Vellasco, 2007a).

Isso dá um panorama do pé em que estão as pesquisas sobre o pensamento jurídico brasileiro imperial e as principais diretrizes investigativas para seu estudo histórico. Entretanto, tudo isso leva-me a uma encruzilhada metodológica: se é verdade que a produção prática da alta burocracia Imperial pode ser um manancial de informações para o estudo do pensamento jurídico brasileiro do século XIX, e que os escritos de nossos professores de direito, ao contrário, não eram especialmente distintivos por sua alta qualidade, é também verdade, por outro lado, que o objeto específico de que aqui se buscam vestígios é muito difícil de ser encontrado em textos dessa natureza, que têm características eminentemente práticas. ${ }^{302}$ Não faz sentido, por exemplo, buscar nos votos dos conselheiros a separação conceitual do direito e do processo penal, ou a posição enciclopédica do direito penal, ou ainda a função metodológica da legalidade para a construção teórica de uma disciplina jurídica, pois a solução de um caso concreto dificilmente precisa chegar a meandros teóricos tão profundos: se um ou dois votos houver em toda a história do Conselho de Estado que ventilem esse assunto, já será muito; e, por serem assim escassos, ${ }^{303}$ esses eventuais votos pouco serviriam para o propósito desta pesquisa, que está muito mais preocupada com a representação teórica do direito penal do que com sua realização prática pelos órgãos de aplicação do direito. Com efeito, em uma pesquisa exploratória das atas da

\footnotetext{
${ }^{302}$ O trabalho de Braz Florentino Henriques de Souza, adiante comentado, corrobora a dificuldade de se encontrar respostas a perguntas tão teóricas em textos de natureza puramente prática.

${ }^{303}$ Em sua pesquisa sobre as atas da Seção de Justiça do Conselho de Estado, Lopes (2007: 29) dá ideia de como são poucos os documentos que poderiam interessar a esta pesquisa: de um total de 860 consultas resolvidas, apenas 16 dizem respeito a matéria estritamente penal (penas e pena de morte).
} 
seção de justiça do Conselho, publicadas quase integralmente nos dois volumes organizado por Caroatá (1884), pouca coisa de proveito foi encontrada.

A saída foi não restringir-se à produção jurídica dos autores brasileiros; mas, ao contrário, buscar importantes autores estrangeiros que eram lidos no Brasil, e, por conseguinte, que mais importância tiveram para a eventual divulgação e estabelecimento entre nós do tipo de direito penal pelo qual se procurava. Com essa orientação, julgo ter evitado o erro metodológico que uma investigação desavisada apenas nos autores brasileiros implicaria, além de fugir do beco sem saída que seria a formulação de perguntas puramente teóricas a fontes que dão respostas eminentemente práticas. Por isso, antes de uma investigação sobre os penalistas brasileiros, o capítulo é na verdade uma investigação sobre o direito penal contemporâneo no Brasil do século XIX, o que necessariamente extrapola os limites dos autores nacionais, mesmo que o propósito seja, ao final de tudo, mostrar como o direito penal contemporâneo tornou-se corrente entre os juristas daqui. Entretanto, o papel dos autores estrangeiros é, por óbvio, secundário no que diz respeito à hipótese da pesquisa. Assim, se de um lado buscou-se escolher apenas autores relevantes e muito citados, não se teve, de outra parte, a pretensão de percorrer todos os autores estrangeiros de direito penal que foram lidos no Brasil; e nem necessariamente todos entre os que se podem considerar relativamente importantes - ainda que o critério da importância tenha sido relevante, bem como a busca por uma certa representatividade desses estrangeiros. O foco deste capítulo foi principalmente cobrir todos os penalistas nacionais que deixaram trabalhos durante o século XIX que pudessem interessar à investigação.

A única possibilidade vislumbrada de se encontrar respostas tão teóricas em textos de caráter prático foi na produção intelectual em torno do Código Criminal de 1830. De fato, lá foi possível colher indícios mais diretamente relacionados ao objeto de análise desta pesquisa, a despeito do caráter pragmático envolvido no trabalho de criação e promulgação de um código. Os debates parlamentares registrados nos Anais da Câmara dos Deputados foram o principal material consultado nesse sentido. Tais debates também tiveram a importante função de cobrir um lapso temporal nas fontes nacionais: como os primeiros livros brasileiros de 
direito penal que interessavam à investigação apareceram somente a partir de meados do século XIX, a documentação relacionada ao Código de 1830 acabou por fornecer informações importantes sobre o objeto de investigação em um período não coberto pelas fontes preferenciais da pesquisa. De resto, as buscas centraram-se preferencialmente em trabalhos de natureza acadêmica, onde as informações necessárias ao teste das hipóteses desta investigação estavam disponíveis com mais facilidade, e não exigiam longos exercícios de interpretação que arriscavam contaminar as fontes com a interpretação do pesquisador.

A estratégia investigativa do capítulo, portanto, foi a de acompanhar, tanto nos autores nacionais, como em alguns dos importantes autores estrangeiros lidos no Brasil do século retrasado, os traços constitutivos do direito penal contemporâneo para, ao final, chegar-se a uma resposta de como esse objeto teórico, hoje naturalizado por nós como o direito penal, consolidou-se no pensamento jurídico brasileiro do século XIX. Os critérios utilizados para selecionar os juristas estrangeiros lidos foram múltiplos. Os autores escolhidos foram aqueles que mais comumente são citados nos textos jurídicos brasileiros de época, como também nas pesquisas sobre o pensamento jurídico de então. Mais ainda, a pesquisa não se restringiu às obras de direito penal: como buscam-se características gerais da disciplina, avaliou-se que seria também relevante consultar obras de natureza mais compreensiva, o que se revelou acertado no curso da investigação. Por isso foram estudadas também as mais importantes obras de Direito Natural utilizadas no Brasil de então, já que tal disciplina equivalia, em termos atuais (e perigosamente anacrônicos), a uma mistura de Introdução ao Estudo do Direito, Filosofia Jurídica e Sociologia Jurídica. ${ }^{304}$

\footnotetext{
${ }^{304}$ Sociologia Jurídica porque uma das tarefas do direito natural era revelar as leis gerais que informavam o direito como prática social, algo de que a sociologia do direito também se ocupa, ainda que com método absolutamente distinto.
} 


\section{Pressupostos teóricos do direito penal Contemporâneo na FormaÇão inicial dos JURISTAS BRASILEIROS}

Antes de apresentar o resultado da análise das obras, alguma coisa precisa ser dita sobre atividade intelectual nos ambientes em que nossos juristas se formaram como tais. Por isso, esta primeira parte do capítulo analisará os pressupostos do direito penal contemporâneo em Coimbra e nos primeiros anos do ensino jurídico no Brasil. Dado que a presença da elite jurídica de formação coimbrã foi majoritária até 1853 (Carvalho, 2003: 81 e ss.), uma compreensão mínima do meio intelectual universitário português parece ser necessária, uma vez que o direito penal contemporâneo está sendo estudado aqui como, no fundo, um trânsito de ideias. Essa incursão é ainda útil porque, como mostrado no capítulo anterior, há uma ligação importante entre os elementos constitutivos do direito penal contemporâneo e um conjunto de pressupostos filosóficos que, como a historiografia das ideias costuma apontar, não tiveram penetração fácil no meio universitário português.

A formação do direito penal contemporâneo é, antes de qualquer coisa, um processo de "modernização" do direito, sem qualquer conotação evolutiva do termo: uma aproximação da doutrina jurídico-penal daquilo que nós no tempo presente reconhecemos como o direito penal enquanto objeto teórico. As características dessa modernização aparecem nos traços constitutivos desse objeto, explicitados no primeiro capítulo e retomados em diversas outras oportunidades. Por isso, alguns elementos progressistas do pensamento jurídico da modernidade - progressistas, claro está, porque visavam a imprimir alterações metodológicas no pensamento jurídico até então hegemônico - são condições para a profusão do direito penal contemporâneo.

Como dito no capítulo passado, essas condições encontraram seus maiores canais de profusão sobretudo no liberalismo, como orientação política, e no iluminismo, como movimento cultural, em que pese: (i) algumas delas já terem sido adiantadas por autores que não eram nem liberais, nem iluministas; e (ii) a perenidade de um núcleo duro da disciplina, trazido de um mundo político e moral bem anterior ao contemporâneo, que existe muito antes de o direito penal contemporâneo ameaçar surgir 
no imaginário dos juristas. Por essas duas vias, foram colocadas à disposição dos juristas do século XVIII temas como a concepção de Estado-gendarme, responsável pela ordem e segurança e condição do pleno florescimento individual; a distinção entre deveres políticos e deveres morais, em sua versão mais sofisticada; o fundamento contratualista da ordem política; e um ideal de racionalidade como ferramenta intelectual de organização de ideias por uma determinada lógica, entre outros tantos. No capítulo III, dedicado ao surgimento do direito penal contemporâneo em Feuerbach, mostrou-se como todos esses elementos têm estreita relação com o nosso direito penal, ajudando a entender inclusive algumas das contradições teóricas e políticas que ele guarda em seus dois pilares constitutivos (a teoria do delito e a teoria da pena). Não por acaso, Feuerbach, que postulo ser um dos percursores desse tipo de direito penal, é visto à unanimidade por seus intérpretes contemporâneos como um ícone tanto do liberalismo, quanto do iluminismo na cultura jurídica alemã (Cattaneo, 1970: passim), e utiliza-se de todos esses elementos na sua construção teórica do direito penal.

Com isso em mente, algumas coisas importantes podem ser ditas sobre a Universidade de Coimbra, onde boa parte de nossa elite intelectual da primeira metade do século XIX fez seus estudos. É praticamente consensual na historiografia atual que aquela universidade só muito tardiamente conseguiu sua libertação em relação a pernósticas influências de dogmatismo religioso. O primeiro passo nesse sentido foi dado sob o governo do Marquês de Pombal. Desde 1537, quando a Universidade voltou a Coimbra - ficara sediada em Lisboa, seu local de origem, desde 1384 -, cessou o predomínio dos "legistas" e o ensino caiu das mãos dos jesuítas, que o controlaram até 1759. Durante o período de domínio jesuítico, "a Universidade se isolou da influência do progresso intelectual e científico europeu" (Carvalho, 2003: 66). No Colégio das Artes, de frequência obrigatória para quem estudasse leis e cânones, implementou-se a Ratio Studiorum, "que privilegiava o latim e o grego sobre a língua pátria, a teologia sobre a filosofia, o aristotelismo e o escolasticismo sobre o cartesianismo" (cit.: idem). Pombal, que chegara ao poder após mostrar-se um homem de ação em meio ao caos deixado pelo terremoto de Lisboa, era um ilustrado que não fazia bom juízo da ordem religiosa, e expulsou os jesuítas de Portugal em 1759. A Universidade de Évora, 
mantida pelo trabalho da Companhia de Jesus, teve seu funcionamento encerrado no mesmo ano, sobrexistindo apenas a de Coimbra, cujos estatutos foram inteiramente alterados pela conhecida reforma de 1772 .

A reforma dos estatutos de Coimbra foi uma de muitas medidas de Pombal voltadas ao "progresso da Ciência e das Artes", como se dizia então. ${ }^{305}$ Antes dela, já havia se dado o estabelecimento da Junta de Providência Literária (1768), também com atuação marcadamente antijesuística. Mas a mudança dos estatutos destaca-se em importância entre suas congêneres, sendo até hoje recordada como a mais impactante iniciativa para o realinhamento cultural de Portugal com o restante do continente europeu. Nesse sentido, o propósito dos novos estatutos era "restaurar as ciências e as artes liberais no Reino e domínio ultramarinos" (Serrão, 1996: 268). A reforma trouxe alterações administrativas de relevo com vistas a esse fim. Houve significativa renovação do quadro de professores, com o jubilamento de muitos antigos lentes e a nomeação de outros tantos novos. Um deles entraria para a história do direito criminal português e, de certa forma, também do brasileiro: Pascoal José de Mello Freire, o maior símbolo do iluminismo jurídico-penal da velha metrópole.

Se, por um lado, a segunda metade do século XVIII pode ser apontada como o momento em que o Iluminismo finalmente atingiu Portugal, a historiografia costuma apontar que, por outro, as luzes portuguesas foram de um tipo muito particular. "O processo de adesão à modernidade [em Portugal] não foi linear nem desprovido de mediações contraditórias. A irredutível singularidade do movimento das Luzes em Portugal resulta, exatamente, dos processo de seleção e adaptação que vão sofrendo as orientações e os valores veiculados pela literatura estrangeira" (Araújo, 2003: 15). A figura de Luis Antonio Verney é exemplar dessas contradições. Descendente de família inglesa e considerado por muitos o precursor do iluminismo lusitano, Verney foi um dos "estrangeirados" que ajudou na penetração da cultura das luzes em Portugal. Suscitou grande discussão pública por ocasião da publicação de $O$ Verdadeiro Método de

\footnotetext{
${ }^{305}$ No campo da legislação, também houve embates entre os reformadores e os defensores da ordem política anterior. Exemplo disso pode ser encontrado no campo do direito das sucessões, onde se buscou a limitação do morgadio e dos legados à Igreja pela criação de regras fixas de sucessão legal. Sobre o tema, v. A. Wehling e M. J. Wehling, 1998.
} 
Estudar, em 1746. Verney representava aquilo que se pode chamar de um ilustrado conservador. José Murilo de Carvalho qualifica-o como um iluminista mais à moda italiana do que francesa, sem nenhuma vocação transformadora (Carvalho, 2003: 67). Carvalho Jr. (2005: 26), por sua vez, aponta que a importância do uso público da razão, à moda kantiana, passava longe de suas propostas, centradas sobretudo no elemento da autoridade. Gizlene Neder (2000) tem posição análoga, defendendo que a cultura das Luzes em Portugal nunca conseguiu estabelecer o dogma da liberdade de ideias que, para Broadie (2001: 9), é a marca central de qualquer movimento intelectual que se queira chamar iluminista. É, portanto, bastante corrente a interpretação de que o Iluminismo português - seja ele um iluminismo "obediente e submisso", nas cores fortes de Neder (2000); ou apenas "alinhado com o Catolicismo", como quer Araújo (2003: 17) - esteve, em alguma medida, preso ao ideário católico, ainda que as razões para tanto não sejam consensuais na historiografia. ${ }^{306}$ Isso tudo sem falar do período posterior à "Viraderia" quando, é claro, os seus traços conservadores viram-se acentuados e aprofundou-se o desencontro de Portugal em relação ao restante da Europa no campo das ideias.

Disso resultava que, na formação intelectual do alunado de Coimbra (como a elite jurídica brasileira até meados do século passado), muita coisa acabava represada. Carvalho (2003: 67) lembra, por exemplo, que os trabalhos de Rousseau (o alicerce político de Beccaria) e Voltaire permaneceram proscritos, mesmo após a reforma pombalina. Os efeitos disso, é claro, sentiam-se no Brasil em alguma medida. Silva Lisboa, que frequentou Coimbra após a mudança dos estatutos, traduziu Adam Smith e defendeu o trabalho livre, mas por ocasião da defesa da liberdade de ensino na Constituinte de 1823, disse que "nenhum governo pode tolerar que em quaisquer aulas se ensinem, por exemplo, as doutrinas do contrato social do sofista de Genebra" (apud Carvalho, 2003: 85). Bernardo Pereira de Vasconcellos, um dos grandes homens públicos da primeira metade do século XIX e redator principal do Código Criminal de

\footnotetext{
${ }^{306}$ Ainda que muitos autores tributem esse fenômeno à influência da Igreja na vida pública portuguesa, por sua proximidade com a Coroa, Carvalho Jr. opina que o fator decisivo para o atraso português em relação ao às ideias das Luzes foi a falta de uma esfera pública de debate, resultante principalmente da fraqueza da imprensa portuguesa à época (Carvalho Jr., 2005: 26-30).
} 
1830, mostrou, ao relatar sua experiência em Coimbra, o quanto essas limitações afetavam a formação dos estudantes:

Estudei direito público naquela Universidade e por fim saí um bárbaro: foi-me preciso até desaprender. (...) o direito de resistência, este baluarte da liberdade, era inteiramente proscrito; e desgraçado quem dele se lembrasse! Estas e outras doutrinas se ensinam naquela universidade e por quê? Porque está inteiramente incomunicável com o resto do mundo científico (apud Venâncio Filho, 2003: 22).

É evidente que havia trânsito de ideias fora do ambiente universitário, pelo qual certamente Rousseau e outros chegavam ao conhecimento dos alunos - tanto Silva Lisboa quanto Vasconcellos demonstraram conhecê-lo, note-se bem. A historiografia costuma atribuir parte desse mérito aos cenáculos, grupos privados de discussões literárias e acadêmicas. No Brasil, apesar de a Lei de 11 de agosto exigir que os livros didáticos não contivessem senão doutrinas concordantes com o "sistema jurado pela Nação" (art. $7^{\circ}$.), uma tal proibição não parece ter existido de fato. O compêndio de direito natural organizado por Avellar Brotero, lente de São Paulo, citava Rousseau em suas lições sobre o Estado, por exemplo (Brotero, 1829: 56). Mas é igualmente razoável supor que o desenvolvimento de uma teoria jurídica que, como o direito penal contemporâneo, era tão dependente de temas principalmente debatidos nos autores proscritos talvez terá sido retardado por sua proibição; pois, por mais que as ideias possam transitar por muitos meios inconvencionais, a definição rigorosa de um objeto teórico é coisa que se faz em geral em um contexto de reflexão predominantemente científica, de que a universidade e os trabalhos nela e para ela gerados são os exemplos mais evidentes.

É importante mencionar também que os primeiros anos do ensino jurídico brasileiro guardam continuidades significativas em relação ao ensino coimbrão: enquanto não ficavam prontos os compêndios dos lentes de São Paulo e Pernambuco, eram utilizadas principalmente as obras portuguesas como referência para o ensino. Além disso, demorou algum tempo para que a maioria do corpo docente fosse formada pelas academias brasileiras. Paulino José Soares de Souza, futuro Visconde do Uruguai, 
que não foi lente mas foi um dos principais juristas do Império, formou-se na primeira turma, em 1831, mas só em meados de 1850 começou a trabalhar no Ensaio sobre o direito administrativo, obra-mestra da disciplina no século XIX, publicada em 1862 (Carvalho, 2002: 26). No ano seguinte formou-se a primeira turma que cursou integralmente seus estudos em São Paulo - Uruguai transferira-se de Coimbra para cá -, sendo Pimenta Bueno um dos bacharelandos. Tido como o principal constitucionalista brasileiro do século retrasado, seu Direito Público e Análise da Constituição do Império só foi publicado em 1857, mais de duas décadas depois da formatura da primeira turma paulista.

Nesse meio tempo, as atividades acadêmicas no Brasil foram marcadas pela maciça presença de obras estrangeiras, de diversas proveniências. Por questão de facilidades idiomáticas, as obras em francês eram as mais comuns. Em direito criminal, Pellegrino Rossi e Ortolan eram muito citados, além, é claro, de Mello Freire. Em direito natural, o compêndio de Avellar Brotero, sempre muito criticado, convivia com franceses e alemães, além, é claro, dos portugueses. Os clássicos da filosofia política do século XVII igualmente aparecem muito: Rousseau é citado com frequência e, em matéria penal, Bentham e Beccaria também. O direito romano, por fim, seguia tendo um papel importante não só na teoria, mas também na prática: conforme iam minguando nas "nações cultas" as leis modernas sobre a escravidão modernidade adentro, era frequente que os problemas jurídicos nessa matéria fossem resolvidos com base nos velhos princípios romanos. ${ }^{307}$ A permanência de uma cadeira de direito romano no currículo das academias de São Paulo e Recife, às custas de muita polêmica entre os deputados, garantiu o espaço da disciplina no meio intelectualjurídico do século XIX.

\footnotetext{
307 "A escravidão é o campo privilegiado, em que majoritariamente se invoca o direito romano no âmbito das consultas pesquisadas. E não sem razão. (...) A escravidão (...) já não era conhecida em nenhum ordenamento europeu moderno, ou seja, não era tratada com o detalhe que se encontrava no direito romano. Assim, dado o silêncio do direito pré-independência, era o direito romano quem supria com elementos jurídicos o embasamento dos votos dos conselheiros" (Lopes, 2007: 31-2).
} 


\section{Os debates em torno do Código de 1830}

A análise do Código de 1830, para os fins desta tese, será feita com todas as ressalvas já expressas na introdução do capítulo quanto à dificuldade de se encontrar, em textos de natureza eminentemente prática, elementos que, como os que são buscados, são destacadamente teóricos. De qualquer forma, seja pela natureza muitas vezes principiológica que presidiu alguns importantes debates em torno do Código (especialmente no tocante à pena de morte), seja ainda pela carência de fontes para uma história das ideias jurídico-penais no Brasil na primeira metade do século XIX, optou-se por incluir tais debates entre as fontes deste capítulo.

Preliminarmente, é preciso mencionar que há uma característica do Código de 1830 e de seus debates que, como fontes, são relevantíssimas para este trabalho: esses documentos dão boa medida da circulação de ideias em matéria jurídicopenal na alta intelectualidade brasileira da primeira metade do século XIX. Tantas foram as influências sofridas pelo Código que a historiografia tem dificuldades em lhe precisar a matriz intelectual. Majoritariamente, tende-se a apontar as suas raízes francesas, que remontariam à legislação napoleônica de 1810 (Zaffaroni e Batista, 2003: 430). De La Rua (1982: 26, n. 65) indica ainda o código napolitano, fazendo a ressalva de que ele era quase uma cópia do francês. Nos debates parlamentares, o Código da Luisiana, do utilitarista Edward Livingston, está entre os mais citados. O trabalho de Livingston, por sua vez, foi fortemente inspirado no Código Penal Austríaco de 1787 (Josefina), que segundo Bravo Lira (2004), serviu de inspiração tanto ao Código da Bavária de 1813 (redigido por Feuerbach), quanto ao projeto de Vasconcellos. Finalmente, o código brasileiro, segundo todos os seus intérpretes, serviu de modelo para o código espanhol de 1848, que por sua vez o impôs a suas colônias, até as Filipinas. Consta também que C. J. A. Mittermaier teria estudado português a fim de poder ler o nosso código imperial, informação a que Basileu Garcia (1956: 43) não dá mais do que o rótulo de boato. ${ }^{308}$ Por aí dá para se ter uma ideia de quanto o movimento de codificação penal serviu para a difusão de um ideário jurídico-penal nascido no

\footnotetext{
${ }^{308}$ Garcia faz bem ao desconfiar da informação, pois além de faltar-lhe respaldo em fontes, havia desde 1834 uma tradução francesa de nosso código feita por Faucher, tornando absolutamente desnecessário o aprendizado do português para se lhe ter acesso.
} 
Iluminismo europeu, e de como a codificação foi um passo importante para a naturalização e universalização de um certo tipo de direito penal.

Passando ao conteúdo dos documentos, os debates revelam que muitos componentes do direito penal contemporâneo já estavam presentes no ideário dos juristas de então. Assim era, por exemplo, em relação à separação entre direito civil e direito criminal e, consequentemente, à especificidade do ilícito e da pena criminais. Diga-se apenas como ilustração que no art. $7 .^{\circ}$ do projeto de Clemente Pereira já se dizia, em seu artigo 12, que

de todo crime, em que houver injuria particular, além da offensa publica, nascem duas acções, uma criminal, para a imposição da pena, e outra civil de despezas, perdas e damnos, a favor das partes offendidas" (Annaes, 03/06/1826: 16). A pena criminal, ao contrário da civil, seria "afflictiva e infamatória, ou afflictiva sómente (cit: 17).

Ainda assim, em alguns momentos é possível detectar traços de um vocabulário de transição: Rebouças vez por outra fazia referência ao código penal como parte das "leis civis", por exemplo (Annaes, 15/09/1830: 515), utilizando a expressão para designar todas as leis positivas.

Entretanto, há três pontos em que as coisas são mais nebulosas, e merecem por isso tratamento mais detido: (i) a posição do Código de 1830 (como, de resto, das codificações em geral), como produto do movimento codificador e sua posição no processo de afirmação do direito penal contemporâneo no Brasil; (ii) a divisão metodológica do "direito criminal" - incluído ou excluído o processo penal, pouco importa - em parte geral e parte especial; e (iii) a autonomia, ou não, do direito penal em relação ao processo penal no ideário dos homens públicos daquele tempo. 


\section{CoDificaÇÃo BRASILEIRA E O DiREITO PENAL CONTEMPORÂNEO}

Quanto à relação do Código com o processo de formação do direito penal contemporâneo no Brasil, os debates deixam um ponto bastante claro: a criação do Código Criminal de 1830 deveu-se muito mais a necessidades pragmáticas (políticas) de um Estado em formação do que ao reconhecimento da autonomia substantiva do direito penal. A hipótese de Cartuyvels (Cap. 2), confirma-se também para o caso nacional. Ainda que a retórica liberal-iluminista tenha jogado um papel importante nas discussões parlamentares, sobretudo em torno da pena de morte, o elemento unificador de todas as divergências entre os deputados foi a necessidade pragmática de uma reformulação do aparelho punitivo estatal, com vistas principalmente à manutenção da paz pública por meio da distribuição dos castigos criminais. A maioria dos deputados fez vistas grossas a princípios e doutrinas então vanguardistas em favor do pragmatismo da segurança pública quando confrontados, por exemplo, com a escolha entre a pena capital e a perspectiva de as forças de segurança perderem o controle sobre a população pobre e, principalmente, sobre a escrava - "dous milhões de escravos, todos ou quasi todos capazes de pegarem em armas!", como alardeou Paula e Sousa (Annaes, 15/09/1830: 514). ${ }^{309}$

O senso prático em torno da necessidade de uma reforma da justiça criminal das Ordenações foi o elemento verdadeiramente capaz de fazer os deputados superarem suas intermináveis controvérsias em torno das penas de morte e de galés e aprovarem o novo diploma em 22 de outubro de 1830. Tal pragmatismo girava em torno de dois pontos: (i) a necessidade imperiosa de substituição da legislação criminal até então vigente, o Livro V das Ordenações Filipinas acrescido de algumas outras leis imperiais, chamada de "legislação bárbara" e outros tantos insultos a cada referência que lhe era feita; e (ii) a estratégia de pacificação social principalmente por meio da legislação repressiva (a despeito de alguns poucos pugnarem concomitantemente por medidas de natureza diversa). ${ }^{310}$ É curioso notar que a pena de morte, que tantos debates

\footnotetext{
${ }^{309}$ Para um curto e clássico argumento sobre a incompatibilidade das ideias liberais com a sociedade escravista brasileira do século XIX, v. Schwartz (2000)

310 Ao combater a proposta de Vasconcellos pela pena de morte, Martim Francisco dizia que "o verdadeiro modo de repelir o crime é a civilização, é a moral, é a instrucção primária" (Annaes,
} 
provocou entre os deputados, era oposta por muitos também por medo de que ela gerasse impunidade e descontrole - as mesmas coisas que os partidários da pena capital queriam, através dela, evitar. Ou seja, tanto os defensores, quanto muitos dos opositores da pena de morte tinham um mesmo valor em vistas: a preservação da paz, sobretudo pela contenção da massa escrava e principalmente pela aplicação severa de penas criminais. Alguns opunham-se à pena capital por questões de princípios, é verdade, se bem que não necessariamente liberais ou iluministas: Linho Coutinho, por exemplo, referiu-se à pena de morte como "obra do demonio", por ser ela "manifestamente contra a divindade e contra a natureza" (Annaes, 15/09/1830: 511). O princípio de que só Deus pode tirar a vida foi muitas vezes invocado. Como bem lembra João Luiz Ribeiro, o argumento religioso contra a pena de morte não era desprezível: "A pena de morte era contrária à religião dos Evangelhos, consagrada como religião de Estado, logo, a pena de morte era contrária à Constituição" (Ribeiro, 2005: 23). Mas, no geral, as posições pró e contra a pena de morte divergiam mais em seus fundamentos axiológicos, e menos em suas estratégias práticas: todos buscavam a melhor forma de conter o potencial de violência que, aos olhos de muitos parlamentares, repousava na massa de gente pobre e escrava. Divergiam uns e outros apenas quanto aos meios aptos para tanto, mas sem deixar de concordar que a violência estatal era o meio preferencial (quase sempre exclusivo, a bem da verdade) para consegui-lo.

Contra a pena de morte, alguns argumentavam, como Ernesto Ferreira França, que a docilidade do brasileiro interferiria na aplicação da justiça:

Sr. Presidente, a pena de morte traz comsigo a impunidade, porque ninguem quer concorrer para a morte de seu semelhante. Quando o crime é de morte as testemunhas não querem depor a verdade e o juiz treme de dar a fatal sentença. (Annaes, 14/09/1830: 506.)

Outros diziam que, no caso específico dos escravos, suas superstições os tornariam destemidos em relação à pena capital, como no caso de Ribeiro Andrade:

14/09/1830: 508). Sua preocupação, entretanto, passava longe do bem-estar dos escravos: ao defender a prisão como pena, dizia que o homem habituado ao trabalho, como o escravo, "morre quando dele é privado", o que garantiria o caráter intimidatório da pena de prisão. 
Grande parte das hordas africanas admittem a metempsycose, e crêem que morrendo voltão a disfructar as delicias de sua cara patria: e lançando um golpe de vista pelo Brazil, elles são talvez os unicos que se suicidão porque a morte é a noite do dia inquieto e penoso que se chama vida, é o delito de repouso para o desditoso escravo. Que terror póde nelles infundir semelhante pena? (Annaes, 15/09/2008: 515).

Mas a favor da pena capital, jogava-se a mesma cartada da impunidade e perda de controle sobre os escravos:

A pena de morte deve com effeito ser abolida nos casos politicos, porém não nos casos de homicidio, e para conter a escravatura, pois que esta é a unica pena que a póde conter. (...) É pois para bem do meu paiz que eu voto á favor da pena de morte em alguns casos; e eu ouso dizer com todo o orgulho, que não cedo em humanidade a pessoa alguma: ao contrário desejo que se saiba que eu, deputado do Brazil em 1830, votei contra a pena de morte nos casos políticos, e a favor della quando a severidade das leis deve exigir vingança do sangue derramado, ou para assegurar a nossa existencia contra os escravos (Rego Barros, Annaes, 15/05/1830. Destaques meus).

Quando as discussões sobre a supressão ou não das penas de morte e galés pareciam não ter fim, eram também de natureza pragmática os apelos para que os deputados aprovassem logo o Código e deixassem a reforma de seus pontos polêmicos para as próximas legislaturas. Carneiro da Cunha, na sessão de 11 de setembro de 1830, manifestou-se nesse sentido: "Por ora, o que julgo mais acertado, é que adoptemos o codigo, sem mais delongas. Adoptemo-lo, senhores! Elle é da ultima necessidade, a nação toda o reclama!" (Annaes, 11/09/1830: 490). Na mesma oportunidade, Paula e Souza foi ainda mais enfático ao solicitar urgência na aprovação do projeto de Vasconcellos: "Restão-nos apenas 30 ou 40 dias de sessão; nós temos tanto objectos essenciaes á tratar, e da maneira com que vai a discussão não só não trataremos desses objectos como mesmo não concluiremos o codigo" (cit.: idem.).

Os defensores da celeridade lembravam aos opositores da pena de morte que a não aprovação do Código significava continuar com as Ordenações 
vigentes, que mandavam aplicar a pena capital em muitos casos mais do que os poucos previstos no diploma em discussão:

Sr. Presidente, qual deve preferir-se, o codigo antigo, o livr. $5^{\circ}$, que á mais leve culpa dava a pena de morte, ou este codigo tão humano que a reduz a quatro casos, e isto em grao máximo? (Paula e Souza, Annaes, 15/09/1830: 514).

Toda a questão que ora se debate, consiste em saber-se se o codigo que discutimos é ou não melhor que o livro $5^{\circ}$ das ordenações. Ninguém dirá que o não seja. Quem poderá preferir uma legislação bárbara, desconexa e gothica, a um codigo humano! Adoptemos, senhores, o codigo proposto e rejeitemos as emendas. O Brazil todo o reclama. (Xavier de Carvalho, Annaes, 11/09/1830: 491).

Quando a discussão de princípios subjacente ao tema da pena de morte ameaçou obstruir intransponivelmente o avanço dos debates, chegou-se a sugerir a criação de uma lei penal específica para os escravos, onde certamente a pena de morte estaria contemplada, o que facilitaria a sua eliminação do "código humano" então debatido. Na sessão de 14 de setembro de 1830, Bernardo Pereira de Vasconcellos, vislumbrando o entrave que a questão provocava, sugeriu, como político habilidoso que era, que os deputados debatessem "se este codigo comprehende os escravos" (Annaes, cit.: 507) - a despeito de defender com unhas e dentes o caráter geral do diploma, que imprimira à nossa legislação a sistematicidade que faltava ao livro $5^{\circ}$ das Ordenações. É provavelmente essa ressalva que Ribeiro tem em mente ao dizer que "quando da discussão do Código Criminal de 1830, aventou-se a possibilidade de um código especial para os escravos" (Ribeiro, 2005: 57). No final das contas, a solução de compromisso que prevaleceu foi a restrição da aplicabilidade da pena capital a três casos muito específicos, que deixavam clara a sua destinação e propósito: insurreição (art. 113), homicídio premeditado (art. 192) e morte para o fim de roubar (art. 271). Sua aplicação, entretanto, seria ampliada e facilitada em relação aos escravos pela Lei $n^{\circ}$. 4, 
de 10 de junho de $1835 .{ }^{311,312}$ Lembrando a pressa com que o código fora aprovado, Thomaz Alves Jr., pouco mais de três décadas após a sua aprovação, apontava que "o systema seguido pelo Codigo não é sem dúvida isento de defeitos", mas que não podia haver sido de outra forma por não haver sobrado tempo a deputados e senadores para aperfeiçoá-lo (Alves Jr., 1864: 37).

Além do aspecto do controle social, havia ainda o propósito de centralização política do poder de criar ilícitos pelo Estado. Cartuyvels lembra que um dos processos-chave do movimento das codificações estava na obtenção do monopólio penal por parte dos reis, o que parece também ter sido um ponto de debate no caso brasileiro: Machado Neto registra que a bancada dos clérigos opôs-se à ideia de que os membros da Igreja fossem julgados pelo Estado de acordo com o futuro código penal, e não mais pelo Poder Eclesiástico; no que foi objetado por Vergueiro, que se valeu da retórica da igualdade perante a lei, à moda liberal: "o ilustre deputado quer uma lei para sua classe e outra para o resto dos homens... Os tempos das isenções, esses tenebrosos tempos, já passaram" (apud Machado Neto, 1977: 61).

Depreende-se de tudo isso que o espírito de aprovação do Código Criminal de 1830 foi muito mais presidido pela necessidade prática de construção do aparato político do Estado do que pelo reconhecimento do direito penal como uma área autônoma do direito que necessitaria, por isso, de leis próprias conformes a seus princípios particulares. Nesse sentido, vale dizer que na Fala do Trono de 1827, D. Pedro I havia especificamente pedido para que o parlamento elaborasse um Código

\footnotetext{
${ }^{311}$ Lei $\mathrm{n}^{\circ}$. 4, de 10 de junho de 1835 , art. $1^{\circ}$.: "Serão punidos com a pena de morte os escravos ou escravas, que matarem por qualquer maneira que seja, propinarem veneno, ferirem gravemente ou fizerem outra qualquer grave offensa physica a seu senhor, a sua mulher, a descendentes ou ascendentes, que em sua companhia morarem, a administrador, feitor, e ás suas mulheres, que com eles viverem. Se o ferimento ou offensa physica forem leves, a pena será de açoutes á proporção das circunstâncias mais ou menos agravantes".

${ }^{312}$ A estranheza da Lei de 10 de junho de 1835 aos princípios do Código de 1830 compunha, diga-se de passagem, as estratégias de defesa de alguns advogados que defendiam os escravos com base nela acusados: eles argumentavam que, como a lei fora concebida a partir de uma situação histórica específica de ameaça de levante de escravos, ela não poderia ser a disciplina jurídico-criminal constante dos crimes cometidos por escravos. Não era incomum que os juristas do século XIX se referissem a esse diploma como uma lei excepcional. Sobre o tema, v. Ribeiro, 2005.
} 
Criminal. ${ }^{313}$ Os macro-temas do direito penal contemporâneo, entretanto, estavam claramente postos. Por meio desse aparato de justiça buscava-se a construção de um sistema punitivo eficiente e politicamente centralizado. Já se registrava, ao mesmo tempo, o repúdio aos excessos da legislação penal filipina: os pedidos de urgência na aprovação do Código de 1830 lembravam a todo momento o rigor excessivo e barbaridade das penas das Ordenações. Todas essas coisas estão, lembremo-nos, entre as componentes principais da temática da parte geral do direito penal contemporâneo: eficiência da punição, centralização política do poder criminal e controle de arbitrariedades. Ainda assim, seria prematuro dizer que a aprovação do Código de 1830 indica, por si só, a presença definitiva desde então dessa representação autônoma do direito penal no Brasil. Os dois outros pontos seguintes deixarão esta minha reticência mais clara. A começar pela representação metodológica do direito criminal, ou penal, como um saber dividido em parte geral e parte especial.

\section{Parte geral e parte especial}

A esta altura, parece importante fazer um esclarecimento, retomando algo que já foi dito dois capítulos atrás. É possível que se considere que a disciplina do direito penal se divida em parte geral e parte especial em consequência de os códigos penais dividirem-se dessa mesma forma: uma vez que as disciplinas definem seu conteúdo mais ou menos a partir da legislação, a divisão transpor-se-ia naturalmente dos códigos penais para os cursos e manuais de direito penal.

Entretanto, como já foi comentado, é um erro pensar assim, ao menos do ponto de vista histórico. É bastante plausível que hoje as coisas se deem dessa forma, mas quando, no século XVII, os livros jurídicos começaram a separar o conteúdo de suas disciplinas com uma mesma lógica de "partes gerais" e "parte especiais" (os princípios e suas deduções), a legislação penal estava longe de ser uniformemente

\footnotetext{
313 "Não há código; não há forma apropriada às luzes do tempo nos processos; as leis são contraditórias umas às outras, os juízes vêem-se embaraçados nos julgamentos, as partes padecem, os maus não são punidos, os ordenados dos juízes não são suficientes para que não sejam tentados pelo vil e sórdido interesse, e, portanto, é necessário que esta assembléia comece a regular com sumo cuidado e prontidão um ramo tão importante para a felicidade e sossego públicos" (apud Machado Neto, 1977: 51).
} 
constituída de códigos com essa mesma característica. O Lehrbuch de Feuerbach é exemplar nesse sentido: a despeito de já ostentar a "cara de código" com que estamos acostumados, o tratado de Feuerbach foi escrito com base nas ordenações penais de Carlos V (1532), que estavam mais para as "legislações góticas e desconexas" préiluministas do que para um código moderno próprio dos "povos cultos". Isso quer dizer que a divisão dos códigos é, juntamente com a do direito penal como objeto teórico (e não antes dela), produto de uma certa concepção de racionalidade como instrumento intelectual de organização de conhecimento e obtenção de verdades confiáveis, da qual também já se falou: o bom método para a construção de um saber seria a dedução de seus pontos mais específicos a partir de princípios gerais válidos para todo o seu campo de relevância, seja nos códigos, seja na ciência jurídica. A relação entre a organização metodológica do direito penal contemporâneo e os códigos modernos com suas partes gerais e especiais não é, portanto, do tipo "o ovo ou a galinha", pois ambas são produtos de uma determinada concepção de racionalidade predominante na modernidade, que seria posteriormente colocada em dúvida no campo da dogmática e da legislação a partir de meados do século XIX. De mais a mais, o reconhecimento de uma parte geral em qualquer ramo do direito não indica, de per si, o conteúdo que ela deva ter. No código penal austríaco de 1787, por exemplo, havia duas partes gerais - ou seja, dois conjuntos de princípios - distintos para dois grupos diferentes de infrações criminais; enquanto no código toscano, a parte geral continha apenas disposições sobre as penas, e nada sobre os delitos.

Seja como for, os debates da Câmara dos Deputados permitem duvidar que essa forma de organizar o direito penal estivesse absolutamente presente no ideário de todos os deputados, a despeito de o código ter sido promulgado com uma organização tipicamente contemporânea. Bernardo Pereira de Vasconcellos, redator do projeto, tinha clareza da importância dessa organização e insistia a todo momento no caráter geral do primeiro livro de seu projeto; outros deputados, ao contrário, perdiamse às vezes na discussões específicas e casuísticas que irritavam o ex-aluno de Mello Freire. O maior exemplo desses desencontros está nos debates havidos na sessão de 
05/05/1827, quando se discutiu o ponto da responsabilização criminal dos ministros de Estado, e vale ser tratado com vagar.

$\mathrm{Na}$ abertura da sessão, vendo que estava pautada a discussão sobre a responsabilidade dos ministros, Vasconcellos fez a seguinte indicação:

"INDICAÇÃO: Que não se discutão as leis regulamentares, que tiverem relação com o codigo criminal, sem que a camara resolva, se devem, ou não, ser admittidos á discussão os dois projectos de código criminal." (Annaes, 05/05/1827: 23.)

O deputado Lino Coutinho insurgiu-se contra a proposta, argumentando que a lei de responsabilidade dos ministros era uma lei particular:

\begin{abstract}
Já se fez a differença entre esta lei, e a de responsabilidade dos empregados subalternos, que entra no codigo penal? Esta lei da responsabilidade dos ministros de estado é uma lei sui generis, que há ainda em codigo penal; e se o codigo falla nisso, a lei já passou nesta camara, e existe no senado, portanto não podemos suspender; e o codigo penal trata dos empregados subalternos, e não dos ministros de estado, que é uma lei sui generis, como já disse; e deve ser inteiramente em separado (cit: idem).
\end{abstract}

A ideia de começar um sistema jurídico-penal com leis sui generis concorrendo com a organização geral do código causava horror ao ilustrado e (àquela altura) liberal Vasconcellos, que se apressou então a explicar toda a lógica de seu projeto para defender a sua proposta de suspensão de discussão das matérias penais. Ele esclareceu que o seu código tratava sim de matéria ventilada naquele debate, a não ser que toda a Câmara quisesse que ela se constituísse em uma regulamentação especial, ideia com a qual ele não parecia concordar (cit: 23-4). Clemente Pereira pediu em seguida a palavra e apoiou Vasconcellos:

O que diz respeito ao codigo será incoherente entrar em discussão. E por isso acho justo que de ates cousas se não tome conhecimento, tendo-se em consideração tudo quanto for penal (cit: 24). 
Em seguida, ergueram-se outros dois deputados contra a indicação de Vasconcellos, Paula Cavalcante e Souza França. Ambos alegavam que a proposta atentava contra a liberdade de trabalho dos deputados, razão pela qual deveria ser rejeitada. Nesse momento, o redator do código interveio e fez um esclarecimento que contém especificamente os pontos que interessam a esta investigação. Em primeiro lugar, rejeitou a ideia de leis penais sui generis, defendida por Lino Coutinho:

\footnotetext{
Depois de aprovado o codigo, para que mais leis, que vão gastar tempo em discussões desnecessarias? Parece-me, que estas duvidas nascem talvez de eu não me explicar bem na minha indicação, mas ella não diz que não possão os Srs. deputados apresentar projectos; antes se fosse possivel, eu desejaria, que todos apresentassem projectos de tudo aquilo que vissem, que era melhor. A minha indicação não exclue que elles proponhão aqueles projetos uteis a esse respeito. Os projectos sui generis são todos contrários à lei; os delictos todos devem ser punidos geralmente, quer a lei recompense, quer castigue. Se o ministro de estado commetteu um delicto, se obrou uma acção contra a lei; se abusou do poder, se commetteu crime de alta traição, etc., está cumplice, está escripto o delicto, e a pena correspondente no codigo criminal, que é sempre geral para todos. Para que pois uma lei sui generis em outros lugar, quando no codigo está o lugar de todos os delictos, e penas com relação ás pessoas, e á natureza dos crimes? (Bernardo Pereira de Vasconcellos, Annaes, 05/05/1827: 24. Destaques meus).
}

Ao contrário do que uma leitura desavisada pode sugerir, Vasconcellos não está principalmente preocupado com a preservação do princípio da igualdade no direito penal. Igualdade não era um ponto cardeal para quem, como ele, defendia a necessidadade da pena de morte para o controle social da massa de pobres e escravos, tendo inclusive aventado a hipótese de uma lei específica, fora de seu "código humanizado", para a punição dos cativos. Sua preocupação era, muito mais, com a defesa do caráter sistemático da sua legislação penal, o que, segundo ele, só poderia ser garantido se ela se constituísse um todo harmonioso, elaborado a partir de princípios gerais e universais. É isso que o fazia repudiar as leis penais sui generis. Tudo indica que ele estava preocupado, mais do que qualquer outra coisa, com a perfeição da sua obra - Vasconcellos refere-se a todo instante ao código em debate como "o meu 
projeto". Isso fica claro no instante seguinte dos debates, quando ele repele apartes dos deputados Almeida e Albuquerque e Paula Cavalcante:

O que quero é que esta commissão especial examine o meu projecto de codigo, dando sobre elle o seu parecer; e que no caso de ser approvado, sejão todas as leis concernentes subordinadas ao codigo e systema geral da nossa constituição; o que não se poderá conseguir, emquanto durar a discussão do codigo e se discutirem outras leis. Ficando a discussão do codigo para outra sessão não se fará nada, nem lei alguma regulamentar sahirá conforme ás luzes do seculo presente, como acontece com todas as leis feitas á maneira do codigo felippino. E queremos nós no século XIX seguir com as leis regulamentares o methodo que se seguio com esse livro de capa tão rota? [falha na taquigrafia]. Como é que se querem que se fação leis regulamentares sem systema? (...) Querem fazer leis destacadas, á imitação de um edifico carunchoso, ainda que para evitar essa falta de unidade é que eu quizera não se discutissem as leis regulamentares a taes respeitos, emquanto a camara não decidisse que o codigo deve discutir-se. Tomára saber, quando a camara approve o projecto do codigo, qual é a utilidade que se pretende tirar de resoluções destacadas sem nexo nem attenção ao todo do systema! (Bernardo Pereira de Vasconcellos, Annaes, 05/05/1827: 25. Destaques meus.)

Esse foi o último pronunciamento de Vasconcellos na sessão daquele dia. Outros três deputados tomaram a palavra em seguida, todos para condenar sua indicação, que acabou derrotada: mais de três anos depois, não só o Código ainda não estava aprovado, e um de seus debates mais candentes, em torno da abolição das penas de morte e de galés, prosseguia efervescente. Mais ainda, a lei sobre a responsabilização dos Ministros de Estado foi votada e entrou em vigor dez dias depois (Lei 22, de 15/10/1827), ficando o "seu" código marcado pelo art. 308, que expressamente a reconhecia como uma lei sui generis, tal qual ele não queria. ${ }^{314}$ Para os fins desta pesquisa, entretanto, importa registrar que, ao menos na cabeça do redator do Código Penal de 1830, a concepção metodológica do direito penal como uma organização

\footnotetext{
${ }^{314}$ Código Criminal de 1830, art. 308: "Este Codigo não comprehende: $1 .^{\circ}$ Os crimes de responsabilidade dos ministros e conselheiros de estado, os quaes serão punidos com as penas estabelecidas na lei respectiva". Nos moldes de muitos códigos europeus daquele tempo, a única excepcionalidade ao caráter geral do Código que Vasconcellos aceitava dizia respeito à punição de militares.
} 
sistematicamente dirigida do geral para o específico estava presente, e ele lutava combativamente por sua preservação.

Quanto a seus colegas de legislatura, porém, o mesmo já não se pode dizer com tanta certeza. Em alguns casos, essa mesma representação metodológica é patente, como se vê na fala de Ferreira França na sessão de 10/09/1830, onde se debateu autoria e cumplicidade (art. $4^{\circ}$ do projeto de Vasconcellos). Também ele defendia que se mantivesse, com o perdão do pleonasmo, a generalidade da parte geral do código:

Este capítulo $\left[1^{\circ}\right]$ trata dos crimes em geral e dos criminosos: não diz crimes em
particular, nem diz criminosos em particular, e parece que um dos artigos que a
comissão offerece como emenda, é particular: não responde a cousas em geral, por
exemplo, este $2^{\circ}$ artigo que aqui está sem numero, offerecido pela commissão, que
diz: "Serão sempre considerados, etc." Isto respeita a coisas em particular e não a
crimes em geral; e aqui trata-se tudo em geral: assim eu creio que esta emenda não
pode ter lugar, e igualmente este outro artigo aqui abaixo que diz: "Não serão, etc.".
Também diz respeito a crimes em particular: por consequência não podem ter lugar
estes dous artigos". (Annaes, 10/09/1830: 487 . Destaques meus.)

Mas o certo é que poucos apoiavam a ideia de Vasconcellos de exaurir os debates em torno da parte geral para só depois entrar na discussão de leis particulares. Contudo, as fontes não permitem dizer que eles o fizeram por não possuírem a mesma representação metodológica do direito penal. As razões para a tal oposição podem ter sido de várias naturezas distintas, desde o simples desacordo com o mérito da proposta, na qual muitos viam uma mutilação da liberdade legislativa da casa, até oposição política pura e simples. Mas é possível que alguns deles simplesmente não enxergassem o direito criminal ou penal como algo necessariamente dividido em parte geral e parte especial, como nós fazemos hoje, ou simplesmente não via muita vantagem ou naturalidade nisso. Lino Coutinho, que fora um dos nossos representantes nas Cortes Gerais de Lisboa, dizia, por exemplo, que em matéria criminal preferia "códigos casuísticos" em lugar das legislações principiológicas, que lhe pareciam excessivamente convidativas ao arbítrio dos magistrados (Annaes, 10/09/1830: 488). É, como se nota, uma curiosa combinação entre um objetivo liberal 
(controle do arbítrio judicial) e uma técnica de legislação própria do Antigo Regime, ilustrativa e detalhista, mostrando o quanto o rompimento com a velha ordem política anterior era menos fácil na metodologia da disciplina do que nos discursos condenadores do "velho livro de capa rota". A fala de Lino Coutinho serve para mostrar que o propósito de contenção do arbítrio passava também pelas discussões sobre a estrutura metodológica do código. Ou seja, escolher entre um código de princípios e um código casuístico envolvia, entre muitas outras discussões, pensar qual a melhor forma de reduzir possíveis arbítrios em matéria criminal, mas sempre com vistas ao propósito político de pacificação social por meio da imposição dos castigos.

\section{Direito Penal e Processo Penal}

O terceiro e último ponto sobre o qual os debates pesquisados permitem extrair conclusões úteis à pesquisa diz respeito à separação conceitual entre direito penal e processo penal. Neste ponto, o direito penal contemporâneo parece estar mais distante do que nos outros dois.

Comecemos pelo primeiro dos projetos de código que a Câmara dos Deputados conheceu, de autoria de Clemente Pereira, em 1826. No seus primeiros artigos, lê-se o seguinte:

Art. $1 .^{\circ} \mathrm{O}$ codigo criminal do Imperio do Brazil será dividido em dous livros: o primeiro tratará dos crimes e das penas, o segundo conterá a ordem do processo criminal.

Art. 2. ${ }^{\circ}$ Ficão desde já reconhecidos como bases os seguintes principios, que formarão os primeiros dous titulos do livro primeiro do sobredito codigo (Annaes, 03/06/1826: 16).

O projeto dá indicações ambíguas quanto à separação entre direito penal e processo penal. No primeiro artigo, sugere uma representação conjunta dos dois saberes; mas no segundo, faz menção a princípios exclusivos do livro primeiro - do 
direito penal, portanto. A hipótese mais provável é que o tratamento conjunto das duas coisas dê-se tanto em razão de Clemente Pereira haver tomado por modelo outros códigos europeus em que isso se dava, quanto pela necessidade prática de se organizar com urgência o sistema judicial brasileiro, que àquela altura ainda era em grande parte regido pela legislação portuguesa. Com isso em mente, é possível não só afirmar que a separação entre direito penal e processo penal já começava a se desenhar do ponto de vista substantivo, e não apenas prático, por contar o direito penal com princípios apenas seus; como também reafirmar a tese de que a iniciativa política de estabelecimento de uma legislação criminal (penal e processual) deveu-se primordialmente às necessidades práticas de formação institucional de um país recém independente. Esta parte geral do projeto de Clemente Pereira já dividia-se em "Dos Crimes em Geral e seus Autores" (Tit. I) e "Das Penas" (Tit. II), em acordo com o direito penal contemporâneo portanto.

Igual ambiguidade estava no projeto de Vasconcellos. Na mesma discussão sobre a "generalidade da parte geral" que acaba de ser relatado, ele apresentou seu código da seguinte maneira:

Sr. Presidente, o meu projecto de codigo contem tres partes, e para dar esta conta ao Sr. Lino Coutinho, mencional-as-hei. A primeira parte trata dos crimes, que se podem commetter na sociedade, e da applicação das penas que lhes são correspondentes; a segunda trata de materias judiciaes, e a terceira da ordem do processo. (Bernardo Pereira de Vasconcellos, Annaes, 05/05/1827: 23.)

Lino Coutinho, mais uma vez crítico do Código, apontava precisamente que alguns pontos da legislação processual ficavam pouco à vontade em um código penal:

Como é pois que esse codigo traz a formatura do processo de um juiz, e as circumstancias que deve notar para se applicar as penas, quando confessa o illustre autor, que elle deve ter muitas contradições? Um codigo penal desses somente; se há de julgar por tal título? É preciso uma lei secundária, e relativa ás circumstancias, e outras considerações, que devem ter os juízes; e isto deve ser por uma lei regulamentar; pois um codigo penal não pode trazer leis semelhantes. (Annaes, 05/05/1827: 24.) 
As matérias penal e processual acabaram regulamentadas em separado, como sabemos: o Código de Processo Criminal veio em 1832, em meio ao domínio liberal de que Vasconcellos foi um importante personagem. Mas a historiografia aponta que o Código de Processo de 1832 foi mais uma ferramenta política para o desenho de uma forma descentralizada de Estado, do que indicativo de qualquer reconhecimento de autonomia entre direito e processo penal (Ferreira: 1999). Os autores de época reforçam a visão de que a separação entre direito e processo penal não era uma coisa tão natural assim. Thomaz Alves Jr., autor dos primeiros comentários ao código imperial, publicados mais de trinta anos após sua promulgação, anota que Foucher, ${ }^{315}$ tradutor do código brasileiro para o francês, criticava o fato de ele ser chamado de Código Criminal e não conter matéria processual. "O Código Criminal no Brasil não corresponde inteiramente a seu título", dizia, "pois não trata nem da jurisdição, nem do processo"; "trata apenas da penalidade" (apud Alves Jr., 1864: 38). ${ }^{316}$ A posição do autor francês indica que, ao menos em seu país, o adjetivo "criminal" era utilizado preferencialmente para trabalhos compreensivos, que cuidassem tanto de direito penal e processo penal. Ou seja, o direito penal era parte de uma disciplina maior, o direito criminal, que abrangia regras materiais e processuais. Isso é reforçado pela obra de Ortolan, comentada pouco mais adiante: aquilo que hoje chamamos de direito penal era por ele tratado como a penalidade (penalité); o direito criminal como um todo continha, além dela, também o processo criminal (Ortolan, 1839). Era também essa a posição de Pimenta Bueno nos seus Apontamentos ao Código de Processo Criminal (1857a: 2), bem como do professor paulista Joaquim Augusto de Camargo, já à vésperas da República (Camargo, 1881-2: 22 e ss.).

Portanto, também em relação a esse elemento do direito penal contemporâneo, as fontes parlamentares são inconclusivas, apesar de já indicarem uma primeira cisão entre direito penal e processo penal, ainda que (i) tal cisão não seja completa como é hoje; e (ii) haja indicações de que a doutrina ainda tratasse o direito

\footnotetext{
315 Thomaz Alves Jr. grava, equivocadamente, "Fauché".

316 "Le Code Criminel de l'Empire du Brésil ne repond pas entièrement à son tître; il est, à proprement parler, qu'un Code pénal, car il ne trate ni de la jurisdiction, ni de la procédure en matière criminelle: comme penalité c'est une oeuvre assez complète".
} 
penal ao lado do processo penal como parte de uma disciplina única. Tudo isso ficará melhor esclarecido a partir da exposição do conteúdo das obras teóricas da época.

\section{Obras Gerais}

A primeira incursão da pesquisa em obras jurídicas de natureza teórica deu-se através dos trabalhos de direito natural. O propósito foi averiguar se nelas já seria possível detectar traços do direito penal contemporâneo, já que quase todas contêm ao menos um grande quadro esquemático com as principais divisões do direito, o que é útil para alguns dos elementos do tipo de direito penal de que se buscam vestígios. Outros pontos mais específicos, como a separação substantiva entre direito penal e processual penal, foram mais difíceis de se encontrar. Mas o conteúdo das obras revelou-se na maior parte das vezes proveitoso, especialmente por indicar o trânsito de alguns pilares da filosofia crítica alemã que se mostraram tão importantes no método específico de Feuerbach para a construção de seu direito penal.

Esse item vem dividido em cinco partes, cada uma delas dedicada a um autor que teve relevo para o estudo teórico do direito no Brasil do século XIX (ainda que alguns tenham sido mais importantes do que outros): José Maria Avellar Brotero, primeiro professor de Direito Natural da Academia de São Paulo; Vicente Ferrer Neto Paiva e José Dias Ferreira, ambos professores de Coimbra no século XIX; e Heinrich Ahrens, professor alemão que deixou uma importante obra em francês, muito lida pelos alunos e juristas brasileiros do século retrasado.

\section{José Maria Avellar Brotero}

O primeiro compêndio feito no Brasil para uso em nossas academias de direito foi Princípios de Direito Natural (1829), escrito por José Maria Avellar Brotero. Trata-se de um livro que, apesar de liberado para a utilização em Olinda e São Paulo, foi muito criticado quando de sua apreciação pela Câmara dos Deputados - a Lei 
de 11 de Agosto de 1827, lembremo-nos, mandava os lentes dos cursos organizarem compêndios que deveriam ser aprovados não só pela Congregação das academias, mas também pela Assembleia Geral. ${ }^{317}$ Relata Venâncio Filho que o Deputado Lino Coutinho teria reagido ao trabalho da seguinte forma:

Foi oferecido aqui à Câmara um compêndio de Direito Natural, feito por um lente dessa escola de Direito, compêndio este que é a vergonha das vergonhas pelas suas imbecilidades, o mesmo compêndio prejudicial pelas más doutrinas que nele se encerram e que não sei como o Sr., ex-Ministro do Império, sem examinar esse compêndio, sem coisa nenhuma, mandasse ou decretasse que se ensinasse à mocidade brasileira por tão infame compêndio. (apud Venâncio Filho, 2003: 48).

Brotero é tido como uma figura curiosa da história da Faculdade de Direito de São Paulo. Formado em Coimbra, foi o primeiro lente nomeado para o curso jurídico paulistano e logo entrou em conflito com o diretor da escola, Toledo Rendon (Venâncio Filho, 2003: 40). Diz-se que Brotero era famoso por seus ataques verborrágicos, conhecidos como "broteradas" (Vampré, 1977: 10).

Feita a ressalva inicial de que a obra de Brotero não é dedicada especificamente ao direito penal, e que o comenta com muita superficialidade, é possível dizer que o seu compêndio está de acordo com a suspeita de que o direito penal contemporâneo não aparecia nos primeiros anos do ensino jurídico no Brasil, e mostra como era difícil a sua compatibilização com o direito aprendido por um aluno de Coimbra do início do século XIX (como era o caso de Brotero). Não há, naquela obra, qualquer indicação de seus elementos característicos. Muito pelo contrário: o direito penal aparece muito menos descolado das demais áreas do direito do que, por exemplo, nas Instituições de Mello Freire, utilizadas como o material bibliográfico da cadeira de direito civil pátrio por Veiga Cabral - com quem Brotero teve sérias rusgas, aliás (Venâncio Filho, 2003: 42).

Princípios de Direito Natural é dividido em cinco capítulos. O primeiro, "Lei e suas divisões" ( $\left.\S 1^{\circ} .-51\right)$, cuida das características e requisitos gerais

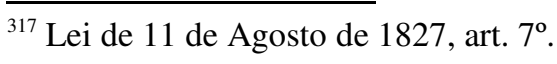


das leis e de sua imputação, das ações e das condições de sua exigibilidade. A primeira definição apresentada é a de "natureza", que significa "cada uma das diferentes espécies de entes creados, ou não creados, espirituaes, ou corporaes", designando o conjunto das características de Deus, que não pode ser conhecido por sua aparência, mas apenas pela perfeição de sua obra: "nós sabemos que ele é o sábio e excelente constructor de todos os entes, e cousas existentes, e pelas causas finaes nós temos certeza de que elle é um ente verdadeiro, infallivel, poderoso, sapientissimo, providente, e omnisciente" (Brotero, 1829: 6-7). Natureza é tomada, portanto, como sinônimo de Deus: "Os Jurisconsultos neste sentido tem tomado o vocabulo natureza, e o Compendio se serve deste termo para designar o mesmo Deos" (cit.: 7).

Desde já é possível notar o quanto será difícil, por esse princípio, acomodar a ideia do delito criminal como ferramenta política, a separação entre ilícitos criminais e morais, e a noção constitutiva de legalidade. A ideia é reforçada pela definição de Brotero de "lei" ( $\$ 6^{\circ}$. ), que abrange tanto leis físicas (regularidades) quanto prescrições normativas, acompanhada por sua postulação de que Deus "Natureza Naturante" - tem o poder de legislar" (\$11). Ao homem não é dado fazer leis, seja para terceiros ou para si mesmo (cit.: 27-8). A maneira de um ente terreno tornar-se moralmente superior ao homem é a união das vontades de vários em uma "força superior". Daí concluir Brotero que "Legislador, só Deos, ou a reunião das forças e vontades dos homens, isto é, a soberania das Nações" (cit.: 28).

A falta de liberdade política na doutrina jurídica de Brotero, que resulta em dificuldade de acomodar a noção constitutiva da legalidade penal que caracteriza o direito penal contemporâneo, aparece com maior clareza quando o autor trata do Estado e suas divisões (§ 44). Diz ele que o Estado,

no sentido stricto, se define -: qualidade moral segundo o qual o homem goza de certos direitos, e é obrigado a certos Officios: divide-se em Natural absoluto, e Hypothetico social. Estado natural absoluto é aquelle, no qual o homem góza de certos direitos, e tem certas obrigações (segundo as suas diferentes modificações) porém plenamente naturaes, não reconhecendo por Legislador, e Superior, senão a Natureza Naturante, por Juiz a mesma Natureza naturante, e a Consciencia, e por Lei 
o dictame da razão: estado natural hypothetico, é quando o homem, por uma modificação, a que deu causa, tem certas obrigações e certos direitos, os quais não obstante serem os mesmo do primeiro estado, com tudo são limitados, ampliados \&c. pela Força Pública (Soberania) a quem o mesmo homem reconheceo como Legislador, Superior e Juiz, e cuja vontade reconhecem como Lei (cit.: 45. Destaques meus).

É fácil ver o quanto a possibilidade criativa de um direito penal concebido a partir dessa matriz, que enxergava o direito do Estado como uma extensão dos deveres morais, é menor do que aquela da doutrina de Feuerbach, que positivamente deduzia da mesma moralidade o direito a ações externas imorais e o dever do Estado de legislar o mínimo possível sobre tais matérias, estabelecendo campos separados para uma e outra coisa.

Mas nem é preciso chegar tão longe. Brotero sequer oferecia uma representação do direito penal como um objeto teórico específico. Isso é indicado pela classificação oferecida por ocasião da definição de "Direito":

O vocábulo direito se usa tomar pela mesma Lei, ou por um complexo de Leis, e neste sentido é que nós o devemos agora tomar, por exemplo; Direito Natural, complexo de leis da natureza; Direito civil pátrio, complexo das Leis da nossa Nação; Direito Eclesiástico, complexo das leis que regulão a Igreja (cit.: 13. Destaques meus).

Brotero toma "Direito Civil" como o conjunto de todas as leis de um país - nosso "direito positivo", em outras palavras. Pode até ser que ele já representasse separadamente o "civil" e o "criminal", pois isso já começava a tornar-se comum na legislação de então; mas o fato é que ele não faz, em todo o compêndio, distinção substantiva entre o civil e o penal, e de resto ainda usa o "civil" para fazer referência a toda a ordem jurídica. Já aí está um indício de que a distinção entre direito penal e direito civil não era importante em sua teoria. Mais adiante, quando fala das divisões da Lei (§ 31), seu Princípios não deixa dúvidas a esse respeito: as leis são divinas ou 
humanas, sendo que "as Leis humanas, ou civis, são ditadas pela Soberania das Nações, as quais ordenão, o que é justo, e prohibem o que é injusto" (cit.: 52. Destaques meus).

As consequências dessa representação unitária do direito revelam-se, por exemplo, em seus ensinamentos sobre imputação. Não há, como temos hoje, regras específicas para uma imputação criminal, distintas da imputação civil, como já aparecia no livro de Ahrens (comentado adiante), escrito mais ou menos na mesa época do compêndio de Brotero:

Não há violação sem imputação: imputação no sentido geral designa a applicação da Lei ao facto: no sentido moral se define - Juízo pelo qual não só se declara alguem author e causa efficiente de qualquer cousa, mas até se explora a razão, e a moralidade da acção, e se applica a mesma acção ao consectario da Lei. - Toda Lei tem uma parte determinativa, ou prohibitiva; para haver conhecimento se esta parte da Lei está ou não cumprida, é necessário haver a indagação: imputação é uma analyse ou exame da acção, que cumprio, ou deixou de cumprir a mesma parte determinativa, ou prohibitiva; logo a imputação é necessaria para se conhecer se houve ou não violação, isto é, não há violação sem imputação. (Não pode haver sentença sem processo) (cit.: 31. Destaques meus).

Por essa passagem, notam-se duas coisas importantes. Primeiramente, ela contém a semente de dois temas que os desdobramentos da história do pensamento jurídico acomodaram preferencialmente no direito penal, a saber, o juízo de imputação e o juízo de subsunção, que hoje estudamos na doutrina da tipicidade penal, mas que Brotero ainda representava como um tema geral e comum a toda a massa uniforme das normas jurídicas. Com efeito, ainda que o tema da responsabilidade seja comum a quase todas as áreas do direito, e que a doutrina da tipicidade jogue também um papel importante em áreas como o direito tributário ou direito contratual, é sem dúvida no âmbito da dogmática penal contemporânea que se concentram os estudos da imputação moral do delito (culpabilidade, imputabilidade) e de adequação típica de uma conduta. Mas Brotero não está aqui fazendo referência ao direito penal, especificamente; mas sim ao conjunto de todas as leis, as morais inclusive. Está portanto, não só longe de 
representar qualquer coisa semelhante ao direito penal contemporâneo, mas também de divulgar uma doutrina que lhe seja compatível.

Seja como for, o fato histórico é que Brotero não reinava sozinho nos estudos de Direito Natural de então. Longe disso, e talvez pelas muitas críticas que sempre sofreu, os estudos dessa disciplina eram muitas vezes realizados com apoio em obras estrangeiras. Convém, por isso, passar pelos trabalhos de três outros importantes autores da área que foram lidos no Brasil do século XIX: os portugueses Vicente Ferrer e Dias Ferreira, além do alemão Heinrich Ahrens.

\section{Vicente Ferrer Neto Paiva}

Vicente Ferrer Neto Paiva, autor de Elementos de Direito Natural, foi professor de Coimbra em meados do século XIX, responsável pela cadeira de Direito Natural e Das Gentes. Para ela, fez publicar a obra em comento, que conheceu sucessivas edições a partir de $1843 .{ }^{318}$ Os Elementos constituíam a primeira parte da Philosophia de Direito de Ferrer, seguidos por um segundo tomo chamado Elementos de Direito das Gentes. Segundo Fátima Moura Ferreira (2004: 2), o compêndio de Ferrer, cuja última edição veio a lume em 1883 , foi o livro oficial da disciplina na Universidade de Coimbra até então, o que dá bem a dimensão de sua importância não só em Portugal, mas também no Brasil, onde a produção de conhecimentos nessa matéria era muito escassa e de qualidade questionável.

Como em muitos outros compêndios de direito natural, o livro de Ferrer não contém a especificidade jurídico-penal necessária para se determinar com clareza a presença, ou não, dos elementos constitutivos do direito penal contemporâneo, uma vez que seu propósito não é especificar os traços de um ramo particular do direito mas, bem ao contrário, apontar as características gerais comuns a todas as suas áreas. Há curtas passagens em que são feitas afirmações específicas sobre o direito criminal

\footnotetext{
${ }^{318}$ Consultei, para esta pesquisa, três edições da obra: a primeira, de 1843 ; a terceira, de 1857 ; e uma outra de 1850, possivelmente a segunda edição (o prefácio indica mudanças em relação às edições anteriores), contudo sem indicação específica nesse sentido.
} 
que servem ao propósito dessa investigação, mas elas não vêm com a extensão e profundidade necessárias para a pesquisa. Além de certos pressupostos teóricos, só alguns dos elementos do direito penal que busco puderam ser encontrados em seu trabalho, portanto.

Feitas essas considerações, é possível dizer que a obra de Ferrer também não compreende todos os elementos necessários para a caracterização do direito penal contemporâneo, mas é mais compatível com a maioria deles do que a doutrina de Avellar Brotero.

Comecemos com as compatibilidades. A primeira coisa a se notar é que Ferrer já faz uso de outras palavras para referir-se às ofensas ao direito em geral, bem como às sanções jurídicas em geral. Relembremos aquilo que já foi dito no segundo capítulo, na esteira de Pires, Cartuyvels e Sbriccoli: nos jusnaturalistas modernos, os conceitos de "crime" e "pena" tinham uma acepção compreensiva: "crime" era utilizado em referência a toda e qualquer ofensa jurídica, e "pena" indicava a parte penal de uma lei jurídica, de que era pressuposta a parte dispositiva ou imperativa da mesma lei. Apenas com o processo de especificação teórica do direito penal contemporâneo é que "crime" e "pena" adquirem os significados específicos, exclusivamente penais, que hoje lhes atribuímos. Pois bem, ao falar das lesões gerais ao direito e das respostas jurídicas que lhes devem seguir, Ferrer não se utiliza desses conceitos amplos de crime e pena; escolhe, ao contrário, duas palavras que ainda hoje podem ser usadas para esse propósito: "lesão" e "sanção". Diz ele:

É pois lesão o facto, pelo qual se invade a esphera da justa actividade dos outros. Tambem se lhe chama injuria no sentido lato; porque no sentido estricto injuria é sómente a offensa de boa reputação. Da lesão resulta o damno, que é todo o detrimento do nosso direito, causado pela lesão; e póde resarcir-se pela reparação, isto é, pela reintegração do lesado no estado anterior à lesão (Ferrer, 1847: 22, nota. Destaque meu).

Sancção é aquela parte da lei, em que o legislador fulmina penas, ou propõe prêmios, como motivos para determinar os subdsídios ao cumprimento do que estabelece na outra parte da lei, que se chama edicto (cit.: 42. Destaque meu). 
A comparação com as já comentadas Instituições de Mello Feire deixa patente a diferença no uso dos conceitos. Dizia Mello Freire, recordemo-nos:

À soberania é inerente a jurisdição, isto é, o conhecimento de qualquer causa, ou seja, o poder de aplicar a justiça (Instituições, III: II). (...) O juízo criminal é exercido pelo próprio Rei, ou por alguém em seu nome (cit., III: III); (...) As penas (...) reduzem-se às capitais e implicam perigo de vida, ou às pecuniárias, que consistem na perda de bens. Também da pena de Talião, que as próprias leis divinas muitíssimas vezes incluem, vêem-se fazer menção as Ordenações (cit., III: IV).

Pela escolha de conceitos diversos para fazer menção àquilo que Mello Freire designava através de "crime" (pelo adjetivo "criminal", no caso) e "pena", é possível suspeitar que essas duas palavras já fossem por ele tratadas como tendo significado mais estrito, e nesse sentido ele estaria mais próximo do direito penal contemporâneo. Isso sugere que Ferrer já poderia reconhecer o domínio do "criminal" como uma área específica dentro do conjunto do direito positivo. Essa suspeição é reforçada por outra obra de Ferrer, essa bem menos conhecida. Em 1869, o autor publicou uma sequencia de três artigos com resenhas da Philosophia do Direito de J. M. Rodrigues Brito, seu conterrâneo. Um dos artigos, pouco depois respondidos por Brito e publicados conjuntamente em um folheto único, contem uma passagem esclarecedora, que reforça a hipótese da acepção estrita do "criminal" nas ideias de Ferrer. Lá ele disse o seguinte:

A theoria [de José Dias Ferreira] cobre pois com o manto da Justiça o roubo, que até agora era um crime. O salteador largará as armas, e exigirá o cumprimento de um dever para obter honestamente aquilo que até agora só podia extorquir pela força, como vil criminoso. (in Brito, 1869: 7).

Ou seja, enquanto nos Elementos ele usa a palavra lesão para falar da ofensa ao direito em geral, no citado artigo ele escolhe "crime" e "criminoso" para referir-se ao roubo e 
a seu executor. Trata-se, portanto, do uso da palavra "crime" para representar um ilícito especificamente penal.

Já a organização do direito penal em parte geral e parte especial não foi objeto de comentário particular de Ferrer, talvez por se tratar de um tema muito específico, ou talvez por isso ser àquela altura algo já evidente no contexto europeu. Mas, da mesma forma, é inequívoco que sua obra não é com ela incompatível, por uma razão bastante contundente: ele mesmo enxergava sua disciplina por uma metodologia semelhante, o que mostra como esse critério organizacional já era corrente a seu tempo. O direito natural era visto por Ferrer como a "parte geral do direito", ou seja, o conteúdo normativo comum a todas as suas áreas específicas, tanto do ramo público quanto do privado. Dizia Ferrer que a Filosofia do Direito - à qual cabia o estudo do direito natural e do ius gentium - estabeleceria os "princípios fundamentais do direito" e estipularia "o modo, por que devem estabelecer-se as relações entre os homens, considerados como sociais, para que sejam conformes à ideias de justiça exterior" (1857: 40-1). Vale dizer, a ordem jurídica seria "deduzida" (cit.: 41) desses princípios gerais, que permeariam todo o direito positivo. Não por acaso, a última parte de seus Elementos de Direito Natural compreende uma série de institutos, hoje estudados preferencialmente no direito privado (matrimônio, locação, entre outros), que Ferrer postula serem desdobramentos lógicos, por dedução, dos primeiros princípios racionais do direito. Ou seja, a construção metodológica de sua disciplina só é sensata se assumirmos que o autor enxergava o direito a partir da estrutura organizacional arborizada que resultaria, no direito penal contemporâneo e nos códigos da modernidade, na estrutura de parte geral e parte especial. Falta, contudo, material para se afirmar que conteúdos ele representaria em uma parte geral de "direito criminal".

Passemos agora ao ponto de incompatibilidade entre Ferrer e o Direito Penal contemporâneo. Ela diz respeito à posição enciclopédica do direito penal. A divisão entre direito público e direito privado está presente em sem compêndio, e seus critérios são os mesmos dos demais autores de seu tempo: 
O Direito Positivo divide-se em Público, que é o complexo das leis relativas á constituição e administração pública da sociedade civil, isto é, á cerca das relações públicas entre os poderes soberanos e os subditos: e Particular, que é o complexo das leis, que regulam as relações particulares entre os cidadãos (Ferrer, 1853: 42).

Entretanto, ao elencar as disciplinas pertencentes a cada um desses ramos, Ferrer situa o direito criminal dentro do direito privado, ou particular:

O direito interno da sociedade é o complexo das condições, que devem ser realizadas pelos seus membros, para a existência e desenvolvimento da sociedade. Estas condições constituem o direito fundamental, expressado pelas leis fundamentaes do pacto da constituição; e o direito secundario, expressado pelas leis secundarias, promulgadas pelo poder legislativo. [O direito fundamental] chama-se também constitucional, politico ou publico interno nas sociedades civis. [O direito secundario] chama-se também particular ou privado; e segundo as relações, que regula, toma diversos nomes, v. g., civil, criminal, commercial, etc. (1857: 200-1, em nota de rodapé.)

Isto pode parecer uma pequena diferença, mas tem consequências brutais não só para a concepção do direito penal como objeto intelectual, como também para a sua realização prática. Metodologicamente, a colocação do direito penal no direito privado esvazia dois dos seus principais sustentáculos, quais sejam, (i) a ideia delito de que o delito criminal é uma lesão grande aos bens fundamentais de uma sociedade, e (ii) a postulação de que é papel do direito criminal evitar essas lesões elementos esses em que ainda hoje se apoiam muitos dos teóricos do delito penal. Do ponto de vista prático, o caminho eleito por Ferrer enfraquece o caráter de obrigatoriedade da persecução penal - a ideia da ação penal pública como indisponível, por exemplo -, por tirar-lhe o principal fundamento, que reside igualmente na ideia de que o crime protege interesses públicos de altíssima importância, dos quais os funcionários do Estado responsáveis pela persecução penal (policiais, juízes e promotores) não podem dispor, e que só a eles cabe perseguir. ${ }^{319}$

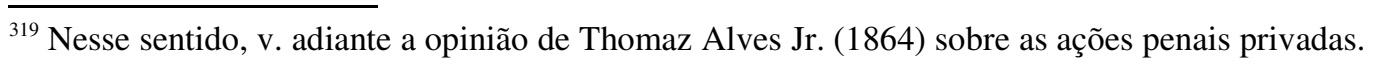


A despeito dessa incompatibilidade, há um dado importante da obra de Ferrer que pode ter relevo para o processo histórico de afirmação do direito penal contemporâneo: seus Elementos de Direito Natural são construídos a partir da filosofia crítica alemã, também utilizada por Feuerbach, e sua doutrina de separação entre direito e moral. ${ }^{320}$

Com efeito, a relativa confusão entre direito e moralidade que há na obra de Avellar Brotero desaparece na teoria de Ferrer, pelo uso da distinção entre moralidade e legalidade e a exigência de liberdade externa dos súditos como requisito para o cumprimento dos "fins racionais do ser humano", como dito repetidas vezes pelo professor português. Para isso, Ferrer principia pela distinção, por ele atribuída a Thomasius e Kant, entre foro interno e foro externo, para chegar à conclusão de que o direito deve ocupar-se apenas do último: "Portanto, apenas póde ser considerado como verdadeiro Direito aquelle, a que os Escriptores antigos chamavam externo e perfeito; e deve banir-se da Sciencia do Direito o chamado imperfeito e interno" (cit.: 10).

Assim como em Feuerbach, isso implicava a renúncia da coação jurídica em relação às normas pertencentes ao foro íntimo dos sujeitos, como condição de realização da moralidade:

O homem deve cumprir, segundo os preceitos da Moral, todos os seus deveres, só porque são deveres, sem que seja movido por qualquer principio sensual ou egoista, que destruiria a parte mais nobre do sentimento de respeito devido á sanctidade das leis. A Moral em fim exige que o homem obre com pureza de motivos, com livre vontade e boa intenção, e julga tudo diante de Deus e no tribunal da consciencia. (cit.: 15.)

O direito, ao contrário, contaria com a coação necessária, que lhe é um elemento conceitual: "o direito comprehende a faculdade da coação, isto é, de repellir pela força as lesões do dirito" (cit.: 22). Daí resultava que direito e moral - e, por

${ }^{320}$ Não espanta que seja assim, dada a confessada influência que a obra sofreu da filosofia alemã, especialmente de Kant e Krause. Basta dizer que o título completo da primeira edição do compêndio é: Curso de Direito Natural, segundo o estado actual da sciencia, principalmente em Allemanha (1843). 
extensão, ciência do direito e ciência da moralidade; obrigação jurídica e obrigação moral; sanção jurídica e sanção moral; etc. - eram coisas distintas, e assim deveriam ser cientificamente tratadas. Ferrer oferece, por isso, uma longa lista de distinção entre deveres jurídicos e morais (cit.: 26-9), inteiramente compatível com a doutrina expressa por Feuerbach em Kritik des Natürlichen Rechts (1796). Ferrer também sustentava a ideia da necessidade do direito como condição para o desenvolvimento das potencialidades humanas, em tom bastante semelhante ao de Feuerbach, separando os momentos de união civil da sociedade ("pacto de união") e da afirmação de uma ordem jurídica positiva necessária ("pacto de constituição") como requisito para o cumprimento do "destino racional do homem" (cit: 196-7).

Pode-se ver, portanto, que começavam a aparecer, na literatura jurídica corrente no Brasil do século XIX, alguns dos pontos de partida que haviam permitido, meio século antes, o estabelecimento do direito penal contemporâneo na doutrina de Feuerbach. A separação entre ilícitos jurídicos e morais, necessária para fundamentar a possibilidade jurídica de proibição de condutas moralmente irrelevantes, é especialmente importante para a fundamentação da propriedade constitutiva da legalidade do direito penal contemporâneo, ideia essa defendida por Ferrer, que diz ser possível a criação de "leis arbitrárias" não determinadas pela moralidade (cit.: 41-2). Mais ainda, merce atenção também a valorização dos elementos formais do direito pela ideia de que o estabelecimento de uma ordem institucional é condição sine qua non para uma vida social plena, que aparece por sua adoção da distinção entre pacto de união e pacto de constituição.

\section{Heinrich Ahrens}

Juntamente com o compêndio de Vicente Ferrer Neto Paiva, tornou-se corrente o uso nas academias brasileiras do Cours de Droit Naturel de Heinrich Ahrens. A teoria de Ahrens ganhou divulgação no Brasil por dois caminhos distintos: o primeiro, e mais importante, foi a tradução francesa da obra completa, que conheceu 
sucessivas edições, desde meados até fim do século XIX. ${ }^{321}$ A outra foi a tradução portuguesa de uma parte menor do livro, que compreendia apenas a filosofia do Estado, feita por um primeiranista de Coimbra em 1844.

Ahrens atuou como professor na Bélgica, na França, na Áustria e na Alemanha, sempre fugindo das complicações decorrentes da instabilidade política da Europa do século XIX. Especialmente em razão das versões em língua francesa de seu curso, feitas para sua atividade docente em Bruxelas, Ahrens foi muito usado no Brasil do século XIX e, assim como Ferrer, ajudou a divulgar as bases da filosofia jurídica de Kant e de Krause - este último foi seu professor em Göttingen, onde se doutorou em 1830. Seu trabalho é, portanto, fundamental para a sedimentação de uma certa teoria do direito que é convidativa ao surgimento do direito penal contemporâneo, na mesma linha do que acaba de se comentar em relação a Ferrer.

Ao contrário das obras dos dois jusnaturalistas anteriormente comentados, o trabalho de Ahrens contem um item todo dedicado ao direito penal, que serve bem para mostrar como o direito penal contemporâneo já aparece com alguma clareza em seu Cours. Na Parte Geral do seu livro, o quinto capítulo cuida das formas de manutenção e restabelecimento do Estado de Direito. Seu primeiro item ( $§ 35$ ) apresenta as diferenças entre as causas civis e criminais em geral.

Sobre as causas civis, Ahrens diz o seguinte:

O estado de direito pode ser alterado por pleitos, litígios, que se promovem entre diversas partes sobre relações ou negócios de direito nos quais uma parte se crê lesionada por outra. O Estado estabelece as formas de procedimento, em que as partes têm de levar adiante seus pleitos sobre o que consideram como seu direito e principalmente em matéria de direito real, sobre aquilo que é meu ou teu. A causa é aqui um pleito concernente a direitos próprios, privados, é uma causa civil (Ahrens, 1875, T. I: 226. Destaques meus) ${ }^{322}$

\footnotetext{
${ }^{321}$ A primeira edição encontrada na biblioteca desta Faculdade data de 1848. A última ( $8^{a}$ edição) é de 1892. A $7^{\mathrm{a}}$. e $8^{\mathrm{a}}$.edições são reimpressões da $6^{\mathrm{a}}$., de 1868 , a última em que Ahrens trabalhou antes de sua morte. Trabalhei com a $7^{\mathrm{a}}$ edição (1875), por ser a de melhor estado de conservação.

322 "L'état de droit peut être troublé par des contestations, des litiges, qui s'élèvent entre diverses parties sur des rapports ou des affaires de droit, dans lesquels l'une des parties se croit lésée par l'autre. L'État établit les formes de procédure dans lesquelles les parties ont à vider leurs contestatons sur ce qu'ils
} 
Sobre as causas penais, por outro lado, diz:

Mas o Estado de Direito pode ser lesionado também por um ataque direto quando a vontade de uma pessoa se dirigiu a realizar um fato (de comissão ou omissão) pelo qual lesiona-se imediatamente o direito de outra pessoa, física ou moral. Tal vontade direito é manifestação de uma disposição perversa de alma e vontade, que apresenta um perigo permanente para a manutenção do estado de direito, de que decorre para o Estado o dever de tomar medidas para garantir a ordem do direito contra a repetição de atos análogos para o mesmo delinquiente, principalmente pela suspensão do exercício de sua liberdade, e depois para reestabelecer nele uma vontade disposta à obediência das leis. A causa neste caso é uma causa criminal (cit.: 227. Destaques meus) $)^{323}$

Prosseguindo, após anotar que a diferença entre o civil e o criminal nem sempre é clara, Ahrens oferece algumas distinções adicionais sobre as duas áreas:

Nas causas civis, a lesão, se teve lugar, é indireta, se reveste de formas legais; pode haver erro ou fraude em uma venda; mas esta é uma forma legal para as transações, e a fraude não é senão um acidente que a vicia; na causa criminal, ao contrário, a lesão é perpetrada contra a lei formal, ataca diretamente uma lei, é patente e absoluta, porque a lei como tal foi violada em seu caráter de defesa absoluta. (cit.: 227-8. Destaques meus). ${ }^{324}$

considèrent comme leur droit et principalement, en matière de droit réel, sur le mien et le tien. La cause est ici une contestation concernant des droits propres, privés, elle est une cause civile".

323 "Mais l'état de droit peut aussi être lésé par une atteinte directe, quand la volonté d'une personne a été dirigée à poser un acte (de commission ou d'omission) par lequel le droit d'une autre personne physique ou morale est immediatement lésé. Une telle volonté directe est la manifestation d'une disposition perverse d'âme et de volonté, présentant un danger permanent pour le maintien de l'état de droit, d'où surgit por l'État le devoir de prendre d'abord des mesures pour garantir l'ordre de droit contre la repetition d'actes analogues de la part du meme delinquent, principalement par une suspension de l'exercice de sa liberté, et ensuite pour rétablir chez lui une volonté prête à obéir à la loi. La cause dans ce cas est une cause criminelle".

324 "Dans les cause civiles, la lesion, si elle a lieu, est indirecte, se couvre de formes légales; il peut y avoir erreur ou même fraude das une vente, mais celle-ci est une forme légale pour les transactions, et la fraude ne forme qu'un accident vicieux; dans la cause criminelle, au contraire, la lésion s'est opérée contre la loi formelle, elle a attaqué directement une loi, elle est patente, absolue, parce que la loi comme telle a été violée dans son caractère de défense absolue". 
A partir das diferenças entre lesões civis e criminais, Ahrens sugere também uma consequência jurídica distinta para cada uma delas:

\begin{abstract}
As consequências de uma lesão civil são, ou a nulidade do negócio jurídico, ou a condenação ao pagamento, ou a prestação de perdas e danos. A consequência de uma lesão criminal é o castigo, destinado a obrar sobre a vontade perversa (cit.: 228. Destaque meus). ${ }^{325}$
\end{abstract}

É fácil ver o quanto já nos é familiar o direito penal e sua relação com o direito civil no desenho teórico de Ahrens. Dessa forma, pode-se dizer que, ao menos entre as fontes consultadas, a sua obra é uma das primeiras a divulgar, nos meios acadêmicos brasileiros, um mapa geral do direito que seja convidativo ao direito penal contemporâneo. Com efeito, o direito penal é por ele representado como um objeto distinto do direito civil. A despeito de Ahrens falar em "causas criminais" e "causas civis", a diferença entre uma e outra coisa não é apenas jurisdicional ("prática"); é também substantiva. Pois, em primeiro lugar, o ilícito penal e o ilícito civil representam formas distintas de lesão ao direito: enquanto o ilícito civil é uma irregularidade que macula um negócio que se dá sob formas legais, o ilícito penal é uma violação frontal e direta à lei - é um ilícito "contra a lei formal", mostrando que sua teoria é ao menos compatível com a ideia de que o crime é a violação de uma lei estatal e está, portanto, de acordo com a ideia de legalidade que configura o nosso direito penal. O crime é, além disso, uma violação direta ao Estado do Direito, porque contraria os mandamentos de uma lei expressamente proibitiva e apenadora, ao passo em que o ilícito civil é a mera inobservância da forma legal prescrita para determinados negócios jurídicos que não são, em si mesmos, ilegais.

Mais ainda, e como corolário, o crime e sua perpetração são perigos para a própria existência do Estado de Direito e o poder público tem o dever de reprimilos inexoravelmente. Por isso, conflitos criminais não se resumem a meras disputas contenciosas entre partes privadas, mas são, ao contrário, matéria de interesse público.

\footnotetext{
325 "Les conséquences d'une lésion civile sont ou la nullité de l'affaire juridique, ou la condemnation au payement, ou la prestation des dommages-intérêts. La conséquence d'une lésion criminelle est la punition, destinée à agir sur la volonté perverse".
} 
Daí decorre que o direito penal pertence ao direito público, como fica claro logo no primeiro capítulo da tradução portuguesa da primeira edição de sua obra:

Há também um direito público ou social contra as infracções do Direito, contra os delictos e crimes, ou o Direito penal, que expoem os principios pelos quaes a sociedade submette aqueles que commettem as infracções a um tratamento de correcção e multa que se lhes faz sentir como pena (Ahrens, 1844: 19).

Essa disciplina de direito público que cuida de um tipo específico e mais significativo de lesão jurídica ("delitos e crimes") opera também com um tipo específico de sanção. Trata-se da pena criminal, que não tem o mero propósito de reparação ou indenização, como no direito civil. Ela é, acima de tudo, um castigo e, como tal, só pode constituir-se em um mal, como claramente disse Ahrens. O professor alemão deixou claro ainda que a cominação concreta desse mal penal depende de um conjunto particular de regras. Essas regras são por ele chamadas de culpabilidade, e destinam-se a medir "o grau em que um ato criminal em si pode ser imputado a um homem" (1875, T. I: 229). A culpabilidade é constituída por um elemento objetivo (a magnitude da lesão) e outro subjetivo, consistente no já mencionado "grau de perversidade da alma e da vontade". Note-se bem o quanto isso é já muito mais específico do que Avellar Brotero, que poucos anos antes falava de um critério de "imputação" comum a todo o direito.

Para que se feche o círculo do direito penal contemporâneo, ficaram faltando apenas: (i) a explícita separação entre direito penal e direito processual penal, ponto sobre o qual Ahrens não chega a se manifestar porque a generalidade de sua obra não contempla um tal nível de detalhamento de uma área particular do direito; e (ii) a indicação de sua divisão em parte geral e parte especial, sendo a primeira dividida em uma teoria do delito e uma teoria da pena, que com toda probabilidade não é feita pelos mesmo motivos, mas com que ele certamente concordaria, pois também o seu direito natural é assim dividido. ${ }^{326}$

\footnotetext{
${ }^{326}$ O primeiro tomo do Cours de Droit Naturel compreende a parte geral da filosofia do direito; o segundo, a parte especial.
} 
Ainda assim, o importante é notar que quase todos os elementos do direito penal contemporâneo já aparecem nítidos e explícitos em sua teoria, muito mais do que nas obras já comentadas, de poucos anos antes: (i) o direito penal é um objeto teórico particular, distinto de outros ramos do direito positivo; (ii) ele difere do direito civil seja pela qualidade dos ilícitos de que cuida, seja pela espécie de sanção com que trabalha, ou ainda pelas regras pelas quais tal sanção é imputada; e (iii) ele pertence ao direito público, enquanto o direito civil situa-se no âmbito do direito privado. Uma teoria geral do direito como a sua está pronta para acomodar o direito penal contemporâneo, portanto.

\section{José Dias Ferreira}

Os caminhos teóricos de Ahrens, porém, não eram hegemônicos no pensamento jurídico europeu e nem o criticismo do prestigioso Ferrer era hegemônico em Portugal. Havia outros autores que continuavam a propagar uma teoria do direito menos convidativa à nossa concepção contemporânea de direito penal. É o caso de José Dias Ferreira e suas Noções Fundamentais de Philosophia do Direito (1864). Ainda que obscurecido pelas obras de Ferrer e Ahrens, o livro de Ferreira não pode ser descartado, sobretudo porque é escrito em língua portuguesa e apresenta conteúdo bastante simplificado em relação aos outros dois, fatores que podem ter servido para uma considerável utilização sua pelos estudantes daquele tempo. ${ }^{327}$

Ferreira começa por negar a separação, já cediça em Ferrer e Ahrens, entre direito e moral. Para fazer isso, rejeita expressamente a doutrina de Kant e invoca a unidade da obra divina, revelando seu descompasso com o estado da arte da filosofia jurídica do terceiro quarto do século XIX:

As doutrinas de Kant, cuja lei suprema nós enunciámos, quando examinámos a noção de direito, que elle considerára como base do seu systema juridico, não podem aceitar-se, por exageradas, num systema philosophico, cujo fito constante seja harmonisar as suas theorias com as vistas do Creador, e com as leis da creação.

${ }^{327}$ As bibliotecas desta Faculdade têm quatro obras de Ferreira. 
Kant, fazendo reviver a distincção de Thomazio, e adjudicando á moral as acções internas, e as externas ao direito, estabeleceu uma separação quasi absoluta entre o direito e a moral, separação verdadeiramente incompatível com a estreitesa do vinculo, que existe entre o objeto das duas sciencias. (Ferreira, 1864: 359).

Excluída a questão da questionável leitura de Kant feita por Ferreira, nota-se primeiramente que o poder político de criação de ilícitos, inerente ao direito penal contemporâneo, ficaria pouco à vontade num sistema cujo propósito era a harmonização do direito com "as vistas do Creador".

Porém, no que diz respeito à consideração do direito penal como um ramo particular do direito positivo, a obra de Ferreira já acusa nitidamente a sua autonomia. Ao falar sobre as origens do direito no espírito humano, Ferreira faz a distinção entre o direito penal e o direito civil e, especificamente, entre as distintas formas de obrigação e responsabilidade civis e penais:

A necessidade de determinar o tempo em que o conhecimento do direito apparece no espirito humano, tão consideravel no campo da psychologia, onde se tenta definir e descrever precisa e cirumstanciadamente todas as phases da vida e riqueza do espirito nos diferentes momentos da sua existencia, sobe de ponto com relação á sciencia juridica, onde é preciso fixar a epocha, em que o homem começa de estar sujeito á responsabilidade penal e civil, pela violação das suas respectivas obrigações juridicas (cit.: 89-90. Destaques meus).

No que diz respeito à especificidade da pena criminal, a obra de Ferreira também parece estar mais para dentro do direito penal contemporâneo do que para fora dele. Dirá ele, sobre a pena criminal, o seguinte:

O direito penal das nações, descrevendo as diversas especies de delictos, e determinando a penalidade correspondente, não faz mais do que expressar o preceito da realisação necessaria do bem. O respeito á personalidade humana é mantido, ainda contra a vontade do individuo; e as violações d'aquelle preceito são vingadas, ainda que seja necessario recorrer ao uso da força (cit.: 373. Destaques meus). 
Ao comentar a "legislação civil", Ferreira não faz qualquer alusão a "delictos" ou "penas". Isso sugere não só que delitos e penas não pertenciam mais ao direito como um todo, mas apenas ao direito criminal; mas também que esses dois elementos eram os caracteres constitutivos do direito penal como ramo autônomo do direito, que não fazia mais do que "descrever as diversas especies de delictos" e "determinar-lhes a penalidade correspondente". Ou seja, o "civil" não servia mais para designar todo o direito positivo.

A obra de Ferreira é um grande reforço à hipótese inicial da pesquisa, mesmo que em alguns pontos ela esteja distante da matriz de pensamento que permitiu o surgimento do direito penal contemporâneo. No início do trabalho, utilizei a analogia dos sistemas operacionais de computador para argumentar que o direito penal contemporâneo era uma espécie de sistema operacional dentro do qual "rodavam" diferentes teorias penais. Pois bem, o trabalho de Ferreira mostra que, mesmo expressando uma visão em parte incompatível com aquilo que possibilitou o surgimento do direito penal contemporâneo, por professar a dependência do direito e suas proibições em relação à moral, ele o faz com uso da linguagem e segundo as divisões que marcam o nosso direito penal: vendo-o como uma parte do direito público, constituído por um corpo de leis interpretadas a partir de princípios próprios, e com os conceitos já restritos de "crime" e "pena". Ou seja, mesmo destoando em matéria filosófica, e soando retrógrado para o seu tempo, Ferreira já era um autor rodando majoritariamente dentro desse sistema operacional.

\section{ObRas ESPECIFICAMENTE PENAIS}

Nos primeiros anos das academias de direito brasileiras, a produção de obras jurídicas foi quase nula em matéria penal. Exceção feita a um discurso de inaugural da aula de Direito Criminal por Francisco Bernardino Ribeiro, cuja existência as fontes indicam, mas que não está disponível nas bibliotecas desta Faculdade, é só na segunda metade do século retrasado que obras penalísticas escritas por brasileiros 
começam a aparecer, em Recife (Braz Florentino Henriques de Souza, Manuel Mendes da Cunha Azevedo e Manoel Januário de Bezerra Montenegro), no Rio de Janeiro (Thomaz Alves Jr.) e em São Paulo (Joaquim Augusto de Camargo). A pequenez da produtividade científica dos professores de São Paulo é um dos pontos-chave da crítica de Adorno à qualidade do pensamento jurídico dela oriundo no século retrasado, diga-se de passagem. ${ }^{328}$

Por essa razão, e como já adiantado na introdução deste capítulo, sobressaem as obras estrangeiras como fontes relevantes para a investigação sobre qual era a imagem de direito criminal ou penal corrente no Brasil durante o intervalo de tempo compreendido por esta investigação. Entre elas, destacam-se os portugueses, especialmente Mello Freire, professor de toda uma geração dos primeiros membros da elite política do Brasil independente que haviam feito seus estudos em Coimbra; bem como os francófonos, não só porque escreviam em uma língua conhecida pela maior parte dos alunos, como também porque o Código Penal francês de 1810 foi uma das importantes inspirações para o diploma brasileiro de 1830. A doutrina italiana era representada por Giandomenico Romagnosi, autor citado com muita frequência não só no século XIX, mas também século XX adentro.

Foram excluídos desta investigação alguns nomes que, à primeira vista, poderiam nela constar. Em que pese sua importância como penalistas europeus do século XIX, e a significativa influência que tiveram no Brasil em fins daquele século, não foram objeto de estudo as obras de Faustin Helié, Jacques Joseph Haus, Enrico Pessina e Francesco Carrara. A exclusão de Helié deve-se ao fato de sua produção haver se concentrado mais em matéria de instrução criminal do que de direito criminal ou penal. Haus, por sua vez, foi excluído por dois critérios: o primeiro vem do fato de ele ter construído sua teoria como um comentário ao direito penal belga, quando os autores brasileiros, entre os penalistas francófonos, preferiam os franceses, uma vez que viam grande semelhança entre os códigos da França e do Brasil. Como os franceses já estão muito bem representados por Ortolan e Rossi, pareceu que a consulta a Haus não traria

\footnotetext{
${ }^{328}$ Para uma lista completa da produção de conhecimentos pelos professores de São Paulo no século XIX, ver Adorno, 1988: 122-31.
} 
nenhum benefício adicional para o teste das hipóteses desta investigação. De mais a mais, Haus produziu a maioria de suas obras na segunda metade do século XIX, quando já havia alguma produção jurídica estritamente nacional em matéria jurídico-penal; e, dado que o propósito deste capítulo é averiguar a chegada do direito penal contemporâneo no Brasil, seus esforços de investigação, no tocante às obras do meio para o fim do século retrasado, concentraram-se nos trabalhos dos autores brasileiros. Por esse mesmo motivo cronológico, ficaram de fora Pessina e Carrara, dois italianos também muito importantes para a história do direito penal brasileiro do século XIX tardio e do início do XX: as obras de ambos foram publicadas majoritariamente no último quartel dos mil e oitocentos, de forma que a sua presença no Brasil não só veio a ser sentida já nos instantes finais do intervalo de tempo desta pesquisa, como também já veio diluída não só nas opiniões dos juristas brasileiros, que já existiam em maior número, como também das doutrinas cientificistas de seus contemporâneos. A lista final dos estrangeiros estudados é a seguinte: Mello Freire, Ortolan, Rossi e Romagnosi.

\section{A influência duradoura: Pascoal José de Mello Freire}

Pascoal José de Mello Freire (1738-1798) $)^{329}$ é figura conhecida do nosso direito penal. Criminalista português de grande prestígio político e intelectual nos séculos XVIII e XIX, foi, como lembra Neder (1998), professor de gerações de juristas brasileiros que se formaram em Portugal nos séculos XVIII e XIX - inclusive daqueles que diretamente trabalharam na elaboração do Código Criminal de 1830. Foi conselheiro de D. Maria I, desembargador da Casa da Suplicação e professor jubilado da Faculdade de Direito de Coimbra, além de sócio efetivo da Academia de Ciências de Lisboa. Colaborou com o projeto de reforma do ensino universitário de Pombal e foi o primeiro professor da cadeira de Direito Pátrio em Coimbra. ${ }^{330}$ Para tal disciplina,

\footnotetext{
${ }^{329}$ As informações sobre a biografia de Mello Freire (como de muitos outros históricos juristas portugueses) estão disponíveis no sítio de Internet da Faculdade de Direito da Universidade Nova de Lisboa (www.fd.unl.pt), na página da Biblioteca Digital.

${ }^{330}$ A criação dessa cadeira é, por si só, indicativa da crescente importância das fontes reais para a cultura jurídica de então, conforme mencionado no item $\mathrm{V}$ do capítulo anterior.
} 
redigiu inicialmente História do Direito Civil Português ${ }^{331}$ e, pouco tempo depois, as Instituições de Direito Civil Português (1789). Redigiu também o primeiro projeto de Código Criminal português, que D. Maria I mandou organizar em 1788. Concluído no ano seguinte, o projeto não vingou. O Código Penal da Nação Portuguesa, redigido por José Manuel da Veiga, só seria aprovado em 1837. Seu principal escrito teórico em matéria criminal foi Instituições de Direito Criminal Português, de 1794.

Mello Freire deixou um conjunto importante de obras jurídicas que bem servem para os propósitos deste item. A despeito de muitas delas não serem especificamente criminais, ele é aqui tratado em meio aos criminalistas porque é assim que foi canonizado na história do pensamento jurídico. Argumentar em favor de sua importância para o ensino do direito no Brasil em seus momentos iniciais é desnecessário. Basta dizer, a título ilustrativo, que Joaquim Augusto de Camargo, professor de Direito Criminal em São Paulo mais de meio século após a publicação das mais importantes orbas do professor coimbrão, referia-se a ele como "um gênio fadado por Deus", salientando que ainda no Brasil de fins do século XIX "suas obras [eram] consultadas com aproveitamento e seu nome [era] acatado e respeitado pelos homens da ciência" (Camargo, 1881-2: 127); e Thomaz Alves Jr., um dos primeiros comentadores do Código Criminal de 1830, dizia que as Instituições de Direito Criminal Lusitano de Mello Freira "vinhão derramar muita luz" no "amontoado de trevas em que se achava a legislação criminal portugueza" (Alves Jr., 1864: 11).

Segundo Lopes (2007: 9), Mello Freire faz parte da doutrina portuguesa pré-liberal. Ele seria, portanto, um autor de transição entre a velha ordem absolutista e o novo mundo liberal. Hespanha (1993) diz que Mello Freire sentiu os impactos dos iluministas como Beccaria, e aponta o caráter modelar de seu projeto de código para futuras codificações - não só a portuguesa de 1837, mas também a brasileira de 1830. Não é surpresa, por isso, que muitos dos elementos do direito penal contemporâneo já estivessem presentes na teoria jurídica de Mello Freire. Contudo, não

\footnotetext{
${ }^{331}$ Esta obra foi objeto de pesadas críticas por parte de António Pereira de Figueiredo, deputado da Real Mesa de Censura - cargo que Mello Freire já havia ocupado. A resposta de Mello Freire às críticas de Figueiredo foram publicadas postumamente, em 1807. Uma versão integral da obra está disponível, em formato digital, no sítio de Internet da Faculdade de Direito da Universidade de Coimbra, na página da Biblioteca Digital.
} 
se poderia ainda dizer que nele já estivesse formado o direito penal tal qual hoje conhecemos.

Quanto às semelhanças, primeiramente deve-se constatar que Mello Freire já trabalhava, em linhas gerais, com a metodologia que possibilitaria a construção do direito penal contemporâneo como objeto teórico dividido em parte geral e parte especial, principiando pelas definições fundamentais que não só uniformizam a linguagem técnica da obra, mas acabam por estipular os limites de um campo de investigação intelectual autônomo. Não por acaso, seu Ensaio de Código Criminal $(1823)^{332}$ abre-se com sete artigos que têm por objeto a definição de delito, que deveriam valer para todos os delitos criminais. Nas notas explicativas ("Provas") que seguem o ensaio legislativo propriamente dito, Mello Freire deixa claro que essa escolha não foi aleatória:

O título dos delictos em geral he o $1^{\circ}$. neste Codigo, pelas mesmas razões, porque foi tão-bem o $1^{\circ}$. título dos Direitos reaes no Codigo do Direito público. E aqui principia a primeira parte da nossa jurisprudencia criminal, segundo a ordem, que me propuz a seguir (...) (Mello Freire, 1823: 227).

Ou seja, Mello Freire esclarece que, nos sete primeiros artigos do Código Criminal, seu propósito foi estabelecer as caraterísticas gerais de todos os ilícitos - o ponto em que principiava (daí os "princípios") a jurisprudência criminal. Em primeiro lugar, a "jurisprudência criminal" trabalha com regras particulares de imputação: "não ha delicto digno de castigo sem dolo ou culpa; pois não o havendo a ninguem se póde imputar". (cit.: 227-8). Em segundo lugar, ela qualifica os delitos a que se refere, se bem que de maneira ainda insuficiente para diferençá-los de outros ilícitos públicos, permanecendo o caráter acentuadamente horizontal do conceito: "He necessario para haver delicto, que haja e se commetta facto, que offenda a sociedade, ou os individuos della" (cit.: 228). Mais adiante, diz que as penas criminais devem guardar proporção com os delitos cometidos: "O conato porém he delicto quando os factos, que se intentarão, são illicitos, e a pena deve corresponder á sua malicia". Não espanta, por

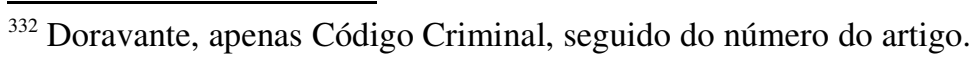


isso, que Mello Freire já empregasse em seu projeto uma organização legislativa bastante semelhante à do direito penal contemporâneo, e comum aos primeiros códigos modernos propriamente ditos: dividia os delitos em públicos e particulares (Código Criminal, art. $7^{\circ}$ ), seguindo-se outras divisões específicas (divisões communs), de acordo com as pessoas, circunstâncias ou diferenças de provas (crimes permanentes ou transeuntes, por exemplo).

Há despeito disso tudo, entretanto, não é possível dizer que a teoria de Mello Freire tenha levado até o fim o processo de construção do direito penal contemporâneo. Um primeiro importante passo que lhe faltou foi a separação substantiva do ilícito penal em relação ao restante dos ilícitos jurídicos. É verdade que Mello Freire apontava ao menos um elemento substancial que viria a tornar-se uma marca distintiva do ilícito criminal, conforme já mencionado: a necessidade de que ele ocasionasse uma lesão à sociedade ou aos indivíduos. Mas, ao dizer isso, ele ainda não se referia a uma característica distintiva do ilícito criminal, que o distinguisse dos demais ilícitos jurídicos; estava, isto sim, marcando a distinção entre ilícitos a leis jurídicas por oposição a violações a outras regras de conduta (morais, religiosas), uma alteração teórica bem percebida por Arno e Maria José Wehling (2004: 553). Mello Freire utilizava-se aqui da conhecida distinção, que os autores da época remetiam a Thomasius, entre foro interno (âmbito moral) e foro externo (âmbito jurídico). Ou seja: como Avellar Brotero, o professor português trabalha ainda com uma noção horizontalizada de "crime", que se refere a toda a massa do ordenamento jurídico, e não apenas aos ilícitos particulares de uma área restrita do direito.

Há duas características do pensamento de Mello Freire que corroboram tal postulação.

A primeira é que o esforço que perpassa toda sua obra penal é mais o de realizar a distinção entre violação às "leis civis" (direito positivo) e violação de regras de conduta morais e religiosas, e menos o de separar o "criminal" do restante do direito positivo. E não espanta que este seja seu foco: lembremos que, como já foi dito, Mello Freire foi levado a Coimbra pela reforma pombalina, que tinha como principal 
objetivo libertar as luzes da Universidade da visão confessional que os jesuítas lhe impunham. A passagem completa onde Mello Freire tratou do caráter substantivo do "delicto" confirma essa interpretação:

He necessario para haver delicto, que haja e se commetta facto, que offenda a sociedade, ou os individuos della. Donde vem que a cogitação não he deliccto civil; que tãobem o não he o simples peccado contra Deos, e o vicio do homem todas as vezes que se não offende o público, ou o particular; e assim se distinguem no fôro humano o crime ou delicto do peccado, ou do vicio. (1823: 228).

Ou seja, as propriedades materiais do "delicto", que fazem dele objeto de um estudo teórico particular, distinto da teologia e da filosofia moral, marcam aqui a separação entre ilícitos religiosos morais e ilícitos jurídicos. Nesse sentido, a separação das coisas em Mello Freire é já muito clara, algo que, lembremo-nos, não se via em seu contemporâneo alemão Carl Grolman (Cap. III). Mas é certo que o professor coimbrão não marcava ainda a distinção dos ilícitos penais em relação aos demais ilícitos civis, e a palavra "delicto" tal qual empregada por ele dizia respeito a toda e qualquer violação às leis civis (positivas): "se diz delicto (...) a acção contra a lei, e a sua transgressão, e nella se comprehendem todas as leis, ou sejão prohibitivas, ou imperativas" (1823: 227).

Com isso, Mello Freire parece estar, no que diz respeito à definição de "crime" ou "delicto", mais próximo dos jusnaturalistas modernos do que do direito penal contemporâneo. Tanto assim que sua definição de delito é, nas Instituições de Direito Criminal Lusitano (I: II), a mesma de Grócio, com Blackstone confirmando-a em nota de rodapé (no Código Criminal, a definição de Blackstone se repete). ${ }^{333} \mathrm{O}$ sincretismo aqui aparece evidente: a definição de "delito" de Blackstone (que era a mesma de Beccaria) e aquela de Grócio, separadas por mais de um século e concebidas em meio a movimentos culturais e políticos absolutamente distintos, aparecem identificadas em Mello Freire, reforçando a percepção de que o direito penal contemporâneo herdou, através do conceito de delito, um papel que antes era de toda a ordem jurídica. Nas Instituições de Direito Criminal Português, ao atacar a doutrina de

333 "Esta definição he de Blackstone; e a dos criminalistas em substancia vem a dizer o mesmo". 
Farinácio ("o príncipe dos criminalistas") e saudar os comentários de António Mateus aos livros 47 e 48 do Digesto, Mello Freire confirma essa reciclagem da doutrina jurídica pretérita dando "louvor e glória" a Grócio, Pufendorf e Montesquieu por suas doutrinas criminais (Mello Freire, 1794: 47).

Também nas Instituições de Direito Civil, Mello Freire dá mostras de que tratava os "delictos" como toda e qualquer violação à lei positiva. O Título I do Livro Primeiro ("Direito Público"), que cuida das Leis, não esboça qualquer especificação de um tipo particular de lei penal. Indica apenas que o fim das leis - todas elas - é proteger a sociedade e garantir a paz. ${ }^{334}$ Esta era, como já foi dito e redito, a tarefa de toda a ordem jurídica no imaginário dos jusnaturalistas modernos. A distinção mais relevante que aparece nesta primeira parte é entre leis "públicas ou gerais, que obrigam a todos e em toda parte; ou leis forais, isto é, sensuais de certo lugar ou região" (1779, Livro I: Cap. V).

Em sua teoria do direito de punir, esta relativa indiferenciação entre ilícito civil e ilícito penal aparece também com clareza. O Título III do mesmo Livro Primeiro tem por objeto o poder de punir (jus gladii). O percurso do raciocínio de Mello Freire é o seguinte: (i) ao poder de jurisdição está indissociavelmente ligado o poder de punir (1779, Livro III: Cap. I); (ii) isto é feito pelos juízes, que são delegados do Rei (cit., Caps. II e III); (iii) tais penas podem ser corporais, pecuniárias ou conforme o Talião (cit., Cap. IV); mas, (iv) seja qual for a pena, só o soberano pode impô-las (cit., Cap. IV); porque (v) o fim das penas é o mesmo fim da sociedade, ou seja, garantir a segurança de todos os cidadãos (cit., Cap. V). Ou seja, os "delictos" a que se refere sua teoria do direito de punir são todas as violações às leis que tem por fim garantir a paz social - todas as leis positivas, e não apenas as criminais. Não se trata aqui de uma distinta teoria do poder de punir criminalmente, como a que mostrava Ahrens; tanto assim que, pouco adiante em sua teoria do direito de punição, Mello Freire dirá que "não têm valor as penas postas num contrato reprovado pelo direito", o que mostra a

\footnotetext{
334 "O fim da sociedade é a segurança dos cidadãos. (...) Para conseguir este nobilíssimo fim de toda sociedade legítima, é necessário, em primeiro lugar o poder legislador" (1779, Livro I, Caps. I, II e III).
} 
acepção ampla de "pena" e "delito" com que ele trabalhava, utilizando ambos os conceitos em matéria contratual, a mais típica do direito privado.

As Instituições de Direito Criminal também corroboram fartamente que era horizontal a sua noção do delito criminal: lá, sua definição de delito é trazido de Grócio ("fato ilícito espontaneamente cometido, contra a sanção das leis e prejudicial à sociedade ou aos indivíduos, pelo qual se incorre na obrigação de, se possível reparar o dano, e sofrer uma pena"). Anota, logo em seguida, que os delitos ou crimes podem ser "públicos ou particulares", na melhor tradição do Digesto (Mello Freire, 1794: 55). Delitos públicos eram para ele aqueles que lesassem a sociedade; e particulares, os que lesassem os indivíduos, "devendo ser perseguidos só por aqueles a quem afectam" (cit.: 57). A diferença entre as duas coisas, portanto, era acentuadamente procedimental, ao menos em parte. Prova disso é que certos crimes que hoje inequivocamente temos por públicos, pelo interesse público a que atendem, eram considerados particulares por Mello Freire, como no caso do roubo sem armas (cit.: 108). Trata-se, portanto, de uma teoria que não diferenciava substantivamente, como um ramo particular do direito, o direito penal e suas formas de punição daquelas praticadas no restante do direito público.

Mas por que então Mello Freire fez um código criminal? Não seria isso, por si só, o indicativo de que o direito penal era representado por ele como um objeto intelectual autônomo? A doutrina de Mello Freire mostra que não. Ao que parece, corroborando a tese de Cartuyvels e à semelhança do que se viu quanto a Klein (Cap. III) e quanto ao Código Criminal de 1830 (item III, retro), o seu projeto de código especificamente criminal estava muito mais ligado a um conjunto de reformas voltadas ao aperfeiçoamento do aparato jurisdicional real em detrimento de outros concorrentes, do que ao reconhecimento de que o direito penal seria uma área autônoma que necessitaria, por isso, de um código dedicado só a ela. Tanto assim que, como em tantos outros autores já vistos, seu Código Criminal contém não só aquilo que hoje tratamos por direito penal, como também por processo penal: formas de denúncia, julgamento, 
execução da pena etc., sem nenhuma separação distintiva em relação ao direito penal material. ${ }^{335}$

Nas Instituições, no mesmo sentido, o adjetivo "criminal" sempre é empregado para qualificar um tipo de jurisdição e nunca um ramo autônomo do direito substantivo: a justiça criminal, por oposição à justiça cível; as causas criminais, por oposição às causas cíveis; os Corregedores das causas-crime, por oposição aos das causas cíveis; e assim por diante. ${ }^{336}$ Os resultados a que isso leva, insisto, são relevantes, pois implicam, no fundo, a montagem de um objeto teórico distinto do nosso: havia uma série de classificações dos delitos em sua doutrina cujo sentido era meramente processual, e que não fazem sentido em um direito penal que, como o nosso, é "purificado" de matéria processual, como, por exemplo, os crimes que deixam vestígios e crimes que não deixam vestígios (Mello Feire, 1794: 57).

Por essa razão, apesar de já indiciar alguma especificidade do "criminal" em relação ao resto do direito positivo, Mello Freire deve ainda ser considerado fora do direito penal contemporâneo.

\section{OS FRANCESES}

A relevância da cultura jurídica de língua francesa no Brasil do século XIX é enorme. Em quase todas as áreas do direito, o impacto de autores francófonos e a influência das instituições francesas no direito brasileiro podem ser sentidos. Lopes (2007: 12) lembra que nosso modelo de inspiração para a definição dos traços principais do nosso Poder Judiciário no Império foi a França, o que foi objeto de muito debate por ocasião da reforma de 1871 (cit.: 6). Em matéria penal, vale lembrar que Batista e Zaffaroni (2002: 493) indicam que o Código Penal francês de 1810 foi o que mais inspirou Bernardo Pereira de Vasconcellos na redação de seu projeto. Entre os penalistas francófonos, dois nomes se destacam: Pellegrino Rossi e J. Ortolan.

\footnotetext{
335 O Título XLIV trata do delito de prevaricação; e, a partir do título seguinte (XLV), começa-se a tratar das provas, seguindo-se outras matérias processuais.

${ }^{336}$ Mello Freire cuida do tema sobretudo no Título II ("Dos Juízos") das Instituições.
} 


\subsection{PeLLeGRINo RosSI}

Pellegrino Rossi (1787-1848) teve expressiva importância para a cultura jurídico-penal brasileira. Um dos principais penalistas de língua francesa ${ }^{337}$ do século XIX, publicou uma das primeiras obras de fôlego sobre o direito penal a partir do código francês de 1810. Como o diploma napoleônico muito influenciou o brasileiro, a obra de Rossi acabou sendo muito usada pela cultura jurídica nacional, inclusive para a interpretação do nosso código. Seu Traité de Droit Pénal conheceu quatro edições, a última delas póstuma. A biblioteca desta Faculdade dispõe de todas elas, desde a primeira, de 1829, até a última, de 1872, que conta com uma longa introdução de Faustin Hélie, conselheiro da Corte de Cassação em Paris e posteriormente vicepresidente do Conselho de Estado francês. Tudo isso ilustra o seu prestígio na doutrina penal europeia do século XIX, e sugere também o seu relevo para países de cultura jurídica periférica como o Brasil. As obras dos penalistas brasileiros comentadas mais adiante são repletas de referências ao tratado de Rossi.

O Traité é denso e demanda atenção especial para sua boa compreensão, o que justificará o maior espaço a ele dedicado aqui. Ele é também interessante para o específico argumento deste trabalho porque, sendo Rossi tido por alguns como um "retributivista clássico" (Pires, 1998a: 14), seria instintivo situá-lo em um grupo apartado daquele a que pertence Feuerbach, o dos utilitaristas. ${ }^{338}$ Por essa razão, a sua obra, quando analisada em conjunto com a de Feuerbach e em oposição a ela, é especialmente importante para ajudar a entender como foi possível que, a partir de influências filosófico-morais tão antagônicas - retributivistas e utilitaristas -, uma só dogmática penal contemporânea, capaz de acomodar as duas correntes, tenha sido formada.

\footnotetext{
${ }^{337}$ Rossi era, entretanto, nascido na Itália, e só perto do fim da vida obteve cidadania francesa. Trato-o como um "penalista francês" porque sua obra foi toda escrita com vistas ao código francês, o que faz dele, do ponto de vista da cultura jurídica, mais francês do que italiano.

${ }^{338}$ Braz Florentino Henriques de Souza (1965: 16, nota 1) considera-o eclético, e não retributivista puro. Permanece, mesmo assim, a diferença com Feuerbach, que é tido como utilitarista puro.
} 
O primeiro fato relevante de se registrar é que Rossi considerava o direito penal como um ramo separado do direito civil, e utilizava os temos-chave da nossa disciplina - "delito", "crime", "pena" - já com a acepção contemporânea, estrita, que lhes emprestamos. Ainda mais digno de nota é o fato de que ele estabelece também uma distinção entre o direito penal e o restante do direito público - o "direito político", em suas palavras. Assim, nas primeiras páginas de seu tratado, Rossi cuida de diferençar uma coisa da outra, com uma sinceridade incomum para quem, como um dogmático, trabalha sobretudo com um discurso normativo:

A lei penal obriga a todos os cidadãos; mas, como comando, ela se volta principalmente às classes mais numerosas e menos esclarecidas, e como sanção penal, é sobre essas mesmas classes que ela recai com maior frequência Ela se distingue, nessa medida, tanto das leis políticas, quanto das leis civis. (1829, T. I: 32-3. Destaques meus.) $)^{339}$

Por esse fato, a lei penal tinha de se cercar de alguns cuidados com os quais não precisavam se importar as demais. Era o caso da clareza nas prescrições penais. Para Rossi, as leis incriminadoras tinham de ser escritas no "dialeto rude, pobre, irregular, mas vivo, franco e pitoresco dos mercados, dos cabarés, das feiras" (cit., T. I: 33). ${ }^{340}$ No último capítulo do seu tratado, dedicado ao problema da legislação criminal e sua redação, diz ele que a lei penal "deve falar uma linguagem positiva e explícita, conter a expressão do estado social do momento, e revelá-lo aos cidadãos" (cit., T. III: 223). O fato de Rossi dedicar todo um capítulo à lei penal formal mostra o quanto a legalidade já havia se tornado um problema fundamental de sua teoria penal: não só o direito penal precisava de leis e formava-se a partir delas, mas essas leis demandavam atenção especial quanto a sua forma e técnica de redação, considerados seus objetivos e

\footnotetext{
339 "La loi pénale oblige tous les citoyens; mais, comme instruction, elle s'adresse principalment aux classes les plus nombreuses et les moins éclairées, et comme sanction pénale, c'est sur ces memes classes qu'elle frappe le plus souvent. Elle se distingue en cela des lois politiques et civiles".

340 "Or, aver nos langues prudes, dédaigneuses et tou embarassées de leur étiquette, esti-il aisé de se faire comprendre de ceux qui n'ont jamais entendu que le dialecte rude, pauvre, irrégulier, mais vif, franc, pittoresque de la halle, des cabarets, de la foire? Cependente, et surtou d'aprés certaines théories pénales, c'est à ceux qui sont les plus exposés à tomber dans le crime qu'il est indispensable de fair comprende la loi".
} 
âmbito de aplicação. Não se trata, portanto, apenas de postular a importância política da legalidade como fator de proteção de direitos e contenção de arbitrariedades, tal qual se vê em Beccaria; mas, isto sim, de dar a ela um papel substantivamente relevante na construção do direito penal como um objeto teórico. O que se vê aqui é a legalidade cumprindo múltiplos papéis, portanto: centralizando o poder criador de delitos, contendo potenciais arbitrariedades, e potencializando a (imaginada) eficiência pacificadora do direito penal a partir da comunicação clara da proibição. É, por caminhos distintos, algo semelhante ao que se viu em Feuerbach.

Isso tudo, diga-se de passagem, apesar do fato de Rossi sustentar uma ligação forte entre moralidade e direito penal. A esse propósito, diz ele no começo de seu tratado que

a lei penal, entre todas as espécies da legislação, é a que mais diretamente pode influenciar sobre as noções universais da ordem moral. É pela lei penal que o poder exerce mais particularmente a missão de declarar, de maneira imperativa, na esfera da ordem pública, os princípios do justo e do injusto, do bem e do mal (1829, T. I: 8 . Destaques meus). ${ }^{341}$

Em que pese essa posição, o autor francês não minimizava a importância das leis estatais, deixando claro que o direito penal dependia, em absoluto, da positivação:

Sem dúvida não é a lei positiva que cria o direito, seja aquilo que nós chamamos de direito penal ou de direito civil, ou outro direito qualquer. O direito preexiste a todas as coisas. As noções de direito se manifestam nos povos antes de o legislador sujeitá-los às leis escritas. Apesar disso, (...) o direito penal, em todo Estado bem regrado, não admite alternativa: ele deve ser verificado pela lei positiva escrita; e não pode ser levado em conta senão nessa condição (cit., T. I: 8-10. Destaques meus). ${ }^{342}$

\footnotetext{
341 "La loi pénale est de toutes les parties de la législation celle qui peut influer le plus directement sur les notions universelles de l'ordre moral. C'est par la loi pénale que le pouvoir exerce plus particulièrement la mission de déclarer d'une manière imperative, dans la sphère de l'ordre public, les princpies du juste et de l'injuste, du bien et du mal".
} 
A postura de Rossi parece ser ambígua no que diz respeito a sua aceitação, ou não, da legalidade constitutiva. Pois se, de um lado, ele reconhece a importância formal da lei penal, de outro lado ele parece impor uma restrição substantiva ao conteúdo do direito penal, restringindo seriamente, à primeira vista, a capacidade política de criação dos delitos (algo que, como vem sendo dito, é uma das propriedades centrais do nosso direito penal). A resolução desse impasse requer, portanto, precisar o que seja esse conteúdo moral necessário das leis penais.

Uma boa pista é dada por uma passagem introdutória de seu tratado, que comenta o atraso relativo dos outros povos europeus em relação à legislação penal napoleônica de 1810. O argumento de Rossi é que a história é recheada de exemplos de povos que foram massacrados por suas próprias leis penais: "a opressão material produz, a longo prazo, a degradação moral do homem", diz (cit.: T. I, 11). ${ }^{343}$ Para corroborar sua tese, cita a falta de liberdades do povo ibérico durante a inquisição católica, das colônias americanas durante o domínio metropolitano europeu e dos católicos pelos protestantes no Reino Unido. (cit.: T. I, 11-13). Daí resulta, para ele, a ligação íntima entre a ordem moral e as grandes formas da ordem política em todas as sociedades civis, incluindo o direito penal.

Entretanto, isso não quer dizer que o delito criminal confunda-se com o mal moral; quer dizer apenas que a atuação estatal como um todo deve ser orientada pelas regras de moralidade, que indicam os fins bons para a vida humana sobre a terra. Como se vê, o argumento é muito semelhante àquele que Feuerbach ventila em suas obras não penais, como Kritik e Anti-Hobbes. ${ }^{344}$ Em palavras simples, Rossi parece dizer que o direito e o Estado servem para ajudar o homem a atingir as suas plenitudes, e não para atrapalhá-lo com uma legislação penal abusiva, retrógrada e contrária aos

\footnotetext{
342 "Sans doute ce n'est pas la loi positive qui crée le droit, pas plus ce que nous appelons le droit pénal que ce que nous appelons le droit civil ou tou autre droit quelconque. Le droit préexiste à toutes choses. Les notions du droit se manifestent chez les peuples avant que le législateur en fasse le sujet de ses lois écrites (1929, T. I: 8-9). Cependent, (...) le droit pénal, dans tou État bien réglé, n'admet pas l'alternative; il doit étre constaté par la loi positive écrite; force ne peut lui être prêtée qu'a cette condition".

343 "L'opression materielle produit, à la longue, la dégradation moral de l'homme".

${ }^{344}$ Lembremos que, como eu já disse um pouco atrás, Rossi (cit.: 112) expressamente reconhecia Feuerbach como o maior penalista alemão de seu tempo.
} 
interesses da sociedade. Em um nível muito elevado de generalidade, isso pode ser visto como concordante com as filosofias políticas de Kant e Hobbes. ${ }^{345}$ Assim, faz perfeito sentido que o conteúdo moral mínimo do direito penal, como de toda ordem jurídica, seja expresso por aquilo que hoje reconhecemos como as condições mínimas para uma vida potencialmente boa, e que Feuerbach defendia abertamente: a "dignidade humana". Isso fica claro logo no início de seu trabalho:

É preciso de um lado evitar de confundir os preceitos da moral com as regras do direito penal. Com efeito, a justiça de Deus e aquela dos homens não seriam as mesmas, nem para a compreensão do direito, nem para a perfeição dos meios. Mas ao mesmo tempo, porque o legislador não pode nem deve aplicar coativamente, em toda sua compreensão, os princípios de ordem moral, deve ele agir como se eles lhes fossem estranhos, e seu poder derivasse de outra fonte? (...) Essa não pode ser a doutrina de qualquer um que reconheça que a lei penal, destinando-se à manutenção da sociedade, deve ter seu ponto de partida nos princípios da justiça absoluta e não pode contrariar os deveres da humanidade e da dignidade do homem (cit., T. I: 18-9. Destaques meus). ${ }^{346}$

$\mathrm{O}$ argumento de Rossi, portanto, leva justamente para o oposto daquilo que a sua moralização de sua teoria do direito parece sugerir à primeira vista: dado que a ordem jurídica é uma criação humana, ela deve submeter-se às mesmas regras de moralidade a que estão sujeitos os demais atos humanos, vale dizer, respeitar a dignidade dos demais seres racionais e respeitar a integridade da humanidade. Não se trata, portanto, de apontar a existência de um direito penal sobrenatural ou divino - ao contrário: "É preciso de um lado evitar de confundir os preceitos da moral com as regras do direito penal", adverte ele. Trata-se, isso sim, de postular que direito penal é absolutamente humano, mas que ele é, contudo, submetido ao mesmo escrutínio

\footnotetext{
${ }^{345}$ Sobre Kant, v. Höffe, 2005: 258 e ss.; sobre Hobbes, v. Ribeiro: 2004, 90 e ss.

346 "Il faut d'un côte se garder de confondre les préceptes de la moral aves les règles du droit pénal. En effet, la justice de Dieu et celle des hommes ne saurient être les mêmes, ni par l'entendue du droit ni par la perfection de moyens. Mais en même temps, parce que le législateur ne put ni le doit appliquer coactivement, dans toute leur entendue, les principes de l'ordre moral, doit'il agir comme s'ils lui étaint étrangers et que son pouvoir à lui dérivât d'une autre source? (...) Telle ne saurait être la doctrine de quinconque reconnaît que la loi pénale, tou en bronant son action au maintien de la société, doit prendre son point de départ das les principes de la justice absolue et ne rien se permettre de contraire aux devoirs de l'humanité et à la dignité de l'homme".
} 
racional de todas as nossas demais ações, com o agravante de que o ofício de legislar penalmente diz respeito, mais diretamente do que qualquer outro, à manutenção dos pressupostos da ordem social (paz, consenso, ausência de conflito) - o que, para muitos autores até então, era o fundamento do próprio Estado e de toda a ordem jurídica inerente a uma sociedade civil.

Seu argumento é, em essência, muito semelhante ao de Feuerbach se considerarmos a totalidade da obra feuerbachiana: o direito penal não é moral no sentido de ser o instrumento para a imposição de uma determinada orientação religiosa sobre a humanidade; é moral no sentido de que é um instrumento político a serviço da dignidade humana, cujo respeito é uma exigência racional-moral. Por isso, é moralmente exigível que a legislação penal se manifeste em conformidade com a dignidade humana, e não em oposição a ela: protegendo o ser humano e a vida em sociedade, e não os destruindo. Eis o porquê de ele abrir seu tratado dizendo que "o direito penal é o ramo mais importante, talvez, sob o ponto de vista moral, da ciência das leis" (cit.: T. I: 2). ${ }^{347}$

Só assim é possível entender as semelhanças e diferenças que Rossi estabelece entre delitos morais e delitos penais. Pois se, de um lado, o delito criminal é sempre uma imoralidade, porque atenta contra os objetivos morais da vida humana ao instrumentalizar um inocente e negar-lhe dignidade, não é qualquer delito moral que pode ser penalizado, pois os delitos criminais têm um requisito adicional, que se pode chamar de "danosidade"(a provocação de dano externo), na mesma linha do que diziam Kant e Feuerbach. O caminho do delito moral para o delito penal é, portanto, uma progressão de especificidade. O caráter fundamental de qualquer delito é a violação de um dever. Sem isso, não há delito, genericamente falando (1829, T. II: 5-6). Mas só é delito penal a violação do dever exigível que prejudique a sociedade, direta ou indiretamente (1829, T. II: 6-7), e que esteja previsto nas leis estatais. Logo, qualquer delito provoca um mal puramente moral, mas esse não é em princípio exigível pela justiça humana (1829, T. II: 29); a punição criminal exige também um mal que seja

347 "Le droit pénal est la branche la plus importante, peut-être, soit sous les rapports moraux, soit sous les rapports politiques, de la science des lois." (1829, T. I: 2). 
social, além de moral. Por isso Rossi diz que a essência do delito criminal é um "mal misto" (1829, T. II: 34-5), mas que não se confunde, de forma alguma, com as violações dos deveres morais. Sua acepção de delito criminal é absolutamente estrita:

Na linguagem técnica mais aceita, entende-se por delito todo ato ligado a uma sanção penal. Apenas disso o legislador francês deu essa significação aos atos criminais em que a pena não ultrapasse determinado limite; ele reservou para os atos mais graves a noção de crime (1829, T. II: $1-2$. Destaques meus). ${ }^{348}$

Os delitos e crimes, sendo imorais por definição (porque anti-sociais), terão ligados a si um outro mal, chamado pena:

A punição consiste na imposição de um mal, intencionalmente, em razão de um fato anterior, irreparável, sem ter em conta a vontade do paciente, e sem ter em vista uma vantagem futura para ele, só pode ser um direito enquanto tem por objeto o ato de um mal injusto; essa é sua essência. Se fazemos a abstração por um só instante da ligação moral que deve existir entre o fato punível e o fato da pena, o direito de punir desaparece. (1829, T. I: 130. Destaques meus). ${ }^{349}$

A pena criminal destacava-se assim da civil, pelo fato de consubstanciar-se em um castigo puro e simples: "A justiça repara e pune; repara pelas condenações civis, e pune pelas condenações criminais" (cit. T. I: 285. Destaques meus). ${ }^{350}$ É da essência da pena ser um mal, que o criminoso faz por merecer em razão do mal por ele praticado. Essa definição é possivelmente a razão pela qual Rossi foi apressadamente colocado por alguns no escaninho dos retributivistas clássicos.

\footnotetext{
348 "Dans le langage technique le plus généralement reçu on entend par délit tout acte frappé d'une sanction pénale. Cependant le législateur français en a borne la signification aux actes criminels don't la peine ne dépasse pas une certaine mesure; il a reserve pour les actes les plus graves le mot de crime."

349 "La punition constitant à infliger un mal, intenrionnellement, en raison d'un fait antérieur, même irréparable, sans tenir compte de la volonté du patient, et nullement en vue d'un avantage future pour lui, ne peut etre un droit qu'autant qu'elle a pour objet l'auter d'un mal injuste; c'est là son essence. Si on fait abstraction un seul instant de la liaison morale qui doit exister entre le fait punissable et le fait de la peine, le droit de punir disparait".

350 "La justice répare; elle punit; Elle répare par les condamnations civiles; elle punit par les condamnations criminelles".
} 
Sua definição retributiva de pena, juntamente com o papel utilitarista de seu direito penal (comentado adiante), davam os pontos de partida para uma reunião entre retributivismo e utilitarismo muito semelhante à feita por Feuerbach, mostrando o quanto esse ecleticismo foi um traço marcante da fundação de nossa disciplina. Pois tanto Feuerbach, tido por todos como utilitarista, quanto Rossi, tido por alguns como retributivista, compartilham certos elementos que são suficientes para a superação de suas contradições supostamente insuperáveis: (i) a pena é um mal, como o é também o crime; (ii) Estado e direito penal têm, além de evidentes fundamentos morais, também um papel político que deve ser inteligentemente exercido considerando seus fins práticos; e (iii) a violência estatal (pena) é o instrumento hábil para garantir as condições sociais que interessam a todos. Por isso é que, a despeito do caráter absoluto do mal-crime e do mal-pena, o desenho do direito penal estatal envolve principalmente uma tarefa de seleção utilitária (preventiva) das condutas que convém criminalizar. A tarefa da legislação penal é, portanto, a de "reconhecer, entre os atos injustos, aqueles que a sociedade deve punir" (1829, T. I: 20) $)^{351}$ - e não o de punir cegamente toda e qualquer imoralidade. E, é claro, a legalidade tem um papel fundamental na criação desse direito penal político.

Num dos capítulos do primeiro tomo de seu tratado, Rossi acusava o interminável debate entre retributivistas e utilitaristas - "espiritualistas" e "sensualistas", nas suas palavras - dizendo que eles brigavam "no mundo, e também no direito penal". Após reconhecer a validade do retributivismo, Rossi rejeita, uma a uma, as doutrinas "sensualistas" enquanto princípios absolutos da punição criminal. Mas isso não quer dizer que ele as tenha expulsado do direito penal, e nem negado sua utilidade; ele apenas não aceita, e diz isso repetidas vezes, que elas sirvam como o fundamento primeiro para a punição, como, na sua leitura, defendiam principalmente os utilitaristas ingleses (cit.: 1829, T. I: 135-82).

\footnotetext{
351 "Faire la li, c'est reconnaître quelles sont, parmis les actions de l'homme, les actions injustes,parmi les actes injustes qui son assez nuisibles pour que la société doive les puinir; enfin, quelle en doit être la punition, pour éviter égalment de dépasser ou de manquer le but de la justice humaine".
} 
Mas ele aceitava, sim, que o utilitarismo tivesse um papel importantíssimo no direito penal, o que é claramente expresso por ocasião de seus comentários sobre as doutrinas penais "sensualistas":

A utilidade não é um princípio supremo, gerador primitivo de nossos direitos e deveres; é um motivo; ela pode e deve ser para a sociedade uma medida, no exercício de poderes derivados de uma fonte mais elevada (cit.: T. I, 184. Destaques meus.)

Dessa forma, a aceitação racional da punição de um outro ser humano só podia ser moral, dado os conceitos de "crime" e "pena" como duas formas de mal. A utilidade seria apenas matéria de fato, orientando uma atuação concreta e particular, corporificada na legalidade, mas sem a propriedade de fundamentar universal e absolutamente a punição (cit., T. I: 185). No exercício particular e estratégico do poder penal como pacificador social, entretanto, ela jogava sem dúvida um papel relevantíssimo, ainda que derivado da permissão moral. Pois, se em seus fundamentos remotos a justiça penal seria uma permissão e um dever moral, em sua atuação concreta ela não deixa de ser informada por objetivos estratégicos (políticos) de natureza distinta, inerentes inclusive ao seu papel (moral) de servir a fins práticos no mundo. Por isso é tão relevante a distinção que Rossi faz entre justiça social e justiça moral:

A justiça humana é um elemento de ordem social; a justiça absoluta, um elemento de ordem moral. O objetivo da justiça absoluta consiste em seu próprio cumprimento; ele é, porque ele é. $O$ objetivo da justiça humana é exterior e delimitado. (cit., T. I: 289. Destaques meus.)

Com isso em vista, é mais fácil entender o que ele quis dizer na abertura de seu livro ao sustentar que

o direito penal se compõe de uma parte absoluta e de uma parte relativa, de uma parte variável e de uma parte invariável, de uma parte sobre a qual o homem nada 
pode, e de uma parte que ele pode modificar ao modificar sua própria maneira de ser; em poucas palavras, de preceitos de justiça e de regras de utilidade. ${ }^{352}$

Assim ele foi capaz de unir utilitarismo e retributivismo em uma mesma teoria penal, como muitos de nós fazemos até hoje.

Cabe agora um último comentário sobre a obra de Rossi, respeitante à representação teórica do direito e do processo penal. O que se percebe aqui é, como no tema da união conceitual entre moralidade e direito penal, uma linguagem ambígua, para fins de sua situação dentro ou fora do direito penal contemporâneo; mas que, como no primeiro caso, já indica um passo importante no sentido da nossa divisão contemporânea das disciplinas, separando uma coisa da outra.

Rossi fala muitas vezes do direito penal como "justiça penal", o que indubitavelmente indica uma representação conjunta entre direito penal e direito processual: pois o termo refere-se não apenas à definição de delito e de pena e às regras de responsabilização, como no nosso direito penal, mas também a todo ofício estatal de pacificação social a partir da criminalização de condutas e administração de penas, unindo, portanto, direito penal, processo penal e política criminal. Assim, na introdução de sua obra e ao explicar os propósitos de seu tratado, diz ele o seguinte:

Nós procuramos estabelecer os princípios de onde derivam [todos os aspectos da legislação penal], segundo nós, e as leis da justiça criminal e as formas que lhe garantem execução; posteriormente, se tivermos razão para crer que este primeiro ensaio é útil, buscaremos aplicar esses princípios a cada delito em particular, à organização judiciária e ao processo. (Rossi, 1829, T. I: VII). ${ }^{353}$

\footnotetext{
352 "Le droit pénal se compose d'une partie absolue et d'une partie relative, d'une partie variable et d'une partie invariable, d'une partie sur laquelle l'homme ne put rien, et d'une partie qu'il peut modifier en modifiant sa propre manière d'être; en un mot, de précepts de justice et de règles d'utilite".

353 "Nous essayons d'établir les principes d'où doivent dériver, selon nous, et les lois de la justice criminelle et les formes qui en garantiraient l'exécution; plus tard, si nous avons quelquer renferme des vues utiles, nous chercherons à faire l'application de ces principes à chaque délit en particulier, à l'organisation judiciaire et à la procédure".
} 
Essa representação unitária aparece em diversos outros momentos do primeiro tomo do tratado. Quando Rossi comenta os principais problemas do direito penal de seu tempo, e as formas de resolvê-los, sua atenção está voltada a alguns pontos que nós hoje consideraríamos puramente processuais, como as formas para o aperfeiçoamento do julgamento pelo juri (cit., T. I: 96 e ss.). Entretanto, o conteúdo das partes seguintes à introdução principiológica de seu tratado mostra um direito penal já "purificado", em sua substância, de preocupações processuais: o segundo volume do tratado é todo dedicado ao problemas jurídicos ligados aos ilícitos criminais (crimes e delitos); e o terceiro, aos da pena criminal. Assim, no que diz respeito a seu conteúdo, a obra de Rossi é, a despeito de sua linguagem ambígua sobre a "justiça criminal", toda ela dedica ao nosso direito penal, em seu estado puro.

Os temas compreendidos em seu segundo e terceiro volumes já nos soam bastante semelhantes, e parecem caber "naturalmente" em um livro didático de direito penal: danosidade do crime, imputabilidade, culpabilidade, causas de escusa e justificação, erro, imputação, negligência, tentativa, comissão e omissão, participação e co-autoria, espécies de pena, lei penal etc. Logo, em que pese a ambiguidade (aos nossos olhos contemporâneos) de sua linguagem, explicável pelo momento histórico de separação entre duas disciplinas que até então apareciam conjuntamente, Rossi parece estar muito mais para dentro do direito penal contemporâneo do que para fora dele. Sua obra reflete o momento de transição que implicaria, como sabemos hoje, a separação do penal e do processo penal. Este ponto específico aparece com clareza na obra de Ortolan, tratada a seguir.

\subsection{J. ORTOLAN}

J. Ortolan foi professor da Faculdade de Direito de Paris e autor de duas obras muito lidas e citadas no período histórico compreendido por esta tese: Cours de Législation Pénale Comparée (1839, 1841) e Éleménts de Droit Penal (1855). O Cours era uma obra didática, uma espécie de compêndio feito por Ortolan para seus alunos de Paris, aos quais é inclusive dedicada a primeira edição do trabalho. Trata-se 
de uma exposição sobre o Código Penal de 1810, com acréscimos de comentários introdutórios que muito interessam a esta pesquisa (formação do direito penal, posição enciclopédica etc.). Divide-se em dois livros: o primeiro, de 1839, é uma introdução ao direito penal escrita pelo próprio Ortolan; o segundo, de 1841, é a transcrição de seu curso na Universidade de Paris por um aluno, M. G. Jarnot. Os Eleménts são uma obra mais extensa e destinavam-se não só às noções introdutórias da disciplina.

Ortolan foi contemporâneo de Rossi. As primeiras edições de suas principais obras têm apenas dois anos de diferença entre si: 1829, a de Rossi; e 1831, a de Ortolan. Tanto um quanto outro prosseguiram publicando durante suas vidas. Considerada a contemporaneidade de ambos, teriam tudo para ser muito semelhantes entre si. Surpreendentemente, a pesquisa mostrou que, no que diz respeito à pertença ao direito penal contemporâneo, se Rossi, com vimos, está dentro dele, ainda que às vezes utilizando-se de uma linguagem ambígua, Ortolan está mais para fora do que para dentro, ainda que sua teoria já acuse os principais caminhos para se chegar ao nosso direito penal.

Um primeiro elemento relevante está na representação acessória do direito penal de Ortolan, ainda muito semelhante à dos jusnaturalistas modernos, de Mello Freire e de Avellar Brotero: o professor de Paris permanece sustentando a tese de que o direito penal é na verdade uma parte de todos os ramos do direito. Para ele, todas as áreas do direito seriam representadas na legislação criminal, que previa crimes e penas para os direitos civil, comercial, político etc. Assim, não surpreende que Ortolan atribua ao direito criminal a função que os jusnaturalistas modernos, que distribuíam "crimes" e "penas" por todo o ordenamento, predicavam ao direito como um todo: garantir a força normativa da ordem jurídica e preservar a efetividade política do Estado pela aplicação de penas e, por esse meio, preservar a ordenação social: "A legislação penal tem por objetivo geral: fazer reinar o direito; e, por instrumento, o mal que se inflige por sua violação" (Ortolan, 1839: 71). ${ }^{354} 355$

\footnotetext{
354 "Ainsi la législation pénale a pour but general: fair régner le droit; et pour moyen, le mal infligé contre sa violation".

${ }^{355}$ Importante mencionar que, a essa altura, o Código Penal de 1810 já vigia há muito tempo, e mesmo assim Ortolan continuava a carregar uma visão pré-contemporânea do penal. Isso mostra como a
} 
A "descaracterização" do nosso direito penal a que leva essa posição fica bem evidente quando Ortolan cuida da posição enciclopédica do direito penal. Como não poderia deixar de ser, ele já conhece a grande divisão do direito entre público e privado: uma vez que o direito só existe em uma reunião de indivíduos em sociedade, diz ele, as relações jurídicas podem ser de quatro tipos distintos: (i) de homem a homem; (ii) de homem a sociedade; (iii) de sociedade a homem; e (iv) de sociedade a sociedade (cit.: 165). Apenas o primeiro caso (homem vs. homem) oferece elementos puramente privados, e só as relações jurídicas nascidas nesse tipo de relação serão de direito privado; todos os demais, por incluírem elementos de interesse social, serão de direito público. (cit: 166). O direito público, prossegue ele, pode ser interno ou externo, de forma que a classificação fundamental do direito contem três elementos: (i) direito privado; (ii) direito público interno; e (iii) direito público externo (cit.: 167).

Essas três categorias gerais subdividem-se mais adiante. $\mathrm{O}$ direito privado pode ser direito civil ou direito comercial. O direito público interno pode ser "direito social, direito político, direito administrativo, direito eclesiástico etc." (cit.: idem). Já o direito público externo ramifica-se em direito da paz, da guerra, das alianças, das relações comerciais, marítimo etc., "tudo à vontade do teórico ou do legislador". Mas Ortolan garante que não há outra combinação possível senão essa por ele indicada, pois ela leva em conta os dois critérios fundamentais de qualquer classificação jurídica: ora os sujeitos (homem e/ou sociedade), ora as matérias da relação jurídica.

Mas onde estava o direito criminal nessa classificação? Ao cuidar das áreas do direito pertencentes ao direito público ou privado, ele não é mencionado por Ortolan. Isso porque, segundo ele, o direito criminal pertenceria a todas as áreas do direito: "a penalidade se liga com todos esses ramos em conjunto, e com cada um deles separadamente, seja ela considerada nos princípios gerais de direito natural, seja em seus princípios de direito positivo" (cit.: 169). ${ }^{356}$

existência de um código não implica, por si só, a consolidação do direito penal contemporâneo na cultura jurídica de seu país, como já foi sustentado no Capítulo II.

356 "La pénalité se lie avec toutes ces branches ensemble, et avec chacune d'elles séparément, considérée soi dans ses principes généraux de droit naturel, soit dans ses principes positifs". 
Por isso, ele passa as próximas muitas páginas do Cours descrevendo o "direito penal" de todas as áreas do direito que definira: o direito penal público externo, o direito penal público interno, o direito penal social e político, o direito penal administrativo, financeiro, florestal, militar, marítimo, eclesiástico etc.

Segundo Ortolan, o direito penal só poderia ser considerado como parte do direito público interno, como hoje fazemos "naturalmente", quando focada apenas a autoridade necessária para a imposição da penalidade: ele não pode ser privado, porque uma pessoa particular não tem superioridade moral sobre a outra para puni-la, apenas a coletividade o tem; e, pela mesma razão, não pode ser público externo, por não haver relação de hierarquia moral entre as nações. Por exclusão, ele só seria parte do direito público interno quando considerado o direito de punição "em si mesmo" e abstraindo-se as relações jurídicas de onde nasce (cit.: 195). Ou seja: se o direito criminal pode ser considerado direito público - e o pode apenas sob um ponto de vista muito particular -, isso não se dá em razão dos interesses relevantíssimos por ele protegidos (interesse público), como hoje dizemos, mas sim pelo critério da autoridade necessária para a imposição de uma pena. De qualquer forma, esse não é o único critério de Ortolan, e nem parece ser aquele ao qual ele dá maior importância, razão por que não se pode dizer que ele inclua o direito penal já no âmbito exclusivo do direito público, ainda que ofereça uma pista de como isso pode ser feito. Trata-se claramente de um jeito bastante diferente de conceber a função do direito penal e os interesses por ele protegidos, mostrando o quanto é contingente a ideia hoje corrente de que o direito criminal (ou penal) é parte do direito público pela qualidade dos interesses que protege.

Um segundo ponto relevante diz respeito à representação do direito penal em relação com o processo penal. Na mais perfeita lógica dedutiva, Ortolan inicia afirmando o princípio de que a primeira divisão epistemológica possível para o direito é o trinômio Ciência / Legislação / Jurisprudência (cit: 63 e ss.). Transportando esse princípio para o direito penal, surgem três divisões também para a disciplina: (i) o direito penal em si mesmo, que ele chama de "penalidade" (pénalité); (ii) a jurisdição penal, entendida como o sistema orgânico de jurisdições e seus funcionários destinados à aplicação das penalidades; e (iii) o processo penal (cit. 74). Ortolan então reorganiza 
esses elementos e acaba por chegar a uma classificação binária, que divide o conteúdo do direito penal entre (i) a penalidade e (ii) o processo.

A penalidade e o processo, diz ele, "repartem as funções necessárias para chegar a seu resultado" (cit.: 72). ${ }^{357}$ À primeira cabe "determinar as violações do direito que receberão uma pena", bem como "determinar a pena para cada uma delas". 358 Ao processo, por sua vez, cabe investigar e constatar o delito, processar e condenar os culpados, pronunciar e fazer executar a pena, com uso dos corpos judiciários e outros funcionários públicos e estipulando seu meio de ação (cit: idem).

Assim sendo, o direito processual penal estava, para Ortolan, mais ligado ao direito político interno de um Estado do que à "penalidade" (o direito penal), que teria um papel mais dogmático e menos empírico do que o processo. O direito penal seria, portanto, mais científico, enquanto o processo penal, mais prático:

É sobre a penalidade que recai, com intensidade incomparavelmente maior, a preocupação da ciência geral. É sobre esse tema que nós vemos professarem-se mais tratados, mais sistemas, mais teorias. $\mathrm{O}$ processo penal nos oferece muito menos. (cit.: 85$){ }^{359}$

Ou seja, pela metodologia dogmática e abstrata exigida pela "penalidade" diante dos seus principais problemas - definição abstrata de crimes e penas -, o processo penal ficava em segundo plano na disciplina. Se Feuerbach já havia expulsado o processo penal por completo dos domínios do direito penal, Ortolan caminhava a passos firmes no sentido dessa mesma separação, ainda que não a tenha levado às últimas consequências em seu trabalho. Vale dizer, ainda que fosse perfeitamente possível enxergar o direito e o processo penal como partes de um mesmo

\footnotetext{
357 "La pénalité et la procédure pénale viennent se partager les fonctions nécessaires pur arriver au résultat".

358 "Déterminer les violations du droit qui entraîneront une peine; Déterminer la peine pouc chacune d'elles".

359 "C'est sur la pénalité que se porte, avec incomparablement plus d'activité, la préoccupation de la science générale. C'est sur ce sujet que nous voyons émettre au jour plus de traités, plus de systèmes, plus de théories. La procédure criminelle nous en offre beaucoup moins".
} 
saber teórico (o "direito criminal"), porque ocupados de um mesmo assunto prático, a doutrina de Ortolan, mesmo tratando-os em conjunto em um único Cours, já aponta elementos importantes para a distinção teórica entre um e outro saber, distinção essa que para nós, quase dois séculos depois, está mais do que sacramentada.

Por tudo isso, fica muito claro que Ortolan estava montando um objeto teórico ainda diferente do nosso direito penal, razão pela qual sua doutrina não pode ser considerada inteiramente como parte dele; mas que já continha algumas pistas sobre os caminhos percorridos para a afirmação do nosso direito penal. Pois se, de um lado, ele insiste na ideia de um direito penal de acompanhamento, acessório a todos os demais ramos do direito, por outro, sua teoria já oferece critérios teóricos, e não meramente práticos, para a separação entre direito penal ("penalidade") e processo penal, bem como para a classificação do direito penal apenas no âmbito do direito público. Do ponto de vista da história das ideias jurídico-penais, seu trabalho é extremamente revelador, por mostrar as possíveis frestas pelas quais alguns dos pontos-chave do direito penal contemporâneo provavelmente emergiram.

O primeiro deles diz respeito a uma das formas possíveis para que o direito penal tenha se tornado uma parte do direito público, a despeito de tantos doutrinadores do século XIX indicarem tantos elementos privados em sua substância. Em um mundo de ideias jurídicas cuja porta de entrada era distinção entre público e privado, uma disciplina híbrida ficava pouco à vontade, e Ortolan parece oferecer um meio para a solução do impasse: a consideração exclusiva da autoridade de punir, que tinha de ser pública e interna, em detrimento das lesão causada pelo ofensor, ou dos bens lesionados do ofendido - que, no mais das vezes, eram, como ainda são, puramente privados. Talvez isso ajude a entender o porquê de, em muitos penalistas, a porta de entrada para o direito penal ser ainda hoje uma teoria do direito de punir criminalmente.

$\mathrm{O}$ segundo tange à separação entre direito penal e processo penal. Se àquela altura já era comum tratar a diferença entre direito e processo penal como uma distinção entre uma parte teórica e uma parte prática de um mesmo saber, Ortolan revela 
que essa "parte teórica" parece ter colonizado as atenções dos professores, que se ocuparam em desenvolver uma metodologia mais apta, por isso, às questões "teóricas" conceituais ou dogmáticas, diria eu - e, por isso, empobreceram a produção desse saber unificado em relação a sua parte prática, o processo penal. Dessarte, enquanto pululavam na doutrina tratados e sistemas de direito penal, o desenvolvimento teórico do processo penal a seu tempo era, segundo ele, insignificante, pois o direito penal tinha de se ocupar da definição estrita de delitos e penas, deixando em segundo plano a realização prática da punição estatal, invertendo destarte o foco pré-liberal da disciplina, que recaía principalmente sobre os aspectos procedimentais da punição.

\section{ItÁlia: Giandomenico Romagnosi}

Romagnosi (1761-1835) foi um pensador italiano de influência duradoura no direito penal brasileiro. A despeito de sua principal obra jurídico-penal haver sido escrita no final do século XVIII, não era incomum que livros de meados do século XX ainda o citassem em abundância. Basileu Garcia, por exemplo, faz-lhe referência em diversas passagens de suas Instituições de Direito Penal, de 1956, além de mencionar o fato de que, em meados do século $\mathrm{XX}$, ele ainda era largamente estudado na Itália (1956, T. I: 67 e ss.). Bento de Faria, em suas conhecidas Annotações Theorico-Praticas ao Codigo Penal do Brazil (1919), também menciona a obra de Romagnosi. Na apreciação das doutrinas do direito de punir de fundamento defensivo, Camargo (1881-2: 178) cita-o ao lado de Feuerbach, como também faz Basileu Garcia (cit: idem). Ou seja, Romagnosi é um autor cujas opiniões foram levadas em conta, em diferentes medidas, na interpretação dos três primeiros códigos penais do Brasil independente.

Sua mais conhecida obra penalística é Genesi del diritto penale, de 1791. Romagnosi começa tecendo considerações gerais sobre as penas de que vai tratar. $\mathrm{Na}$ introdução do livro, esclarece o seguinte: 
Dizem os publicistas do direito que as penas são necessárias para a segurança interna do Estado; por conseguinte, o soberano, que é seu defensor e vindicador, tem o direito de estabelecê-las e infligi-las (1791: 5. Destaques meus). ${ }^{360}$

A passagem, note-se bem, é ambígua no que diz respeito à existência ou não de um direito penal como objeto autônomo, pois ela tanto pode fazer referência a um direito de penalidade à moda pré-contemporânea (um direito de impor penas em geral), quanto ao direito de punir criminalmente, no sentido contemporâneo. Mas não deixa dúvidas quanto à velha representação da pena como o instrumento de preservação da paz no corpo social.

Um pouco mais adiante, é possível concluir que Romagnosi ainda está utilizando o "penal" no sentido pré-contemporâneo da palavra, ou seja, para designar toda e qualquer reação estatal a um ato ilícito:

Se ao vocábulo pena se une de ordinário a ideia de um mal que alguém sofre, por haver cometido uma ação indevida, o direito penal será portanto, o direito de infligir esse mal ao delinquente (cit.: 14. Destaques meus.) ${ }^{361}$

O fato de que Romagnosi seja tido por nós, hoje, como um penalista do século XVIII, e não como um teórico geral do direito de então, é mais um indicativo de como o nosso direito penal contemporâneo herdou, por apropriar-se dos conceitos e das justificativas de "crime" e "pena", a missão ampla de pacificação social e eliminação de dissenso, que no início da modernidade era a missão por excelência de todo a ordem jurídica. Em Genesi del diritto penale, com efeito, Romagnosi não está nem de perto trabalhando com um objeto teórico que seja parecido com o nosso direito penal contemporâneo; está, isto sim, investigando, no plano filosófico, o direito de punir amplamente considerado - o direito estatal de impor penas em resposta a atos ilícitos jurídicos, sem

\footnotetext{
360 "Dicen los publicistas del derecho que las penas son necesarias para la seguridade interna del Estado; por conseguinte, el soberando, que es su defensor y vindicador, tiene el derecho de estabelecerlas y infligirlas".

361 "Si al vocablo pena se une de ordinario la idea de un mal que alguno sufre, por haber cometido una acción indebida, el derecho penal será, por tanto, el derecho de infligir ese mal al delincuente".
} 
qualquer especificação de um ramo do direito em particular. Ele não faz, por exemplo, a diferença que décadas depois Ahrens faria entre as respostas jurídicas civis e criminais, as primeiras destinadas à compensação e as últimas à punição. É clara a falta de especificidade do "direito penal" com que trabalha. Apenas para ilustrar, tome-se a sua definição de delito: "um ato realizado com inteligência e liberdade de execução, nocivo para os demais e injusto". (cit. 219).

Mas nem por isso sua obra deixa de nos fornecer importantes pistas sobre alguns dos porquês do direito penal contemporâneo, pois, como já foi dito, ele foi uma fonte importante para os argumentos dos penalistas que, no século subsequente, construíram o nosso direito penal. Nesse sentido, há, além da já citada apropriação por parte do direito penal do propósito geral de pacificação social, dois outros pontos que precisam ser comentados com vagar: (i) a composição entre utilitarismo e retributivismo em sua teoria; e (ii) a representação de um objeto teórico segundo a metodologia da parte geral e parte especial.

Se tomarmos a sua primeira aproximação à definição de pena em Genesi, já citada ("se ao vocábulo pena se une de ordinário a ideia de um mal que alguém sofre, por haver cometido uma ação indevida, o direito penal será portanto, o direito de infligir esse mal ao delinquente"), é possível acessar o tema da conciliação entre retributivismo e utilitarismo em sua teoria. Essa primeira etapa da conceituação de Romagnosi é, note-se bem, cabível tanto às teorias utilitaristas quanto às retributivistas; pois ele simplesmente conceitua o ilícito como uma "ação indevida", e a pena como um "mal". Romagnosi reconhece isso ele próprio, ao dizer que sua posição, se tomada como uma definição, seria "excessivamente vaga", por não permitir distinguir a pena da vingança. Entretanto, ao buscar o princípio fundamental de todo direito de punir, Romagnosi deduz, a partir de pressupostos antropológicos tipicamente iluministas, o princípio da igualdade como fundamento primeiro do direito e da moral:

Qualquer coisa que no estado de natureza se afirme de um homem em particular, verifica-se em todos; e aquilo que se pode exigir dos demais, pode-se também exigir dele da mesma forma. Em suma, falando de direitos, em tal estado tudo é recíproco e igual. Esse princípio da igualdade, fundamento primeiro da chamada equidade 
rigorosa, e medida única do direito e da moral social, traduz-se da seguinte forma: aquilo que não queres que façam a ti, não faça aos outros; e o que exige dos demais, faça em benefício deles (cit.: 17). ${ }^{362}$

Vale dizer, mesmo rejeitando a sinonímia entre pena e vingança, tal qual usualmente atribuído aos retributivistas por seus críticos, Romagnosi deduz, como princípio primeiro do direito e da moral, uma regra muito semelhante à "regra de ouro", que sabidamente fica bastante à vontade nas teorias punitivas de índole retributiva. ${ }^{363}$ Porém, ele deixa claro que esse princípio tem um papel restrito - a despeito de importantíssimo - em uma teoria da pena: ele dá a medida da justiça do direito de punir, ou melhor, de toda e qualquer relação de direitos entre seres humanos (cit.: 18).

Mas o fato é que Romagnosi é tratado pela vasta maioria dos penalistas como um utilitarista. Basileu Garcia sustenta que a pena em Romagnosi não tinha por escopo "atormentar seres sensíveis" e sim "evitar os crimes" (Garcia, 1956, T. I: 70). Camargo, em sentido semelhante, dizia que para Romagnosi a pena seria "um meio de intimidação que a sociedade emprega para manter a ordem", desaconselhando os "futuros delinquentes" pelo exemplo (1881-2: 185). De fato, Romagnosi registra diversas passagens que suportam a sua eternização como utilitarista. A terceira parte do trabalho, que mais diretamente interessa aos penalistas por entrar diretamente em discussões estritamente penais (as duas primeiras partes de Genesi são puramente filosóficas), amplamente sustenta essa visão, ao postular que a única pena justa é aquela

\footnotetext{
362 "Cualquier cosa que en el estado de naturaleza se afirme de un hombre en particular, se verifica en todos; y lo que é puede exigir de los demás, ésto lo pueden exigir de é en la misma forma. En resumen, hablando de derechos, en tal estado todo es recíproco e igual. Este principio de la igualdad, fundamento primeiro de la llamada equidad rigurosa, y medida úncia del derecho y de la moral social, se traduce así: lo que no quieras que te hagan a ti, no lo hagas a los otros; y, lo que exiges de los demás, practícalo con ellos".

${ }^{363}$ Sobre a semelhança entre a regra de ouro e o imperativo categórico de Kant, v. Kaplov e Shavell (2001: 1062).
} 
necessária para evitar delitos em sociedade, ${ }^{364}$ ideia que é repetida à exaustão até o fim do livro.

Mas, como vem sendo dito desde o início desta tese, uma parte importante da compreensão do nosso direito penal contemporâneo está em, ao invés de focar as diferenças pontuais entre todos os autores que o deram forma, buscar os seus pontos de semelhança. E as primeiras páginas de Genesi mostram que no ditoutilitarista-puro-Romagnosi, encontra-se como primeira abordagem conceitual da "pena" a ideia, compartilhada com retributivistas, de que a pena é um "mal" aplicada a um "ato mal indesejável", cuja medida primeira está na relação de igualdade que é inerente a todas as relações jurídicas e morais. Note-se bem: todos esses pontos (crime como mal; pena como mal; relação de igualdade (proporcionalidade) entre o crime-mal e a pena-mal; e direito e moral como partes da moralidade) estão também nas bases da teoria kantiana, que se costuma dizer puramente retributiva.

O fato de esse primeiro passo ser tido por Romagnosi como uma mera aproximação de um conceito, e não como uma definição pronta, não significa ele não tenha sido dado e nem que seja um passo desimportante. Muito ao contrário, ele representa uma escolha fundamental que limitará todas as etapas posteriores de sua definição. A ideia de que um direito penal possa atuar com recompensas, por exemplo, é difícil de ser sustentada quando a pena é essencialmente definida como um mal. Assim como também o é a punição de inocentes em benefício da coletividade diante da postura de que a pena é um mal perante outro mal. Como nas obras de outros penalistas aqui já vistos, o utilitarismo entra como uma medida para a aplicação concreta da pena com vistas a seus objetivos, mas a essência da pena é retributiva, na linha do "um mal para outro mal". A pena ganha assim a feição, ainda comum em nossas teorias atuais, do mal útil diante de outro mal: "Só em virtude da necessidade nascida do fato nocivo, pode ver-se o homem autorizado a causar um dano a outro homem". (cit.: 21. Destaques meus).

\footnotetext{
364 "Toda pena debe ser necesaria para que sea justa. (...) El fin único de las penas consiste en apartar los delitos de la sociedad. Luego una pena será justa únicamente cuando sea necesaria para alejar los delitos de la sociedad" (cit.: 158). Ou ainda, mais adiante: "Qual es el princpio que justifica el uso de las penas? Univamente la necesidad. (...) Por conseguinte, la necesidad constitue el único y gran principio del cual nunca le será permitido al filósofo y al legislador separarse en lo más mínimo" (cit.: 160).
} 
O tratamento de Romagnosi como utilitarista puro obscurece o fato de que sua primeira conceituação de pena como mal devido em virtude de um mal praticado é um ponto compartilhado com o retributivismo. Tanto assim que, pouco adiante, ele se antecipa àquilo que era a crítica fundamental aos utilitaristas e esclarece que não aceitava a punição de inocentes por critérios utilitários:

\footnotetext{
Se a necessidade atribui a alguém o direito de causar dano a outros para não sofrê-lo, por identidade da razão deve assistir aos demais o direito de causar-lhe dano para não sofrê-los eles mesmos. Dessa forma, não existindo outra razão que não a pura necessidade para causar um mal a um semelhante seu, com o fim de preservar a si mesmo de um mal, um homem não terá qualquer preferência de direito sobre outro (cit.: idem. Destaques meus). ${ }^{365}$
}

É importante notar o quanto essa postulação do utilitarista Romagnosi é semelhante à de Pellegrino Rossi, tido por alguns como retributivista. Rossi, como já foi dito, dizia que o retributivismo dava a permissão moral para o exercício da punição (seu "princípio supremo", em suas palavras); enquanto a utilidade indicava o "motivo" que "pode e deve ser para a sociedade uma medida" no exercício do poder de punir (Rossi, 1829, T. I: 184. Destaques meus). Romagnosi diz aqui coisa muito semelhante: do ponto de vista ideal-racional, a ideia de que um mal pode ser aplicado por um homem a seu semelhante só se sustenta diante do pressuposto de que tal semelhante tenha feito um mal a outrem; nesses casos, pelo princípio fundamental da equidade, o mal é cabível diante do mal, e existe um verdadeiro direito de apenar. Mas esse princípio não fornece, por si só, os elementos suficientes para a aplicação concreta desse mal: é preciso saber, também, a forma útil de aplicá-lo dentro das hipóteses do moralmente possível e estar ciente inclusive da possibilidade prática de não aplicá-lo se ele mostrar-se inútil, ainda que moralmente permitido por um critério estrito de justiça igualitária. Mas tal consideração prática não prescinde por completo da autorização moral para a aplicação do mal-pena. Quando, diz Romagnosi, um homem quer provocar

\footnotetext{
365 "Si la necesidad atribuye a alguno el derecho de causar daño a otros, para no sufrir-lo él, por identidad de razón debe asistir a los demás el derecho de causarle a él daçno, para no sufrirlo ellos mismos. De consiguiente, no existiendo otra razón que la sola necesidad de hecho para causar un mal a un semejante suyo, con el fin de preservarse a sí mismo de un mal, un hombre no adquirirá preferencia alguna de derecho sobre otro".
} 
um mal a outrem fundando-se apenas na utilidade, o outro, pelo mesmo princípio de utilidade, tem o direito de resisti-lo; e, em casos tais, não há como racionalmente predicar-se superioridade a um ou outro, o que exclui a existência de um direito de punir propriamente dito:

Sendo assim as coisas, produzir-se-ia uma luta de direitos igualmente fortes, os quais, chocando-se entre si em sentido contrário, suspenderiam, digamos assim, a moralidade, e não deixariam campo senão para o exercício da força (cit.: idem).

Portanto, para que o violador da lei tenha, por direito, de receber a punição sem poder em contrapartida reagir justificadamente com igual violência, é necessário que a punição contra ele perpetrada seja, além de útil, também fundada em um ato injusto ${ }^{366}$ por ele anteriormente cometido:

Para autorizar apenas o ofendido a causar dano ao agressor, sem que a este seja lícito perpetrar outro tanto contra o homem probo que se defende; e para que ele que se defende a si mesmo possa conseguir uma superioridade de direito contra o adversário, além do já citado requisito da necessidade, é mister que esta mesma necessidade seja ocasionada pela injustiça ${ }^{367}$ da ofensa (cit.: 28). ${ }^{368}$

Não é por acaso que, ao conceituar o delito, Romagnosi exige que ele constitua-se em uma injustiça, um mal, pois sem isso o aplicador da pena não teria a superioridade moral necessária à aplicação da pena ao ofensor:

Se o delito não fosse um ato injusto, quer dizer, contrário ao que exigem as relações de ordem suprema da natureza, independentemente de toda convenção humana, ${ }^{369}$ não poderia ser objeto de verdadeira pena, ainda que fosse racional, livre

\footnotetext{
366 "Injusto" na doutrina de Romagnosi significa, lembremo-nos, em desacordo com a regra de ouro da moralidade, que manda não fazer com os outros aquilo que não se quer ver feito a si mesmo, bem como reconhecer como dever seu aquilo que se exige de terceiros.

${ }^{367}$ V. nota anterior.

368 "Para autorizar sólo al ofendido a causar daño al agresor, sin que a éste le sea lícito hacer otro tanto

${ }^{369}$ Romagnosi já está aqui nos princípios do direito penal, e não mais na consideração ideal do estado de natureza. $\mathrm{O}$ fato de ele expressamente dizer que o caráter apenável do ilícito independe de convenção humana mostra o quanto ainda era pequena em sua teoria a importância da legalidade enquanto
} 
e danoso. Não poderia conduzir o seu autor à privação ou diminuição de direito, em virtude da qual o poder punitivo poderia licitamente submetê-lo a sofrer um mal, sem que ele tivesse um direito igual contra o dito poder, para resistir. (cit.: 220. Destaques meus.)

Assim, trinta anos antes de Rossi, e concomitantemente a Feuerbach, já é possível ver em Giandomenico Romagnosi a mesma combinação que tornaria possível a convivência, em um único tipo de dogmática penal, de utilitarismo e retributivismo: enquanto a retribuição é inerente à ideia de que a pena é algo ruim que se dá a quem praticou um ato ruim, a sua aplicação concreta não prescinde de um juízo de utilidade.

Mais ainda, a doutrina do professor italiano traz também a combinação de um traço comum de utilitaristas e retributivistas que, segundo Pires (1998a: passim), constitui um dos pilares da racionalidade penal moderna: a recomendação política da inexorabilidade da aplicação da pena. A despeito de salientar a todo momento que as penas só são justas quando forem úteis como instrumento de prevenção de delitos futuros, Romagnosi deixava clara a importância política da pena infalível, tornando muito remotas, para não dizer inexistentes na prática, as hipóteses de não aplicação da pena por falta de utilidade. Nesse ponto, lembra muito Hobbes e Beccaria, exemplos já vistos de utilitaristas da punição infalível (Cap. II). Após dizer que a pena precisara ser eficaz para ser justa, o autor esclarece o que quer dizer com isso:

A eficácia da pena, considerada em suas últimas causas reais e verdadeiramente ativas, é um resultado da essência e da qualidade da alma sensível e racional, combinada com a natureza da pena. De outra parte, o que se deriva da natureza ou essência das coisas é certo e invariável. Portanto, as relações que dela derivam e seus resultados, são da mesma forma certos e variáveis. Tal, pois, será também a eficácia da pena. Por aí se vê, ademais, que a certeza e a constância de que falamos não devem derivar-se de outras qualidades de coisas, pois nascem da essência mesma de pena, ou, melhor dizendo, da alma humana, da qual a pena é um modo de sentir. (cit.: 168).

constituidora do ilícito penalmente relevante. 
Vale dizer, para ser eficaz, a penha tem de ser, segundo Romagnosi, certa e inconstante, o que deriva de sua natureza - um mal sensível à alma humana. Note-se bem: trata-se da aplicação de uma pena conceitualmente retributiva (a penamal), com o objetivo de prevenção ao crime pensado de maneira também conceitualmente retributivo (o crime-mal) e a partir de um permissivo punitivo retributivista (o mal pelo mal), mas administrada de acordo com uma racionalidade utilitarista (eficácia na prevenção de crimes), calculada segundo pressupostos que, seja pela via utilitarista, seja pela retributivista, levam à mesma recomendação prática de infalibilidade da pena.

Essa maneira de pensar depende também de uma concepção antropológica comum aos autores da modernidade, de um ser humano contraditório, dividido entre razões que os permitem reconhecer seus deveres morais, e paixões que o impulsionam a comportamentos sensivelmente influenciáveis. Isso permite que Romagnosi sustente tanto a capacidade racional do homem de reconhecer seu dever de não prejudicar injustamente a terceiros, ou a capacidade de reconhecer a justiça da pena quando aplicada eficazmente contra um mal; mas também de construir uma economia da punição baseada na capacidade intelectual de evitar o crime por meio do impulso humano de evitar a dor e o sofrimento: "A eficácia da pena sobre o ânimo do delinquente é, em geral, o resultado das relações que há entre a dor cominada ou irrogada e a alma sensível e racional, que se intima e se faz sentir". (cit. 168. Destaques meus).

Do ponto de vista da organização metodológica do trabalho, e aqui passa-se ao segundo elemento importante para fins de caracterização do direito penal contemporâneo, a lógica da parte geral e especial já estão presentes em Genesi, ainda que, por diferirem os conteúdos a que ela foi aplicada (pela falta de concepção estrita de um direito penal propriamente dito), o objeto teórico resultante não seja ainda semelhante ao nosso direito penal. 
O livro de Romagnosi é organizado da seguinte forma: de uma parte filosófica geral, que considera o direito de punir em absoluto, ele passa à construção de princípios de direito penal destinados à punibilidade dos casos em particular. Isso fica claro em sua introdução à terceira parte do livro:

Até aqui tratamos da origem metafísica do direito de castigar em geral, isto é, fazendo abstração de suas diversas espécies e graus. Com tudo isso, em virtude da escala das relações e da conexão ontológica das coisas, é mister que esses mesmos princípios, que produzem o direito genérico de castigar e que subministram as regras universais sobre seu uso, é mister, repito, que produzam igualmente o direito de escolher e graduar as penas em particular (cit.: 155).

É muito curioso registrar que apesar de seu livro já ter uma "parte geral" e uma "parte especial", esta última corresponde àquilo que no direito penal contemporâneo chamamos de parte geral, ou seja, as regras gerais sobre a maneira de punir os crimes de acordo com as diferentes circunstâncias em que ocorram: por ação ou omissão, individualmente ou em co-autoria, na presença ou falta de determinadas causas de aumento e diminuição da penalidade etc. Isso só vem reforçar a postulação inicial de que Romagnosi está, na obra em comento, falando de um direito de punir em geral - o direito jurídico de reagir a ilícitos mediante penas -, e não especificamente de um ramo particular do direito como o nosso direito penal contemporâneo. E mostra também como a determinação do conteúdo de uma parte geral não é coisa que "naturalmente" leva a uma teoria do delito e uma teoria da pena, como hoje. Mais ainda, sugere com mais clareza aquilo que fica ocultado pela separação feita por Feuerbach entre suas obras estritamente penais e as outras de natureza puramente filosófica, como Kritik ou Anti-Hobbes: nosso direito penal é a ponta de um iceberg construído acima de uma base filosófica que a especificação do direito penal contemporâneo ajudou a esconder, e que é um dos propósitos deste trabalho revelar pela via histórica; ele tem suas formas-mestras desenhadas a partir de um conjunto de tomada de posições diante de problemas institucionais e teóricos de seu tempo, sendo um deles - a disputa entre utilitaristas e retributivistas - bastante claro na obra de Romagnosi. Pois ele representa, como se viu, uma solução de compromisso entre duas correntes rivais da filosofia moral 
daquela época, que diretamente impactavam os fundamentos do direito penal por suas necessárias repercussões sobre as origens do direito de punir em abstrato, e do exercício da punição em particular.

\section{Os PRIMEIROS PENALISTAS BRASILEIROS}

É a partir da década de 1850 que começam a aparecer escritos científicos de autores brasileiros ocupados com os fundamentos do direito penal ou criminal. A historiografia das ideias penais no Brasil costuma apontar que, nesse aspecto, Recife e São Paulo distinguiam-se bastante, sendo a faculdade pernambucana mais aberta à vanguarda do pensamento jurídico do que a de São Paulo (Reale Jr., in Camargo, 1881-2: 9-10). Ao menos no tocante ao direito penal, isso parece ser verdade, pois foi em Recife, e não em São Paulo, que apareceram as primeiras obras de divulgação do positivismo criminal em sentido lato - que foi um movimento de vanguarda -, pelos trabalhos quase concomitantes de Tobias Barreto (Menores e Loucos em Direito Criminal, 1884), João Vieira de Araújo (Ensaio de Direito Criminal, 1884) e, um pouco depois, Clóvis Beviláqua (Criminologia e Direito, 1896) (Alvarez, 2003). Mas a verdade é que a produção intelectual em matéria jurídico-penal não se restringia a esses dois centros. O Rio de Janeiro ainda era, lembremo-nos, a sede do Império, e concentrava os principais órgãos da burocracia estatal, e por conseguinte diversas cabeças pensantes do nosso direito. O propósito deste item é buscar, nesses principais centros da intelectualidade jurídica do Brasil imperial, os traços do direito penal contemporâneo nas primeiras obras compreensivas sobre o direito criminal ou penal.

\subsection{MANUEl Mendes da CUNHA AZEVEDo}

Não foi possível encontrar quaisquer informações biográficas sobre Manoel Mendes da Cunha Azevedo, autor de Observações sobre varios artigos do Codigo de Processo Criminal e outros da Lei de 3 de Dezembro de 1841 (1852) e $O$ 
Codigo Penal do Império do Brasil, com observações sobre alguns de seus artigos (1851). Pode-se inferir que ele exercia sua atividade profissional no Nordeste, dado que ambas as obras foram publicadas em Recife. Na história da Faculdade de Direito pernambucana escrita por Clóvis Beviláqua (1977), seu nome não aparece entre os bacharéis; e nas memórias da faculdade paulista escritas por Spencer Vampré (1977), tampouco ele consta entre os formados até 1900.

Se diversas marcas do direito penal contemporâneo já aparecem na obra de Manuel Januário de Bezerra Montenegro, conterrâneo de Azevedo que escreveu menos de uma década depois dele (v. subitem seguinte), o mesmo não se pode dizer dessa obra, uma das primeiras dedicadas à exposição acadêmica do direito criminal brasileiro. Infelizmente, o autor não se preocupou em escrever, como era comum à metodologia de então, uma introdução para dar a posição enciclopédica da disciplina: não deu, portanto, uma definição de direito penal (ou criminal), o que prejudica a análise da separação entre direito material e processual em seu trabalho. Tampouco situou seu objeto entre os direitos público ou privado, algo que teria sido útil para esta investigação. Ainda assim, o trabalho de Azevedo trouxe algumas pistas importantes.

O primeiro ponto digno de nota refere-se ao título do livro, que fala em Código Penal, em lugar de Código Criminal - que era o nome oficial do Código de 1830. Não é possível saber inequivocamente o por quê dessa escolha, dado que o autor não oferece uma definição sintética da disciplina. De qualquer maneira, é possível ao menos supor uma razão para isso, na esteira das outras obras consultadas: uma vez que o Código de 1830 cuidava apenas da penalidade (ou seja, não tratava do processo criminal), nos dizeres de Ortolan, ele era mais um código penal do que criminal. Era essa a opinião de Victor Foucher e Thomaz Alves Jr. (v. subitem 4.3. adiante). Ademais, lembremo-nos que, pelos discursos de apresentação do projeto de código feitos por Bernardo Pereira de Vasconcellos (v. item III, retro), a sua ideia inicial era que o diploma de 1830 regulasse, em conjunto, os direitos material e processual; por isso ele recebeu o nome de Código Criminal. Por isso, é correto dizer que na cultura jurídica da primeira metade do século XIX, o código de 1830 era um código penal, e 
não criminal. Isso talvez explique a opção de Azevedo pelo título de seu trabalho, ainda que faltem postulações expressas suas nesse sentido.

Em que pese essa possível sintonia com o estado da arte da cultura jurídica de seu tempo, o trabalho de Azevedo era, para além disso, totalmente desconexo com a marcha metodológica de formação do direito penal contemporâneo. Isso se depreende sobretudo de sua definição de "delito", dada nos comentários ao artigo $1^{\circ}$ do Código de 1830. Ela é um tanto longa, mas por demais reveladora para ser omitida:

Os Iscts Romanos definirão delicto factum illicitum sponte admissum, quo quis et ad restitutionem, si fieri possit, et ad poenam obligatur, si fieri possit, et ad poenam obligatur. Nesta definição não há huma palavra occiosa. Factum. Senão houvesse um facto, o pensamento ficaria impune. Cogitationis poenam nem patitur. L. 18 C. ad leg. Jul. mag. Se o facto não fosse prohibido por huma lei natural ou civil, não seria um delicto. $\mathrm{O}$ uso das armas, por exemplo, posto que permittido por direito natural, prohibido, como he por direito civil, torna-se hum facto illicito. Sponte admissum. Se não fosse espontaneamente commetido, seria hum facto accidental, ou constrangido; mas não hum delicto. Si dolus malus absit, cessat Edictum L. 3. C. de incend. ruin, etc. Ad restitutionem, et ad peonam. Quem offende livremente a outrem he obrigado á restituição pelo damno e á pena pelo delicto. Si fieri possiti. Porque póde acontecer, que o mal seja irreparavel, como a perda da vida do offendido, e a grande indigencia do offensor para satisfazer o damno estimado. Obligatur. Porque não depende da vontade do delinquente; mas da força coactiva da lei o preenchimento das condições de seu delicto: neque imperare sibi, neque se prohibere quisquam potest. L. 51 ff. de receptis. (Azevedo, 1851: 6).

O ponto que mais chama atenção dessa definição é o fato de ela não contar com nenhuma referência contemporânea, em que pese ela ter sido dada em comentário a um corpo legislativo inequivocamente moderno, como era o Código de 1830. Todas as ideias, autores e fontes citadas vêm do velho direito romano. Assim, o delito acaba ganhando uma definição nitidamente pré-contemporânea, de caráter amplo, que não o circunscrevia aos estreitos limites do que hoje temos por um "delito criminal", ou "crime". Note-se, aliás, que a definição de Azevedo é amplíssima: o delito 
refere-e não só a toda e qualquer violação de uma lei jurídica, mas também à violação de qualquer lei natural: "Se o facto não fosse prohibido por huma lei natural ou civil, não seria um delicto".

Sua postura é reforçada pelo uso que faz do adjetivo "civil": enquanto Manuel Januário Bezerra Montenegro, seu conterrâneo e contemporâneo (v. sub-item 4.2. seguinte), já utilizava "civil" em oposição a "criminal", para bem marcar a divisão entre os dois terrenos da dogmática jurídica moderna e contemporânea, Azevedo empregava "civil" por oposição a "natural": ou seja, o "direito civil" era, bem à moda pré-contemporânea, o conjunto de todas as leis positivas, e não um ramo específico do direito positivo. As normas "penais" seriam, por corolário, aquelas que, pelas leis "civis", impunham penas pela violação de suas regras. Trata-se de uma clara permanência de um "delito" ou "crime" de acepção horizontalizada, como já comentado no Capítulo II. A indistinção entre penal e civil mostra-se até mesmo quando Azevedo refere-se ao plano prático, o que é surpreendente, visto que há muito no Brasil já se separava o julgamento de uma matéria e de outra (Wehling, 2002): "He preciso satisfazer a justiça Natural para não deshonrar a justiça Civil. Quam vis ferro percusserit, tamen non occidendi animo, lendiam poenam ejus. ff. L. $1 \S 1$."". (cit.: 17).

O resultado dessa interpretação das instituições modernas a partir das categorias jurídicas do passado é que muitos dos desenvolvimentos específicos da dogmática penal contemporânea acabam passando ao largo da leitura que Azevedo faz do Código. Talvez um dos melhores exemplos disso esteja na interpretação que ele dá ao artigo $3^{\circ}$ do Código Criminal, ${ }^{370}$ que estabelecia o crime doloso como regra e permitia conceituar o dolo criminal já em sentido bastante restrito, com os elementos cognitivo ("conhecimento do mal") e volitivo ("intenção de o praticar"). Como bem sabemos, o dolo assim definido situava-se no âmbito da culpabilidade (culpa em sentido amplo), que era a categoria dogmática que tinha por papel determinar o grau de responsabilidade do agente tendo em vista o vínculo subjetivo de sua conduta com o fato criminoso. Hungria, referindo-se à época, definia a culpabilidade de então como a

\footnotetext{
${ }^{370}$ Código Criminal de 1830, art. 3. ${ }^{\circ}$ : "Não haverá criminoso, ou delinquente, sem má fé, isto he, sem conhecimento do mal, e intenção de o praticar".
} 
"relação subjetiva ou de causalidade psíquica vinculando o fato ao agente", de maneira que a imputação exigiria que o agente tivesse "querido livremente a ação ou omissão e o resultado (dolo), ou, pelo menos, a ação ou omissão (culpa strico sensu)" (Hungria, 1958, V. I, T. II: 25). A preocupação com esse liame subjetivo do agente em relação à conduta era, tal qual aparece em Feuerbach, uma marca importante da especificação do direito penal contemporâneo: nos crimes que não fossem "de direito das gentes", por exemplo, essa regra permitia a alegação de ignorância, algo que estava na base do chamado "erro de direito". João Vieira de Araújo, em sua obra escrita majoritariamente em atenção ao Código de 1830, dizia que "a ignorância e o erro excluem o dolo porque implicam a falta de proposito em não prever as conseqüências da propria determinação" (Araújo, 1896: 256). No fundo, isso implicava, de um lado, (i) que os crimes por excelência eram aqueles de expressiva gravidade, em relação aos quais ninguém poderia sensatamente alegar desconhecimento legal (ainda que outros crimes pudessem ser criados por critérios de conveniência política), o que ajudava na formulação de um conceito mais restrito de "crime"; e, de outro, (ii) que as regras de determinação da responsabilidade penal tinham de levar em conta a relação da vontade do agente com esse mal representável por qualquer pessoa racional, bem como o seu ânimo de agir em contrariedade à regra, o que demandava também uma especificação das regras de imputabilidade e responsabilidade criminais. Ainda que o dolo e a culpa sejam já há muito tempo tidos como elementos subjetivos do tipo penal, ${ }^{371}$ e não mais como os pilares da culpabilidade, e mesmo que a culpabilidade tenha passado por importantes mudanças na dogmática penal, o elemento da motivação do agente, pela qual ela responde ao menos em parte, permanece sendo hoje um de seus pontos centrais. ${ }^{372}$ Por essa via, a responsabilidade objetiva foi sendo alijada do direito criminal ou penal, ao

\footnotetext{
${ }^{371}$ Este é um dos principais postulados da doutrina finalista da ação. Sua principal divulgação dá-se a partir da década de 1930, na Alemanha, com Hans Welzel; no Brasil, o finalismo difunde-se a partir da reforma da parte geral de 1984. Sobre o assunto, v. Salvador Netto, 2006: 69 e ss.

${ }^{372}$ Miguel Reale Jr. (2002: 178) esclarece que a apreciação dogmática desse elemento subjetivo mudou com a passagem de uma culpabilidade psicológica para uma culpabilidade normativa, de um mero vínculo subjetivo entre agente e conduta, para a apreciação da reprovabilidade da conduta em face do ordenamento. Contudo, o importante é anotar que, independentemente dessa mudança posterior, a culpabilidade foi o elemento dogmático pelo qual os requisitos subjetivos particulares do direito penal permitiram a especificação dos requisitos penais de responsabilização, e continuam ainda hoje diferençados, independentemente das mudanças dogmáticas internas ao direito penal.
} 
passo em que sobreviveu no direito civil. Mas essa diferença, que para nós parece brutal, mas que à época ainda se apresentava sutil, não podia ser apreendida por quem, como Azevedo, interpretava os códigos modernos a partir dos Evangelhos. Nos comentários ao art. $3^{\circ}$ do Código - justamente o que trata do dolo -, ele diz o seguinte:

O Codigo Austriaco art $4 .^{\circ}$ exige expressamente a gravidade da intenção para compor o delicto, e alguns criminalistas entendem, que as faltas muito ligeiras não devem ser incriminadas, fundando-se nestas palavras do Cap. 15, v. 19 e 20 do Evangelho de S. Matheus: de corde enim exeunt cogitationes malae, homicidia, adulteria, fornicationes, furta, falsa testimonia, blasfemiae. Hoec sunt que coinquinant hominem. (cit.: 26).

Por tudo isso, pode-se dizer, inequivocamente, que o direito penal exposto por Azevedo ainda está distante do direito penal contemporâneo, apesar de a exposição ter por pretexto o comentário a um código que facilmente se lhe amolda.

\subsection{Manuel Januário de BezerRa Montenegro}

Manuel Januário de Bezerra Montenegro publicou, em 1860, Lições acadêmicas sobre artigos do Código Criminal, obra dedicada, em longo prefácio, a João José Ferreira d'Aguiar, importante político nordestino da primeira metade do século XIX, que, além de presidente das províncias de Rio Grande do Norte e Ceará, foi também professor da cadeira de Direito Criminal em Recife. Trata-se de uma obra de juventude de Montenegro, que teve uma ativa vida política por pelo menos mais vinte anos após a publicação da obra em comento - também ele foi presidente da Província do Rio Grande do Norte, entre os anos de 1878 e 1879. A bem da verdade, Montenegro sequer era bacharel quando fez publicar esse trabalho: segundo o levantamento de Beviláqua (1977: 108), Montenegro bacharelou-se apenas em 1862. Com toda probabilidade, esse trabalho foi baseado nas preleções de Aguiar: no século XIX, era comum que alunos publicassem as anotações de aula de seus mestre, e Montenegro 
aparentemente tinha por hábito fazê-lo, já que publicara, no mesmo ano, as Lições Acadêmicas do Professor Manuel Dias de Toledo (Beviláqua, cit.: nota 211).

O trabalho de Montenegro tem algumas particularidades, provenientes de sua época e local de origem. De um lado, ela foi escrita quando uma cultura jurídicopenal brasileira já estava razoavelmente firmada - sua geração nasceu já para um mundo onde havia leis criminais brasileiras, bem como instituições encarregadas de sua aplicação segundo uma constituição e regras processuais nacionais. Ademais, ela provém de um importante centro intelectual do século XIX brasileiro, que continuamente deu berço a destacadas figuras da vida política e científica do Império, desde os liberais do Seminário de Olinda até os pensadores sociais da chamada Escola de Recife. Presumindo-se que ela seja minimamente fiel ao conteúdo da disciplina de Direito Criminal ministrada por Aguiar, ela é, ademais, uma ótima fonte para revelar que tipo de direito penal era ensinado aos alunos de Recife em meados do século XIX.

Como muitas outras analisadas, o trabalho de Montenegro mostra-se transitório: de uma parte, insere-se perfeitamente dentro do direito penal contemporâneo; em outros pontos, porém, revela ainda as marcas do pensamento jurídico historicamente prevalecente à época.

O primeiro ponto de se notar é que Montenegro reconhece ainda uma íntima ligação, de natureza conceitual, entre direito e moral. "O direito", diz ele, "é o laço que prende os homens na sociedade; (...) é a regra das relações sociais impostas pela razão e pela justiça" (1860: 19). Assim, rejeitava, por exemplo, que o direito se pudesse conceituar como uma "vontade social solemnemente promulgada": "isto é a lei, e não o direito", dizia (cit.: 18). Rejeitava ainda que o direito pudesse ser tido como a vontade do maior número: se assim fosse, o direito seria móvel e não absoluto: "por esse systhema, o Direito perderia o caracter de universalidade, que o acompanha sempre, e as maiorias, pelo que se observa, podendo tornar-se menorias, viria assim o direito a tornar-se variável" (cit.: 18). 
Apesar disso, Montenegro não relegava o problema da constituição do crime a segundo plano: mesmo reconhecendo a ligação necessária entre direito e moral, o autor dizia que a lei criminal era fundamental para a constituição do ilícito criminal:

Todas as acções criminosas se acham comprehendidas no Codigo, e por esta razão toda e qualquer acção, que porventura se possa dar contra a moralidade e segurança pública, se não estiver prevenida pelo Codigo, não poderá ser julgada criminosa (cit.: 22).

Mais do que uma função protetiva - Montenegro expressamente advertia quanto à proibição de interpretações extensivas do Código de $1830^{373}$-, a lei penal tinha o papel de marcar a extensão da disciplina do Direito Criminal. Afinal, havia vários tipos de proibição jurídica que poderiam recair sobre as condutas humanas; mas apenas aquelas impostas pelo Código Criminal é que se podiam propriamente qualificar como "crimes":

As acções podem ser consideradas de diversos modos, ou como criminosas, dignas de uma punição, ou ainda não criminosas, porém que sam também punidas, porque sam infracções d'alguma lei, alvará ou postura etc. (cit.: 21).

Assim, sua doutrina, em que pese ligar conceitualmente o direito e a moral, reconhecia expressamente o papel constitutivo da legalidade penal, e firmava um conceito restrito de "crime", separando-o das demais ofensas jurídicas, o que garantia um terrento de exclusividade teórica para o direito penal. Isso deve ser guardado em mente, pois trata-se de uma diferença importante em relação a outras teoria jurídicas que serão comentadas pouco adiante, como a de Joaquim Augusto de Camargo: o professor paulista igualmente reconhecia a ligação necessária entre direito e moral, mas não dava a mesma atenção aos requisitos institucionais de constituição dos delitos, fazendo com que "crimes" e "pecados" às vezes apareçam relativamente indiferençados.

\footnotetext{
373 "[a legislação penal] não admite ampliações nem restrições; - deve-se applicar exactamente no sentido grammatical e logico das palavras" (Montenegro, 1860: 23).
} 
No que tange à separação entre direito penal e direito processual penal, o pensamento de Montenegro ainda está distante do direito penal contemporâneo, pois ele ainda representa as duas coisas em uma mesma disciplina. Sua definição do Direito Criminal é a seguinte:

O Direito Criminal é um complexo de regras estabelecidas pelas leis, designando os factos criminosos e creando para cada um deles, segundo a sua gravidade, penas respectivas; - a maneira de processar e executar as leis criminais, a fim de conservar a ordem social. (cit.: 20).

Note-se bem: o autor postula que, além dos papéis que hoje tranquilamente atribuímos ao direito penal - definir crimes e cominar penas -, cabemlhe também (i) o processamento e (ii) a execução das leis criminais, tarefas que hoje situam-se nas searas do direito processual penal e do direito de execuções penais, respectivamente. Mas o mais curioso é o fato de que essa representação ampla do "Direito Criminal", abrangendo ainda o seu processo e execução, dá-se em uma obra de comentários aos artigos do Código Criminal, que não se confundia com o Código de Processo Criminal. A comunhão das duas áreas em uma só disciplina parecia ser, para o autor, firmemente estabelecida, pois mesmo não tendo a obra por objeto o Código de Processo Criminal, ele não se esquivou de definir também o processo e suas finalidades: "Processo é o methodo para o conhecimento das verdades jurídicas: elle dá as regras para o conhecimento destas verdades, quando trada de conhecer os crimes". (cit.: idem).

No mesmo sentido, quando, na primeira seção de seu livro, Montenegro se propõe a dar um panorama da legislação criminal anterior ao Código Criminal de 1830, bem como as modificações legislativas que o "Direito Criminal" do Brasil havia sofrido desde a promulgação do Código de 1830, os diplomas penais e processuais embaralham-se sem qualquer distinção: leis de definição de crimes e penas misturam-se com outras referentes à criação do júri e à modificação de competência dos Juízes de Paz, por exemplo. Tudo isso mostra não só que a indistinção entre direito material e direito processual era ainda forte na doutrina brasileira século XIX adentro, como também, na linha do que já foi argumentado no Capítulo II, que a formação 
teórica do direito penal contemporâneo não é um fenômeno histórico com uma relação de causalidade necessária com o movimento moderno de codificação: mesmo em uma cultura jurídica onde a distinção entre os códigos materiais e processuais era já cediça, como o Brasil de meados do século XIX, havia autores que continuavam a representar conjuntamente as duas disciplinas correspondentes.

Contudo, a obra de Montenegro é uma das poucas que apresenta indícios de uma importante mudança de significados no adjetivo "criminal", que o aproxima ainda mais de nós. Na obra de J. Ortolan, já vista, bem como nas de outros autores brasileiros que comentarei em seguida, "criminal" referia-se a tudo aquilo que tomasse, em conjunto, direito material e direito processual; ao passo em que "penal" referia-se, estritamente, àquilo que tinha a ver com a penalidade cominada pela lei. Pois bem, na obra de Montenegro, nem sempre é isso que se vê. Como um homem de seu tempo, é claro que muitas vezes ele refere-se ao "Direito Criminal" como a união de regras materiais e processuais, à moda de Ortolan; entretanto, ao desenvolver a primeira parte de sua definição de Direito Criminal - "designar fatos criminosos, e criar para cada um deles penas respectivas" - Montenegro explica que a definição de Direito Criminal tem duas partes distintas: a primeira delas é a "criminal"; e a segunda, a "penal":

Nesta definição temos a notar duas partes distinctas - a criminal e a que trata das penas, no que muito se assemelha nosso Codigo ao Francez e aos de todas as Nações, porque todo Codigo tem uma parte criminal e outra penal (cit.: 20).

Ou seja, "criminal" passa a referir-se, no seu trabalho, à tarefa de criação de crimes; e "penal", à cominação das penas respectivas. Essa mudança é importantíssima: se o velho direito penal, ou criminal, impunha penas aos delitos espalhados por todo o ordenamento, como diziam Rossi e Bentham, o novo direito criminal / penal que aparece na obra de Montenegro cuida não só da definição das penas, mas também da constituição dos crimes. Por esse caminho, o "Direito Criminal" vai conseguindo emancipar-se completamente dos demais ramos do direito: ele deixa de ser, como queria Ortolan, o mero estipulador de penas para ilícitos criados em outras 
disciplinas jurídicas. Por esse motivo, dizia o jurista pernambucano que uma única conduta humana poderia representar múltiplas lesões jurídicas:

Sirva de exemplo - um depositario, que, tendo por lei obrigação de entregar em 24 horas aquillo, que lhe foi commettido, não só não o faz; mas ainda declara, que dispõe do objecto depositado, ou diz, que se extraviou, é punido com alguns dias de prisão, soffre a parte disciplinar - soffre a pena de infracção das leis, que regulam os contractos e ainda é julgado pelo crime de furto, se se provar, que elle converteo o deposito em utilidade sua. (cit.: 21).

Em que pese faltar-lhe a especifidade do penal em relação ao processual, a obra de Montenegro mostra a criação de uma disciplina autossuficiente, que tem seus próprios princípios, cria seus próprios ilícitos (agora exclusivamente chamados "crimes"), comina suas próprias penas, processa, executa, pune, absolve e extingue a pena quando cumprida; uma disciplina dona de si mesma, do começo ao fim.

Contudo, a despeito da especificidade conferida ao "Direito Criminal" e o fato de ele estar na companhia de outras tantas áreas do direito, o jurista pernambucano segue com a postulação de que "evitar os crimes" significa "conservar a sociedade", o que acaba por fazer com que ele reduza o propósito de pacificação social ao direito criminal. Isso está presente na última parte de sua definição da disciplina, que convém agora relembrar:

O Direito Criminal é um complexo de regras estabelecidas pelas leis, designando os factos criminosos e creando para cada um deles, segundo a sua gravidade, penas respectivas; - a maneira de processar e executar as leis criminais, a fim de conservar a ordem social. (cit.: 20. Destaques meus.)

Mais adiante, no mesmo sentido, Montenegro acrescenta que "o Código tem em vista fazer diminuir as acções criminosas, para fazer progredir a sociedade em paz e harmonia". (cit.: 21.) Ou seja: na linha do que já se viu em praticamente todas as obras até aqui analisadas, a circunscrição do conceito de "crime" a uma área específica do direito, por conta de seu novo e restrito significado, não impediu que ele atraísse as 
velhas doutrinas jurídicas que o acompanhavam, fazendo com que o direito criminal tenha se espalhado no imaginário jurídico de então como sendo o direito da pacificação social, em detrimento de qualquer outro.

Finalmente, no que respeita à presença das teorias morais retributivistas e utilitaristas, Montenegro acusa as mesmas dificuldades dos demais autores de seu tempo: "O espiritualismo e o sensualismo tem dividido entre si o mundo intellectual; - mas rivaes e inimigos, cada um pretende possui-lo com exclusão". (cit.: 35.). Após comentar longamente as disputas entre uma e outra corrente, tomando o tratado de Rossi como único guia, o autor passa então a expor os diferentes sistemas penais: "sistema da convenção primitiva", "sistema da defesa indireta", "sistema da utilidade", "sistema do interesse individual", "sistema da justiça", "sistema das teorias absolutas, "sistema das teorias relativas" etc. (cit.: 38-42).

Ao cuidar das bases do sistema brasileiro, entretanto, Montenegro é absolutamente evasivo: após dizer que é difícil saber, pela simples redação dos códigos, se eles se posicionam por uma ou outra teoria, ele simplesmente esquiva-se de dar uma resposta quanto ao Código de 1830:

Se pois nenhuma certeza temos sobre o fundamento do Codigo Francez, mesmo depois da leitura dos lindos discursos, que acompanharam sua redacção, como poderemos nós conhecer o principio, que fundamenta o nosso Codigo, quando sabemos, que foi elle apresentado por uma comissão á Assembléa Geral, e approvado sem discussão em todos os seus artigos?... (cit.: 43).

Não importa aqui comentar o equívoco metodológico do autor, que toma por empírico um problema que é, em essência, normativo. O que cumpre salientar, na linha do argumento geral desta tese, é o fato de que o direito penal contemporâneo vai se construindo, como disciplina dogmática, relativamente alheio às disputas teóricofilosóficas da filosofia moral de seu tempo, o que é bem ilustrado pela postura de Montenegro em relação a esse ponto.

\subsection{THOMAZ ALVES $J_{R}$.}


Entre as obras inaugurais do pensamento sistemático brasileiro em matéria jurídico-penal, a mais significativa (porque mais completa) veio do Rio de Janeiro, cidade que perdera a disputa para sediar um dos cursos jurídicos brasileiros, mas que reunia a elite da burocracia estatal e da advocacia. Thomaz Alves Jr., lente da Escola Militar do Rio de Janeiro e advogado formado pela Faculdade de Direito de São Paulo, ${ }^{374}$ publicou em 1864 suas Annotações Theoricas e Praticas ao Código Criminal. A obra é um comentário extenso à parte geral do Código de 1830, até o art. 66. O próprio autor registra, na introdução da obra, que se motivou a escrevê-la porque as obras até então existentes "não satisfazião o estudo, que constantemente é preciso fazerse, da sciencia do Direito Criminal" (Alves Jr., 1864: 10).

Sendo a obra um comentário ao Código de 1830, um dos pontos de pertença ao direito penal contemporâneo verifica-se presente de pronto, qual seja, a representação do direito criminal como um saber dividido em parte geral (com teoria do delito e teoria da pena) e parte especial, pela razão evidente de que a obra seguia a lógica do código. Os pontos mais reveladores a que ela se presta para os fins desta pesquisa, e que serão comentados com mais detalhe a seguir, são: (i) a clara especificação do penal em relação a outros ilícitos jurídicos, mesmo os de natureza pública; (ii) a indicação da separação entre o direito penal e o processo penal; e (iii) a união de utilitarismo e retributivismo em uma mesma teoria da pena.

Quanto ao primeiro ponto, Alves Jr. já acusava a especificação do penal em relação a outras perturbações do direito, bem como à moral (cit.: 11 e 12). $\mathrm{O}$ contraste mais interessante aqui não é com o direito civil, mas sim com os "delitos de polícia", ou pequenos atos de desordem pública. Nesta parte, o autor inspira-se em Feuerbach, a partir de sua introdução ao Código da Bavária traduzida para o francês por Vatel poucos anos antes. Na esteira do código bávaro, Alves Jr. dizia que o direito penal deveria ocupar-se sobretudo dos atos que são ilícitos por justiça absoluta, aqueles que "perturbão directamente a ordem externa do Estado, que encerrão um ataque aos direitos do Estado ou dos particulares" (cit.: 42); os delitos menores, "policiais" ou de

\footnotetext{
${ }^{374}$ Segundo consta da introdução escrita pelo próprio autor, seu professor de Direito Criminal nesta Faculdade de Direito foi Manuel Dias de Toledo.
} 
"contravenção", deveriam ser tratados como um outro tipo de ilícito, de natureza administrativa, e formar um novo código, excluindo-se do direito penal em sentido estrito.

Ainda que, como ele bem reconhecia, a indistinção que nosso Código de 1830 fazia entre crimes e contravenções ${ }^{375}$ tornasse sua opinião um mero reclamo por reforma, em lugar de uma dogmática a partir da legislação vigente, sua insistência no ponto é relevante para a hipótese desta tese. Afinal, ela indica a marcação de um terreno substantivo para o direito penal, na mesma linha do que fizera Feuerbach: os delitos importantes, que atentassem diretamente contra o Estado e seus indivíduos, seriam os verdadeiramente criminais; os de menor importância poderiam ser combatidos pelas autoridades policiais por questões de conveniência prática, mas não se confundiriam, em substância, com os verdadeiros crimes. Note-se bem: se na maioria dos autores até agora vistos havia já uma separação entre o ilícito penal e os outros ilícitos de direito privado, em Alves Jr., vê-se também a separação do penal até mesmo em relação a outros ilícitos de natureza pública.

A distinção que Alves Jr. faz entre os ilícitos públicos e privados é interessante, por revelar ainda mais a autonomia do ilícito penal e do campo material do direito penal contemporâneo Em muitos dos autores até agora vistos, a separação entre o civil e o penal era sobretudo jurisdicional: havia ações civis e criminais, como na doutrina de Mello Freire. As duas coisas confundiam-se com frequência no âmbito da justiça criminal, pois a persecução de alguns ilícitos que hoje são puramente criminais dava-se pelo rito civil. Lembremo-nos de que um dos importantes pontos de crítica do Conselheiro Ribas à ideia de que o direito criminal seria parte do direito público vinha justamente do fato de pertencer à parte privada a iniciativa de muitas ações para a imposição de penas corporais (cf. Cap. II). Alves Jr. combate esse estado de coisas e pugna pela circunscrição, em definitivo, da persecução criminal ao rito das ações públicas, totalmente alheia à intervenção da parte ofendida:

\footnotetext{
${ }^{375}$ Código Criminal de 1830, art. $1^{\circ}$. "Não haverá crime ou delicto (palavras sinonimas neste Codigo) sem uma lei anterior que o qualifique".
} 
A acção criminal deve ser sempre publica, á parte offendida deve só competir o direito de pedir a reparação do mal do delicto, e associar-se ao ministerio publico, auxilia-lo e offerecer-lhe esclarecimentos e provas.

E acrescenta, após pedir a reforma da legislação nesse ponto, que se deve de uma vez por todas

acabar com o direito da parte offendida de accusar pedindo a applicação da penal, devendo ficar tudo a cargo do ministerio publico, cuja organisação é de uma necessidade palpitante. (cit. 51.)

A importância disso para a autonomização característica do direito penal contemporâneo é enorme. Além de indicar a presença forte da mentalidade que transformaria o ilícito em um problema entre a autoridade pública, representante da sociedade, e o delinquente, que à sociedade teria atingido, relegando por conseguinte a vítima a uma posição de insignificância, ${ }^{376}$ tal proposta eliminava também um importante ponto de contato, embora meramente "prático" como se dizia à época (jurisdicional), que ainda havia entre o direito privado e o direito penal. Por essa via, reforçava-se portanto a posição de autonomia do direito penal.

Tal autonomia mostrava-se também na outra ponta das ilicitudes, por Alves Jr. postular ainda uma separação forte entre direito e moral, e defender a importância da legalidade penal nesse sentido. $\mathrm{Na}$ introdução histórica ao direito criminal brasileiro feita na primeira parte de suas Annotações, ele critica as Ordenações Filipinas pelo fato de elas não distinguirem claramente entre os ilícitos jurídicos, de um lado, e os morais e religiosos, de outro:

A legislação criminal portugueza, filha daquellas épocas, elaborava no erro, que a havia dominado, e que das escolas de então sahia autorisado. Assim é que, sem fazer uma distincção completa entre a moral e o direito, factos que pertencem ao fôro da consciencia, que importão relações de deveres sem força coercitiva externa, erão

${ }^{376}$ Esta é uma das características que Pires (1998a) aponta na racionalidade penal moderna. 
considerados como crimes sujeitos á repressão e punidos. (...) na Ordenação do L. $5^{\circ}$ encontramos esta confusão da moral, da religião e do direito (cit.: 12).

A legalidade tinha alguma importância para a punibilidade desse ilícito especificamente penal. Na introdução ao livro, Alves Jr. Diz: "Nosso Código principia dizendo que não ha crime sem uma lei anterior que o qualifique. É um principio verdadeiro". Em seguida, transcreve um dos brocardos feuerbachianos - Nulla poena sine lege - e credita-o devidamente a Feuerbach. É verdade que, ao fazer-lhe referência, Alves Jr. errou a grafia do nome do jurista alemão: fez constar "Fauerbach"; o que se poderia atribuir a um erro do tipógrafo, não fosse o fato de o nome do tradutor do Código da Bavária, Charles Vatel, também ter sido grafado erradamente - uma vez Watel, e outra Vattel. Mais ainda, considerando que ele citava Feuerbach apenas para confirmar o artigo $1^{\circ}$ do Código de 1830 , que dizia não haver crime sem lei anterior que o definisse, melhor seria que tivesse escolhido o último dos três brocados ao invés do primeiro (Nullum crime sine poena legali). Tudo isso leva a concluir que o professor carioca não era um leitor aplicado de Feuerbach, e que interessava-lhe sobretudo o Código da Bavária, como comparação legislativa, e não tanto a teoria penal de Feuerbach propriamente dita. Mas o fato é que isso mostra como um dos pontos-chave da teoria de Feuerbach, a legalidade como um dos pontos de entrada na disciplina, transitava no mundo das ideias jurídicas e, aos trancos e barrancos, apareceu em um dos primeiros livros de direito penal da história da cultura jurídica brasileira. Coincidência ou não, ela aparece justamente na obra do primeiro autor nacional que afirmou no Brasil um objeto teórico com as características do direito penal contemporâneo.

A legalidade de Alves Jr. já era parecida com a de Feuerbach, considerando as duas funções de legalidade defendidas nesta tese, mas não idêntica. Ao cuidar especificamente do art. $1^{\circ}$ do código imperial, o jurista brasileiro coloca-se a questão de ser ou não verdadeiro o princípio de que não há crime sem lei anterior que o qualifique. Sua resposta deixa clara à sua posição: "não há dúvidas que esse princípio é de uma verdade maravilhosa" (cit.: 140). Nas três páginas seguintes, o autor saúda o princípio pela sua função política, de "proteção da liberdade individual" por oposição ao "caos" 
que havia quando vigiam as Ordenações. Não aparecia clara ainda a ideia de que a legalidade fosse constitutiva da ilicitude criminal, e nem a ideia de que ela marcava o campo de investigação da disciplina, como aparece nas obras feuerbachianas. Ela era, isso sim, mais um pré-requisito para a penalização da conduta do que a constituidora da ilegalidade em si. Ou seja, a legalidade de Thomaz Alves Jr. está mais para a de Beccaria - segurança política e controle de arbitrariedades - do que para a de Feuerbach, que, além dessa função política, tem também o papel metodológico mencionado no capítulo anterior. Mas o fato é que o instituto da legalidade já tem um papel relevante em seu objeto teórico e aparece com algum destaque em sua obra.

Antes de passar ao ponto seguinte, e ainda com relação ao processo de especificação teórica do direito penal, é importantíssimo mencionar que também em Alves Jr. verifica-se o mesmo fenômeno já visto em outros autores: a despeito de ganhar uma especificidade que o colocava ao lado de outras áreas do direito, seu restrito direito penal chamava para si a larga missão que era de todo o ordenamento: "O legislador deve empregar penas, que, pelo exemplo e pela correcção moral, alcancem a conservação e o bem estar social, que tal é o fim do direito penal em sua expressão mais geral" (cit.: 82. Destaques meus). Já estava positivamente afirmada na doutrina brasileira, portanto, a ideia de que o direito penal é o ramo do direito ao qual cumpre com primazia a tarefa de obtenção da pacificação social.

Passando ao segundo ponto de análise, nota-se que, no que diz respeito à separação entre direito penal e processo penal, a obra de Alves Jr. pode ser apontada como indicativa de um claro apartamento entre um e outro saber. Como já comentei, foi em sua obra que encontrei a referência à crítica de Foucher relativa à nomenclatura do código brasileiro, que se chamava "criminal" a despeito de só tratar de matérias de "penalidade". Mais adiante em suas Annotações, Alves Jr. leva essa postulação um pouco além. Após rememorar a crítica de Foucher, o autor anota que "ha razão nessa observação do traductor francez" (cit.: 71).

Lembra ele que os códigos que se assemelhavam em conteúdo ao brasileiro eram códigos chamados penais, e não criminais: o francês (1810), o português 
(1837), o espanhol (1848), o bávaro (1813) e o de Luisiana (1825); e que por isso o nome de nosso código era uma impropriedade:

$\mathrm{Na}$ verdade o que entre nós se diz Codigo Criminal não é mais do que um Código Penal; a expressão criminal abrange mais do que a de penal, e comprehende no complexo as disposições que tratão das penas, dos crimes e da natureza do processo em matéria criminal. (cit.: 71. Destaques meus).

Ou seja, Alves Jr. reconhece que seu trabalho - por tratar-se de um comentário a um código propriamente penal, em que pese seu nome de "criminal"- é também um trabalho de direito penal, apenas, por cuidar apenas de "crimes e penas", prescindindo da análise "da natureza do processo em matéria criminal". Estava, portanto, positivamente afirmada em seu livro a distinção que ainda hoje fazemos entre direito penal e processo penal.

Chega-se por fim ao terceiro ponto relevante: a representação conjunta de fundamentos retributivistas e utilitaristas em uma mesma teoria da pena. Essa confluência aparece em sua definição de "pena":

A pena é um mal em consequencia de outro mal, mas com o fim de produzir um bem. Logo, aquelle que incorre na sancção da lei sujeita-se a soffrer um mal, que é a pena, porque fez um mal, que é a violação do direito. Este mal, porém, não é improductivo, elle vem operar um resultado, já sobre a sociedade, já sobre o individuo; - sobre a sociedade por meio do exemplo, e sobre o individuo por meio da correção moral. (cit.: 83. Destaque meus).

Mais especificamente, Alves Jr. tem em mente efeitos preventivos como resultado da pena: o sofrimento representado pela pena faz o agente "receiar por si, e fugir de commetter factos identicos" (cit.: idem). E mais adiante, esclarece:

Não basta a prisão, isto é, o impedimento physico de reproduzir crimes, é preciso que essa prisão, que sem duvida é um mal, faça produzir um bem, concorrendo para que o homem se torne convertido e regenerado. (cit.: 85-6). 
Ainda que a obra de Alves Jr. seja muito mais empobrecida do que suas congêneres estrangeiras nesse tema, que discutem longamente os embates entre "idealistas" e "sensualistas", é possível perceber o quanto ele - que nesse ponto cita muito Ortolan - aproxima-se também da estratégia de dar à pena uma essência retributivista (um mal devido em razão de outro mal), mas exigir-lhe uma administração utilitária (evitar o crime pela exemplaridade e emenda moral do criminoso).

Finalmente, é importante consignar que a obra de Alves Jr. mostra o trânsito de ideias na doutrina jurídico-penal brasileira de então, confirmando algumas das escolhas de fontes desta pesquisa. O Código da Bavária de 1813 é um dos mais citados pelo autor, senão o mais citado, revelando que, ao menos por essa via, o tipo de direito penal especificamente construído por Feuerbach influenciava na representação teórica do direito penal do Brasil. Além dele, também os códigos da França, de Portugal (este quase sempre em tom de crítica) e o Espanhol (inspirado no Código do Brasil) apareciam com frequência. As Annotações do advogado carioca têm também uma seção toda dedicada à suposta influência do utilitarismo benthamiano no Código de 1830, que lhe rendeu duras críticas do lente paulista Joaquim Augusto de Camargo (1881-2: 1603), como comentado mais adiante. Alves Jr. Cita também com frequência Rossi, Ortolan e com menor frequência outros autores francófonos, como Tissot, Bertauld e Trébutien.

\subsection{Braz Florentino Henriques de Souza}

Quase concomitantemente a Thomaz Alves Jr., e antes da geração da chamada Escola de Recife, outro professor já havia lançado um conjunto de textos esparsos sobre temas fundamentais de direito penal, que tiveram ampla circulação à época. Trata-se de Braz Florentino Henriques de Souza (1825-1870), professor de Direito Civil da Faculdade de Recife, mas que se tornou conhecido principalmente por sua produção em matéria penal. Seus vários opúsculos, publicados sobretudo nas décadas de 1850 e 1860, foram postumamente reunidos por seu filho sob o título geral 
de Lições de Direito Criminal (1872), obra editada não só no século XIX, como também por duas vezes no século XX. ${ }^{377}$

Por se tratar de uma coleção de poucos textos, o livro não apresenta a completude de um compêndio didático, ainda que partes suas tenham sido escritas com esse fim: B. A. Henriques de Souza, filho de Braz Florentino, anota na introdução à primeira edição das Lições que seu pai estava a preparar um comentário completo ao código criminal quando morreu, e que partes do livro editado eram compostas pela apreciação dos primeiros artigos, que estavam já quase todos acabados quando de seu falecimento. Por isso, muita coisa de que eu precisaria, para os fins desta pesquisa, não chegou a ser escrita por Souza; mas decidiu-se incluir aqui as poucas conclusões decorrentes da leitura de sua obra pelo fato de suas Lições representarem uma das primeiras tentativas de elaboração de uma obra compreensiva sobre o direito penal brasileiro a partir do Código de 1830.

Não fazem parte do livro as lições introdutórias típicas de um manual de direito penal, onde possivelmente estariam a definição de Souza para o direito penal, sua posição enciclopédica e seus ensinamentos quanto à autonomia da disciplina em relação ao processo penal. O foco da investigação teve, por isso, de ser muito específico: analisou-se sobretudo o comentário de Souza ao primeiro artigo do Código de $1830,{ }^{378}$ pois lá estavam as informações que mais diretamente interessavam.

Primeiramente, vale dizer que Souza dava clara indicação de que o direito penal era uma disciplina específica que, por isso, tinha algumas exigências particulares em relação às demais. Assim, ao comentar a proibição de retroatividade das leis penais, diz que:

Sendo a lei uma regra com a qual devemos conformar nossas ações, e não podendo alguém ser razoavelmente obrigado a cumprir um preceito que, por não existir, não pode ser conhecido, está claro que é da essência da lei não reger senão

\footnotetext{
${ }^{377}$ A primeira edição da coletânea é de 1872. A segunda, feita pela Universidade de São Paulo, é de 1965, e saiu com o nome Do Delito e do Delinqüente. A terceira, de 2004, foi feita pelo Conselho Editorial do Senado Federal, novamente com o nome de Lições de Direito Criminal.

${ }^{378}$ Código Criminal de 1830, art. 1. ${ }^{\text {: }}$ "Não haverá crime ou delito (palavras sinônimas neste Código) sem uma lei anterior que o qualifique".
} 
ações futuras, e que a retroação é justamente reputada como subversiva da essência da mesma lei. (...) Se a importância do princípio de que acabamos de falar é incontestável nos diversos ramos da legislação positiva de um povo, porque sem ele nenhuma segurança haveria para os direitos adquiridos, podendo sempre o cidadão ser perturbado no gozo desses direitos por uma lei posterior, é evidente que essa importância sobe ainda de ponto, e torna-se por assim dizer decisiva quando se trata daquelas leis que imediatamente jogam com os direitos naturais do homem, como a vida, a liberdade e a honra. Se as leis penais pudessem retroagir, ou para nos servirmos das expressões do nosso artigo [do Código Criminal de 1830], se pudesse haver crime ou delito sem uma lei anterior que o qualificasse, não poderia por isso mesmo haver liberdade civil, nem segurança individual: a vida, a liberdade e a honra dos cidadãos estariam constantemente em perigo, achando-se à mercê dos caprichos de um legislador arbitrário e tirânico (Souza, 1956: 1-2. Destaques e esclarecimentos meus).

Nessa pequena passagem, algumas coisas importantes merecem nota. A primeira delas é a separação substantiva entre o direito penal e o restante do direito: as "leis penais" compreendem matérias que diretamente relacionam-se aos fundamentos da vida humana, "como a vida, a liberdade e a honra"; e têm, portanto, um qualificativo de importância, ocupando-se apenas das coisas mais relevantes. O penal protege os fundamentos da vida social, portanto. (Aqui há semelhança com a doutrina de Feuerbach, para quem os crimes verdadeiros eram proibições evidentes pelo direito das gentes.) Por essa razão, e aqui vem a segunda coisa digna de nota, o direito penal requer atenção especial no que diz respeito à irretroatividade das leis, sob pena de inviabilizar a liberdade civil e a segurança dos indivíduos. Por isso, os ilícitos penais - "crimes ou delitos" - exigem uma lei anterior que os defina. Mas, ao falar da legalidade, o autor diz que a falta de lei impede a punição do autor, e não que implica a inexistência do crime: parece faltar-lhe ainda a noção constitutiva da legalidade penal, ainda que (i) seu papel político de garantia já esteja claro, e (ii) ela já seja uma das portas de entrada à disciplina. Como era majoritário na tradição acadêmica sobre a matéria criminal, percebe-se também em Souza a metodologia de focar-se mais sobre a pena e menos sobre os fundamentos constitutivos do delito, herança de uma cultura que diferençava o "criminal" mais pela sanção do que pelo crime. 
Um pouco no mesmo sentido de indicação do caráter de transição de sua noção de legalidade, é curioso registrar que para introduzir o princípio da irretroatividade das leis, Souza invoca as lições de Blackstone e Portalis, dois autores que, pela época em que escreveram, estavam fora do direito penal contemporâneo por várias razões, uma delas sendo a representação unitária entre direito penal e o restante do direito público, quando todo o direito positivo (cf. Cap. II). Entretanto, ambos são invocados para reforçar o argumento de que o direito penal é um parte especial do direito que cuida de coisas mais importantes do que as demais áreas e que, por isso, precisa de alguns institutos com propriedades qualificadas, como a legalidade penal. Isso sugere um dado extremamente importante para a história do direito penal, não só como área do pensamento jurídico, mas como prática social, reforçando a percepção da permanência de elementos de uma teoria da punição de um velho mundo político: ao puxar para si os conhecimentos anteriormente produzidos sobre "crimes" e "penas", os penalistas do século XIX estavam ungindo a nova disciplina que se formava, o direito penal contemporâneo, com um objetivo que, na doutrina dos modernos (como Blackstone, Hobbes e Pufendorf) pertencia a todo o direito, e não apenas ao direito penal. O paralelo com Mello Freire é esclarecedor nesse sentido, com o dado importante de que Souza já estava falando do direito penal como ramo autônomo do direito, ao contrário de Mello Freire, que ainda guardava uma acepção generalizante e acessória do "delito criminal". Isso mostra o processo histórico pelo qual o direito penal assumiu com primazia, na contemporaneidade, um papel que antes cabia a toda ordem jurídica: a pacificação social.

Essa pequena passagem de Souza aponta para a presença do direito penal contemporâneo e afirma a sua autonomia por diversos caminhos distintos: pela separação substantiva e formal do direito penal em relação às demais áreas do direito; pela importância das matérias de que se ocupa; pela legalidade especialmente rígida com que trabalha; e ainda pelo tipo particular de ilícito que lhe dá conteúdo.

Mais ainda, Souza utiliza o tema da legalidade no mesmo ensaio para apresentar outro ponto-chave do nosso direito penal: a união entre utilitarismo e 
retributivismo. Ao comentar lições de outros autores sobre a importância da lei pena prévia, indaga:

\begin{abstract}
O que importa, com efeito, que um ato tenha sido ou não previsto anteriormente? Se ele é bom ou mau em si, merece, aos olhos desta justiça, recompensa ou castigo. (...) Mas, não se baseando a penalidade social sobre as ideias de justiça absoluta, e devendo ter por base ao mesmo tempo o justo e o útil, é necessário ver se, quanto a esta penalidade, alguma consideração maior de utilidade pública não exige que seja de outra sorte (cit.: 3).
\end{abstract}

Sem muitas explicações de filosofia moral, não cabíveis em um breve ensaio sobre o art. $1 .^{\circ}$ do Código de 1830 , o autor deixa claro que justiça e de utilidade são, em conjunto, os fundamentos morais das nossas práticas penais. Em lições subsequentes, Souza aprofunda algumas dessas noções e deixa ainda mais evidente que já estava, sem dúvida, dentro do direito penal contemporâneo. Assim, em primeiro lugar, ele marca a distinção entre delitos criminais e delitos morais, levando a termo final a separação que já fizera no início do seu livro ao apartar o ilícito penal do civil. Para afirmar exatamente o ponto de separação entre os ilícitos penalmente puníveis e ilícitos puramente morais, externos e não puníveis, Souza invoca a doutrina das fases de cometimento do delito: aquela segundo a qual a consumação de um crime é precedida por três etapas (cogitação, preparação, execução), sendo que somente a última legitima a intervenção penal contra o agente:

\begin{abstract}
Ainda quando o homem, longe de combater, acaricia e afaga o mau pensamento, ainda em tal caso deve este ficar fora do alcance da justiça humana, porque com ele não ofende o homem os seus semelhantes de modo que a sociedade seja interessada na sua punição. O pensamento, pois, de violar a lei acha-se justamente ao abrigo da repressão social. (cit.: 19).
\end{abstract}

A doutrina do professor pernambucano é, nesses poucos pontos avaliados, já muito semelhante ao direito penal contemporâneo. Entretanto, seria ainda prematuro afirmar que o nosso direito penal já estava, por isso, absolutamente estabelecido entre nós a esta altura. É preciso incluir na pesquisa ao menos uma fonte 
proveniente da Faculdade de São Paulo, uma vez que a historiografia costuma apontar grande falta de sintonia entre alguns dos professores paulistas e o estado da arte do pensamento jurídico do século XIX.

\subsection{Johquim Augusto de Camargo}

Na Faculdade de Direito de São Paulo, a primeira obra didática de direito penal escrita por um lente da casa foi Direito Penal Brasileiro (1881-2), de Joaquim Augusto de Camargo (1839-1882), que substituiu José Bonifácio de Andrada e Silva, afastado por compromissos políticos, na cadeira de Direito Criminal. Segundo a investigação de Adorno (1988: 122 e ss.), ${ }^{379}$ confirmada pelas pequisas feitas nas bibliotecas desta Faculdade, nenhum dos professores da casa produziu qualquer obra científica em direito criminal antes dele, ${ }^{380}$ a despeito de haver uma ou outra obra de processo criminal. Contudo, ao contrário do que Adorno indica, Direito Penal Brasileiro nunca chegou a ser publicado em três volumes, apesar de Camargo fazer menção a eles na introdução da obra. Provavelmente ele morreu antes de concluir o trabalho, que não passou do art. 13 do Código Criminal de 1830 e saiu apenas com dois dos três volumes originalmente pretendidos pelo autor. Note-se, nesse sentido, que o ano de publicação do segundo volume é o mesmo da morte de Camargo, 1882.

Camargo começa explicando que os Estados políticos compreendem duas ordens de interesses distintas: uma que "protege o bem-estar coletivo e só remotamente se ocupa com a individualidade"; e outra que "preside as relações do interesse particular, dos indivíduos entre si, e só secundariamente se ocupa da coletividade" (1881-2: 21). Por aí o direito divide-se em público e privado. O direito público

\footnotetext{
${ }^{379}$ Há alguns lentes que escreveram obras de Processo Criminal, sobretudo comentários ao Código de 1832.

${ }^{380}$ Exceção feita ao já mencionado discurso de inauguração da cadeira de Direito Criminal, de Francisco Bernardino Ribeiro (presumivelmente em 1836).
} 
estabelece o complexo de preceitos que regulam as relações entre as associações políticas e cada um dos seus membros; ou a reunião das condições pelas quais as associações podem, com o concurso dos seus membros, cumprir o fim comum, estabelecendo os direitos políticos e as obrigações que resultam das mesmas relações (cit.: idem).

Já o direito privado "estabelece o complexo de preceitos que regulam as relações dos indivíduos entre si" (cit.: idem).

O direito público subdivide-se, por sua vez, em interno e externo: esse último diz respeito às relações dos Estados uns com os outros, enquanto o primeiro "estabelece os preceitos que regulam as relações do poder público ou social em seu interior" (cit.: 22). O direito público interno subdivide-se, por sua vez, em universal e positivo. O direito público interno universal "estabelece os princípios racionais relativos à organização dos poderes públicos", bem como aos que devem existir entre tais poderes e os cidadãos (cit.: idem), enquanto o direito público positivo estabelece "a organização dos poderes políticos" e "as relações dentre entre si e com os cidadãos", de forma a estabelecer "os direitos e obrigações políticas de cada membro da associação" (cit.: idem).

Em seguida, Camargo passa a apresentar o direito penal, e principia pela mesma distinção com a qual Foucher (in Alves Jr., 1864: 38) criticava a nomenclatura do código brasileiro de 1830. O direito criminal em sentido lato é o "complexo de leis criminais de um Estado", ou o "complexo de leis tendentes a punir um delito". Tomado nessa acepção ampla, "direito criminal" compreende tanto direito penal quanto processo penal. Emprestado a definição do jurista francês Rauter, postula: direito criminal é "o complexo de princípios e regras estabelecidas pelas leis de um país, relativamente aos delitos e penas e aos modos de executar a lei penal", e abrange não só a "enumeração dos delitos" e a "definição dos delinquentes", como também "a ordem e competência das autoridades criminais" e "as formalidades dos processos para a aplicação e execução das penas" (cit.: 22). Em sentido estrito, contudo, o direito criminal define-se como "a coleção de princípios e regras que presidem os crimes, 
estabelecendo o modo pelo qual eles têm vida e fixando as penas com as circunstâncias que as elevam ou diminuem" (cit: idem. Destaques meus). Camargo esclarece que "ao direito criminal, nesse sentido estrito, se denomina direito penal". Está aí, portanto, já o conteúdo de nossa parte geral: uma teoria do delito e uma teoria da pena. Por isso, sempre segundo o autor, os juristas que tratam de direito penal e processo penal em conjunto escrevem "Códigos e Tratados de Direito Criminal", entre os quais ele inclui o Código da Toscana e as Instituições de Mello Freire; os que separam uma coisa da outra escrevem "Códigos e Tratados de Direito Penal", como é o caso, segundo ele, do código bávaro de Feuerbach e do código napoleônico de 1810, além dos tratados de Rossi, entre outros. O código brasileiro de 1830, por não cuidar do processo, é um código meramente penal; e sua obra, que é escrita a partir dele, é por isso uma obra de "direito penal brasileiro" (cit.: 23) - daí o título do livro.

Camargo acusa a existência do debate sobre a classificação do direito penal em público ou privado. Coloca, de um lado, como defensores de sua pertença ao direito público, Feuerbach, Rauter e Ortolan - a despeito da ambígua posição de Ortolan, já comentada; e como defensor de sua pertença ao direito privado, cita o Conselheiro Ribas (cit.: 23-4) e, mais adiante (cit.: 27), menciona também a já citada posição de Pimenta Bueno, para quem, segundo Camargo, o direito criminal pertencia tanto ao direito público, quanto ao privado. Posiciona-se, ao fim, pela pertença do direito penal ao direito público, pela seguinte razão:

O Estado exerce grande influência sobre o direito privado, conquanto este não se ocupe do interesse geral. Independente mesmo de todo interesse privado, o Estado mantém o direito e, por meio das penas, reprime a sua violação, assim como estabelece os modos e formas pelos quais essas penas devem ser impostas e cumpridas. Tudo isto o Estado faz porque o crime abala o seu interesse, produz o sobressalto e, mais ou menos, traz perturbações sociais; porque dar jurisdição e competência às autoridades civis ou criminais para julgarem os criminosos e violadores das leis é delegar uma parte do poder social. Estes são os motivos que influíram para se considerar como pertencentes ao domínio do direito público, que é o que se ocupa do Estado em todas as suas manifestações, o processo civil e criminal, o direito penal (cit.: 24). 
Essa passagem é esclarecedora por indicar os caminhos do direito penal contemporâneo a partir de uma linguagem ainda carregada de elementos de um imaginário jurídico remanescente de ao menos dois séculos antes, reforçando aquilo que já foi visto em outros autores já tratados neste capítulo. Pois logo após especificar o direito penal como um objeto apartado do direito processual penal, e de postular sua pertença ao direito público, em perfeita consonância com nosso direito penal contemporâneo, Camargo segue dizendo, como faziam os jusnaturalistas modernos, que o Estado serve para "manter o direito" e para "reprimir a sua violação por meio das penas", bem como que o crime abala os interesses de toda ordem estatal. Estes são, como visto no Capítulo II desta tese, os pilares para a concepção pré-contemporânea de "crime" e "pena": o crime é uma violação do direito, cujo propósito é preservar a ordem social; e a pena é a forma oficial de lidar com essa violação e, por conseguinte, de dar efetividade ao direito como instrumento de preservação da ordem pública. Vê-se aqui um fenômeno muito semelhante com aquele verificado em Ortolan: a especificação contemporânea dos conceitos de "crime" e "pena" ao universo estrito do direito penal (no caso de Ortolan, do direito criminal), mas aliada à sobrevivência précontemporânea, pelas opiniões doutrinárias de pré-contemporâneos que seguiam utilizados, das noções generalizantes de "crime" como violação da ordem jurídica como um todo (e não apenas do direito penal) e de "pena" como a resposta jurídica por excelência para a violação do direito e, por corolário, como a principal garantia do cumprimento da principal função da ordem jurídica: a manutenção da paz dentro de uma comunidade política chamada Estado.

Em razão da pertença exclusiva do direito penal aos limites do direito público, fora de qualquer relação de natureza privada, Camargo postulava também uma acepção estrita para a pena criminal, que não se confundia com as respostas jurídicas típicas do direito privado:

É certo que todo crime sujeito a delinquente a sofrer a pena correspondente ao mal que praticar e a satisfazer ao ofendido o dano que por esse modo lhe causou. $\mathrm{O}$ direito, porém, de exigir indenização é individual e só compete ao ofendido, pelo que só pode ser pedido como direito particular. (...) O direito criminal só se ocupa 
com a imposição da pena correspondente ao delito e nada tem que ver com a indenização. As questões, portanto, relativas a esta ou à satisfação são alheias ao mesmo direito criminal e, por isso, não se pode dizer que este tenha uma parte particular que pertence ao direito privado. O direito criminal, conseqüentemente, é, como ficou demonstrado, um ramo do direito público interno positivo. (cit: 27).

No que diz respeito à autonomia do ilícito criminal, Camargo é menos claro. Pode-se dizer, e isso o deixa um pouco fora do direito penal contemporâneo nesse aspecto, que uma caracterização específica do delito criminal, pela via formal ou substantiva, não é uma grande preocupação de sua teoria, ainda que ela possa timidamente existir. Ele reconhece o princípio da legalidade como uma parte importante e necessária do direito penal, é verdade (cit.: 199 e ss.); mas, por outro lado, sustenta uma espécie de jusnaturalismo que pouco combina com a legalidade constitutiva dos delitos no direito penal contemporâneo. Isso é algo que convém comentar com mais vagar.

Miguel Reale Jr., na apresentação à recente re-edição de Direito Penal Brasileiro, diz que Camargo é um exemplar do "conservadorismo do pensamento da nossa Faculdade do Largo de São Francisco", por combinar "as conquistas humanistas do Iluminismo" com " a fundamentação em uma justiça absoluta" (cit.: 11-2). Essa é uma forma bondosa de registrar o ecleticismo reacionário de Camargo; pois, na verdade, sua obra não faz mais do que aplicar um verniz iluminista a um direito penal que, por sua passionalidade religiosa, é quase barroco. Se lembrarmos que, por essa mesma época, a Faculdade de Recife já vivia as influências de Tobias Barreto e as polêmicas de Sílvio Romero, bem como já acusava os primeiros sinais da chegada do positivismo criminal no Brasil, ganha força a mais do que conhecida hipótese da estagnação intelectual da escola de São Paulo em comparação com a de Pernambuco no século XIX, ao menos em matéria criminal.

Isso se percebe bem quando Camargo vai tratar das teorias mais "vanguardistas" em matéria de punição. As aspas vêm porque quando da publicação da obra de Camargo, o positivismo europeu já havia produzido seus primeiros trabalhos, 
mas eles são absolutamente ignorados pelo professor paulista; a "vanguarda" contra quem Camargo se rebela é o utilitarismo benthamiano (Camargo, cit.: 160-3), doutrina que àquela altura já tinha aproximadamente um século de vida, ${ }^{381}$ isso sem contar trabalhos utilitaristas anteriores a Bentham. O autor polemiza com Thomaz Alvez Jr., já tratado aqui, por ele haver dito que o Código de 1830 teria moldado suas teorias sobre o sistema de utilidade do filósofo inglês. "Não podemos admitir semelhante opinião" (cit: 160), diz, por não aceitar que o direito penal possa ter "o utilitarismo sensualista" como fundamento.

É verdade que a constituição exigia a utilidade pública das leis, ${ }^{382}$ mas não uma utilidade do tipo benthamiano, dizia Camargo; e sim uma "utilidade moral", de promoção do "bem supremo absoluto":

Esse bem do maior número não é o bem moral, o bem em si, necessário, absoluto, o justo enfim, que é o princípio de todo dever; visto como o justo atravessa as condições de tempo e lugar, sendo sempre o mesmo invariável, seja qual for o número, maior ou menor, grande ou pequeno. (...) A ideia do prazer, do bem do maior número, é toda relativa; (...) não é absoluta, eterna, imutável como acontece com o princípio do justo, no qual todas as leis, todos os preceitos existentes nas sociedades se devem basear, para poderem obrigar e para poderem promover o respeito e acatamento. (cit.: 161.)

Em seguida, acrescenta:

A lei para ser justa deve se conformar com os princípios eternos da moral, deve respeitar os direitos individuais e todas as condições de existência da natureza humana. Desde que assim seja, sendo reclamada pela utilidade social, a lei terá os elementos da vinda indispensáveis, e será necessária. (cit.: 162.)

Essa segunda passagem é ambígua, pois não esclarece se (i) a "utilidade social" é um segundo requisito além da conformidade com "os princípios do

${ }^{381}$ Introduction to the Principles of Morals and Legislation de Bentham foi publicada pela primeira vez em 1789.

${ }^{382}$ Constituição de 1824, art. 179, § 2. o: "Nenhuma Lei será estabelecida sem utilidade publica". 
eterno e do justo", ou se (ii) essa simples conformidade, por implicar respeito aos direitos individuais e às condições de existência da natureza humana, já implica a tal utilidade. A segunda hipótese parece inicialmente a mais provável, por comentários que Camargo faz ao cuidar do parecer da Comissão Mista em torno do projeto de código de Vasconcellos:

O projeto [de Código Criminal] reprovava o sistema antigo em que se condenava por ódio, sanha e ira; que o projeto reprovava a perseguição aos infelizes culpados e suas famílias; que o projeto reprovava os favores concedidos a certos indivíduos, a desigualdade da lei; que o projeto finalmente sancionava os sagrados princípios da ordem e justiça, de onde faz decorrer, como a Constituição do Império, toda utilidade social (cit.: 162).

Porém, no segundo volume de seu trabalho, Camargo deixa clara a sua posição em sentido contrário, e em favor da primeira hipótese:

Se se tratasse da questão ventilada no artigo perante o domínio do direito absoluto seria inteiramente ocioso declarar que os atos do homem, para serem considerados crimes, devem constar de uma lei que os declare tais. E seria ocioso porque o princípio eterno que rege as ações do homem mostra-lhe que matar o seu semelhante, roubar, feri-lo em seus direitos ou em sua pessoa é um mal que viola essa grande lei que está gravada em seu coração e é reconhecida pela sua consciência, pelo que ele deve sofrer uma punição. A penalidade social, porém, não só se apoia nesse princípio eterno e imutável, mas ainda é decretada segundo as circunstâncias e necessidades do Estado. Assim é que a posição, o desenvolvimento, a civilização e as diferentes ideias que lavram na sociedade, influem sobre a sua legislação e fazem que sejam considerados crimes, certos e determinados atos. Por esse motivo é necessário que a lei positiva declare antes quais são esses atos que constituem crimes e que, como tais, são punidos (cit.: 205. Destaques meus).

Note-se que apesar da brutal diferença entre os traços de religiosidade de Camargo em comparação com o laicismo de Feuerbach e Rossi, os três estão, em linhas gerais, falando coisas semelhantes. Feuerbach e Rossi entendiam que o 
estabelecimento de uma ordem jurídica era uma exigência moral por ser o melhor meio, racionalmente concebível, de se atingir os fins morais da humanidade; mas reconheciam também, paralelamente a isso, que as instituições políticas que poderiam promover esses fins eram de muitos tipos, e que havia um leque variado de escolhas que as sociedades deveriam fazer, baseadas em critérios de utilidade política. Tanto Feuerbach quanto Rossi concordariam com a posição de que o direito devesse proscrever "ódio, sanha e ira" entre as pessoas; e ambos reconheciam, Feuerbach muito mais explicitamente que os demais, que essas linhas-mestras da moralidade social deixavam ainda um grande terreno institucional a ser preenchido por escolhas políticas, sendo uma delas a decisão de quais condutas seriam criminalizadas, ou não.

A diferença significativa de Camargo em relação aos outros dois está na perene presença de argumentos teológicos em sua teoria. Enquanto Feuerbach e Rossi tratam os princípios de moralidade em que se funda o direito como puramente racionais, o autor brasileiro os concebe como derivados da natureza do homem tal qual ser feito "à imagem e semelhança de Deus":

Estudemos, pois, o homem para desse estudo deduzir o princípio que para nós, fundamenta o direito de punir. Cada ser criado tem a sua constituição própria, a sua organização, a sua natureza. Conhecida esta, fica conhecido o fim que o ser tem de realizar e, portanto, o destino que tem de cumprir no mundo. O fim de cada ser é o que se chama seu bem. Cumprir o seu destino, chegando a esse fim, eis em que consiste esse bem. Se a cada ser o Criador deu uma natureza especial, e segundo essa natureza assim é o seu fim, haveria contradição no Criador se não desse a cada ser os meios próprios para chegar a esse fim. Daqui resulta que o homem, ser criado, com sua natureza especial, tem à sua disposição os meios próprios para chegar a esse fim, que é o seu bem (cit.: 190-1).

Como já se comentou no Capítulo II, um dos grandes feitos metodológicos dos jusnaturalistas do século XVII foi a relegação de Deus, e dos argumentos teológicos, à posição de um pressuposto que, eventualmente, tornar-se-ia substituível por outros elementos capazes de fornecer bons pontos de partida para uma teoria jurídica, como, por exemplo, uma certa visão antropológica ou uma concepção 
universal de racionalidade humana (Hochstrasser, 2000: 41). Os trabalhos filosóficojurídicos de Feuerbach são exemplares dessa última opção, e a noção de que os seres humanos têm o dever moral de realizar a moralidade pelo simples fato de serem seres humanos é, ao mesmo tempo, muito semelhante e muito diferente da postulação de Camargo de que os homens têm fins segundo a natureza para eles escolhida por Deus.

Ambos são semelhantes porque têm o mesmo papel metodológico de atribuir alguma finalidade às ações humanas, a partir dos quais elas possam ser interpretadas e avaliadas. Para o direito, esse papel metodológico é relevantíssimo, já que permite não só postular o porquê de sua existência, algo de que ele, por ser uma criação humana, não pode prescindir; como permite também o estabelecimento de algum parâmetro normativo comum para o desenvolvimento de teorias jurídicas subsequentes, predicando o bom e o ruim em matéria jurídica com vistas a esse princípio finalístico unificador do direito como um todo. Ao mesmo tempo, tais postulações são diferentes pelas distintas possibilidades de desdobramentos teóricos que cada uma proporciona. A doutrina de Feuerbach, por exemplo, exige atenção muito maior aos fundamentos constitutivos dos ilícitos criminais, já que a moralidade inerente ao direito é um pressuposto já distante de seu argumento, ainda que permaneça como um pano de fundo constante. Daí o porque de ele dar tanta atenção à legalidade penal como instituto criador de ilícitos, no âmbito de um ordenamento penal em conformidade com as exigências da moralidade humana. Em Camargo, a moralidade teológica aparece na superfície de sua teoria, e há pouca necessidade de dedicar-se às minúcias do processo político de criação dos delitos quando todos os crimes são apresentados como proibições auto-evidentes em função da natureza racional com que fomos brindados pelo criador. Neste caso, há uma curiosa coincidência com Feuerbach, que ajuda a mostrar a diferença entre as teorias de ambos: os dois citavam em suas obras a frase, comumente atribuída ao apóstolo Paulo, de que "está inscrita em nossos corações" a proibição do ilícito; mas enquanto Feuerbach a usava como parte de sua lição sobre o juízo de proibição nos fundamentos subjetivos da punição, Camargo trazia a mesma ideia à tona para tratar da existência do delito, o que só mostra o quanto o aspecto formal era, para ele, menos importante na constituição do crime. A diferença 
entre uma coisa e outra, com o desenrolar desses pressupostos, pode tornar-se muito grande: tanto assim que, se é possível falar em Feuerbach como um precursor do princípio da taxatividade, pela grande atenção por ele dedicada aos requisitos descritivos da lei penal, não há qualquer coisa em Camargo que indique o mesmo. Além disso, Camargo parece muito pouco preparado para, como Feuerbach, reconhecer que temos o direito a praticar ações imorais

Porém, o importante aqui é notar que, a despeito das profundas divergências entre Feuerbach e Camargo, as diferenças teóricas entre eles já são comparáveis a partir dos quadros de um mesmo objeto teórico: tratando o direito penal como um objeto estrito, distinto inclusive do processo penal; que define crimes e estipula penas criminais, que são diferentes dos ilícitos civis e das respostas jurídicas próprias do direito privado (indenizações, perdas e danos); e que por isso pertence ao direito público, e não ao direito privado. Por essa razão, Camargo já pode ser considerado um autor muito mais dentro do direito penal contemporâneo do que fora dele, ainda que uma parte importante do nosso direito penal the falte, qual seja, a legalidade constitutiva. Frise-se que, como venho dizendo desde o começo, é isso que caracteriza o direito penal contemporâneo: ele dá as fronteiras teóricas do direito penal, dentro dos quais diferentes posições teóricas podem ser debatidas enquanto divergências jurídico-penais. Ou seja, ele dá os limites dentro dos quais pensar problemas jurídico-penais é possível, e fora dos quais as disputas deixam de ser jurídico-penais e passam a ser de outra natureza qualquer (civis, morais, religiosas etc.).

Além disso, ele fornece também os primeiros padrões avaliatórios de uma dogmática penal. Se Hobbes, Pufendorf, Mello Freire e Ortolan têm de ser considerados autores fora do direito penal contemporâneo por representarem o "criminal" como um objeto teórico ainda muito diferente do nosso, Camargo, ao contrário, pode ser considerado como parte dele. Mas, por ainda estar um pouco destoante de um dos pontos fundamentais do nosso direito penal, ele poderá ser considerado, como foi por Miguel Reale Jr., como conservador e atrasado, ainda que ele indubitavelmente seja um penalista na acepção contemporânea do termo, como Fuerbach o era, mas Romagnosi não. 
O dito "atraso" de Camargo se constata sobretudo ao compará-lo com um trabalho de direito penal produzido no ambiente intelectual da Escola de Recife, em anos já muito próximos do Código Penal de 1890, mas apenas três anos após a obra de Camargo, o professor de São Paulo. É o último trabalho brasileiro aqui tratado: Ensaio de Direito Penal (1884) de João Vieira Araújo (1844-1922).

A leitura de Araújo não deixa dúvidas de que o direito penal contemporâneo estava, às vésperas da República, definitivamente estabelecido entre nós. Sua obra reveste-se de especial interesse porque ela, tendo sido produzida no ambiente progressista pernambucano, é bastante diferente, em orientação científica, do livro de Camargo: o positivismo criminal não passava perto do trabalho do professor de São Paulo, mas já estava bastante permeado no de seu colega pernambucano. Com efeito, o ano de 1884 costuma ser apontado como o do início da penetração do positivismo criminal no Brasil, e a obra de Araújo, juntamente com a de Tobias Barreto (Menores e Loucos em Direito Criminal, 1884) é inauguradora desse marco. Estudos históricos atuais consideram João Vieira de Araújo como "o primeiro autor [brasileiro] a mostrar-se informado a respeito das novas teorias criminais, ao comentar as teorias de Lombroso em suas aulas na Faculdade do Recife e também em textos sobre a legislação criminal do Império" (Alvarez, 2002: 682-3). Por essa razão, a investigação de seu Ensaio foi importante para mostrar que, mesmo sendo ele filiado a uma orientação tida por muitos como adversárias do classicismo de Camargo, ${ }^{383}$ ambas tinham uma noção compartilhada do que seria o direito penal e podem, por isso, ser colocadas dentro do marco do direito penal contemporâneo - ainda que, tomando o direito penal contemporâneo como um parâmetro normativo de avaliação, Camargo seja um "atrasado" em comparação com seu colega pernambucano.

\footnotetext{
${ }^{383}$ Eu mesmo faço parte desse grupo: em A modernização do direito penal brasileiro (2006), desenvolvo meu argumento a partir da percepção de que positivismo e classicismo são coisas totalmente distintas. Hoje, reconheço que ambas têm muita coisa em comum, inspirado principalmente pela teoria da racionalidade penal moderna de Álvaro Pires.
} 
Araújo apresenta seu trabalho esclarecendo que pretende "imprimir uma feição mais moderna" ao direito criminal. Menciona que a obra de Césare Lombroso, L’uomo delinquente, é exemplar dos "progressos estupendos" porque passava então o direito penal em "diversos paizes adiantados da Europa" (1884: V). Por isso, ele diz que tomou por modelo os professores italianos; e que não consultou os alemães por falta de tempo, e aproveitou muito pouco "as ideias dos escriptores franceses, belgas e de outros paizes que incontestavelmente se acham na retaguarda do movimento scientifico moderno nesta parte" (cit.: V-VI). Dessa forma, não surpreende que seu livro dedique longas considerações a coisas tratadas com muito menos vagar (e com uma metodologia absolutamente distinta) por seus antecessores menos sujeitos às influências positivistas, como as condições psico-físicas de formação do caráter humano e sua relação com o crime (cit.: 31-47). Mas, para os fins desta pesquisa, o importante de se registrar é que em sua obra já se vê a representação plena do direito penal contemporâneo.

Primeiramente, Araújo concebia o direito penal como algo apartado de todas as outras disciplinas jurídicas, tanto do direito público, quanto do direito privado. Diz ele na apresentação da obra:

Esforçamo-nos por fazer conter na obra que publicamos a título de ensaio toda a matéria philosophica pertinente á respectiva cadeira, pondo de parte aquellas que ou pertencem hoje á esphera da jurisdicção civil, como a satisfação do dano causado pelo crime, ou tem uma importância não propriamente theorica, mas prática, senão processual (cit.: VI).

O direito penal cuidava, portanto, do estabelecimento de certos conceitos-chave e não se confundia com as matérias de direito privado ("civil"), nem com a realização prática da justiça criminal ("processo penal"). Seus princípios, disse ele mais adiante, giravam em torno dos temas da definição do delito criminal, da pena criminal, e do juízo de responsabilidade criminal que liga o autor do delito à respectiva pena:

Os princípios comuns e fundamentais de toda legislação penal são: 
I. Uma lei que determina quaes as acções que são delictuosas. (...)

II. Uma infração de lei que parte de um autor que seja moralmente imputável. (Cod. Dr. Arts. $2^{\circ}, 3^{\circ}$ e 10.)

III. A sanç̧ão da lei consistente em uma pena aplicavel ao autor responsavel pela culpa na medida da lei prevista. (Cod. Cr. Art. 33.)

Estes são os fundamentos, os limites da legislação penal (cit.: 15. Destaques meus).

A disciplina tal qual concebida por ele dividia-se em três partes: uma parte preliminar, chamada "theoria fundamental do direito penal". Em seguida, chegavase à "penalidade propriamente dita", com "regras communs sobre os factos puniveis e sobre os castigos, sobre o caracter, os gráos diversos e a correlação necessária de uns e de outros", parte essa que Araújo chamava de "parte geral do direito penal". Enfim, após as regras gerais, cuidava-se de "cada facto punivel em particular", em uma terceira parte chamada de "parte especial do direito penal" (cit.: 15-6). Estavam presentes em sua obra, portanto, o conteúdo mínimo do direito penal contemporâneo, bem como grande organização teórica que lhe é característica, reunidos em um objeto teórico isolado, distinto das demais áreas do direito penal. Note-se, ademais, que ele já diz que a lei "determina quais ações são delituosas", e não apenas que qualifica o ilícito, ou que seja mero pressuposto garantista da punição. É, claramente, uma noção da legalidade como fator constitutivo da criminosidade da conduta, e não apenas como garantia política dos súditos em face do soberano.

Araújo também dizia que o direito penal distinguia-se pelo seu conteúdo das demais áreas do direito, pela magnitude dos problemas sociais de que cuidava. Assim, mesmo sendo tido por um autor vanguardista, e apesar de sua autopropagada repulsa à doutrina francesa e alemã em favor do positivismo italiano, partes importantes de sua obra lembram muito ideias de seus adversários intelectuais:

Como a sciencia nos ha provado, a propriedade e fim ultimo das funcções de todo individuo e de suas varias aptidões é explanar a sua actividade e prover á sua conservação pelos modos e meios a que as suas aptidões correspondem, daqui 
segue-se: que todas as acções do homem devem conformar-se á esta lei, emquanto tenderem a constituir o individuo e a sociedade em estado de liberdade activa e conservadora. (...) Essa observação nos adverte que a sociedade humana tem reprovado e reprova o delicto, não tanto porque se sinta offendida nos seus interesses, quanto porque se sente offendida naquela parte mais íntima e delicada que constitue a sua própria humanidade (1884: 23).

A passagem revela, claramente, a concepção do direito penal como o principal agente responsável pela consecução dos fundamentais objetivos do corpo social, descritos por Vieira como a "liberdade ativa e conservadora" do indivíduo e da sociedade; o que estaria em concordância com as leis sociais mais elementares. O delito será, por isso, um ato substantivamente contrário ao caráter de humanidade que se espera de cada ser racional:

O caracter essencial do delicto consistirá na manifesta opposição que se encontra nelle á todas aquellas propriedades que constituem a verdadeira humanidade de nossa natureza, considerada no que o sentir, o aspirar, o conhecer e o obrar reunem em nós de egregio e sublime (cit.: 28).

Por essa razão era possível advogar a pertença do direito penal ao ramo do direito público, se bem que Araújo registra, ainda em 1884, o acirrado debate quanto a este ponto:

Sendo dificil discerninr quaes as acções criminosas que mais immediatamente affectam as relações do direito privado, ou as do publico e em maior ou menor gráo, dahi nasceu a controversia dos Juristas sobre a classificação do Direito Criminal ou Penal em um systema de direito, opinando uns que este direito é um ramo do direito publico e outros que é um ramo de direito privado.

Se nós aprofundarmos a analyse no estado dos elementos componentes do Direito Criminal, chegaremos afinal ao resultado de poder consideral-o, ora como um ramo do Direito Publico, ora como um ramo do Direito Privado, se nós ainda considerarmos as duas ordens de relações jurídicas que o facto delictuoso póde perturbar. 
Mas se nós considerarmos que o facto delictuoso dá nascimento a um novo genero de relação entre o homem que delinque e o Poder Publico, é innegavel que não é possivel considerar o Direito Criminal como um ramo do Direito Privado; ainda mesmo tendo-se em vista o uso da acção privada, cujos efeitos são públicos (cit.: 6. Destaques meus).

Ou seja, mesmo reconhecendo que muitas vezes, e certamente na grande maioria numérica dos casos, o delito criminal é cometido (i) por um agente privado, (ii) contra outro agente privado, (iii) tendo por objeto um direito privado seu (propriedade, honra, integridade física) e (iv) causando prejuízos materiais ou morais trabalháveis na esfera privada, essas condutas "dão nascimento a um novo gênero de relação entre o homem que delinque e o Poder Público", que faz do agente um perturbador de toda ordem social, e não apenas de uma vítima particular; e da sociedade como um todo a vítima do crime. Por isso o direito penal deveria pertencer ao direito público. É, note-se bem, um caminho diferente daquele escolhido por Ortolan, que se baseava na autoridade moral para a aplicação da penal para considerar o direito penal como parte do direito público interno. Mas, mesmo assim, esses caminhos distintos levam a um mesmo ponto: a colocação exclusiva do direito penal no âmbito do direito público, e a postulação de que sua missão é garantir a ordem e resguardar a paz interna de um Estado.

\section{RESUMINDO}

Por tudo o que foi visto neste capítulo, creio haver suficiente apoio nas fontes para confirmar a hipótese histórica de que a chegada e consolidação no pensamento jurídico-penal brasileiro do direito penal como o objeto teórico que hoje conhecemos, dotado das propriedades metodológicas elementares que compõem uma particular construção normativa que vem sendo chamada nesta tese de de "direito penal contemporâneo", não se deu como simples divulgação de uma área do direito com características elementares que todos aceitaram sem polêmicas. Ela operou-se muito depois de sua afirmação na teoria de Feuerbach e construiu, ainda que por caminhos 
muitas vezes diferentes, uma teoria que, como a sua, materializa o direito penal contemporâneo. Isso que hoje vemos como os traços mais básicos, "naturais" e não problemáticos do nosso direito penal é resultado de uma construção histórica que se deu às custas de muitas disputas intelectuais. Os resultados dessas disputas representam as escolhas normativas fundamentais sobre as quais ergueu-se o direito penal como área autônoma do direito. Nessa qualidade, eles dão ainda hoje os limites políticos que condicionam os instrumentos legais com o quais lidamos com fenômenos ligados à violência e à busca da pacificação social.

Em primeiro lugar, ao final do século XIX já se via na doutrina brasileira, ao menos em João Vieira de Araújo, uma legalidade penal com as propriedades muito particulares que se postula aqui serem as do direito penal contemporâneo, um tanto diferentes da legalidade meramente garantista do Iluminismo. Lembremos que uma das hipóteses iniciais desta pesquisa era que a legalidade é um dos pilares do direito penal contemporâneo, mas que ela é de um tipo especial: não se trata, como muitos pensam, de uma legalidade com função puramente asseguradora, destinada apenas a evitar arbítrios judiciais; nossa legalidade penal contemporânea tem, adicionalmente, um papel metodológico constitutivo que se acresce a esse papel garantista. Joaquim Augusto de Camargo (1881-2), por exemplo, reconhecia que a punição de um crime dependia de uma lei prévia que o qualificasse, mas ao mesmo tempo afirmava que todos nós sabíamos da "criminosidade" de certos atos independentemente de declarações legais, por eles representarem violações dos mandamentos naturalmente inscritos em nossos corações, por sermos criaturas feitas à imagem e semelhança de Deus. Ou seja, os crimes já existiriam, e apenas a sua punição dependeria da lei penal. Essa legalidade puramente protetiva era, entre os autores lidos, mais fácil de se achar nas obras mais antigas: Giandomenico Romagnosi, por exemplo, dizia em 1791 que todo ato apenável em virtude de leis humanas tinha de ser "realizado com inteligência e liberdade de execução, nocivo para os demais e injusto". Não há qualquer menção ao fato de ele ser criado, enquanto ilícito, pela lei. Antes do direito penal contemporâneo, a constituição do delito, mesmo aquele punido com uma pena criminal, era um problema secundário, quando não extrapenal. 
Para nós do tempo presente, ainda está faltando algo na legalidade penal assim concebida. Pois é verdade que não há pena sem prévia cominação legal; mas, sobretudo, tampouco há crime sem lei anterior que o defina. ${ }^{384}$ Essa peça faltante do quebra-cabeças aparecia já em João Vieira de Araújo, que escreveu pouco tempo depois de Camargo, mas já sob a influência direta das novas correntes teóricas europeias. ${ }^{385} \mathrm{Em}$ seu trabalho, lei penal é tida como aquilo que "determina quais ações são delictuosas" (1884: 15). A função protetiva da lei penal, é claro, permanecia; mas o delito era representado como algo criado pela lei, e não que apenas dela dependia para sua punição criminal, e o problema de sua constituição tornava-se restrito ao direito penal. A mudança conceitual na legalidade é nesse caso evidente e já representa algo muito mais alinhado à legalidade com que hoje trabalhamos.

A afirmação de uma legalidade desse tipo prefere, também por razões metodológicas, uma teoria do direito que postule a separação forte entre legalidade ou moralidade, já que o direito penal sempre foi um campo privilegiado para a mistura desses dois saberes. Tal separação não precisava de expurgar em absoluto quaisquer considerações de ordem moral do campo jurídico-penal, mas deveria ao menos colocar a moralidade como um pano de fundo distante da ilicitude jurídico-penal (ainda que seja possível mantê-la, por exemplo, no tocante ao juízo de proibição). Isso dá consequentemente à lei penal o papel principal de determinar através da positivação aquilo que será ou não considerado crime, dentro de um largo campo de possibilidades. Não é por acaso que o autor em cuja obra a legalidade mais tardiamente permanece apenas com sua função protetiva (e não ainda com a constitutiva) foi Joaquim Augusto de Camargo, que professava uma teoria do direito ainda repleta de influências religiosas.

Não só pelo que foi mostrado no Capítulo II em relação à filosofia moral de Kant e no Capítulo III em relação à teoria jurídica de Feuerbach, mas também por aquilo que foi visto neste capítulo nas obras de Vicente Ferrer, Heinrich Ahrens e

\footnotetext{
${ }^{384}$ Código Penal de 1984, art. $1^{\text {o } .: ~ " N a ̃ o ~ h a ́ ~ c r i m e ~ s e m ~ l e i ~ a n t e r i o r ~ q u e ~ o ~ d e f i n a, ~ n e m ~ p e n a ~ s e m ~ p r e ́ v i a ~}$ cominação legal".

${ }^{385}$ Isso sugere, como eventual desdobramento desta pesquisa, uma segunda pauta de investigação, qual seja, a importância do positivismo criminal para a formação do direito penal contemporâneo no Brasil.
} 
Thomaz Alves Jr., é possível afirmar que a filosofia alemã dos séculos XVII a XIX teve decisiva importância na divulgação das bases teóricas para uma tal separação, inclusive na doutrina jurídica corrente no Brasil do século XIX. Os autores vistos neste capítulo costumam apontar Christian Thomasius (séc. XVII), Immanuel Kant e Karl Christian Friedrich Krause (séc. XVIII e XIX) como os desenvolvedores de teorias filosóficas que permitiram tal separação no campo do direito, coisa que, como mostrado no capítulo anterior, foi feita exemplarmente por Feuerbach. Alves Jr. e Araújo, expressamente, fazem constar a importância da "desmoralização" do direito penal para a construção de suas teorias.

Por que esse tipo de legalidade assumiu um papel central no direito penal contemporâneo? A resposta parece vir de dois caminhos que, apesar de contraditórios, podiam ambos encontrar na doutrina da legalidade um ponto de contato. Para a necessidade política de afirmação do poder criminal estatal, situar a lei estatal como condição sine qua non para a punibilidade de um delito, como já faziam os précontemporâneos, implica enfraquecer qualquer ordem jurisdicional alternativa; e dar-lhe o papel exclusivo de definir o que é crime, mais além, implica liquidar com a concorrência em absoluto. Quando os clérigos protestaram, nos debates do Código de 1830, contra a sua punibilidade perante uma justiça não clerical, foi o discurso da igualdade de todos perante as leis penais que se utilizou para contraditá-los; ${ }^{386}$ assim como foi também pela prerrogativa de legislar que Mello Freire afirmou que só o soberano podia impor penas a delitos. ${ }^{387}$ Do ponto de vista da fundamentação moral do direito de punir, porém, houve mais continuidades do que rupturas: permaneceu, em todos os autores lidos, a ideia pré-contemporânea de que a pacificação social conseguese preferencialmente pela administração da violência estatal (pena criminal), bem como que negligenciar a punição devida equivaleria a uma espécie de prevaricação em relação aos deveres mais básicos do soberano.

\footnotetext{
386 "O ilustre deputado quer uma lei para sua classe e outra para o resto dos homens... Os tempos das isenções, esses tenebrosos tempos, já passaram" (apud Machado Neto, 1977: 61)

387 "Assim como só ao rei pertence fazer leis, determinar a ordem dos juízos e constituir magistrados, assim também só a ele cabe impor penas pelos delitos públicos e particulares, e ninguém, seja de que dignidade for, se pode arrogar esse poder" (Instituições, III, V).
} 
Esse continuísmo político-moral veio a somar-se a uma legalidade que jogava também um papel evidentemente protetivo a partir do século XVII. Como visto com Beccaria no capítulo anterior, os autores lidos no Brasil, bem como os juristas brasileiros, não cansavam de repetir que só mediante uma lei punitiva é que os delitos poderiam ser punidos. Essa postulação mostrou-se presente em todos os autores consultados, desde Mello Freire e Romagnosi até os brasileiros mais tardios. Aquilo que poderia à primeira vista parecer uma contradição em face de movimentos políticos distintos (mais poder criminal ao Estado versus mais limitação ao exercício desse poder) acomoda-se bem em uma legalidade de tipo constitutivo, como a do direito penal contemporâneo: ao mesmo tempo em que a criação mesma dos delitos pertence ao poder político soberano, a punição dos indivíduos depende da prévia existência de uma lei. Essa duplicidade aparece exemplarmente na obra de Thomaz Alves Jr.: ele dizia, a um só tempo, que as partes privadas e seus interesses tinham de ser alijados das matérias criminais, ficando tudo a cargo de um Ministério Público cuja criação era de "uma necessidade palpitante" (1864: 51), mas dizia também que "só a lei penal podia criar delitos", um princípio verdadeiro de proteção individual, mas também o reconhecimento do monopólio estatal em dizer o certo e o errado em matéria de relações políticas. ${ }^{388}$ Com essas múltiplas utilidades, não espanta que a legalidade constitutiva tenha ganhado, como ganhou, o relevante papel de ser uma das duas pernas que sustenta, por meio da teoria do delito, o direito penal contemporâneo; e nem que ela tenha ficado como uma das duas matérias que integram a parte geral de nosso direito penal.

Esse capítulo mostrou também o quanto foi tardia na doutrina jurídica do século XIX a separação do direito penal e do processo penal. Mais ainda, elel

\footnotetext{
${ }^{388}$ A crítica de Alves Jr. ao caráter privado da justiça criminal sugere um ponto de contato com a historiografia das práticas policiais no Brasil do século XIX, que costuma apontar para a desorganização, falta de estrutura e falta de direção que imperavam no funcionamento dos órgãos públicos de vigilância ostensiva, criados tão às pressas e sem muita meditação quanto a seu funcionamento e estratégias (Vellasco, 2007b). No mesmo sentido, vale lembrar as muitas críticas dos conservadores às atribuições policiais dos juízes de paz, tidos muitas vezes como facilmente corruptíveis pelos interesses privados. A publicização do direito penal e sua submissão à exclusiva lógica do interesse público poderia, portanto, prestar-se a um papel defensivo não só contra os públicos, mas também contra a corrupção das forças públicas por setores privados. Esta é outra pauta de pesquisa sugerida por esta investigação, mas que demanda outro método e outras fontes em relação aos que foram empregados aqui.
} 
revelou um processo de mudança no nome da disciplina que muitas vezes é ignorado por penalistas do tempo presente, qual seja, a passagem do "Direito Criminal" ao "Direito Penal". Juntando isso com o argumento do Capítulo II, de que as noções de "pena" e sobretudo de "crime" eram antes eram horizontais e diziam respeito a todo o direito, é possível anotar três grandes fases da representação teórica do "penal" que viriam a desembocar no direito penal contemporâneo. O primeiro compreende a noção horizontalizada dos "crimes", que aparece não só nos jusnaturalistas modernos, mas também em autores que, como Mello Freire e Romagnosi, representam os ecos tardios dessa modernidade clássica na cultura jurídica século XIX adentro. Entre os brasileiros pesquisados, Avellar Brotero foi o autor que mais claramente representou esta posição: faltava-lhe ainda a dimensão compartida do direito positivo, por ele tratar toda a massa de leis como um único "direito civil", com regras totalmente gerais quanto ao que eram ilícitos, penas, imputação etc. Mas também na doutrina europeia foram encontrados vestígios dessa posição quase em meados do século XIX: J. Ortolan tratava o direito penal como um ramo acessório de todas as demais áreas do direito (porque todas previam ilícitos e penas) e sustentava haver tantos direitos penais quantas fossem as subdivisões que legisladores ou doutrinadores apontassem no direito positivo.

A segunda etapa compreende uma noção mais restrita do que seja um "direito criminal". Em Ferrer e Ahrens, bem como na maioria dos penalistas comentados, é possível testemunhar esse primeiro passo no processo de especificação da disciplina: passa-se a postular a existência de um "direito criminal", que seria o competente para cuidar das definições crimes e penas, bem como por fazer processar e punir os violadores das leis criminais através de um rito processual próprio. A especificação do ilícito criminal fez-se não só em relação aos ilícitos privados, como mostrado exemplarmente em Ahrens; ${ }^{389}$ mas também em relação a outros ilícitos de natureza pública, como em Pellegrino Rossi. Nessa fase, porém, há ainda relativa indistinção entre o direito penal e o processo penal: em que pese alguns autores dizerem

\footnotetext{
${ }^{389}$ Relembrando: "Dans les cause civiles, la lesion, si elle a lieu, est indirecte, se couvre de formes légales; il peut y avoir erreur ou même fraude das une vente, mais celle-ci est une forme légale pour les transactions, et la fraude ne forme qu'un accident vicieux; dans la cause criminelle, au contraire, la lésion s'est opérée contre la loi formelle, elle a attaqué directement une loi, elle est patente, absolue, parce que la loi comme telle a été violée dans son caractère de défense absolue" (Ahrens, 1875: 227-8).
} 
que a "penalidade" definia abstratamente crimes e penas, enquanto o "processo" daria as regras para a sua persecução prática, o fato é quem ambas eram inicialmente vistas como partes de uma só disciplina, chamada por alguns autores de Direito Criminal, ainda que tal nomenclatura não fosse unânime. As fontes pesquisadas mostraram claramente como a autonomização do criminal foi, em um primeiro momento, sobretudo procedimental: a diferença estava mais no procedimento, no tipo de juízo, do que nas propriedades substantivas dos "crimes".

Apenas nas fontes da segunda metade do século XIX é que se começa a encontrar a afirmação de uma disciplina autônoma que corresponderia apenas à parte penal desse direito criminal mais amplo - apenas à "penalidade" de Ortolan, portanto. $\mathrm{O}$ jusnaturalista português José Dias Ferreira, em 1864, já dizia que "O direito penal das nações" tinha por papel "[descrever] as diversas especies de delictos, e [determinar] a penalidade correspondente" (cit.: 373). Em alguns penalistas brasileiros, como Camargo e Alves Jr., esta distinção entre o Direito Criminal, que cuidava de crimes, penas e processo, e o Direito Penal em sentido estrito, voltado apenas à criminalização e penalização em abstrato, foi razão para crítica ao nome do código imperial, que a despeito de se chamar "criminal" não continha matéria processual, mas apenas "penal". Do ponto de vista histórico, porém, e reforçando o que aqui se conclui, a crítica era improcedente, pois tanto Bernardo Pereira de Vasconcellos quanto José Clemente Pereira submeteram à Assembleia projetos de código que cuidavam de penas e processo, e por isso chamavam-se "criminais"; foram as circunstâncias políticas da época que fizeram com que o código criminal de Vasconcellos fosse aprovado apenas como penal, ainda que tenha preservado o nome original - "Código Criminal do Império do Brazil".

A razão de um tal descolamento do "penal" em relação ao "criminal" foi sugerida na obra de Ortolan: como os professores de direito criminal ocupavam-se mais da penalidade que do processo, o direito criminal acabou por desenvolver uma metodologia acentuadamente abstrata, diante da qual os problemas práticos procedimentais eventualmente perderiam lugar. Essa separação ajudava a resolver, ademais, um impasse que surgia do fato de o direito penal haver deixado de ser apenas o 
direito da afirmação do poder político do soberano, e passado a ser, ao mesmo tempo, também o direito de proteção das individualidades. Pimenta Bueno percebia isso, e dizia, na introdução de seus Apontamentos sobre o Código de Processo Criminal, que as leis criminais "de um lado protegem, e de outro punem; inspirão confiança e igualmente o temor" (1857a: I). Ora, dado que o direito penal era - como visto na doutrina da legalidade - ao mesmo tempo a representação do poder soberano e a proteção contra a realização arbitrária desse poder, então os "criminalistas" tinham de, a um só tempo, determinar os limites estritos das permissões legais punitivas (delitos e penas) a fim de evitar excessos punitivos, e também postular as formas de realização prática e eficiente desse poder criminal.

O jeito mais fácil de fazer isso era aproveitar-se de uma cisão que já era corrente, entre parte teórica e parte prática, e destinar à primeira o papel de definir os limites estritos da "penalidade", enquanto à segunda caberia a realização prática da justiça penal. É essa inflexão que permitirá que, num curto espaço de um século, um "direito criminal" que era visto por Mello Freire como a expressão maior do supremo poder político do soberano, de "ora aplicar, ora remitir penas conforme convier à República" (Instituições, III, I), transforme-se em um direito penal que é "a Carta Magna do delinquente" e "barreira intransponível" de toda e qualquer iniciativa punitiva estatal. $^{390}$ Parece estar aqui a explicação histórica para a crítica feita pelo contemporâneo Claus Roxin (2002) à metodologia da dogmática penal préfuncionalista, desde Liszt e Belling até o finalismo, que era a seu ver excessivamente conceitual, abstrata e descolada da realização prática da justiça criminal.

A especificação do penal em relação aos demais ilícitos jurídicos, públicos ou privados, teve como fundamento formal a crescente importância teórica da legalidade penal, já comentada; e, como fundamento substantivo, a noção de que os "crimes" e as "penas" eram as formas jurídicas preferenciais para definir ilícitos jurídicos especialmente danosos e suas respectivas sanções. Tais ilícitos eram vistos como especialmente graves seja porque postulava-se serem eles tendentes a romper com

\footnotetext{
${ }^{390}$ Essa é uma ideia famosa de Liszt, que dizia que a dogmática penal deveria constituir-se na estabelecedora de limites das iniciativas criminais do Estado, dentro de um modelo integrado de ciências criminais (Liszt, 1917: 70).
} 
a ordem social como um todo, seja ainda porque eram tratados como violações frontais aos direitos individuais mais relevantes. Dessa forma, o direito criminal ou penal construído por todos os autores aqui vistos herdava dos jusnaturalistas modernos a ideia de que "crimes" e "penas" tinham estreita relação com os objetivos políticos de pacificação social, garantia da segurança e preservação da vida. Contudo, é importante ter em mente que os modernos trabalhavam com conceitos horizontalizados de "crimes" e "penas", que correspondiam a todas as violações do direito, bem como a todas as respostas jurídicas oficiais a essas violações; de forma que o propósito de pacificação social pertencia, em suas teorias, ao direito como um todo.

Como mostrado neste capítulo, "crimes" e "penas" foram paulatinamente circunscritos aos domínios estritos do direito criminal, e depois penal. Mas as doutrinas dos modernos sobre esses conceitos continuavam a ser aproveitadas, especialmente para a fundamentação do direito de punir. O resultado disso: ao mesmo tempo em que os autores do século XIX tardio já postulavam a existência de um direito penal bastante específico, que convivia ao lado de outros ramos do direito público e privado, eles continuavam defendendo que a tarefa da criminalização e da penalização, então já circunscritas ao direito penal, era promover aquilo que até o século anterior era visto como uma tarefa de todo o ordenamento: evitar a violência e preservar a paz, assegurando a sobrevivência da sociedade. Na primeira edição do Codex Juris Bavarici Criminalis, de 1751, a figura da Justiça aparece diante de uma faixa onde se lê Vindicta Publica, sentada sobre uma fogueira, duas rodas, um pelourinho, uma forca e uma espada, abaixo das quais vem a seguinte inscrição: "uma mãe punidora de delitos é paz e saúde pública". É uma boa ilustração do imaginário jurídico-político em que nasceu o direito criminal, que foi se apropriando da nobre e difícil tarefa de todo o ordenamento jurídico: garantir a existência da sociedade e preservar a paz. Braz Florentino, por exemplo, já defendia um direito penal bastante específico como objeto teórico, à moda contemporânea, distinto inclusive do processo penal; mas fundamentava sua doutrina sobre o crime em Blackstone. Também Mello Freire e Romagnosi, autores da modernidade tardia, tinham suas doutrinas pré-contemporâneas sobre crimes e penas usadas a todo o momento, com o mesmo efeito de buraco negro: o direito penal sugava 
para dentro de si aquilo que até pouco tempo figurava na doutrina como o propósito de todo o direito e dever fundamental de toda a ordem política. A linguagem das velhas teorias de um "crime" horizontalizado e visto como a parte penal de todo o direito aparece latente ainda na obra de um constitucionalista liberal da segunda metade do século XIX como Pimenta Bueno, não obstante ele já se referisse indubitavelmente ao "criminal" em acepção restrita: "as leis criminais", dizia ele, "formão a sanção geral da ordem social", que é necessária "para manter a harmonia e a justiça, a segurança e a tranquilidade publica e individual" (1857a, 2). Isso tem um terrível efeito mutilador para o tempo presente, pois circunscreve a uma parte reduzida do ordenamento jurídico - o direito penal - o propósito amplo de manutenção da paz em sociedade, que à primeira vista poderia ser melhor realizado se perseguido conjuntamente por todos os ramos do direito.

Essa situação foi também alimentada pela necessidade metodológica, em vista do quadro mais amplo do pensamento jurídico da modernidade, de acomodar o direito penal dentro do direito público ou privado. Julgo que nesse assunto particular estão as conclusões mais surpreendentes da pesquisa; pois se para nós esta é uma discussão sem sentido de tão óbvia - "é claro", dirá qualquer contemporâneo, "que o direito penal faz parte do direito público!" -, as fontes mostraram que durante todo o século XIX esse problema dividiu a comunidade jurídica internacional e polarizou opiniões de juristas igualmente brilhantes e capazes. O Conselheiro Ribas, um dos grandes administrativistas do século XIX, e Vicente Ferrer, maior jusnaturalista português do mesmo século, defendiam ambos que o direito criminal era parte do direito privado, por questões processuais e também materiais; Ortolan, por sua vez, tinha grandes dificuldades em situá-lo exclusivamente dentro do direito público, dadas as óbvias relações jurídicas de natureza privada a que dizia respeito. Na prática brasileira, isso também se mostrava: o Código Criminal de 1830 dividia sua parte especial em "crimes públicos" e "crimes privados"; e os ministros da Justiça do Império apresentavam relatórios divididos entre "segurança individual" e "ordem pública", com a matéria criminal aparecendo nos dois lugares. O confinamento do direito penal ao 
direito público não seria capaz, por isso, de eliminar completamente alguns dos traços "privados", interpartes, que compõem a disciplina.

O caminho para a colocação do direito penal dentro do direito público abriu-se por duas vias. A primeira invocava autoridade moral para punir, como visto em Ortolan: a punição só é moralmente aceitável quando a sociedade pune o indivíduo e isso só pode dar-se em uma relação de direito público interno. A segunda, que ao final teve maior acolhida, foi a postulação de que o crime fazia nascer duas relações jurídicas distintas, uma privada, entre autor e vítima, resolvível pecuniariamente; e outra de natureza pública, entre o criminoso e a sociedade (o Estado), que era paralela à relação civil mas que com ela não se confundia. Esta é, como sabemos, a nossa posição ainda hoje: a conduta criminosa gera, a um só tempo, responsabilidade penal e civil. Mas a dificuldade de sua aceitação na época em que primeiro foi aventada mostra como não há nada de natural nesta percepção; e a lição de Alves Jr. sobre a negação dos interesses do ofendido revela, com clareza, o sub-produto dessa opção teórica, de que Foucault e Pires já falaram: a absoluta desconsideração por parte do direito penal contemporâneo em relação aos interesses da vítima e à efetiva resolução do conflito entre ofensor e ofendido, preferindo-se a sua supressão autoritária por um juiz e um promotor público.

Esse ponto presta-se também à desnaturalização interna de um outro ponto-chave do direito penal atual, qual seja, a ideia de que o crime é público pelos interesses relevantíssimos nele protegidos. A postulação da faceta pública de todo delito criminal aparece nas fontes muito mais no contexto de solução do problema teórico de sua classificação entre o direito público ou privado do que na descrição dos elementos "naturalmente" nocivos do crime. A crítica à naturalização da gravidade do crime é coisa que se assiste ao menos desde de a década de 1970 do século passado pelas vias da chamada criminologia radical (Shecaira, 2004: 340). As fontes aqui consultadas apontam no mesmo sentido, só que de um ponto de vista interno (dogmático), e não sociológico. 


\section{QUE SIGNIFICA TUDO ISSO?}

\section{Retomando}

Esta pesquisa teve por tema a análise histórica da formação do direito penal contemporâneo, como objeto teórico-jurídico. Esse direito penal, como descrito no primeiro capítulo, é um tipo normativo que agrupa as características constitutivas daquilo que nós hoje entendemos como o direito penal, enquanto área autônoma do direito. Tal tipo foi construído a partir dos elementos da dogmática do direito penal sobre os quais há razoável consenso, e que, porque fundamentais, acabam por estipular os limites dentro dos quais as discussões penais são travadas. Fora desses limites, as discussões, se houver, não serão penais (ainda que possam ser penalmente relevantes). Se reunidos em uma frase, todos os traços do tipo normativo do direito penal contemporâneo resultam em algo que pode ser visto como uma definição elementar e, à primeira vista, não problemática da disciplina: "o direito penal é um ramo do direito que pertence ao direito público, definindo crimes e estipulando-lhes penas criminais por meio das leis penais, contando com uma parte geral, que estabelece regras iguais para todos os crimes, e uma parte especial, com regras particulares para os crimes em espécie".

Essa definição elementar poderia ser contestada sociologicamente, como tem sido há tempos pela criminologia crítica: dizendo que o direito penal protege mais interesses particulares, ou de pequenos grupos politicamente dominantes, do que públicos; ou dizendo ainda que a noção substantiva de crime, como algo distinto de 
todos os demais ilícitos, é empiricamente indemonstrável; ou que a igualdade conceitual que está por trás de uma "parte geral" escamoteia o fato de que, na prática, o direito penal tem atuação seletiva. Tais críticas, ainda que válidas, são todas produzidas externamente ao raciocínio jurídico-penal. Do ponto de vista interno, elas são irreproduzíveis enquanto definições dogmáticas, pois, se internalizadas, implodem o direito penal como hoje o conhecemos. Nenhuma obra atual de dogmática penal poderia dizer que o direito penal não existe como área autônoma do direito, ou que ele não tem nada a ver com crimes e penas criminais, ou que o direito penal é parte do direito privado: se uma tal obra existisse, seu autor seria considerado, na melhor das hipóteses, alguém que não estaria escrevendo sobre direito penal; e, na pior delas, alguém que não tem ideia do que o direito penal seja. Alessandro Baratta, um dos mais conhecidos criminólogos críticos, sabia bem disso. Por essa razão, dizia que o direito penal do presente não poderia conviver com uma criminologia que, como a sua, mirava justamente a deslegitimação sociológica desses pilares normativos que sustentam a dogmática penal: uma tal criminologia só seria compatível, talvez, com um direito penal do futuro (Baratta, 1981).

O sentido das críticas de Baratta e da criminologia crítica era principalmente o de mostrar como as coisas óbvias, naturais e (ditas) justas que o direito penal propaga aos quatro ventos como seus fundamentos evidentes não têm nada nem de óbvias, nem de naturais, e muito menos de justas quando analisadas pela ótica de sua realização empírica por meio dos aparelhos de justiça criminal. Esta pesquisa pode ser vista como um mesmo trabalho de desnaturalização, mas sob um ponto de vista histórico-hermenêutico.

Como trabalho de desnaturalizar, foi-lhe conveniente principiar pelos pontos óbvios e indiscutíveis de nossas construções penais do presente, todas incluídas na singela definição que foi dada na abertura desta conclusão, que formam o tipo do direito penal contemporâneo. O propósito elementar da pesquisa foi mostrar como os argumentos jurídicos e filosóficos que resultaram nesses pontos elementares não foram, à época de sua consolidação na teoria jurídico-penal, vistos como descrições de pontos pacíficos e naturais da disciplina; foram, isto sim, respostas normativas a problemas 
políticos e teóricos que muitas vezes dividiam cabeças brilhantes da filosofia política e jurídica.

Essa divisão dava-se em torno de dois grupos de problemas, que tinham a um só tempo dimensões teóricas e institucionais. Um deles dizia respeito à representação teórica dos poderes criminais dentro de um Estado - ou seja, das prerrogativas de definir condutas ilícitas, perseguir os culpados e impor-lhes penas. O embate aqui dava-se por meio de dois movimentos políticos com sentidos opostos: o primeiro era a centralização do poder criminal nas mãos do soberano, em detrimento de qualquer outro poder político; o segundo, que veio pouco tempo depois, foi o de limitação desse mesmo poder criminal em face de direitos individuais. Essas duas correntes tangenciavam muitos dos mesmos problemas, mas com sentidos obviamente distintos. Como também eram distintos os sentidos imprimidos por utilitaristas e retributivistas no tocante à teoria do direito de punir - o segundo grupo de problemas. Aqui, os temas do exercício político do poder criminal por uma lógica de estado e dos limites impostos a esse exercício pelos direitos individuais somavam-se a duas visões antropológicas adversárias, cada uma com uma concepção de racionalidade humana em face da qual a pena tinha de se adequar: a primeira moral-idealista de índole retributiva, a segunda psicológico-associativa de índole utilitarista.

Mesmo diante dessas diferenças, a pesquisa mostrou, em seu terceiro capítulo, como Paul Johann Anselm von Feuerbach, tido como o pai da dogmática penal contemporânea, reuniu todos esses elementos em um edifício teórico que ostentava, já em 1801 e antes da vasta maioria de seus colegas europeus, todas as características do tipo normativo do direito penal contemporâneo. Sua dogmática penal sustentava-se em dois pilares principais: (i) uma teoria do delito fortemente escorada no instituto da legalidade penal; e (ii) uma teoria da pena que casava o permissivo moral para a punição com uma política utilitarista para a sua administração em concreto. Isso dava o conteúdo de sua parte geral, com uma teoria do delito e uma teoria da pena.

De forma também relativamente pioneira, a teoria de Feuerbach situava o direito penal dentro do direito público e separava-o em absoluto do direito 
processual penal. Como uma disciplina cuja autonomia começou a desenhar-se em face da concentração política do poder criminal nas mãos do soberano, a separação do direito penal material em relação ao processual não tinha nada de natural, já que as duas coisas pertenciam ao mesmo ofício político de perseguir criminosos e impor penas com vistas à manutenção da ordem política interna. Os aspectos processuais do direito penal eram, aliás, mais importantes do que os aspectos substantivos do delito nos momentos iniciais de autonomização do "criminal". Foi só no século XIX que o direito penal substantivo virou o jogo e colocou o processo penal em uma posição "adjetiva", para usar um termo ainda hoje empregado. Tampouco era evidente a colocação do direito penal no âmbito do direito público, já que diversos crimes eram particulares (os bens jurídicos eram privados, como propriedade e honra) e a ideia dos direitos individuais, que são particulares por definição e que desde o século XVIII já tinha forte presença na seara criminal, não ficava inteiramente à vontade no âmbito do direito público, que seria o direito dos interesses do Estado. O velho direito público teve de arrumar uma forma de relacionar-se com os direitos individuais. A solução de Feuerbach foi, de um lado, definir o direito criminal como "um direito do Estado contra o delinquente", o que o situava exclusivamente dentro do direito público; e, de outro, vincular esse direito à absoluta conformidade com às "leis criminais" (Lehrbuch, 1), submetendo isso tudo ao sentido supremo da moralidade humana, que era, à moda kantiana, pensada de maneira individualista. Com isso, o direito de criar delitos e impor penas dava-se com exclusividade ao soberano, ao mesmo tempo em que se garantia seu estrito exercício a partir das leis, que deveriam ter ademais a característica de ajudar (e não atrapalhar) na realização das individualidades das pessoas. Dessa maneira atendia-se, concomitantemente, ao projeto político centralizador do poder criminal e ao projeto liberal e protetivo de limitação formal desse mesmo poder, enquanto a moralidade garantia que o fundamento teleológico de todo esse arranjo girasse em torno da preservação da liberdade externa dos cidadãos.

Um pressuposto teórico importante para que isso pudesse ser feito foi a separação aguda entre direito e moral, feita por Feuerbach em Kritik des natürlichen Rechts (1796). Lá, ele postulava por caminhos kantianos, mas de maneira diferente da 
de Kant, a colocação do moral e do legal em domínios absolutamente distintos, não só quanto ao foro de atuação (interno versus externo), mas principalmente quanto ao âmbito de cada um dentro de uma mesma racionalidade prática: a moral cuidaria de deveres e o direito de liberdades. Mas essas últimas não seriam os meros terrenos não alcançados pelos deveres morais, pois todos nós temos direitos a ações imorais. Esse passo, que aparentemente arruinava a unidade da razão prática defendida por Kant, era defendido por Feuerbach pelo argumento wolffiano-kantiano de que quem quer os fins quer também os meios. Ora, se a moralidade tem de ser motivada apenas pela máxima de respeito ao dever, então é preciso também que a ação imoral esteja disponível, garantindo-nos um direito externo à imoralidade. O terreno dos ilícitos jurídicos separava-se com mais clareza dos morais e a legalidade tornava-se ainda mais importante como elemento criador dos delitos, transformando-os num problema essencialmente político e resguardando, por forma (lei) e substância (separação em relação à moral), a individualidade dos cidadãos.

A mesma duplicidade aparecia também na teoria de punir: o elemento moral, conceitualmente necessário à punição, impedia o castigo de inocentes por critérios utilitários e limitava a intensidade da pena ao grau da responsabilidade moral do agente. Do ponto de vista político, ainda que o castigo fosse sempre limitado por parâmetros retributivos, dava-se um sentido à punição que fosse além de um mero toma-lá-dá-cá em relação ao castigo: a pena preveniria delitos, como um efeito necessário (em razão da parte sensualista da natureza humana) de sua administração empírica, o que casava-se perfeitamente com o caráter público do direito penal por ele professado. Sua teoria da pena criminal fundava-se, destarte, tanto em uma teoria política sobre a legitimidade da punição (aliando, também aqui, o munus público de manutenção da paz e as limitações a ele impostas pelas liberdades individuais), quanto em um sincretismo filosófico-moral entre fundamentos retributivos e utilitários para a pena. Sua doutrina casava, ademais, as duas antropologias que hoje autores como Norrie e Pires veem como contradições que convivem dentro do direito penal: nosso intelecto reconheceria racionalmente a legitimidade da punição e guiar-se-ia sensualmente pela prévia representação do mal-pena, abstendo-se do crime. 
No caso brasileiro, um mesmo direito penal se estabeleceu com o passar dos anos, ainda que nem sempre com referências à teoria de Feuerbach. $\mathrm{O}$ certo, porém, é que grupos semelhantes de problemas teóricos e institucionais apresentavamse por aqui, se bem que com suas particularidades. Em que pese as diferenças, os problemas que Feuerbach resolveu em sua teoria, e que dão os pontos de partida de seu direito penal, eram suficientemente generalizantes para serem facilmente adaptáveis à realidade de qualquer país que vivesse problemas ligados à manutenção da ordem pública interna à limitação e regramento dos ofícios punitivos do Estado (policiais, prisionais). A representação do Estado como o ente que garante a ordem pelo monopólio da violência era, e continua sendo, um ponto central da teoria política moderna, e isso não é coisa que se restringia à Bavária. $\mathrm{O}$ "criminal" sempre foi, por isso, a parte do direito que se ocupa da ordem e da segurança, na velha lógica de que a pacificação social consegue-se pelo respeito às leis, e que isso se obtém preferencialmente por meio da punição. Lembremos da frase de abertura do código bávaro de 1751: "a mãe que pune garante paz e saúde". Essa lógica ganhou grande importância no imaginário da elite intelectual do Brasil recém independente. A urgência com que foi votado o Código Criminal de 1830, expressamente solicitado por D. Pedro I em sua Fala do Trono três anos antes, deu clara amostra de como o exercício da força criminal por meio das penas criminais era mesmo visto como fundamental para a consecução dos fins estatais.

A presença, entre a elite política brasileira, do consenso de que a pacificação social consegue-se pelo exercício superlativo da força estatal mostrou-se claramente presente por ocasião das discussões sobre os escravos, quando era debatido o Código de 1830. O controle do potencial de violência que repousava na massa escrava tornou-se o fio condutor dos primeiros debates brasileiros sobre a construção do direito penal nacional. Ao mesmo tempo, as lembranças dos horrores do "velho livro de capa rota", como Bernardo Pereira de Vasconcellos se referia ao Livro V das Ordenações Filipinas, colocavam os deputados todos a postos em defesa de um direito penal com traços protetivos e limitadores de arbitrariedades. Estavam aqui, portanto, os elementos que davam concretude, no caso nacional, à primeira das contradições que repousa 
dentro do direito penal contemporâneo: pacificação social pelo exercício absoluto do poder versus limitação desse mesmo poder diante das liberdades individuais. No tocante aos escravos, essa dualidade fez Bernardo Pereira de Vasconcellos aventar a possibilidade de criar duas leis penais distintas, e sugerir isso nas entrelinhas dos intermináveis debates sobre a pena de morte às vésperas do Código de 1830: o primeiro, seu "código humanizado", não se aplicaria aos cativos, enquanto o segundo, contemplando fartamente a pena capital, sim. O Código "humanizado e geral" foi aprovado em 1830, mas o clamor em torno de uma revolta escrava em 1835 fez o "subdireito penal dos escravos" sair do baú e consolidar-se na Lei n. 4, de 10 de junho de 1835, que distribuía a pena máxima com fatura aos delitos cometidos pelos cativos. Num país que vivia a fantasia do liberalismo contando com uma grande parte da população composta por escravos, não era uma tal lei que faria alguém ruborescer de vergonha por contrariedade a seus princípios políticos. Aos escravos, e também à população pobre, destinava-se, portanto, a força criminal em benefício da pacificação. Se Feuerbach lidava com as contradições substantivas do direito penal punitivo e protetor costurando tudo isso em uma só teoria, os brasileiros não tiveram o mesmo apreço pela unidade: o código humanizado e liberal, que encantava estrangeiros por sua harmonia e rigor, convivia com uma lei excepcional - "horrenda exceção", dizia-se à época -, que encarnava, com a mesma exemplaridade, o espírito de que a tranquilidade pública só pode ser preservada pelo exercício inexorável da punição.

Por isso, o binômio pacificação pela força versus limitação do poder criminal tinha por aqui um solo fértil. $\mathrm{O}$ caso brasileiro, tão específico pelo fato de tratar-se de um país carente de instituições e repleto de escravos, mostra como os problemas e contradições que o direito penal contemporâneo "resolvia" eram suficientemente fundamentais para se encaixarem em diversos tipos de sociedades. Talvez por isso Pellegrino Rossi, em 1829, já tinha tanta certeza de que o novo direito penal eventualmente ganharia o mundo:

A civilização caminha lentamente. A poucos dias de viagem [da França], há governos que conservam a tortura, e outros que defendem, com um prestígio quase religioso, o processo secreto. Nós gostaríamos também escrever, não para dar a 
esses governos a inveja que os fará reformar os seus hábitos, mas para inspirar em seus administradores o desejo de fazê-lo. Nós esquecemos sempre que vivemos nos estados mais civilizados da Europa. É preciso portanto trabalhar um pouco para levar ao mundo o império dessa civilização ainda imperfeita sem dúvida, mas da qual temos todo direito de nos orgulhar (Rossi, 1829: IX). ${ }^{391}$

\section{O TOQue DE Midas do diReito PENAL}

No início deste trabalho, uma das razões que foram apontadas para justificar a sua relevância dizia respeito à necessidade de uma pesquisa de história do pensamento jurídico que enxergasse, por um ponto de vista interno, alguns fenômenos de transformação na história das ideias penais que já foram desenvolvidos com olhares externos, mais ligados à teoria social do que ao pensamento jurídico propriamente dito. O principal exemplo então citado foi a teoria da racionalidade penal moderna de Álvaro Pires. Ao longo do trabalho, um outro estudo da mesma linhagem, D'ou vient le code pènale (1996), de Yves Cartuyvels, foi também muito mencionado. Digo que são da mesma linhagem porque ambos têm forte inspiração metodológica em Foucault, que é um clássico sobre as transformações do pensamento punitivo no momento de surgimento da sociedade disciplinar.

Entretanto, mesmo reconhecendo a utilidade de todos esses trabalhos, que ficou ademais atestada pela ampla utilização que tiveram no texto da pesquisa, é importante ressaltar dois pontos que, julgo, asseveram a postulação de que há determinados assuntos na história do pensamento jurídico-penal que só podem ser adequadamente compreendidos com uma visão hermenêutica da dogmática jurídica do passado. Nesta pesquisa, há dois temas que especialmente comprovam o acerto dessa

\footnotetext{
391 "La civilisation ne fai pas si vite son chemain. A quelques journées d'ici se trouvent des gouvernemens qui conservent la torture, d'autres qui défendent avec un respect presque religieux la procédure secrète. Nous voudrions aussi écrire, non pour donner à ces gouvernemens l'envie de réformer leus habitudes, mais pour inspirer à leurs administrés le désir de les y amener, Nous oublions toujours que nous vivons au milieu des états les plus civilisés de l'Europe. Il faut aussi un peu travailler à étendre das le monde l'empire de cette civilisation encore imparfaite san doute, mais dont nous avons quelques droits d'etre fiers".
} 
opção metodológica: (i) a consolidação do direito penal dentro do direito público, e (ii) a construção definitiva do direito penal como um objeto autônomo, apartado inclusive do processo penal. Com efeito, no que diz respeito ao primeiro tema, os trabalhos de Pires, Cartuyvels e Foucault tratam a publicização da matéria "criminal" como um dado operado no instante de consolidação do poder político dos reis (em meados da modernidade, portanto); e assumem que, pouco depois, o direito penal já estava naturalizado como parte do direito público, dado o discurso então predominante (visto em Beccaria e, entre os juristas, em Blackstone) de que todo crime continha uma infraação ao rei (de natureza pública, por conseguinte), mesmo quando dirigido a um particular. No tocante ao segundo tema, a distinção entre direito penal e processo penal é-lhes pouco relevante, especialmente para Foucault e Pires; afinal, juntos ou separados, o direito penal e o processo penal modernos fazem parte, ambos, da sociedade disciplinar e da moderna racionalidade penal que nela opera.

Esta pesquisa mostrou que, do ponto de vista de uma história do pensamento jurídico penal, as coisas não foram assim tão simples. Pois, durante todo o século XIX, as fontes apontaram que na maioria dos trabalhos persistia a representação unitária, em um mesmo "direito criminal", dos direitos substantivo penal e processual penal; e, principalmente, continuava a haver muita polêmica sobre a posição enciclopédica desse novo saber.

No que respeita à colocação do direito criminal no âmbito do direito público, basta lembrar que um importante autor como J. Ortolan, por não conseguir situar o direito criminal adequadamente entre o direito público e o direito privado, chegou a quebrar a sua unidade e postular que haveria tantos direitos criminais quantas fossem as disciplinas do direito - um direito criminal político, outro marítimo, outro comercial etc; e que outros, como o Conselheiro Ribas, Vicente Ferrer Neto Paiva e Pimenta Bueno, situavam-no no âmbito do direito privado. A curta passagem em que Ribas cuidou do tema mostra que um dos problemas para a colocação do direito penal no direito privado era a excessiva presença de elementos dispositivos no processo criminal - que ficavam portanto sujeitos à conveniência e discricionariedade da vítima, o que a seu ver não cabia em um direito que se pretendia exclusivamente público. Em 
todos os trabalhos consultados no Capítulo IV os autores registram os acalorados debates em torno desse tema - mesmo no de João Vieira de Araújo, escrito já no último quarto do século XIX.

A separação entre direito e processo convinha também às diferentes necessidades metodológicas de cada disciplina. Ortolan comentava que o direito criminal foi se ocupando cada vez mais de definir minuciosamente crimes e penas, deixando de lado a realização prática do ofício de perseguir e punir. De forma que, como segundo elemento sugestivo da separação entre direito penal e processo penal, pode-se apontar a acomodação teórica de dois papéis contraditórios que repousavam em um velho e amplo "direito criminal": a realização prática do ofício de punir ficou para outras disciplinas das ciências criminais que não o direito penal, notadamente a política criminal e o processo penal; enquanto a proteção dos direitos individuais contra o poder punitivo do Estado ficou para o direito penal, agora centrado em uma metodologia de interpretação e definição restritiva dos conceitos com que operava. Entretanto, o direito penal não abandonaria, como ainda hoje não abandonou, o velho princípio de que a pacificação social tem tudo a ver com o exercício incontrastável da violência estatal por meio da pena. "A pena criminal é o instrumento pelo qual protegem-se os fundamentos da unidade social" - essa frase poderia vir tanto de Hobbes quanto de diversos penalistas contemporâneos progressistas, defensores da ideia de que o direito penal deve proteger os nossos bens jurídicos mais relevantes.

Por internalizar essa contradição, o direito penal acaba tendo, em seu discurso normativo, uma performance igualmente contraditória: ao mesmo tempo em que a dogmática penal assume o papel de proteger a todos conformando a penalização a um conjunto de regras estritas, os fundamentos da punição convidam à ampliação do espectro da punição: afinal, se o direito penal é duplamente bom - de um lado, porque garante uma punição regrada e não arbitrária; e, de outro, porque ele protege as coisas de maior importância que temos, conservando toda a ordem social -, não espanta que ele tenha se transformado na panaceia da ordem política do presente. Essa linha de raciocínio indicará sempre que a melhor forma de que dispomos para mostrar que realmente nos importamos com alguma coisa é a criminalização das condutas que lhe 
sejam lesivas. O direito penal contemporâneo ganhou uma vara de condão que eleva os interesses por ele protegidos à posição de "fundamentais para a conservação da ordem social", além de fazer presumir o caráter regrado e não arbitrário da punição. Ungido pelos fundamentos da dogmática penal contemporânea à única área do direito com esse toque de Midas, não espanta que ele seja um dos instrumentos político-jurídicos mais utilizados para mostrar o quanto nós realmente valorizamos a paz e a vida ordeira, em detrimento de um mundo de crimes e insegurança; e tampouco espanta que ele tanto se preste a jogos políticos e pressões de grupos sociais que queiram dar proteção máxima a determinado interesse.

Além desse problema dos sentidos políticos, havia ainda outra etapa a se cumprir para a formação do direito penal contemporâneo: situá-lo adequadamente em face da divisão entre direito público e direito privado. A purificação do direito substantivo em relação ao direito processual desfazia o problema apontado pelo Conselheiro Ribas, é verdade; mas persistia aquele registrado por diversos outros autores: se a vítima é particular, o bem jurídico é particular, e o autor é particular, porque então o direito penal pertenceria ao direito público? Note-se bem: o problema não estava nos crimes públicos, como a insurreição, o Lesa-majestade ou a perturbação da ordem pública; estava, isto sim, nos crimes privados, como furtos, roubos sem armas, injúrias e calúnias, que presumivelmente eram à época presumivelmente majoritários, como hoje.

Entre as diversas saídas teóricas apontadas, as que mais tiveram acolhida foram as que (corretamente) davam ao problema moral da punição um papel central. Ortolan, mais uma vez, dizia que o poder de punição supunha uma autoridade que só se podia ter como existente no âmbito do direito público interno, com o Estado (em nome da coletividade) punindo e o súdito sendo punido. Nesse ponto, o direito penal mostrou precisar profundamente de uma teoria filosófica do direito de punir. No Capítulo II, as obras de Hobbes e Beccaria mostraram com era difícil representar o direito de punição a partir de uma lógica contratualista. Mas Kant advertia que a punição não necessitava de um contrato, e sim do seu reconhecimento racional na metafísica da moralidade: há ações corretas, e outras incorretas, e a punição é a resposta 
racional a essas últimas. Ao mesmo tempo, o discurso de que a ordem pública mantinha-se através do exercício do castigo estatal mantinha a ideia da pena fortemente associada ao exercício do munus público do soberano na teoria política de então.

Por essa razão, a contradição entre utilitarismo e retributivismo, que no campo filosófico sempre mostrou-se um problema, foi no direito penal muito benvinda. Aqui, mais uma vez, marca-se a distinção metodológica dada pelo ponto de vista hermenêutico a partir do qual se conduziu esta pesquisa: essa mesma contradição é também apontada por Pires na racionalidade penal moderna, mas só uma investigação nas origens do direito penal contemporâneo é capaz de mostrar, para além do resultado, os sentidos da incorporação desse sincretismo no edifício teórico do direito penal. Pellegrino Rossi percebia o quanto a noção de moralidade da punição era fundamental para a teoria jurídica da pena criminal, bem como o quanto ela eliminava o problema da punição excessiva e arbitrária, garantido a não punição de inocentes: o fundamento do castigo é o mal do crime, só e nada mais. É isso que faz da punição algo que todos nós podemos racionalmente compreender, como diz Kant. Mas, ao mesmo tempo, Rossi percebia também que a administração concreta do castigo tinha de ser presidida por uma lógica de utilidade que é inerente a todo ato político, como é a pena estatal. Essa segunda parte de sua teoria, porém, é ignorada pelos seus leitores no tempo presente: sua insistência de que a justiça moral é o único princípio possível para a pena criminal rendeu-lhe o rótulo de absolutista puro, ainda que ele por diversas vezes tenha clamado que o critério da utilidade pode e deve ser levado em conta, como um motivo (uma razão particular para a ação), na administração da punição. Dessa forma, as duas contradições do direito penal contemporâneo davam-se as mãos em um mesmo saber: o reforço do poder criminal do sobreano casava-se bem com uma teoria utilitarista, que por sua vez era limitada por uma teoria da justiça absoluta que ia na contramão de práticas punitivas autoritárias que um poder criminal discricionário do soberano poderia implicar.

Do ponto de vista metodológico, esse dado propicia reflexões úteis, que talvez sejam as mais importantes desta pesquisa. Não seria exagero dizer que há uma ideia razoavelmente difundida de que as mudanças na teoria do direito e na prática 
do direito dão-se de maneiras absolutamente distintas: instintivamente, diríamos que é mais fácil mudar as coisas na teoria, onde tudo se resolve entre o escritor e um pedaço de papel, do que na prática, onde todo aparato burocrático e as instituições políticas são envolvidos. Pois bem, esta investigação mostra que mesmo no nível puramente teórico, as grandes mudanças no direito não devem ser tomadas tão singelamente, pois quando os autores inovadores escrevem suas teorias inovadoras, eles o fazem sob o peso de uma tradição jurídica que, no caso do sistema romano-germânico, é milenar, o que os torna adversários intelectuais de bibliotecas inteiras e de doutrinadores do passado que contam com a força da tradição. A perenidade das doutrinas jurídico-filosóficas sobre os fundamentos da punição e a relação entre penas, crimes e pacificação social é, na formação do direito penal contemporâneo, um exemplo disso: trata-se de peças fundamentais de um quebra cabeça que, mesmo montado de muitas formas diferentes por muitos autores diferentes, estiveram presentes desde antes do surgimento da disciplina, e ainda hoje continuam lá.

Basta dizer que mais de dois séculos depois de tudo isso, as mesmas marcas desnaturalizadas neste trabalho revelam-se claramente na obra de Claus Roxin, autor que, diz-se, empreendeu uma reviravolta na dogmática penal atual. Como sabemos, Roxin, ao mesmo tempo em que rechaça todo fundamento retributivo para uma teoria da pena e reclama que a teoria da punição funde-se apenas em critérios puramente preventivos, permanece também insistindo que: (i) o crime deve ser um fato socialmente danoso $($ crime $=$ mal); (ii) passar férias em Palmas de Mallorca não poder ser considerado uma pena (pena = mal); e que (iii) nenhuma pena imposta por critérios preventivos pode ultrapassar os limites da proporcionalidade ou desrespeitar a culpabilidade do condenado (punição depende de culpa; proibição de punir inocentes). Como foi visto, todos esses elementos pertenciam historicamente às doutrinas retributivas, que presumivelmente não teriam lugar em sua doutrina puramente preventiva.

Isso ocorre porque o trabalho de Roxin, mesmo que inovador, é um trabalho de direito penal, e só o é porque se amolda ao tipo do direito penal contemporâneo. Rompidas as ideias dogmáticas de que o crime é um mal especialmente 
danoso e de que a pena é um contra-mal ou privação que lhe serve de resposta oficial (sendo-lhe devida por culpa e utilidade), estaríamos, ao menos em parte, deixando o direito penal, cambaleando de um lado para o outro da linha borrada que o separa de outros ramos do direito que, como o direito administrativo, podem prescindir das ideias da pena-mal, da culpa penal e da preservação da sociedade por meio do castigo.

Para os que se ocupam de pensar mudanças para o sistema penal vigente, este trabalho sugere possíveis caminhos a serem considerados: romper, no nível do discurso normativo jurídico-penal, com a noção - que já carregamos conosco desde antes do direito penal contemporâneo, mas com outros significados - de que os crimes atentam contra a existência da sociedade, bem como com o corolário de que a pena criminal é o último recurso da salvação social, o que envolve postular uma nova substância para o delito, um novo papel para a pena e, sobretudo, uma nova missão para o direito penal. Para isso, seria necessário deixar de definir o direito penal a partir da pena criminal, pois ela é a única distinção firme entre o penal e os demais ramos do direito, uma vez que as supostas diferenças substantivas do delito criminal nem sempre resistem a uma comparação mais rigorosa com os ilícitos civis e administrativos.

Se isso acontecer, entretanto, é provável que, a médio ou longo prazo, o direito penal como hoje conhecemos - o direito penal contemporâneo - deixe de existir, sendo substituído por outra forma de disciplinamento jurídico dos conflitos sociais, talvez menos dependente da pena criminal e mais atenta a certos pontos que o direito penal de hoje negligencia, como a efetiva superação do conflito social subjacente ao crime ou os interesses individuais da vítima. Não é garantido, porém, que esse novo ramo do direito mude de nome com a mesma facilidade com que mudará sua lógica operativa: daqui a quinhentos anos, os juristas continuarão falando, provavelmente, em "direito penal", "crimes", "penas" e "culpa", mesmo que eles se arranjem de forma a resultar em um objeto teórico diferente daquele que hoje conhecemos. Será tarefa do futuro historiador mostrar o processo histórico de mudança que levará do direito penal contemporâneo ao "direito penal" do futuro, tenha ele esse nome ou não. 


\section{REFERÊNCIAS BIBLIOGRÁFICAS}

\section{Códigos, leis e documentos}

Áustria. 1815. Codice de’ Delitti e delle gravi trasgressioni politiche. Venezia: Pietro Pinelli.

Bavária (Alemanha). 1813. Strafgesezbuche für das Königreich Baiern. 3 T. München.

Bavária (Alemanha). 1751, Codex Juris Bavarici Criminalis. München: Johann Jacob

Brasil. 1826-30. Annaes da Câmara dos Deputados. Disponível em: http://www.camara.gov.br/publicacoes.

Brasil. 1830. Código Criminal do Império do Brazil. Rio de Janeiro: Typ. Nacional.

Brasil. 1890. Código Penal da República dos Estados Unidos do Brasil (Decreto 847/1890). Disponível em: http://www6.senado.gov.br/legislacao/ListaPublicacoes.action?id=660 49

Brasil. 1984. Código Penal da República Federativa do Brasil (Decreto-lei 2.848/40, com redação dada pela Lei 7.209/84). Disponível em: http://www.planalto.gov.br/ccivil_03/Decreto-Lei/Del2848.htm 
Áustria. 1803. Gesetzbuch über Verbrechen un schwere Polizen-Übertretungen. Wien: Johann Thomas Edlen.

Sardenha (Itália). 1770. Leggi, e costituzioni di Sua Maesta. Loix, et constitutions de Sa Majeste. T. I e II. In Torino: Stamperia Reale.

Prússia (Alemanha). 1794. Allgemeines Landrecht für die Prussischen Staaten. Berlin: Nauck, 1804.

Toscana (Itália). 1786. Codice Penal del Granducato di Toscana. Firenze: Gaetano Cambiagi Stampatore.

Espanha. 1807. Las Siete Partidas del Rey Don Alfonso el Sábio. Madrid: Imprenta Real. Disponível em: http://fama2.us.es/fde/lasSietePartidasEd1807T1.pdf.

Império Romano Bizantino. Digesto (Justiniano). Livros 47 e 48 . Baseado na edição de Mommmsen, Berlin: 1954. Disponível em: http://web.upmfgrenoble.fr/Haiti/Cours/Ak/.

\section{Livros, capítulos e artigos de periódicos.}

ADORNO, Sérgio. 1988. Os Aprendizes do Poder: o Bacharelismo Liberal na Política Brasileira. Rio de Janeiro: Paz e Terra.

AHRENS, Henri. 1875. Cours de Droit Naturel ou de Philosophie du Droit. $7^{\mathrm{a}}$ ed. T. I e II. Leipzig: Brockhaus.

ALEXY, Robert. 2008. On the Concept and the Nature of Law. Ratio Juris 21 (3): 28199. 
ALVAREZ, Marcos César. 2003. Bacharéis, Criminólogos e Juristas: saber jurídico e nova escola penal no Brasil. São Paulo: Método.

2002. A Criminologia no Brasil ou Como Tratar Desigualmente os Desiguais. DADOS - Revista de Ciências Sociais 45 (4): 677-704.

ALVES JR. Thomaz. 1864. Annotações Theoricas e Praticas ao Codigo Criminal. Rio de Janeiro: Francisco Luiz Pinto \& Co.

ARAÚJO, Ana Cristina. 2003. A Cultura das Luzes em Portugal. Temas e Problemas. Lisboa: Livros Horizonte.

ARAÚJO, João Vieira de. 1896. Código Penal Comentado. Rio de Janeiro e São Paulo: Lammert \& C. Editores.

ARAÚJO, João Vieira de. 1884. Ensaio de Direito Criminal ou repetições escriptas sobre o Código Criminal do Império do Brasil. Recife: Typ. do Jornal do Recife.

ARNOLD, Jörg. 2003. Neue Fragen an den Satz "nullum crimen, nulla poena sine lege". In: R. Gröschner, G. Haney, Die Bedeutung P. J. A. Feuerbachs (1775-1833) f'r die Gegenwart. Wiesbaden: ARSP / Franz Steiner Verlag, p. 107-23.

AZEVEDO, Manuel Mendes da Cunha. 1851. Código Penal do Império do Brasil, com observações sobre alguns de seus artigos. Recife: Typographia Commercial de Meira Henriques.

BARATTA, Alessandro. 1982. Criminologia critica e critica del diritto penale. Introduzione alla sociologia giuridico-penale. Bologna: Società editrice il Mulino.

1981. Criminologia e dogmática penal: passado e futuro do modelo integral da ciência penal. Revista de Direito Penal 31, p. 5-37. 
BATISTA, Nilo. 2002. Matrizes ibéricas do sistema penal brasileiro - I. $2^{\mathrm{a}}$. ed. Rio de Janeiro: Revan / ICC.

BECCARIA, Cesare Bonesana [Marquês de]. 1991. Des délits et des peines. Trad. Maurice Chevallier. Paris: Flammarion.

. 1979. Dos delitos e das penas. Trad. Marcílio Teixeira. Rio de Janeiro: Editora Rio.

. 1834. Dei delitti e delle pene, coi commenti de varj insigni scrittori. Livorno: Glauco Masi.

. 1774. Tratado de los delitos y de las penas. Madrid. Edição fac-similar. Madri: Centro de Publicações do Ministério da Justiça, 1993.

BENTHAM, Jeremy. 1830. Traités de Législation Civiel et Pénale: ouvrage extrait des manuscrits de Jérémie Bentham, par Ét. Dumont. $3^{\mathrm{a}}$. ed. Paris : Rey et Gravier.

1823. Introduction to the principles of morals and legislation. Oxford: Oxford, 1907. Disponível em: http://www.laits.utexas.edu/poltheory/bentham/ipml/

BENTO DE FARIA, Antonio. 1919. Annotações Theorico-Praticas ao Codigo Penal do Brazil. $3^{\mathrm{a}}$ ed. Rio de Janeiro: Francisco Alves.

BERMAN, Harold J. 1983. Law and Revolution. The Formation of the Western Legal Tradition. Cambridge (MA): Harvard University Press.

BEVILÁQUA, Clóvis. 1977. História da Faculdade de Direito do Recife. 2. ed. Brasília: Instituto Nacional do Livro, Conselho Federal de Cultura.

BLACKSTONE, William. 1765-9. Commentaries on the Laws of England. Oxford: Clarendon Press. 
BOHNERT, Joachim. 1982. Paul Johann Anselm Feuerbach und der Bestimmtheitsgrundsatz im Strafrecht. Heidelberg: Carl Winter Universitätsverlag.

BRAVO LIRA, Bernardino. 2004. Bicentenario del Código Penal de Austria: Su proyección desde el Danubio a Filipinas. Revista de estudios histórico-jurídicos, Valparaíso, 26: 115-55.

BRITO, J. M. Rodrigues. 1869. Respostas ás breves reflexões do Exm. Sr. Dr. Vicente Ferrer sobre a Philosophia do Direito. Coimbra: Imprensa da Universidade.

BROADIE, Alexander. 2001. The Scottish Enlightenment: An Anthology Canongate Books: Edinburgh.

BROTERO, José Maria Avellar. 1829. Princípios de Direito Natural. Rio de Janeiro: Typographia Imperial e Nacional.

BUCHENBERGER, Eduard. 1932. Der Zweckgedanke in Anselm v. Feuerbachs Lehre von der Zurechnungsfähigkeit. Breslau-Neukirch: Alfred Kurtze.

BYRD, Sharon. 1989. Kant's Theory of Punishment: Deterrence in Its Threat, Retribution in Its Execution. Law and Philosophy 8 (2).

CABRAL DE MONCADA, Luís. 1950. Estudos de História do Direito. Século XVIII Iluminismo Católico, Verney: Muratori. v. III. Coimbra: Imprensa da Universidade.

CAMARGO, Joaquim Augusto de. 1881-2. Direito Penal Brasileiro. $2^{\text {a }}$ ed. [1881-2], adaptada à ortografia vigente. São Paulo: RT, 2005.

CAROATÁ, José Próspero Jehovah da Silva. 1884. Imperiaes Resoluções tomadas sobre Consultas da Secção de Justiça do Conselho de Estado. T. I e II. Rio de Janeiro: B. L. Garnier. 
CARR, Craig L., SEIDLER, Michael J. 1996. Pufendorf, Sociality and the Modern State. In: K. Haakonssen, Grotius, Pufendorf and Modern Natural Law. Aldershot: Ashgate Dartmouth.

CARTUYVELS, Yves. 1996. D’où vient le code pénal? Une approche généalogique des premiers codes pénaux absolutistes au XVIIIe siècle. Montreal, Ottawa, Bruxelles: Les Presses de l'Université de Montréal, Les Presses de l'Université d'Ottawa, De Boeck Université.

CARVALHO, José Murilo de. 2003. A construção da ordem: a elite política imperial. Teatro de sombras: a política imperial. Rio de Janeiro: Civilização Brasileira.

(org.). 2002. Paulino José Soares de Souza, Visconde do Uruguai. São Paulo: Editora 34.

CARVALHO JR., Eduardo Teixeira de. 2005. Verney e a questão do Iluminismo em Portgual. Dissertação de Mestrado. Curitiba, Universidade Federal do Paraná. Mimeo.

CATTANEO, Mario A. 1989. Legalità e Processo Penal nel pensiero di Karl Grolman. In: M. Cattaneo, 1993, Illuminismo e Legislazione Penale: saggi sulla filosofia del diritto penale nella germania del settecento. Milano: Edizione Universitarie di Lettere Economia Diritto: 273-88.

1984. Paura e Pena (Hobbes, Feuerbach e Kant). In: M. Cattaneo, 1993, Illuminismo e Legislazione Penale: saggi sulla filosofia del diritto penale nella germania del settecento. Milano: Edizione Universitarie di Lettere Economia Diritto: 181-94.

. 1981. Dignità umana e pena nella filosofia di Kant. Milano: Giufrè Editore.

- 1980. Savigny e Feuerbach. Quaderni fiorentini per la storia del pensiero giuridico 9: 307-317. 
1979. Una recente interpretazione dell'ultimo Feuerbach. Quaderni fiorentini per la storia del pensiero giuridico 8: 423-436.

. 1973. La dottrina penal di Karl Grolman nella filosofia giuridica del criticismo. In: M. Cattaneo, 1993, Illuminismo e Legislazione Penale: saggi sulla filosofia del diritto penale nella germania del settecento. Milano: Edizione Universitarie di Lettere Economia Diritto: 195-272.

_. 1970. Anselm Feuerbach: filosofo e giurista liberale. Milano: Edizioni di comunità.

CAVANNA, Adriano. 1975. La codificazione penale in Italia: le origini lombarde. Milano: Giuffrè Editore.

CHAVEAU, Antoine; HÉlIE, Faustin. 1863. Theorie du Code Pénal. T. I e II. Bruxelles: Bruylant-Christophe et Compagne, Eds.

CONRAD, Herman. 1985. Das Allgemeine Landrecht von 1794 als Grundgesetz des friederizianischen Staates. Berlin: Walter de Gruyter \& Co.

COSTA, Pietro. 1974. Il progeto giuridico. Ricerche sulla giurisprudenza del liberalismo classico. V. I. Da Hobbes a Bentham. Milano: Giuffrè Editore.

CUNHA, Paulo Ferreira da. 1994. La pelomique du premier manuel d'histoire du droit portugais, de Mello Freire. Quaderni fiorentini per la storia del pensiero giuridico moderno 23: 487-97.

DE LA RUA, Jorge. 1982. La Codificacion Penal Latinoamericana. Caracas: Universidad Central de Venezuela.

DYZENHAUS, David. 2001. Hobbes and the Legitimacy of Law. Law and Philosophy 20 (5): 461-98. 
DUVE, Thomas. 2002. Die Feuerbach-Rezeption in Lateinamerika. In: R. Gröschner, G. Haney, Die Bedeutung P. J. A. Feuerbachs (1775-1833) für die Gegenwart. Stuttgart: ARSP / Franz Steiner Verlag, p. 154-67.

DOMAT, Jean. 1828. Traité des Loix Civiles. In: Ouvres de Jean Domat, ed. Joseph Remy. Paris: Firmin Didot Père et Fils.

FERRAJOLI, Luigi. 2000. Derecho y razón. Teoría del garantismo penal. $4^{\mathrm{a}} \mathrm{ed}$. Trad. P. A. Ibánez, A. R. Miguel, J. C. Bayón Mohino, J. Terradillos Basoco, R. Cantarero Bandrés. Madrid: Ed. Trotta.

FERREIRA, Fátia Moura. 2004. Do individualismo ao(s) sociologismo(s) na formação jurídica: as relações entre o processo de cientifização dos saberes e a teorização sobre o social. VIII Congresso Luso-Africano-Brasileiro de Ciências Sociais, Centro de Esidade de Coimbrafaculdade de Economia, Universidade de Coimbra. Disponível em: http://www.ces.uc.pt/lab2004/pdfs/FatimaMouraFerreira.pdf.

FERREIRA, Gabriela Nunes. 1999. Centralização e Descentralização no Império: o debate entre Tavares Bastos e Visconde de Uruguai. SP: Editora 34.

FERREIRA, José Dias. 1864. Noções Fundamentais de Philosophia do Direito. Coimbra: Imprensa da Universidade. Disponível em: http://www.fd.unl.pt/Anexos/Investigacao/1257.pdf

FERRER, Vicente [Vicente Ferrer Neto Paiva]. 1857. Elementos de Direito Natural. $3^{\mathrm{a}}$. ed. Coimbra: Imprensa da Universidade.

1850. Elementos de Direito Natural, ou Philosophia do Direito. Coimbra: Imprensa da Universidade. Disponível em: http://www.fd.unl.pt/Anexos/Investigacao/2143.pdf

. 1843. Curso De Direito Natural, segundo o estado actual da sciencia, principalmente em Allemanha. Coimbra: Imprensa da Universidade. 
FEUERBACH, Paul Johann Anselm. 1969. Über Philosophie und Empirie in ihrem Verhältnisse zur positiven Rechtswissenschaft. Darmstadt: Wissenschaftliche Buchgesellschaft.

. 1833. Einige Worte über historische Rechtsgelehrsamkeit und einheimische teutsche Gesezgebung. In: P. J. A. Feuerbach, Kleine Schriften vermischten Inhalts. Nürnberg: Theodor Otto Verlag.

. 1800. Über die Strafe als Sicherungsmittel vor künftigen Beleidigungen des Verbrechers, nebst einer näheren Prüfung der kleinischen Strafrechtstheorie. Chemnitz: Georg Friedrich Tasché.

1799/1800. Revision der Grundsätze und Grundbegriffe des positiven peinlichese Rechts. 2 V. Erfurt: Henningschen Buchhandlung.

. 1798a. Philosophisch-juridische Untersuchung über das Verbrechen des Hochverraths. Erfurt: Henningsschen Buchhandlung.

. 1798b. Grundsätze der Criminalrechtswissenschaft, von D. Karl Grolman (Rezension). Allgemeine Literatur-Zeitung, 113-4, p. 65-79.

. 1797. Anti-Hobbes, oder über die Grenzen der höchsten Gewalt und das Zwangsrechte der Bürger gegen den Oberherrn. Gießen: Müllerschen Buchhandlung, 1797.

. 1796. Kritik des natürlichen Rechts als Propädeutik zu einer Wissenschaft der natürlichen Rechte. Altona: s.e., 1796.

. 1795. Über die einzig möglichen Beweisgründe gegen das Dasein und die Gültigkeit der natürlichen Rechte. Leipzig und Gera.

FILANGIERI, Gataneo. 1827. La Scienza della Legislazione. 3 T. Livorno: Glauco Masi. 
FOUCAULT, Michel. 1987. Vigiar e Punir. Nascimento da prisão. Trad. Raquel Ramalhete. Petrópolis: Vozes.

FRANCO, Afonso Arinos de Melo. 1972. O Constitucionalismo de D. Pedro I no Brasil e em Portugal. Rio de Janeiro: Ministério da Justiça / Arquivo Nacional.

GARCIA, Basileu. 1956. Instituições de Direito Penal. T. I e II. $4^{\text {a }}$ ed. São Paulo: RT

GRAFSTEIN, Robert. 1987. The significance of modern State of Nature theory. Polity 19 (4): 529-50.

GROLMAN, Karl. 1805. Grundsätze der Criminalrechtswissenschaft. Gießen und Darmstadt: G. F. Heyer.

. 1799. Ueber die Begründung des Strafrechts und der Strafgesetzgebung, nebst einer Entwicklung der Lehre von dem Maaßtabe der Strafen und der juridischen Imputation. Gießen: G. F. Heyer.

GROPP, Walter. 1992, Deliktstypen mit Sonderbeteiligung. Tübingen: Mohr.

GRÜHNHUT, Max. 1922. Anselm v. Feuerbach und das Problem der strafrechtlichen Zurechnung. Hamburg: W. Gente Verlag.

HART, H. L. A. 1994. The Concept of Law. $2^{\mathrm{a}}$ ed. Oxford: Clarendon Press.

HARTMANN, Richard. 1961. P. J. A. Feuerbachs politische und strafrechtliche Grundsanschauungen. Berlin: V.E.B. Deutscher Zentralverlag.

HESPANHA, António Manuel. 1997. Panorama Histórico da Cultura Jurídica Européia. Mem Martins: Publicações Europa-América.

1993. Da justiça à disciplina - textos, poder e política penal no Antigo Regime. In: Justiça e litigiosidade, história e prospectiva. Lisboa: Calouste Gulbenkian, 287-379 
. 1990a. Una historia de textos. In: F. Tomás y Valiente et. al., Sexo barroco y otras transgresiones premodernas. Madrid: Alianza Editorial, 187-96.

. 1990b. Le projet de Code pénal portugais de 1786. Un essai d'analyse structurelle. In: L. Berlinguer (org.), Le politiche criminali nel XVIII Secolo ("La Leopoldina). V. 11. Giuffrè: Milano.

. 1988. Sábios e rústicos: a violência doce da razão jurídica. Revista Crítica de Ciências Sociais, 25/26: 31-60.

HOBBES, Thomas. 1650. Elements of Law, Natural and Politic. London: Simpkin, Marshall \& $\quad$ Co, $1889 . \quad$ Disponível em: http://etext.lib.virginia.edu/etcbin/toccernew2?id=Hob2Ele.sgm Is=images/modeng\&data=/texts/english/mode ng/parsed\&tag=public $\partial=$ teiHeader

. 1651a. Leviathan, or The Matter, Forme \& Power of a Common-Wealth Ecclesiasticall and Civill. London: Andrew Crooke, at the Green Dragon. Edição fac-similar. Oxford: James Thornton, 1881.

—. De Cive. 1651b. London: R. Royson. Disponível em: http://socserv2.socsci.mcmaster.ca/ econ/ugcm/31l3/hobbes/index.htm 1

HOCHSTRASSER, Tim. 2000. Natural Law Theories in the Early Englightenment. Cambridge: Cambridge University Press.

HÖFFE, Otfried. 2005. Immanuel Kant. Trad. Crhistian Viktor Hamm e Valério Rohden. São Paulo: Martins Fontes.

HOFFMANN-HOLLAND, Klaus. 2007. Der Modellgedanke im Strafrecht. Tübingen: Mohr Siebeck.

HUNGRIA HOFFBAUER, Nélson. 1958. Comentários ao Código Penal. $4^{\mathrm{a}}$ ed. Rio de Janeiro: Revista Forense. 
JAKOBS, Günther. 1998. Sobre la Teoria de la Pena. Bogotá: Univ. Externado de Colombia.

JENKINS, Philip. 1984. Varieties of Enlightenment Criminology: Beccaria, Godwin, de Sade. British Journal of Criminology 24 (2): 112-30.

KANT, Immanuel. 1797. Metaphysik der Sitten in zwei Theilen, und Pädagogik. ${ }^{\mathrm{a}}$. ed. In: Immanuel Kant's Sämmtliche Werke. Ed. K. Rosenkranz, F. W. Schubert. T. IX. Leipzig: Leopold Voss, 1838.

. 1785. Grundlegung zur Metaphysik der Sitten. In: Immanuel Kant's Sämmtliche Werke. Ed. K. Rosenkranz, F. W. Schubert. T. VIII. Leipzig: Leopold Voss, 1838.

KAPLOV, Louis, SHAVELL, Steven. 2001. Fairness versus Welfare. Harvard Law Review 114 (4): 961-1388.

KAULBACH, Friedrich. 1972. Naturrecht und Erfahrungsbegriff im Zeichen der Anwendung der kantischen Rechtsphilosophie; dargestellt an den Thesen von P. J. A. Feuerbach. In: M. Riedel (ed.), Rehabilitierung der praktischen Philosophie: Geschichte, Probleme, Aufgaben. Freiburg: Rombach.

KOERNER, Andrei. 1999. Habeas corpus, prática judicial e controle social no Brasil (1841-1920). São Paulo: IBCCrim.

KINDHÄUSER, Urs. 2006. Strafrecht. Allgemeiner Teil. Baden-Baden: Nomos.

KLEIN, Ernst Ferdinand. 1796. Grundsätze des Gemeinen Deutschen und Preussischen Peinlichen Rechts. Halle: Hemmerde und Schewtschke.

KNOPF, Werner. 1936. Die Entwicklung der Religionsvergehen feit Anselm von Feuerbach. Berlin: Triltsch \& Huther. 
LANGBEIN, John H. 1976. The Historical Origins of the Sanction of Imprisonment for Serious Crime. The Journal of Legal Studies 5 (1): 35-60.

. 1974. Prosecuting crime in the Renaissance. England, Germany, France. Cambridge (MA): Harvard University Press.

LISZT, Franz von. 1917. Tratado de Derecho Penal. T. I-III. $18^{\mathrm{a}}$ ed. Trad. Quintiliano Saldaña. Madrid: Reus.

LOMBROSO, Cesare. 1897. L'Uomo Delinquente, in Rapporto all'Antropologia, alla Giurisprudenza ed alla Psichiatria. Causa e Rimedi. Torino: Fratelli Boca Editori.

LOPES, José Reinaldo de Lima. 2007. Consultas da Seção de Justiça do Conselho de Estado (1842-1889). A formação da cultura jurídica brasileira. Almanack Brasiliense 5: 4-36.

2004. As palavras e a lei. Direito, ordem e justiça na história do pensamento jurídico moderno. São Paulo: Editora 34.

MACCORMICK, Neil. 2005. Rhetoric and the Rule of Law. A theory of legal reasoning. Oxford: Oxford Univeristy Press.

1986. Law as institutional fact. In: N. MacCormick, O. Weinberger, An institutional theory of law: new approaches to legal positivism. Dordrecht: D. Reidel, 49-76.

MACHADO NETO, Zahidé. 1977. Direito Penal e Estrutura Social. Comentário sociológico ao Código Criminal de 1830. São Paulo: Saraiva / Ed. da Universidade de São Paulo.

MAESTRO, Marcello. 1973. Cesare Beccaria and the origins of penal reform. Philadelphia: Temple University Press. 
MARRA, Realino. 2001. La giustiza penale nei principi del 1789. Materiali per una storia della cultura giuridica 31 (2): 353-65.

MELLO FREIRE, Paschoal José de. 1823. Ensaio do Código Criminal a que mandou proceder a Rainha Fidelíssima D. Maria I. Lisboa: Typographia Miagrense.

. 1779. Instituições de Direito Civil Português. Tanto público como particular. s.1.: s.d. em: http://www.fd.unl.pt/Anexos/Investigacao/1077.pdf.

1794. Instituições de Direito Criminal Português. s.l.: s.d. Disponível em: http://www.fd.unl.pt/Anexos/Investigacao/1012.pdf.

MIRABETE, Júlio Fabbrini. 2000. Manual de Direito Penal. Parte Geral. 5a . ed. São Paulo: Atlas.

MONTENEGRO, Manuel Januario Bezerra. 1860. Lições acadêmicas sobre artigos do Código Criminal. Recife: Typographia Universal.

NAPOLI, Paolo. 2001. Police et justice dans les débats révolutionnaires (1789-91). Les enjeux d'une question toujours actuelle. Quaderni fiorentini per la storia del pensiero giuridico moderno 30: 159-97.

NAUCKE, Wolfgang. 1975. Paul Johann Anselm von Feuerbach. Zeitschrift für die gesamte Strafrechtswissenschaft 25 (87): 861-87.

_. 1962. Kant und die psychologische Zwangstheorie Feuerbachs. Hamburg: Hansischer Gildenverlag.

NEDER, Gizlene. 2000. Iluminismo jurídico-penal luso-brasileiro: obediência e submissão. Rio de Janeiro: Freitas Bastos.

. 1998. Coimbra e os juristas brasileiros. Revista Discursos Sediciosos: Crime, Direito e Sociedade, 3 (5-6): 195-214. 
NORRIE, Alan W. 2001. Crime, reason and history. A critical introduction to criminal law. London: Butterworths.

1991. Law, ideology and punishment: a historical critique of the liberal ideal of criminal law justice. Dordrecht: Kluwer Academic Publishers.

OLIVEIRA, Cecília Helena de Salles. 2007. O Conselho de Estado e o complexo funcionamento do governo monárquico no Brasil do século XIX. Almanack Brasiliense 5: 46-53.

ORTOLAN, J. 1855. Éléments de Droit Pénale. Paris: Librerie de Plon Frères. 1841. Cours de Législation Pénale comparée. Introduction Historique Analyses du Cours de 1839-40 par M. F. Narjot. Paris: Joubert.

. 1839. Cous de Législation Pénale comparée. Introduction Philosophique. Paris: Jouvert.

PASTOR, Daniel R. 2005. Recodificación penal y principio de reserva de código. Buenos Aires: Ad Hoc.

PIMENTA BUENO, José Antonio. 1857a. Apontamentos sobre o Processo Criminal Brasileiro. Rio de Janeiro: Empreza Nacional do Diário.

1857b. Direito Publico Brazileiro e Analyse da Constituição do Imperio. Rio de Janeiro: Typographia Imp. e Const. de J. Villeneuve e C.

PIRES, Álvaro P. 1998a. Aspects, traces et parcours de la rationalité pénale moderne. In: C. Debuyst, F. Digneffe, A. P. Pires, Histoire des savoirs sur le crime \& la peine. 2. La rationalité pénale moderne et la naissance de la criminologie. Montreal, Ottawa, Bruxelles: Les Presses de l'Université de Montréal, Les Presses de l'Université d'Ottawa, De Boeck Université. p. 3-52. 
. 1998b. Beccaria, l'utilitarisme et la rationalité pénale moderne. In: C. Debuyst, F. Digneffe, A. P. Pires, Histoire des savoirs sur le crime \& la peine. 2. La rationalité pénale moderne et la naissance de la criminologie. Montreal, Ottawa, Bruxelles: Les Presses de l’Université de Montréal, Les Presses de l'Université d'Ottawa, De Boeck Université. p. 83-144. 1998c. Kant face à la justice criminelle. In: C. Debuyst, F. Digneffe, A. P. Pires, Histoire des savoirs sur le crime \& la peine. 2. La rationalité pénale moderne et la naissance de la criminologie. Montreal, Ottawa, Bruxelles: Les Presses de l'Université de Montréal, Les Presses de l’Université d'Ottawa, De Boeck Université. p. 145-220.

. 1998d. Un noeud gordien autur du droit de punir. In: C. Debuyst, F. Digneffe, A. P. Pires, Histoire des savoirs sur le crime \& la peine. 2. La rationalité pénale moderne et la naissance de la criminologie. Montreal, Ottawa, Bruxelles: Les Presses de l'Université de Montréal, Les Presses de l’Université d'Ottawa, De Boeck Université. p. 209-219.

POCOCK, John G. A. 1971. Languages and their implications: the transformation of the study of political thought. In: Politics, language and time. Essays on political thought and history. Chicago: The University of Chicago Press. 3-41.

PORTALIS, Jean-Étienne-Marie, TRONCHET, François Denis, BIGOTPRÉAMENEU, Félix-Julien-Jean, MALEVILLE, Jacques. 1801. Preliminary Address on the First Draft of the Civil Code. Department of Justice of Canada, International Cooperation Group, 2005. Disponível em: http://www.justice.gc.ca/eng/pi/icggci/code/index.html.

PUFENDORF, Samuel von. 1682. The Two Books on the Duty of Men and Citizen according to the Natural Law. Trad. Frank Gardner Moore (1964). 
Cambridge: House of John Hayes. Disponível em: http://www.constitution.org/puf/puf-dut.htm.

RADBRUCH, Gustav. 1934. Paul Johann Anselm Feuerbach. Ein Juristenleben. Wien: Julius Springer.

REALE JR., Miguel. 2002. Instituições de Direito Penal. v. I. Rio de Janeiro: Forense.

REATH, Andrews. 1994. Legislating the Moral Law. Noûs 28 (4), p. 435-464.

RIBAS, Antônio Joaquim. 1866. Direito Administrativo Brasileiro: lições preliminares. Rio de Janeiro: F. L. Pinto \& C., Livreiros.

RIBEIRO, João Luiz. 2005. No meio das galinhas as baratas não tem razão: a Lei de 10. de junho de 1835: os escravos e a pena de morte no Império do Brasil: 1822-1889. Rio de Janeiro: Renovar.

RIBEIRO, Renato Janine. 1999. Ao leitor sem medo: Hobbes escrevendo contra o seu tempo. Belo Horizonte: Editora UFMG, 2004.

RODRIGUES, José Honório. 1973. Atas do Conselho de Estado. V. 1 - 8. Brasília: Senado Federal.

ROMAGNOSI, Giandomenico. 1791. Génesis del Derecho Penal. Bogotá: Editorial Temis Bogotá, 1956.

ROSSI, Pellegrino. 1872. Traité de Droit Pénal. T. I e II. Paris: Librairie Guillaumin et Cie.

1829. Traité du Droit Pénal. T. I-III. Genève: J. Barbezat \& Cie., Libraires.

ROUSSEAU, Jean-Jacques. 1772. Du Contrat Social, ou Principes de Droit Politique. Amsterdam: Marc-Michel Rey.

ROXIN, Claus. 2006. Strafrecht. Allgemeiner Teil. Band I. Grundlagen: Der Aufbau der Verbrechenslehre. $4^{\mathrm{a}}$ ed. Münche: Verlag C. H. Beck. 
2002. Política Criminal e Sistema Jurídico-Penal. Rio de Janeiro: Renovar.

RUGGIERO, Vicenzo. 2006. Underestanding political violence. A Criminological Analysis. Cardiff: Open University Press.

SALVADOR NETTO, Alamiro Velludo. 2006. Tipicidade penal e sociedade de risco. São Paulo: Quartier Latin.

SBRICCOLI, Mario. 2004. Giustiza criminale. In: M. FIORAVANTI, Lo Stato moderno in Europa. Istituzioni e diritto. Roma-Bari: Editori Laterza, p. 163-205.

1974. Crimen Laesae Maiestatis. Il problema del rato politico alle soglie della scienza penalistica moderna. Milano: Giuffrè Editore.

SCHMIDT, Eberhard. 1980. Beiträge zur Geschichte des preussischen Rechtsstaates. Berlin: Duncker \& Humblot.

SCHUBERT, Gernot. 1978. Feuerbachs Entwurf zu einem Strafgesetzbuch für das Königreich Bayern aus dem Jahre 1824. Berlin: Duncker \& Humblot.

SCHWARTZ, Roberto. 2000. Idéias fora do lugar. In: Ao vencedor as batatas. São Paulo: Duas Cidades / Ed. 34, 9-32.

SEARLE, John. 1995. The construction of social reality. New York: The Free Press.

SEELMANN, Kurt. 2001. Gaetano Filangieri e la proporzionalità fra reato e pena. Imputazione e prevenzione nella filosofia penale dell'Illuminismo. Materiali per una storia della cultura giuridica 31 (1): 3-25.

SERRÃO, Joaquim Veríssimo. 1996. História de Portugal. O despotismo iluminado (1750-1807). T. VI. Lisboa: Editorial Verbo.

SHECAIRA, Sérgio Salomão. 2004. Criminologia. São Paulo: RT. 
SILVA FERRÃO, F. A. F. da. 1856. Theoria do Direito Penal applicada ao Código Penal Portuguez. Lisboa: Typ. Universal.

SKINNER, Quentin. 1989. The State. In: T. BALL, J. FARR, R. L. HANSON, Political innovation and conceptual change. Cambridge: Cambridge University Press. p. 90-131.

1966. Hobbes and his disciples in France and England. Comparative Studies in Society and History 8 (2): 153-67.

SOUZA, Braz Florentino Henriques de. 1965. Do delito e do delinqüente. São Paulo: Saraiva / Editora da Universidade de São Paulo.

STERN, Laura Ilkins. 1994. The Criminal Law System of Medieval and Renaissance Florence. Baltimore / London: The Johns Hopkins University Press.

STÜBEL, Christoph Carl. 1795. System des allgemeinen Peinlichen Rechts mit Anwendung auf die Chursachsen geltenden Gesezze, besonders zum Gebrauche für academische Vorlesungen. Lepizig: Sommerschen Rechtswissenschaft.

TARELLO, Giovanni. 1976. Storia della Cultura Giuridica Moderna: I. Assolutismo e codificazione del diritto. Bologna: Società editrice il Mulino.

THIBAUT, Anton Friedrich Justus. 1802. Beyträge zur Critik der Feuerbachischen Theorie über die Grundbegriffe des peinlichen Rechts. Hamburg: Friedrich Perthes.

TOLEDO, Francisco de Assis. 1991. Princípios básicos de direito penal. $4^{\mathrm{a}}$ ed. São Paulo: Saraiva.

TOMÁS Y VALIENTE, Francisco. 1992. El Derecho penal de la monarquía absoluta (siglos XVI, XVII y XVIII). 2a ed. Madrid: Tecnos. 
et. al. 1990. Sexo barroco y otras transgresiones premodernas. Madrid: Alianza Editorial.

TUCK, Richard. Hobbes. Trad. A. U. Sobral e M. S. Gonçalves. São Paulo: Edições Loyola.

. 1979. Natural law theories. Their origin and development. Cambridge: Cambridge University Press.

ULLMAN, Walter. 1968. A history of political thought. The Middle Ages. Middlesex: Penguin Books.

VAMPRÉ, Spencer. 1977. Memórias para a História da Academia de São Paulo. 2. ${ }^{\text {a }}$ ed. Brasília: Instituto Nacional do Livro, Conselho Federal de Cultura.

VAN MILL, David. 1995. Hobbes's Theories of Freedom. The Journal of Politics 57 (2): 443-59.

VELLASCO, Ivan de Andrade. 2007a. A cultura jurídica e a arte de governar: algumas hipóteses investigativas sobre a Seção de Justiça do Conselho de Estado. Almanack Brasiliense 5: 37-45.

2007b. Policiais, pedestres e inspetores de quarteirão: algumas questões sobre as vicissitudes do policiamente na província de Minas Gerais (1831-50). In: J. M. de Carvalho, Nação e cidadania no Império: novos horizontes. Rio de Janeiro: Civilização Brasileira.

VENÂNCIO FILHO, Alberto. 2004. Das Arcadas ao bacharelismo: 150 anos de ensino jurídico no Brasil. São Paulo: Perspectiva.

WEHLING, Arno. 2002. A questão das juntas criminais das colônias e as origens do direito penal militar. Revista do Instituto Histórico e Geográfico Brasileiro, 163 (416): 155-60. 
WEHLING, Arno, WEHLING, Maria José. 2005. Direito e Justiça no Brasil Colonial: o Tribunal da Relação do Rio de Janeiro (1751-1808). Rio de Janeiro: Renovar.

1998. Racionalismo ilustrado e prática jurídica colonial - o direito das sucessões no Brasil (1750-1808). Revista do Instituto Histórico e Geográfico Brasileiro 401: 1607-25.

WOLFF, Chrsitian. 1758. Principes du Droit de la Nature e des Gens. Trad. J. H. S. Formey. Amsterdam: Marc Michel Rey.

ZAFFARONI, Eugenio Raúl; BATISTA, Nilo. 2003. Direito Penal Brasileiro - I. Rio de Janeiro: Editora Revan 


\title{
RESUMO
}

Esta tese de doutoramento cuida do processo histórico de formação teórica do direito penal contemporâneo. Inicialmente, apresenta os conceitos básicos do direito penal na doutrina jurídica e política pré-contemporânea. Em seguida, analisa a formação teórica do direito penal contemporâneo na obra de P. J. A. Feuerbach. Por fim, cuida da formação desse mesmo tipo de direito penal em meio à cultura jurídica brasileira do século XIX. Palavras-chave: direito penal contemporâneo - direito criminal - P. J. A. Feuerbach - metodologia do direito penal - metodologia da história do penamento jurídico - história do direito penal brasileiro.

\begin{abstract}
This doctoral thesis handles the historical development of the theoretical formation of contemporary Criminal Law. It starts off with the presentation of basic Criminal Law concepts in pre-conteporary legal and political thinkers. Then, it handles the theoretical formation of contemporary Criminal Law in the works of P. J. A. Feuerbach. Finally, it handles the formation of this same type of Criminal Law within the Brazilian legal culture of the $19^{\text {th }}$ Century. Keywords: contemporary Criminal Law - Penal Law - P. J. A. Feuerbach - methodology of Criminal Law - methodology of Legal History - History of Brazilian Criminal Law.
\end{abstract}




\section{ZUSAMMENFASSUNG}

Diese Dissertation beschäftigt sich mit der historischen Entwicklung des zeitgenössischen Strafrechts. Die Arbeit präsentiert zunächst die Grundbegriffe des Strafrechts vorzeitgenössischer Juristen und politischer Philosophen. Im Folgenden, beschäftigt sie sich mit dem Aufbau des zeitgenössischen Strafrechts in den Arbeiten von P. J. A. Feuerbach. Abschließend, wird die Entwicklung dieses Strafrechts in den Werken der brasilianischen Juristen des 18. Jahrhunderts aufgezeigt. Schlüsselwörter: zeitgenössisches Strafrecht - Kriminalrecht - P. J. A. Feuerbach - Methodologie des Strafrechts - Methodologie der Rechtsgeschichte - brasilianische Strafrechtsgeschichte. 